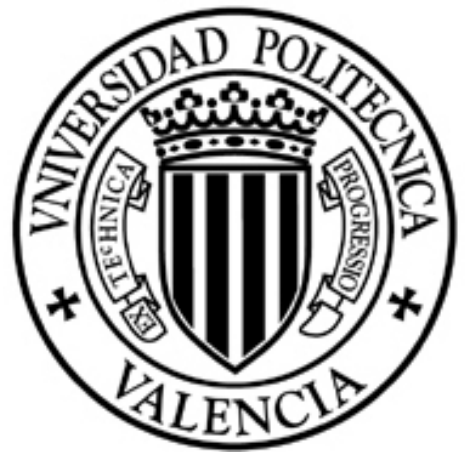

UNIVERSIDAD

POLITECNICA

DE VALENCIA

FACULTAD DE BELLAS ARTES DE SAN CARLOS

Departamento de Dibujo

\title{
ESTUDIO DE LA OBRA GRÁFICA DE PILAR DOLZ
}

TESIS DOCTORAL

Presentada por:

SUSAN MERCEDES GÁLVEZ SÁNCHEZ

Dirigida por:

Dra. Dña. BLANCA ROSA PASTOR CUBILLO

Valencia, 2009 

A mi madre

La mujer más valiente y luchadora que he conocido, causa de todas mis inspiraciones, quien en todo momento ha sabido estar a mi lado para guiarme y apoyarme.

A mi hija

Que sepa que nada es imposible en la vida, que la constancia y la dedicación son la clave para conseguir todas las metas que se proponga. 



\section{AGRADECIMIENTOS}

Quiero expresar mis sinceros agradecimientos a Pilar Dolz, por las facilidades dadas para la realización de este trabajo, con la aportación de todo tipo de documentación y charlas concedidas.

A la Dra. Dña. Blanca Rosa Pastor, directora de esta investigación por la orientación y profesionalidad con que me ha dirigido.

A Vicente, Trini y toda su familia por la ayuda y el apoyo inquebrantable mantenido durante todos estos años. 



\section{INDICE}

\section{INTRODUCCIÓN}

Introducción............................................ 13

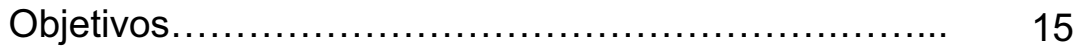

Metodología........................................ 17

Estructura y contenido................................. 18

\section{CAPÍTULO 1}

BIOGRAFÍA DE PILAR DOLZ

1.1. GRÁFICA DE MUJERES ARTISTAS EN ESPAÑA. 23

1.1.1. Valencia........................................ 35

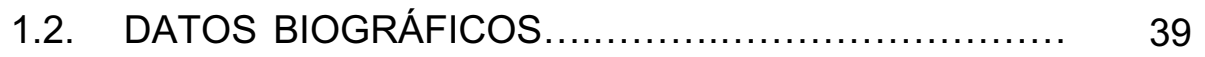


1.3. EVOLUCIÓN ARTÍSTICA................................. 55

1.3.1. Inicio............................................... 55

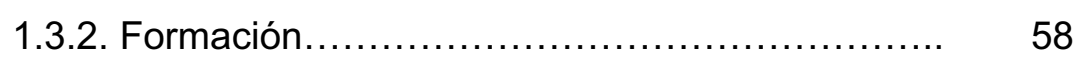

1.3.3. Perfeccionamiento.................................... 72

1.3.4. Madurez artística........................................ 74

1.4. ACTUALIDAD DE PILAR DOLZ

1.4.1. Pilar Dolz galerista..................................... 80

1.4.2. Trabajo editorial.................................... 83

CAPÍTULO 2

ANÁLISIS DE LA OBRA GRÁFICA

2.1. CONSIDERACIONES PREVIAS ........................ 91

2.2. ESTUDIO ANALÍTICO...................................... 93

2.2.1. Concepción............................................. 94

2.2.2. Aspectos compositivos............................... 99

2.2.3. Proceso técnico ....................................... 105

\section{CAPÍTULO 3}

ESTUDIO PORMENORIZADO DE LA OBRA GRÁFICA DE PILAR DOLZ: LAS SERIES

3.1. De formas.................................................. 109

3.2. De mujeres.............................................. 159

3.3. Cordes.................................................. 211

3.4. Reixes................................................ 237

3.5. Ocells morts.......................................... 281

3.6. Insectes.............................................. 315

3.7. Finestres................................................. 351

3.8. Pedres i paisatges dels Ports............................... $\quad 379$ 
3.9. Parets de pedra seca................................ 409

3.10. Espais i paisatge .................................... 455

3.11. Herbes................................................ 477

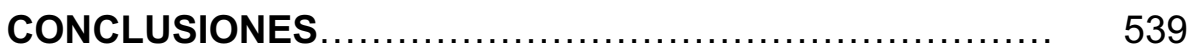

\section{BIBLIOGRAFÍA}

1. Bibliografía general................................. 553

2. Bibliografía de técnicas............................... 561

3. Bibliografía específica................................. 562

4. Páginas web de interés................................ 566

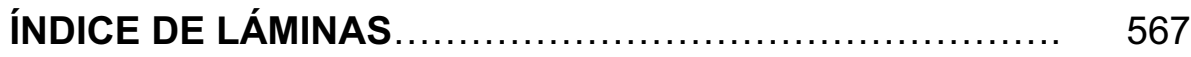

\section{APÉNDICE}

1. Currículum vitae de Pilar Dolz........................ 577

2. Actividad de la Galería Cànem en los últimos 10 años. 588

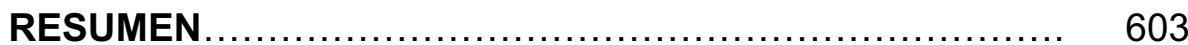



NTRODUCCIÓN 



\section{INTRODUCCIÓN}

El primer trabajo de investigación previo a esta tesis doctoral, estuvo determinado por diversas inquietudes, situaciones personales e ideológicas, además del gran interés hacia el campo de creación gráfica original.

El traslado desde mi país a España por estudios, mi profesión de grabadora, y sobre todo mi condición de mujer, hizo que al llegar a este país me interesara inmediatamente por el trabajo gráfico que las mujeres estaban realizando en la Comunidad Valenciana. 
Es evidente que la Historia del Arte desde su creación como disciplina académica, ha sepultado todo aquello que fue hecho por las mujeres artistas, marginando a la mujer con base en una diferencia sexual. La Historia del Arte, de H. W. Janson, publicada en 1959 no cita ni una sola artista. Nos atrevemos a decir que es a partir de la década del 70 , cuando verdaderamente se ha empezado a realizar estudios con las mujeres como protagonistas, cuyo principal objetivo ha sido rescatar del olvido a muchas artistas.

Con estas premisas nos planteamos aquel primer proyecto de investigación que se presentó bajo el título Gráfica actual de mujeres artistas valencianas, que intentó mostrar un panorama del trabajo realizado por las mujeres seleccionadas para reivindicar el fundamental papel que está jugando la mujer en el mundo de la creación artística.

Así surge por primera vez el nombre de Pilar Dolz como una de las grabadoras más representativas de la Comunidad Valenciana, autora de una de las propuestas artísticas dentro de la obra gráfica original, más interesantes del panorama artístico valenciano, y consagrada por completo a esta práctica desde 1970, una época difícil para la mujer, pues su trabajo artístico era considerado como un adorno o una distracción; sin embargo ella ha sabido abrirse campo con gran profesionalidad.

Conocerla fue conocer a una gran mujer y una gran artista, llena de vitalidad y energía, con gran amor y confianza hacia el Arte. Su facilidad de palabra y capacidad de comunicación, su interés por la técnica, la investigación y su tenaz labor artística como grabadora, 
galerista y editora, hizo que nos interesáramos cada vez más en su obra. Así, descubrir su personalidad y su trabajo culminó con nuestra convicción sobre el interés de dedicar nuestra investigación doctoral al estudio de su obra gráfica

La presente investigación se plantea dos vertientes de estudio; una dedicada a la biografía, desde sus inicios por el camino del arte hasta la actualidad. Y la otra dedicada al análisis de la obra gráfica, cuerpo fundamental de la tesis. Este apartado se encuentra apoyado por un material visual, esencial para dar testimonio de las aportaciones que esta artista ha generado en el ámbito de la gráfica valenciana. La disposición de las imágenes en cada apartado, se halla dispuesta en la medida de lo posible según su cronología, pero en el apartado de análisis de la obra las imágenes guardan un orden a criterio de la doctoranda según requiera su trabajo analítico.

\section{OBJETIVOS}

El objetivo fundamental de este trabajo es analizar la obra gráfica de Pilar Dolz, una consagrada y magnífica grabadora, con el fin de tener una visión lo más completa posible del papel desempeñado por la artista en el panorama del arte valenciano y mostrar que entendió que el grabado es una técnica con una peculiar cualidad expresiva con la suficiente fuerza como para volcar su actividad creadora en ésta.

En consecuencia el principal objetivo es determinar las aportaciones que Pilar Dolz ha desarrollado dentro del mundo de la 
gráfica; definir las líneas de ruptura o continuidad que permanecen en su obra a lo largo de toda su vida profesional, con el fin de hacer una exposición simple, razonada y global de su evolución artística. Se completa este objetivo con los siguientes.

- Extraer las propuestas más clarificadoras y definitorias de la configuración formal de su obra.

- Diferenciar las distintas etapas de su evolución artística.

- Analizar la evolución de la iconografía propia de su obra gráfica, estableciendo paralelismos de relación entre las diferentes etapas.

- Conocer la personalidad de la artista inserta en su época, como hecho representativo de la actividad artística de las mujeres artistas coetáneas de ella, en la Comunidad Valenciana.

- Valorar esta obra artística como fuente de riqueza y legado que se debe transmitir a generaciones futuras.

- Ampliar el número de estudios que posicionen la actividad artística femenina en unos parámetros reales desde los que podamos acceder a un conocimiento más adecuado del hecho artístico contemporáneo.

El ámbito de estudio se limita a la obra gráfica, por ser ésta su principal campo de expresión artística. Por otro lado el grabado en el 
contexto contemporáneo ha experimentado un gran desarrollo, de manera que no se puede entender el arte actual sin el apartado gráfico. Sin embargo el público que sabe distinguir las diferentes técnicas es reducido, por lo que nuestro interés es difundir el papel del grabado como técnica de expresión artística que sigue abriendo posibilidades de proceder de acuerdo a las propias necesidades expresivas.

\section{METODOLOGIA}

Con el fin de poder desarrollar con eficacia la investigación, planteamos un método de trabajo con diferentes etapas.

La primera etapa, corresponde a la recopilación de información generada alrededor de la artista, en museos, galerías, bibliotecas, Internet, siendo una fuente importantísima la propia artista, quien con generosidad puso a nuestra disposición todo tipo de documentación archivada celosamente en su taller, que nos han sido de gran utilidad para el desarrollo de este trabajo.

Esta etapa de recopilación de documentos, se complementa con visitas periódicas al taller de la artista ubicado en Castellón de la Plana, para fotografiar y catalogar su obra, así como para realizar entrevistas a la autora, con el fin de obtener información inédita sobre su biografía, experiencias, ideas, procedimientos técnicos y demás. Estas visitas se dan entre el 7 de marzo del 2002 y el 13 de diciembre del 2007. Sin duda las entrevistas son uno de los mejores instrumentos de información a lo largo de toda la investigación, pues 
el tener acceso a la fuente original, nos permite adquirir datos con ecuanimidad, lo que supone el enriquecimiento y la fidelidad a la realidad de la persona estudiada y su obra. Completamos esta fase con la búsqueda de material bibliográfico y documentación historiográfica para fundamentar la obra.

En la siguiente etapa abordamos la obra gráfica de Pilar Dolz, por series, por conjuntos de grabados con un mismo tema y características comunes, ya que la totalidad de su obra ha sido producida bajo esta concepción. El análisis estará apoyado en las diferentes teorías establecidas sobre psicología de la forma, pero fundamentalmente a partir de la experiencia personal con la propia artista y la formación conseguida en el campo de las bellas artes, lo que nos permitirá obtener la información sin perder objetividad. En este apartado analizaremos todo lo concerniente al proceso de creación de la obra, además de un análisis técnico.

Como consecuencia podremos establecer las conclusiones, una vez efectuados los análisis de todos los procesos.

\section{ESTRUCTURA Y CONTENIDO}

El presente estudio está dividido en tres apartados fundamentales:

El primer capítulo hace referencia a la biografía de Pilar Dolz, que comprende tres fases de desarrollo; una que hace mención cronológicamente a los datos biográficos de la artista, desde sus 
inicios por los caminos de la arte hasta la actualidad. La segunda etapa hace referencia a la actividad artística y la evolución estética de la autora. Este apartado lo clasificamos en cuatro períodos artísticos; inicio, formación, perfeccionamiento y madurez artística. En una tercera etapa, hacemos referencia a su actividad como galerista y editora, para mostrar una artista multifacética que armoniza y conecta las diversas actividades con su pasión por el grabado.

El segundo capítulo, Comentarios respecto de la obra gráfica, hace referencia a las causas que motivaron a realizar el estudio por series, así como el proceso de análisis a seguir. En él explicamos los diversos puntos a tener en cuenta en el proceso de la obra gráfica. Así se plantea el análisis desde tres puntos de vista; Concepción, Aspectos compositivo y Proceso técnico.

El apartado Concepción, considera los aspectos históricos, sociológicos e ideológicos que envuelven a la artista y nos permitirá comprender las claves del discurso artístico de la autora que se manifiestan directa o indirectamente en su obra.

En cuanto al apartado Aspectos compositivos, analiza el estudio de la obra gráfica desde un punto de vista temático, lingüístico y descriptivo. En él analizamos los aspectos formales más importantes en una obra de arte como son: la composición, que tiene que ver con el espacio; la línea, que es la huella gestual ejecutada por la acción de la artista y por último el color, las manchas pigmentadas presentes en la obra. 
El tercero, Proceso técnico, como su nombre indica, tiene que ver con el estudio de la técnica, los materiales y las herramientas empleadas en la creación de la obra.

El tercer capítulo, bloque principal de la investigación, hace alusión al estudio de la obra gráfica en sí, siguiendo los parámetros antes mencionados.

Una vez realizados todos los análisis, es el momento de proceder a sacar conclusiones y establecer los parámetros relacionados con la producción gráfica de Pilar Dolz y su entorno, para plantar las bases para reconocer y considerar en su justa medida el trabajo que ha desarrollado y que marca su singularidad en el ámbito de la actual Comunidad Valenciana. 
CAPÍTULO 1

IOgRAFía de PILAR Dolz 



\subsection{GRÁFICA DE MUJERES ARTISTAS EN ESPAÑA.}

Este apartado tiene como intención establecer una sucinta serie de consideraciones que sirvan de marco para posicionar la actividad artística de Pilar Dolz dentro del panorama artístico tanto valenciano como español. ${ }^{1}$

Este trabajo no trata de situar el debate de la diferencia sexual en el arte desde ningún punto de vista, sino simplemente de mostrar que la presencia de la mujer antes y hoy en todos los aspectos sociales de la vida es tan válida como la actuación del hombre, incluso en el mundo de la creación artística, aunque hasta ahora no haya sido reconocido adecuadamente.

\footnotetext{
${ }^{1}$ Realizado a partir de un anterior trabajo de investigación titulado "Gráfica actual de mujeres artistas valencianas" realizado por la autora de esta investigación en el año 1999.
} 
La historia del arte desde su creación ha sepultado a las mujeres artistas mostrando diferentes grados de opresión y marginación hacia ellas, con base en una diferencia de naturaleza sexual. Las mujeres siempre han producido arte, lo que sucede es que el comportamiento sexista y la desigual división del trabajo otorgó la posibilidad de dedicarse a la creación sólo a una minoría femenina dentro del sector productivo, mayoritariamente masculino, relegando a la mujer al trabajo doméstico y a la reproducción del género humano como si esto fuera algo normal y lógico.

Sin embargo esta realidad socio-cultural se rompió y hoy la mujer ha logrado ser admitida totalmente en el área de la producción en general y de la producción artística en particular. Un ejemplo de este cambio de orientación lo encontramos en la exposición titulada "La otra mitad de la vanguardia" que se llevó a cabo en Milán en el Palazzo Reale en 1989, donde se mostraba más de cien obras de creadoras del nuestro siglo. ${ }^{2}$

Cuando se instituyó la historia como materia de estudio, fue la responsable de contarnos todo a partir de hitos singulares $y$ mediante la exaltación de lo sublime y extraordinario. Fuera de este proceso quedaron las mujeres a pesar del movimiento ilustrado, pues la jerarquización impuesta por la academia infravaloró el trabajo femenino ya que como vemos, las condiciones de su género las excluyó de una formación artística completa que limitaba temas y forma de decirlos.

\footnotetext{
${ }^{2}$ Sobre mujeres artistas véase De Diego, E.: 1987. p. 23
} 
Las limitaciones del acceso a las academias comportaban graves deficiencias en la formación de las artistas. Poco a poco las academias amplían formación en las distintas secciones de pintura, escultura o grabado, se van abriendo aulas específicas para mujeres, en las que se mantiene la prohibición total y absoluta de las clases de desnudo, lo que las excluía definitivamente de la práctica de la escultura, y limitaba a las pintoras en el estudio de la figura humana. Generalmente los temas tratados y admitidos como adecuados para las mujeres eran cuadros de género, bodegones, temas religiosos, paisaje, algún retrato.

En el caso de España Estrella de Diego, cuenta que unas costumbres mucho más estrictas que en otros países europeos forzaron a muchas mujeres, en un primer momento a un aprendizaje autodidacta a base de tratados y cartillas de dibujo. ${ }^{3}$

Las primeras escuelas de dibujo de niñas creadas bajo el patrocinio real en 1819 se crearon en Madrid, en dos centros; el de la Merced y el de Fuencarral, los mismos que cerraron sus puertas el 28 de noviembre de 1854 debido a una real orden.

Por otra parte, en España, al igual que en el resto de Europa, el oficio de grabador tradicional, reservado a los hombres, desaparece casi por completo, quedando prácticamente suprimido en el ámbito de la industria de las artes gráficas, solo quedan unos pocos que quedan como profesores de grabado o como grabadores al servicio de la Casa de la Moneda. No obstante si sabemos que siempre ha habido una minoría de artistas que trabajan en este

\footnotetext{
${ }^{3}$ Opus cit. p. 177
} 
campo y su papel fue determinante para la realidad actual en la que es una manifestación más del arte.

Superados los años de hambre posteriores a la Guerra civil (1936-39), comienza a surgir lentamente el grabado artístico con la incorporación de la vanguardia, gracias a la reorganización de las agrupaciones madrileñas y catalanas. Ya en las últimas décadas vemos una muestra exuberante de gráfica, todas las tendencias de la pintura, escultura se acercan al grabado, pero son pocos los y las artistas que verdaderamente trabajan y se expresan con las técnicas gráficas.

El grabado madrileño se recuperó muy lentamente en la posguerra bajo el amparo de los centros oficiales y de las escuelas de Bellas Artes, algunos artistas como Francisco Esteve-Botey (1884-1955), Manuel Castro Gil (1891-1961), Julio Prieto Nespereira (1896-1991), sirvieron de enlace entre aquellas generaciones de preguerra y los nuevos grabadores, que aparecen a partir de 1960, en las exposiciones nacionales y en los salones de grabado, casi todos ellos procedentes de las escuelas de Bellas Artes y la Calcografía Nacional.

En cuanto al desarrollo del grabado por parte del sector privado, destacamos entre las primeras manifestaciones importantes la que fue debida a la colaboración de la editora de la Rosa Vera (colección barcelonesa) con la galerista Juana Mordó, que lanzó en Madrid la colección Artistas Grabadores (1953). En la segunda edición de esta colección participa Carmen Arocena (1917) una de los pocos artistas que se expresan frecuentemente con grabado. 
A lo largo de los años 50, se produce un intenso trabajo y experimentación, y tanto los miembros del grupo El Paso del cual formó parte Juana Francés (1924) y los de Equipo 57 produjeron numerosas estampas.

Sin embargo ninguna actividad fue tan atractiva como la del movimiento Estampa Popular que presentó una crónica de la realidad, su intención era simplemente abrir camino a la difusión de las estampas mediante un lenguaje que fuese comprendido por todos, tomando como ejemplo la revolución mexicana, eligieron la técnica de la xilografía y el linóleo para expresarse. Cultiva técnicas que hasta entonces no habían tenido especial predilección y lo hace de forma programática, apartándose así de las pautas del grabado tradicional presentándose como alternativa. ${ }^{4}$

Valeriano Bozal en su Historia del Arte en España, publicado en 1973, distingue tres estilos; expresionismo social, ingenuismo social, y realismo épico, ${ }^{5}$ del que sobresale la artista María Dapena (1924-1995), que utiliza el grabado como vehículo de reflexión personal. Su imagen es un canto a la lucha de los trabajadores, utiliza formas que en muchas ocasiones recuerdan el realismo anterior a 1936. Esta producción cubre una etapa importante del grabado español de la posguerra, poco a poco triunfante cuando la

\footnotetext{
${ }^{4}$ Estampa Popular fue el movimiento grupal más considerable en el campo del grabado tras la guerra civil, concibió el grabado como un arma, un instrumento de transformación de la realidad social, cuenta entre sus filas con artistas muy estimables, algunos de los cuales estaban ligados a organizaciones clandestinas y defendían la necesidad de un arte activamente comprometido en el cambio político y social. GANDIA CASIMIRO, J.: 1996.

${ }^{5}$ Aunque todos los grabadores de Estampa se reclaman del realismo, existen algunas diferencia estilísticas. El expresionismo social mantiene los rasgos estilísticos propios de la vanguardia expresionista. El ingenuismo introduce un matiz en las imágenes expresionistas que conectan estas estampas con la tradición del grabado popular. La épica realista enlaza la renuncia social con la creación de un mundo nuevo, producido por las clases trabajadoras. Véase BOZAL, V \& CARRETE, J.: 1988, p. 759.
} 
abstracción ha ido cediendo $y$ en ocasiones se ha teñido de hiperrealismo; así Isabel Baquedano (1936), recrea escenas realistas con entornos urbanos, en los que aparecen ocasionalmente figuras envueltas por la soledad. Amalia Avia (1930), cronista de la vida urbana madrileña y miembro de Equipo realidad, incorpora a sus estampas elementos del lenguaje del pop cuando hace falta.

La verdadera renovación del grabado madrileño viene de la mano de los "jóvenes maestros de la estampa" formados en la escuela de Bellas Artes, que supusieron la alternativa y en algunos casos exploraron la abstracción a través del grabado. Entre sus miembros más destacados encontramos a María Antonia Sánchez (1941), dotada de una espléndida fuerza poética no exenta de ironía. Discípula de Ollé en Barcelona y de Alegre en Madrid Irene Iribarren (1934), cultiva una exquisita visión del mundo en la que prevalecen temas intemporales excelentemente llevados a la estampa. Junto a ellas una nueva generación de grabadoras de diversas procedencias se ha encontrado en las aulas de la Escuela de Bellas Artes y se han hecho notar en los salones de grabado, artistas como Teresa Grasa (1945), Monique de Roux (1948), dentro de lo que podríamos llamar nueva figuración. Alrededor de Álvaro Paricio han trabajado también el grabado Marina Llorente (1937) que han participado en el taller gráfico Smithsonian de Madrid. ${ }^{6}$

Muy distinto significado tuvo la actividad catalana, cuyos intentos renovadores son fruto sobre todo de la iniciativa del sector privado, hasta cierto punto sólo se salvó el grabado del arte del exlibris que ya había experimentado un auge en los últimos años del

\footnotetext{
${ }^{6}$ Véase ESTEVE BOTEY, F.: 1993, p. 153
} 
siglo XIX. En una época en que se suprimieron todas las cátedras de grabado en las escuelas de Bellas Artes excepto en Madrid, sólo la escuela de Artes y Oficios de Olot cuenta con un aula de grabado creada en 1934, donde se enseña el aguafuerte y la litografía y que fue el único foco académico de Cataluña.

La actividad grabadora de posguerra se refugió en la bibliofilia. Las diferentes editoras de colecciones bibliófilas como la Hora, Armiño, la Horta y la más conocida, la Rosa Vera, se encargaron de editar las diferentes publicaciones, en las que intervinieron como ilustradoras artistas como Laura Albéniz (1890), Marta Ribas (1921), Rosario Velasco (1910), Amelia Riera (1934) y Carmen Serra (1921), que a comienzos de los años cincuenta forma parte de grupo de Amigos del Libro y de las Artes del Grabado, integrado por artistas con un nexo común: su afición por las artes del libro.

Otro significado tuvo la mencionada actividad de Estampa Popular, que se manifiesta en Barcelona mostrando el grabado como instrumento de transformación social, cultural y política, con el que intentan que la obra plástica llegue a un abanico social más amplio y con una iconografía reconocible. Cuenta entre sus filas con artistas como María Girona (1923), Esther Boix (1927), que en 1954 realiza un viaje de estudios por Londres, Bélgica, Holanda, Alemania, Suiza e Italia. De los muchos viajes que realiza, fueron especialmente relevantes para su obra el viaje a México y Venecia.

Con mucho más cuidado en la ejecución de la obra gráfica y con un matiz más culto, encontramos al grupo Tarot, uno de los 
grupos de grabado más profesionales de Estampa Popular, que intentó también aprovechar las ventajas del grabado económico, tanto en la difusión de imágenes como de ideas. De 1966 a 1975 el grupo compuesto por escritores y artistas, (entre los que sobresalen Mercedes y Rosa Biadiu) lanzaron nueve cuadernos de grabados y realizaron diversas exposiciones. Aunque fue un grupo muy

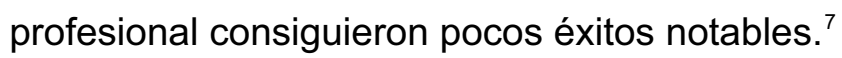

En lo que respecta a la enseñanza oficial o de las escuelas de arte, en 1942 la antigua escuela de la Lonja se divide en dos; La Escuela de Artes y Oficios, y la Escuela de Superior de Bellas Artes de San Jorge, ha sido tal vez el foco más importante donde han empezado su vida artística algunas de las más importantes grabadoras catalanas, y una tercera institución surgida en el seno de la primera, el Conservatorio de las Artes del Libro que vino a incorporarse al panorama oficial ligado al grabado, en él han dictado clases algunas artistas estimables como María Josefa Colom (1926) ${ }^{8}$ profesora de calcográfico, Carmen Pérez Dolz ( ¿ ?) de serigrafía, y María Asunción Raventós (1930) de dibujo.

En líneas generales estos centros transmitieron una técnica sólida, atados a una concepción tradicional de la obra gráfica y marginados de la experiencia europea y americana, pero su labor fue extraordinariamente positiva al poner las bases técnicas de una renovación que luego se complementará con viajes de estudio en el extranjero y participación en exposiciones internacionales.

\footnotetext{
${ }^{7}$ Véase GALLEGOS, A.: 1979, p.461

${ }^{8}$ Que influyó de manera decisiva en Pilar Dolz, como veremos más adelante. Véase Cáp.1 Apdo. 1.3.
} 
En la década de los cincuenta algunos grabadores catalanes marchan al exterior en búsqueda de nuevos aires renovadores. Algunas exposiciones realizadas en Barcelona mostraron estas novedades, como por ejemplo la exposición internacional de xilografía a color realizada en Londres en 1955 con la participación de España, con artistas como Montserrat Casanova (1909) que se acerca a la xilografía popular desde un punto de vista culto. ${ }^{9}$

Esta apertura provocó el interés de muchos artistas por aprender las nuevas técnicas con los más grandes maestros del grabado, artistas como Maria Asunción Raventós marcharon a renovar conocimientos a talleres como Atelier 17 de S. Hayter.

Otro factor importante para el desarrollo del grabado fue la creación de diversos premios específicos de grabado, aparte de los premios nacionales e internacionales ya institucionalizados, así como otros creados por la iniciativa privada. Recordamos el premio Ciudad de Barcelona, que se crea en 1965 patrocinado por el excelentísimo Ayuntamiento para pintura y grabado; en él también han obtenido premio Josefa Colom en 1971, y María Asunción Raventós en 1973.

Merece especial mención por su profesionalidad María Josefa Colom de obra fecunda y con especial investigación en técnicas con menos incidencia en el grabado, como el grabado al humo o manera negra en el que obtienen resultados de gran expresividad. Se conoce también la actividad de Rosa Biau (1944) del Grupo 15, que cultiva un neorrealismo de fuerte intensidad; serie de flores,

\footnotetext{
${ }^{9}$ Véase BOZAL, V \& CARRETE, J.: 1988, p. 744.
} 
animales, que llega hasta la utilización del fotograbado en sus paisajes. La mallorquina Antonia Vilá Martínez (1951), se interesa por un constructivismo de frías gamas. Ambas han viajado con becas March. No podemos dejar de mencionar la actividad grabadora de la barcelonesa Isabel Pons (1912) aunque su profesión la ejerce en Brasil su formación académica fue catalana y sus numerosas exposiciones en España han estimulado el mundo del grabado que domina a la perfección. ${ }^{10}$

En lo que respecta a Galicia, a partir de 1950 una nueva generación de artistas comienza a dar señales de vida, en 1967 se crea Estampa Popular Galega. A lo largo de 1968 divulga su actividad a través de diversas exposiciones colectivas en las podemos ver un nivel artístico irregular. Muchas de estas exposiciones acaban cerrando sus puertas por orden gubernamental y con algún que otro componente en la cárcel, si bien su repercusión es menor que en otros lugares de España.

Un intento de ofrecer cuidadas imágenes gallegas $o$ de artistas de aquel entorno lo constituyó Serigrafía Gallega, empresa dirigida por Álvaro Álvarez Blázquez, en la que colaboraron diversas artistas grabadores y algunas pintoras que rara vez se han asomado a la obra gráfica como María Antonia Dans (1924) y Victoria de la Fuente (1927).

En Andalucía la cátedra de grabado de la Escuela de Bellas Artes de Sevilla, ha sido el centro oficial donde se ha estimulado más la obra gráfica. Hasta 1960 se puede decir que el grabado sevillano

\footnotetext{
${ }^{10}$ Opus cit, p.744.
} 
es individualista. A partir de esta fecha se realizan una serie de exposiciones colectivas que nos aportan una información más globalizada del grabado. Destacamos tres hechos; en 1961 expone por primera vez el llamado Grupo Sevilla de Grabadores; en 1966 la Galería Pasarela organiza una muestra de dibujos y grabados de artistas de la ciudad; en 1974 se celebra la exposición Grabadores sevillanos en la Casa de Damas.

A finales de los años setenta en Málaga se creó el Grupo Palmo, con la clara intención de difundir los valores del grabado entre los artista de formaron parte del grupo, entre ellos se encuentra Josefa Caballero (1943). En la escuela de Bellas Artes de Sevilla se forma Teresa Duclós (1934), que consigue el gran premio en la exposición de la Dirección General de Bellas Artes en 1974; sus paisajes y sus interiores son narrados con impecable técnica.

La actividad del País Vasco de posguerra aparece dominada por uno de los grandes grabadores de nuestro tiempo, el escultor Chillida, que ha practicado diferentes modalidades del grabado. Pero aquí llamamos la atención sobre la figura de la importante grabadora vasca Mari Puri Herrero (1942). Uno de los artistas más renombrados de la escena vasca. Mari Puri Herrero optó desde el principio por el arte figurativo, dando mayor protagonismo a la figura humana. Sus personajes de rasgos anticlásicos aportan toques humorísticos que permiten múltiples lecturas. Ello la diferencia de la corriente más conocida del arte vasco, marcada por la abstracción y el esquematismo geométrico. En 1964 realiza algunos linóleos para 
varias publicaciones y se dedica intensamente a la actividad gráfica, destacando especialmente sus aguafuertes. ${ }^{11}$

En marzo de 1962 nace Estampa Popular en Vizcaya y formó parte de ella María Dapena (1924), quien en junio del mismo año es detenida y encarcelada junto con la mayor parte de los componentes del movimiento. Esta experiencia traumática fue reflejada en duras obras que manifiestan esa realidad perversa de este periodo del franquismo. Su carrera artística está situada al margen del mundo comercial, sus óleos, sus grabados, son la expresión de un arte que demuestra la preocupación constante por los temas sociales y políticos.

Estampa Popular desapareció como movimiento por el encarcelamiento de la mayoría de sus miembros, pero su idea fue continuada por nuevos artistas como Sol Panera (1946), que siguió fielmente sus propuestas, realizando grabados de temática social y estética figurativa. En los años setenta seguía conectada con asociaciones de vecinos, haciendo murales y exposiciones, abriendo así la ideología a otras organizaciones políticas. ${ }^{12}$

En Castilla se da un pequeño foco de actividad grabadora, bastante aislado y motivado por el impulso individual de muy estimables artistas. En Burgos merece especial atención la actividad de María Viedma ( $i$ ?) formada en el taller de grabado del artista peruano Francisco Espinosa Dueñas. Sólo Salamanca se ha acercado a la actividad del grabado con Luís Horta grabador

\footnotetext{
${ }^{11}$ Véase BOZAL, V \& CARRETE, J.: 1988, p.782.

${ }^{12}$ Véase GANDIA CASIMIRO, J.: 1996, p.78.
} 
autodidacta que luego se formó en la escuela de Sevilla y a su vuelta fundó el taller de grabado en la Escuela de Artes y Oficios donde aglutinó a numerosos artistas locales. Así la Caja de Ahorros celebra la primera exposición de artistas salamantinos (1976) de la que formaron parte; Rosario Bondía (¿?), Cecilia Martínez (¿?), Carmen Navarro (¿?), Marisol Núñez García (1951) y Pilar Sánchez (¿?) entre otros.

\subsubsection{Valencia.}

La actividad valenciana en la posguerra tuvo como aglutinador a Ernesto Furió (1902-1982), quien obtuvo en 1942 la cátedra de grabado calcográfico en la Escuela Superior de San Carlos, ganador de varios premios de grabado, autor de exlibris, estampas religiosas, paisajes y retratos.

La mayoría de artistas valencianos que se interesaron por el grabado pasaron por esta escuela. A partir de los años cincuenta muchos artistas y una parte minoritaria de público comenzaron a interesarse por los procedimientos clásicos del grabado y estampación. La posibilidad de usar otros procedimientos y el descubrimiento de posibilidades diferentes de las tradicionales desarrolló la imaginación de muchos artistas que vieron en el grabado el medio idóneo para volcar sus energías y desarrollar sus ideas creadoras en otro medio.

Las instituciones oficiales secundaron estos desvelos y así en 1958 el Excmo. Ayuntamiento de Valencia crea el premio Senyera 
de grabado, orientado a estimular la labor de los jóvenes grabadores. Fueron galardonadas con este premio, Carmen Lloret Ferrándiz (1957) en 1977, María Montes Payá (1948) en 1979 y Victoria Cano (1957) en 1986.

Hay que señalar que una serie de artistas nacidas alrededor de los años treinta se incorporaron al devenir artístico valenciano durante la década de los cincuenta. Destacamos a Irene Iribarren (1934) una grabadora que estudia en diversos lugares de Europa, que además es muralista y cultiva una tendencia polivalente de símbolos y elementos surrealistas. Su aguafuerte titulado Ciclo vital, presentada en el XX Salón de grabado de Valencia, revela la creatividad estilizada, narrativa y tremendamente lírica y sugerente de esta grabadora que sabe aunar con un verismo figurativo. ${ }^{13}$

Entre las artistas más destacadas en esta época por su labor en Valencia, encontramos a Ana Peters (1932) descendiente de una familia alemana dedicada al tráfico marítimo. Al estallar la II Guerra mundial, su familia abandona Alemania para instalarse en Valencia, aquí estudia y realiza varias exposiciones individuales y colectivas entre 1961 y 1965, y se incorpora a las de Estampa Popular de Valencia. La última vez que su obra se presentó al público fue en 1966, en una exposición de la Galería Edurne en Madrid. En 1973 Ana Peters se instala en Inglaterra, junto a su marido y sus hijos. En 1985 regresa a España desde donde ha continuado su actividad artística. $^{14}$

\footnotetext{
${ }^{13}$ Véase CATALÁ, M.: 1978, p. 262

${ }^{14}$ Opus cit, p. 230
} 
Es ineludible hablar de Antonia Mir (1928), un ejemplo de artista polifacética que cultiva la creación pictórica con imágenes figurativas de carácter expresionista no exento de contenido poético agridulce como una personalizada propuesta artística. En 1962 fue becada por el Excmo. Ayuntamiento de Valencia para una estancia en la Casa Velázquez en Madrid, donde estudia grabado. En 1963 le prorrogan la beca. En 1982 estudia en la Escuela Internacional de Gráfica de Venecia (Italia) donde amplia sus conocimientos sobre la pedagogía de las artes visuales, la realización de vitrales y grabado. En su condición de grabadora se hace acreedora a varios premios y becas de grabado. ${ }^{15}$

En 1975 surge el Grup d'art seriat del País Valencià L'Eixam, que defiende la revaloración del grabado como expresión plástica de gran solera tradicional y a la vez de inéditas posibilidades, gracias a la utilización de nuevos sistemas de estampación cada vez más apreciados por el público, vinculadas a este grupo encontramos a un grupo de mujeres como; Eva Mus (1940) que cultiva el nuevo realismo a través de la figuración, Joana Francés (1924-1990), Ángeles Marco (1947-2008), María José Martí (1944), Cristina Navarro (1921) y Cristina Pastor (1951), quienes pueden ser consideradas como verdaderas artistas polifacéticas.

Desde la década de los setenta hallamos un grupo de mujeres artistas que comienzan a dar a conocer sus propuestas a través del grabado aunque éste no sea su único medio de expresión, pero tienen el grabado como principal actividad. Estas artistas nacieron en diferentes localidades de la Comunidad Valenciana alrededor de la

${ }^{15}$ Opus cit, p. 232 
década de los cuarenta y cuya actividad artística empieza a finales de los sesenta e inicios de los setenta, la mayoría de ellas han cursado estudios en escuelas oficiales de Bellas Artes y poseen un amplio currículo académico, con una larga nómina de premios, becas y exposiciones. Entre estas destacamos por su actitud consecuente ante el panorama artístico español a Francisca Lita (1948), Josefa Gilabert (1950), Carmen Grau (1950), Ana Juan (1961), Xelo Garrigós (1959), Cáliz Pallarés (1954), Rosa Torres (1948), Amparo Berenguer (1959), Victoria Cano (1957), Tola Clérigues (1944), María Montes (1948), y la protagonista de esta investigación, Pilar Dolz (1945). 


\subsection{DATOS BIOGRÁFICOS}

María Pilar Dolz Mestre nace en la localidad de Morella, ${ }^{16}$ provincia de Castellón, el 16 de Abril de 1945. Los primeros años de su vida transcurren en esta comarca, ligada al mundo rural, rodeado de la naturaleza, pero también de historia. Se trata de una parte de su mundo con el cual se siente plenamente identificada. Esta etapa de su vida quedará guardada en su memoria y en su corazón, según podemos apreciar en las siguientes palabras:

Jo que soc dels Ports, que sempre he estimat la meua terra i m'ha paregut una comarca meravellosa, pot ser com ens ho pareix a tots els que per una o altra raó hem tingut que emigrar d'ella (i esta és, sense dubte, una de les comarques que per abandó i per manca de recursos, més emigrants té) voldria explicar la seua bellesa i resaltar l'excelència d'algún dels seus monuments; no d'eixos monuments extraordinaris, nobles, religiosos o militars (...), sinó d'eixos monuments, ordinaris, cotidians i cívics que omplim la comarca, una comarca feréstega, aspra, dura i seca que molts han senyalat com la pitjor del País Valencià (...). No crec que sigue "lo peor", ben al contrari, però si és una comarca dura, la pedra i la roca formen les tres quartes parts del sòl, però la gent d'allí és també dura i els nostres avantpassats no sols han sabut fer pobles extraordinaris per la seua bellesa, funcionalitat, unitat y gràcia, solcan els barrancs i al cap damunt de les penyes, pobles que jo crec són veritables "monuments" integrats a la natura que els envolta (i que com no són contemplats com a tals sofreixen veritables atentats tan d'arquitectes "creautius" que fan allí les coses mes exòtiques com de companyies, com la que darrerament

\footnotetext{
${ }^{16}$ Situada aproximadamente a unos cien kilómetros, al norte de la provincia de Castellón, en el vértice que linda con Aragón y Cataluña. Su término municipal es el más grande de las comarcas valencianas con $383.549 \mathrm{Km}$ cuadrados y 2.800 habitantes. Se halla a $984 \mathrm{~m}$. de altura. Es un peñón situado en una zona muy montañosa. Véase en http: // www.morella.net. $(08 / 10 / 2005)$
} 
a sargit amb cables entre si, cases i carrers de Morella, no se si per a donar lum o per a que no caiguen. Com deia no sols han sabut fer estos pobles y cases, sinó que han sabut pedra a pedra milions i milions de pedres, transportades una a una, arenglerades i ajustades, fer quilòmetres y quilòmetres de parets de pedra seca que han dominat la muntanya i els barrancs guanyant en este esforç titànic, pam a pam, les terres de cultiu i de pastura $\mathrm{i}$ que han canviat totalment el paisatge, creant i consolidant els plans on posar cases, eres i corrals. ${ }^{17}$

Este sentimiento va a ser años más tarde parte substancial de su obra, en la que aparecen imágenes, que de una u otra forma están relacionadas con su entorno.

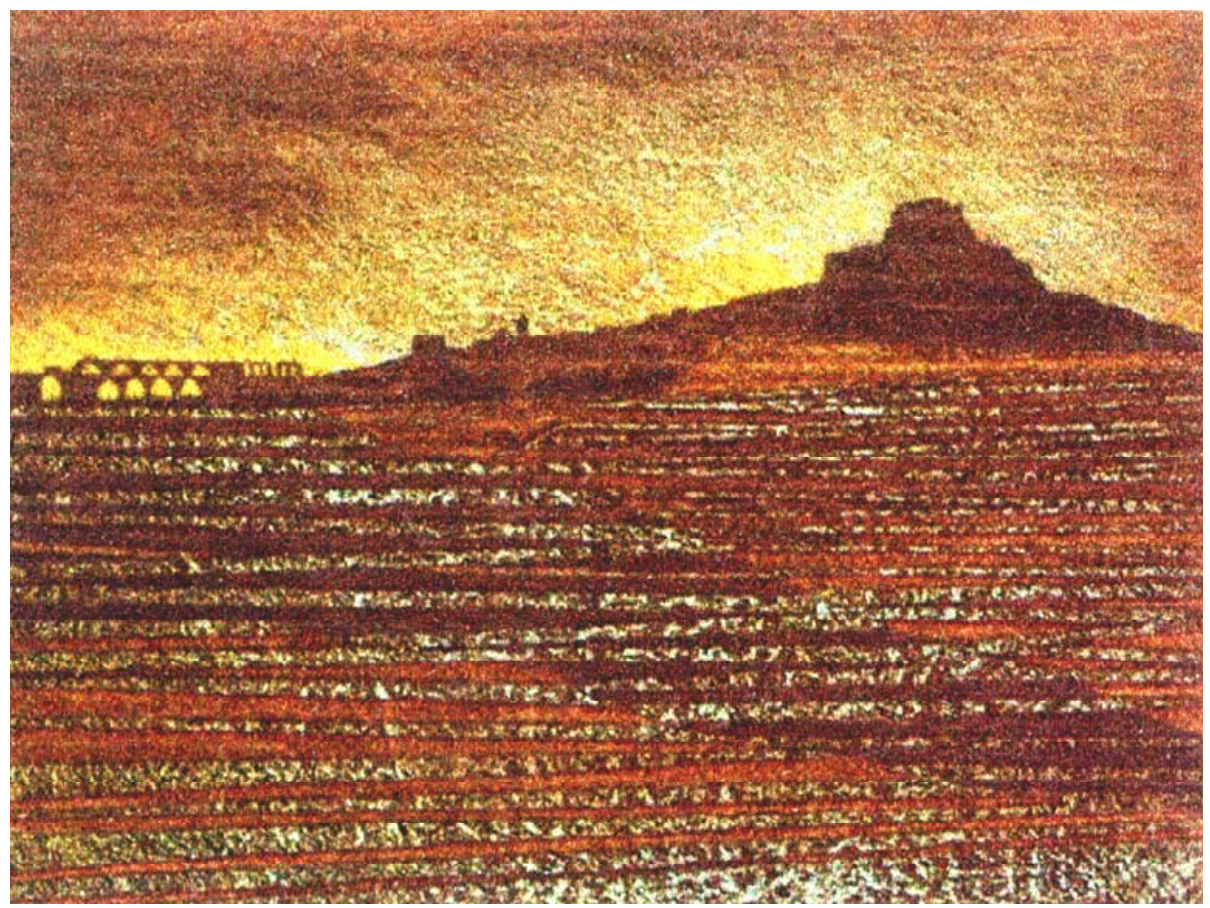

Fig.1. Pilar Dolz, “Morella-Sexenni 52” Aguafuerte. 2006.

\footnotetext{
${ }^{17}$ Véase DOLZ, P.: "Art ecològic a la comarca dels Ports". Mediterráneo, Castellón de la Plana, 12/07/1983. s/p
} 
Remontándonos a sus orígenes, diremos que Pilar Dolz, hija mayor de un tratante de caballería, Joaquín Dolz (el galán), nace en el seno de una familia económicamente privilegiada, gracias a la actividad ganadera que ejerce su padre. En su ascendencia familiar siempre se había respirado un ambiente cultural, pues algunos miembros de su familia desde tres generaciones anteriores habian estudiado carreras universitarias. En este punto su padre es el único sin estudios universitarios, porque según la costumbre local de su época, su obligación como hijo mayor era el quedarse en casa a trabajar y ayudar a los padres en la crianza y manutención de los hermanos menores.

Con estos precedentes Pilar Dolz se desarrolla en un entorno favorable para los estudios. Es así como ella y sus cuatro hermanos; Manel, Gregori, Conxa y Joaquim llegan a cursar diferentes carreras universitarias. La afición por el dibujo y la ruptura con la tradición o la costumbre, hace que Pilar se incline por las Bellas Artes. 


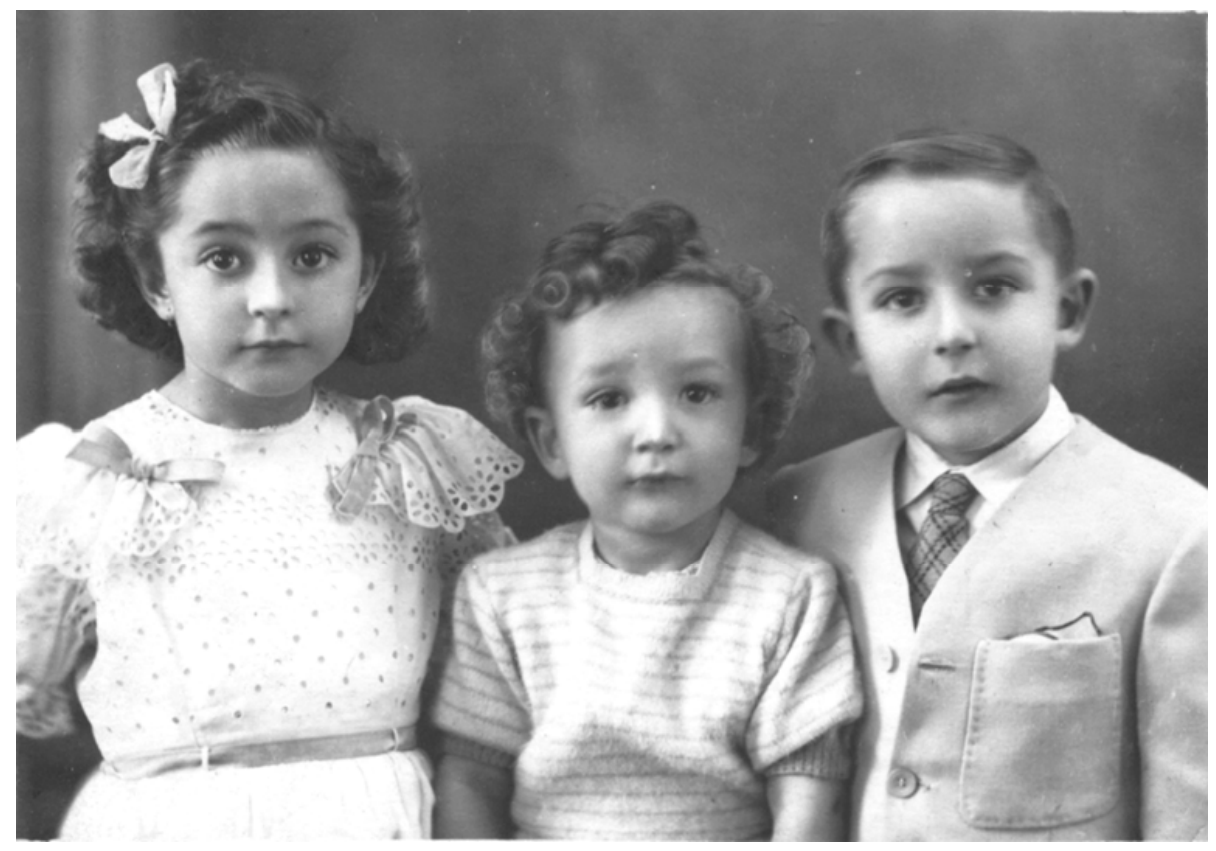

Fig.2. Pilar Dolz junto a dos de sus cuatro hermanos. De izquierda a derecha: Pilar, Manel y Gregori Dolz.

Nos explica la artista que Morella, en una época de pobreza, en la que la gente no podía estudiar, era una de las ciudades donde más estudiantes universitarios habían, quizá debido al desarrollo de la industria textil, la agricultura y la tradición ganadera mantenida en estos años. ${ }^{18}$ Hay que tomar en cuenta que España en este período, (hablamos de mediados del siglo $\mathrm{XX}$ ) es un país bastante pobre. Acabada la guerra civil, la reconstrucción de la economía nacional costó mucho de sacar adelante, es a finales de los años 60 cuando empieza a producirse un creciente desarrollo económico en el país.

\footnotetext{
${ }^{18}$ La industria textil se desarrolla en esta comarca a partir del siglo XIV de manera notable por el impulso del comercio de la lana, que generó una sólida economía que tuvo proyección a lo largo de los siglos en la arquitectura y en la demanda de diversas artesanías, especialmente la textil. Véase GRACIA, C.: 1998, p.256.
} 
Regresando a su historia biográfica diremos que a sus padres nunca les gustó que estudiara Bellas Artes, especialmente a su padre quien decía que Pilar era la hija mayor y que no podía estudiar una carrera que no servia para nada, estableciendo estos conceptos tal vez porque había visto a gente con estudios similares, que no habían tenido éxito o porque consideraba al arte como una labor de adorno y de entretenimiento, más que como una profesión.

Fíjate que tengo más de 25 años una galería de arte y mi taller de grabado hace muchísimos años, por lo menos 30 años, pero yo creo que a mi madre y a mi padre todavía no les parece una cosa seria. Es decir entienden que yo haga eso, como una cosa para distraerme, pero no como una profesión. Me parece, no lo sé, a lo mejor me equivoco, pero no veo que... En cierto modo sí que lo aceptan porque soy una mujer y eso está bien. ¡Total ella se distrae con eso! ¡Qué le vamos a hacer! Para mí no es verdad, yo creo que es una profesión. Yo, desde la mañana a la noche y con la galería y con mi taller, quemo no sólo 8 horas diarias sino muchísimas más. ${ }^{19}$

Sus primeros estudios los realiza en una escuela privada $L a$ Consolación, de carácter religioso, en la que en cierta medida en una sociedad clasista y conservadora, los estudiantes de los colegios privados no se mezclaban con los de los públicos. En esta escuela se instruye durante algunos años, donde según palabras de la artista aprende muy pocas cosas, a rezar, hacer labores y poco más, aunque también acude a unos cursos adicionales de dibujo y pintura que se dictan después de clase.

\footnotetext{
${ }^{19}$ Entrevista personal con la autora en Castellón de la Plana. 27/04/2006
} 
Yo pintaba. A mi madre le gustaba mucho, más de lo que hago ahora, porque eran estampas convencionales que yo copiaba al óleo y después le poníamos un marco precioso y eso era lo que la gente ponía en las casas. ${ }^{20}$

En la etapa adolescente con muchas ganas de aprender, estudia música, piano y diversas actividades. En aquel momento los estudios en el colegio de las chicas se realizaban hasta los 12 o 13 años, no así en el de los chicos, a los que se les preparaba hasta $4^{\circ}$ de bachiller. Sin muchas alternativas, se dedica a estudiar todo lo que se enseña en el colegio; mecanografía, francés, alemán y la carrera de Comercio. Nos cuenta que le daba igual estudiar una cosa u otra, porque lo que ella realmente tenia era mucho interés por las cosas.

Yo decía: Si voy a dar clases en algún sitio, da igual que estudie Química, Física o Bellas Artes. A mí me gustaban muchas cosas. Me hubiera gustado escribir, pero tenía facilidad para ciertas cosas; me gustaba dibujar, moldear y por eso pude estudiar artes. $^{21}$

Es a partir de los 15 o 16 años, cuando Pilar, que desde niña había practicado el dibujo y la pintura, decide estudiar Bellas Artes, una decisión que ella convierte en cuestión de vida o muerte.

Naturalmente ése era un ideal infantil que ahora me da risa. De todos modos estoy contenta de haberlo hecho; no ya por lo que haya podido aprender de mi oficio, sino también porque el trabajo de creación y de

\footnotetext{
${ }^{20}$ Ibidem

${ }^{21}$ Entrevista personal con la autora en Castellón de la Plana. 16/05/2005
} 
desarrollo de la sensibilidad me han ayudado a conocerme más a mí misma, respetar más a los demás y saber valorar las pequeñas cosas. ${ }^{22}$

En 1964 se traslada a Barcelona, ${ }^{23}$ para ingresar en el Conservatorio Municipal de Artes Suntuarias "Massana", ${ }^{24}$ centro de enseñanza pública donde se imparten clases de oficios artísticos, como esmaltado, tapicería, cerámica, repujados, joyería, vidriería, y otras actividades llamadas artes suntuarias, además de dibujo y pintura. Los alumnos que después querían estudiar Bellas Artes hacían el llamado bachillerato artístico, que consistía en unos cursos comunes de dibujo, dibujo lineal, además de los talleres ya mencionados.

Este centro era interesante porque en Bellas Artes se enseñaba, pintura, dibujo, restauración. En cambio en Massana se estudiaban cosas manuales, el horario era por las tardes; 2 o 4 horas de artes manuales, para que la gente se pudiera formar después del trabajo. Ahí podías aprender desde hacer alfombras de nudo, hasta lacas, esmaltes y demás. ${ }^{25}$

\footnotetext{
22 Véase PUERTO, G.: "Maria Pilar Dolz; artista especializada en grabado", Mediterráneo. Castellón de la Plana. 19/03/1972. p.23

${ }^{23}$ Era muy común que los estudiantes de Morella continuaran sus estudios en Barcelona. Entrevista personal con la autora en Castellón de la Plana. 27/04/2006

${ }^{24}$ Centro de oficios artísticos, referente importante en Barcelona. Ibidem

${ }^{25}$ Entrevista personal con la autora en Castellón de la Plana. 16/05/2005
} 


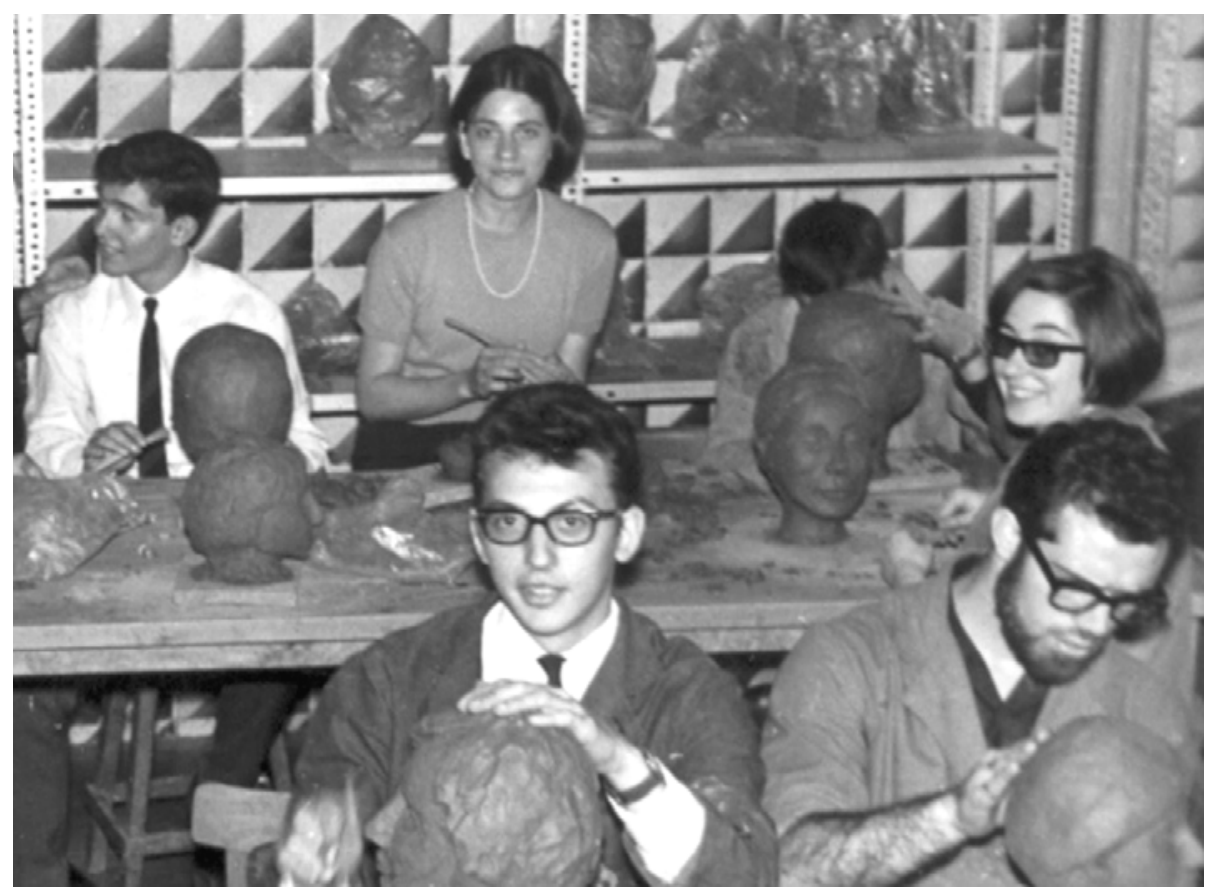

Fig. 3 Pilar Dolz en la clase de modelado del Conservatorio Municipal de Artes Suntuarias Massana. 1963.

Un año más tarde supera el examen de ingreso de la Escuela Superior de Bellas Artes de San Jorge, de Barcelona, para la que indiscutiblemente había que tener unos conocimientos previos. A partir de entonces estudia de forma paralela en los dos centros, en Massana durante el período de cuatro años y en Bellas Artes durante cinco años.

En Barcelona estaba la escuela de Bellas Artes, donde empezábamos muy temprano; a las 8:00 de la mañana. Allí teníamos clases todo el día. Yo podía dejar alguna clase a la tarde, que era cuando empezaba Massana, porque por el día tenía arte litúrgico, anatomía y las clases prácticas de dibujo, pintura por la tarde. Entonces tenía bastante libertad para ir a Massana, porque allí las clases eran por las 
tardes de 5:00 a 9:00 de la noche, con lo cual tenía todo el día libre para hacer una serie de cosas. ${ }^{26}$

Sus ansias por ampliar conocimientos artísticos le llevan a investigar en otros campos, por lo que en mayo de 1970 se matricula en la Escuela de Artes Aplicadas y Oficios Artísticos, en la sección de las Artes del libro, para realizar un curso de grabado calcográfico, ya que entonces es el único sitio donde se puede aprender a hacer grabado. Esta experiencia va a suponer su primer contacto con este campo de creación, que le va a cautivar. Nos comenta la artista que así como cuando siendo aun adolescente va a ser seducida por la pintura, en estos momentos va a quedar prendada por el grabado, por el dibujo, por sus efectos de luz, debido a las relaciones de valoración que se pueden conseguir desde el blanco al negro, y por su carácter artesanal.

En junio de este mismo año termina los estudios en Bellas Artes, excepto la asignatura de Dibujo Geométrico y Proyecciones, que aprobará un par de años más tarde. ${ }^{27}$ Durante ese verano viaja a Perugia (Italia) con una beca de estudios a la Accademia di Belle Arti Pietro Vannucci para realizar estudios de pintura, pero realmente se dedica a cultivar las técnicas de dibujo y grabado.

Fui un verano sólo. Después fui otra vez, pero realmente no hice pintura, hice grabado y dibujo. Era una escuela que estaba muy bien. Ésa me llevó después a Urbino, pero yo tenía una beca y tuve que justificar, que yo estuve allí por lo menos un mes. ${ }^{28}$

\footnotetext{
${ }^{26}$ Entrevista personal con la autora en Castellón de la Plana. 27/04/2006

${ }^{27}$ El 7 de febrero de 1972

${ }^{28}$ Entrevista personal con la autora en Castellón de la Plana. 06/05/2005
} 


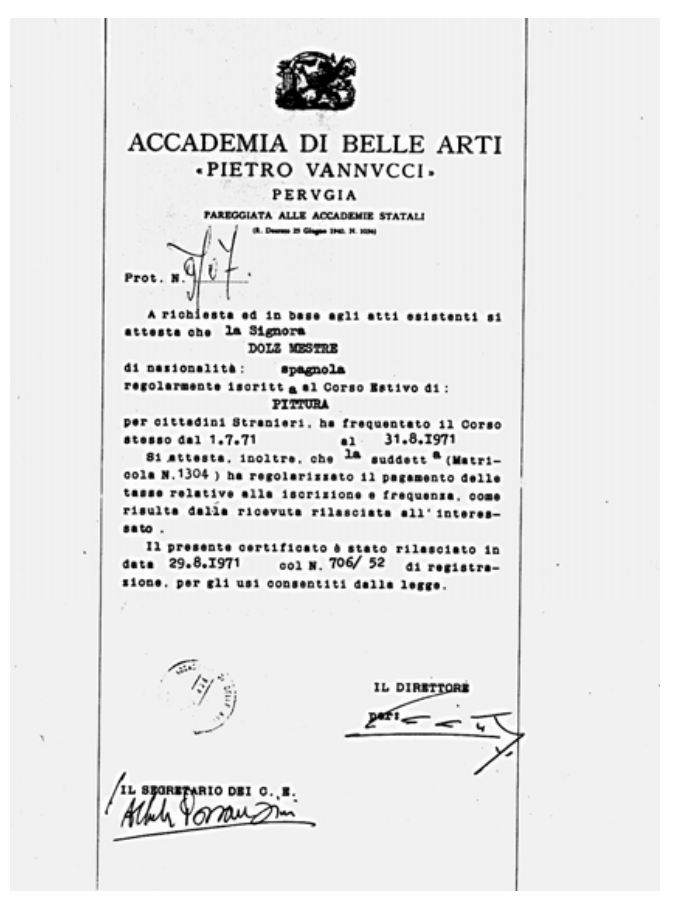

Fig.4. Certificado de la Accademia di Belle Arti Pietro Vannucci, Italia.1971.

De regreso a España se replantea la situación y decide dedicarse en serio al grabado, lo que determina que en septiembre del mismo año (1970) ingrese de forma oficial por el periodo de tres años a la Escuela de Artes Aplicadas y Oficios Artísticos, iniciando así una nueva etapa en el campo de la creación gráfica.

Complementa su formación con cursos de grabado en diferentes sitios. Se apunta así al Instituto Americano de Cultura, en Barcelona; un taller de libre ingreso donde no se necesita ningún tipo de titulación para ingresar y en el que les facilitan incluso el material para trabajar. 
En el verano de 1972 vuelve a Italia, esta vez al Istituto Statale d'Arte di Urbino, ${ }^{29}$ a realizar un curso de grabado calcográfico. Durante el verano de 1973 repite experiencia, iniciando así unos estudios de litografía, que se prolongaran durante varios años.

Asimismo, en el año 1973 acude a un taller de libre ingreso similar al del Instituto Americano de Barcelona, ubicado en Ginebra (Suiza) para continuar aprendiendo grabado, animada por la presencia de unos compañeros de las Artes del Libro que se encontraban estudiando en esta ciudad:

En 1973 obtengo la beca Castellblanch. Nos la dieron a cuatro compañeros; uno de ellos viene conmigo a Italia, y los otros dos van a Suiza. Estábamos muy poco tiempo, pero encuentran en Ginebra un taller libre y ellos van a Suiza y yo paso después. Es un instituto libre como el Instituto Americano; ellos prestan el taller, tú pagas un alquiler y puedes trabajar. Tienen prensas de todo tipo. Eso se daba mucho en ese momento. ${ }^{30}$

Una vez terminados sus estudios de grabado, en 1974 se traslada a vivir a Castellón con su esposo el farmacéutico Falo Menezo y su pequeña hija Laia. Allí, lo primero que va a hacer es instalar un taller de grabado, al que se dedica completamente dejando de lado la idea de dedicarse a la enseñanza que había tenido en un primer momento.

\footnotetext{
${ }^{29}$ Instituto situado en el primer edificio renacentista de la zona del palacio de Federico Montes Feltro, de Urbino, con un entorno majestuoso. Entrevista personal con la autora en Castellón de la Plana. 09/04/2002
} 
A veces hay accidentes que te sitúan en un sitio u otro. Yo siempre digo que es una cosa accidental. Cuando vine a vivir a Castellón por el año 1974, lo primero que me puse fue un taller de grabado calcográfico. Yo al principio lo que quería era una prensa de litografía antigua, no de las modernas. Como el calcográfico lo miraba menos me daba igual que fuera una prensa u otra y compré una prensa calcográfica, y pensé en que ya iría situando lo otro cuando pudiera. Empecé así trabajando el grabado y estoy muy a gusto en él. ${ }^{31}$

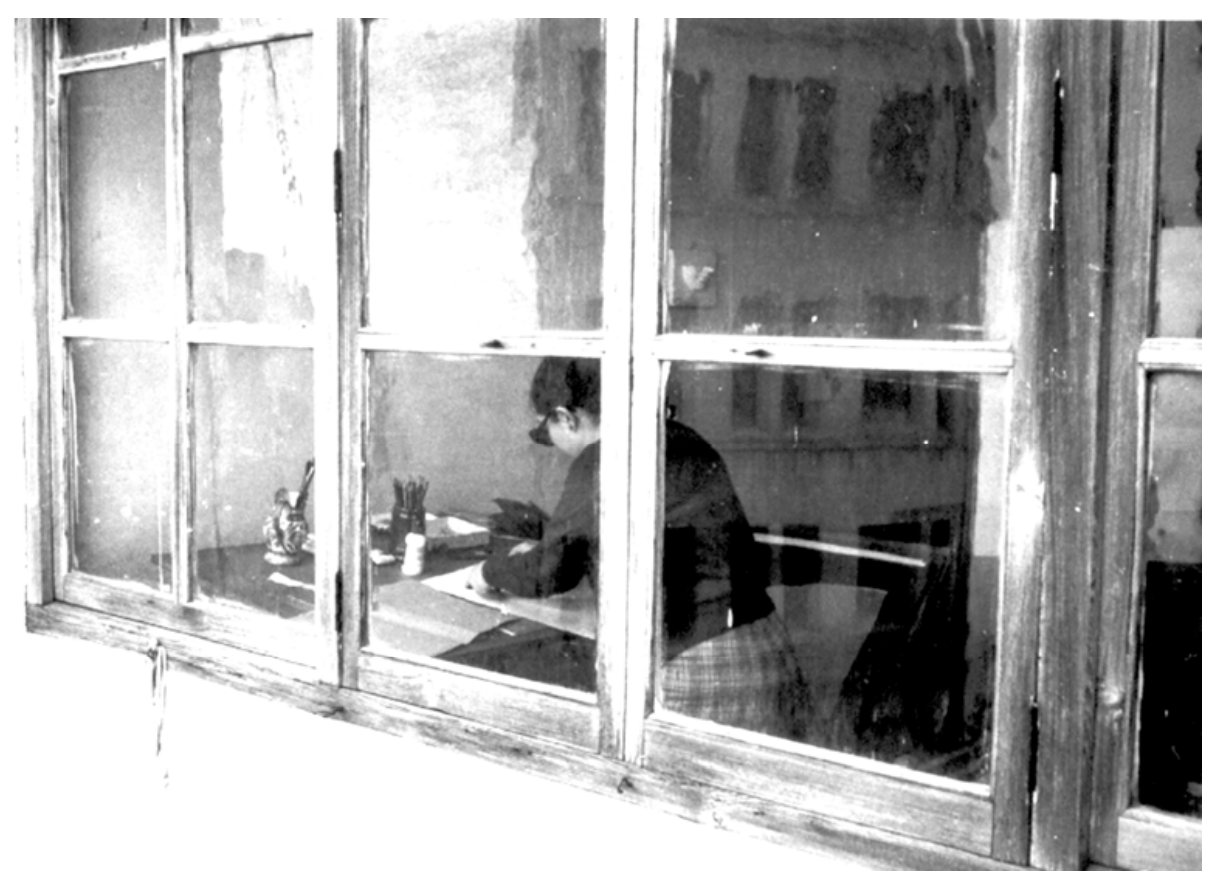

Fig.5. Primer taller de grabado de Pilar Dolz, ubicado en la calle Mayor de Castellón. 1973-1974.

\footnotetext{
${ }^{30}$ Entrevista personal con la autora en Castellón de la Plana. 27/04/2006
} 
Durante este año se funda la Galería de Arte Cànem, que surge en el cenáculo vanguardista de Castellón, gracias a la feliz idea de un grupo de amigos y compañeros como Daniel Gozalbo, Lalo Blay, Víctor Menezo, Alex Querol, Román Pallarés, Alberto Ollé, la misma Pilar Dolz, su esposo y otros, que consiguieron materializar la creación de esta galería, ${ }^{32}$ en un intento por transgredir los conceptos tradicionales del arte. Son tiempos en los que en Castellón no hay muchas galerías de arte, uno de los pocos espacios artísticos existentes es el Ateneo Mercantil, con unas características determinadas.

Así surge Cànem, como una galería que actúa como aglutinante cultural, cuyo principal interés es dejar hablar al arte actual; de esta manera se llevan acabo exposiciones con artistas del momento comprometidos políticamente, con la creación y con el arte.

Es una época donde la plástica es un medio contestatario y la cultura sinónimo de subversión; Cànem se convierte en algo más que una galería, es un centro de reuniones, de tertulia, con presentaciones de libros, proyecciones de videos y cine, debates y conferencias, en definitiva actividades vinculadas al momento histórico-político que se vive entonces. En este sentido supone un hito en esta ciudad, desde donde se desarrolla una importante tarea a favor de la renovación de las artes, poniendo especial empeño en obra gráfica, de la que la autora posee una colección muy considerable.

\footnotetext{
${ }^{31}$ Entrevista personal con la autora en Castellón de la plana. 07/03/2002

32 Véase RUBIO, V.: "Pilar Dolz: Rompiendo esquemas", Levante. Valencia, 06/10/1991. p.30
} 
Si bien la sala nace como un proyecto colectivo al final es Pilar Dolz, quien se encarga de su dirección en solitario desde hace más de treinta años, fiel al testimonio, y en pro del reconocimiento del arte de vanguardia como un compromiso de su tiempo.

La galería nos permitió contactar con figuras que fueron historia en la defensa de la libertad de nuestro pueblo y de nuestra cultura, y al tiempo presentar un arte comprometido con la vanguardia; función que para mí fue la fundamental y prioritaria... ${ }^{33}$

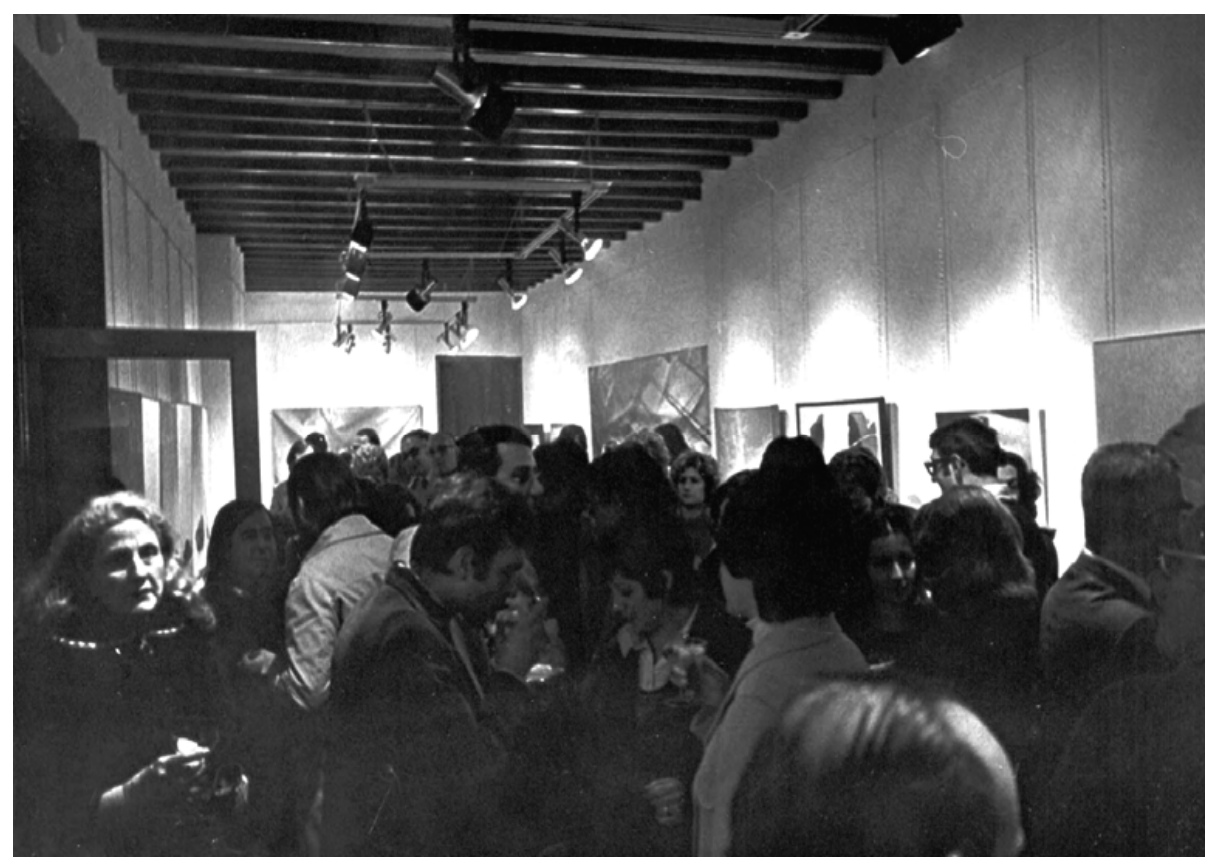

Fig.6. Inauguración de la Galería Cànem, 21 de diciembre del 1974.

Desde esta ciudad va a desplegar una intensa actividad artística, en paralelo a su acción como galerista, que complementa con viajes periódicos hasta 1978, a sus antiguas escuelas tanto de

${ }^{33}$ Véase GASCÓ, A.: "Pilar Dolz; Una artista que ignora su leyenda". Levante. Valencia, 20/10/1995. p. 8 
Italia, como de Barcelona en práctica del grabado, pero sobre todo la litografía, ya que su taller no disponía de una prensa litográfica.

En 1983 marcha a París, por el período de dos años para estudiar y reciclar conocimientos sobre grabado con Stanley William Hayter. ${ }^{34}$ Aquí justamente aprende a practicar la técnica de estampación calcográfica a color llamada Roll-up, inventada por él, que va a suponer una experiencia muy importante, y con la que inicia una nueva etapa de avance creativo.

Al mismo tiempo asiste al Atelier de Henri Goetz, donde practica las técnicas tradicionales del grabado, pero particularmente la técnica del grabado al carborundum, ${ }^{35}$ aunque lamentablemente las estampas realizadas en esta etapa, se perdieron.

Lo que trabajé en Goetz lo perdí en el metro, llevaba dos carpetas, jasí de grandes! (...) Todo el trabajo de Goetz de uno o dos años, cuando recogí las carpetas para traérmelas aquí y cogí el metro, llevaba dos carpetas y me las deje allí. Claro, fui a objetos perdidos, pero como me tenía que venir aquí, tampoco podía perder tres días buscando las carpetas. ${ }^{36}$

\footnotetext{
${ }^{34}$ En su taller se reúnen estudiantes de todo el mundo, y por él que pasaron grandes maestros como Dalí, Picasso, Miró, y otros. Véase RAMBLA, W.: "Pilar Dolz, una grabadora del País Valencià", Reull $N^{\circ} 7$, Ed. Universitat Literària de Valencia, 1984, p.9.

${ }_{35}$ Inventado al alrededor de 1970 por el artista Henri Goetz. Consiste en crear efectos pictóricos a partir de la adición de una materia sobre una superficie de metal. Entrevista personal con la autora en Castellón de la Plana. 25/04/2006
} 


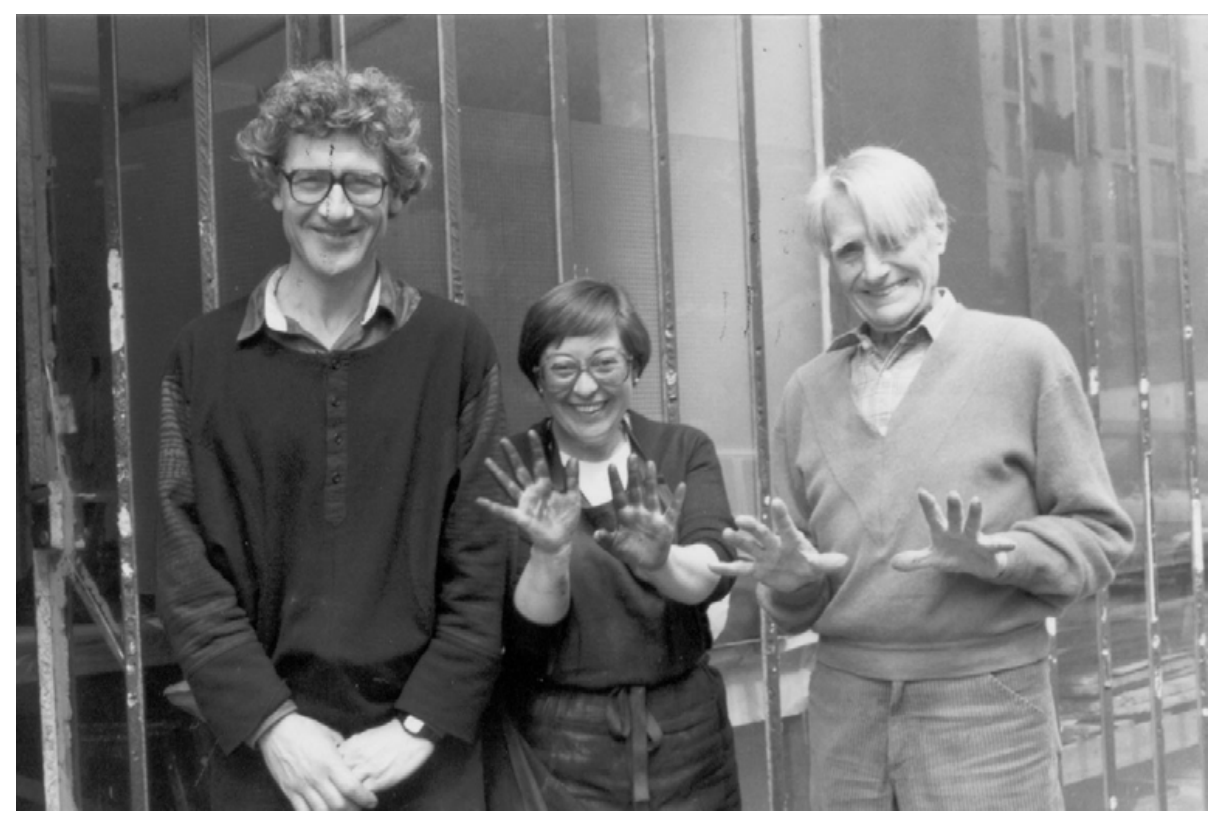

Fig.7. Pilar Dolz en la puerta del Atelier 17, junto a S. W. Hayter a la derecha y su ayudante Héctor Saunier a la izquierda. 1985.

Pilar Dolz lleva más de 30 años, desarrollando una importante labor artística como galerista, grabadora y editora, como muestran sus múltiples exposiciones, tanto individuales como colectivas.

Su obra ha sido expuesta en diversas ciudades del estado español como: Barcelona, Madrid, Tarragona, Gerona, Castellón, Valencia, Ibiza, Alicante, Gijón, Zaragoza, entre otras. Así como también fuera del país, Urbino, Brescia, Milán (Italia) Paris, Provence (Francia) Kettwing (Alemania) Bradford (Inglaterra) Sjobo (Suecia) Lodz (Polonia) Kioto (Japón) y Ginebra (Suiza).

${ }^{36}$ Entrevista personal con la autora en Castellón de la Plana. 16/05/2005 


\subsection{EVOLUCIÓN ARTÍSTICA}

Para un mejor entendimiento de la evolución en la obra artística de Pilar Dolz es necesario dividirla en cuatro etapas: Iniciación, formación, perfeccionamiento y madurez artística.

\subsubsection{Inicio}

Las primeras incursiones en la expresión plástica se remontan a su infancia, cuando aún siendo niña asiste a los cursos adicionales de dibujo y pintura en el mencionado colegio religioso $\mathrm{La}$ Consolación. Estos cursos según nos cuenta nuestra artista, no daban mucha libertad, pues se limitaban a la reproducción de láminas religiosas, capiteles, o la copia de dibujos realizados en la pizarra por alguna religiosa, que después pintaban al óleo. Asimismo se hacían grandes tapices. En fin actividades con escaso margen para la creación y en las que nunca se dibujaba ni pintaba del natural.

Pilar Dolz siempre fue una niña con una gran afición por el dibujo porque, como ella misma nos cuenta, para dibujar necesitaba poca cosa; en cuanto tenía un papel en blanco o un margen disponible lo llenaba de dibujos. Como su niñez se desarrolla en la época de la posguerra, en la que había muy pocos medios de arte y los que había eran de mala calidad, realiza los dibujos con el material que encuentra a mano, le da igual si es un lápiz, una tinta o un betún de zapatos, justamente uno de los primeros pinceles que está a su alcance es precisamente el del betún de los zapatos. 

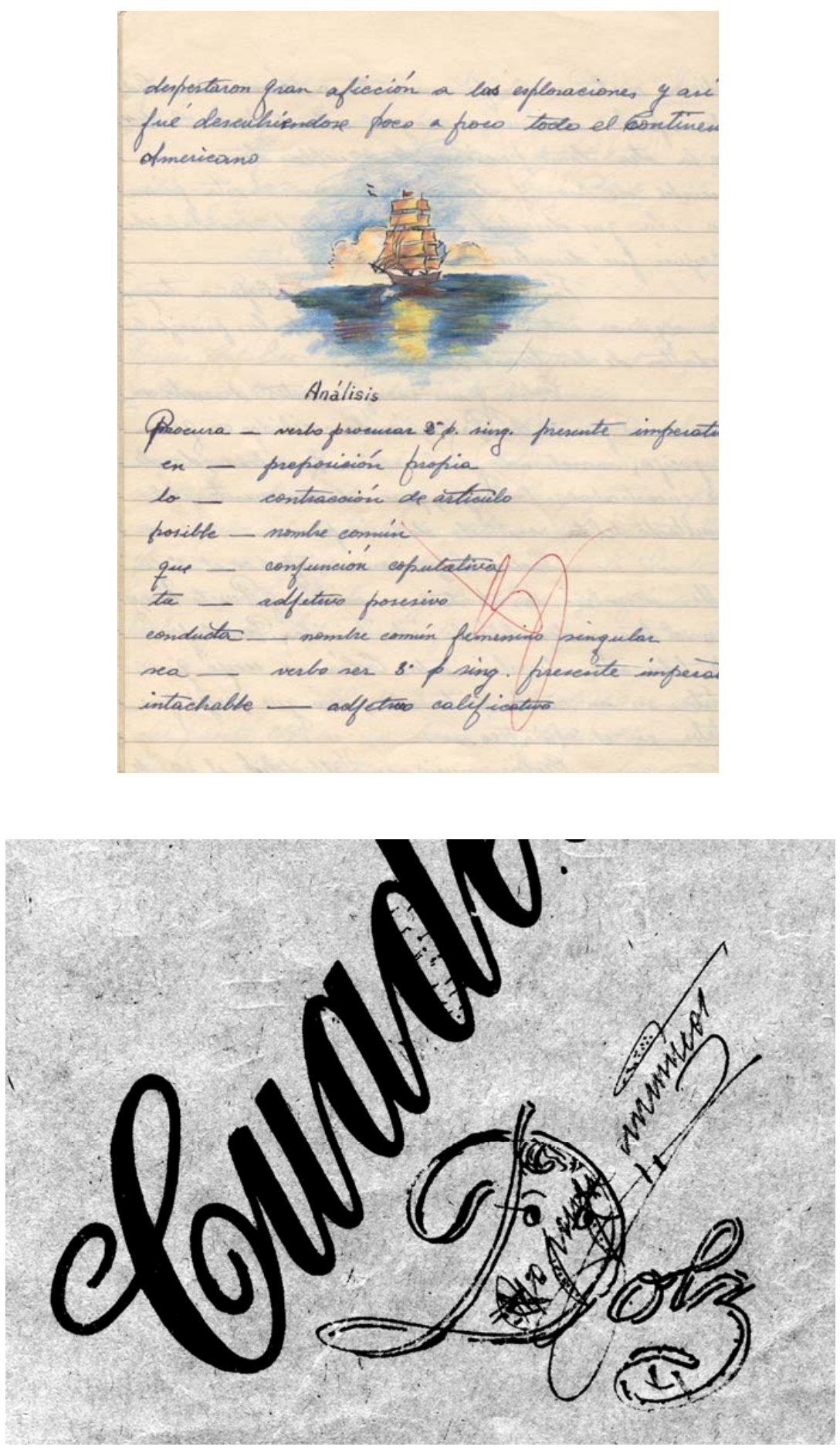

Fig. 8. Pilar Dolz. Dibujos. 1953-1955 
Sus dibujos son espontáneos y su iconografía se limita a representaciones imaginadas de mujeres, cosas y animales, a veces alguno del natural, como por ejemplo el dibujo de su abuelo durmiendo la siesta, que su madre aun conserva con ternura; expresiones que una niña de su edad experimenta como un juego, pero que pronto se convertirá en una necesidad.

Yo dibujaba siempre y sigo dibujando mucho, y en cualquier papel; no siempre es algo que se puede ver después (...) pero dibujo mucho y creo que se tiene que dibujar mucho (...) Utilizaba esa tinta de mojar, con lo cual, ya cuando se te caía, hacía un borrón con el dedo y ampliaba, y hacía como estrellas o como flores. Yo creo que es la génesis de lo que hago ahora. ${ }^{37}$

Quizá una de las cosas que más definió su afición, que recuerda con mucho cariño, fue que su padre, en uno de sus constantes viajes al sur de Francia, le trajo una caja de lápices de colores de buena calidad, de colores vivos y punta suave. También influirán mucho los comentarios de personas cercanas sobre su gusto por el dibujo, que solicitaban le llevaran a una escuela especializada para aprender a pintar, pero eso no era cosa que agradara mucho a su familia, que no consideraba al arte como una profesión seria; una cosa era que Pilar se dedicara al dibujo como un entretenimiento, otra que decidiera tomárselo como una carrera.

\footnotetext{
${ }^{37}$ Entrevista personal con la autora en Castellón de la Plana. 09/04/2002
} 


\subsubsection{Formación}

Ya hemos comentado que su etapa de formación artística la inicia en el Conservatorio Municipal de Artes Suntuarias Massana, por el período de cuatro años. En esta escuela va a aprender realmente a dibujar, pintar, pero sobre todo a trabajar el claroscuro. Aquí le van a enseñar a mirar un objeto; nos cuenta la artista que cuando llegó a Massana, le sorprendió mucho que le pusieran a dibujar una taza de porcelana. Se trataba de una taza blanca, muy bien iluminada; dibujó su contorno y le puso un poco de sombras por abajo y dijo ¡Ya está, es blanco! No había tenido una auténtica formación artística. Nos explica Pilar que cuando el profesor, le dijo: "Fíjate bien, no es igual de blanco allí que aquí. Intenta sacar todos esos grises." Cuando por fin pudo ver toda la cantidad de luces y sombras que había en la taza, fue un gran hallazgo para ella.

Yo dibujaba a la buena de Dios, hacía lo que quería. También copiaba del natural, pero de una forma completamente espontánea. Pero mirar lo que se dice de verdad para poderlo dibujar, no. Yo no me había dado cuenta de eso; yo copiaba las sombras que a mí me parecía. Es más, yo las ponía donde yo quería. ${ }^{38}$

Un año más tarde, se adentra en el mundo de la pintura de manos del profesor Vidal Gomá, con una paleta impresionista de cuatro o cinco colores, con los que mezcla, combina, crea y pone color sin ensuciarlos.

\footnotetext{
${ }^{38}$ Entrevista personal con la autora en Castellón de la Plana. 27/04/2006
} 


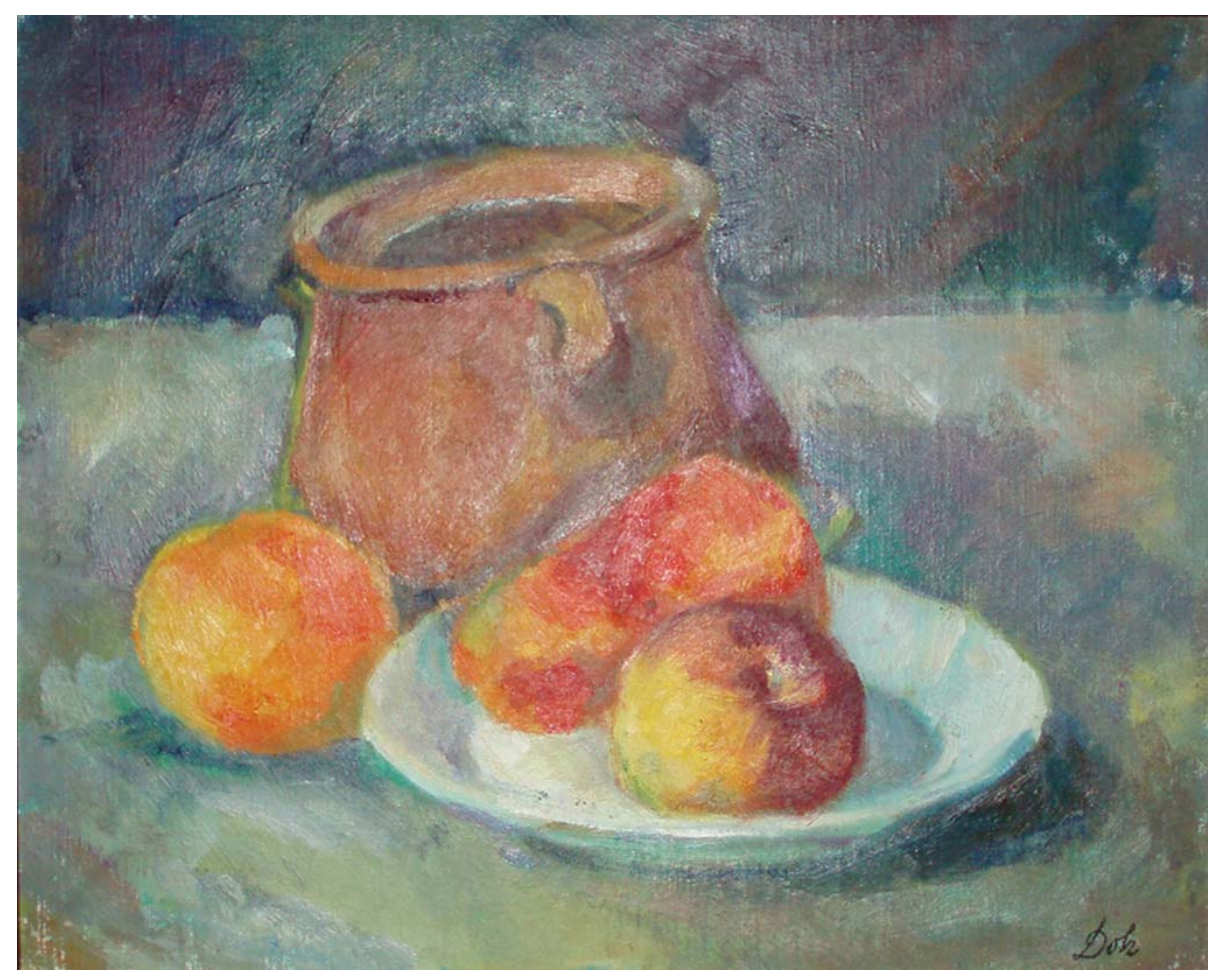

Fig.9. Bodegón pintado al óleo. Clase de pintura del profesor Vidal Gomá. 1966.

Cuando empecé el segundo año, porque en el primero no te dejaban pintar si no sabías sombrear, empecé la pintura con un profesor que se llamaba Vidal Gomá, que partía de una paleta muy impresionista; solamente ponía rojo, amarillo, y azul, creo que teníamos blanco, pero teníamos poquísimos colores. En ocasiones se mezclaba en el mismo cuadro como si fuera un postimpresionismo, un puntillismo, y empecé a pasármelo bien pintando. Yo miraba mucho a Cezanne. Nosotros mezclábamos así de una forma muy impresionista y empezó a gustarme la pintura y empecé a pintar bodegones. ${ }^{39}$

\footnotetext{
${ }^{39}$ Entrevista personal con la autora en Castellón de la Plana. 16/05/2005.
} 
Estudiar en Massana fue una experiencia muy importante, pues en un principio había decidido enfocar sus estudios hacia algo práctico, como publicidad, diseño gráfico, o quizá algo orientado a la estampación de telas, carreras que en ese momento eran bastante nuevas. Sin duda la experiencia obtenida durante esta etapa, le va a llevar por el camino del arte.

Su paso por La Escuela Superior de Bellas Artes, de San Jorge, no fue tan agradable. Cuando Pilar se traslada a Barcelona encuentra una ciudad grande y de vanguardia, en contraste con el ambiente conservador que había vivido, sin embargo la disciplina que impera en la escuela es aun rígida y estricta, a pesar de que es una época de cambio y tolerancia. ${ }^{40}$

Hablamos de la década de los 60 , en España se está produciendo una progresiva modernización de la sociedad y la economía, a la vez de una creciente innovación artística. Las artes desarrollan una conciencia política identificada con el pueblo; son años en los que la oposición empieza a organizarse y tanto en la universidad como en el entorno obrero surgen grupos políticos clandestinos. Su progresiva radicalización tiene claro reflejo en el campo del arte, aludiéndose por primera vez desde el final de la guerra civil, a la unión de la vanguardia política y la vanguardia artístico-cultural. ${ }^{41}$

\footnotetext{
${ }^{40}$ En el contexto internacional, mayo del 1968 francés fue el crisol en el que se fundieron todos los síntomas del malestar social, bajo el lema "Alto a la represión, libertad, democracia, viva la unión de obreros y estudiantes". Este fenómeno tuvo mucha influencia en España, que resucita de su aridez cultural de cuatro décadas. Véase http:// www.elmundo.es/especiales/2008/04/internacional/mayo68/francia. (28/06/2005) ${ }^{41}$ Véase JULIÁN, I.: 2002, p.125.
} 
En la escuela de Bellas Artes fue distinto. Había disciplinas que te enriquecían mucho, pero había otras que no puedo decir que me lo pasé bien. En lo de pintura no acababa de ubicarme, porque había como una forma, que aunque te dejaban bastante libertad en cierta cosas, no acababa de... Yo tuve suerte, porque fue un período que fue cambiando todo, pero yo recuerdo que era muy duro; había una disciplina bastante antigua. ${ }^{42}$

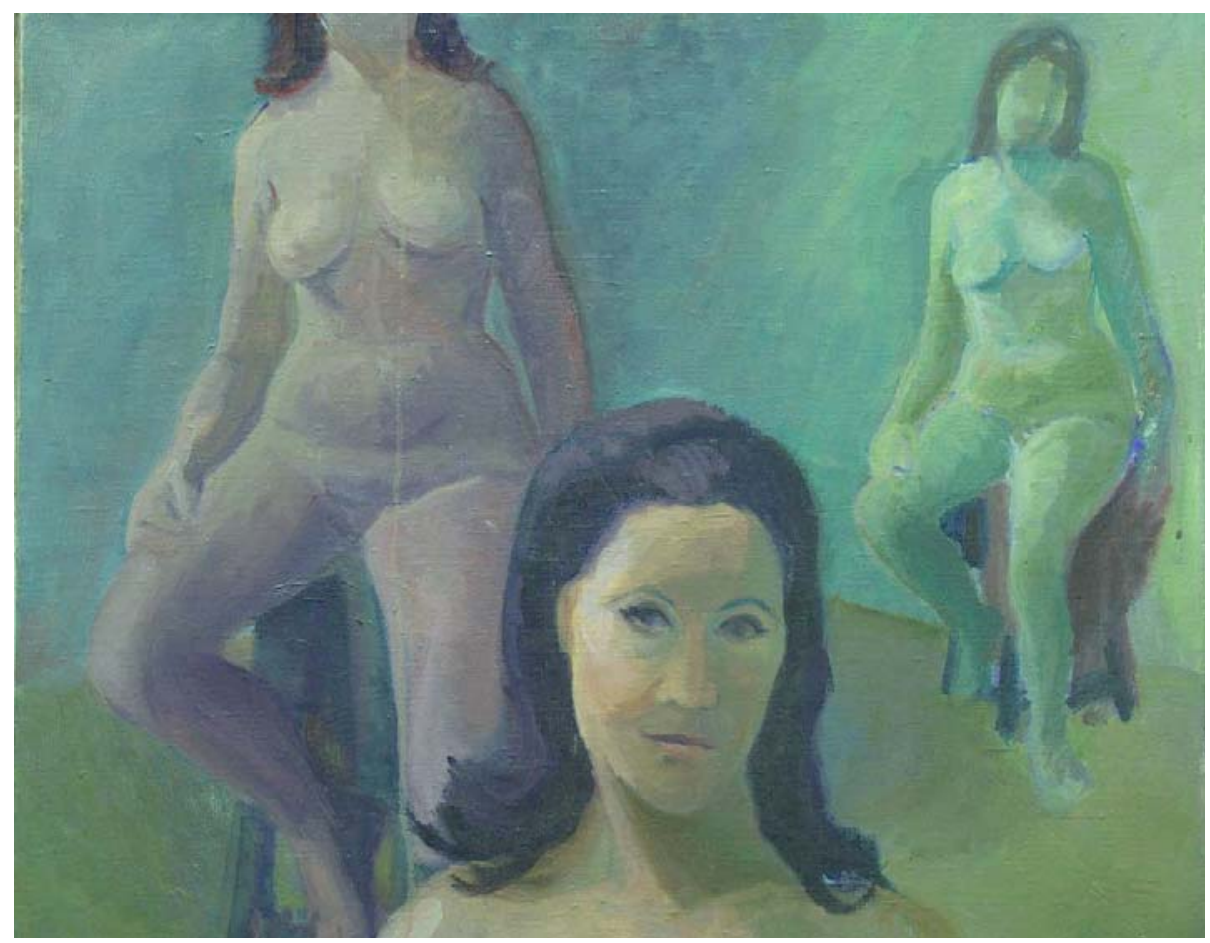

Fig.10 Óleo sobre tela, pintado en la Escuela de Bellas Artes de Barcelona, 1967

En estos momentos según nos comenta, en la escuela de Bellas Artes estaba bastante de moda la pintura inglesa, en especial la obra de Francis Bacon, y aunque ella no pintaba obras de este

${ }^{42}$ Entrevista personal con la autora en Castellón de la Plana. 09/04/2002 
estilo, si reconoce que se sintió influida por el color, por el empleo de los azules y los carmines.

Este desnudo es del 67. Ya busco otra forma, porque ¿ves? aquí les corto la cabeza y la hago más lejos en la misma modelo, y aquí pongo la cabeza en primer término. No es como la gente la hacia normalmente. Yo ya busco otra cosa. (Fig.10) ${ }^{43}$

Su formación en el campo de la gráfica, lo inicia en el curso de grabado de la Escuela de Artes Aplicadas y Oficios Artísticos de Barcelona, pero una vez terminada la carrera es cuando se replantea su vida y empieza a hacer grabado en serio.

Quizá uno de los aspectos que influye en esta decisión es el estar embarazada de su hija Laia, pues piensa que con el grabado podría dedicarse a trabajar obra de pequeño formato, posiblemente porque siempre había relacionado el grabado con una visión más de tamaños pequeños, con la ilustración de libros, la creación de sellos de correos y de estampas de santos. Nos explica Pilar que ella pensaba que el grabado era una técnica que en una mesa pequeña o en cualquier otro sitio lo podía realizar. Lo curioso es que cuando llega a las Artes del Libro lo primero por lo que se interesa es por la litografía, técnica que se trabaja con piedras de gran volumen y peso.

Al acabar la escuela de Bellas Artes me replanteo una serie de cosas. Yo sería muy feminista y tal, pero voy y tengo una hija y me caso. Ya cambio la pintura por el grabado. No sé por qué, también tiene

\footnotetext{
${ }^{43}$ Entrevista personal con la autora en Castellón de la Plana. 27/04/2006
} 
gracia que en Bellas Artes hacíamos telas bastantes grandes y de eso paso a un grabado no excesivamente grande. ${ }^{44}$

En este centro va a tener como profesores a grandes artistas, como Jaime Coscollá, maestro de taller, Juan Conmelerán profesor de litografía, y Maria Josefa Colom, ${ }^{45}$ profesora de grabado calcográfico; sin duda una de los profesores que más consecuencia tiene sobre ella y desde el principio le causa respeto y admiración por su gran profesionalidad, por su amor al arte y porque es una de las primeras mujeres que tiene como profesora. Se convertirá en un modelo para Pilar Dolz, a quien le va a conquistar su actividad y dedicación profesional a un trabajo donde por entonces las mujeres no sobresalen.

En este centro, se practica el dibujo directo sobre la plancha o la piedra, sin boceto previo; tanto si se utiliza pincel para las aguatintas, como si se utiliza lápiz, pluma o tinta para las litografías, los errores se corrigen en la misma plancha: "Era una forma de dibujar diferente, era como pintar, como cuando te enfrentas directamente a la tela". ${ }^{46}$

La decisión de ser artista y de hacer del arte el motor de su vida le va llevar a cuestionar desde el principio de la creencia porque los hombres "hacían arte" y las mujeres artesanía. Según la grabadora

\footnotetext{
44 Entrevista personal con la autora en Castellón de la Plana. 09/04/2002

${ }^{45}$ Nace en Cervera, en 1926. Considerada una de las primeras grabadoras de España. Formada en la Escuela de la Lonja de Barcelona, forma parte del grupo de la Rosa Vera y de la Asociación de Exlibristas de Barcelona. De obra fecunda, investiga en el grabado al humo o manera negra, en el que obtiene resultados de gran virtuosismo y bronca expresividad. Véase GALLEGOS, A.: 1979, p.471.

46 Entrevista personal con la autora en Castellón de la Plana. 09/04/2002
} 
eso ha influido en la orientación del mundo creativo de las mujeres; por ejemplo en su caso recurre al grabado, donde es esencial el trabajo artesanal de contacto y conocimiento de los materiales.

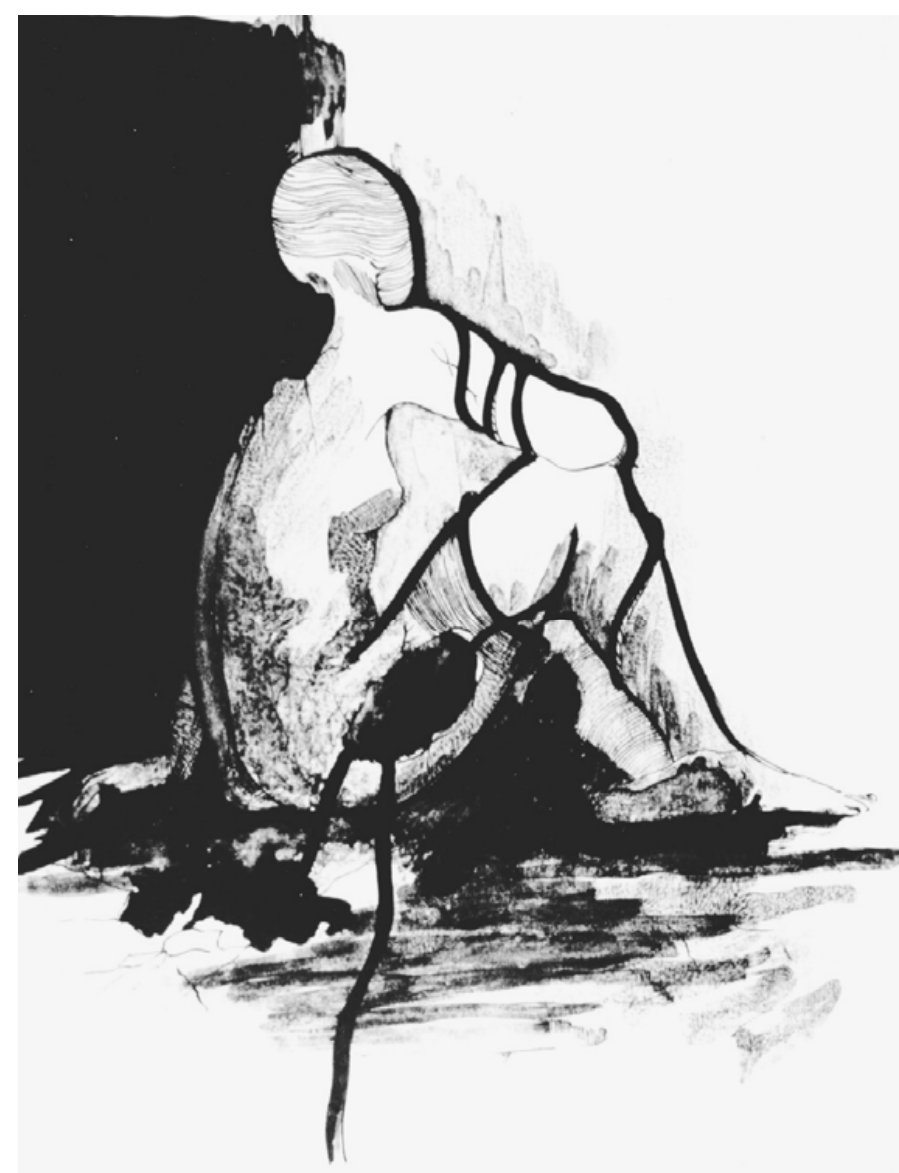

Fig.11 Pilar Dolz “Sin título”. Serie De mujeres. Litografía. 1972

El grabado ejerce sobre mí una gran atracción, por lo que tiene de artesanal, por su elegancia, y porque creo que reúne las condiciones para llegar al 
gran publico: belleza, sencillez y un precio al alcance de todos. ${ }^{47}$

Pilar Dolz es consciente de que con el grabado, su obra tendría más posibilidades de acceder al gran público, pues considera que éste es un medio de adquirir arte a un precio asequible, ya que una de sus cualidades es la reproducción múltiple. Por otra parte la estampa, reservada sólo hasta hace algunos años a un pequeño número de aficionados, cada día iba teniendo más aceptación en amplios sectores de la población, que querían tener una obra de arte original realizada y firmada por la mano de los propios artistas. Este factor, va desde un principio a influir en la temática de carga social elegida por la artista, aunque sus primeras obras sean de carácter surrealista.

Durante esta etapa inicial, en 1970 realiza su primera serie de grabados De formas. Se trata de ciertas formas surgidas del inconsciente, que aparecen atadas y atravesadas por cuerdas, hilos y demás. Sus representaciones, entre formas inanimadas y formas vividas, se transformarán más adelante en imágenes realistas que darán origen a una nueva serie. (Véase Cap. III.1.1)

Este conjunto de obras desde el principio se presentan ya como un trabajo articulado bajo un mismo tema. Apenas iniciada su carrera, no es consciente de que su obra está ejecutada bajo unas pautas que agrupan su trabajo en una serie. Lo cierto es que, consciente o inconscientemente, a partir de este momento toda su

\footnotetext{
${ }^{47}$ Véase PUERTO, G.: "Maria Pilar Dolz; artista especializada en grabado". Mediterráneo, Castellón de la Plana. 19/03/1972. p.23
} 
obra tendrá un mismo denominador y dará origen a las sucesivas series.

Uno de los aspectos que influye en el tipo de obra que va a realizar a continuación proviene de la experiencia vivida en su mencionado viaje de estudios a la Accademia di Belle Arti Pietro Vannucci, en Perugia (Italia), en el verano de 1970 y en 1971. Se encuentra con una ciudad inquieta y alborotada, que está pasando por momentos políticos muy importantes para las mujeres italianas, que se encuentran en plena lucha por la igualdad de derechos. Es la época del boom de la liberación femenina, ${ }^{48}$ con una serie de movimientos sociales en contra de la opresión. La impresión que le produce le llevará a hacer un tipo de obra reivindicativa, con nuevas aportaciones conceptuales que le llevan a evolucionar hacia una figuración de connotaciones surrealistas. Así surge la serie De mujeres, conjunto de imágenes femeninas que presenta atadas, torturadas y crucificadas con un claro trasfondo social. (Véase Cap. III.2.1)

Al segundo año de estar estudiando en las Artes del Libro, recibe la beca para ampliar estudios de grabado en el Istituto statale d'Arte di Urbino", a donde acude a efectuar un cursillo de grabado calcográfico. Al año siguiente vuelve ya con su beca Castellblanch, para cultivar la técnica litográfica. Desde este momento va a realizar viajes periódicos a Italia, incluso cuando años más tarde tiene el taller y la galería, para practicar sobre todo la técnica litográfica.

\footnotetext{
${ }^{48}$ Hay en Italia una serie de movimientos sociopolíticos de los que surgen varios colectivos de mujeres que luchan por la igualdad de derechos. Pronto se propagaron por toda Europa, sobre todo en Francia, afianzándose más tarde en otros países como EEUU. En España toma más fuerza después de la muerte de Franco. Véase en http: // www.portalplanetasedna.com.ar/feminismo.htm. (15/10/2005).
} 
Los continuos viajes a este país le van a influir lógicamente, no sólo por el contexto sociopolítico que vive mientras se encuentra allí, sino también por el ambiente cultural que se respira. Nos manifiesta Pilar que cuando viaja a Italia tiene la oportunidad de ver de forma directa toda una colección de obras clásicas, pinturas, grabados, litografías, al contrario de lo que ocurría en España donde no se veía tanto grabado, y donde apenas había revistas de arte.

Los talleres a los acude son verdaderas obras de arte. La Accademia di Belle Arti Pietro Vannucci, se encontraba ubicada en el antiguo convento de San Bernandino, un edificio renacentista rodeado de esculturas del Renacimiento. Por otra parte el Istituto statale d'Arte di Urbino se encontraba situado en el primer edificio renacentista que se hizo en la zona, el palacio ducal de Federico Montes Feltro. "Yo creo que el taller nuestro era el gabinete de la duquesa", con puertas y bajorrelieves renacentistas.

El tener acceso a tantas obras de arte renacentistas va a influir indiscutiblemente en su vocación y forma de ver el arte.

Yo creo que si que influye, el primer día que llegamos a Perugia. Fuimos a comer en un sitio donde comen los estudiantes, y había grabados enmarcados en las paredes. Yo no veía grabados en las paredes, ni en las casas. En los restaurantes más o menos decentes había obras; no eran maravillas, pero eran cosas que estaban muy bien hechas de técnica, bien resueltos. Se podía ver eso que te hacía sentir algo claro, que influye ¡Cómo no puede influirte eso! ${ }^{49}$

\footnotetext{
${ }^{49}$ Entrevista personal con la autora en Castellón de la plana. 07/03/2002
} 


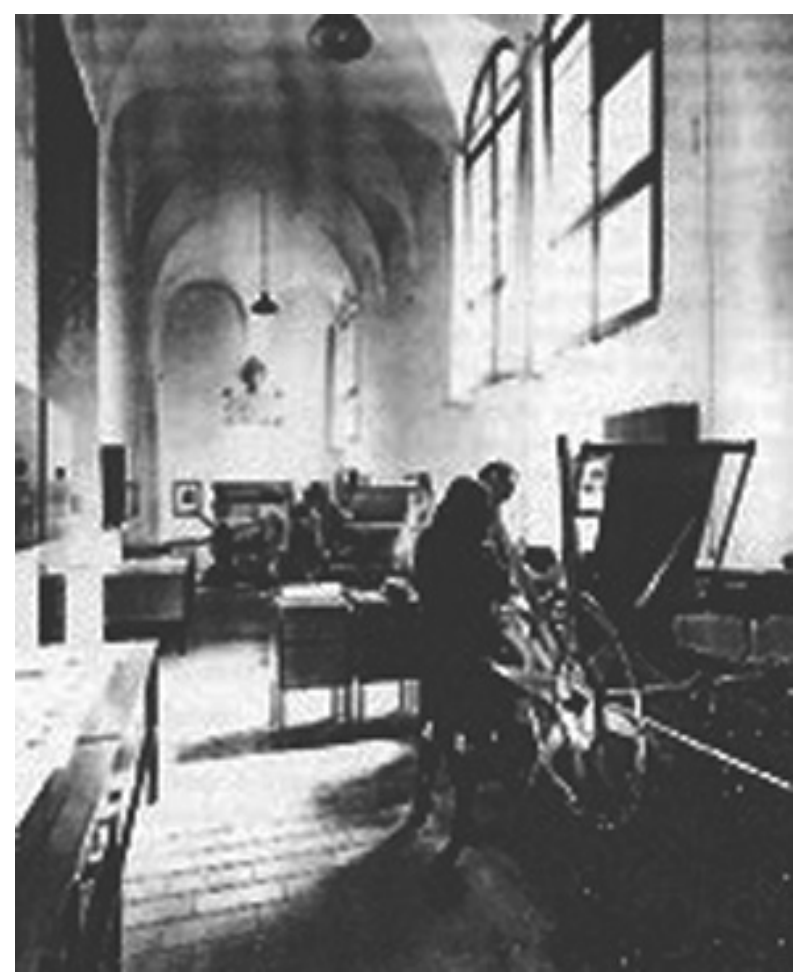

Fig.12. Taller de Litografía, Instituto "Raffaello Urbino". 1972.

La enseñanza que se imparte en este centro, es muy clásica, con un trabajo riguroso y duro. Había profesores que habian trabajado con gente muy importante, con una forma de grabar distinta a la que se tenía en las Artes del Libro más directa y espontánea. "Las imágenes no tenían nada que ver, era distinto". ${ }^{50}$

En este centro tiene como profesores a, Pietro Sanchini, profesor de Xilografía, Renato Bruscaglia, de Calcografía, autor de algunos textos sobre dicha técnica. ${ }^{51}$ Pero quizá uno de los

\footnotetext{
50 Entrevista personal con la autora en Castellón de la plana. 04/08/2006

51 BRUSCAGLIA, R.: Incisione Calcográfica e Stampa Originale d'Arte. Ed. Quattroventi, Urbino, 1988.
} 
profesores que más repercusión tiene sobre ella es Carlos Ceci, ${ }^{52}$ profesor de Litografía, la figura central de la vida artística y cultural de Urbino. Con él aprende la técnica litográfica clásica, hasta llegar a conseguir un gran dominio.

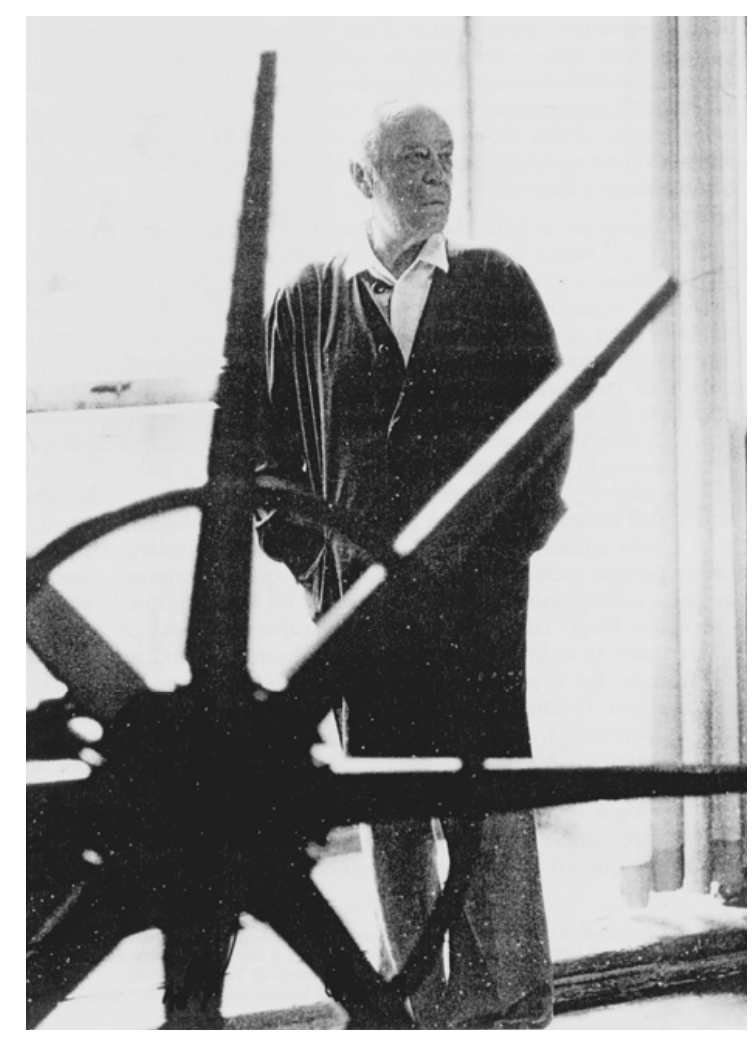

Fig.13 Carlos Ceci, Italia. 1973

Durante esta etapa, trabaja la serie Reixes, que se fundamenta en formas planas y lineales, sin valoración de claroscuro, con una técnica básica y elemental, que poco a poco va depurando para buscar mayor contraste y profundidad. Esta obra

52 VOLPONI, P.: "Carlos Ceci; Le Tempere e le Litografie”, Ed. Quattroventi, Urbino, 1990, p.p.17-45. 
viene de un realismo pop no académico, en el que da mayor importancia a la línea y su expresividad, apartándose poco a poco de la figuración surrealista desarrollada en la etapa anterior.

Durante este período de formación, en 1972 realiza su primera exposición individual en el Círculo Mercantil de Castellón de la Plana, no va a poder ser mejor. Joan Fuster hace su presentación y destaca aspectos que serán constantes en su producción. La obra que expone es trabajo de formación, sin embargo tiene notable éxito, tanto por la singularidad, como por la calidad.

La muestra está compuesta en su totalidad por grabados y litografías, técnicas muy poco conocidas en esta época en España, lo cual supone un riesgo que no todos los artistas estaban dispuestos a correr. Se compone de un conjunto interesantísimo y completo de obra realizada entre los años 1970 y 1972, con xilografías y grabados en cobre y zinc, aguatintas de resina y cera, aguafuertes con aguatinta, punta seca, buril y aguatinta, aguafuerte y barniz, aguafuerte y sal, y litografías. ${ }^{53}$ Es decir un conjunto de obras en las que hace una prueba exhaustiva de los recursos técnicos, trabajo, estudio, investigación, intuición y azar, que nos demuestra su madurez y seguridad.

\footnotetext{
${ }^{53}$ Véase PUERTO, G.: "Maria Pilar Dolz, artista especializada en grabado", Mediterráneo. Castellón de la Plana. 19/03/1972, p.23.
} 


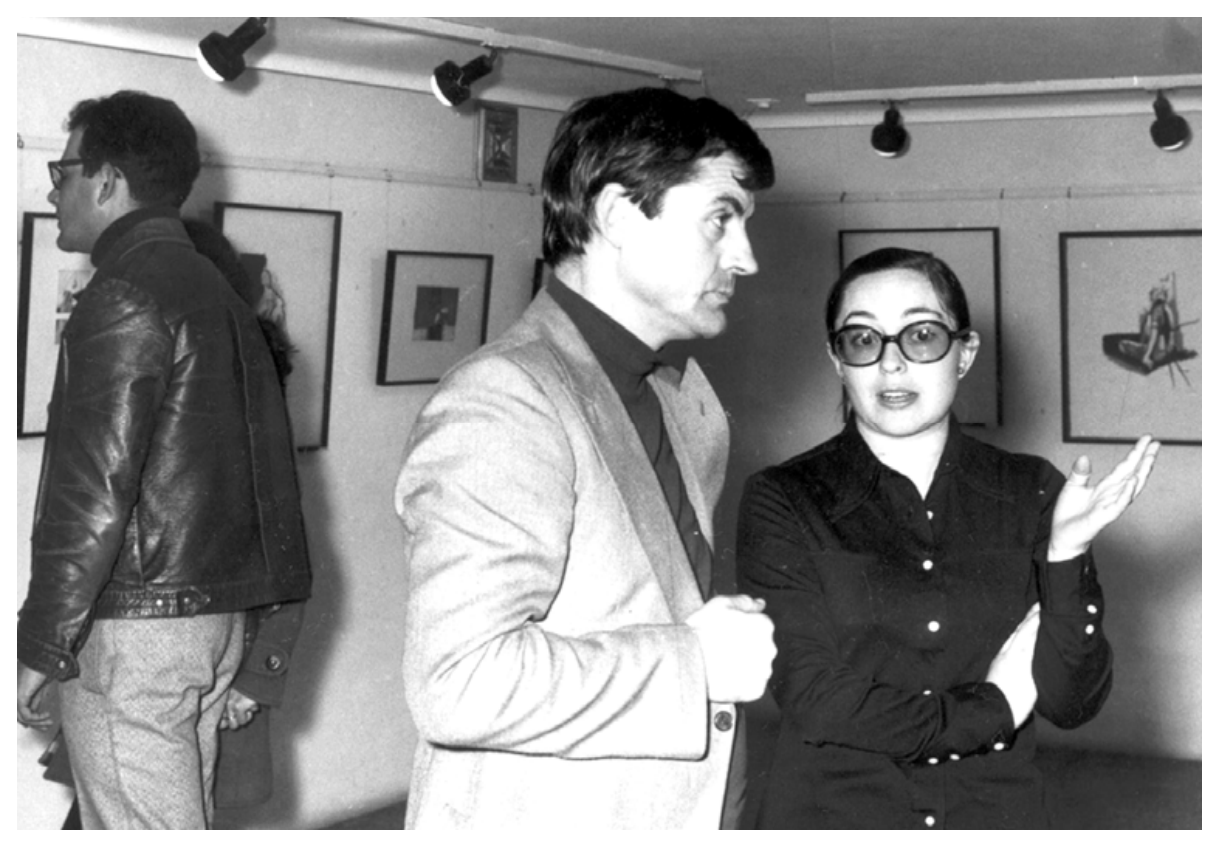

Fig.14. Primera exposición de grabados de Pilar Dolz. Círculo Mercantil de Castellón de la Plana. 1972.

Al año siguiente, en su segunda exposición individual, en la Galería Fort de Tarragona, se puede apreciar su evolución; la técnica poco a poco deja de ser de oficio para dejar paso al protagonismo de cosas más profundas, que permiten reconocer la madurez de la artista. Sus grabados y litografías se presentan llenos vida, ejecutados con unos recursos técnicos en los que llega a sentirse segura. En cuanto al tema, presenta todo un repertorio de dolor, pasión e iras, a través de una serie de imágenes violentas y duras de rejas y mujeres atadas. ${ }^{54}$

${ }^{54}$ Véase FUSTER, J.: 1972 


\subsubsection{Perfeccionamiento}

La etapa de perfeccionamiento, la enmarcamos a partir de su traslado a Castellón de la Plana en 1974. Tras 12 años de permanecer entre Barcelona y Urbino, una vez terminados sus estudios, regresa a su ciudad natal. Pilar Dolz que se encuentra plenamente identificada con las ciudades pequeñas como la ciudad italiana de Urbino, va a desplegar aquí una intensa actividad artística.

Al comenzar a vivir en esta ciudad, se da cuenta de que tiene una comunicación directa con la gente de su alrededor; ella que procede de un pueblo pequeño ligado al mundo rural, siente que existe una conexión que la va a hacer sentirse parte de esta comunidad. Este sentimiento que le liga a la tierra, va a ser parte consustancial de su obra en futuras series.

Durante este período se dedica a cultivar la técnica calcográfica en su primer taller de grabado, abandonando la práctica de la pintura, técnica que había ejercitado durante los años de estudios en Bellas Artes. En esta nueva etapa su arte va dirigiéndose hacia una figuración más marcada, se vuelve más realista; desarrolla una obra en la que podemos apreciar una evolución técnica y conceptual. Su discurso es una metáfora de la existencia humana, a través de la cual expresa su carga ideológica. Aparece así la serie Ocells morts (1974) donde combina las rejas de la serie anterior con nuevos elementos que simbolizan su inquietud y compromiso con el ser humano. 
La serie Insectes (1976) presenta un minucioso estudio de la anatomía de unas moscas, trabajadas con un total dominio del claroscuro que encaja dentro de un cierto hiperrealismo.

A partir de 1977 se sucede un trabajo intenso, con nuevos retos y temas que suponen el origen de diferentes series que se suceden en el tiempo. Surgen dos nuevas series, Finestres que cierra definitivamente su etapa inicial y Pedres i paisatges dels Ports que marca un antes y un después, debido a un claro salto cualitativo en su obra. Ésta serie le une iconográficamente a su ciudad natal, a su paisaje, pues desarrolla formas empíricas como piedras y paisajes que simbolizan la manera de ser y actuar de los hombres y mujeres de la parte montañosa de El Maestrat.

Al año siguiente inicia otra nueva serie de Parets de pedra seca (1978), muy ligada a la serie anterior, en la que trabaja imágenes relacionadas con las comarcas interiores del País Valenciano. Esta serie iniciada en Castellón, la va a continuar en Urbino, a la que viaja a realizar un curso de litografía. De ahí que la mayoría de obras de esta serie estén realizadas por medio de las diferentes técnicas litográficas aprendidas, como el spruzzo (salpicado de tinta) y el sbalzzo (estampación a relieve) que proporcionan a su obra extraordinarias calidades. Durante unos años trabaja este tema de piedras, bancales, muros y paredes, en los que pone en práctica todas las técnicas del grabado, especialmente las ya mencionadas. Sin duda ésta es una etapa clave de su evolución artística. 
En Espais i paisatges (1980) aparecen elementos de la serie anterior combinados con otros que también surgen en Herbes, serie iniciada en este mismo año. La composición se va abriendo paso paulatino a nuevos ritmos gestuales y combinaciones espaciales, en compañía de ciertas estrategias cromáticas que culminan en la mencionada serie Herbes, que se consolidará más tarde, entre 1981 y 1983, con un conjunto de obras de pequeño formato nacido en paralelo con Parets de pedra seca. Con las primeras obras de esta serie identificadas como Herbes, Pilar Dolz se centra en pequeños fragmentos de la naturaleza, de la tierra, para apropiarse del paisaje de siempre e ir recreando su propio paisaje, con un lenguaje caligráfico más gestual.

El incesante trabajo desarrollado a lo largo de estos años y el continuo aprendizaje al que se somete, le permite evolucionar y adquirir conocimiento y lograr la madurez artística, que hace que su obra vaya alcanzando cualidades plásticas y conceptuales propias de su singularidad.

\subsubsection{Madurez artística}

A nuestro criterio la etapa de madurez, se inicia con la realización de la ya nombrada serie Herbes, pero es a partir de 1983 cuando se produce un salto cualitativo, precedido por una nueva estancia de estudio e investigación en París.

La necesidad de informarse, de adquirir nuevos conocimientos, en especial sobre color, le llevan a Atelier 17 de 
Stanley William Hayter, ${ }^{55}$ uno de los más grandes maestros del grabado. Alli trabaja primero en una plancha experimental, que sirve como una especie de autoselección, ya que se trata de practicar en una misma plancha durante varios meses; el carácter excepcional del taller hace que muchos artistas acudan allí a trabajar, aparte de la asistencia de los propios alumnos, por lo que el trabajo se hace más lento, situación que muchos de los alumnos no son capaces de sobrellevar.

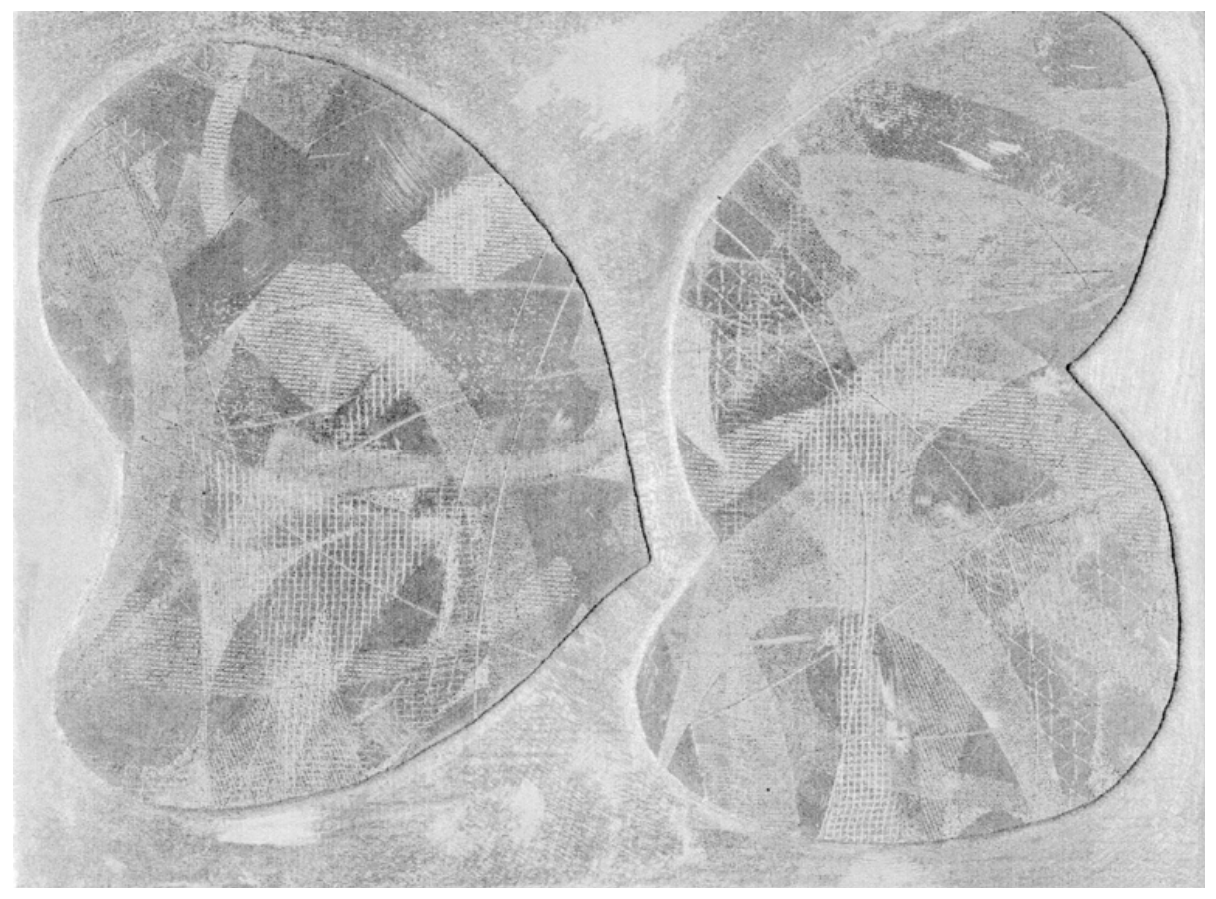

Fig.15. Pilar Dolz: Plancha experimental realizada en Atellier 17 París. 1983.

\footnotetext{
${ }^{55}$ En 1927 funda Atelier 17. Dos de sus más importantes obras son New ways of gravure (1949) y About Prints (1962). Véase RODRIGUEZ, C.: "Hayter, la retórica del grabado", El país, Madrid, 07/01/1984, p.3.
} 
Ésta es la plancha experimental (Fig. 16). A mí no me había contado nadie nada, pero después cada uno grababa como quería y lo que quería, pero dentro del contrapunto. Al principio aunque había leído algo no entendía nada. ${ }^{56}$

En Atelier 17 descubre nuevas experiencias gráficas sobre todo en el color. Trabajará con Hayter que había ideado su propia técnica a partir de los efectos de una gota de aceite, que al caer accidentalmente sobre la plancha no deja que el color se mezcle, sino que se repele. Allí va a poder trabajar y compartir con él y se dará cuenta de las enormes posibilidades que le ofrece esa técnica. Esta experiencia le va a cambiar completamente la forma de ver y trabajar el grabado, con una técnica distinta, donde los colores se mezclan y adquieren valor por sí mismos.

Sin duda Hayter es uno de los artistas grabadores que más le impactan, porque desarrolla una técnica que tiende a simplificar la impresión a color: "Yo tomo la técnica de Hayter, porque es más simple, está creada para facilitar no para hacer más compleja una cosa. Es una técnica muy limpia, donde el color lo cambia todo" 57

\footnotetext{
${ }^{56}$ Entrevista personal con la autora en Castellón de la Plana. 09/04/2002

${ }^{57}$ Entrevista personal con la autora en Castellón de la plana. 04/08/2006
} 


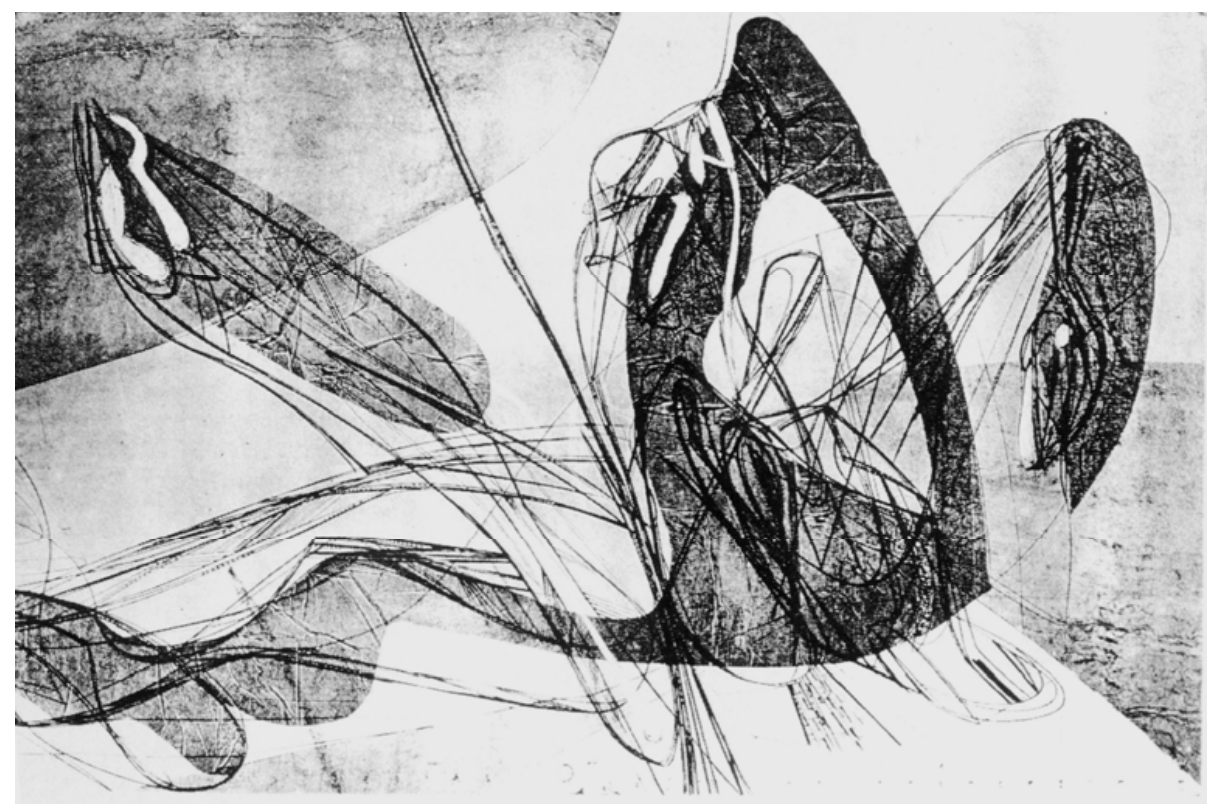

Fig.16. S.W.Hayter. Blason des arbres. Aguafuerte, 1982.

Otro de los profesores con los que se encuentra allí es George Ball, artista norteamericano que le va a iniciar en la práctica del buril. Sólo tiene clase un día por semana, en ella se habla de la técnica y después se practica sobre una plancha experimental, similar a la de Hayter. Nos cuenta la artista que esta clase fue importante porque para realizar la técnica de Hayter hay que acabar dominando ciertas cosas, como mantener el control de la mano:

Con el buril tienes que acabar dominando ciertas cosas. Esto es la plancha experimental de George Ball. Yo voy haciendo cosas. Tienes que controlar la mano. Es como cuando los niños hacen una muestra. Éstos son pequeños. Tienes que frenar y controlar. $Y$ después estos gordos. Tienes que aprender a cortar donde toca. ${ }^{58}$

${ }^{58}$ Ibidem. 
Durante este período, va también al Atelier de Henri Goetz. En este taller va trabajar las técnicas aditivas del carborundum, pero finalmente termina por desecharla, ya que no se siente identificada con ese medio:

El carborundum es muy duro y se te van pegando esas cositas al rodillo, y los rodillos son muy caros. Yo creo que la técnica la utilizas según las necesidades, (...) y para que las técnicas aditivas funcionen tienes que quemar, estropeas los rodillos. De hecho no lo he utilizado y estuve un año entero allí, pero no lo utilizo. Me siento a gusto con el metal y los ácidos. ${ }^{59}$

Mientras estudia en París, es invitada a dirigir el taller de grabado de la Casa de España en esta ciudad, con la finalidad de proporcionar un mayor acercamiento de las artes plásticas a los españoles residentes en esta ciudad. La retribución económica que le genera esta actividad le permite permanecer un año más allí, para continuar los estudios que inicialmente sólo había proyectado para un año.

Conjuntamente a esta actividad lleva a cabo una exposición individual en la Sala Goya de este centro, en la que expone obras de etapas anteriores y unas estampaciones en color de grabados calcográficos en los que pone en práctica la técnica del roll-up, recién aprendida. La exposición prácticamente presenta dos temas casi obsesivos; piedras y hierbas que han sido durante los últimos años, motivo de su producción, en los que podemos ver un afán

${ }^{59}$ Entrevista personal con la autora en Castellón de la Plana. 21/03/2007 
perfeccionista por el detalle, por el cuidado de su ejecución, y donde el sentido del mensaje trasciende la percepción del espectador.

Los conocimientos adquiridos en este período son esenciales para su nueva etapa de creación. Aparecen así nuevos trabajos pertenecientes a la ya existente serie Herbes, en los que incrementa la complejidad compositiva e introduce mayores contrastes de forma y textura. Sus grabados creados bajo una concepción particular de la naturaleza, sugieren un mundo vegetal sugerente, donde la composición, el ritmo y el color son consecuencia del quehacer investigador, que le permite crear y definir su propio lenguaje. ${ }^{60}$

Otra de sus experiencias en esta ciudad que le hace sentirse cada vez mejor con el grabado, es justamente la visita en su tiempo libre a la Biblioteca Nacional de París. En esta institución tiene la oportunidad de tener en manos las mejores obras del grabado universal; desde los más clásicos, como Rembrant, Durero, Goya, hasta los más contemporáneos. Estas obras le aportan mucha información técnica y plástica. Después, normalmente intenta en el taller ciertas cosas que ha visto, sobre todo gestos de los grabados clásicos.

En esta etapa de gran actividad investigadora, podemos apreciar múltiples soluciones creativas, auténticas variaciones del paisaje, como tallos, hojas, troncos, espigas y otras, que abrigadas bajo la magistral serie Herbes, las irá trabajando de forma paralela a lo largo de más de 25 años de producción artística.

${ }^{60}$ Véase ARAZO, Ma Á.: "Pilar Dolz: La estrategia cromática", Las Provincias Valencia, 02/06/1989. p.34 


\subsection{ACTUALIDAD DE PILAR DOLZ}

\subsubsection{Pilar Dolz galerista}

Es difícil entender la actualidad de Pilar Dolz sin ser galerista. Mujer inquieta y apasionada, enciende su voz cuando habla de su profesión como grabadora compaginándola con la mencionada galería de arte Cànem que dirige desde hace más de treinta años.

No es exagerado decir que uno de los mayores capítulos escritos en el arte de esta tierra, lo ha hecho Pilar Dolz, apostando decididamente por la actividad de vanguardia, que le llevo a ofrecer un espacio cultural a esta cuidad cuando las autoridades políticas sólo apostaban por la tradición y el clasicismo. En este sentido, Cànem ha sido el espacio artístico más importante de Castellón, donde se ha expuesto lo más significativo del arte contemporáneo valenciano de la segunda mitad del siglo.

Se inauguró en 1974, en una época de represión, donde todo se tenía que hacer en la clandestinidad, buscando justificación y cobertura legal para cualquier actividad, la gente no se podía reunir, ni hacer agrupaciones, entonces Pilar Dolz y diez socios más pusieron un capital cada uno y empezaron con la galería, aunque los criterios eran muy diferentes unos de otros, lo que realmente importaba era que de esta manera se podían reunir y realizar una serie de actividades colectivas para las cuales se tenía que sacar un permiso especial. Con el tiempo Cànem se convirtió en la época de 
la transición política, en la plataforma cultural más relevante de Castellón.

La galería desde un principio ha tenido un fin determinado; difundir un tipo de arte. Soy consciente del compromiso con el arte antes, ahora y siempre, sobre todo con lo que tiene que ver con abrir un mercado de arte moderno, que resultó y sigue resultando difícil. Más todavía en una ciudad como Castellón, donde hace falta una política cultural, sobre todo en el campo de la plástica. Hay que irse a Madrid o Barcelona para ver exposiciones. Creo que en esto Cànem ha servido para algo. Nuestra intención fue ayudar a salir de la miseria cultural que existía entonces en Castellón. ${ }^{61}$

No es nada fácil mantener una galería con una línea coherente como ésta; una galería heroica como escribe Vicente Rodes, seguramente porque Pilar Dolz antes que galerista es artista y el amor que ella tiene por el arte, es lo que diferencia su galería de otras más condicionadas probablemente por el aspecto comercial.

Ésta es su doble personalidad; la profesionalidad de la galerista y la vocación de la grabadora. En ambos casos trabaja con entusiasmo en beneficio del arte, aunque reconoce que la galería cada vez ha ido ganando más espacio en su vida profesional. Una de las razones más importantes es su idea de que la galería es un punto de encuentro, donde se crea una dinámica que no puede cortar, ya que de ella depende un grupo de artistas a los que representa y a los que no puede dejar colgados,

\footnotetext{
${ }^{61}$ Véase TORRENT, R.: "La galería de arte "Cànem" una plataforma cultural, Mediterráneo, Castellón de la Plana, 02/08/1983. p. 14.
} 
porque tiene un compromiso con ellos y con el arte que no quiere eludir.

Yo tenía el taller tan grande como esta galería. La compré aquí porque arriba tenía el taller, y pensé: 'Así lo tengo más junto y no me muevo.' Pero resulta que ahora todo mi taller es oficina y almacén de la galería, y me ha quedado de taller lo que es el despacho. Es decir, cada vez el taller es más pequeño, porque le doy más importancia a la galería y porque hay circunstancias accidentales en la vida y cosas que van tomando espacio. Quizás porque estás a gusto y muy bien con lo que haces. ${ }^{62}$

Sin duda otro de los factores que contribuye a la madurez artística, personal y profesional, tanto como ir a Hayter, es su labor como galerista, actividad que hace que tenga relación directa con artista y grabadores. El hablar y compartir con ellos es una acción que le enriquece mucho, pero también la actividad de gestión que guarda con la galería le permite viajar a diferentes ferias de arte por todo el mundo, lo que hace que conozca obra de otros artistas y se dé cuenta de las diferencias en la producción artística de unos sitios y otros.

La relación con el mercado no hay que eludirla. Yo defiendo que la galería es comercial; una sala más, que lo que pretende es vender, porque esto sería un síntoma de que esto a la gente le interesa y es lo que se pretende. Lo que no tiene porqué hacer una galería es didáctica; esto es, mostrar lo que se está haciendo Esa labor debería ser obra de las instituciones que se dediquen a eso, pero resulta que aquí no hay, o no ejercen de manera suficiente. Sería necesaria una seria labor del Ayuntamiento, de la Diputación que

\footnotetext{
${ }^{62}$ Entrevista personal con la autora en Castellón de la Plana. 27/04/2006
} 
trajeran a Castellón cosas que las galerías no pueden traer por su alto costo y que no hicieran al revés, que a veces organizan exposiciones que las mismas galerías comerciales rechazan. ${ }^{63}$

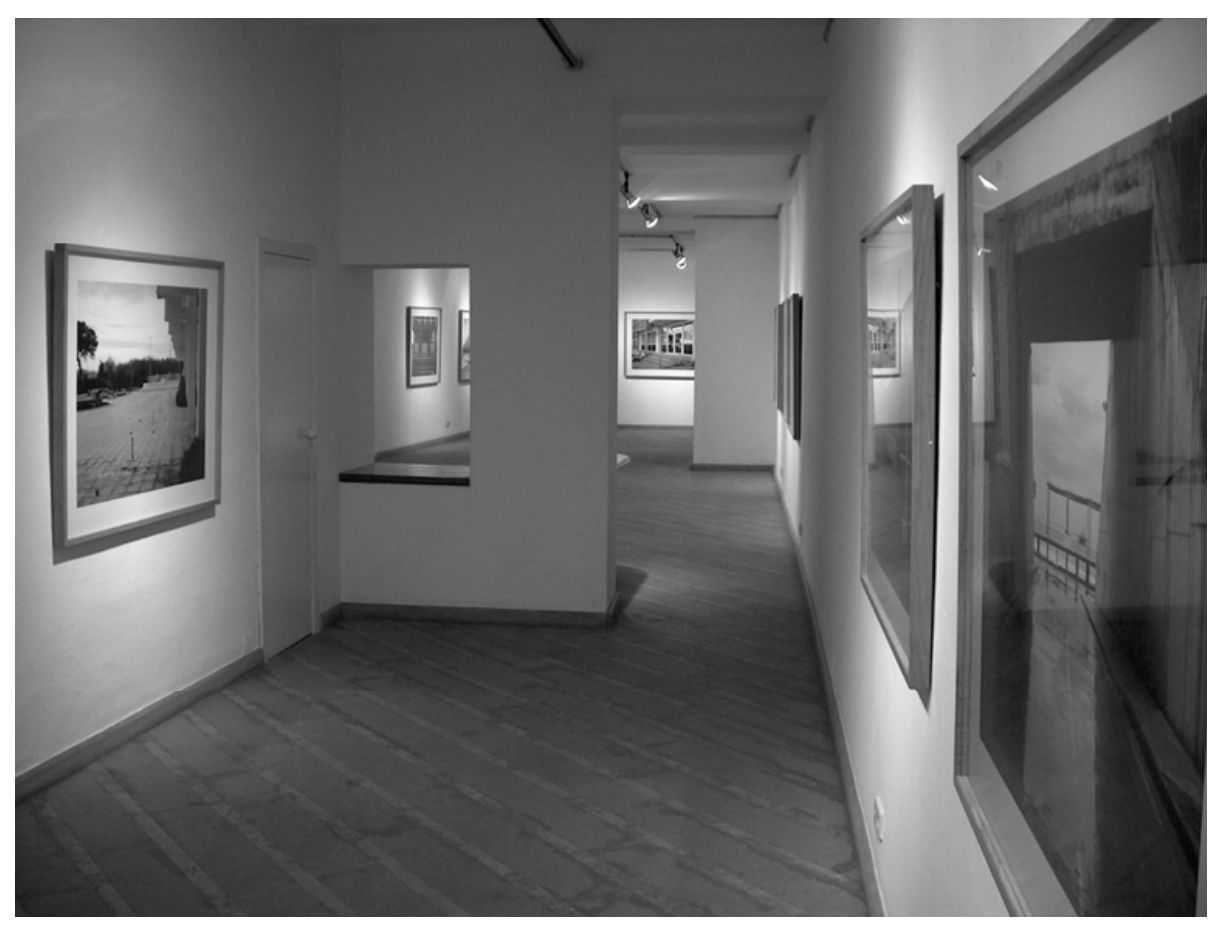

Fig.17. Galería de arte Cànem. C/ Antonio Maura n 4, Castellón de la Plana.2007

\subsubsection{Trabajo editorial.}

Cuando Pilar Dolz llegó a Castellón no había conocimiento de lo que era una estampa original. Entonces la artista comenzó a difundir las técnicas gráficas haciendo mesas redondas en la galería.

${ }^{63}$ Ibidem 
Su labor como editora la inicia mas tarde en la década de los ochenta, cuando algunos artistas residentes allí, que estaban trabajando cosas actuales y que no habían practicado grabado, comienzan a llegar a su taller con esa inquietud. Apoyados por ella empiezan hacer grabados, pero posteriormente sus trabajos serán estampados por Pilar, pues considera que ésta puede ser otra forma de sentir el arte. Pero no es si no hasta 1991 cuando lleva a cabo las primeras ediciones con obra de Pepe Nebot y Manolo Sáez. Después también ha editado obra de Vicent Cardá, Ramón MartíQuinto, Rosa Torres, Joan Cardells, Manuel Rey Fueyo, Joan Verdú, Carme Vidal, Ramón Roig, Evarist Navarro y otros.

Yo creo que he empezado a editar cuando han venido artistas y yo he visto su obra, y he dicho: '¿Por qué no pruebas a hacer una obra?' y han subido arriba al taller y han hecho su obra. Luego he estampado porque a mí me gusta estampar incluso lo de otra gente, porque me da un meterme un poco en la vida, en la creación del otro; porque mientras voy estampando me va dando la riqueza de otras cosas, es decir es una forma de observarlo. Era gente que nunca había hecho grabado y yo le dirigía un poco, pero entonces se entusiasmaban y hacían grabados más grandes. Les preparaba planchas más grandes y entonces editábamos las piezas, pero empezamos un poco en broma. ${ }^{64}$

Otras de las cosas que ha producido Cànem Edicións son algunos libros de artistas como Plaza del árbol. ${ }^{65}$

\footnotetext{
${ }^{64}$ Entrevista personal con la autora en Castellón de la Plana. 27/04/2006

65 Con poemas de Juan Manuel Bonet y aguatintas de Juan Manuel Rey Fueyo, elaboradas en planchas de hierro y cobre, estampados por Pilar Dolz. Impreso y encuadernado en Barcelona, con un edición de 55 ejemplares.
} 
Este libro surge como un divertimento, lo hicimos porque Juan Manuel Bonet, que era director del IVAM, dijo: '¿Por qué no hacemos un libro? Y dije: 'Cuando quieras.' Y él escogió un artista. El libro está hecho muy clásico, porque él es un amante de la tipografía y todo eso. Son poemas de Bonet y obra de Manolo Rey, al principio hicimos 13 grabados y él escogió $7,{ }_{66}$ y después escribió los poemas sobre los grabados. ${ }^{66}$

Document de Morella (2000), una pieza excepcional editada para un público de bibliófilos, contiene 11 poemas del escritor Vicent Andrés Estellés junto a otros tantos aguafuertes de Pilar Dolz que corresponden a paisajes de Morella, concebida por la artista como piedra mineral ancestral. La aportación de Pilar se convierte en una especie de homenaje a la figura de Estellés como poeta y hombre comprometido con su tiempo y sus circunstancias. ${ }^{67}$

Yo no pierdo nunca de vista que el grabado tiene que ver con cosas pequeñas, como los sellos de correos, estampas de culto, cartas de juego. A mí me gusta mucho y me duele mucho cuando la gente los enmarca. Se han editado 3 o 4 libros. Tampoco es que hayamos hecho mucho, tampoco es que tengamos mucho tiempo. Uno tenemos que no sé cuándo lo terminaremos; esto es así. Hay dos en marcha, pero uno ya tenemos que terminarlo. ${ }^{68}$

De igual manera ha editado también algunos trabajos por encargo para empresas e instituciones, como carteles, tarjetas de navidad. Según la artista, ésta es una de las formas en

\footnotetext{
${ }^{66}$ Ibidem

67 Editado con el auspicio de la Generalitat Valenciana y la Fundación 50 Sexenni de Morella.

${ }^{68}$ Entrevista personal con la autora en Castellón de la Plana. 27/04/2006
} 
que la obra gráfica es más rentable, pues en una exposición para que el esfuerzo quede compensado tendría que venderse mucha obra a un precio asequible, mientras que cuando se trabaja por encargo es mucho más fácil vender obra, porque se trabaja con una cantidad determinada previamente. Es también otra forma de presentar la obra para que llegue a mucha gente y que no sea una exposición.

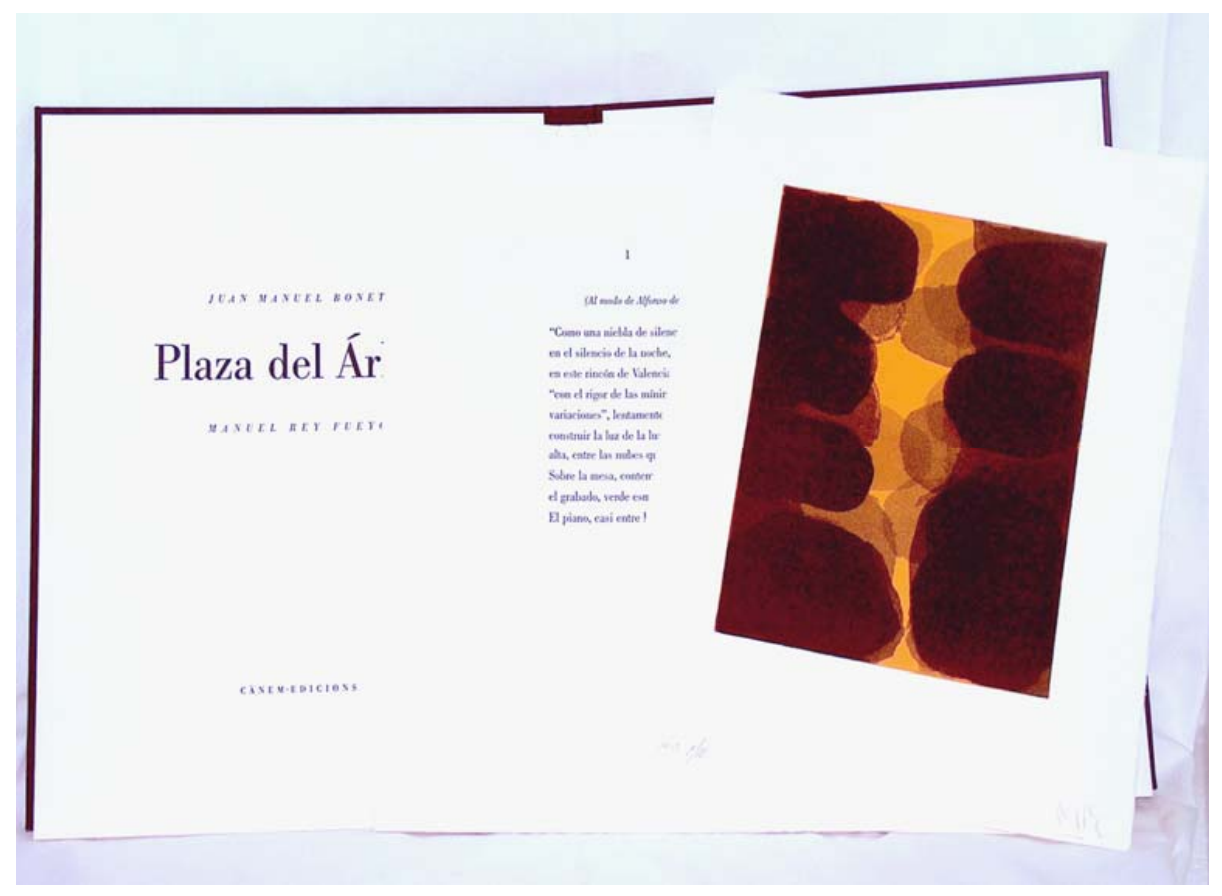

Fig.18. Juan Manuel Bonet. Plaza del Árbol con aguatintas de Manuel Rey-Fueyo. Editado por Cànem Edicions, 2000.

Nos explica Pilar Dolz que las galerías y ferias de arte no quieren hacer exposiciones de grabado, porque no compensa, a no ser que sea una obra de artistas famosos. Mientras que en la pintura 
con la venta de un solo cuadro se puede recolectar la misma cantidad de dinero que con una exposición de grabado completa. Por eso dedicarse exclusivamente al grabado es algo difícil en el mercado, y los artistas grabadores apenas son invitados a algún sitio.

La artista conoce muy bien el terreno que pisa, muchas galerías del estado español han podido funcionar en estos años, porque las instituciones se han convertido en sus clientes, pero esto no ha pasado en Castellón. Indiscutiblemente para tener una galería se debe disponer de dinero o se debe tener tanta ilusión como la que tiene Pilar Dolz. Por eso para continuar adelante, para promocionar el arte y facilitar a sus clientes la compra de obras de arte, ha creado su propia estrategia; ha creado el Club de Amigos para la Promoción de las Artes de Castellón (CAPAC). ${ }^{69}$ La idea del club ha dado resultado. Cuando se empezó con las ediciones se inició con 20 personas, ahora llegan a más de 60 las personas suscritas.

Hoy podemos apreciar la larga trayectoria recorrida por Pilar Dolz, en la cual vemos a una artista profundamente testimonial, que trabaja desde su galería y desde su acción como artista, editora y ciudadana comprometida en la defensa de los derechos de la mujer y en la lucha por las libertades.

\footnotetext{
${ }^{69}$ Cada amigo o socio paga una cuota al mes, y cada año o cada dos años, puede comprar una obra de arte más importante; todo depende de la cuota. Al final del año cada socio recibe como regalo un grabado editado para la ocasión, siempre del mismo formato y el mismo número de estampa. Entrevista personal con la autora en Castellón de la Plana. $27 / 04 / 2006$
} 
CAPÍTULO 2

NÁLISIS DE LA OBRA GRÁFICA 



\subsection{CONSIDERACIONES PREVIAS}

Antes de desarrollar este apartado es necesario hacer ciertas aclaraciones. El estudio de la obra gráfica está ordenado por series, ya que está ejecutada casi en su totalidad bajo esta concepción, excepto algunas estampas que se han realizado de forma aislada y por encargo.

Entendemos por serie el conjunto de obras que tiene como factor común un mismo tema, un mismo título y una misma propuesta conceptual, unificando de esta manera las diferentes obras que la componen y que tienen rasgos propios que las diferencian. 
Veamos la personal forma que tiene de explicar esta artista como consigue ella una serie:

Un grabado me lleva a otro. No intentaba trabajar en serie, dependía de muchas cosas; de la plancha que tenía, la plancha que encontraba en la basura. Un año, dos años, estás haciendo lo mismo sin darte cuenta. A veces haces una escapada para otro lado pero de una forma inconsciente; de hecho siempre trabajo dos o tres series distintas a la vez, porque el grabado te da eso. Al estar estampando, le vas dando vueltas; si lo pones así te dice una cosa, si lo pones así otra y eso tiene otro significado. Eso te hace hacer series, porque mientras vas estampando vas viendo la plancha desde otro punto de vista y eso te lleva a algo parecido y a la vez diferente. ${ }^{70}$

La casualidad, el azar, la visión reflexiva a la hora de estampar, y sobre todo su carácter investigador, le han llevado a producir casi por completo su obra en series. Muchas veces utiliza la misma matriz para realizar un conjunto de grabados, en los que recorta la plancha, le da vueltas, la estampa con distintos tonos, distinto papel, emplea plantillas auxiliares. El resultado es una obra totalmente distinta, donde pasa de unas rejas a unos pájaros muertos, de unas hierbas a un paisaje; de esta manera una misma matriz le sirve para realizar diferentes grabados. Pilar Dolz deja hablar primero al material, al lápiz, a la punta y a la plancha, para después potenciar lo que éstas le sugieren.

Yo corto las planchas, si hago sólo esto es un trocito de paisaje. Si hago esto es otra cosa. Empiezo una plancha grande y después eso me lleva a un

${ }^{70}$ Entrevista personal con la autora en Castellón de la Plana. 06/06/2005 
montón de planchitas pequeñas. Esto no se podría hacer en pintura, pero el grabado te da eso. ${ }^{71}$

Esta forma de trabajo es una de las constantes que nuestra artista va a desarrollar desde sus inicios en el grabado, cuando aun era estudiante, y que va a seguir manteniendo hasta la actualidad. La serie se convierte en una fuente inagotable de inspiración, llevándole a desarrollar un mismo tema durante varios años, incluso décadas, convirtiendo el tema de la serie en una especie de obsesión.

Otro aspecto curioso es que también es capaz de ejecutar una misma imagen de manera incansable, probando e investigando con diferentes técnicas, texturas, colores, en fin todos los aspectos que intervienen en su creación hasta conseguir los efectos deseados.

\subsection{ESTUDIO ANALÍTICO.}

Durante el desarrollo de este trabajo haremos un meticuloso estudio de los aspectos que intervienen en la creación de la obra, tanto de los aspectos formales como conceptuales, en el cual analizaremos lo que nos transmiten. Para ello tomamos como punto de referencia el estudio a través de las series que configuran su obra. Para una mejor organización y comprensión haremos el estudio aplicando los puntos tal y como se han expuesto en la

${ }^{71}$ Ibidem 
introducción de este documento; presentamos así los tres apartados que vamos a considerar: Concepción, Aspectos compositivos y Proceso técnico.

\subsubsection{Concepción}

Como primer paso para conocer bien la obra hacemos un reconocimiento general desde el punto de vista conceptual de la artista, en el que analizaremos la creación a partir de sus propias experiencias personales; inquietudes, preocupaciones, reflexiones que motivaron la creación, ideas que ella ha expresado de forma verbal a través de diversas entrevistas y conversaciones. También hablaremos de las influencias externas, estilos o personajes así como aspectos de orden social, ideológicos e incluso geográficos, ya que la relación que se establece entre sus obras de arte y su lugar de nacimiento es muy significativa. El ambiente rural de su tierra, de su pueblo natal, marca hondamente el desarrollo de gran parte de su actividad.

\subsubsection{Aspectos compositivos}

En cuanto al análisis de la obra desde el punto de vista puramente formal, primero haremos una visualización global de la obra guiados por la estructura, para posteriormente adentrarnos en un estudio más detallado de los rasgos más característicos de cada imagen. Así pues estudiaremos los siguientes aspectos: 
composición, grafismo y color, elementos de vital importancia para la adecuada investigación de esta obra.

\section{- Composición}

En el estudio de la composición propiamente dicha, estudiamos la distribución de las formas en el espacio y las relaciones entre forma y fondo, como argumentos que justificarán la validez del mensaje.

El espacio permite que se manifiesten las formas. Podemos analizarlo como plano bidimensional que muestra a su vez otras dos vertientes o dimensiones conceptuales.

La primera dimensión, constituida por una senda lineal, elemento básico utilizado en la etapa más primaria de manifestación creadora en toda obra de arte, donde no se hace alusión a ninguna forma concreta, sino que sugiere la apariencia de líneas sueltas, ${ }^{72}$ esta dimensión se corresponde a una caligrafía automática que no tiene forma concreta, se trata de gestos espontáneos que surgen del inconsciente, para controlar el espacio. Pilar Dolz, nos explica que los primeros trazos que realiza los hace como si estuviera en trance, como si fuera una práctica en la que se deja llevar por el ritmo de la línea. A continuación realiza un trazo que le sugiere algo, pero al principio, "la idea es controlar esta caligrafía que surge del inconsciente, hasta crear cierto ritmo, pero un ritmo del inconsciente". ${ }^{73}$ (Véase Fig. 19)

\footnotetext{
${ }^{72}$ Véase ARNHEIM, R.: 1993, p.245.

${ }^{73}$ Entrevista personal con la autora en Castellón de la Plana. 27/04/2006
} 


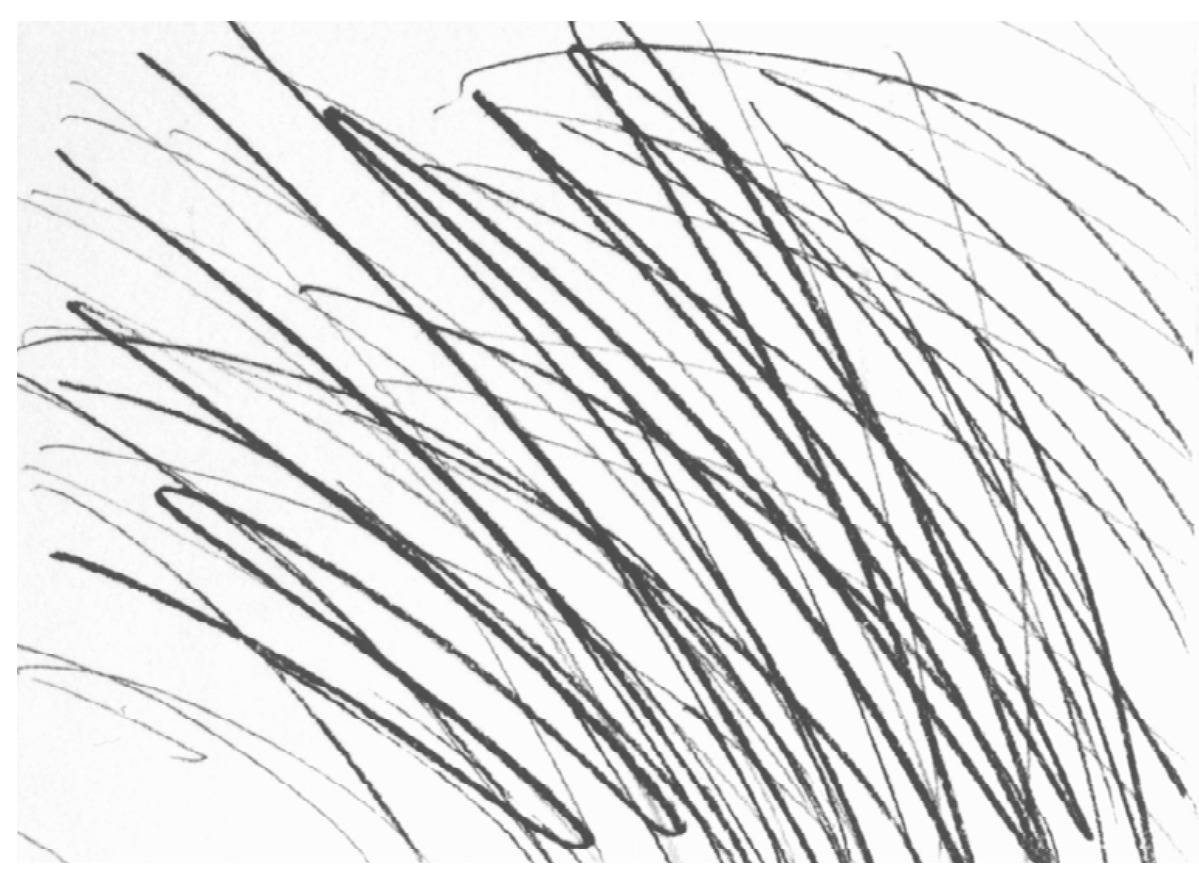

Fig.19. Pilar Dolz, "Herbes XLIII" Serie Herbes. 1988.

La segunda dimensión, hace alusión a la percepción bidimensional del plano sobre el que se manifiestan los grafismos, una extensión en el espacio donde se puede distinguir las formas tal como nos permite nuestra propia percepción visual.

En esta dimensión la artista potencia los gestos primarios realizados en el espacio, proporcionándoles una apariencia figurativa, de tal manera que la caligrafía automática se convierte en hierbas, troncos y matorrales. (Véase Fig.20) 


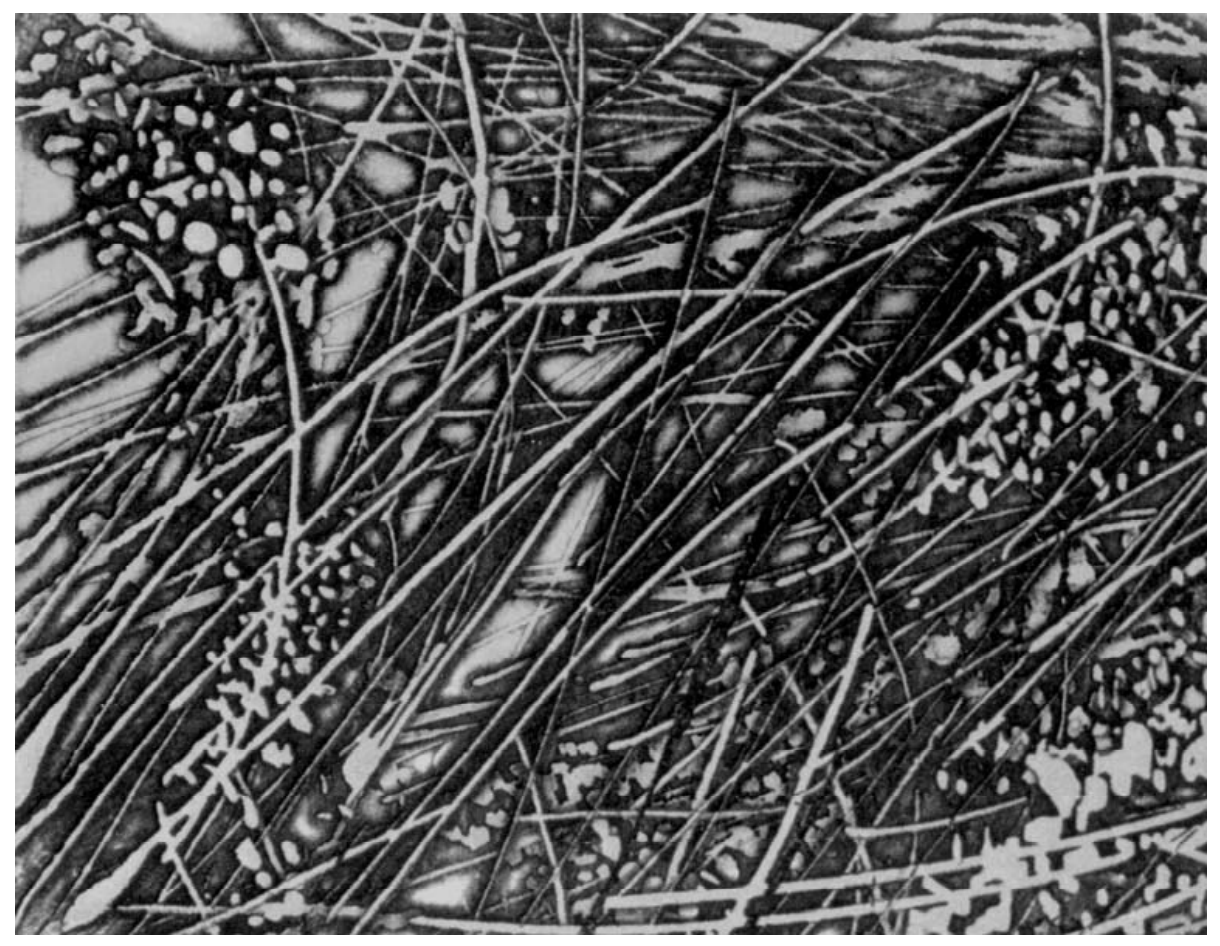

Fig.20. Pilar Dolz, "Herbes LV" Serie Herbes. 1989

En cuanto a la forma puede comprender diversos planteamientos de reflexión; puede ser composición, espacio, soporte, pero también materia, color, técnica y textura. ${ }^{74}$

En este punto estudiaremos la distribución de la forma en relación con el espacio, teniendo en cuenta el plano como la representación física del mismo, que adopta el formato sobre el cual vemos proyectada la imagen. En el caso de Pilar Dolz vemos que hay épocas en que le gusta recurrir a formatos pequeños como constante, mientras que en otras tiene preferencia por formatos mayores, pero nunca excesivos:

${ }^{74}$ Véase PUERTA, F.: 2001, p.102. 
Yo trabajo formatos pequeños. Me gustan mucho los formatos pequeños, porque yo empecé el grabado como una cosa más intimista. Nunca hago grabados excesivamente grandes. ${ }^{75}$

Generalmente los formatos que utiliza son rectangulares y cuadrados $^{76}$ aunque en sus inicios recurría con frecuencia a formatos irregulares, adaptados a la forma de la figura representada, de esta manera las formas convencionales son sustituidas por otras propias y personales.

En este apartado haremos un estudio formal sobre la estructura de la composición en la que analizaremos la distribución espacial de las formas, estudiamos los distintos factores de combinación en el espacio y la forma de los elementos, su proporción, compensación de masas, equilibrio, ritmo, sugerencia de profundidad de la forma y juegos de superposición en base al traslapo, ${ }^{77}$ al claroscuro en su etapa más realista, en definitiva todos los componentes de la composición.

También trataremos los recursos en los que investiga para sugerir el efecto volumétrico de las formas asociados a la presencia de la luz, para ello lo que hace es generar relieve a partir de dejar la plancha sin entintar y después pasarla por el tórculo; eso le da una serie de formas suaves y tenues que se aprecian por el efecto de la luz más o menos rasante. (Véase Fig. 21)

\footnotetext{
75 Entrevista personal con la autora en Castellón de la Plana. 07/03/2002

${ }^{76}$ Entrevista personal con la autora en Castellón de la Plana. 06/06/2005

${ }^{77}$ Al respecto véase ARNHEIM, R.: 1993, p.141ss.
} 
Esos eran de mis primeros grabados, es más una curiosidad por saber qué te da ciertas cosas. Esa curiosidad de ir probando qué posibilidades tienes con las cosas que utilizas, casi más que el querer decir algo. Es como tomar experiencia de lo que tienes a mano, y esto era esa cosa tan suave que te puede dar sólo la luz, con unos pequeños relieves; es probar ciertas cosas. ${ }^{78}$

Fig.21. Pilar Dolz, "Sin título" Fragmento LAM. VII. Serie De formas. 1971.

- $\quad$ Grafismo

El grafismo es uno de los recursos más característicos de la obra a analizar, sobre todo en las últimas series donde se experimenta un salto cualitativo, desde una etapa figurativa a otra

${ }^{78}$ Entrevista personal con la autora en Castellón de la Plana. 27/04/2006. 
con un trazo más gestual, utilizando la naturaleza como un referente de ficción para recrearla. Nos comenta la artista que para ella la línea tiene vida propia, sin duda es una de las cosas más importantes del grabado. ${ }^{79}$ El grafismo es la huella que se hace visible en el papel gracias al resultado producido en la plancha de metal por la acción motora del brazo y el cuerpo en general; la forma y la orientación que toma, reflejan el temperamento, el estado de ánimo de su creadora a través del ritmo construido por sus relaciones.

No hago bocetos, ni tomo apuntes. A partir de unas manchas que suelo hacer con un dedo comienzo a inventar; creo que el movimiento, los tonos, todo expresa un estado de ánimo, emociones e ideas -es por este orden- que me gusta trasmitir. ${ }^{80}$

Estudiamos los grafismos desde tres puntos de vista: como contorno, como objeto y como textura para crear masas, ${ }^{81}$ además de sus cualidades de movimiento y calidad gráfica.

El primer contacto que Pilar Dolz tiene con el grabado es la línea como contorno, la que utiliza para contornear algún objeto aunque éste no sea reconocible. Con ella delimita las formas con carácter claramente de protagonismo lineal. La encontramos sobre todo en las primeras series, donde representa las imágenes claramente definidas en el espacio (Véase Fig.22)

\footnotetext{
79 Entrevista personal con la autora en Castellón de la Plana. 27/04/2006.

${ }^{80}$ ARAZO, Ma Ángeles: "Pilar Dolz: La estrategia cromática." Las Provincias. Valencia. 02/06/1989, p. 34.

${ }^{81}$ Véase ARNHEIM, Rudolf: 1993, p.246.
} 


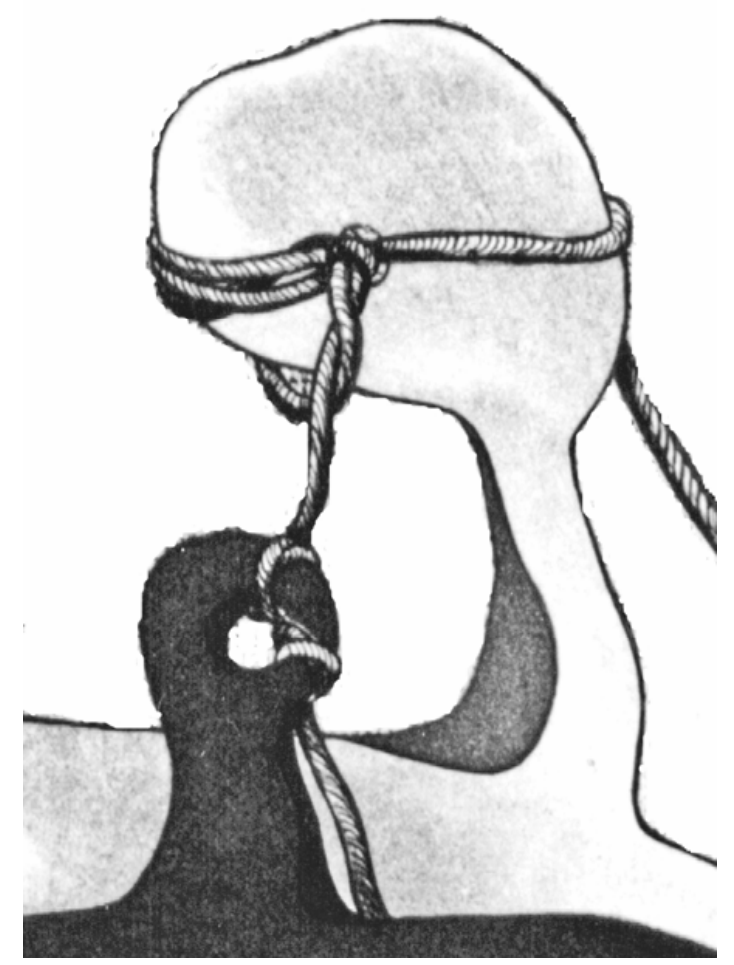

Fig.22.Pilar Dolz “Sin título” Serie De formas.1970.

La línea como objeto, hace referencia a la línea concebida como un elemento formal unidimensional, con características propias, y aunque haya varias que se entrecrucen y se mezclen entre sí, siguen manteniendo sus características individuales. Este tipo de línea lo encontramos desde la primera serie, pero más especialmente a partir de la segunda y tercera series, donde la línea aparece de forma entrecruzada a manera de raíces de árboles donde cada una mantiene su independencia. En la tercera serie, Reixes, esta línea aparece como hilos sueltos o tentáculos que recorren las rejas. Su carácter gestual hace que se identifiquen con formas encrespadas; raíces, hilos, cuerdas, hierbas, ramas, 
especialmente en la última serie, Herbes donde adquieren un carácter caligráfico. (Véase Fig.23)

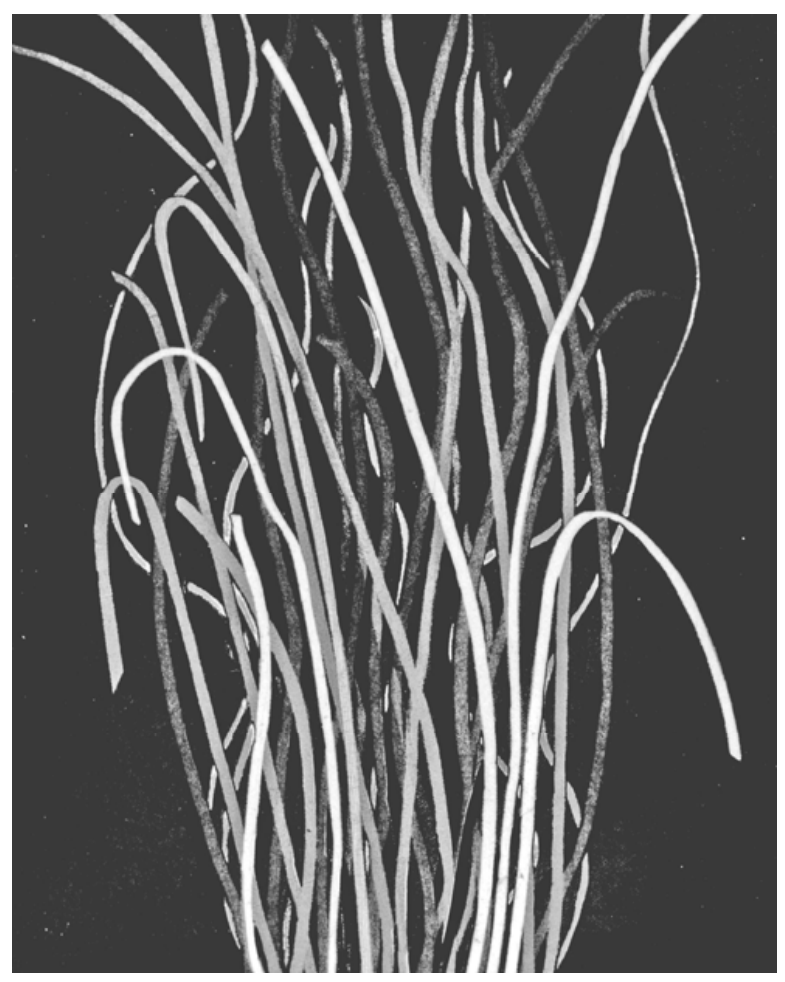

Fig.23. Pilar Dolz, "Herbes" (Acuario de Madame Poulete) Serie Herbes. 1984.

La línea como textura para crear masas se analiza como un conjunto de líneas, trazos o manchas que se superponen para crear amplios planos, superficies, o para generar niveles de profundidad. Este grafismo lo encontramos en las series iniciales creando planos, en su etapa más figurativa construye la ilusión de volumen, pero es sobre todo en su última serie donde aparece yuxtapuesto creando diferentes planos de profundidad. (Véase Fig.24) 


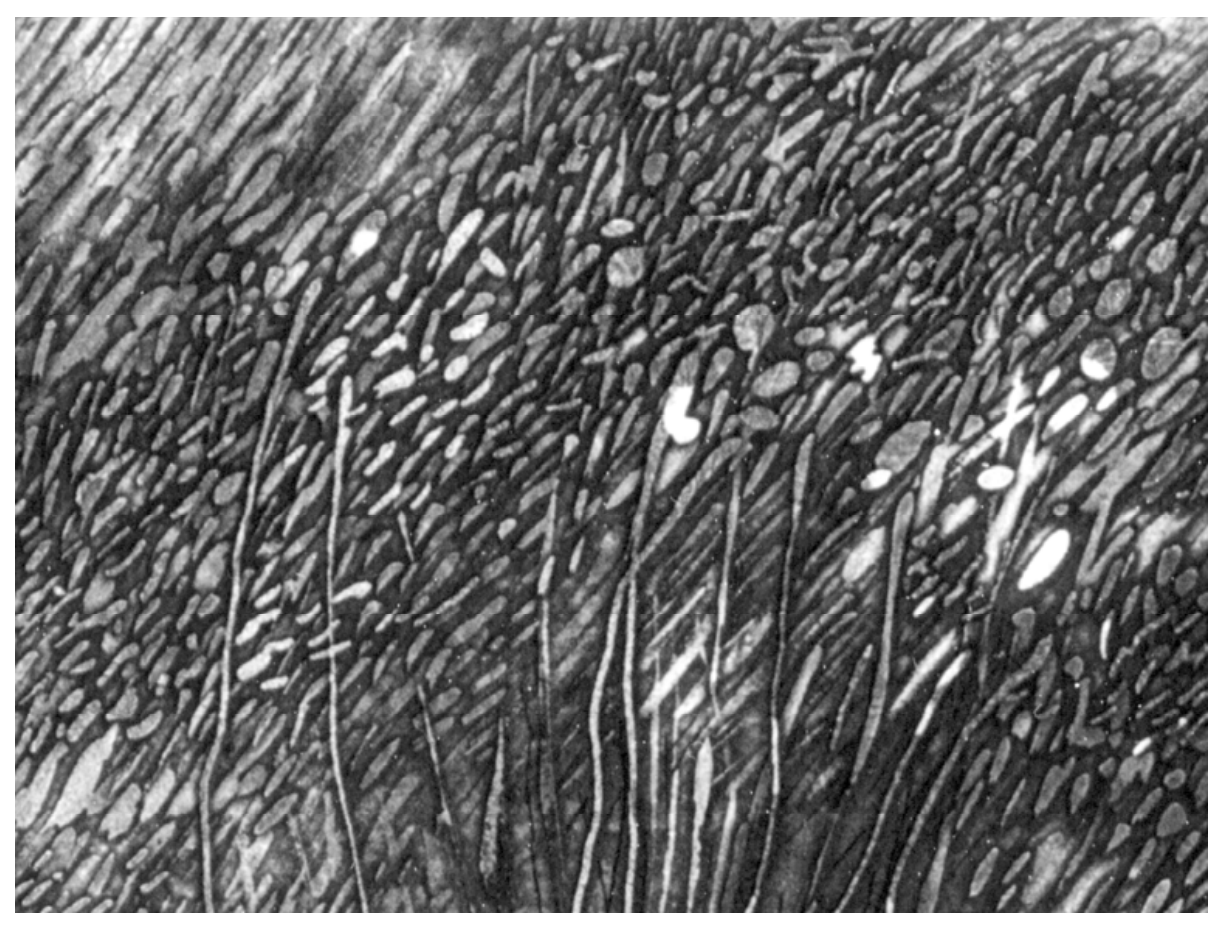

Fig.24. Pilar Dolz, “Herbes XXXVIII”. Serie Herbes. 1989.

\section{- $\quad$ Color}

Desde los inicios por los caminos del arte, el color se convierte en una necesidad imperiosa para Pilar Dolz, desde sus primeros grabados, encontramos una serie de obra gráfica estampada en tonos sepias, naranjas y negros, en los que la artista busca imprimir algunas notas de color con un carácter sobrio. Más adelante experimenta para introducir el color en la obra, aunque lo hace de manera limitada y tímida. Es en la tercera serie cuando aparece el color de una forma más gráfica, en la que la tinta negra tiende a dibujar sobre la tinta de color, buscando una integración. Pero donde realmente empieza a introducir el color de una forma 
más plástica, es a partir de la serie Herbes, donde el color funciona de forma pictórica. Lo cierto es que desde aquellos primeros intentos que hace con el color, nunca más lo deja de aplicar. (Véase Fig.25)

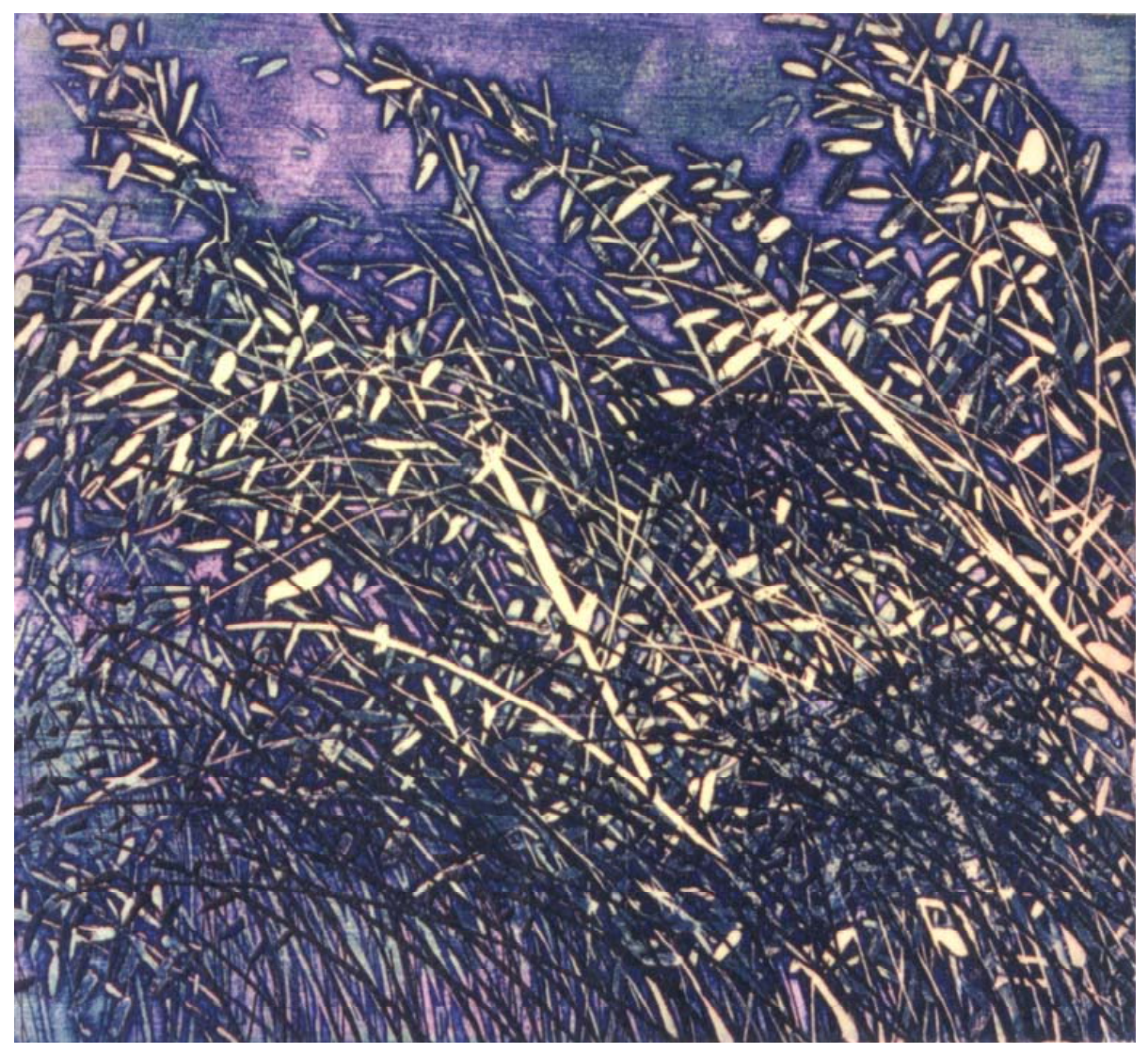

Fig.25. Pilar Dolz, "Herbes XXII" Serie Herbes. 1988

Sin duda este elemento es una de las características más importantes de su obra, no sólo por el aspecto plástico sino por otros valores de tipo psicológico y sensorial que transmite al espectador. 
El estudio de este apartado trata de las cualidades físicas del color, de tono, saturación y matiz, así como su capacidad de expresión, sugestión y emoción. ${ }^{82}$ Para la autora el color tiene valor por sí mismo, posee la cualidad de cambiar completamente la percepción de una cosa, y se puede crear infinidad de colores, de esta manera lo que en unas ocasiones aparece delante, en otras ocasiones emerge por detrás, allí radica la belleza del color. ${ }^{83}$

\subsubsection{Proceso técnico}

La técnica es el medio empleado para plasmar sus ideas, la artista recurre a diversos materiales de gran expresividad, como la piedra, el metal, la madera, entre otros con los que alcanza a conseguir distintas calidades.

El estudio de la técnica se hace necesario, en la lectura de una obra de arte, puesto que para un completo análisis se observa la forma, la iconografía o la capacidad imaginativa del autor, pero también la habilidad técnica, los diferentes procedimientos empleados, la presencia de planchas, la calidad de la estampación, elementos necesarios para entender cómo y de dónde procede la obra, aunque como nos explica la artista:

Las técnicas no tienen mucha importancia, porque toda la vida con un lápiz y un papel se ha podido decir las cosas. Pero a veces al principio tú buscas las técnicas, para expresar lo que quieres decir, pero primero tienes que hacerte con las técnicas. Yo a

\footnotetext{
${ }^{82}$ Véase PUERTA, F.: 2001; p. 205.

${ }^{83}$ Entrevista personal con la autora en Castellón de la Plana. 27/04/2006.
} 
veces la misma obra la hago en litografía y en grabado, porque para mi era una imagen que tenía bastante fuerza. ${ }^{84}$

Para Pilar Dolz el grabado es una técnica que siempre va cambiando, sólo con que se estampe de una forma un poco diferente ya cambia todo. Según la artista se puede hacer una exposición entera con una sola plancha estampada de forma diferente, la calidad de impresión que se obtiene con el grabado, el negro del calcográfico, el aterciopelado de la litografía, no se consigue con ningún otro medio.

Otro aspecto importante a tener en cuenta es el tamaño de los medios, pues éstos han de ser de una medida que se los pueda controlar, que no se caigan, que no se hagan daño cuando se está trabajando.

Siempre digo que un formato tiene que ser la medida física de uno mismo, yo soy mi medida, el rodillo tiene que ir hasta donde lleguen mis brazos, el papel igual. Es decir una medida que uno pueda controlar. Tengo una relación con el grabado y el papel, muy personal, después que a la plancha la pueda mover. (...) Es decir si yo me los estampo, tiene que ser una cosa que yo lo pueda controlar, el papel mojado grande es un problema y no quiero tener problemas, quiero disfrutar. Eso es mi medida. ${ }^{85}$

\footnotetext{
${ }^{84}$ Entrevista personal con la autora en Castellón de la Plana. 27/04/2006

${ }^{85}$ Ibidem
} 
CAPÍTULO 3

\section{STUDIO PORMENORIZADO DE LA} OBRA GRÁFICA DE PILAR DOLZ:

LAS SERIES 



\section{DE FORMAS}





\subsubsection{CONCEPCIÓN.}

La primera serie llevada acabo por nuestra artista surge entre los años 1970 y 1973, perteneciente a sus primeros años de formación artística en el campo del grabado.

Esta obra inicialmente no fue creada bajo el concepto de serie, sino que surge poco a poco de manera automática, como un proceso en cadena donde una forma le lleva a otra, es algo que se tropieza allí en el mismo proceso de trabajo. Hay que tener en cuenta que esta es una época de aprendizaje, en la que se encuentra asimilando la técnica, que era lo que realmente le interesaba, según apreciamos en las siguientes palabras: 
Es una cosa que me encuentro allí, un grabado me lleva a otro (...) porque el grabado es muy reflexivo, porque como tienes mucho tiempo que estas estampando y estas viendo la obra (...) le das vueltas a la plancha, la manipulas sin darte cuenta, porque es un trabajo mecánico, porque cuando estas estampando estas pensando en el próximo grabado prácticamente, porque dices: si a esta forma yo le soluciono así es otro grabado. $^{86}$

Se trata de una serie de formas que vienen de manos del automatismo, son el origen de sus primeras series de grabados, cuyo objetivo es simplemente la más pura expresión de la sensibilidad.

De esta primera serie, brotan obras con clara influencia del surrealismo automático, ${ }^{87}$ de lo que nuestra artista es plenamente conciente, basa la ejecución de la obra de una forma muy parecida a los médiums cuando entran en un estado modificado de conciencia, deja que su mano actué libremente sobre el papel o la plancha, plasmando lo que su mente le dicta de forma irracional, sin el control de la razón, porque se realiza independientemente de la propia voluntad.

\footnotetext{
${ }^{86}$ Entrevista personal con la autora en Castellón de la Plana. 06/05/2005.

${ }^{87}$ Históricamente el surrealismo surge como una respuesta dialéctica a la destrucción estéril preconizada por los dadaístas. Desde el principio se singulariza entre los ismos vanguardistas por el valor que otorga a lo irracional e inconsciente. Surgió por tanto como un movimiento que se concibe como consecuencia plástica de la poesía. Breton que había estudiado medicina, puso en práctica las teorías de Freud sobre el inconsciente, de las que extrajo una nueva propuesta estética. "En su psicología surrealista" expone que el inconsciente es la región del intelecto donde el ser humano no objetiviza la realidad, sino que forma un todo con ella. El arte en esa esfera, es comunicación directa del individuo con el todo, que se expresa de forma privilegiada en las casualidades significativas, en las que el deseo del individuo convergen imprevisiblemente. El surrealismo propone trasladar esas imágenes a la esfera del arte por medio de un ejercicio mental libre, sin la intromisión de la conciencia. De ahí que elija como método el automatismo, recogiendo en buena medida las prácticas mediummínicas espiritistas, aunque cambiando radicalmente su interpretación: lo que habla a través del médium no son los espíritus, sino el inconsciente. Véase PUELLES R, L.: 2002, p.21.
} 
El objetivo de estos trabajos no tiene otra justificación que la suya propia, que no es otra que la emoción del alma y de los sentimientos, se trata simplemente de expresar el funcionamiento real del pensamiento sin ningún tipo de preocupación estética o moral. Esto no quiere decir que sea una práctica puramente mecánica, porque dentro de ésta hay una raíz psicológica que aunque sea automáticamente ofrece sus sugerencias. La autora prefiere llamarles formas del inconsciente, idea que ha expresado en relación a las intenciones que le motivaron a realizar esta obra:

Estas primeras formas son formas del inconsciente, no quiero decir mecánicas o automáticas, sino parece que fuera como una máquina, pero son unas formas del inconsciente, entonces son unas formas que yo no sé ni lo que son ni nada, pero sí que son cosas del inconsciente y que entonces tal y como vas trabajando ves las formas, al mismo tiempo son balbuceos porque aprendes la técnica, pero en aquel momento yo me dejaba ir, nunca ha sido una cosa buscada. En esta época éramos jóvenes y yo no tenía un discurso claro, eran formas que a veces se me hacían divertidas, a veces son como pruebas, de aquí salieron una serie de cosas que después se convirtieron en serie. ${ }^{88}$

En estos momentos se encuentra muy interesada en el psicoanálisis, la psicología humana y el mundo de los sueños, por ello se muestra muy interesada en el pensamiento de Kant, Arp, y sobretodo Freud ${ }^{89}$ pero lo que más le interesa es la escritura

\footnotetext{
${ }^{88}$ Entrevista personal con la autora en Castellón de la Plana. 06/05/2005

${ }^{89}$ El psicoanálisis es una disciplina creada en principio para tratar enfermedades mentales, basada en la revelación del inconsciente. Fue inventada en Viena por Sigmund Freud, un médico neurólogo interesado en encontrar un método efectivo de tratamiento para pacientes que sufrian histeria u otros tipos de neurosis. Tras hablar con estos pacientes, planteó la teoría de que sus problemas tenían como causa los deseos y fantasías reprimidas e inconcientes de naturaleza sexual, social inaceptables. Desde que Freud dio a
} 
automática, el dejar actuar al azar, en la más pura expresión de la forma, sin un referente externo que requiera la presencia de lo reconocible, sino en algo que emerge del inconsciente con toda naturalidad

Su obra no tiene la influencia de un artista en concreto, pero sí su proceso de trabajo, que se basa en la escritura automática tal y como lo hicieran artistas como Matta, Hayter, Miró y Masson, ${ }^{90}$ a los que el automatismo ayudó a alcanzar la absoluta espontaneidad.

Cuando Pilar Dolz realiza estos trabajos, no tiene una idea preconcebida de ejecutar una obra dentro de este estilo en particular, aunque las influencias son evidentes, más bien la intención es simplemente dejarse llevar, utilizando para ello la caligrafía del inconsciente, a través de la cual plasma una idea distinta de la realidad, con un lenguaje simbólico, donde la imaginación y el azar hacen el resto. Su obra se convierte en una expresión del subconsciente a través de formas sensitivas que habitan enigmáticos mundos.

Su manifiesta preocupación sobre el ser humano, no es una idea que podemos apreciar visualmente en su obra ya que las

\footnotetext{
conocer el psicoanálisis en la década de 1890 , ha ido evolucionando y ramificándose en varias escuelas y técnicas de intervención. Véase SCHNEIDER ADAMS, L.: 1996, p.14.

${ }_{90}$ Artistas vinculados al surrealismo que practicaron el automatismo, cuyos medios expresivos de investigación experimental pretenden dar al artista, mayor posibilidad de exteriorizar la verdad interior sin que nada lo obstaculizara. La técnica del automatismo se propago velozmente entre los miembros del movimiento surrealista, siendo uno de los más grandes representantes André Masson, quien comienza su fructífera carrera haciendo dibujos automáticos que expresaba su mundo interior, dentro de la forma y la línea. El surrealismo no ha definido ninguna sigla formal a la que los artistas tuvieran que atenerse, se define como una actitud del espíritu hacia la realidad y la vida, no como un conjunto de reglas formales, ni de medidas estéticas. Véase FER BRIONY.: 1999, p. 187.
} 
formas representadas son de carácter subjetivo, pero sí la percibimos a través de sus planteamientos ideológicos, que nos hablan de su interés por el ser humano y su mundo interior.

Debemos tener en cuenta que España, en la década del setenta está viviendo momentos difíciles debido al régimen dictatorial de Franco, hecho que se refleja con un gran dramatismo en nuestra artista.

Los efectos avasalladores de la represión franquista condicionaron la evolución ideológica de las generaciones surgidas en la posguerra, cuyos momentos se hacen incontenibles al crecimiento de la conciencia crítica, que se identifica con una reacción contra la política centralista. Pilar Dolz pronto encontrará conciliar los dos puntos, el de la conciencia artística y la conciencia social a través del surrealismo, movimiento artístico con el que muchos artistas se sintieron identificados. ${ }^{91}$

\footnotetext{
${ }^{91}$ Para el Surrealismo el problema de la libertad presenta dos facetas: la de la libertad individual y la de la libertad social; por tanto, también deben ser dos las soluciones, para lograr la libertad social a la que se ha de llegar a través de la revolución es fundamental primero alcanzar la libertad del alma. El surrealismo se politiza a partir 1925 a raíz del estallido de la guerra de Marruecos, se producen entonces los primeros contactos con los comunistas que culminarían con la adhesión al Partido Comunista de Breton. Desde este momento, se abrirá una disputa entre aquellos surrealistas que conciben el surrealismo como un movimiento puramente artístico y los que acompañan a Breton en su giro a la izquierda. Véase BRETON, A.: 1970, p.112.
} 


\subsubsection{ASPECTOS COMPOSITIVOS}

\section{Composición}

En esta serie encontramos dos grupos de obras similares en cuanto al planteamiento espacial, pero distintos en cuanto a forma. El primer grupo resulta de la repetición de un mismo grabado, trabajado tres veces con diferentes planteamientos técnicos. Se trata de un grabado de forma irregular, semejante a estructuras geométricas cuadrangulares y rectangulares superpuestas unas a otras, que crean diferentes planos por medio de la intensidad tonal. (Véase LAM. I y II)

El otro en cambio representa formas irregulares abstractas, más dinámicas, producto de la caligrafía automática o el azar, estas representaciones son más suaves y livianas, debido a su estructura fluctuante. A pesar de estar solucionadas con la misma fórmula, es decir por medio de grandes masas tonales de distinta fuerza.

Este primer grupo de obras de apariencia geométrica, son duras y pesadas debido a su propia estructura de forma, pues intervienen en su realización líneas con intenciones horizontales y verticales. Pero contribuye a suavizar esta situación la presencia de cierta forma irregular y espacios blancos, que se ubican en la parte inferior.

El nivel de profundidad en estas obras se logra mediante traslapo, donde los contornos de las distintas formas se entrecruzan 
unas con otras cortando parte de las figuras, a las que ya no las podemos visualizar como una figura completa.

La tendencia perceptiva hace que las veamos como una superposición de formas, así percibimos que una figura pequeña equivalente a un cuadrado ubicada en el centro de la parte inferior, se halla delante de otra de aspecto rectangular, situada también en la parte inferior en sentido horizontal. A la forma rectangular la percibimos incompleta debido a que parte de su contorno se encuentra oculto por la figura que se halla ubicada delante, la misma que por otra parte la distinguimos entera ya que no se encuentra superpuesta por ninguna imagen. Esta situación crea una tensión visual, pues la figura situada detrás lucha por liberarse de la interferencia que sufre su integridad, condición que da a la imagen cierto margen de libertad para que pueda completarse por detrás de la cubierta. Las relaciones espaciales se encuentran resueltas siempre de manera sencilla buscando la simplicidad en todos los sentidos, tanto compositiva como técnica.

En cuanto al grupo de obras que se corresponden a las formas más abstractas y dinámicas, estas toman una forma alargada, cuya parte superior termina por lo general en un perfil redondeada, como si se tratara de una especie de cabeza, estas imágenes actúan primero sobre la sensación llevándonos hacia el hecho reconocible, lo que nos hace pensar en figuras humanas fantasmagóricas, etéreas, debido a la irregularidad de su estructura. (Véase Fig. 26) 

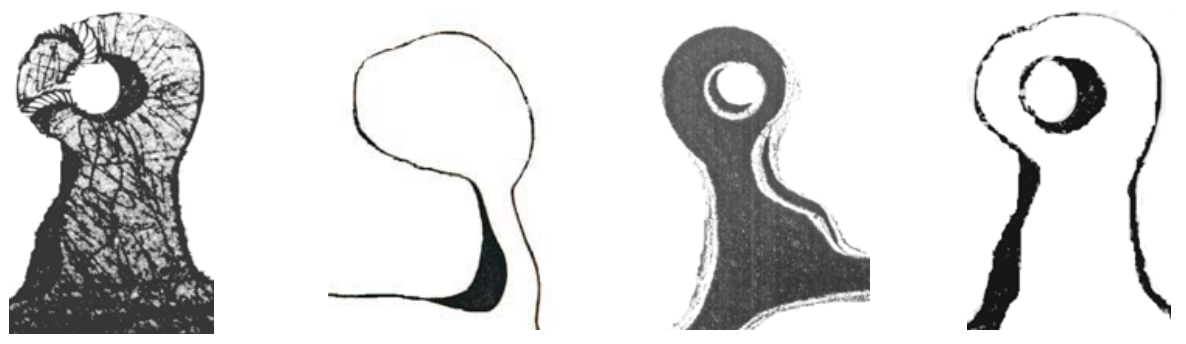

Fig.26. Pilar Dolz. Serie De formas. De izquierda a derecha: Detalle LAM. IX. Barniz blando. 1972, Detalle LAM. III. Aguatinta y barniz blando. 1970, Detalle LAM. V. Aguafuerte y ceras. 1971.

Estas imágenes casi siempre se encuentran representadas en espacios vacíos y también en espacios similares a paisajes desérticos, o incluso siendo parte de ellos. Otra característica permanente de esta obra, es la presencia de una concavidad en la forma, que aparece atravesando la imagen y por la que podemos mirar hacia el otro lado, chocándonos con el vacío y la desolación, con un paisaje espectral ante el que reaccionamos con espanto y angustia. (Véase LAM. III)

En cuanto a su distribución en el plano, se encuentran dispuestas cada una en un lugar determinado, de acuerdo a la escala de ubicación en el espacio, creando un escalafón de superposiciones en la construcción espacial. (Véase LAM. IV)

Otras veces estas formas se encuentran entrecruzadas y entrelazadas unas a otras por medio de unos agujeros, que acercan y alejan la forma, de un plano a otro, originando cierto movimiento en los diversos planos de profundidad. (Véase LAM. V) 
Otra forma de ubicar la imagen en el espacio es a través de un esqueleto de peldaños de distintas tonalidades, que sitúan a la forma en una especie de montaña escalonada, a través de la cual podemos visualizar los distintos niveles de profundidad. (Véase Fig. 27)

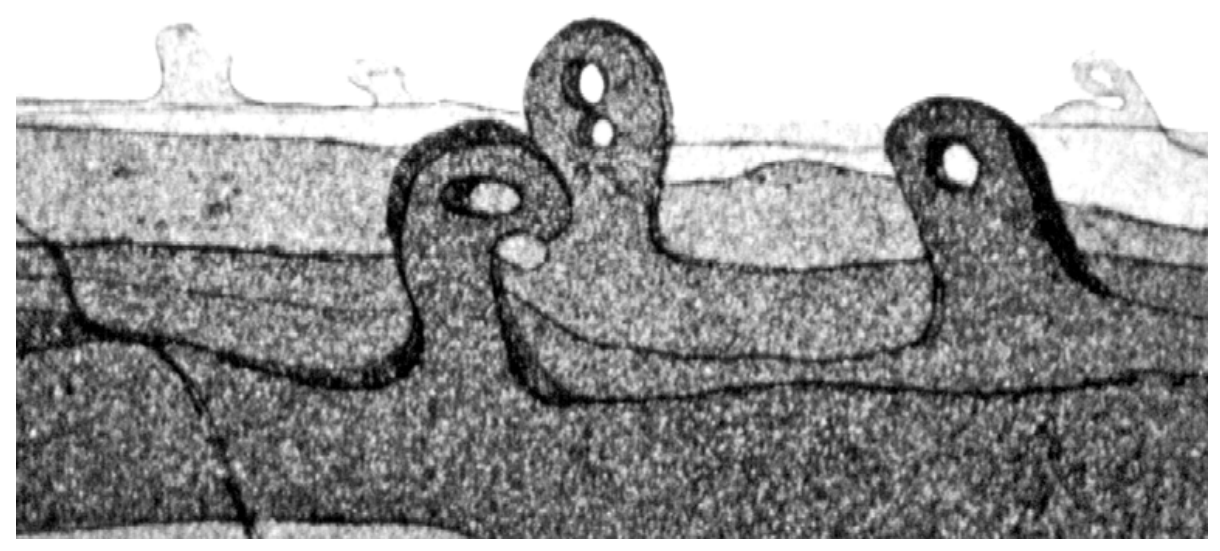

Fig.27. Pilar Dolz. Detalle LAM. VI. Serie De formas. Aguatinta y azúcar. 1970

Con la superposición de la forma, Pilar Dolz crea con acierto una secuencia visual de profundidad, ya que la construcción espacial carece de otro tipo de perspectiva.

Otra manera de trabajar sobre el espacio, es el de intervenir directamente sobre éste, cortando la plancha que se va a estampar previamente en una forma determinada, de esta manera el espacio ocupado por la imagen adopta esta forma particular. En este caso la matriz toma la forma de la figura incorpórea que se encuentra 
dibujada en el grabado y el papel de estampación se convierte en el fondo de la forma, en un juego espacial donde un espacio se inscribe dentro de otro espacio. (Véase LAM. VII)

Otro planteamiento espacial es la relación de lleno y vacío, donde juega con dos trozos de plancha recortada. La una, de formato relativamente más pequeño que la otra y situada en la parte superior derecha, representa en su parte exterior un formato normal cuadrado, mientras que en su parte interna se halla recortada y vaciada, siguiendo la forma de un hueco irregular troquelado en la plancha, estampada sobre el papel con tinta negra. La otra plancha en cambio se encuentra recortada por su parte externa, siguiendo la forma de la imagen recortada y vaciada de la plancha anterior, a manera de una cabeza larga y redondeada que sale de una base rectangular. Esta plancha se encuentra estampada sobre el papel sin tinta, dejándonos ver unos suaves gofrados, que sobresalen de la superficie blanca del papel, como unos delicados relieves perceptibles a la incidencia de la luz, a través de los que podemos distinguimos la huella dejada por la mano de la artista. Los cortes realizados en las planchas, permiten que estas dos piezas se ensamblen entre sí, como si de un puzzle se tratara. Distinguimos así como el vacío, representado por la plancha gofrada, se integra con el lleno caracterizado por la plancha entintada, diferenciando y armonizando a simple vista el tratamiento de las dos planchas. (Véase LAM. VIII) 


\section{Grafismo}

El tratamiento de la forma esta dado por la caligrafía automática, uno de los factores dominantes de la serie, por lo que la línea es un elemento gráfico que lo define muy bien.

En el primer grupo de obras antes mencionado, la línea destaca visiblemente sobre la forma, porque el tipo de línea empleada para realizar la imagen, es la línea que denominamos de contorno, como su nombre mismo lo dice es utilizada para contornear y dar forma a la imagen. Esta caligrafía sobresale de entre el resto por su aspecto grueso y profundo, característica que hace que la forma resalte de manera más evidente. La rigidez del trazo y su espesor nos transmiten fuerza y agresividad.

En LAM. I, la disposición de sus elementos se encuentran ubicados por oposición, así una forma irregular de estructura semejante a un cuadrado emerge de la parte superior, como si estuviera colgando de la línea límite superior de la matriz, mientras que otra muy parecida a ésta, de forma un poco más grande, surge de la parte inferior central. Con esta disposición, las líneas que la conforman también cambian de sentido, así el trazo de la parte inferior toma sentido ascendente, mientras que el rasgo de la parte superior toma sentido descendente, creando cierta armonía de relaciones espaciales.

Hemos de aclarar que estas líneas nunca son del todo rectas, porque son realizadas a mano alzada, respetando el gesto de la artista, cada una lleva un tratamiento diferenciado. El trazo inferior, 
de la forma que cuelga de la parte superior presenta una curvatura muy pronunciada orientada hacia su parte interior, rompiendo con el estatismo y dureza de la imagen, aportando mayor sutileza a la forma.

El espacio encerrado entre esta forma, conforma una mancha gris compacta, creada por la superposición de una serie de líneas verticales e inclinadas realizadas en un solo sentido, de izquierda a derecha, creando un entramado con cierto dinamismo, en el que podemos distinguir el movimiento realizado por la línea oblicua, originando un cierto efecto vibrátil cuando nuestros ojos fijan la mirada hacia estas. En cuanto a su forma y textura, se caracterizan por ser muy finas y delgadas en contraste con las que conforman el contorno de factura granulosa y espesa. (Véase Fig. 28)

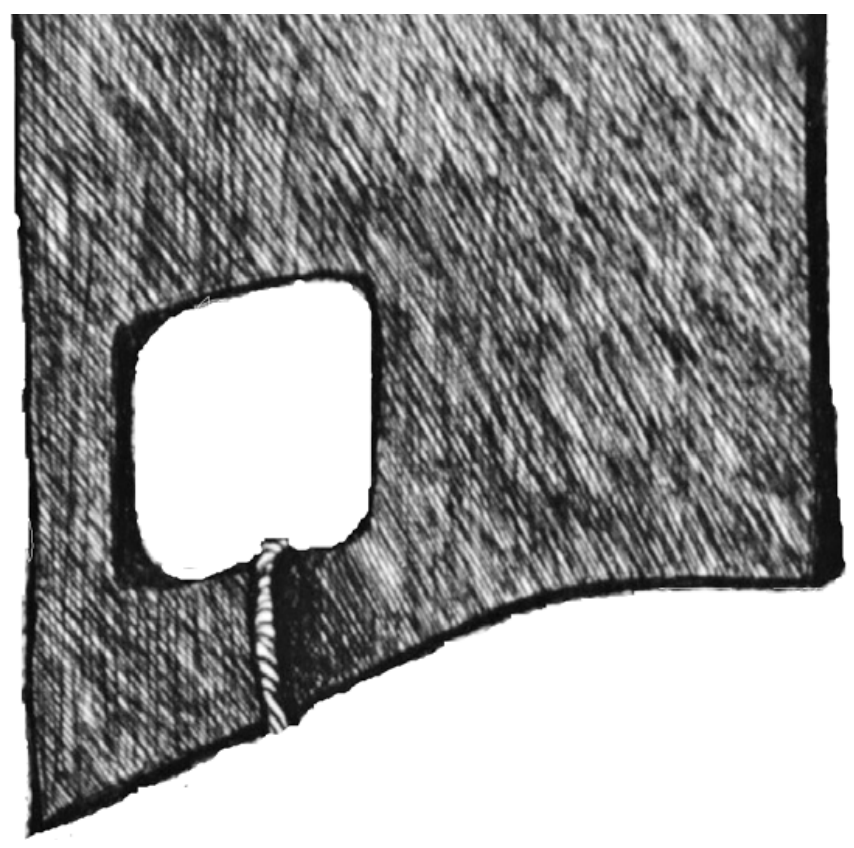

Fig.28. Pilar Dolz. Detalle LAM. I. Serie De formas. Aguafuerte. 1970. 
La figura ubicada en la parte inferior en cambio se encuentra realizada por una línea doble, dura y quebrada, con la que crea una sombra densa y gruesa. La línea que contornea la parte superior de la forma, es igual de dura y gruesa que el resto, pero lleva cierto movimiento que agita la raya de arriba hacia debajo de forma suave, en cuya trayectoria tropezamos con una especie de peldaño angular, áspero, que termina en una punta cortante que surge como un relieve justamente en la parte centro de la línea, rompiendo con esto la armonía de la imagen con cierta agresividad. Observamos la ausencia de una cuarta línea que debería cerrar la forma cuadrangular, sustituida por la línea límite del soporte, debido a que estas imágenes surgen como si emergieran del espacio exterior. Su superficie se caracteriza por estar trabajada con un entramado de líneas en todas direcciones; horizontal, vertical y oblicua, poco reconocibles individualmente, creando una espesa mancha plana de tono muy oscuro. (Véase Fig. 29)

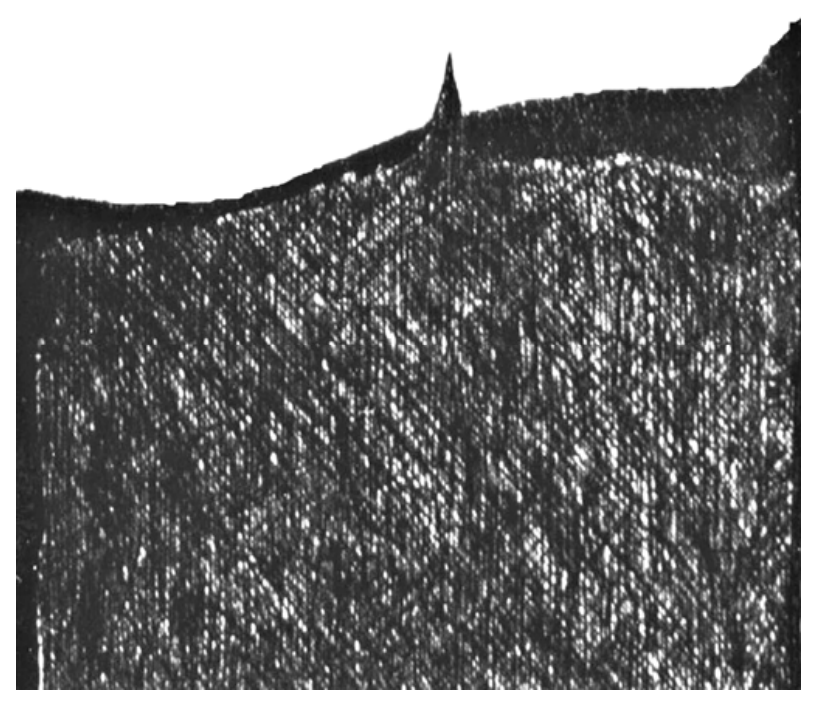

Fig.29. Pilar Dolz. Detalle. LAM. I. Serie De formas. Aguafuerte. 1970. 
Tenemos la presencia de una tercera imagen que aparece por detrás de las dos ya mencionadas, esta se encuentra ubicada en la parte inferior del plano en sentido horizontal y aparece cruzando toda la superficie del plano. Su forma está dada por un trazo único variable que camina toda la superficie, y en cuya recorrido surge una forma extraña y voluminosa, como si de una ola gigantesca se tratara, esta imagen nos transmite paz y serenidad, a la vez que rompe con la monotonía del sentido unidireccional del trazo, para crear una forma más dinámica y activa. Esta forma que surge aproximadamente en el centro del plano se ubica por detrás de las dos ya mencionadas, colisionando todas estas en este punto central del plano. En cuanto a la imagen que emerge de entre esta línea, ésta posee un forma semicuadrangular, cuyos ángulos están redondeados y es de tamaño relativamente grande, similar a las dos anteriores, en cuya parte central posee una gran abertura interior, a través de la cual podemos mirar hacia el otro lado, y por la que vislumbramos el espacio exterior, que se extiende libremente. El área encerrada en el interior de la forma, no se encuentra sometida a ningún tipo de trazo, por lo que vemos el blanco del papel en la estampación, situación que da un aspecto más sólido a la forma, por el sólo hecho de estar limitada por una línea, lo que nos remite a pensar en una forma plana, mientras que el área que se extiende fuera de estos límite es más libre porque no está limitada o encerrada por ningún tipo de línea o mancha.( Véase Fig. 30) 


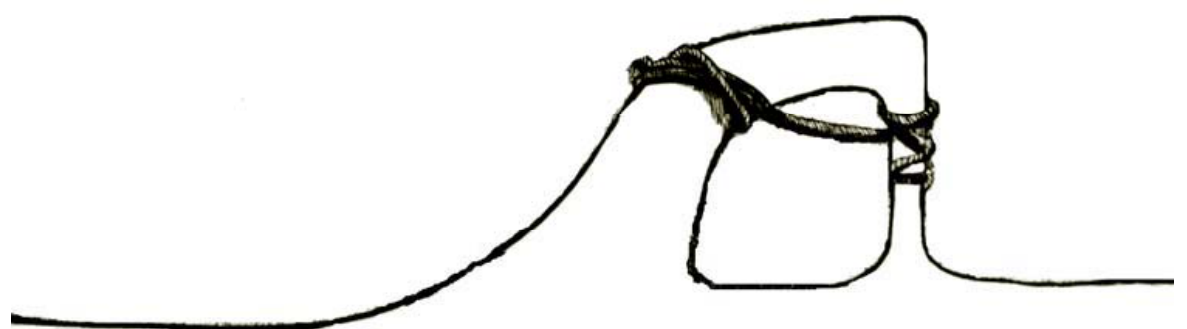

Fig.30. Pilar Dolz. Detalle LAM. I. Serie De formas. Aguafuerte. 1970.

El espacio exterior representado por el espacio que queda fuera de estas formas, está resuelto por dos tipos de líneas, un trazo largo diagonal en los dos sentidos; derecha-izquierda, izquierdaderecha, de factura muy fina, creando una película muy suave y delicada. $Y$ el otro en cambio es un trazo corto y desornado, que se superpone sobre esta película fina, a manera de minúsculas líneas, cortas y fragmentadas que aparecen como puntos y comas, distribuidos irregularmente por toda la superficie de modo desordenado, originando movimiento y consiguiendo un efecto lumínico en la superficie atmosférica.

En el segundo grupo de obras el tratamiento de la línea es mucho más suave, precisamente porque el perfil de la forma al ser intangible, la línea que lo borde sigue ese camino ondulante y sinuoso, concibiendo una línea suave y delicada. (Véase LAM. IX)

La línea se abre paso por el espacio siguiendo un camino sinuoso, de entrantes y salidas, subidas y bajadas, transformando este espacio en un objeto bidimensional de forma irregular. Se trata 
de formas realizadas de manera inconsciente, impulsiva, y espontánea, donde no existe tanto interés por el resultado final como por la sensación de experimentar su propia realización. Estas formas están resueltas por un trazo continuo, en algunos casos la línea de contorno esta sustituido por la línea que marca la aguatinta, realizada por medio de mordidas más o menos profundas. (Véase LAM. IV)

En LAM. III en contraste con la suavidad de estas líneas, nos encontramos con otro tipo de línea realizada por medio del barniz blando donde se reproduce la huella de una textura orgánica, que nos presenta un entramado de líneas horizontales y verticales, dispuestas de manera racional y ordenada, pero que no llegan a dibujarse por completo en la plancha, sino que solamente sobresalen los puntos de unión más altos del tejido, y que se hacen evidentes en el momento en que se pasa la plancha por el tórculo, creando de esta manera una red de puntos, que aparecen ante nuestra vista como un efecto óptico al estilo impresionista, en el que la disposición de estos se completan perceptualmente en una serie de líneas horizontales y verticales formando una especie de retícula, sobre la que se dibujan estas formas espontáneas y armónicas que rompen con este estatismo del fondo. (Véase LAM. III)

En LAM. XII asimismo nos encontramos con un trazo más suelto, mecánico que se caracteriza por su simplicidad. Se trata de un grupo de líneas muy finas que recorren un sinuoso camino de forma muy pegada entre ellas, normalmente de manera ordenada, que aunque estas estén muy juntas podemos mirar la forma y las 
características propia de cada una en cuya trayectoria llegan a tropezar entre ellas, es un trazo muy activo, que cambian de dirección pero siguiendo un camino ordenado, mantienen su autonomía, tanto así, que si nos propusiéramos contarlas una a una no tendríamos problema alguno. (Véase Fig. 31)

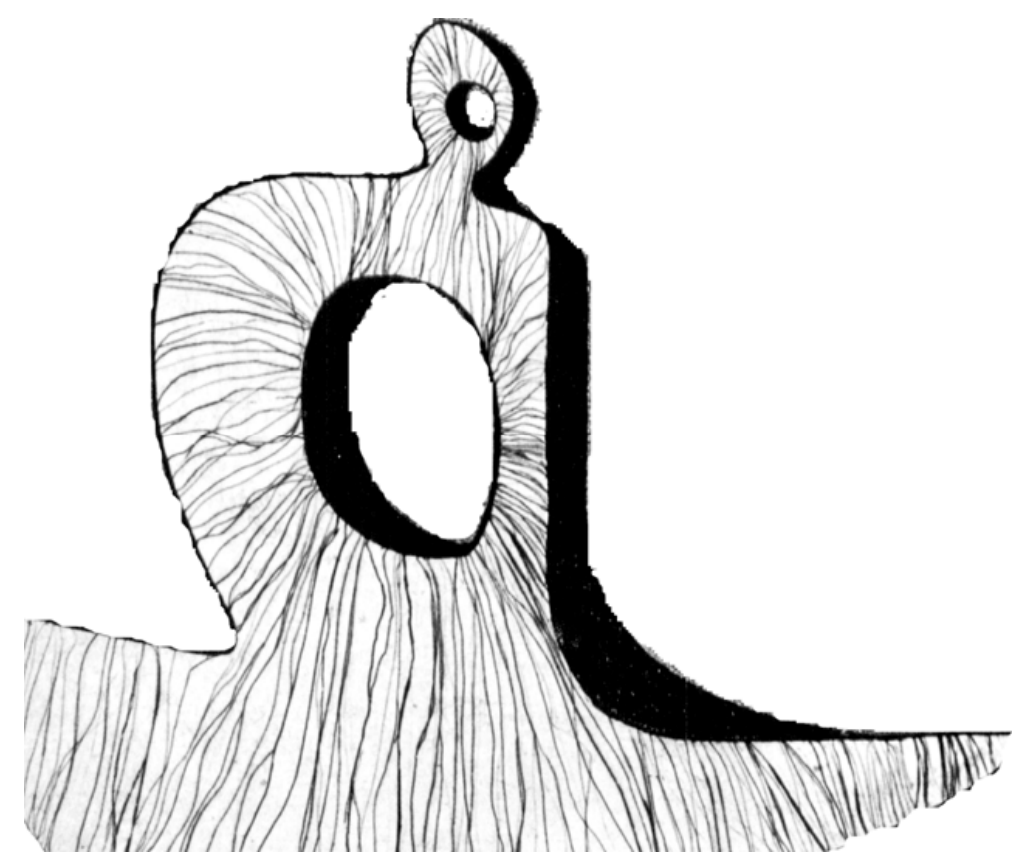

Fig.31. Pilar Dolz. Detalle LAM. XII. Serie De formas. Aguafuerte y aguatinta. 1970.

Igualmente en LAM. V encontramos otro tipo de línea producida por la ausencia de tinta con un planteamiento distinto al del dibujo con tinta negra sobre un espacio blanco. El procedimiento es distinto, se trata de unas masas tonales lisas y planas, producidas por medio de la aplicación de resina y mordidas al ácido a distintos tiempos, obteniendo con esto diversidad de tonos que van del gris al negro. La línea aparece alrededor de estas formas dibujando su 
silueta, por medio de unas líneas blancas reservadas con ceras, o bruñidas sobre las manchas obtenidas por la resina, y en las que la línea aparece como un resplandor de luz que sobresalen de entre las diferentes masas tonales, especialmente sobre el negro del que emana con gran fuerza. Con esto se presenta un planteamiento negativo-positivo, luz y sombra, donde el negativo esta identificado por la ausencia de tinta y el positivo por la presencia de esta. (Véase Fig. 32)

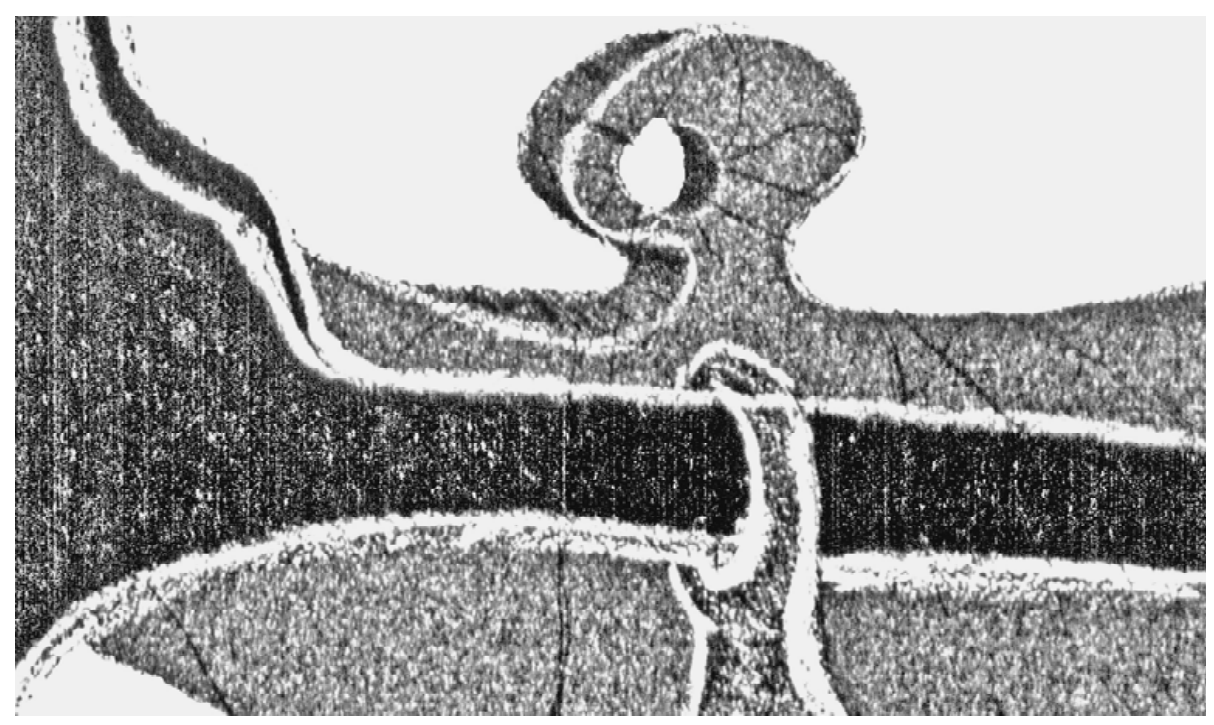

Fig.32. Pilar Dolz. Detalle LAM. V. Serie De formas. Aguafuerte y ceras. 1971

Como ya se ha visto antes, esta no es la primera vez que Pilar Dolz presenta esta propuesta de trabajo, donde la línea de dibujo no se representa por medio de un pigmento. En otro grupo de grabados el grafismo que da forma al objeto no existe como tal, como materia pigmentaria, sino que aparece a nuestra vista como el contorno de la forma del soporte, es decir que el soporte mismo como matriz de 
estampación es la misma obra, sobre la que se refuerzan elementos accidentales existentes en la misma plancha. Este contorno de la plancha es producido por la acción motora de la mano y el brazo de la artista, en la que no interviene la punta o el pincel, sino una sierra manual para cortarla y darle la forma. Lógicamente este contorno al depender de una herramienta es vacilante y tosco, tampoco la artista busca la perfección al recortar la plancha, sigue manteniendo esas formas, los agujeros, que presentan el camino ondulante, sinuoso de su estructura, resultado de un proceso dinámico y armonioso. (Véase LAM. VII)

Otra manera de hacer presente el trazo, lo encontramos en LAM. VIII a través de suaves gofrados realizados sobre la plancha de zinc, donde su ejecución es puramente lineal, son unos trazos más controlados y mecánicos, que siguen la forma del formato de la matriz, que por otro lado representa una forma etérea, incorpórea. Estos trazos son más cortos o más largos dependiendo del sitio de la forma por donde circule la línea, normalmente son más largos en las zonas donde la superficie es más amplia, pero es un trazo continuo que se realiza sin interrupciones, y sigue caminos individuales que en ningún momento llegan a superponerse, pero todos llegan a concentrarse en varios punto, estos gofrados se encuentran solucionados a través mordidas suaves al aguafuerte, por lo cual los gofrados lo percibimos suave y delicado, la proyección de la luz sobre estos relieves nos permiten vislumbrar la huella del acto gestual de la artista, sin la necesidad de la intervención de la tinta para hacerse visibles. (Véase Fig. 33) 


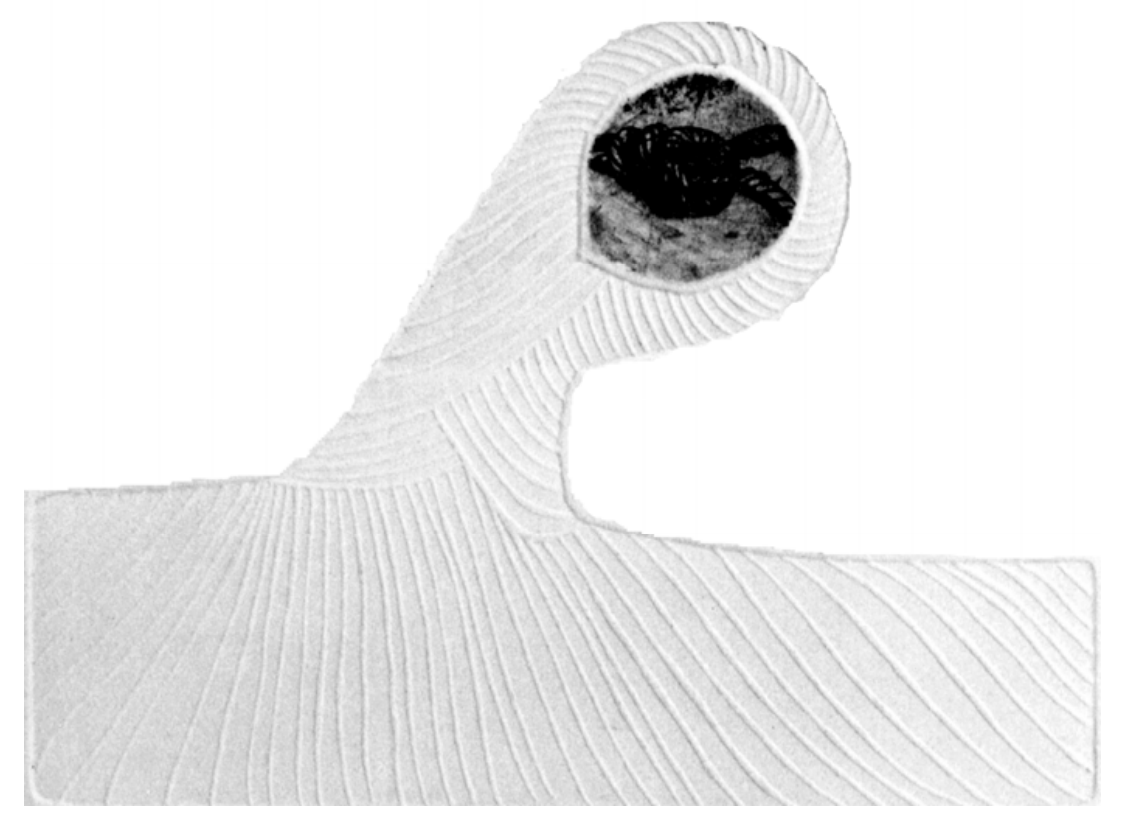

Fig.33. Pilar Dolz. Detalle LAM. VIII. Serie De formas. Aguafuerte y gofrado. 1971.

\section{Color}

En esta serie aun no podemos hablar de color, ya que este elemento no existe, por tanto este es un trabajo monocromático, realizado con una sola tinta, normalmente de color negro, aunque en varias ocasiones suele emplear también tintas de color sepia y naranja, pero que siguen siendo monocromáticos, basada en una escala de tonos que van del más claro al más oscuro.

Normalmente estos tonos se corresponden a manchas planas lisas, aunque en otras ocasiones estas manchas adquieren aspecto irregular, producidas por alguna mancha preexistente en una plancha vieja, potenciada posteriormente con la 
técnica. Otras veces se corresponde al trazo gestual de nuestra artista que a resuelto a través de diferentes pincelas sueltas sobre la matriz y puesta a morder al ácido con diferentes tiempos, creando de esta manera diversidad de tonalidades. Normalmente estos tonos sirven para crear varias escalas de profundidad o para diferenciar unas formas de otras, pero nunca para crear volumen. (Véase LAM. VI)

Si bien en esta primera serie todavía no interviene el color, encontramos excepcionalmente una única obra correspondiente a esta serie, fechada en 1971 en la que podemos hallar la intención más temprana de nuestra artista en la introducción del color.

En LAM. X el color se introduce por medio de dos planchas; una impresa en tinta negra y otra en roja.

La primera matriz estampada en tinta negra, lleva dos formas horizontales, dispuestas en el centro del plano de forma paralela, resueltas a base de una serie de líneas extremadamente finas realizadas a buril, que caminan de manera ondulante por el interior de la forma, con la intención de proporcionarle un efecto volumétrico.

La segunda plancha impresa en tinta roja, lleva consigo una mancha irregular en sentido vertical, que cruza las dos formas horizontales, sin llegar a sobreponerse. Esta mancha se encuentra realizada por la fricción continua de un trapo empapado de barniz blando, que deja grabada la huella de su textura. 
Al momento de la estampación, las dos tintas no llegan a superponerse, pues la tinta roja no cruza la negra sino que la atraviesa. Para conseguir este efecto, la artista cortar la plancha, dejando vacíos los espacios que se corresponden a la tinta negra, con el fin de que no se mezclen los colores y después con mucho cuidado y haciéndola coincidir con un perfecto registro se procede a estampar la matriz

Eso es una forma muy gráfica, yo corté esta raya roja y después la hago coincidir, que más daba que pasara por encima del buril o que el buril pasara por encima de lo otro. Yo ahora es cuando pienso que la superposición de los colores es una riqueza...

Después de los conocimientos acerca del color obtenidos en Massana y en la Escuela de Bellas Artes al más puro estilo impresionista, cuando Pilar Dolz llega a las Artes del libro le resulta difícil trasladar esos conocimientos al grabado, pues la técnica en un principio se le presenta muy rígida y fría, como nos cuenta Pilar Dolz en una entrevista:

Yo tenía un profesor en pintura que tenía una paleta muy impresionista con poquísimos colores, (...) nosotros mezclábamos así, todavía con unos principios muy impresionista, una cosa que después me ha ido bien con el grabado. (...) La pintura que hacíamos era así, en cambio cuando llego al grabado eso no lo podía hacer, no lo sabía hacer y no había nadie que me enseñase. $^{93}$

\footnotetext{
${ }^{92}$ Entrevista personal con la autora en Castellón de la Plana. 16/05/2005

${ }^{93}$ lbidem
} 


\subsubsection{PROCESO TÉCNICO}

Este conjunto de obras corresponde a su etapa de formación en este campo de la gráfica, por tanto la técnica es relativamente nueva para nuestra artista, quién desde sus inicios dedica todos sus esfuerzos a indagar en la técnica, materiales, herramientas, así como dentro de sus propuestas artísticas.

Esta primera serie se encuentra realizada en su totalidad por la técnica calcográfica, sobre la que interviene siempre con los distintos procedimientos tradicionales del grabado, con los que la artista según nos comenta, no pretende investigar nada nuevo, sino que prefiere utilizar ciertos elementos ya existentes, para realizar su obra.

A mi no me divierte investigar, para mí investigar quiere decir que tú vas trabajando y vas aportando cosas, por eso cuando alguien dice investigar en grabado, me da un poco el pánico, es que en el grabado tú puedes hacer todo lo que quieras, porque puedes quitar, cortar, poner, todo lo paso por el tórculo y esta allí. Quiero pensar que aporto algo, pero algo tan pequeño, que si aporto algo bien, pero yo no pretendo nada por encima de los demás. ${ }^{94}$

Normalmente las técnicas con las que trabaja son las más habituales y los materiales utilizados los más comunes, como ella misma nos dice, "tomo lo que encuentro a mano". Pero sin duda lo más importante de este trabajo es el planteamiento conceptual, que le lleva a la búsqueda de una simplicidad técnica y estética, donde

\footnotetext{
${ }^{94}$ Entrevista personal con la autora en Castellón de la Plana. 07/03/2005.
} 
una buena raya al aguafuerte o una pincelada al azúcar, pueden ser suficientes para decir lo que se quiere contar. Con este planteamiento la artista pretende que su trabajo sea una cosa comprensible, fácil y sencilla, pues nos cuenta que en muchas ocasiones en grabado o en pintura se tiende a investigar algo, y lo que realmente se hace es añadir una serie de elementos que lo hace más difícil todo. Por eso para ella es muy importante llegar a una simplicidad, donde el espectador pueda entender y comprender su obra y que además se quede emocionado con lo que esta mirando.

Si para hacer grabados de color necesitamos tres planchas y lo podemos conseguir con una, ipara que vamos hacer tres planchas! si después en los resultados se esta viendo que es más rico. Si una persona no necesita color y es bueno con el blanco y negro, para que necesita meter color. Hay que sumar técnicas si eso te ayuda a decir lo que quieres, pero sino, no hace falta. ${ }^{95}$

La ejecución de su obra se realiza con lo que encuentra a su alrededor, pero sobretodo apuesta por aquellos que tiene más a su alcance, como pinta labios, ceras, lacas de cabello, planchas tiradas a la basura, le da igual si una plancha es de cobre o zinc, o si es nueva o vieja, porque lo que realmente le importa es lo que se dice y como se dice.

Numerosos grabados surgen de circunstancias accidentales, donde el automatismo se pone de manifiesto por el impulso gratuito de una mancha eventual que actúa como provocador óptico, y que

\footnotetext{
${ }^{95}$ Entrevista personal con la autora en Castellón de la Plana. 16/05/2005
} 
hace que se intensifique aquella mancha a través del pensamiento de la artista. ${ }^{96}$ Muchas de estas manchas encontradas o producidas accidentalmente estimulan su fantasía y le sugieren mirar una serie de formas extrañas.

En continuas ocasiones estas manchas que resultan del óxido de la plancha, de una quema involuntaria en el ácido, por el derramamiento accidental o provocado de algún elemento, pierden su carácter original y se convierten ante los ojos de Pilar Dolz, en una serie de formas inesperadas, que después potenciará lo que le sugieren, apoyada lógicamente en el conocimiento técnico y artístico que posee. (Véase Fig. 34)

\footnotetext{
${ }^{96}$ Este procedimiento es un análogo del fotomontaje, el collage y el frottage. La aplicación de este procedimiento se remonta a 1925, y el precursor de la teoría del provocador óptico fue Leonardo da Vinci, quién habla de la mancha en el muro, que excita la imaginación a seguir la formación de las más extrañas imágenes. El procedimiento del frottage fue inventado por Max Ernst, que nos recuerda a un juego infantil, el de colocar una hoja de papel sobre una moneda y frotar con un lápiz sobre esta para hacer salir su imagen. Ernts ejercitó este juego con las más disparatadas materias trozos de madera, tela de saco deshilachada, que luego tomaban el aspecto de una serie de insólitas formas que nacían ante la mirada estupefacta de Ernst, cabezas humanas, de animales, rocas, el mar y la lluvia. Véase DE MICHELI, M.: 1998, p.184.
} 


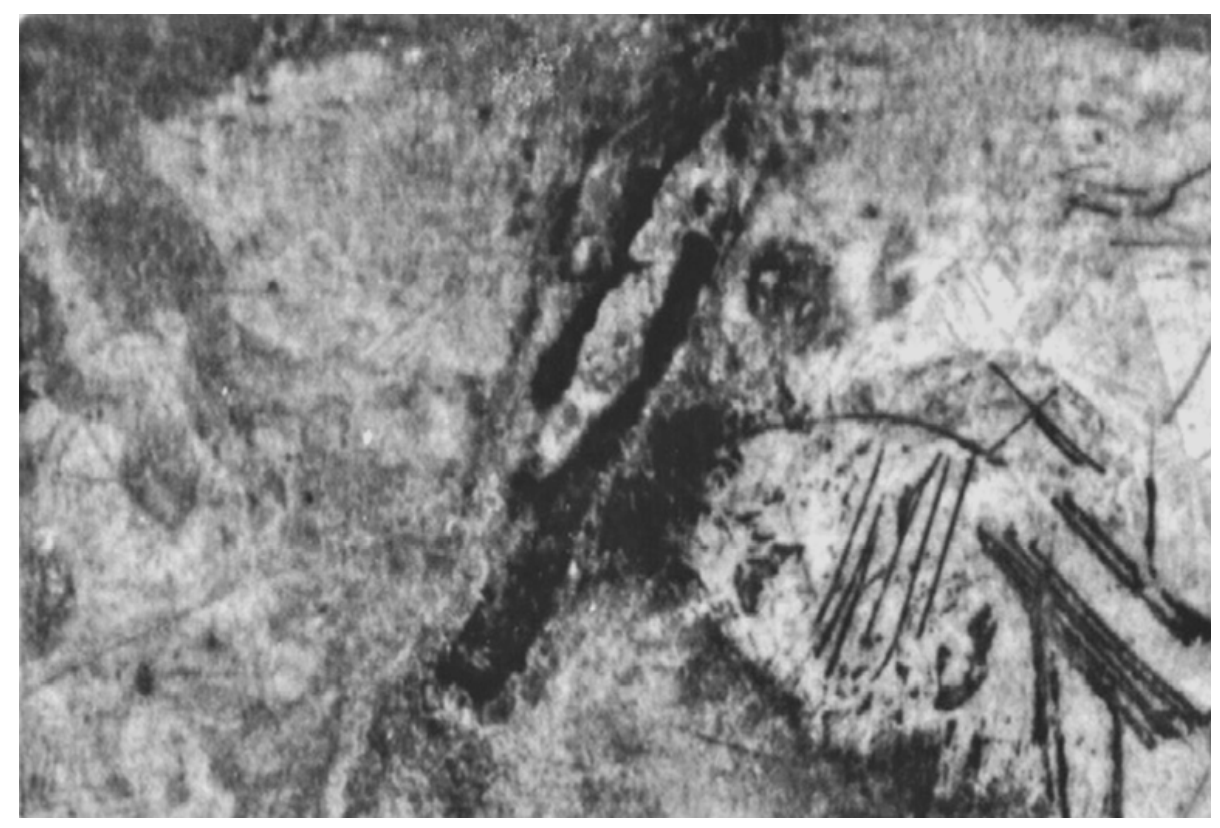

Fig.34. Pilar Dolz. Detalle LAM. VIII. Serie De formas. Aguafuerte y gofrado. 1971.

En otras oportunidades deja simplemente fluir la punta sobre el barniz, haciendo surgir espontáneamente estas formas etéreas, las mismas que en muchas ocasiones se encuentran ubicadas dentro de una especie de paisajes, que luego seguirán saliendo en otras series. Estos paisajes habitualmente surgen de su memoria, de su interior, quizás porque los ha visto en algún sitio. Por esta razón alguna de las cosas que parece que sean figurativas, en realidad resulta que son caligrafías del inconsciente, formas que después son reforzadas con la técnica, y adoptan formas reconocibles o no, motivo por el cual algunas de estas imágenes se nos presentan más figurativas y otras no. 
Muchas veces el material utilizado es material reciclado, pues el hecho de trabajar en un taller grande, y con muchísima gente, siempre le da la oportunidad de encontrar planchas y demás materiales tirados en la basura, ya sea porque se han estropeado, por algún rayón o alguna mancha, accidentes que ella aprovecha para realizar su obra.

Otra de sus prácticas más habituales es la de realizar una misma obra varias veces a través de los diferentes procedimientos del grabado, lo que le brinda la oportunidad de comparar y ver las distintas posibilidades y resultados que le ofrece una técnica y otra. Frecuentemente recurre también a grabados realizados con anterioridad, para volver a incidir sobre estos, o para trabajarlos con diferente técnica, así observamos como una misma obra realizada años atrás, vuelve a reaparecer en años posteriores. Un ejemplo de esto lo encontramos en el primer conjunto de grabados de esta serie donde encontramos una misma obra realizada tres veces con diferentes técnicas.

La primera obra se encuentra realizada al aguafuerte trabajada de manera tradicional, solucionada a través de pequeños trazos lineales efectuados con una punta metálica sobre la plancha de zinc, cubierta con barniz y posteriormente puesta a morder al ácido, proceso que se vuelve a repetir varias veces yuxtaponiendo la línea en diversas posiciones, sensibilizando la superficie del soporte. (Véase LAM. I) 
Posteriormente encontramos el mismo grabado reproducido a la aguatinta, con la finalidad de que estas grandes áreas, adquieran un aspecto más suaves y pictórico. Situación que se consigue con la aplicación de una suave resina espolvoreada y distribuida de manera uniforme sobre la plancha limpia y desengrasada, y puesta a la acción del ácido con diferentes tiempos para conseguir distintos tonos. (Véase LAM. II)

En el siguiente grabado se vuelve ha incidir sobre la misma plancha de aguatinta, en la que interviene con el fin de extraer blancos de entre las zonas más saturadas. Este proceso de trabajo se realiza de manera tradicional, a través de la utilización de un bruñidor fino, con el que realiza una línea larga y escabrosa que bordea la zona más oscura de la superficie, de la que elimina la textura rugosa y granulada, rebajando y aplastando completamente dicha superficie. Este espacio lineal al quedar liso no es capaz de recoger tinta, por tanto esta zona quedará blanca al momento de la estampación. (Véase LAM. XI)

Como hemos podido ver la obra de nuestra artista tiene su origen en el automatismo, el azar y causas circunstanciales y accidentales, tanto de la propia materia como de la propia naturaleza del proceso, que le obligan a ir tomando decisiones en el transcurso de este. Lógicamente el método de trabajo que se realiza sobre la matriz es una labor directa que guarda una íntima relación entre la artista y la materia. 
Otra de las técnicas empleadas es la de aguatinta al azúcar, producida por el acto gestual de la artista, que consiste en la realización del trazo directo sobre la plancha a través de la utilización de un pincel cargado de un producto que resulta de la mezcla saturada de tinta china y azúcar, situación que permite que se vaya viendo la imagen en positivo mientras se va realizando el dibujo, es decir forma oscura sobre un fondo claro y con el que se consigue el efecto de grandes pinceladas. Una vez seca esta mezcla se procede a recubre la plancha con un barniz líquido, cuando este ha secado se levanta la tinta aplicada con el pincel con abundante agua caliente, dejando al descubierto el metal en las zonas dibujadas con el pincel, que son las zonas donde actuará el ácido, mientras que el resto de la plancha queda protegida por el barniz impidiendo que el ácido actúe sobre esta área. (Véase Fig. 35)

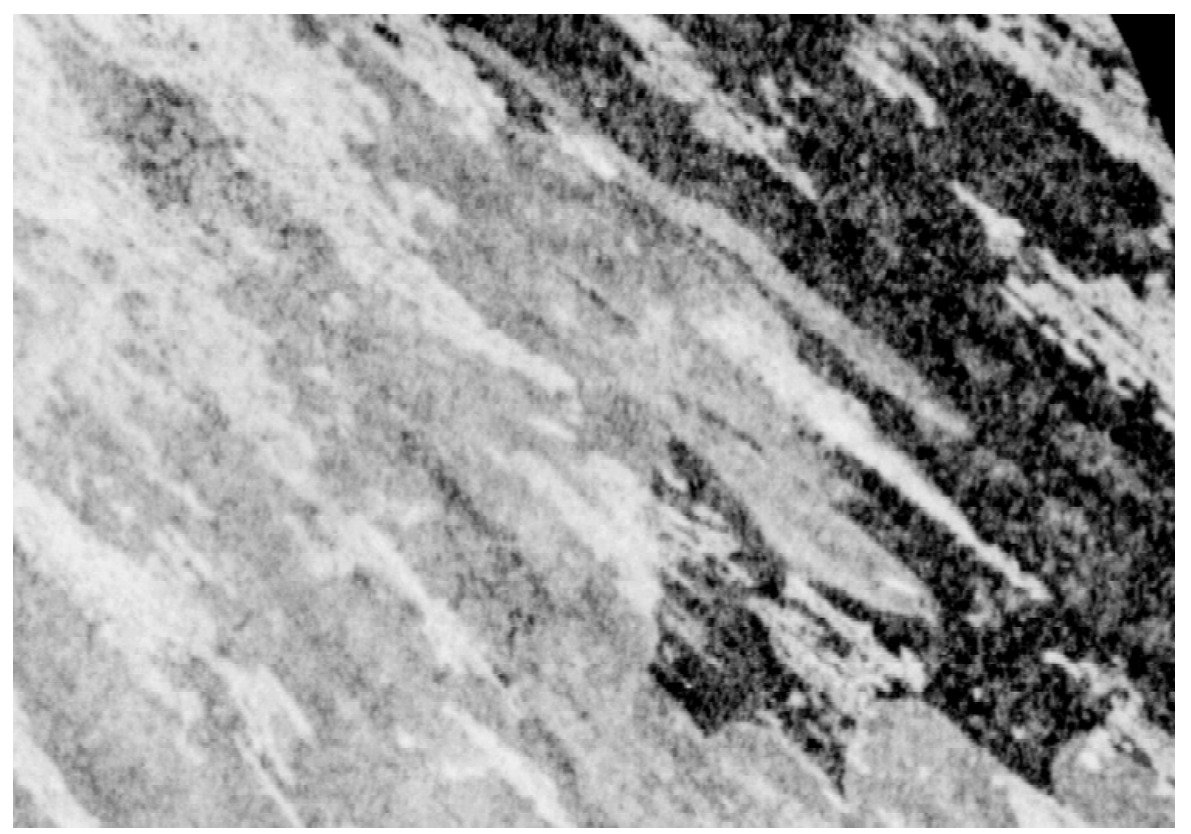

Fig.35. Pilar Dolz. Detalle LAM. VI. Serie De formas. Aguatinta y azúcar. 1970. 
Un aspecto importante es que este trabajo con pincel nos exige una síntesis de la forma e intensifica el contraste existente entre fondo y forma. Al ser el pincel un instrumento de cierta flexibilidad, nos permite realizar unos trazos lineales y manchas de forma fluida y ágil sin ofrecer mayor resistencia, con el que podemos crear formas abstractas amplias a la manera de grandes barridos, pero no trazos más complejos y detallados. Normalmente estas manchas realizadas al azúcar aparecen formando parte de la obra y no como protagonistas, en la que coexiste conjuntamente con otras técnicas, como aguafuerte, buril, aguatinta, entre otras.

Otra de las técnicas empleadas es la del barniz blando, producto que resulta de la mezcla de cera, resina y sebo. Esta técnica permite reproducir la textura de cualquier tipo de objeto que entre en contacto con él. Así nos encontramos con la presencia de una mancha producida por el frotamiento continúo y espontáneo de un trozo de tela sobre el barniz blando, creando de esta manera una mancha totalmente libre y abstracta que se combina con el buril. (Técnica empleada fundamentalmente para trazar líneas que mantienen su independencia). Así encontramos una serie de líneas individuales dispuesta de forma paralela una a lado de otra. La línea se realiza directamente sobre la superficie de metal ejerciendo una tenue presión sobre esta. La distinta intensidad tonal se consigue aumentando o disminuyendo la presión del buril a medida que se avanza. Las líneas se diferencian por sus características individuales. (Véase Fig. 36) 


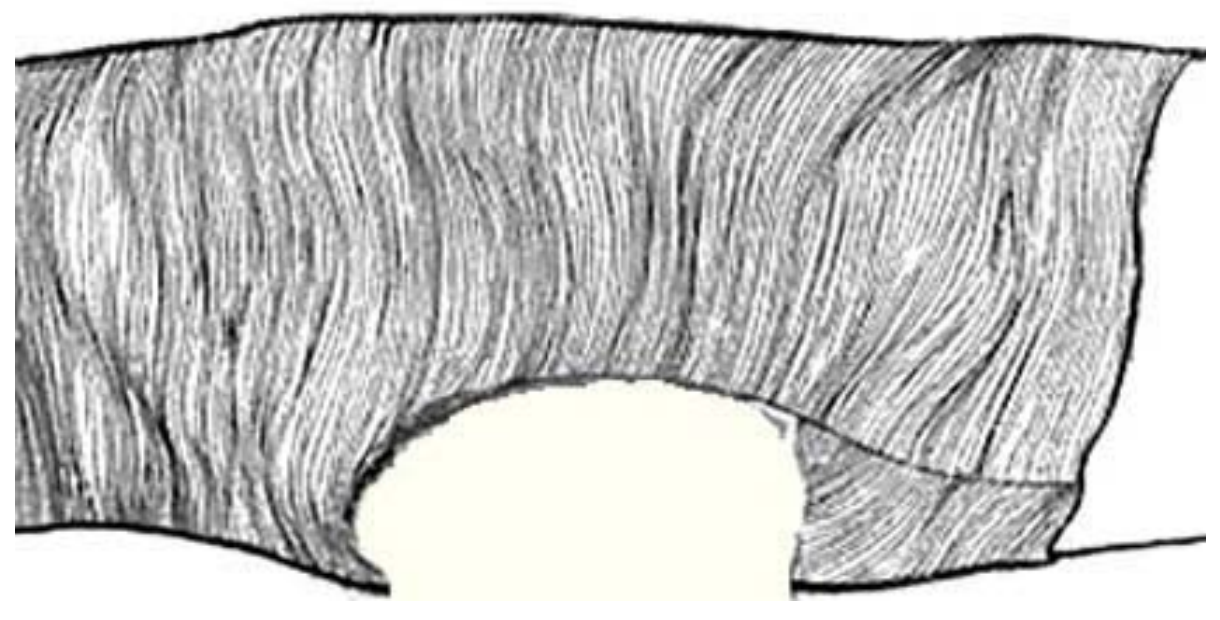

Fig.36. Pilar Dolz. Detalle LAM. X. Serie De formas. Buril y barniz blando. 1971.

Quizás una de las técnicas utilizadas con más frecuencia es la de la cera, que consiste en realizar el trazo con un lápiz o una barra de material graso, que se aplica directamente sobre la plancha a través del acto gestual. Con este ejercicio la zona por donde pasa el lápiz graso queda reservada, aunque de forma irregular, ya que la cera que se adhiere a la plancha, no lo hace de una manera uniforme sino que se agarra en unos sitios más que en otros, dando origen a un trazo irregular y entrecortado como si estuviera realizado a través de puntos y líneas. La zona donde se incrusta la cera queda protegida de la actuación del ácido mientras que las partes donde se ha desprendido queda vulnerable a la acción de este. (Véase Fig. 37) 


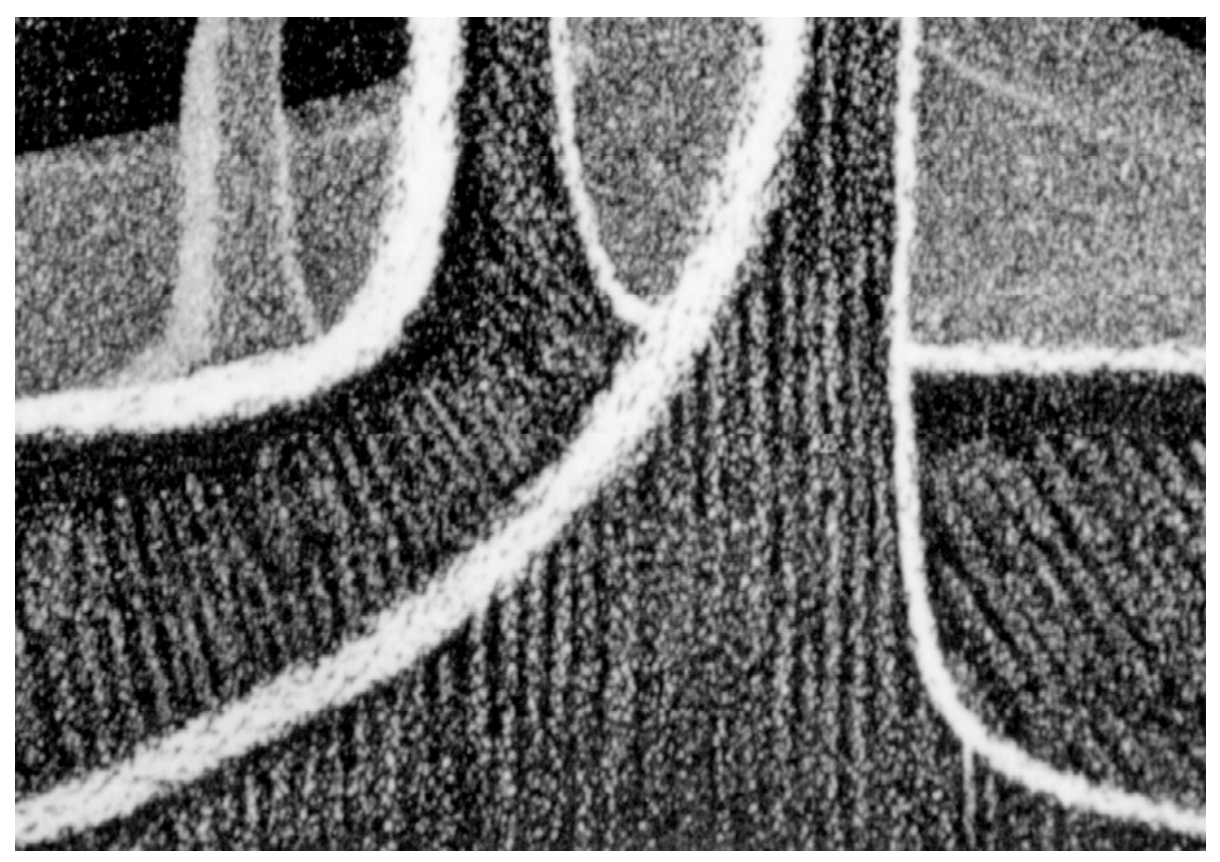

Fig. 37. Pilar Dolz. Detalle LAM. IV. Serie De formas. Aguatinta y ceras. 1972.

El gofrado es otra de las técnicas presentes, aunque en menor medida, como en LAM. VII donde ésta aparece en combinación con otras técnicas, nunca individualmente o como protagonista. Los gofrados se realizan de forma semejante a como lo hacia en el buril, es decir a través del trazado de líneas individuales dispuestas de forma paralela sobre la superficie, siguiendo el camino de una forma determinada. En el gofrado el trazo se convierte en amplias líneas con relieve, provenientes de surcos realizados en la plancha debido a la acción directa del ácido sobre la matriz a tiempos más o menos prolongados, dependiendo de la intensidad o profundidad que se quiera obtener. Se estampa sobre el papel sin tinta creando así unos altos relieves. (Véase Fig. 38) 


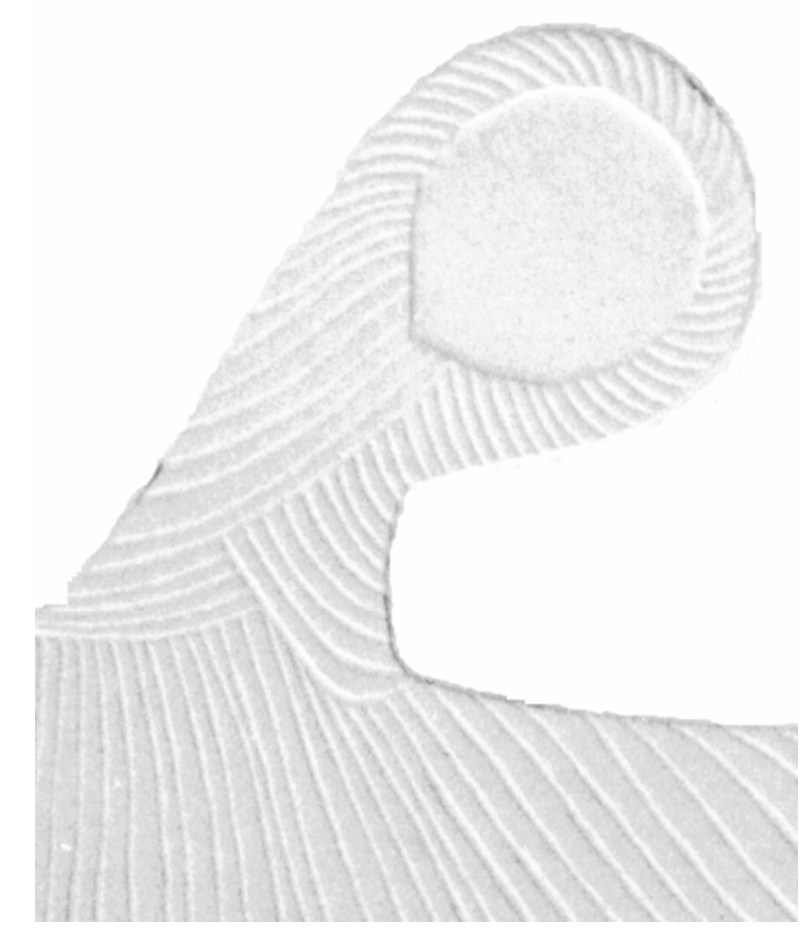

Fig. 38. Pilar Dolz. Detalle LAM. VII. Serie De formas. Aguatinta y gofrado. 1972.

Otro de las prácticas muy comunes de nuestra artista es la de recortar la plancha siguiendo formas muy personales, semejantes a las de las formas incorpóreas representadas en sus grabados, creando de este modo formatos nuevos y singulares. Así en LAM. VII, el recorte de la plancha se realiza con una sierra manual, con la que se llega a todos los puntos de la plancha y con la que recorta cuidadosamente el delicado perímetro del dibujo. Al ser ésta una herramienta de difícil manipulación, no permite confeccionar un trazo libre y espontáneo, sino que se elabora un trazo más controlado. 
Esta acción de corta la plancha, será uno de los ejercicios que practicará constantemente a lo largo de toda su producción, subrayando en unas series más que otras, pero que sin duda será una de las características principales de su obra. (Véase Fig. 39)

Estas eran planchas rotas o con manchas que yo recojo de la basura, este por ejemplo aquí recorto esta que era simplemente un trozo que no era nada, y siempre dejo hablar un poco a algo que ya esta allí. ${ }^{97}$

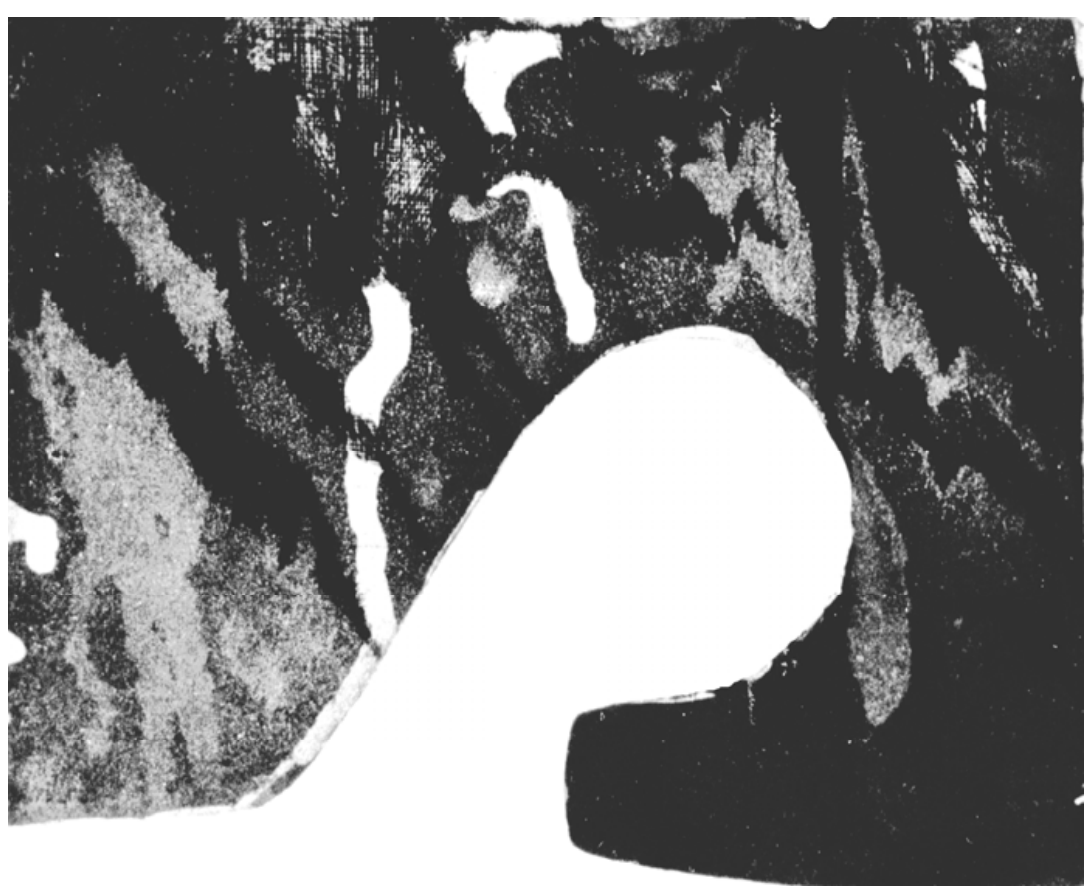

Fig.39. Pilar Dolz. Detalle LAM. VII. Serie De formas. Aguatinta y gofrado. 1972.

\footnotetext{
${ }^{97}$ Entrevista personal con la autora en Castellón de la Plana. 16/05/2005
} 


\section{LÁMINAS}

E FORMAS 



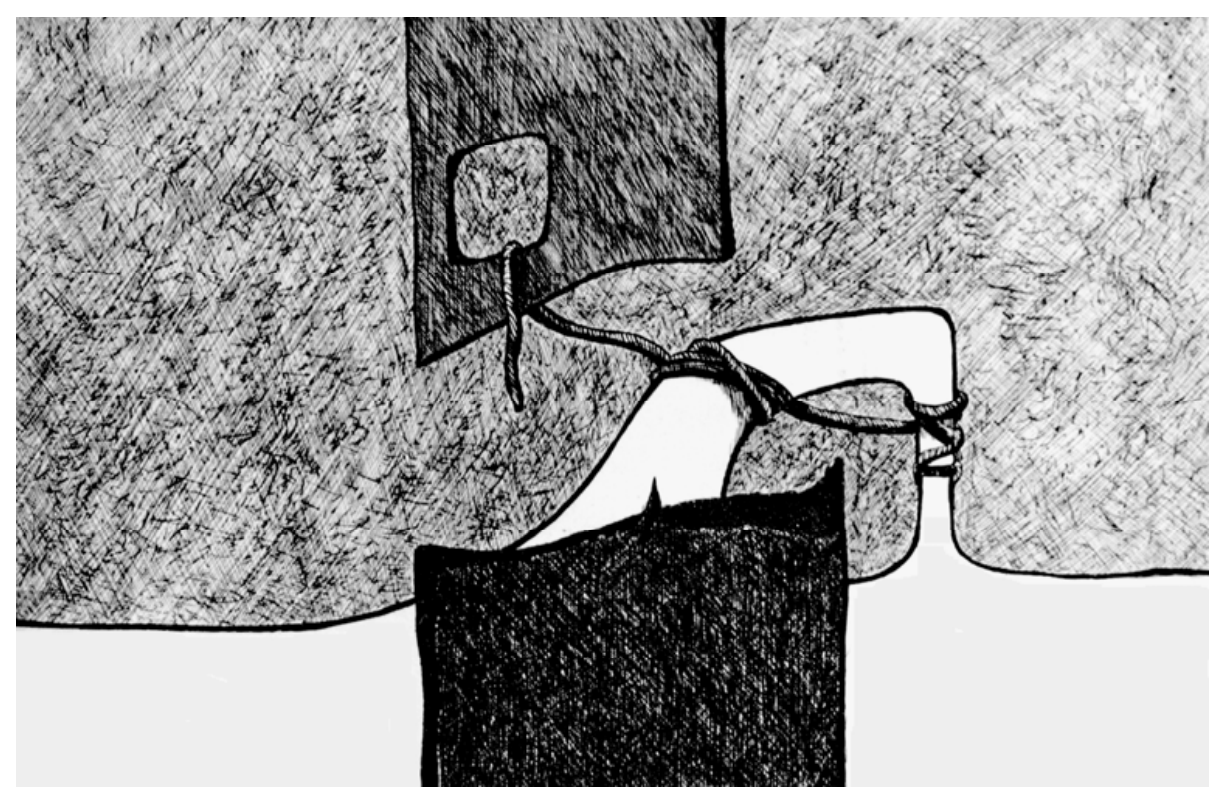

\section{LÁMINA I}

"Sin título"

Aguafuerte en zinc

$16 \times 25 \mathrm{~cm}$.

1970 


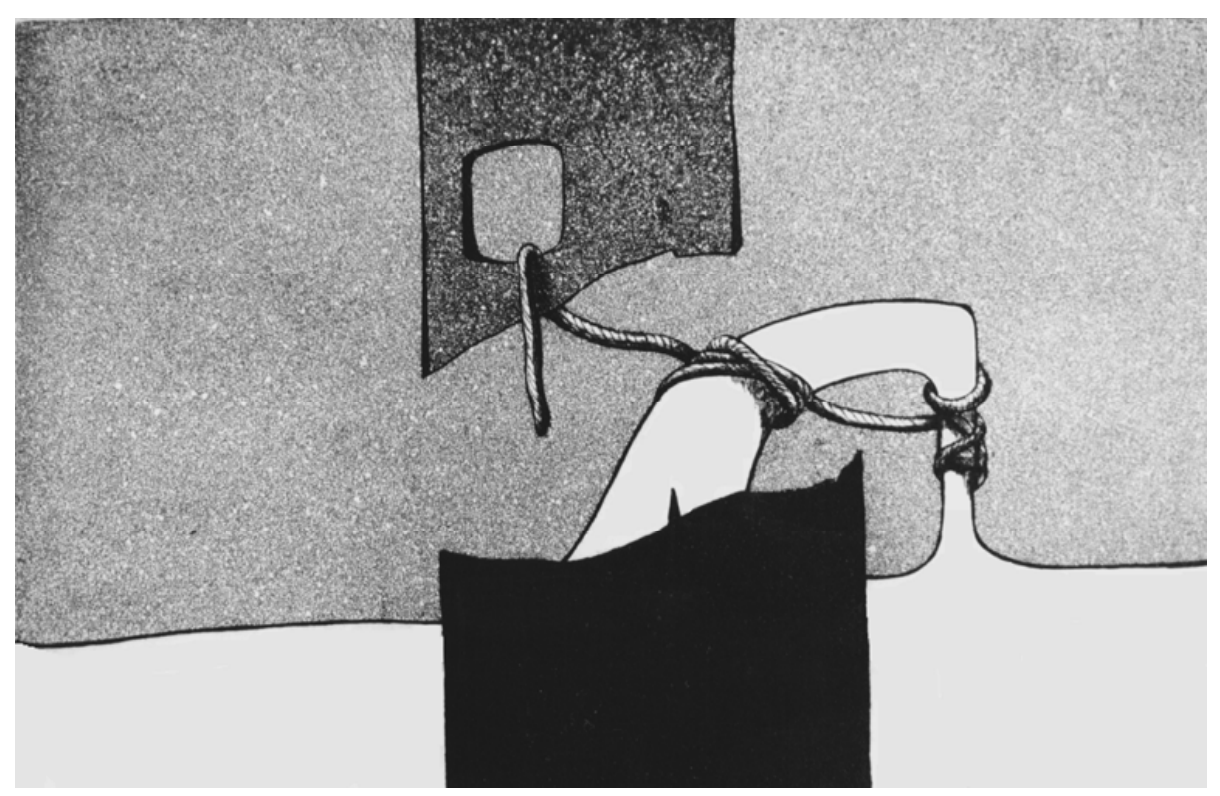

\section{LÁMINA II}

"Sin título"

Aguatinta en zinc

$16 \times 25 \mathrm{~cm}$.

1970 


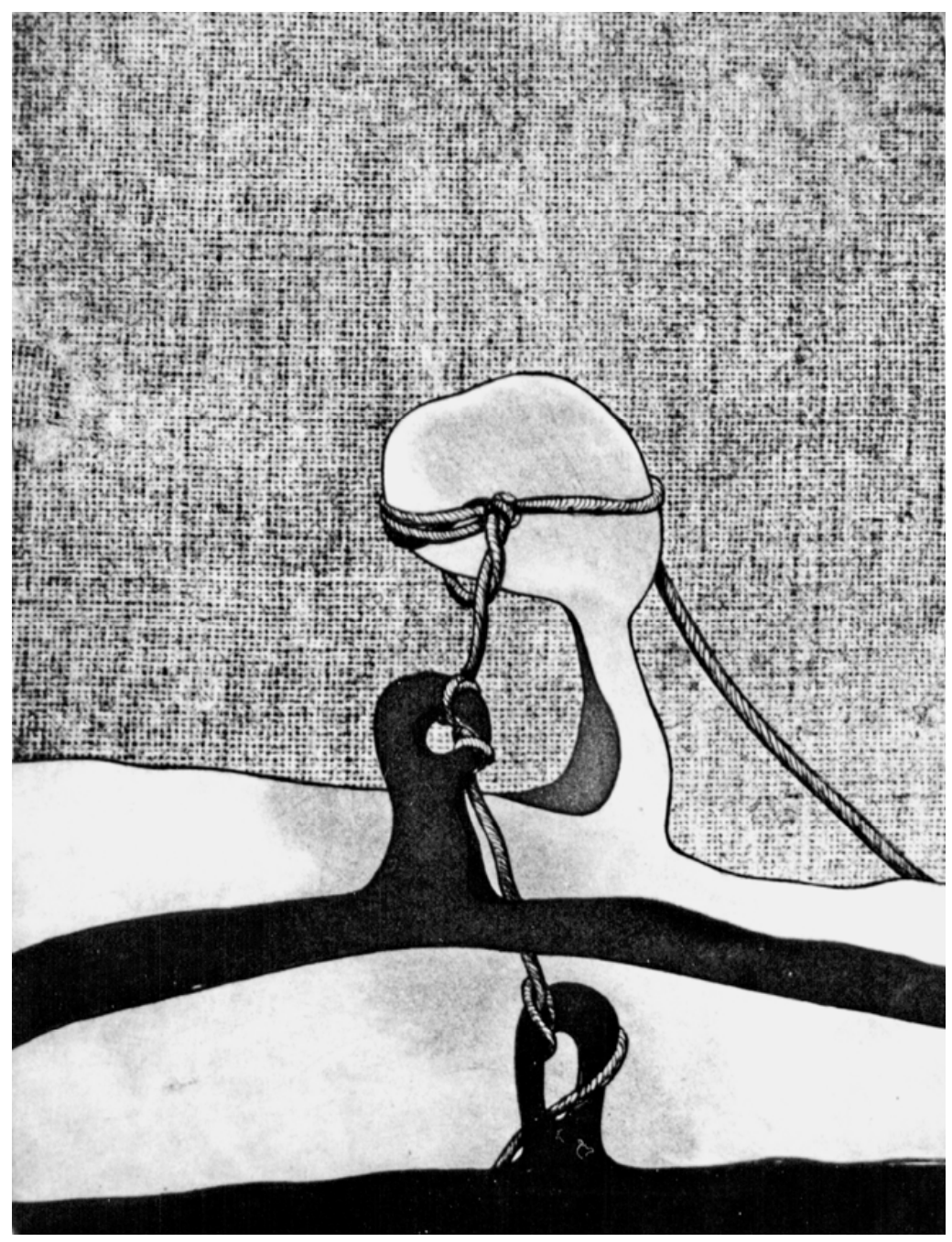

\section{LÁMINA III}

"Sin título".

Aguatinta y barniz blando

$32 \times 24.5 \mathrm{~cm}$.

1970 


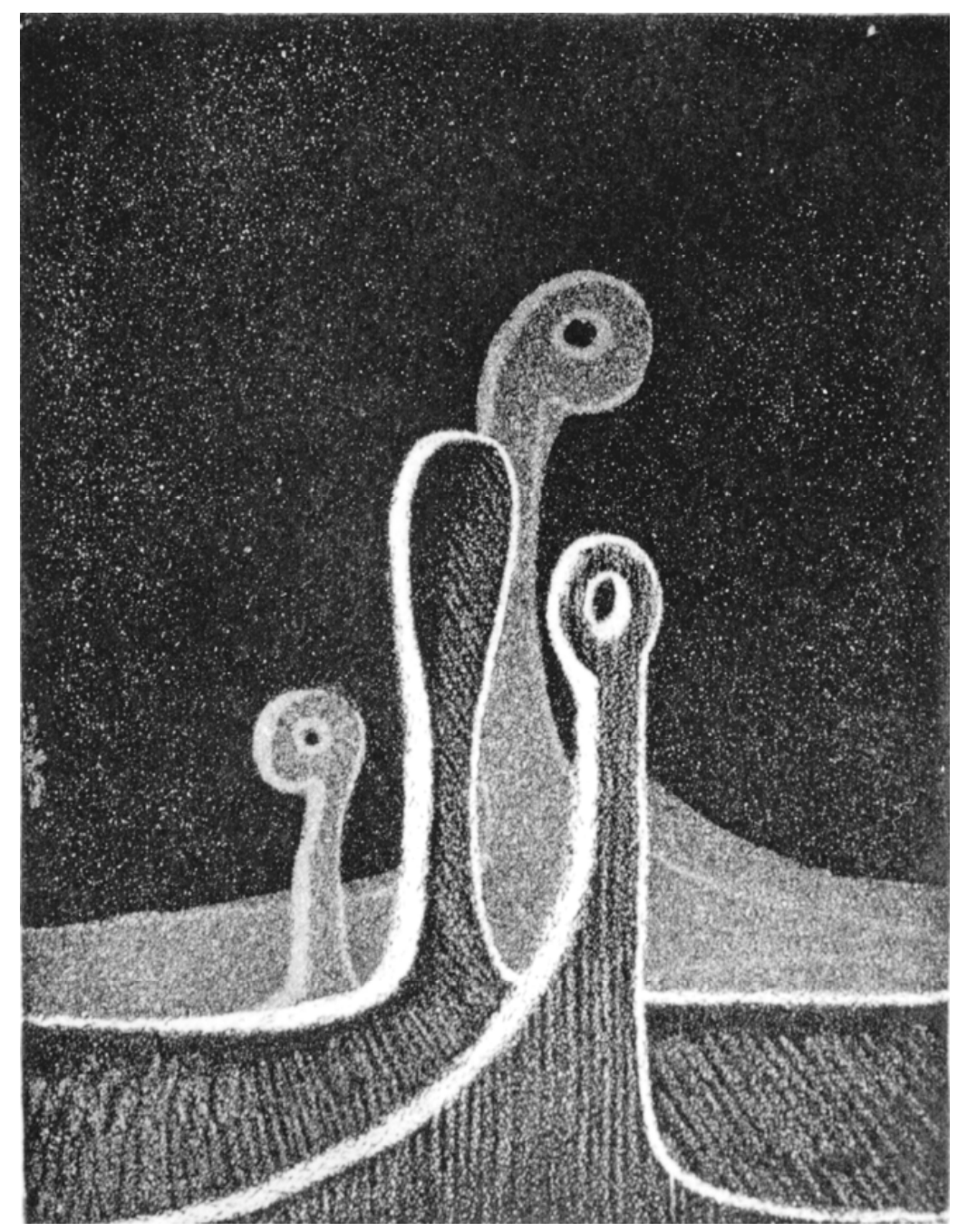

\section{LÁMINA IV}

"Sin título"

Aguatinta y ceras

$16 \times 12.2 \mathrm{~cm}$.

1972 


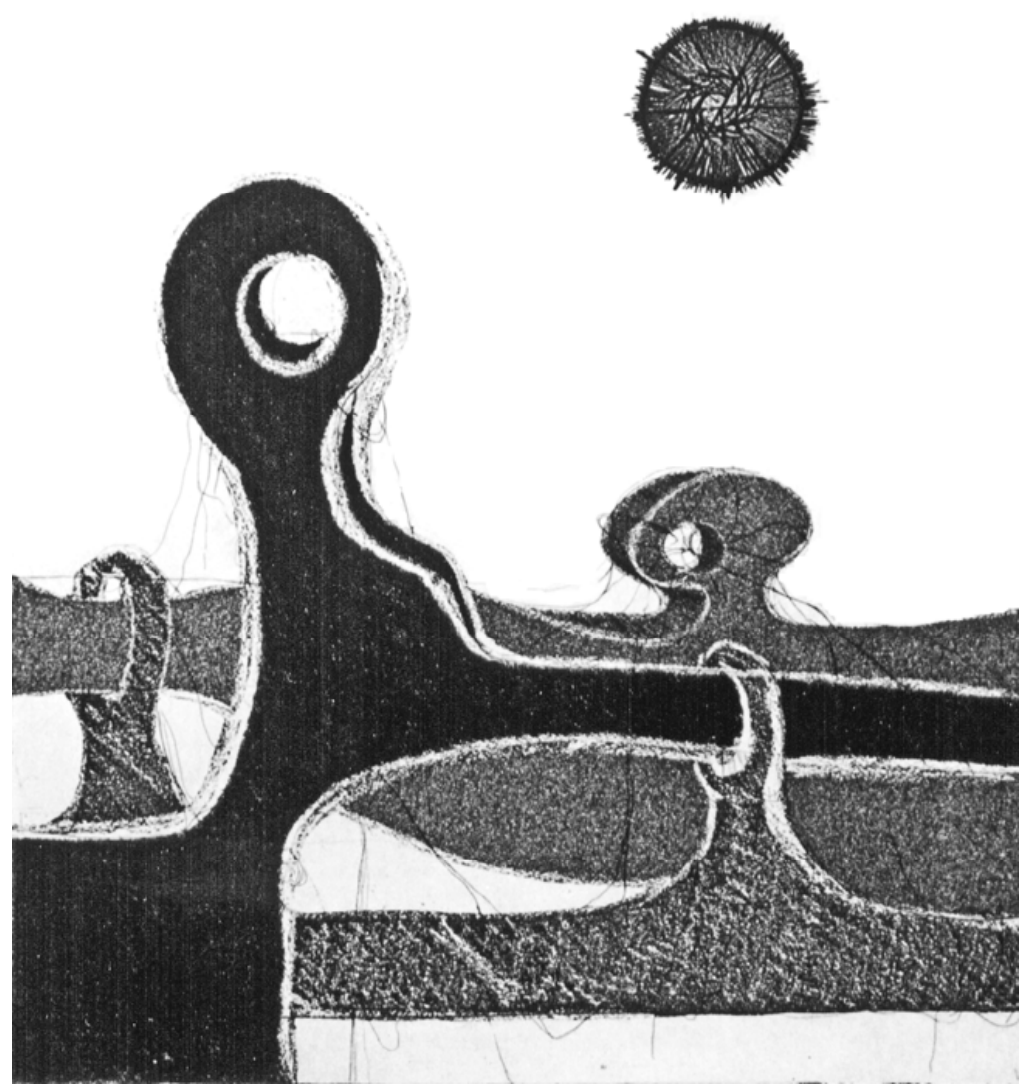

\section{LÁMINA V}

"Sin título"

Aguafuerte y ceras

$32 \times 24.5 \mathrm{~cm}$.

1970 


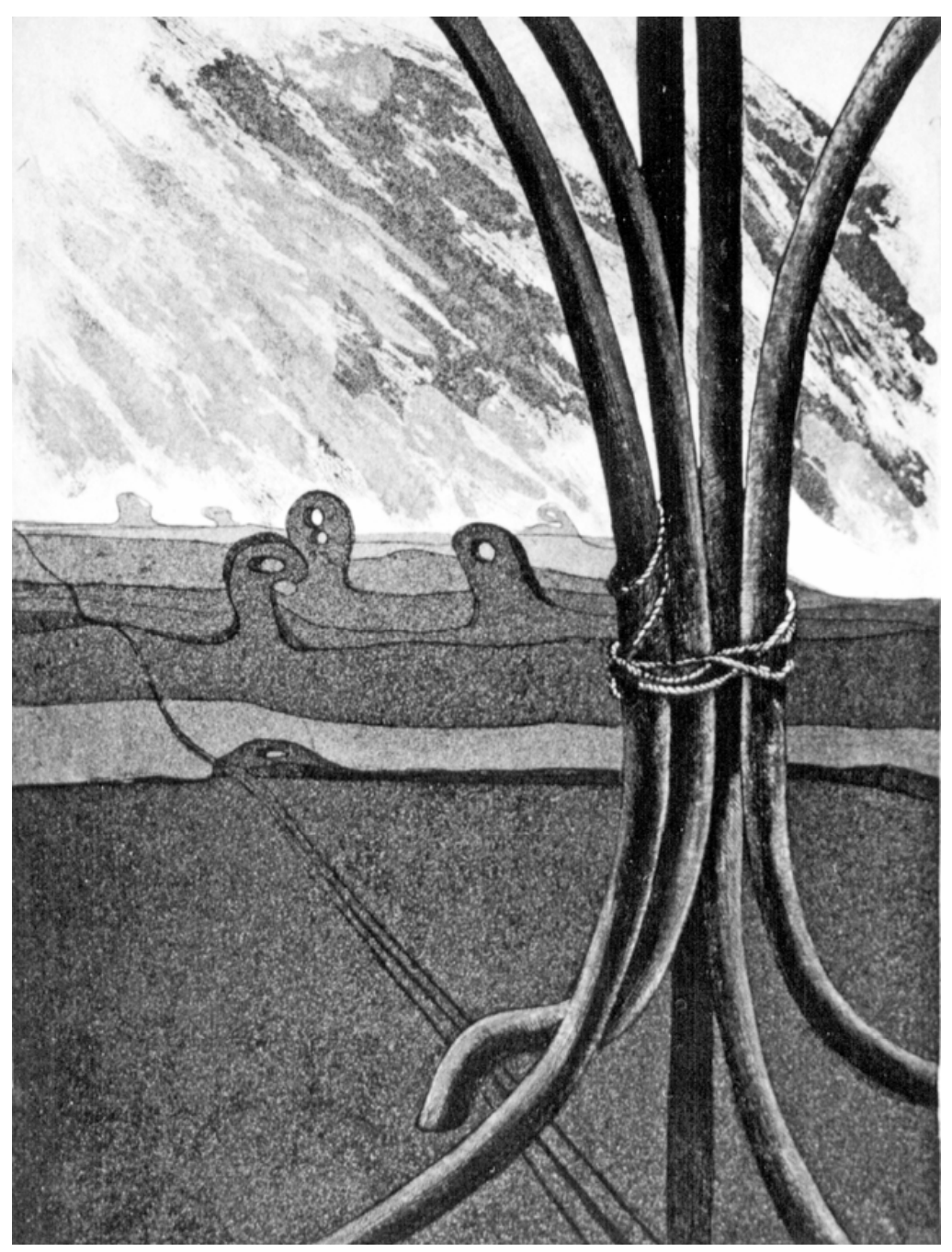

\section{LÁMINA VI}

"Sin título"

Aguatinta y azúcar

$32 \times 24.5 \mathrm{~cm}$.

1970 


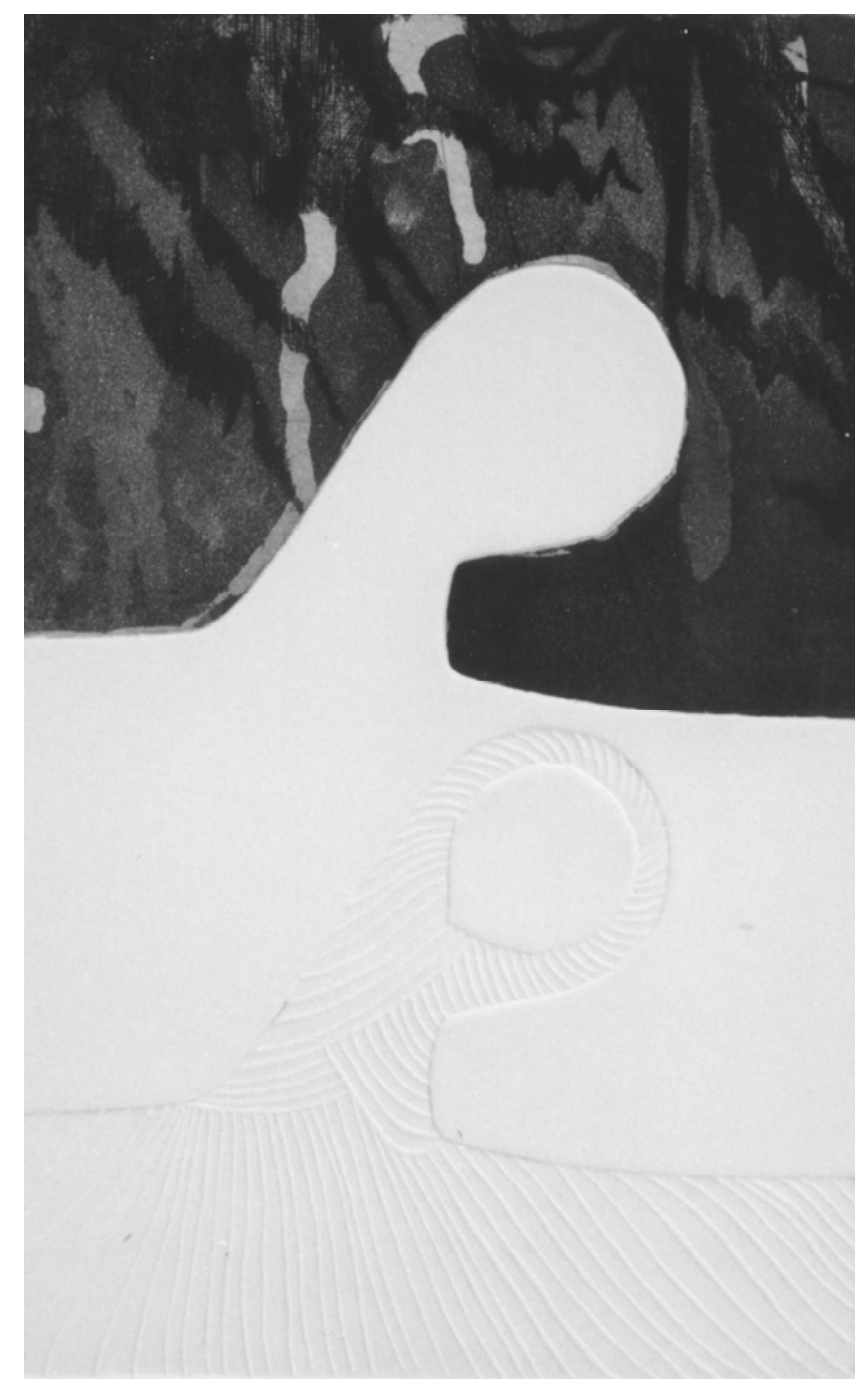

\section{LÁMINA VII}

"Sin título"

Aguafuerte y aguatinta

$26 \times 17 \mathrm{~cm}$.

1972 


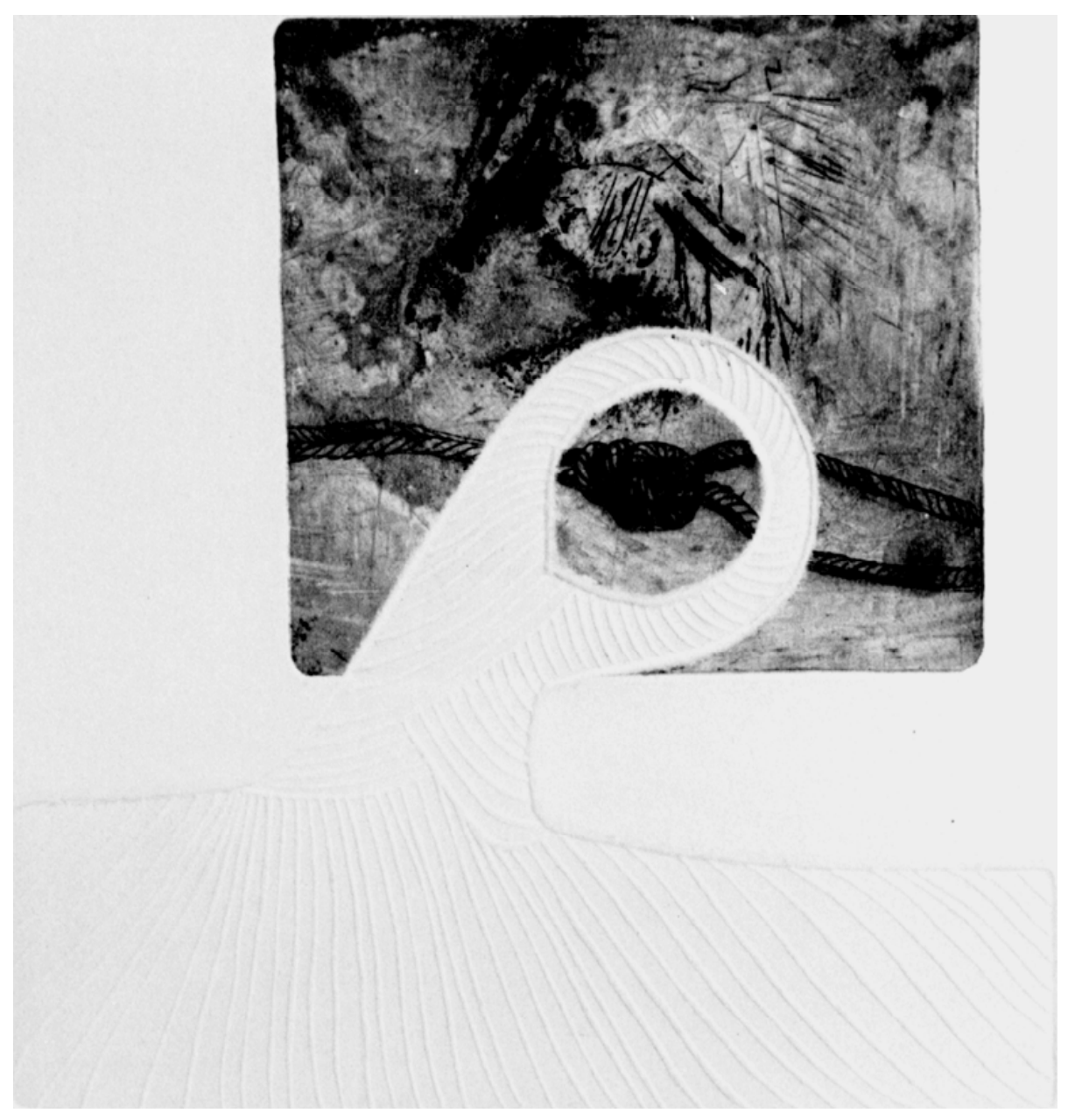

LÁMINA VIII

"Sin título"

Aguafuerte

$17.2 \times 17 \mathrm{~cm}$.

1971 


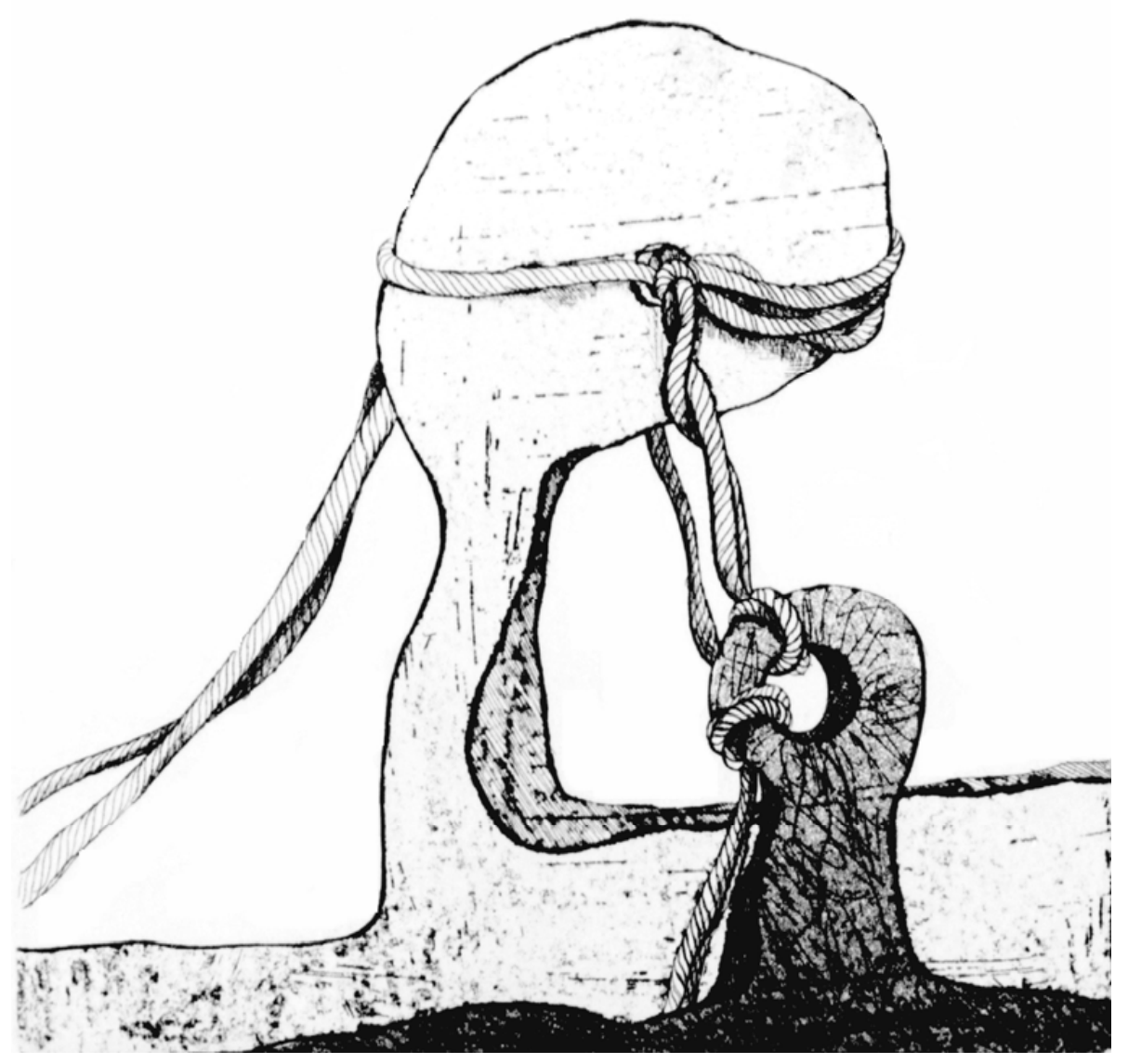

LÁMINA IX

"Sin título"

Barniz blando

$15.5 \times 15.5 \mathrm{~cm}$.

1972 


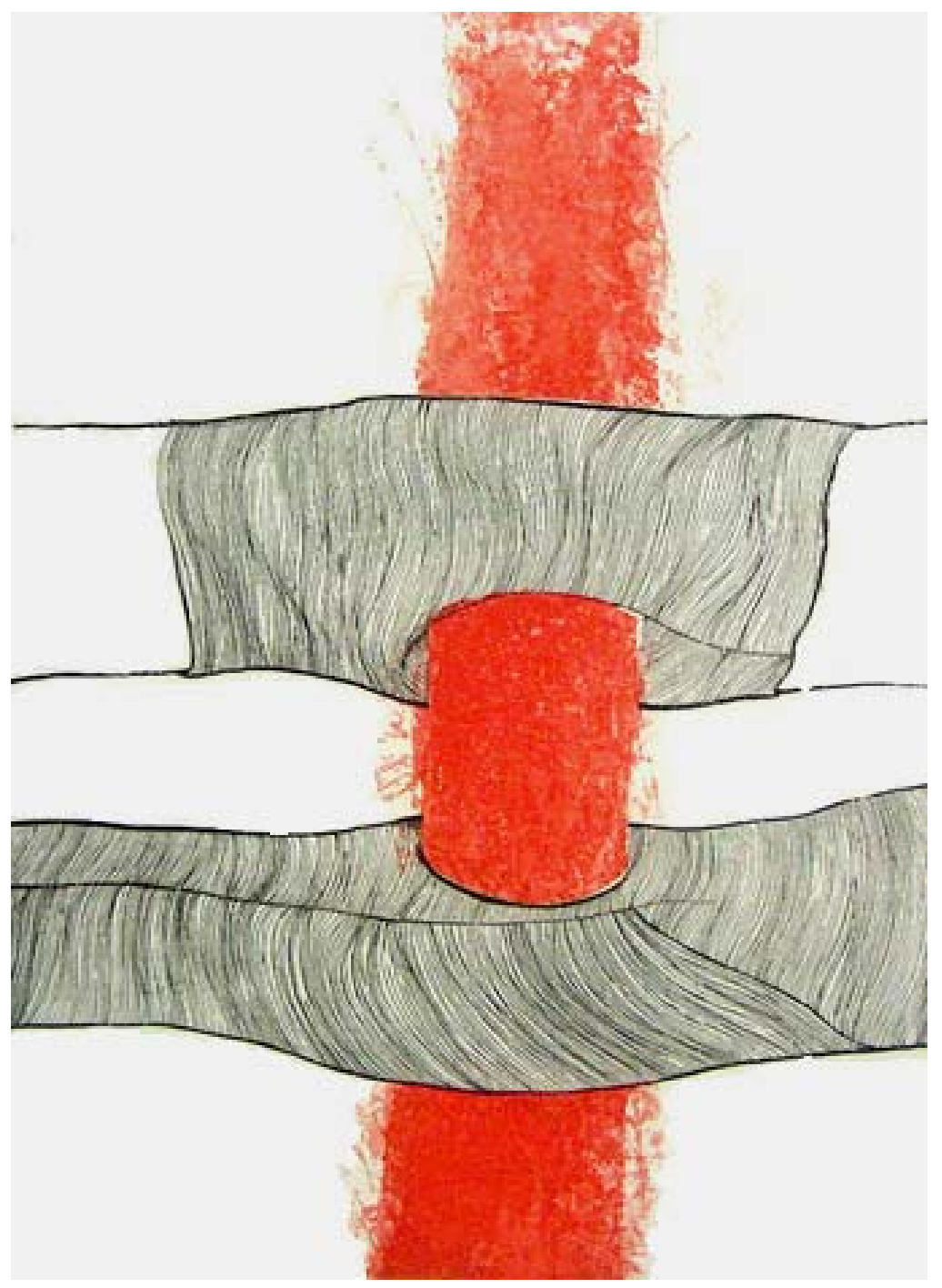

\section{LÁMINA X}

"Sin título"

Buril y aguatinta

$52 \times 23 \mathrm{~cm}$.

1971 


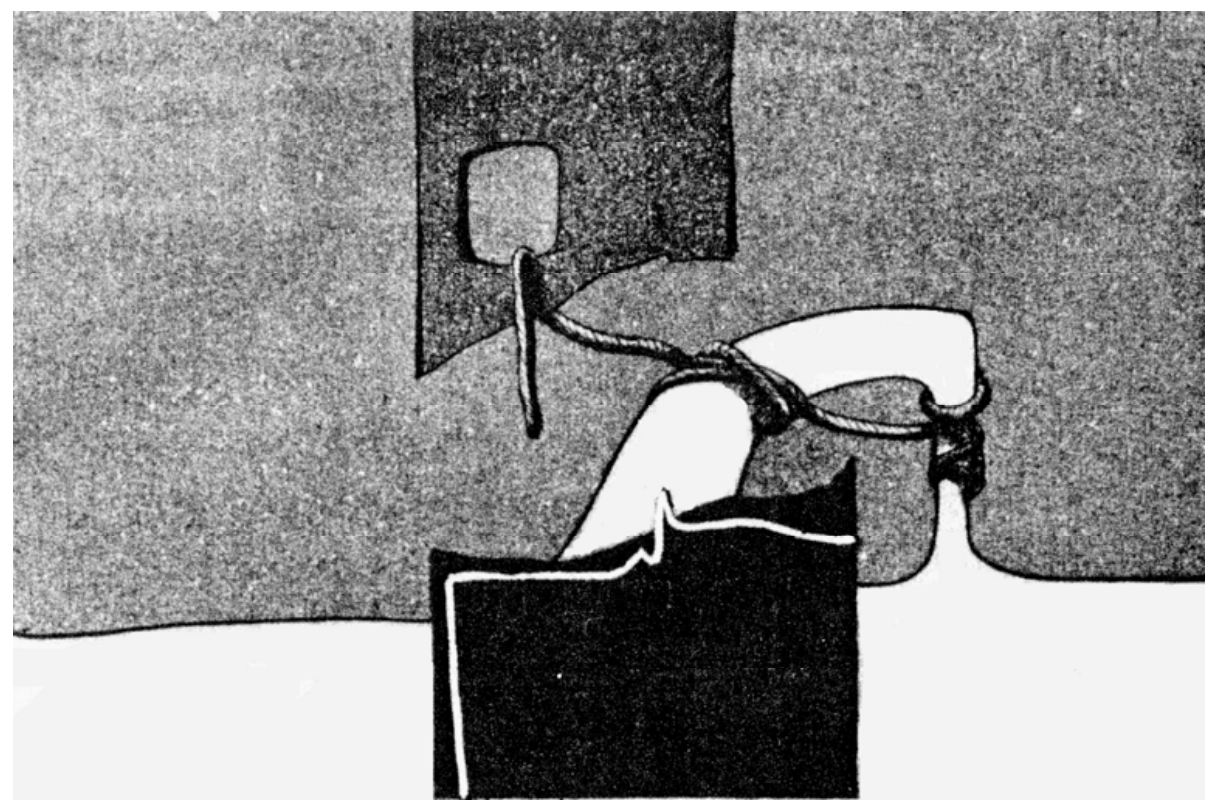

\section{LÁMINA XI}

"Sin título"

Aguatinta.

$16 \times 25 \mathrm{~cm}$.

1970 


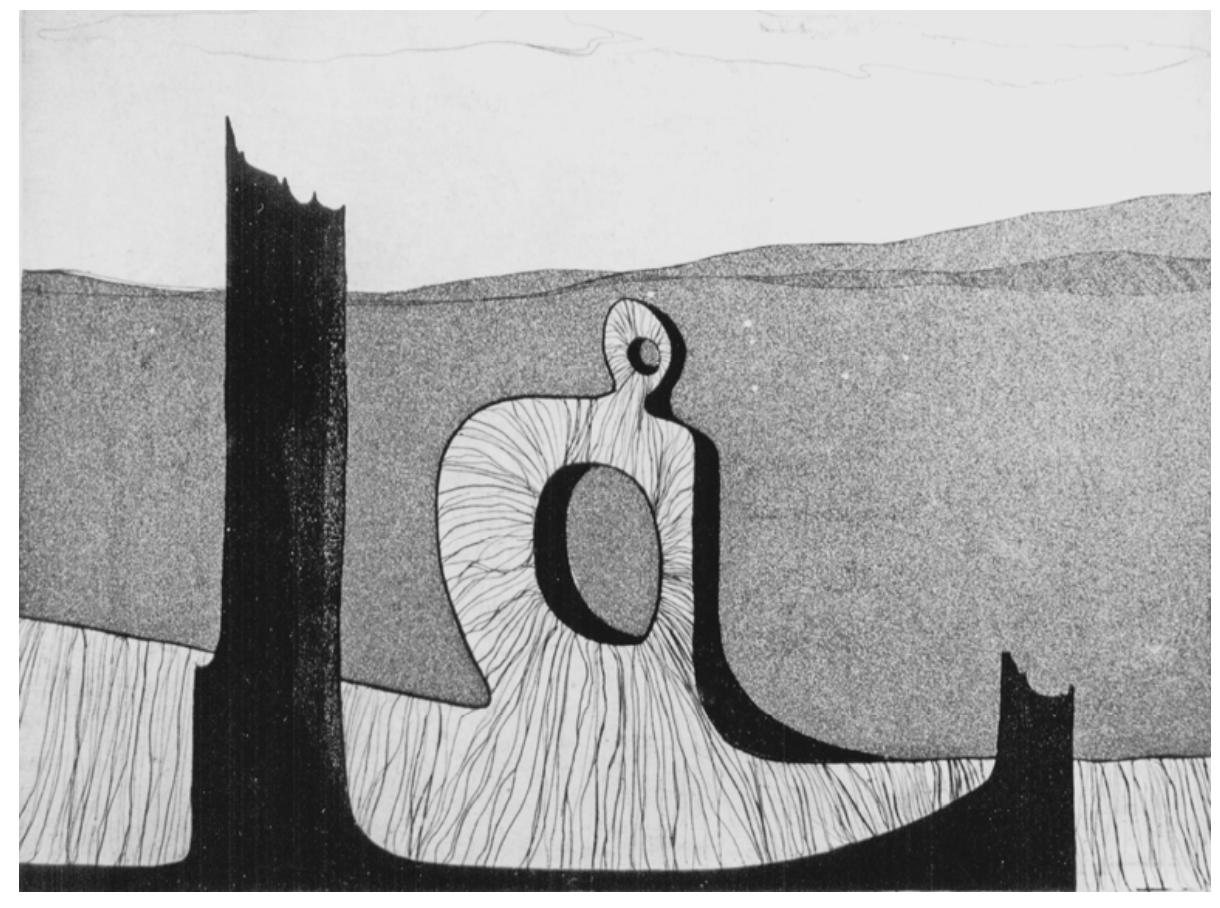

\section{LÁMINA XII}

"Yerma"

Aguatinta y aguafuerte.

$25 \times 32 \mathrm{~cm}$.

1970 


\section{DE MUJERES}





\subsubsection{CONCEPCIÓN}

Esta serie realizada entre 1971 y 1972, se sumerge en el mundo de la figuración, se convertirá en el único conjunto de obras, donde aparecerá la presencia de la figura humana, pues en series posteriores hallaremos la presencia de otro tipo figuración como: piedras, insectos, ventanas y demás, pero la presencia de la figura humana no volverá a aparecer jamás. Así el manifestado interés de la artista por el ser humano, quedará registrado a través de una metáfora que hace alusión a las cosas que éste representa. 
Las primeras manifestaciones de esta serie, aparecen en el año 1971, y son el resultado de la metamorfosis de las formas etéreas trabajadas en la serie anterior, en la que Pilar Dolz veía ya la presencia de ciertas figuras humanas. Estas formas se van transformando poco a poco en más figurativas hasta terminar por convertirse en mujeres, provenientes de una influencia del surrealismo onírico, ${ }^{98}$ basado en la representación figurativa de imágenes surgidas del inconsciente que dan origen a una realidad ilógica y absurda que escapa a los dominios de la razón.

Los temas presentados afloran quizás de sueños y fantasías relegados en el subconsciente, que reflejan un gran dramatismo y violencia, que por otra parte, nada tienen que ver con su personalidad simpática y jovial, pero sí con la dura realidad política y social que se vive entonces en España. ${ }^{99}$

Quizá las primeras influencias feministas registradas en esta serie, le vienen de sus primeros viajes de estudios realizados a Italia entre 1970 y 1972. Su estancia en esta ciudad estuvo acompañada

\footnotetext{
${ }^{98}$ El surrealismo se manifiesta a través de dos vertientes; el surrealismo figurativo, que se encuentran más interesados por la vía onírica, cuyos máximos representantes son Magritte, Dalí, entre otros, que alcanzan su máxima expresión a través de las imágenes oníricas que surgen de las profundidades del inconsciente, y de los deseos y los temores más reprimidos, hallados en buena parte de los sueños, imágenes que son proyectadas en sus obras a través del realismo y de técnicas y recursos pictóricos tradicionales. La simbología onírica se convierte para los surrealistas en una fuente inagotable de información sobre la parte más sombría de nuestro yo. La otra vertiente, la del surrealismo abstracto en cambio pone en práctica el automatismo psíquico en la realización de su obra, sus investigaciones se basan en la reacción espontánea de la mano sobre el medio. Véase ADES, D.: 1975, p.34

99 En 1970 se produce en España una imparable lucha por la libertad, que surge en un contexto social de fuertes movilizaciones sociopolíticas, que registran un gran auge de movimientos ciudadanos, que pasan de luchas meramente defensivas a incorporarse a reivindicaciones referidas a la calidad de vida. Se va pasando de la reivindicación a la acción, al intento de transformar estructuras que generan marginación. Estos años suponen un protagonismo importante de la participación ciudadana que negada en años anteriores pasa a ser uno de los grandes protagonistas. Véase http: //. www.arbil.org/(77)torr.htm. (06/12/2005)
} 
de un conjunto de importantes acontecimientos que sin duda vistos en la distancia, observamos que influyeron de forma decisiva no sólo en la realización de esta serie, sino también en el crecimiento artístico y personal de la artista. ${ }^{100}$

La década de los setenta se presenta para Italia como una década con la presencia de importantes movimientos políticos y sociales que representan el último escalón de una cadena de revueltas y rebeliones que se extienden a lo largo de todo el siglo $X X$. En el seno de este movimiento confluyen todas las culturas y tradiciones políticas, revolucionarias, marxistas, anarquistas y feministas, que realizan un trabajo de masas y mantienen una alta lucha social. De entre estos movimientos debemos destacar la presencia de la mujer, que empieza a jugar un papel importante bajo el colectivo feminista, sus primeras manifestaciones surgen en Italia alrededor de 1965, pero el acontecimiento más importante se produce alrededor de 1970, con la publicación del manifiesto de Rivolta femminile de Rossana Rossando y el escrito Escupamos sobre Hegel, de Carla Lonzi, una de las más grandes teóricas del feminismo italiano, que lucha con fuerza y vitalidad, en defensa de los derechos y la reivindicación de la mujer. ${ }^{101}$

\footnotetext{
${ }^{100}$ A partir de 1968 se da en Italia una serie de acontecimientos que duran hasta 1977. Estos acontecimientos no se consideraron una guerra civil, porque el objetivo no era el poder del Estado. Se trató de un inmenso movimiento de luchas sociales que en un principio defendian las reivindicaciones relacionadas con los hechos de mayo del 68 en Francia (voluntad de modernización, antiautoritarismo, feminismo, tercermundismo, etc), pero más tarde el movimiento se incorporó a las luchas de la clase obrera por los salarios y se radicalizó a medida que la crisis económica y social de los años 70 se hace más violenta. La principal característica de este movimiento fue estar presente en los grandes acontecimientos sociales, como las luchas por la liberación de la mujer, la reducción del tiempo de trabajo o un salario garantizado. En Italia cerca de doscientas personas continúan hoy en día en la cárcel tras haber sido condenados por delitos cometidos en los años 70. Otras doscientas se encuentran en el exilio. Véase http: // www.rebelion.org/noticia. php?id=68051. $(05 / 10 / 2006)$

${ }^{101}$ Las primeras manifestaciones del feminismo italiano surge en 1965 , y se encuentran muy influenciadas por las tesis del "feminismo de la diferencia", tesis que nace a mediados de
} 
Pilar Dolz, que se halla estudiando en estos momentos en Italia, se ve fuertemente influenciada por el feminismo italiano, movimiento que le impresiona mucho y le lleva a realizar un arte crítico, muy feminista. Entonces efectúa una serie de mujeres atadas de origen surrealista, un poco del inconsciente, que nacen de las primeras formas del automatismo, para luego ir atando mujeres.

A finales de los 60 y principios de los 70 , surgen una serie de movimientos sociales, y hay un arte de una forma reivindicativa, yo hice feminismo, piensa que en el 68 empezó el feminismo, y que entonces surgieron muchos movimientos. Yo recuerdo los primeros años 70 y 71 , cuando el feminismo en Italia me impresionó realmente, yo leía ciertas cosas de las feministas americanas y tal, lógicamente eso te influye, claro entonces yo hice en ese momento un arte muy panfletario y muy feminista. ${ }^{102}$

Pero no es sino hasta el año 1975, cuando entra a militar de forma activa en el colectivo feminista español. Para entonces España se encuentra en los últimos años de la dictadura franquista, régimen alejado de toda democracia, donde no había libertad de asociación, de hecho los partidos políticos sólo empiezan a organizarse después de la muerte de Franco, cuando empieza a crecer la manifestación de un sentir rebelde, que inspiró a todos los órdenes de la vida española, y el feminismo comienza a tener un nuevo significado. ${ }^{103}$

los 70 en EEUU y Francia. Proveniente de grupos feministas radicales cuyo lema era "ser mujer es hermoso"; la alegría de ser mujer formaba parte de esa expresión, porque era una etapa de reafirmación de una nueva identidad, que abogaba por identificar y defender las características propias de la mujer. Consideraban que los hombres son por naturaleza, agresivos y depredadores, y por tanto, las mujeres no deben entrar en ese juego e intentar imitarles. Este feminismo tuvo muchas seguidoras en Francia e Italia y después en España. Véase OSBORNE, R.: 1993, p. 165.

${ }^{102}$ Entrevista personal con la autora en Castellón de la Plana. 03/03/2000.

${ }^{103}$ En España a partir de 1960 surgen varias organizaciones clandestinas que luchan por reconquistar la democracia, los derechos y libertades vetados bajo el régimen franquista. En 
Pilar Dolz, una persona de una amplia conciencia social, mantiene una participación muy activa con los grupos feministas de España, más concretamente con el colectivo feminista de Castellón, del cual es cofundadora en el año 1975, año en que se declara el día Internacional de la Mujer, celebrado por la UNESCO, el cual sirve de pretexto para organizar y agrupar a las mujeres feministas. Este movimiento surge de manera similar a los colectivos feministas italianos, independientemente de partidos políticos, su primer nombre fue Grup de Dones de la Plana, después tomó el nombre de Colectivo Feminista de Castellón. Movimiento que lleva a cabo toda una serie de actividades de enseñanza y aprendizaje conjunto, a través de las cuales realiza reuniones, debates, proyección de películas y lecturas de textos según las inquietudes y deseos del grupo.

El feminismo siempre influyó mucho en mí, y sigue influyendo, yo creo realmente que las mujeres somos las que hemos cambiado el mundo y lo seguimos cambiando, creo que somos las que lo podemos cambiar y hacerlo un poco más justo, porqué no decirlo, lo que ocurre es que en ese momento, la primera sensación, no es esa seguridad, como la que puedo tener ahora, entonces yo era estudiante y vas (sic) haciendo cosas de este tipo un poco del inconsciente. ${ }^{104}$

1970 se consolida la oposición a la dictadura y se produce una imparable lucha por la libertad. En este ambiente surge el feminismo español, integrado en su mayoría por mujeres con cierta orientación cultural o profesional, que pretenden reemplazar los ideales nacionalcatólicos de las mujeres, basados en la dedicación exclusiva a la familia. Dos semanas después de la muerte de Franco se celebró la primera reunión feminista en Madrid, con el propósito de oponerse a las posturas gubernamentales. Fue el primer mitin político organizado en España después del régimen franquista. En 1976 se estableció el Frente para la liberación de la mujer y en las I Jornadas de la Mujer organizadas en Barcelona, aparecieron nuevas agrupaciones feministas, en su mayoría con vínculos estrechos con los partidos de izquierda, que comenzaban a interesarse por las reivindicaciones de las mujeres. Véase ROMEU ALFARO, F.: 2002, p. 34

${ }^{104}$ Entrevista personal con la autora en Castellón de la Plana. 16/05/2005. 
En cuanto al contenido temático de su obra, ésta nos presenta todo un conjunto de mujeres, atadas, crucificadas, torturadas de fuerte carga expresiva, temas vinculados a la problemática de la mujer acordes con sus sueños utópicos de libertad.

Mas adelante entre 1973 y 1975, trabaja un nuevo conjunto de mujeres realizadas con un lenguaje más acorde con la obra que se encuentra trabajando en estos momentos.

Se trata de unas imágenes que nada tiene que ver con las mujeres surrealistas de estos años, sino de unas imágenes más figurativas trabajas con un estilo más realista, en el que aparece el rostro de una mujer con la boca tapada y amordazada, o la figura de una muñeca suspendida en el espacio que hace alusión a las fiestas de su pueblo. De esta obra la artista realiza cuatro versiones diferentes, empleando distintos entintados, papeles, con los que consigue resultados desiguales. En algunas estampas incluso alcanza un carácter muy dramático por medio de la utilización del color.

Pilar Dolz nos demuestra, tanto en los temas representados como en las resoluciones técnicas, una gran madurez personal, que desde entonces permitió el augurio de una brillante carrera que apenas acababa de iniciar y cubría etapas de formación. 


\subsubsection{ASPECTOS COMPOSITIVOS}

\section{Composición}

Esta serie de grabados está compuesta por un conjunto de imágenes figurativas, que resultan de la evolución de unas formas del inconsciente producto de la caligrafía automática trabajadas en la anterior serie, en la que nuestra artista ya distinguía ciertas formas figurativas, que son las que dan origen a esta serie.

Este grupo de mujeres se nos presenta hasta cierto punto como figuras deshumanizadas, con una factura de aspecto mineral; como mujeres rocas, mujeres árboles, mujeres raíces, mujeres troncos, donde sigue presente la influencia surrealista que viene más de manos del surrealismo onírico, que del surrealismo automático de la etapa preliminar.

En las primeras obras de esta serie, resulta más evidente el paso de transición de unas formas a otras. Así en LAM. XIII podemos distinguir cómo la imagen de una figura femenina presente en un primer plano, se nos muestra compuesta por dos partes desiguales, una que hace referencia a las formas minerales de la serie anterior y otra que hace alusión a una forma humana, motivo de inspiración en esta serie, donde cada una de las partes se integran entre sí dando origen a una única imagen. (Véase Fig. 40 y 41 ) 


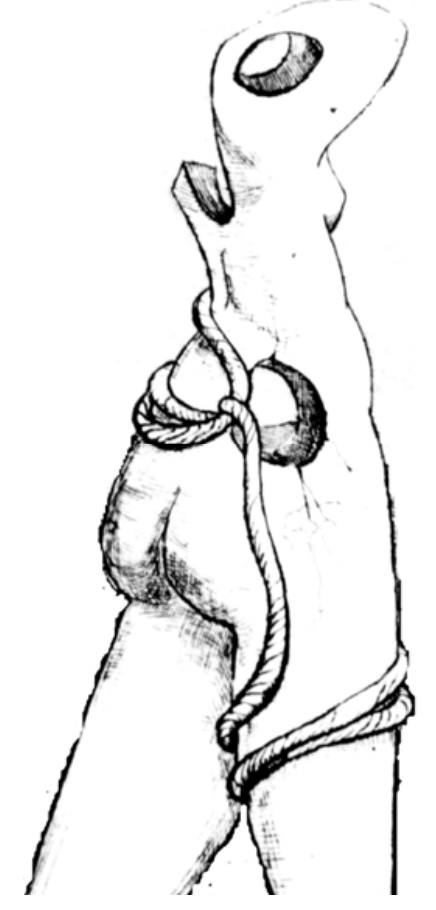

Fig.40. Pilar Dolz. Detalle LAM. XIII. Serie De mujeres. Aguatinta.1971.

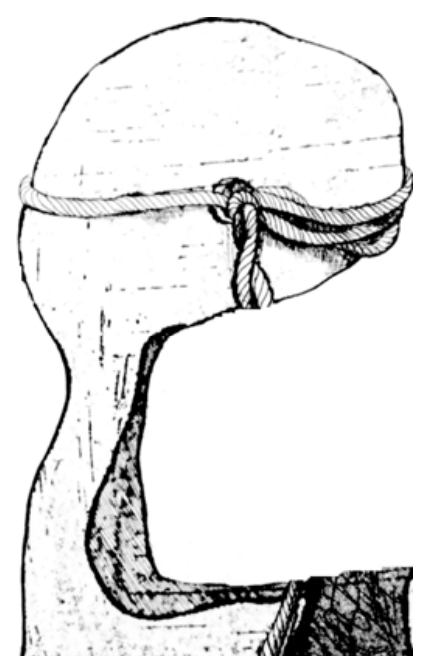

Fig.41. Pilar Dolz. Detalle LAM. IX. Serie De formas. Barniz blando.1972. 
La parte superior de la imagen, representa una forma de aspecto pétreo, cuya apariencia nos invita a pensar en una especie de naturaleza inorgánica, como si se tratara de una roca, o de una piedra, cuya representación va desde la cabeza, hasta la altura de la cintura.

La parte inferior constituye una figura femenina, cuya imagen surge desde el punto donde termina la forma pedregosa, a la altura de la cintura y se prolonga hasta la altura las rodillas, justo en el punto donde termina la realización de la figura. El resultado de esta mezcla, es una imagen, mitad humana, mitad mineral, que nos recuerda sin duda a aquellas figuras antropomorfas de la mitología griega.

Nos referimos a los minotauros o centauros, seres monstruosos, en los que su cuerpo de cintura hacia arriba adopta un aspecto de hombre, y de cintura hacia abajo adquiere la forma de un caballo, estos personajes a veces también eran representados como hombres erguidos, de cuya parte trasera sale el cuerpo de un caballo. ${ }^{105}$ (Véase Fig. 42)

\footnotetext{
105 Según la mitología, los centauros son una raza de seres mitad humano y mitad animal. Sus costumbres son salvajes y primitivas, comen carne cruda y cazan armados de palos y piedras. En antiguas vasijas áticas, los centauros eran representados como seres humanos de frente, con el cuerpo y las patas traseras de un caballo sujetos a la espalda. Posteriormente, fueron hombres sólo hasta la cintura. Véase BIEDERMANN, H.: 1993, p.98.
} 


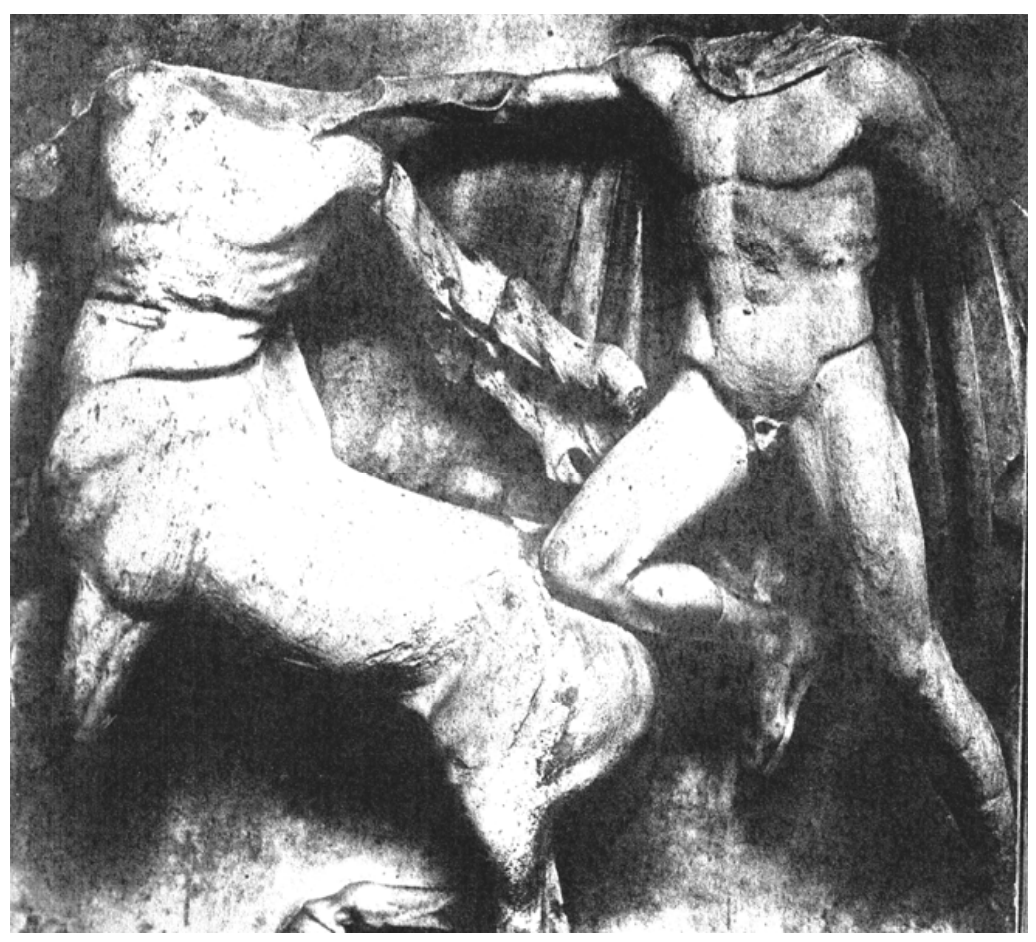

Fig.42. Lapita y Centauro, metopa del Partenón. 447-443 a.C. Londres, Museo Británico.

Esta imagen femenina aparece representada en un primer plano, llamando la atención por su gran luminosidad, debido a que su forma se encuentra realizada sólo mediante una silueta ejecutada por una única línea continua, sin la presencia de sombras, lo que nos obliga a ver la superficie blanca del papel, ganando con esto mayor luminosidad en la figura, frente a un fondo más oscuro, que se encuentra dividido casi simétricamente en dos partes, por una línea horizontal que cruza todo el espacio. La parte inferior está representa por un tono oscuro que atrae la atención por su peso visual, mientras que la parte superior de un tono gris claro atrae la mirada por su resplandor, esta situación provoca que estos dos espacios compitan entre sí por llamar la atención, a la vez que 
provocan una reacción de atracción mutua, ya que estos espacios en la percepción visual no permanecen estáticos, la situación de simetría provoca que la parte oscura ubicada en la parte inferior aparezca como si quisiera seguir trepando, mientras que la parte superior da la sensación de querer seguir descendiendo.

En cuanto a la relación entre figura y fondo, encontramos que la disposición de ésta que se encuentra desplazada hacia el extremo derecho de la superficie, provoca tensión en el espacio al estar alejada del centro, situación que se ve compensada por la horizontalidad del paisaje, que da estabilidad y equilibrio.

Otros puntos de tensión visual que encontramos en esta figura, están provocados por la presencia de un par de agujeros, ubicados estratégicamente uno cerca del otro, en el interior de la imagen. Uno de estos agujeros aparece en el centro de la figura, mientras que el otro está en la parte superior, a la altura de la cabeza, su cercanía hace que estos dos puntos se atraigan y se repelan a la vez, atrayendo la mirada del espectador hacia estos puntos en concreto, pero a la misma vez hacia la figura entera.

Este grupo de mujeres, por la dureza de su tratamiento nos da la impresión de ser esculturas de mujeres talladas en piedra, en las que la presencia de estos agujeros invade el cuerpo y traspasa la figura, permitiéndonos incluso en algunas ocasiones mirar hacia el otro lado, como si de una ventana se tratase, lo que nos trae a la memoria, imágenes de las esculturas de Henry Moore, ${ }^{106}$ escultor

${ }^{106}$ En la obra de Henry Moore se consigue una cualidad pasiva y receptiva no sólo a través de la postura de la imagen, sino aún con mayor fuerza a través del carácter hueco de la forma. De este modo la figura llega a encarnar el efecto de una fuerza exterior, que se 
inglés que introduce volúmenes cóncavos en su obra, en rivalidad con las convexidades tradicionales de la escultura normal. Sus esculturas nos muestran siempre la presencia de unas cavidades que traspasan la imagen, y que en ocasiones incluso llegan a formar la propia efigie, cuestión que va en contrasentido de la escultura usual, donde las formas y volúmenes salen hacia fuera. (Véase Fig. 43)

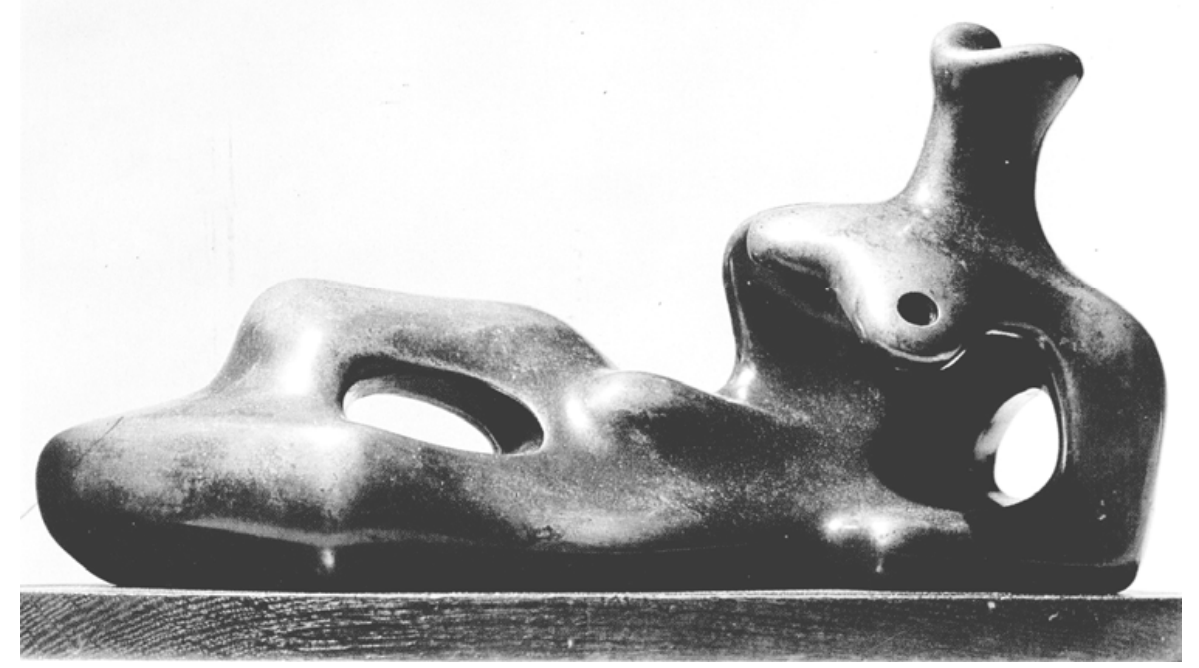

Fig.43. Henry Moore. "Figura reclinada" Escultura en bronce. 1939.

El grafismo de estos agujeros es algo muy característico de ésta y la anterior serie, además continuará vigente en la cuarta

entromete e interfiere en la sustancia material. Se ha añadido un elemento femenino a la masculinidad tradicional de la forma escultórica, un aspecto particular del tema, más universal, de la actividad y la pasividad. Hemos señalado que la convexidad hace a la estatua esencialmente autónoma e independiente. El volumen vació como elemento legítimo de la escultura ha conducido a obras en las que el bloque material se reduce a una cáscara que rodea un cuerpo central del aire. El Yelmo de Moore, una cabeza vacía, ofrecería a un visitante del tamaño de un ratón la experiencia de estar centro de una escultura. Véase ARNHEIM, R.: 1993, pp. 271-273 
serie, a la que se trasladarán convertidos en rejas, en la que mantiene su contenido conceptual. Otros elementos constantes que aparecen en esta serie y la preliminar, y además es el tema protagonista de la siguiente serie, son las cuerdas, dispositivos que surgen atando, colgando y amordazando mujeres. (Véase LAM. XIV)

Otras imágenes producto de esta metamorfosis son las mujeres-árboles, mujeres-troncos, mujeres-raíces, que siguen manteniendo un aspecto hierático y formando parte de un contexto vegetal, al igual que sucede con las imágenes que forman parte de un contexto mineral.

En LAM. XV vemos cómo la imagen de una mujer que mantiene un aspecto femenino da más la impresión de ser el pedazo de un tronco caído, que un cuerpo humano. Su estructura presenta la forma de una figura femenina carente de extremidades superiores y cabeza, cuya parte inferior desde las rodillas hasta el pecho adquiere un aspecto femenino, y la parte superior desde el pecho hasta la altura del cuello un aspecto vegetal, obteniendo como resultado, una figura parecida a un tronco de madera del cual brotan raíces o ramas gruesas "alguien dijo que estas raíces se parecían a las raíces de mandrágora", ${ }^{107}$ una planta alucinógena, raíces que también surgen en piernas y vientre. En definitiva todo el conjunto da la apariencia de ser un pedazo de tronco seco. (Véase Fig. 44)

${ }^{107}$ Entrevista personal con la autora en Castellón de la Plana. 06/05/2005. 


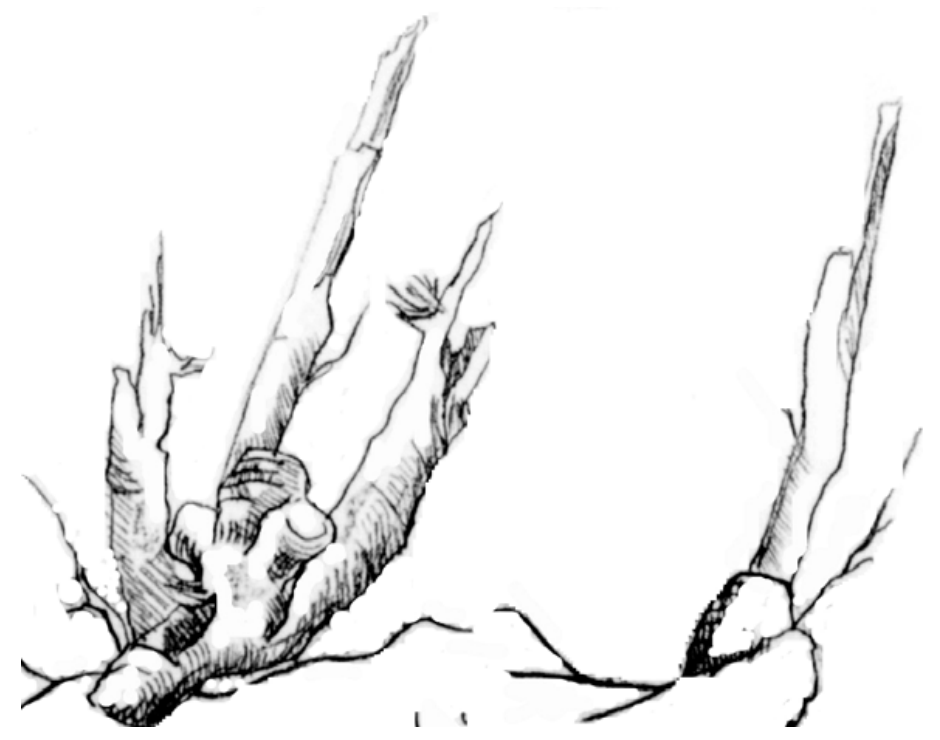

Fig.44. Pilar Dolz. Detalle LAM. XV. Serie De mujeres. Litografía. 1972.

En cuanto a su situación en el espacio, esta figura se encuentra ubicada en la parte central de la superficie, consiguiendo con esto un equilibrio, una coherencia interna entre los espacios que quedan a su alrededor. Por su forma se convierte en una fuerza activa ubicada sobre un fondo pasivo, la forma hace referencia a una imagen conseguida a través de líneas curvas y ondulantes, que llaman la atención, por ser más dinámica, frente a un fondo más neutro, producido por una serie de líneas rectas en sentido oblicuo, que proporciona reposo.

De manera general cuando miramos este grabado percibimos calma y tranquilidad, ya que la imagen no compite de ninguna manera con el fondo para llamar la atención, su ubicación central en el espacio y su posición horizontal de igual manera que la línea que 
divide el fondo, hace que nuestros sentidos perciban paz y serenidad al mirar la obra en conjunto.

La representación de la forma es sencilla y directa, la figura femenina atrae fuertemente la atención debido a su gran tamaño, en relación con un fondo menos espacioso, pues a mayor tamaño, mayor potencia visual.

La figura se encuentra dispuesta en el espacio de forma surrealista, asentada sobre una base horizontal que divide el espacio en dos partes más o menos iguales, donde la parte inferior se encuentra sombreada por una serie de líneas diagonales de forma paralela sin saturar la superficie. Alrededor de la imagen encontramos dibujada una fuerte sombra con la que se pretende asentar la imagen a la superficie, pues la base y la imagen nos presentan dos perspectivas opuestas. La base compuesta por una serie de líneas oblicuas en un sólo plano, da la impresión de ser una perspectiva angular por la dirección de las mismas, mientras que la orientación de la imagen nos da una perspectiva casi frontal, creando un juego perceptivo e ilusionista. Para que la imagen se asiente y no quede suspendida en el espacio es necesario crear una sombra de carácter surrealista, para acoplar estas dos formas.

Siguiendo este tratamiento de mujeres-raíces, mujeresárboles, encontramos otro tipo de figuras, se trata de imágenes trabajadas de una manera más clásica. En LAM. XVI, percibimos perfectamente la forma de una figura humana, más concretamente un retrato femenino, de cuya cabeza brotan esas formas retorcidas y sinuosas de las raíces que conservan y repiten los movimientos del 
crecimiento de la naturaleza, cada una de las cuales siguen diferentes direcciones produciendo fuerzas y tensiones activas en la forma.

El tratamiento de estas imágenes es más clásico, ya no dan tanto la impresión de ser un tronco o un cuerpo inerte, sino más bien son mujeres humanas, en las que la cabellera de sus cabezas están sustituidas por esas formas cartilaginosas en las que se hace presente una cierta intención caligráfica. En esta imagen encontramos un prefecto dibujo académico, bien proporcionado, con una ligera intención de claroscuro, donde la disposición de la forma y de la composición es simple y sencilla, característica principal de la obra, que no busca explorar, ni llenar todo la superficie del espacio, sino que fuera del contorno de la imagen siempre queda un espacio libre e ilimitado que tiende a prolongarse más allá de los bordes, provocando con esto que la imagen ejecutada no tenga límites, no se restrinja hasta al borde del soporte sino que continúe más allá de la demarcación del papel.

A medida que la artista va trabajando, estas mujeres van tornándose más humanas, pero a su vez también más violentas y agresivas. Los huecos o agujeros siguen estando presentes pero ya no de una manera tan evidente, como cuando traspasaban la imagen y se podía mirar a través de ellos, esta vez no llegan a traspasar, sino que se pierden en su interior, integrados dentro de la misma figura. 
Estas imágenes se tornan en formas cada vez más humanas, aunque la dureza de su tratamiento y la presencia de estas aberturas, le siguen dando un aspecto mineral.

Generalmente estas representaciones se encuentran dispuestas espacialmente en dos planos, uno que hace referencia a la forma y el otro al fondo. Normalmente la forma no avanza nunca hasta los bordes del soporte llenando el espacio, sino que se ubica en su centro. En lo que respecta a la imagen, se encuentra delimitada por un contorno que no hace referencia a un dibujo silueteado, sino más bien a unas manchas que determinan sus límites, dejando fuera del contorno un espacio ilimitado que se prolonga hasta más allá de la superficie del papel. El carácter de estas imágenes es irregular, ya que su estructura está compuesta por manchas y líneas gestuales y autónomas, que desmaterializan el objeto.

Normalmente estas figuras se encuentran sentadas 0 apoyadas, en una especie de nube o alfombra voladora, que se encuentra flotando en medio del espacio, porque todo alrededor de ella se encuentra rodeado de un entorno circundante de vacío; por tanto no llegan a apoyarse sobre algo sólido. Se intenta asentarla sobre una base de intensas manchas oscuras ubicadas en su parte inferior, cuyo peso visual hace que la fuerza de gravedad tire hacia abajo, pero también la forma de las imágenes genera un poder de atracción. En LAM. XVII vemos la composición de estructura triangular, que se percibe como una flecha en dirección hacia arriba, contrarresta el tirón gravitatorio descendente de la mancha inferior, produciendo una tensión de fuerzas, que hace 
que la figura no vaya ni hacia arriba, ni hacia abajo, sino que permanezca flotando en el espacio sin una dirección determinada. (Véase Fig. 45)

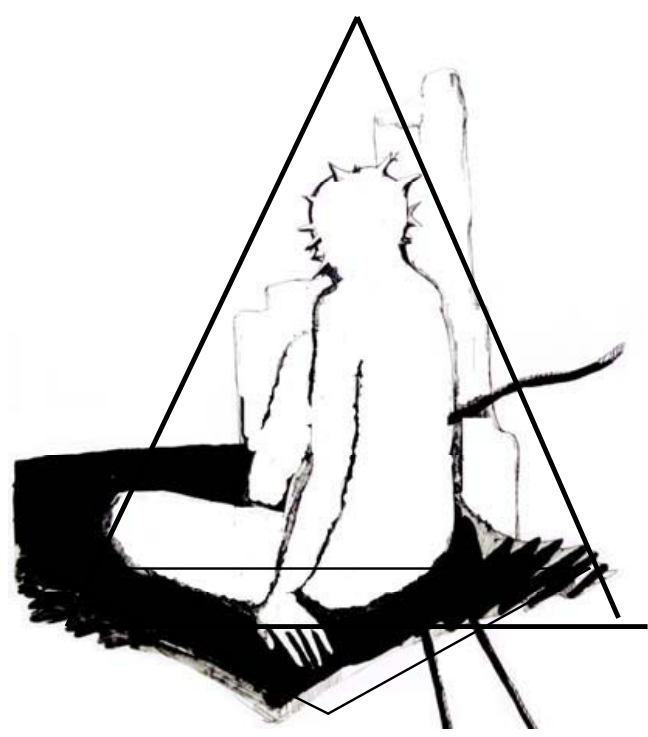

Fig.45. Pilar Dolz. Detalle LAM. XVII. Serie De mujeres. Litografía. 1972.

En otras imágenes el peso gravitatorio está contrarrestado por la presencia de varios puntos focales ubicados en diferentes partes. En LAM. XVIII vemos que estos puntos se encuentran ubicados en la espalda y la cabeza de la imagen distribuyendo el peso de la composición. Se observa que se basa en un juego de punto y contrapunto, entre elementos que se contrarrestan entre sí, entre fuerzas que no son contradictorias, ni conflictivas, que no luchan, sino que juntas equilibran mutuamente la estructura de la obra. 
La perspectiva de estas obras se asienta sobre la creación de un ámbito perceptivo que aparece extenderse indefinidamente, por detrás de la superficie trabajada, debido a que la forma del objeto no sólo depende de la proyección visual que vemos, sino también de las experiencias visuales que tenemos y que se guardan dentro de nosotros en un contexto de espacio y tiempo. Así por ejemplo la mayoría de mujeres representadas de esta serie, se encuentran dibujadas de espaldas, nunca de frente, de esta manera podemos apreciar que estas mujeres se encuentran mirando hacia una perspectiva abierta e imaginaria, que aunque no las podamos mirar el rostro, nuestra experiencia visual nos dice que todos los seres humanos estamos provistos de ojos, oídos, boca, sentidos que nos permiten visualizar el mundo exterior.

Estas imágenes se encuentran dando la espalda al espectador quizás de la misma manera que se encuentran dando la espalda al mundo material, horroroso y violento, que la artista ha querido contarnos, buscando un futuro esperanzador, a lo mejor no sólo para estas mujeres sino para la humanidad.

\section{Grafismo}

El trazo se hace presente en la obra a través de un planteamiento común y normal de ejecución de la línea a través de la acción motora de la mano. El trazo en esta serie, es más controlado, a pesar de que la obra se sigue haciendo directamente sobre la plancha, su ejecución es más pensada y premeditada, no tan automática y accidental como la hacía anteriormente. Aunque hay 
ciertas obras, como aquellas mujeres con apariencia de tronco, árbol o roca, que mantienen cierto automatismo, cuando hablamos de la realización de aquellas formas cartilaginosas, especies de raíces que brotan de sus cabezas o de sus cuerpos yacentes, y que surgen como grandes caligrafías orgánicas, realizadas a través de una disposición desordenada y caprichosa de líneas que se superponen unas a otras, tejiendo una especie de red transparente sobre un fondo libre y abierto, creando un efecto tridimensional en el que podemos distinguir varios planos de profundidad difíciles de diferenciar uno de otro y de saber de cuantos planos se tratan, debido a que estos trazos, retorcidos y sinuosos están constantemente entrecruzados, avanzando, interrumpiendo, subiendo y bajando en un diagrama de fuerzas. Estas líneas se perciben como si estuvieran hechas de un material sólido, que se mezcla y confunde entre ellas, pero que siguen siendo objetos independientes con autonomía propia, en los que incluso se las puede llegar a contar si se quisiere.

Estos trazos se materializan en el propio proceso de trabajo que se realiza directamente sobre la matriz, circunstancia que da lugar a una serie de formas abstractas que coexisten con el evidente reconocimiento figurativo de raíces o ramas de árboles. Su realización se ejecuta a través de un indudable acto gestual, producido por la fuerza motriz externa del brazo y del hombro, en el que se puede reconstruir los movimientos de la mano a partir de la huella que deja el lápiz sobre la plancha. (Véase Fig. 46) 


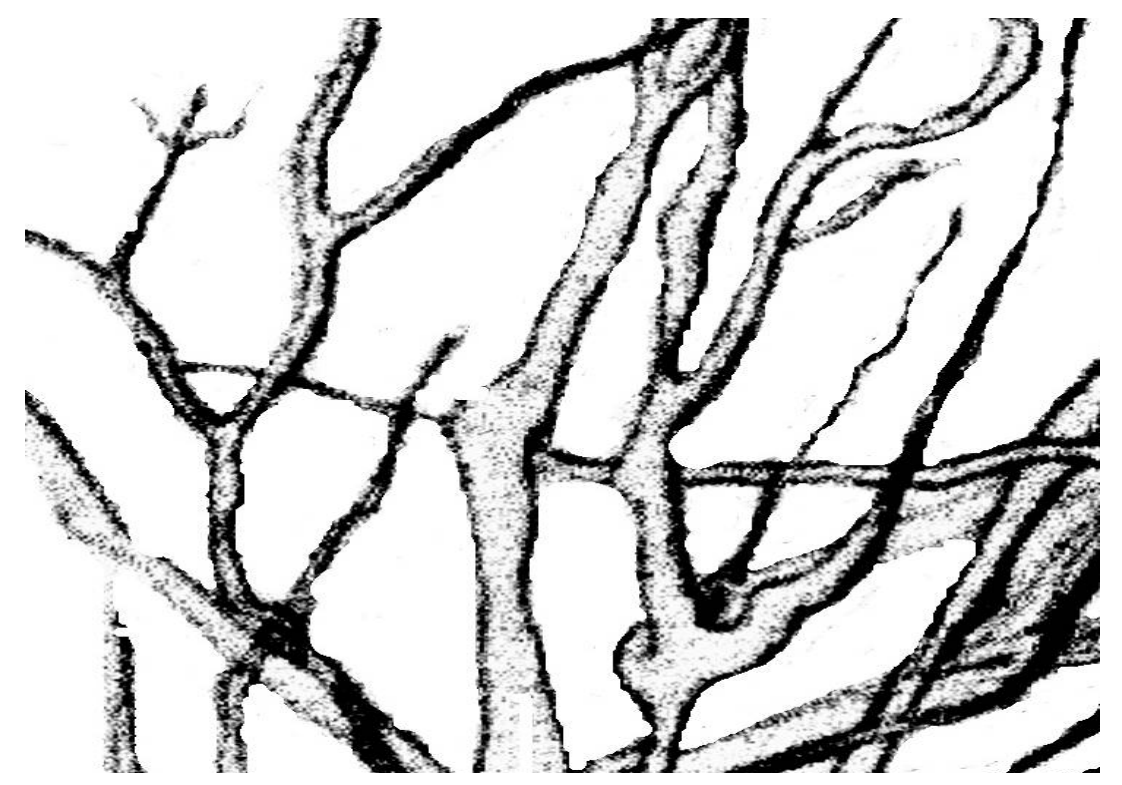

Fig.46. Pilar Dolz. Detalle LAM. XVI. Serie De mujeres. Barniz blando. 1972.

En otras obras, encontramos la presencia de otro tipo de trazo, el de contorno, que lo visualizamos como una especie de línea de alambre que dibuja la forma en el espacio. Este hecho significa la reducción al mínimo de la figura a su contorno, que en realidad no existe como tal en la naturaleza, sino que es una traducción de la mente.

Podemos percibir fácilmente esta situación, cuando la imagen de una figura femenina encuentra limitada su representación al perfil de su contorno, en cuyo interior encontramos un espacio vacío, que en el momento de la impresión nos obliga a ver el color del papel. 
Esta experiencia visual gana en simplicidad, ya que la forma encerrada entre estas líneas la percibimos como un objeto palpable, mientras que el espacio que queda fuera de estos límites se visualiza como un fondo libre. En LAM. XXI el trazo que dibuja el perfil de la imagen se caracteriza por ser único y continuo. (Véase Fig. 47)

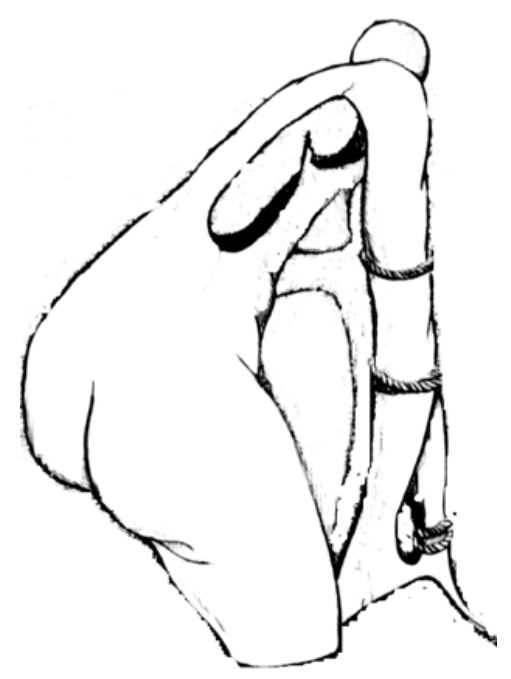

Fig.47. Pilar Dolz. Detalle LAM. XXI. Serie De mujeres. Aguafuerte y laca de cabello. 1972.

En otras obras la línea de contorno comparte protagonismo con la de la sombra, utilizada para realizar entramados, con los que se consigue una sensación de volumen, aunque en la mayoría de las obras estas sombras sólo se utilizan para sugerir un espesor. La combinación de estas líneas nos da como resultado visual una sombra, que no es más que la suma de líneas individuales, realizadas por separado y vistas en su totalidad, en un esquema global simple. 
En LAM. XV, podemos apreciar como se mezclan los diferentes tipos de trazos, curvos, rectos, tenues y suaves empleados, unas veces en superposición, y otras individualmente para insinuar simplemente un volumen, más que para crear una sombra. Estos trazos por su tratamiento dan lugar a una caligrafía un tanto rígida y áspera, con la que se pretende indicar el volumen de los músculos de piernas y del cuerpo inerte de la figura.

El trazo empleado para sombrear la superficie, la base donde se asienta la imagen, resalta entre los demás, por ser un trazo rígido y severo, realizado en una sola dirección, en sentido diagonal, y donde la línea no llega a superponerse, sino que se desarrolla en sentido paralelo, por lo que destaca más fuertemente, frente al trazo ondulante e irregular de la imagen. La disposición paralela y repetitiva del trazo recrea cierto movimiento y vibración en este espacio. (Véase Fig. 48)

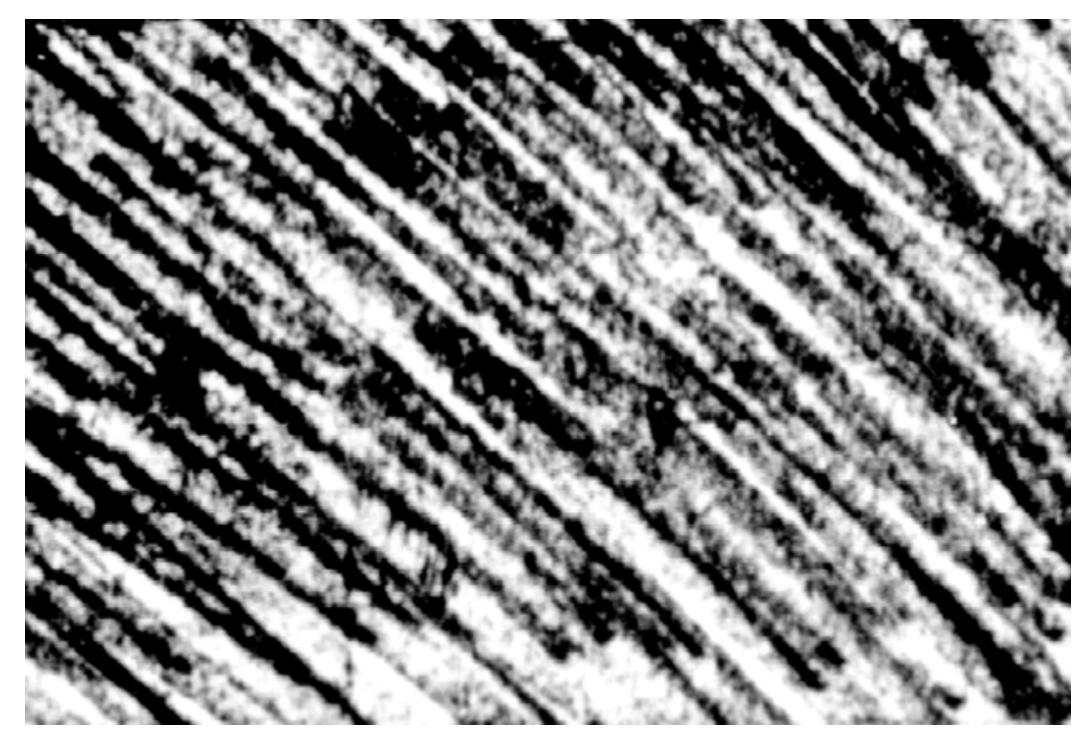

Fig.48. Pilar Dolz. Detalle. LAM. XV. Serie De mujeres. Barniz blando.1971 
En otro grupo de obras realizadas por la técnica litográfica, el trazo aparece más suelto a manera de manchas que son las protagonistas de la obra. Se basan sobre todo en la posibilidad de realizar la mancha directamente sobre la matriz, utilizando del pincel como vehículo para dejar la impronta, que facilita el desarrollo de un trabajo más fluido y espontáneo con el que podemos obtener diversas soluciones gráficas como; trazos finos, gruesos, anchos, delgados, lisos, rugosos, accidentales, barridos y otros, que suponen el desarrollo de diversas posibilidades en el tratamiento de la imagen.

El trazo realizado es suelto y sencillo con el que se intenta dar el carácter expresivo en la obra. El pincel y la pluma trabajados de una manera muy clásica y tradicional le permiten obtener diferentes calidades gráficas.

Su método de trabajo es a través de unos acuarelados litográficos, con el que se consiguen unas manchas duras y ásperas, debido a que aún no controla la técnica, ya que esta obra pertenece a su etapa de formación.

Las manchas producidas en este grupo de obras, tienen diferentes calidades gráficas, así tenemos un tipo de mancha descriptiva, empleada para dar volumen a los cuerpos femeninos, se trata de una mancha rugosa, producida por la huella que deja el pincel cargado con poca tinta, y que al ser arrastrado por la superficie deja una huella áspera. En algunas ocasiones esta mancha se presenta brusca, desabrida, con constantes golpes y 
barridos de pincel sobre la misma zona, dejando una marca un tanto agresiva, con una caligrafía espontánea.

En otras ocasiones se presenta más suave y continua, como en LAM. XVII, donde da la sensación de ser más blanda y transparente, donde se puede buscar distintas calidades tonales apenas perceptibles, por ello en ocasiones se hace necesario reforzar esta mancha con otro juego de líneas más delicadas y diminutas realizadas con una pluma o la punta de un pincel fino, para dar mayor dinamismo a la mancha. (Véase Fig. 49 y 50)

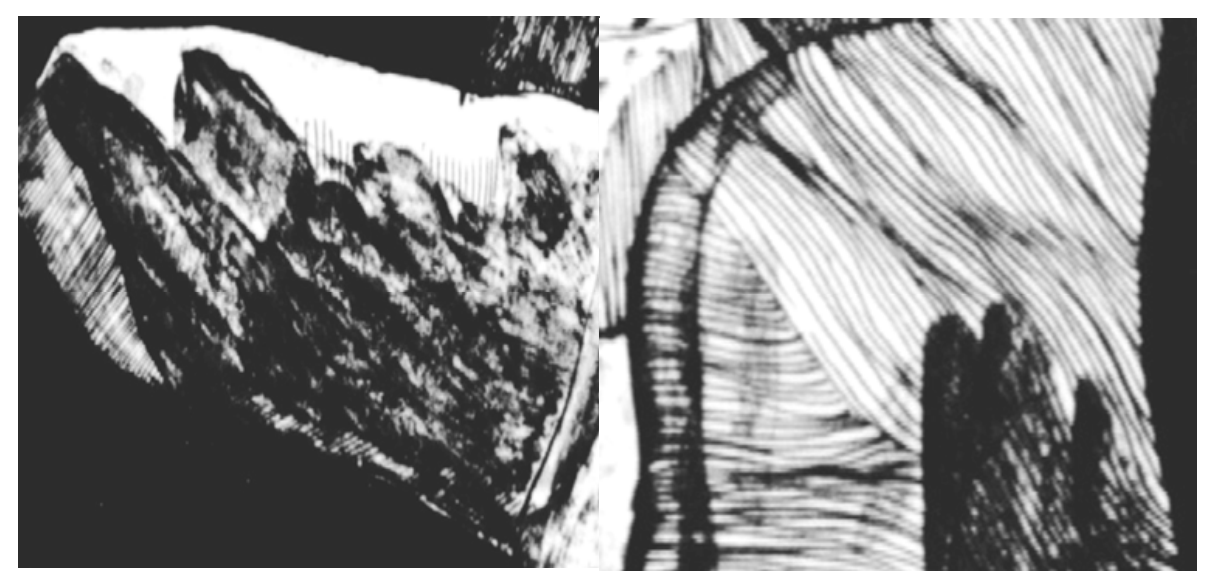

Fig.49-50. Pilar Dolz. Detalle LAM. XVII. Serie De mujeres. Litografía.1972.

En LAM. XIX en cambio esta mancha es más difusa, más acuarelada, en la que la diversidad de tonos se funden, dándonos una gran riqueza tonal, por medio de mezclas y superposiciones de tonos, incluso para dar mayor fuerza a la mancha, algunas partes se encuentran reforzadas por una mancha dibujada con un pincel de un grosor más fino y cargado con un poco más de tinta, arrastrado de 
manera rápida y suelta, en las que percibimos una gran fuerza. (Véase Fig. 51)

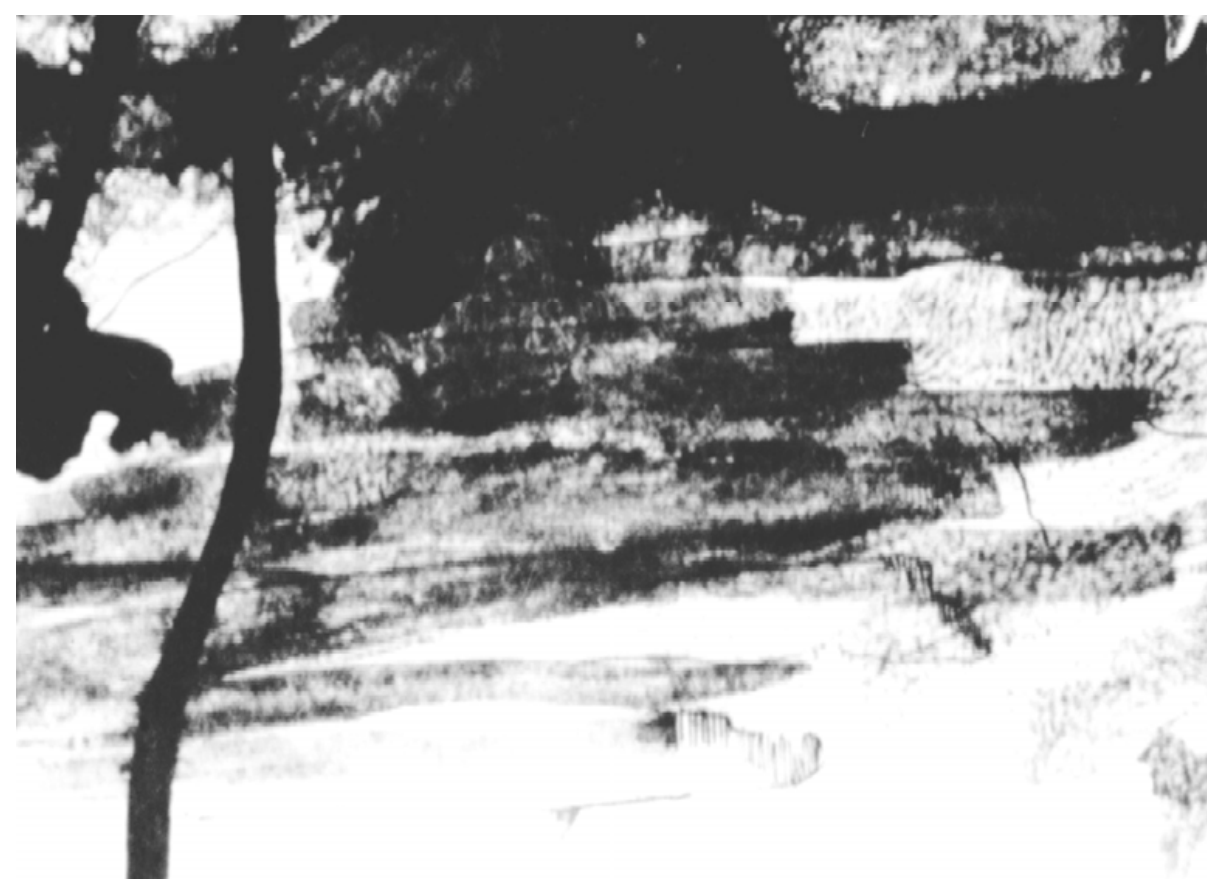

Fig.51. Pilar Dolz. Detalle. LAM. XIX. Serie De mujeres. Litografía.1972.

También descubrimos la presencia de otro tipo de trazo, como el realizado en LAM. XVIII, resuelto a golpes de pincel cargado con bastante tinta, se trata de unos trazos bien amplios e insistentes, que aparecen formando auténticas masas planas de tintas, en las que no se aprecia ninguna textura, ni ningún barrido; se trata de una mancha plana y espesa con la que se consigue un negro muy saturado. En otras ocasiones esta mancha se nos presenta menos densa y más traslúcida, y es empleada para sombrear el interior de la imagen, pero en la que se sigue manteniendo el carácter plano de la mancha. (Véase Fig. 52 y 53 ) 


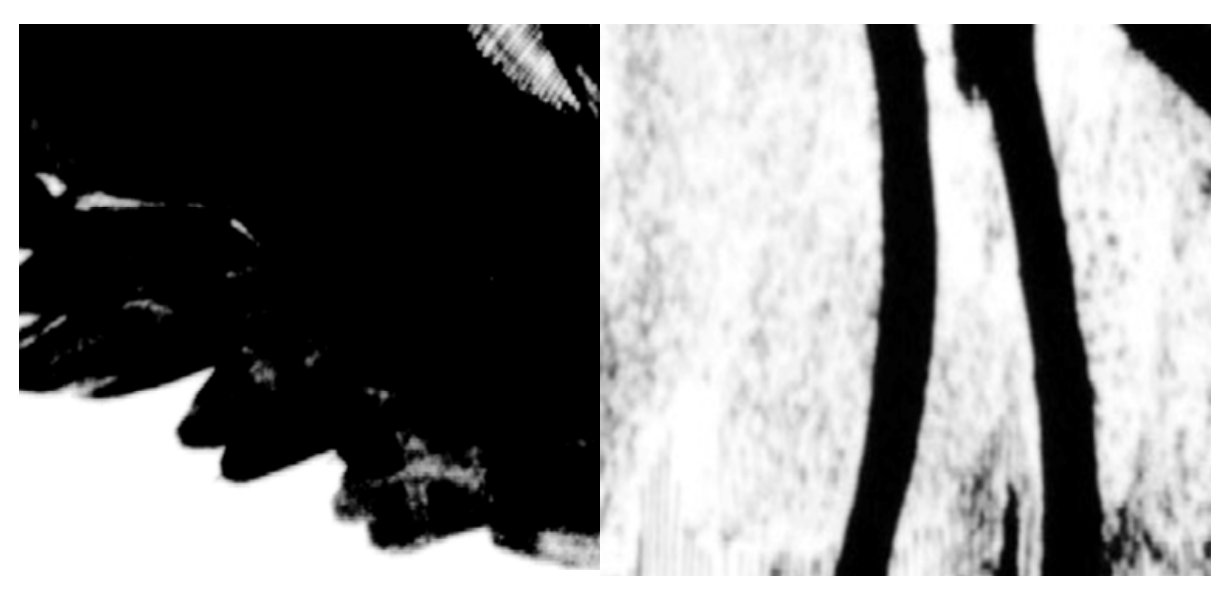

Fig.52-53. Pilar Dolz. Detalle LAM. XVIII. Serie De mujeres. Litografía. 1972.

En 1972 encontramos esta misma obra (LAM. XX), realizada en litografía offset, con los distintos tipos de grafismos dispuestos a través de varios niveles de profundidad que se superponen unos sobre otros, para dar mayor fuerza en ciertas zonas. Así en un primer plano tropezamos con un conjunto de líneas muy finas dispuestas de forma paralela, realizadas con la punta de un pincel fino a manera de plumilla.

En un segundo plano hallamos otro grupo de líneas texturadas, producidas por la huella que deja el pincel al ser arrastrado sobre la superficie, y por último tenemos la presencia de una mancha totalmente plana en la que no se distingue la marca del pincel. Estos grafismos conviven en una sola imagen, gracias a la participación de dos planchas trabajadas de una manera tradicional. (Véase Fig. 54) 


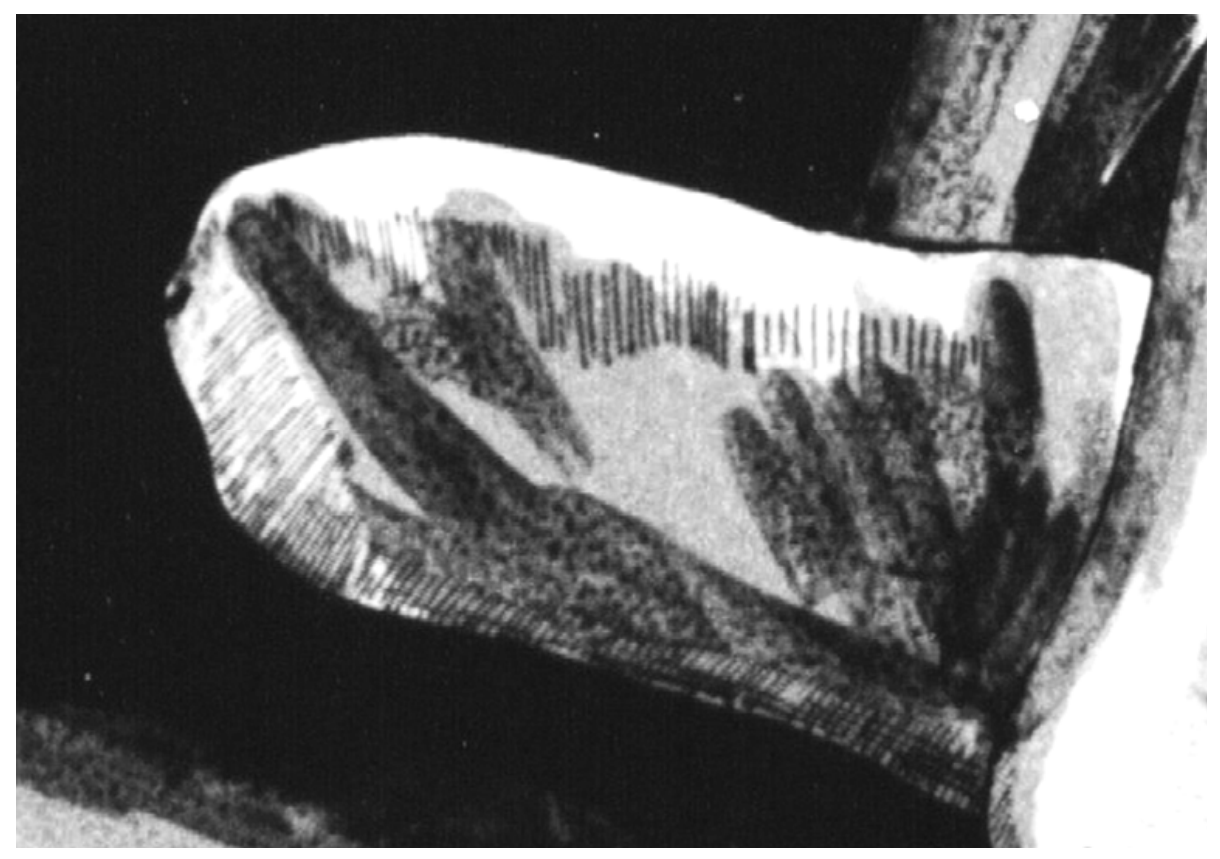

Fig.54. Pilar Dolz. Detalle. LAM. XX. Serie De mujeres. Litografía offset. 1972

En resumen, podemos decir con respecto al trazo realizado con pincel, que encontramos tres tipos; un trazo caligráfico espacial, que funciona más como mancha, conseguido con una simple pasada del pincel, con el que se obtiene cierta textura, por medio de los diferentes estados de dureza de sus cerdas y por la distinta densidad de tinta. Otro es aquel que se utiliza para dibujar o acentuar algunas partes de la imagen y para hacer esa especie de hilos o cuerdas que atan e inmovilizan las figuras, éste es un trazo liso, regular, saturado de tinta, que camina por el espacio sin titubeos, como una serpiente, con movimientos suaves y armoniosos. El siguiente trazo es una caligrafía modular con efecto volumétrico, realizado a través de la aplicación de la tinta litográfica con una pluma que permite una delicada modulación del trazo, esta línea también se dispone de 
forma paralela, para la creación de espacio, capaz de un mayor detallismo, similar a los efectos conseguidos con la plumilla. ${ }^{108}$ (Véase Fig. 55, 56, 57 y 58)

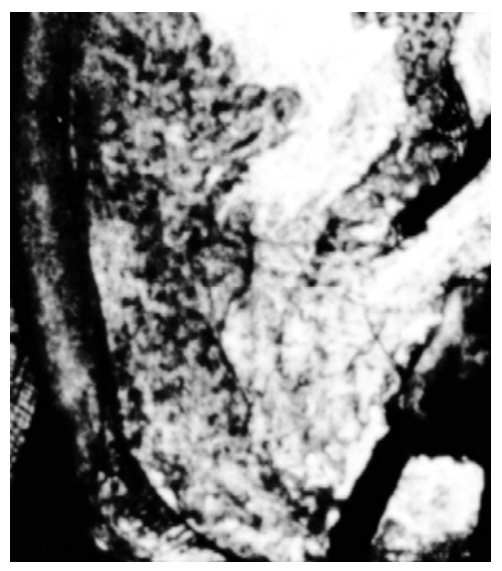

Fig.55. Pilar Dolz. Detalle. LAM. XVII. Serie De mujeres. Litografía.1972 Trazo caligráfico texturado, realizada con pincel grueso, para crear manchas.

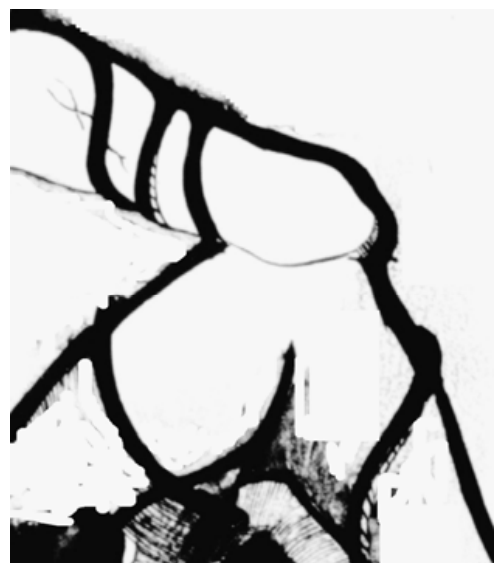

Fig.56. Pilar Dolz. Detalle. LAM. XIX. Serie De mujeres. Litografía. 1972 Trazo caligráfica liso realizada con pincel mediano para dibujar o contornear.

\footnotetext{
${ }^{108}$ La técnica de la pluma o el pincel en litografía, se basa en el dibujo sobre la matriz litográfica con pluma y tinta litográfica, con resultados casi iguales a un dibujo a tinta china. La superficie de la piedra debe estar completamente lisa para que la plumilla no encuentre obstáculos. Si se usa pincel, la superficie puede ser lisa o granulosa, según los resultados que se quiera obtener. Si la tinta aplicada con el pincel se diluye en agua para obtener los matices, se presentan algunas dificultades técnicas. El ácido de la preparación debilita los tonos medios especialmente si son ligeros, y la delicadeza del dibujo no permite grandes tiradas. Por este motivo la acuarela sobre piedra litográfica exige una gran habilidad técnica por parte del estampador. Véase WORK, T.: 1987. p. 15.
} 

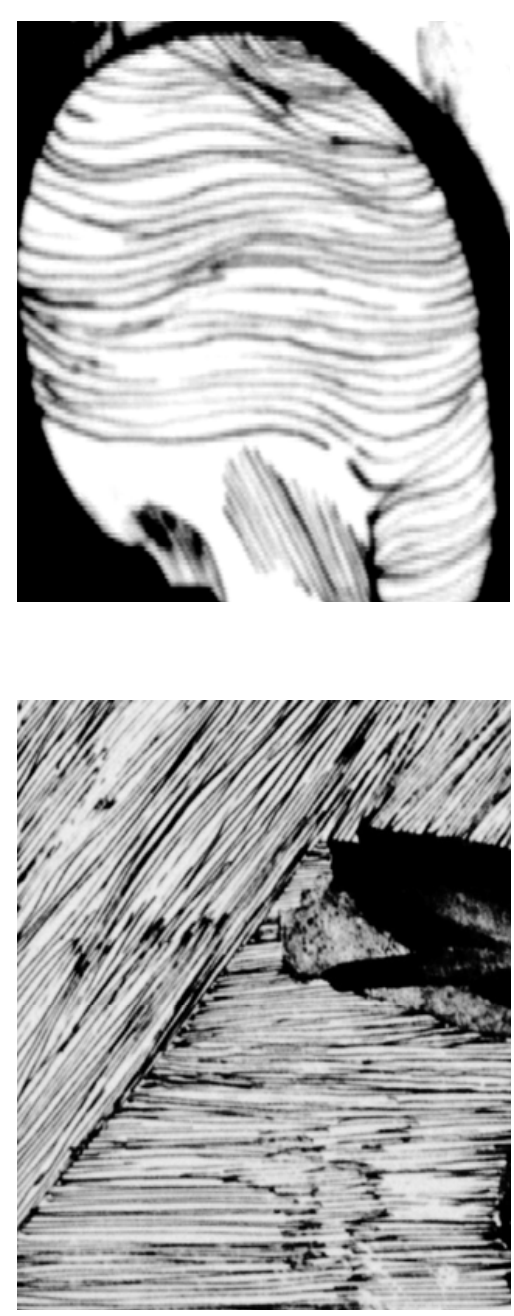

Fig.57. Pilar Dolz. Detalle LAM. XIX.

Serie De mujeres. Litografía.1972. Trazo modular realizada con pluma o pincel fino para crear volumen.
Fig.58. Pilar Dolz. Detalle LAM. XIV.

Serie De mujeres. Litografía. 1972. Trazo recto realizada con pluma o pincel fino para crear espacio

\section{Color}

La ausencia del color es un recurso formal propio de esta serie, trabajada de forma monocroma y con el predominio de la mancha, quizá la única obra que hace alusión a la exploración del color es una litografía offset, que resulta de una experiencia personal mantenida por la artista en una exposición de grabados de Pablo Picasso, realizada en Barcelona en el año 1972, en la que queda 
fuertemente fascinada por las litografías y las aguatintas presentes en la muestra. (Véase Fig. 59)

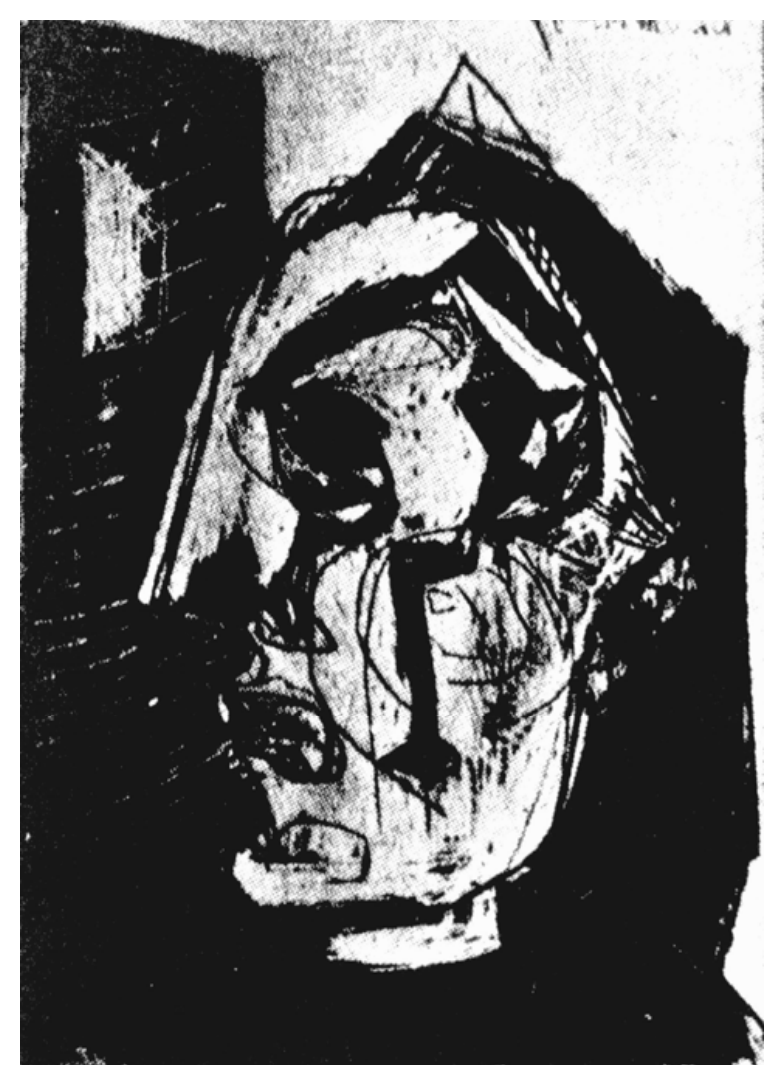

Fig.59. Pablo Picasso. "Cabeza de hombre perfil a la izquierda". Aguatinta y punta seca. 1937.

Se trata de una obra resuelta con dos planchas litográficas y por medio de la técnica de la aguada. La primera matriz dibuja la imagen con la utilización de distintos tipos de trazos caligráficos realizados con pincel, la fuerza del trazo y la dureza de los tonos hace que la imagen sea muy dura y agresiva, por lo que intenta calmar esta situación con una segunda plancha de fondo, trabajada 
a base de manchas y con la que quiere conseguir una variedad tonal y suavizar el rasgo.

Esta plancha se encuentra estampada en color plata, pero la claridad de su color no permite distinguir las distintas calidades de mancha y la variedad de tonos trabajados sobre la matriz, más bien lo único que podemos apreciar es una mancha plana de uno o dos tonos. (Véase LAM. XX)

Yo aquí estoy intentando, (...) tengo una litografía hecha con un solo color y luego otra con dos planchas, me resultaba muy dura, yo no controlaba, entonces hice esta otra obra con dos planchas, es un poco absurdo pero cuando no consigues el resultado deseado, hago otra plancha, aunque sea la misma imagen es una litografía diferente, si te das cuenta no es la misma, una es más pequeña que la otra, lo que ocurre es que, la misma imagen la he dibujado dos veces (...), pero es que aquí estoy probando una técnica, una técnica clásica, porque he visto un grabado de Picasso (....). ${ }^{109}$

${ }^{109}$ Entrevista personal con la autora en Castellón de la Plana. 16/05/2005. 


\subsubsection{PROCESO TÉCNICO}

En esta serie de obras intervienen varias técnicas clásicas del grabado; como el aguafuerte, aguatinta y barniz blando, técnicas empleadas en menor medida, ya que la mayor parte de obras de esta serie se encuentran trabajadas con la técnica litográfica.

Otro planteamiento al que recurre a menudo Pilar Dolz, es el de comprobar los efectos que le puede dar una técnica y otra, así prueba como los distintos resultados que obtiene con la técnica litografía, los puede obtener también a través del barniz blando, a la manera lápiz, técnica que emplea con un tratamiento ortodoxo. ${ }^{110}$ (Véase LAM XV y XXII)

En estas obras en concreto, tiene la intención de probar la manera lápiz con dos técnicas distintas. Hay que entender que es una etapa en la que se encuentra constantemente cambiando de taller, de Bellas Artes, a la Escuela del Libro, al Instituto Americano, y a los distintos talleres de Italia, y en cada uno tiene que seguir una forma determinada de trabajar, con distintos materiales, diferentes técnicas, o nuevas formas de trabajo, también son años de aprendizaje en los que va intentando y probando técnicas.

\footnotetext{
${ }^{110}$ Se trata de una técnica realizada en planchas de metal y con un procedimiento muy sencillo; se cubre la plancha con un barniz blando y cuando seca, se coloca sobre ésta un papel normal de gramaje muy fino y se dibuja sobre él con un lápiz, consiguiendo de esta manera que el dibujo del papel pase a la plancha por la presión ejercida, que levanta el barniz de las zonas donde se pasado con el lápiz, reproduciendo sus calidades caligráficas. Véase DAWSON, J.: 1982, p. 64.
} 
Su obra está trabajada con una técnica muy tradicional, pero quizá lo más importante es la manifiesta opinión de la artista de la búsqueda de la realización de una obra sencilla, tanto si es en el lenguaje, como en la utilización de la técnica, y los elementos que intervienen en ésta, por eso es su práctica habitual emplear los diversos materiales que encuentra más a su alcance. Así en LAM. XXI vemos como en un grabado realizado al aguafuerte, hace uso de la técnica únicamente para fijar el dibujo de la imagen, mientras que el fondo se encuentra solucionado por el empleo de un spray de laca de cabellos, con el que intenta conseguir los mismos efectos que se obtiene con la resina. Con el spray los sitios donde cae la laca quedan reservados como si se tratara de un barniz, por eso al pulverizar este producto, unos espacios quedan más recubiertos que otros, obteniendo un efecto agradable. (Véase Fig. 60)

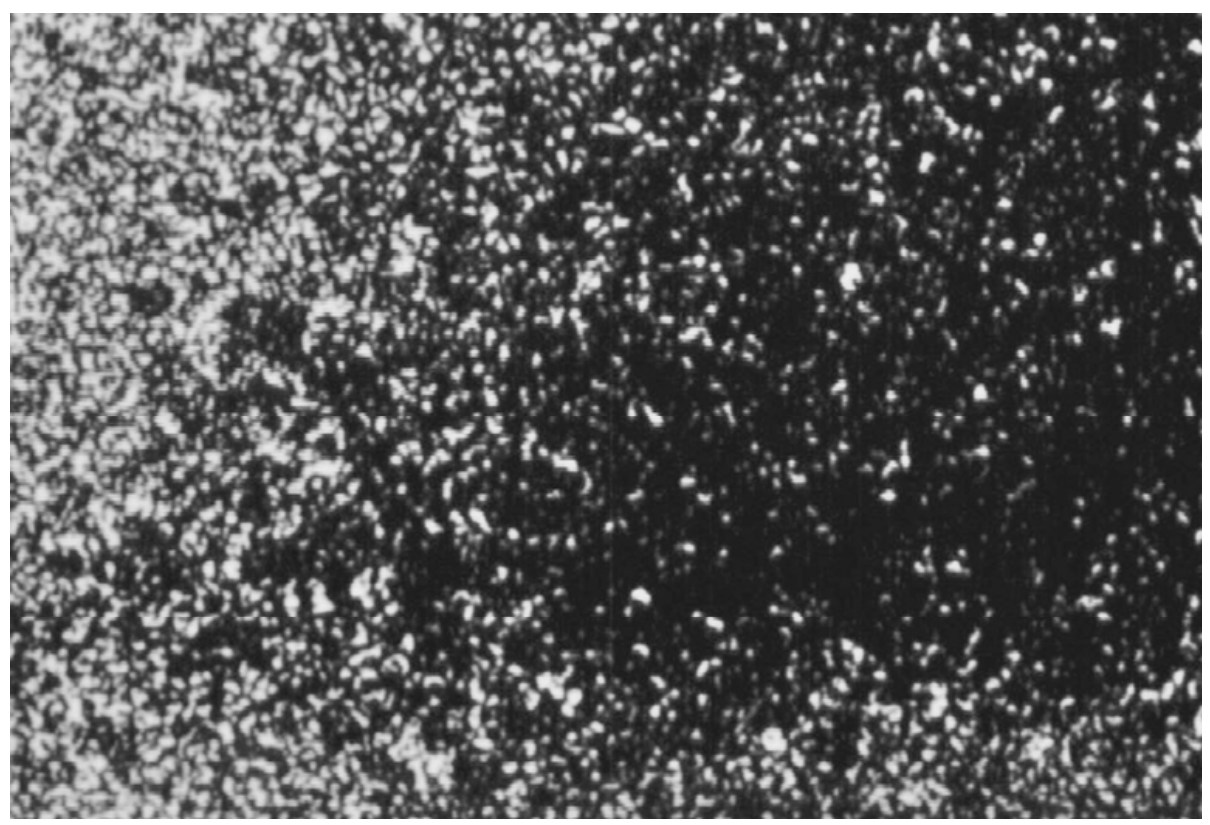

Fig.60. Pilar Dolz. Detalle LAM. XXI. Serie De mujeres. Aguafuerte.1972 
Yo a veces pruebo ciertas cosas, no digo que investigo, yo pruebo, eso lo hacia con laca de cabello y probaba a ver si esto me servía como resina, yo pruebo, porque creo que esto puede funcionar, (...) trabajo con cosas que tengo a la mano, porque pienso en todos los grabadores de todas las épocas como Goya, lo de las resinas, pues seria con lo que tiene a mano, por eso yo utilizo este tipo de cosas. Ésta es una laca de cabello, pero yo usaba cosas de todo. ${ }^{111}$

La litografía offset es la técnica más trabajada en esta serie tanto en piedra como en planchas de metal. ${ }^{112}$ Esta técnica es uno de los medios de expresión artística que mayor interés y encanto presenta en la serie. Las litografías realizadas en piedra, están resueltas por medio de la utilización del lápiz litográfico, mientras que las litografías en plancha, están solucionadas a través de aguadas litográficas de la manera más tradicional, como lo hacían los antiguos grabadores, sin la intención de buscar nada nuevo, sino más que desarrollar su propia obra.

La litográfica es la técnica con la que ha logrado salir de los límites de la expresión puramente lineal, a través de la realización de la obra con el uso del pincel, con los que se puede obtener efectos del lavis, de la acuarela, efectos que también se han conseguido con

\footnotetext{
111 Entrevista personal con la autora en Castellón de la Plana. 16/05/2005

112 Hoy en día se utilizan procedimientos casi idénticos sobre diversos tipos de soporte, ya que la piedra litográfica es cada vez más escasa y cara. Los más comunes son la plancha de cinc (cincografía) o de aluminio (algrafía), con los que se logran resultados semejantes. Debe emplearse un graneador de bolas para el pulimento, y ácido fosfórico para el acidulado. Se precisa un buen secado. La estampación tiene el riesgo de emborronar la superficie provocando manchas irreparables. Aparte de las otras ventajas prácticas, la plancha de zinc presenta la ventaja de poder dibujar sobre ella con un lápiz normal de grafito, con el cual se puede obtener trazos mucho más sutiles que con el lápiz litográfico. La prensa litográfica puede ser una prensa manual o una prensa offset según el procedimiento. Véase BLAS, J y BARRENA, C: 1995, pp. 236-237
} 
otras formas de grabado, pero a través de recursos complicados y forzando la naturaleza del material.

La técnica de la aguada litográfica la trabaja aplicando la tinta litográfica con diferentes densidades, por lo que se consigue obtener distintos matices en la mancha; su aplicación con diferentes pinceles de distinta anchura y grosor, le permite obtener diferentes calidades y tipos de manchas. Los trazos lineales se consiguen con la utilización de una pluma o un pincel de punta fina. Esta técnica exige una gran habilidad técnica, ya que el ácido que se elabora para la preparación de la plancha, debilita los tonos medios, especialmente si son ligeros, lo que no permite una gran tirada.

Hemos comprobado que el dominio de esta técnica le resulta un tanto difícil, porque no controla la intensidad de la mancha, algunas veces, llega a saturarlas, al repasar varias veces el pincel sobre la misma zona, dando lugar a unos tonos negros muy duros, que dan la sensación de ser unos agujeros, tanto así que llega a repetir la obra varias veces.

La experiencia de ver cosas, gestos, trazos, técnicas de otros artistas, e intentar imitar ciertas cosas que ha visto, es una práctica confesada por la artista, que ejerce en su etapa de aprendizaje, tanto en Barcelona como en Italia, y que se prolongará hasta años más tarde en 1983, cuando viaja a París a atelier 17, con William Hayter. 
Las obras de esta serie nos muestran un amplio repertorio de soluciones técnicas con manchas y elementos lineales, donde el trazo se realiza directo sobre la matriz. La construcción de la imagen es realizada de la memoria, sin la necesidad de fijarse en un modelo del natural, debido al conocimiento de la figura humana que lo había adquirido en sus años de estudios en Massana y Bellas Artes. 


\section{LÁMINAS}

\section{E MUJERES}





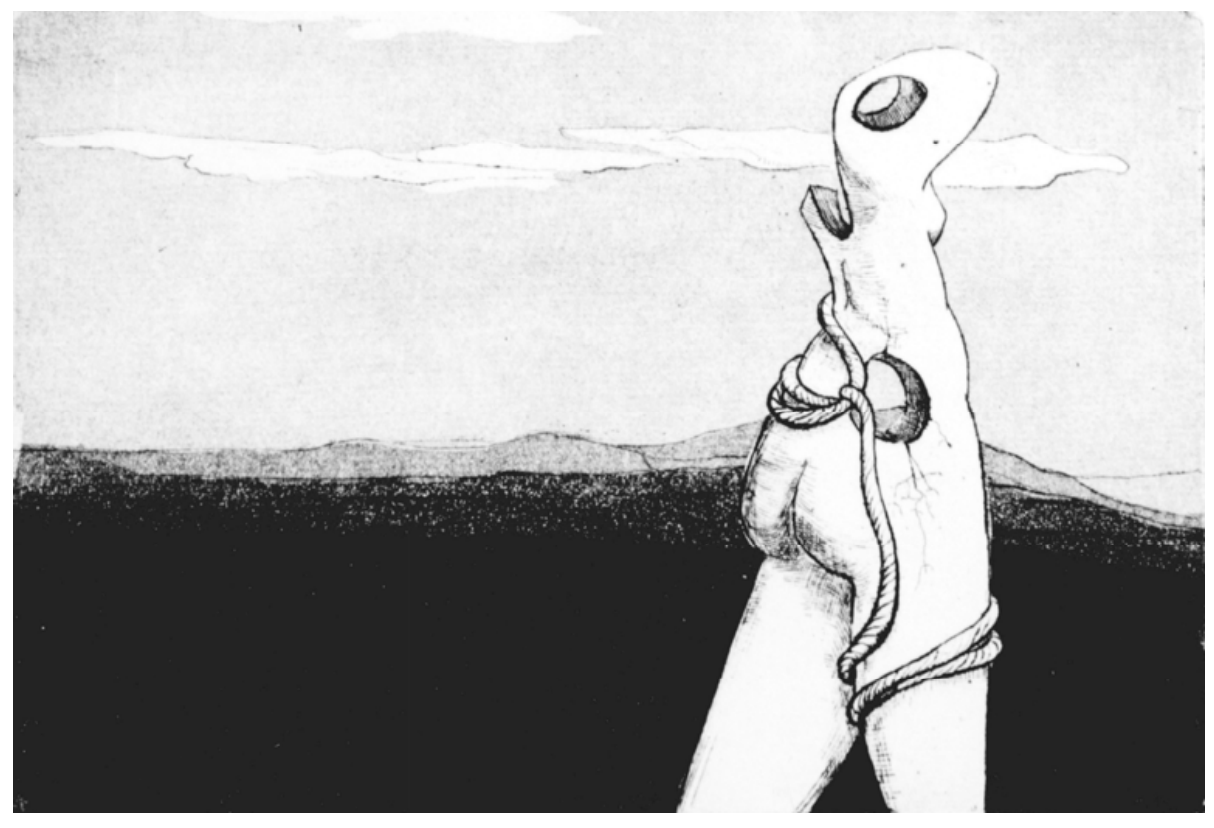

LÁMINA XIII

"Sin título 1"

Aguafuerte y aguatinta

$13 \times 19 \mathrm{~cm}$.

1971 


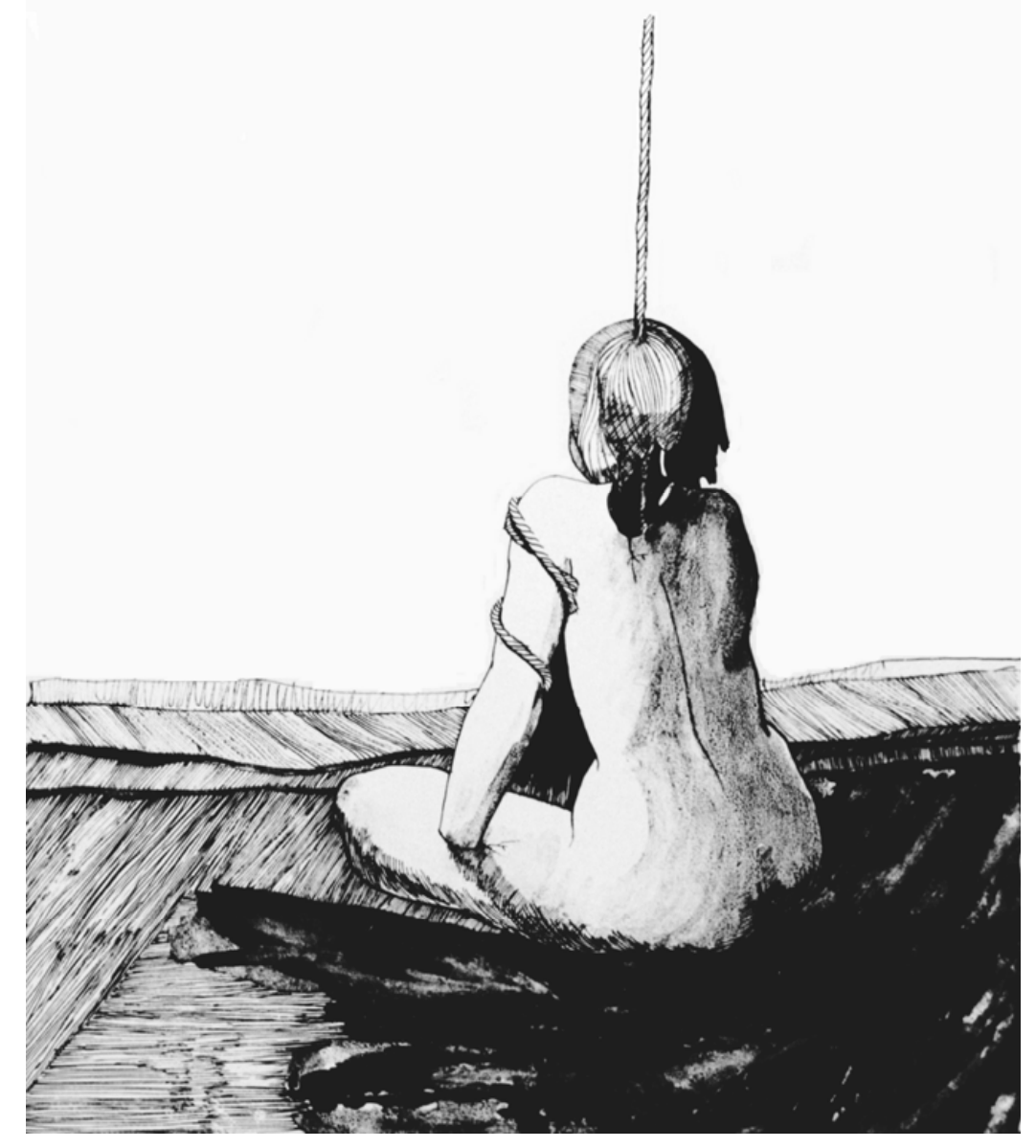

LÁMINA XIV

"Sin título 5"

Litografía offset.

$36 \times 31 \mathrm{~cm}$.

1972 


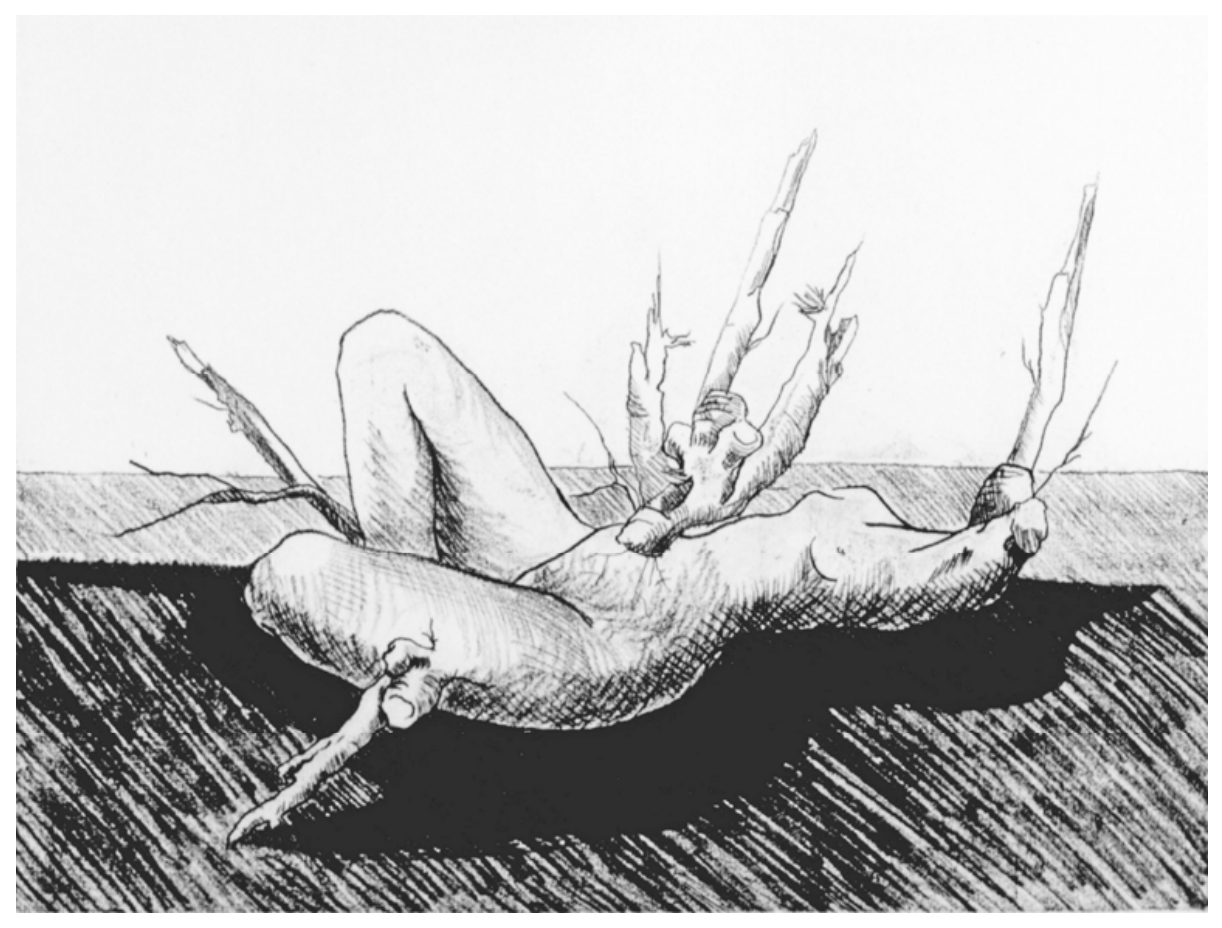

LÁMINA XV

"Sin título"

Barniz blando

$28 \times 32 \mathrm{~cm}$.

1971 


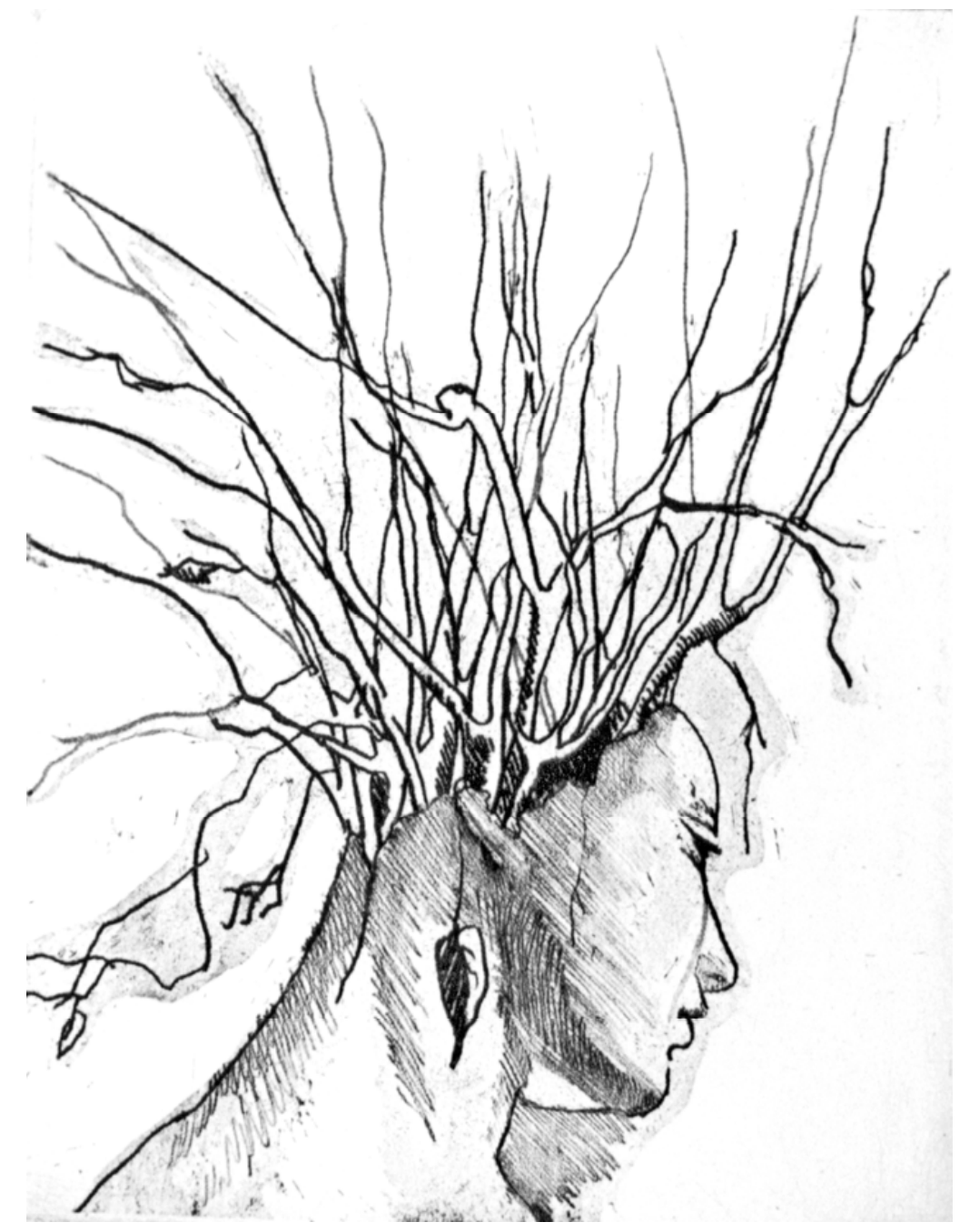

LÁMINA XVI

"Sec"

Barniz blando

$16 \times 12.5 \mathrm{~cm}$.

1972 


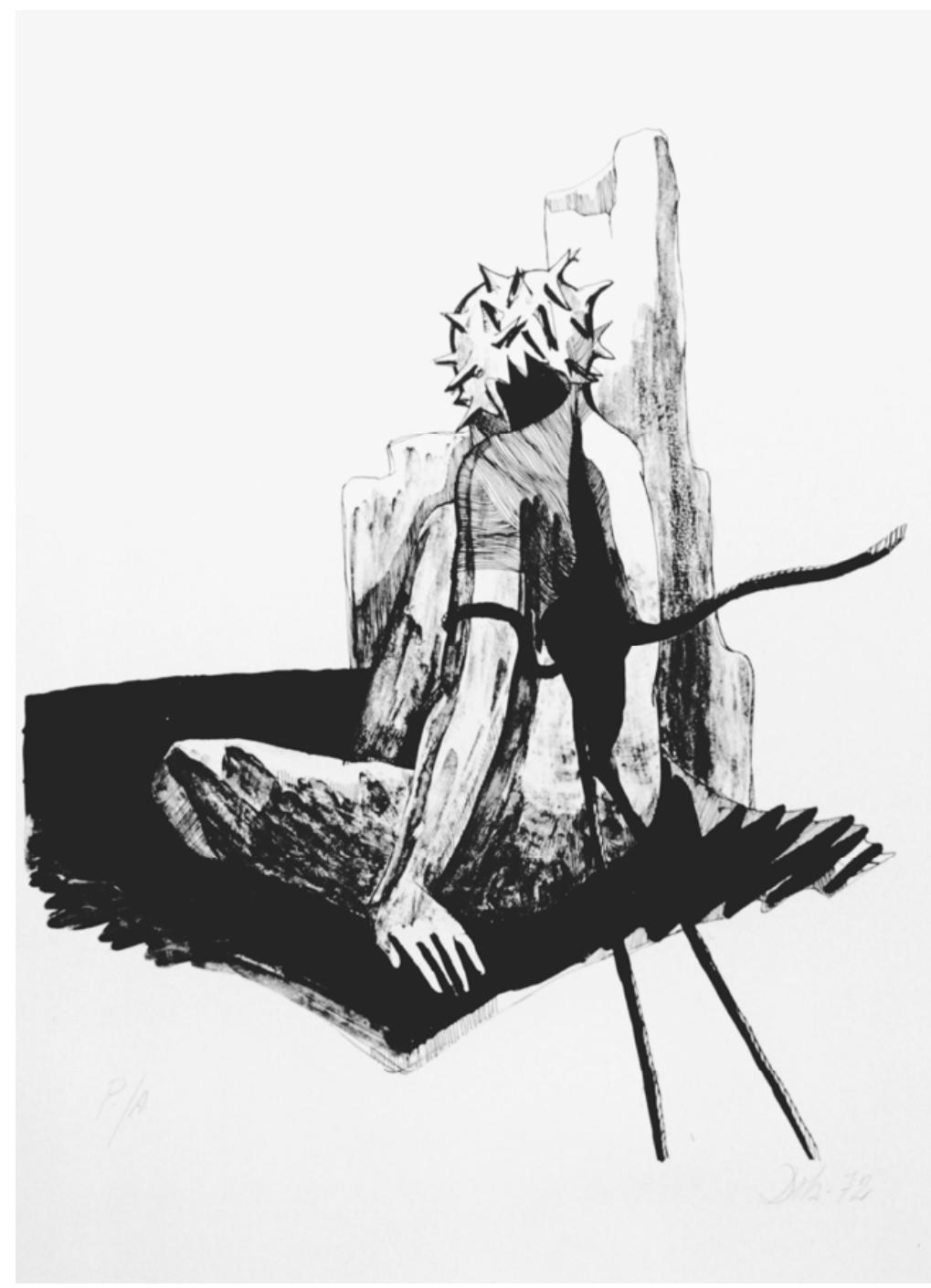

\section{LÁMINA XVII}

"Sin título 3"

Litografía offset

$36 \times 33 \mathrm{~cm}$.

\section{2}




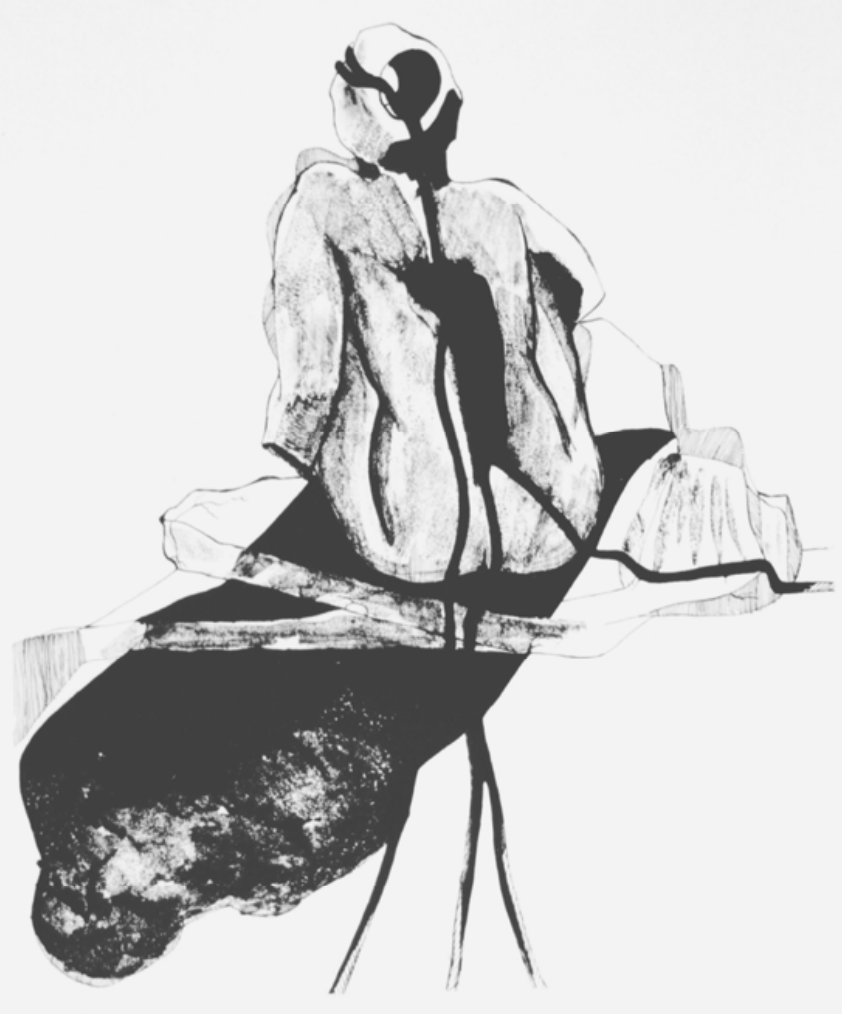

LÁMINA XVIII

"Sin título 6"

Litografía offset.

$36.3 \times 31 \mathrm{~cm}$.

1972 


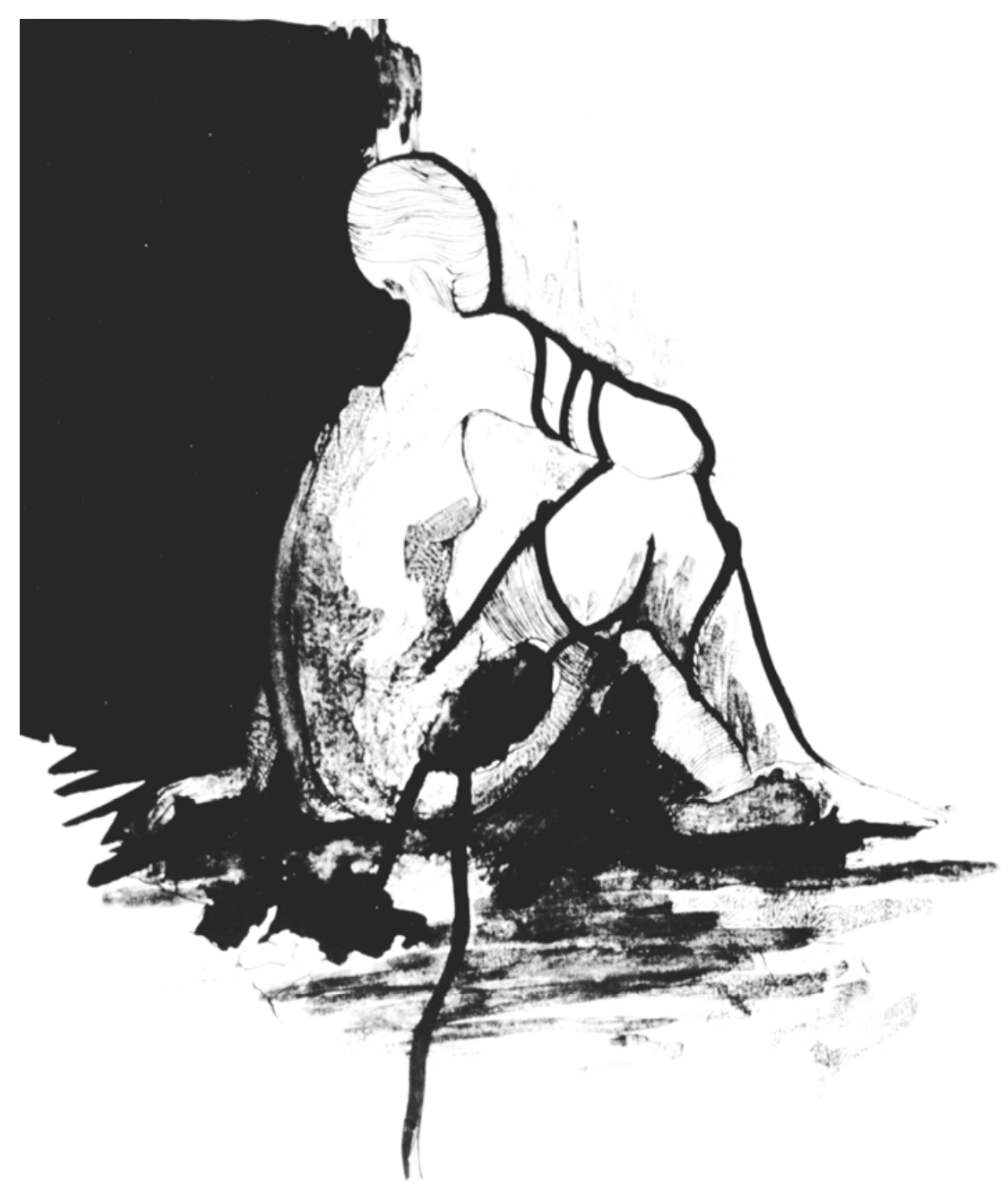

LÁMINA XIX

"Sin título 4"

Litografía offset

$34.5 \times 33 \mathrm{~cm}$.

1972 


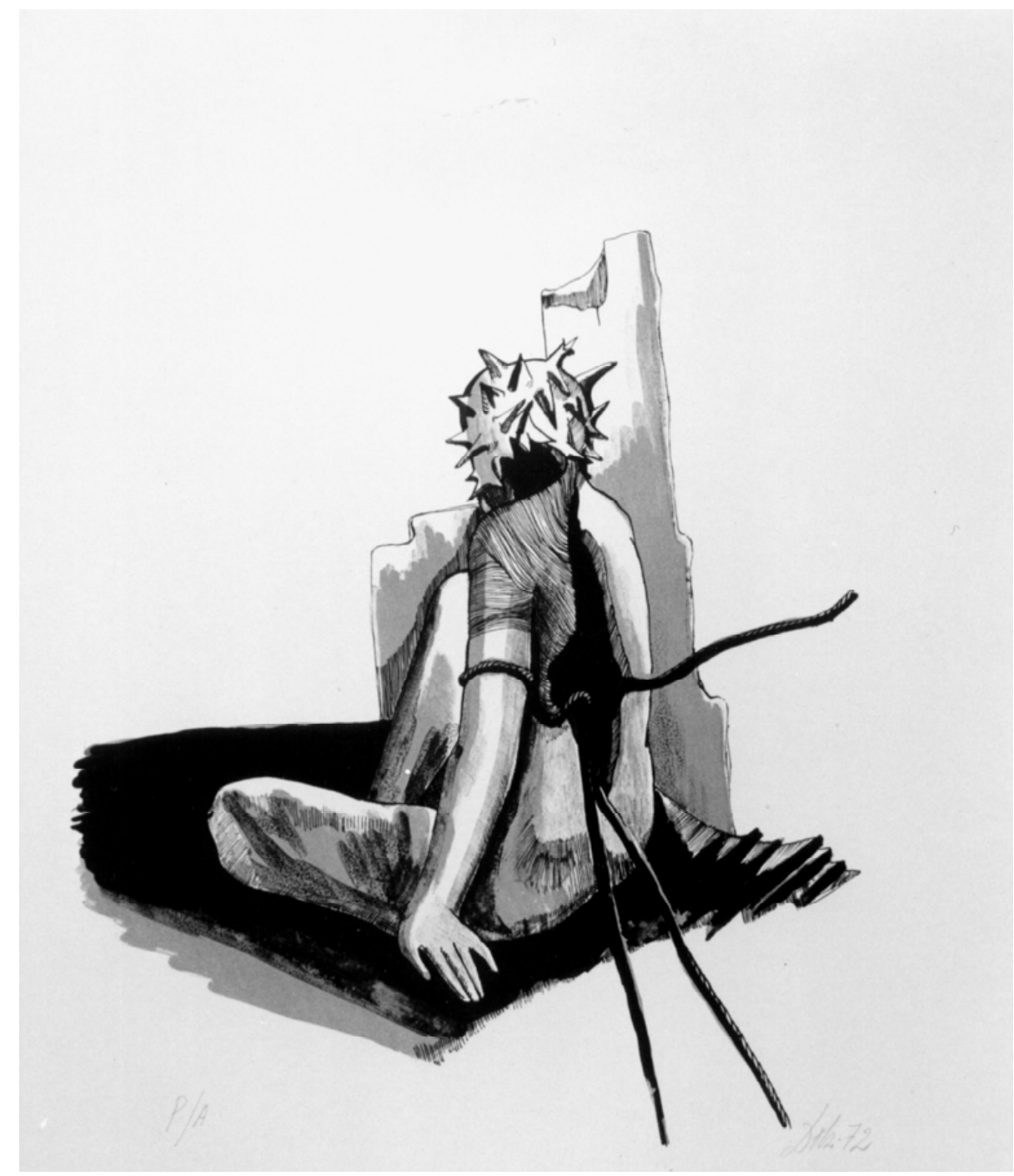

\section{LÁMINA XX}

"Sin título"

Litografía offset.

$36 \times 32 \mathrm{~cm}$.

1972 


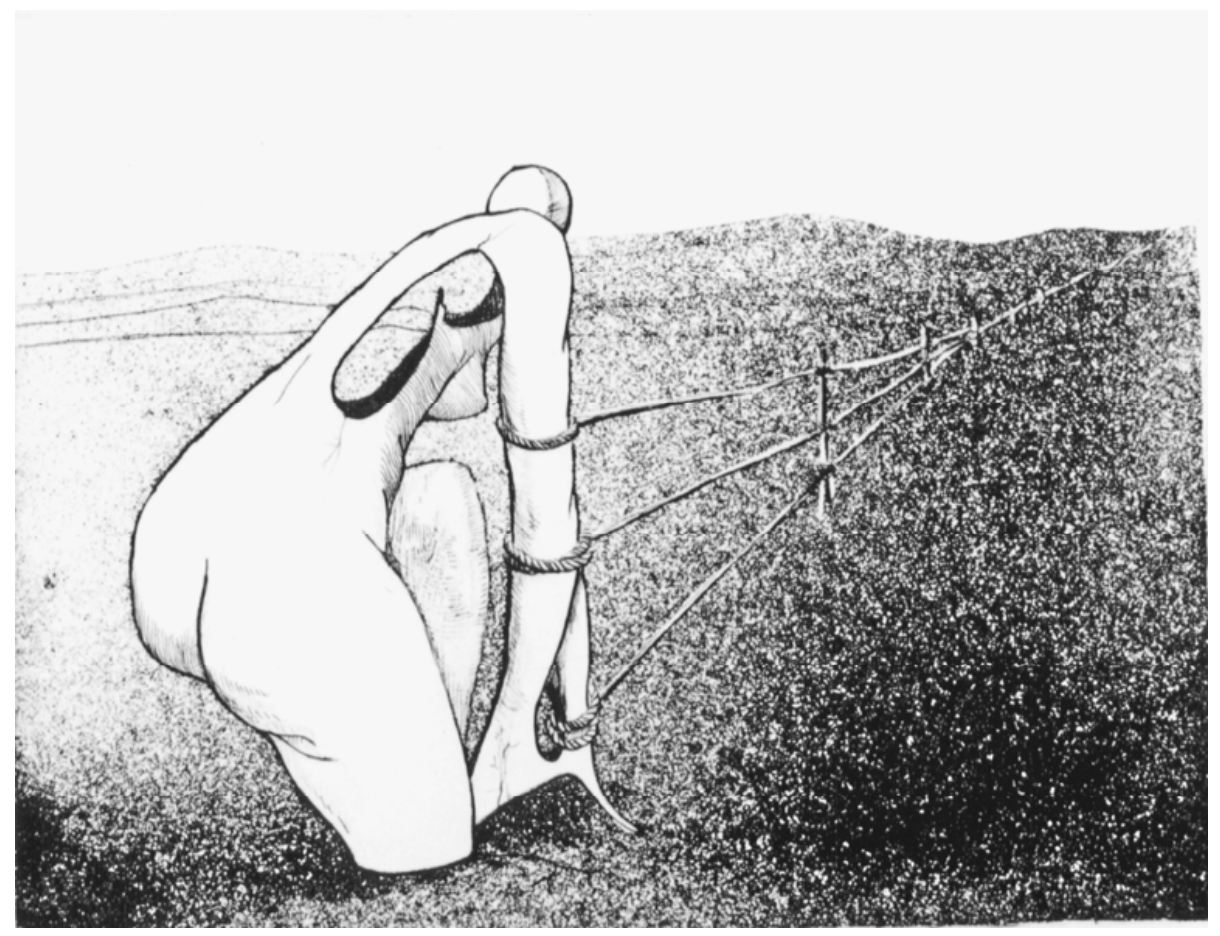

\section{LÁMINA XXI}

"Fita"

Aguafuerte y laca de cabello

$12 \times 16 \mathrm{~cm}$.

1972 


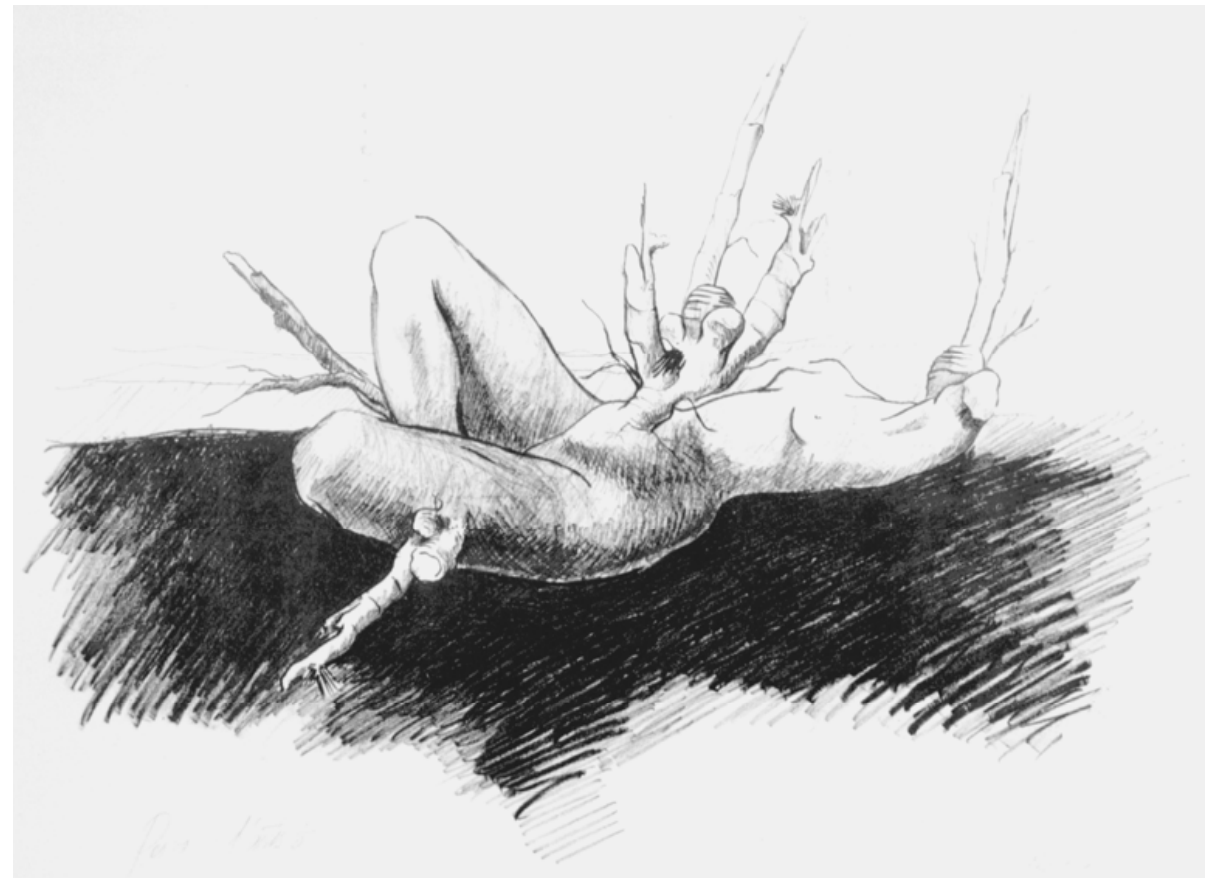

\section{LÁMINA XXII}

"Sin título"

Litografía

$28 \times 32 \mathrm{~cm}$.

1972 
- CORDES 



\section{离}

\subsubsection{CONCEPCIÓN}

La serie Cordes surge en 1971 y se prolonga hasta 1972, y es un trabajo simultáneo a las series De formas y De mujeres, ya que generalmente la artista, suele trabajar dos o tres series de modo combinado.

El origen de esta serie al igual que la anterior se encuentra en motivos de carácter humano como consecuencia del ambiente social, político y cultural que se vive en España, y más especialmente en Italia, país al que acude en su etapa de estudiante y donde es testigo de una serie de acontecimientos en los que la mujer asume un gran protagonismo por la lucha de sus derechos. 
Los años de estudio en Italia estuvieron marcados por el crecimiento y enriquecimiento personal, ideológico y artístico de Pilar Dolz, como ya hemos mencionado en el capítulo anterior. (Véase Cap. III.2.1)

Sin duda estos hechos quedarán reflejados en su obra, como símbolo de la violencia hacía el género femenino, pensamiento que marca hondamente la sensibilidad de la artista. Iconográficamente este conjunto de obras, guarda una íntima relación con las anteriores, pues la presencia de las cuerdas aparece en la primera serie atando y amarrando formas, mientras que en la de mujeres se presenta liando y anudando figuras de este género.

Nos comenta la artista que los recuerdos que tiene de estos momentos, son de sentirse atada o ligada a ciertas cosas que no podía cambiar y de las que no podía desasirse fácilmente; quizás producto de este pensamiento nacen aquellas cuerdas de forma instintiva e inconciente que coartan la libertad de las mujeres.

En ese instante la primera sensación no es esa seguridad que yo tengo ahora, entonces yo era estudiante y no te importa tanto, pero una vez terminas de estudiar(...) pues te sientes atada a muchas cosas, entonces la conciencia que yo tenía en ese tiempo es que te sientes atada, pero eso lo veo ahora. Yo hacía esas formas que vienen del inconciente, todo va mezclado, todo va atado a otra cosa, en estos momentos hay poca esperanza, no obstante a mí me parece que los años 70 , eran épocas de mas creatividad y más esperanza que ahora. Yo me servía mucho en la utopía que realmente se podría cambiar todo rápido, ahora sabes que puedes cambiarlo pero 
muy poquito a poco. (...) No sé porqué hacía siempre estas cuerdas atadas, quizá me sentía así. ${ }^{113}$

En esta colección de grabados, las cuerdas dejan de ser parte circunstancial de la obra, para convertirse en protagonistas, donde el objetivo de la representación son las cuerdas en sí, que aparecen independientes y en solitario ocupando un primer plano, y acaparando la atención del espectador.

La tendencia surrealista sigue siendo incuestionable, el azar y lo casual continúa atrayendo su atención y siendo un punto clave en la creación de su obra. La caída accidental o directa de una botella de ácido o barniz, o una quema circunstancial producida por el olvido involuntario de cubrir la plancha, provocan ciertos efectos que le fascinan; así, cuando Pilar Dolz ve una mancha o una gota de aceite sobre una superficie la deja correr y la hace deslizarse en una dirección u otra con el movimiento de la plancha mientras piensa que esa forma le recuerda o le sugiere algo. ${ }^{114}$

El planteamiento de la lógica espacial no responde a la razón, la forma emerge al espacio de la nada, de una mancha, de un nudo, de un pretexto; son imágenes inventadas que se hacen visibles gracias a la fantasía y la imaginación, fruto de los recuerdos del mundo exterior guardados en su memoria.

\footnotetext{
113 Entrevista personal con la autora en Castellón de la Plana. 16/05/2005

${ }^{114}$ Salvador Dalí fue uno de los surrealistas que utilizó la técnica de la fijación de imágenes tomadas de los sueños, inventó lo que él llamó Método paranoico-crítico, una mezcla entre la técnica de observación de Leonardo da Vinci, por medio de la cual observando una pared se podía ver como surgían formas, y la técnica del frottage; fruto de esta técnica son las obras en las que se ven dos imágenes en un sola configuración. Véase BRIHUEGA, J.: 1993. p. 67
} 
Con estas cuerdas parece acercarse cada vez más a la figuración; estas figuras surgen del inconciente, pero se muestran con una figuración que puede ser reconocible, incluso algunas se diría que son muy clásicas. Hay que pensar que muchas de estas obras pertenecen a su etapa de formación, cuando la artista se halla experimentando la técnica.

El ejercicio del trazo se presenta sinuoso y suelto, en un primer momento las cuerdas son el resultado de un trazo vivo y enérgico, con una forma que se muestra esquemática y rápida, en cambio que en otras obras presenta un trabajo más suave y detallado que las hace más figurativas.

En cuanto al color, la totalidad de obras que componen la serie presentan un trabajo monocromático, por tanto obviaremos el estudio de este tema en su correspondiente apartado. 
3.3.2. ASPECTOS COMPOSITIVOS.

\section{Composición}

Esta serie como, su nombre indica, hace referencia a la representación de cuerdas, sogas, cabos, formas que antes aparecían ocupando un segundo plano y en compañía de otros elementos, ahora se presentan primordiales y sólidas. Dejan atrás el aspecto deshilachado y desgastado de las series anteriores para pasar a convertirse en consistentes cuerdas y ser el centro de atención de la obra. (Véase Fig. 61)

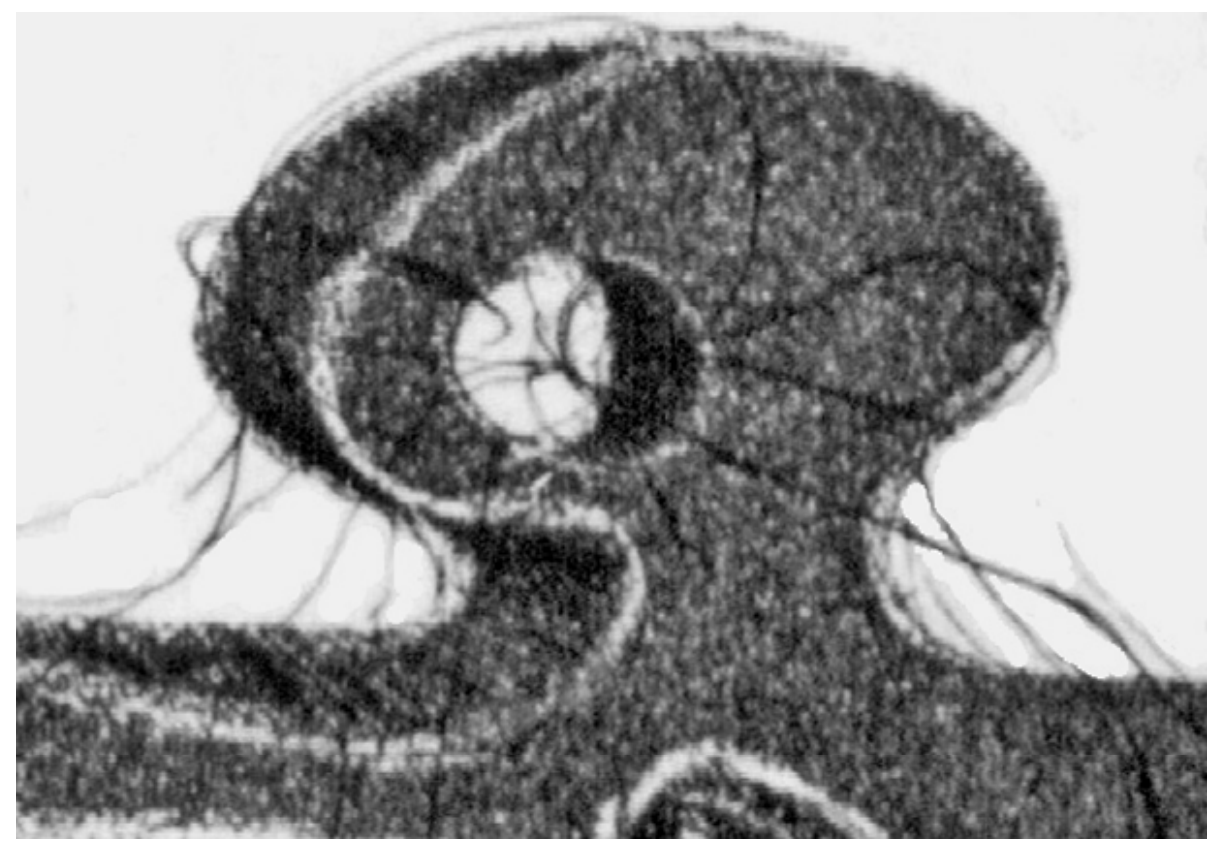

Fig. 61. Pilar Dolz. Detalle LAM. V. Serie De formas. Aguafuerte y ceras. 1971 
El tema de la composición se afronta con la ejecución de la imagen en un primer plano irrumpiendo sobre toda la superficie. En LAM. XXIII podemos apreciar cómo la imagen de una cuerda ejecutada en sentido vertical atraviesa el espacio cerca del centro y lo divide en dos partes. La imagen de la cuerda ligeramente desplazada hacia la derecha evita la simetría de la obra, a la vez que compensa este deslizamiento con el trazo de un par de líneas horizontales situadas en la parte superior ya en los límites del formato, insinuando la existencia de un paisaje que podemos visualizar en profundidad por la relación de tamaño existente entre forma y fondo. Sin esta relación cada una de las partes se vería como espacios planos. La medida del formato, de $26 \times 28 \mathrm{~cm}$. de estructura casi cuadrada favorece también a la distribución equilibrada del espacio.

No existe un interés definido por la profundidad ni por el volumen, el trazo de la imagen con una cierta diferencia de luminosidad sirve para proporcionar un indicio de perspectiva en la forma, sobre la que no se quiere puntualizar. En lo que respecta al fondo, éste se encuentra solucionado a través de una sola mancha amplia, ya sea irregular o plana, que cubre toda la superficie. Este fondo se emplea únicamente como lugar donde se realiza el gesto para convertir las cuerdas. (Véase LAM. XXIV)

En obras realizadas más adelante, en 1972, se acerca algo más hacia el realismo y el dibujo de la imagen es más escrupuloso y preciso, no así los fondos que siguen siendo un pretexto para la ejecución de la forma; son espacios tonales planos que en ocasiones llegan a cubrir toda la superficie y en otras avanzan sólo hasta la 
mitad o simplemente se dejan sin resolver, vacíos; de esta manera permite ver el blanco del papel sobre el que se dibuja la imagen. (Véase LAM. XXV)

En LAM. XXVI la profundidad de la forma se plantea con un dibujo más meticuloso y con un tratamiento más intencional del claroscuro que no llega a ser académico. Se crean varios niveles de profundidad por medio de la distribución de los elementos en superposición, las cuerdas se intercalan entre sí y quedan dispuestas unas delante y otras detrás. Para marcar más el sentido de profundidad otras veces se deja el dibujo sólo insinuado linealmente y relega esta forma inacabada a un segundo plano. (Véase Fig. 62)

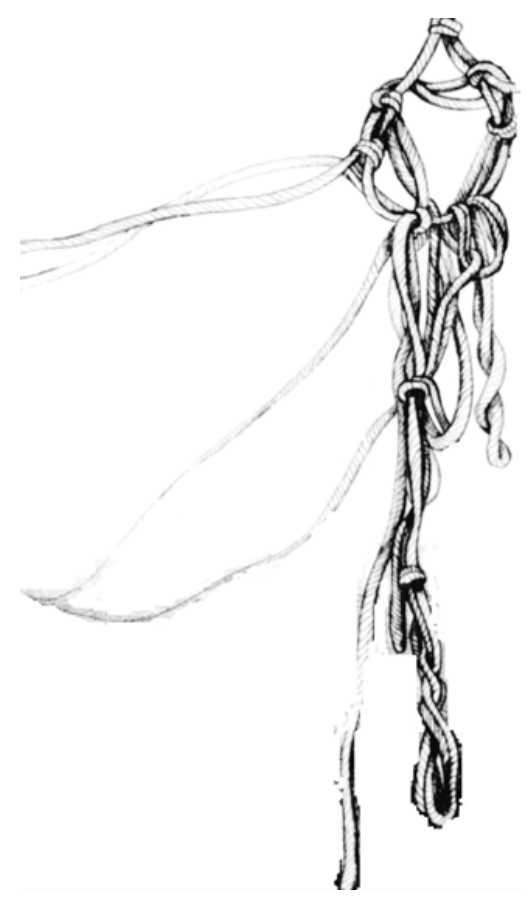

Fig. 62. Pilar Dolz. Detalle LAM. XXVI. Serie Cordes. Aguafuerte y barniz blando. 1971. 
En otras obras utiliza la perspectiva como punto para la construcción del espacio, pero sin la intención de querer hacer una representación visual igual o parecida a la que la percepción visual puede tener de estos elementos, es una perspectiva imaginaria, surrealista en la que las distintas líneas que conforman la composición no llegan a converger en un único punto de fuga. Así en LAM. XXVII vemos como las líneas paralelas que dibujan la valla toman sentido de horizontalidad en el plano buscando profundidad en el sentido espacial esperado, mientras que las líneas que conforman los postes que sujeta dicha valla toman sentido inclinado que cambia la dirección de la perspectiva. Este recurso se emplea sólo en la forma que se encuentra situada delante, ya que el fondo sigue siendo un espacio llano concentrando toda la atención en la forma. (Véase Fig. 63)

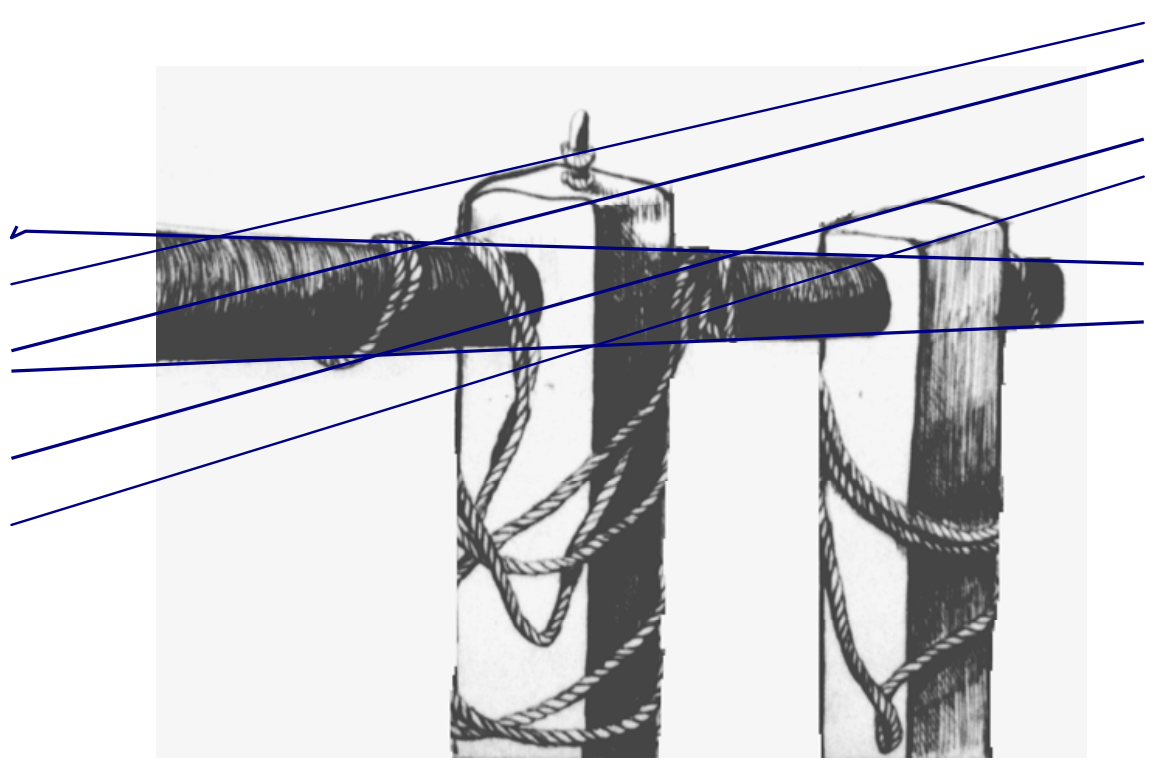

Fig. 63. Pilar Dolz. Detalle LAM. XXVII. Serie Cordes. Aguafuerte y lavis. 1972. 


\section{Grafismo}

Se confirma la atracción de la artista por un planteamiento gráfico variado, en esta colección asistimos a la ejecución de un trazo con cierta diversidad formal en el que podemos apreciar la existencia de tres tipos de trazos diferentes; uno para la construcción de la forma donde la línea actúa como elemento para dibujar la imagen. Se trata de una línea curva, retorcida y escurridiza que entra y sale, sube y baja, se anuda entre sí y ocasiona ciertas colisiones en su recorrido; ésta es utilizada para crear las cuerdas. También en contraste con esta línea, hallamos otra, recta y severa, que camina en una sola dirección manejada normalmente para representar horizontes, a pesar de ser una línea rígida e inflexible es más frágil y delicada que la curva, puesto que ha sido solucionada con mordidas poco profundas en el ácido nítrico. Entre tanto la línea curva más potente, se ha conseguido con mordidas más fuertes. (Véase LAM. XXIII)

Asimismo nos encontramos con otro modelo de trazo más gestual, se tratan de unas manchas extensas y alargadas solucionadas a través de amplios movimientos en las que no existe ningún tipo de trama, son manchas lisas realizadas por la fricción del pincel en una sola orientación y que coexisten junto con otro modelo de trazo más lineal. Estas manchas se utilizan simplemente para insinuar el volumen en la imagen. (Véase LAM. XXIV)

Por último tenemos un trazo puramente gestual ejecutado por ejemplo en LAM. XXIII, que constituye lo que viene a ser el fondo, cuyo equilibrio se consigue con la representación estructural 
del elemento cuerda, dispuesta en posición vertical en el centro del plano buscando la simetría espacial, la forma se soluciona mediante un trazo simple y estructurado. No sucede así con el fondo, que se remedia con un trazo abierto y complejo realizado con una intención meramente pictórica a través de la acción del betún de Judea, que se dispone de forma irregular y espontánea sobre la superficie, acumulándose en unas zonas más que en otras. El resultado de este ejercicio es una mancha irregular realizada de manera desordenada y azarosa sin ninguna disposición formal preconcebida; su factura enérgica refleja claramente la densidad de la materia, de aspecto texturado y rugoso que genera un contraste visual que nos sugiere cierto movimiento y dinamismo. (Véase Fig. 64)

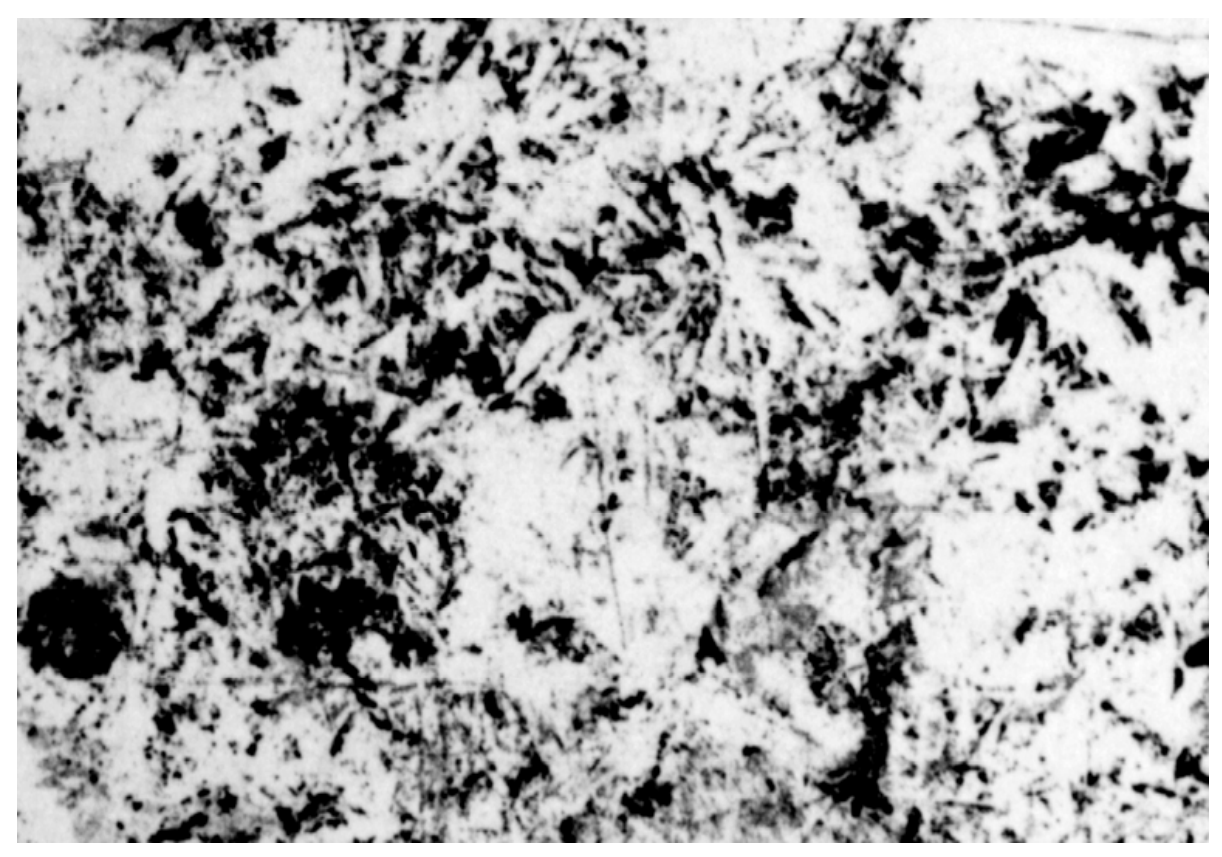

Fig. 64. Pilar Dolz. Detalle. LAM. XXIII. Serie Cordes. Aguafuerte y betún de Judea. 1971. 
En otro grupo de obras de carácter más realista, la línea se torna más elástica y sensual, deja de ocupar el centro del plano para distribuirse por todo el espacio a través de ágiles movimientos y la representación dinámica del trazo crea la sensación de un desplazamiento suave y pausado. Habitualmente la línea aparece descendiendo, aunque no es raro verla también elevándose. La manera más simple de conectar unas cuerdas con otras es anudándolas entre sí, para crear una especie de maraña; a este conjunto de rasgos les atribuimos afinidad con la serie anterior por su carácter sólido, que aunque se mezclan y se confunden entre sí siguen manteniendo cierta independencia, al igual que los trazos retorcidos y sinuosos de aspecto vegetal que daban vida a aquellas mujeres. (Véase Fig. 65)

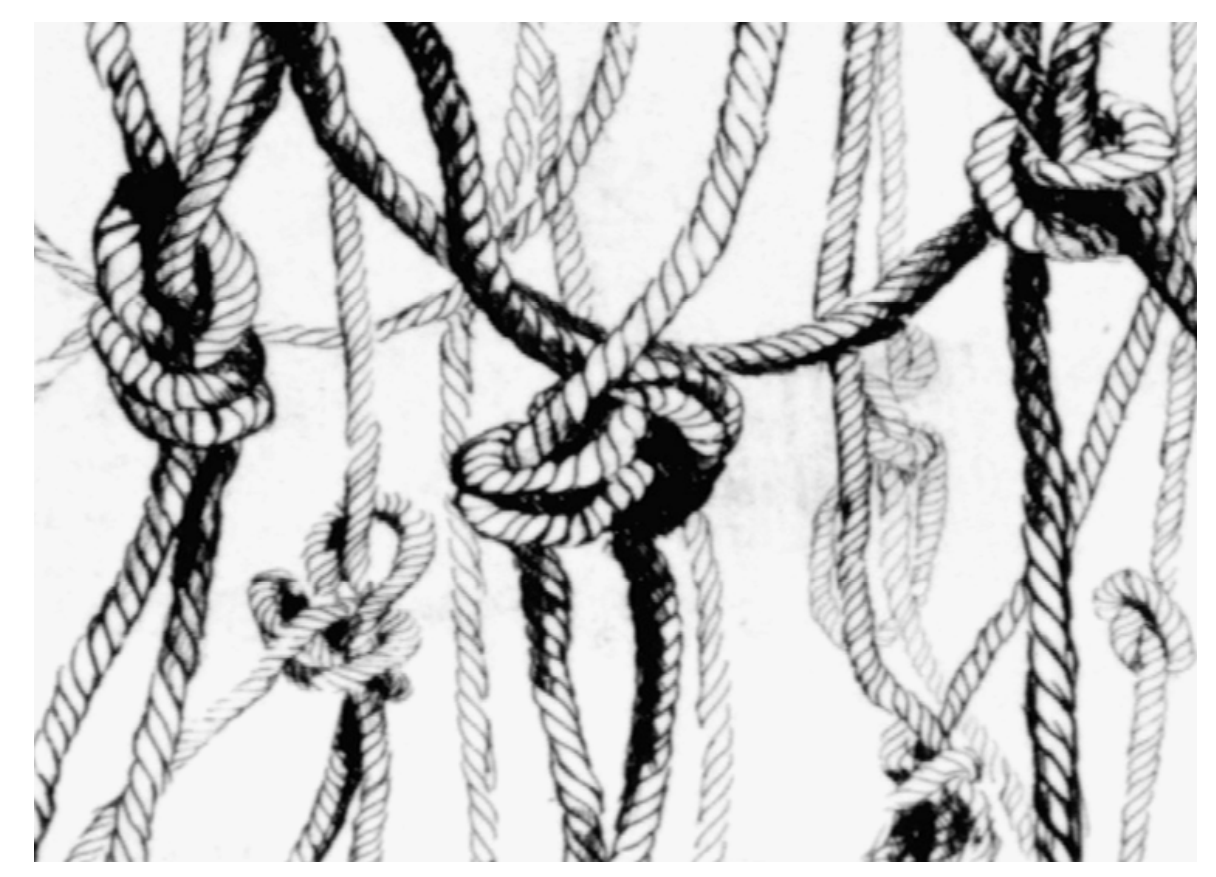

Fig. 65. Pilar Dolz. Detalle. LAM. XXV. Serie Cordes Aguafuerte y barniz blando. 1971. 


\subsubsection{PROCESO TÉCNICO}

El proceso técnico se plantea con la intervención de la plancha de metal de zinc o de cobre por medio del procedimiento de grabado calcográfico utilizado de forma personal en la que combina diferentes técnicas, sobretodo con el aguafuerte, que lleva a cabo en compañía del barniz blando, el lavis y demás. La voluntad de explotación y aprovechamiento de los recursos técnicos, de dejar actuar al azar y de la búsqueda de materiales sencillos, es una constante que viene manteniendo desde las series iniciales. Vuelve a repetir el uso de materiales como, por ejemplo, la laca de cabello. En LAM. XXIV, la aplicación de la mencionada laca de cabello se hace de manera uniforme y continuada por toda la superficie creando una capa homogénea muy fina semejante a lo que se podría conseguir con la resina, para obtener así una mancha que a la distancia la podemos apreciar uniforme, pero cuando nos acercamos le observamos una cierta textura de puntos irregulares, producto de la aplicación manual y caprichosa de la laca. (Véase Fig. 66)

Cuando trabajo con las ceras, con los lápices de ojos, no he visto a nadie que lo haga, y no digo que sea una investigación, pero una cera líquida o

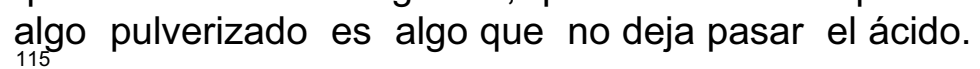

\footnotetext{
${ }^{115}$ Entrevista personal con la autora en Castellón de la Plana. 16/05/2005
} 


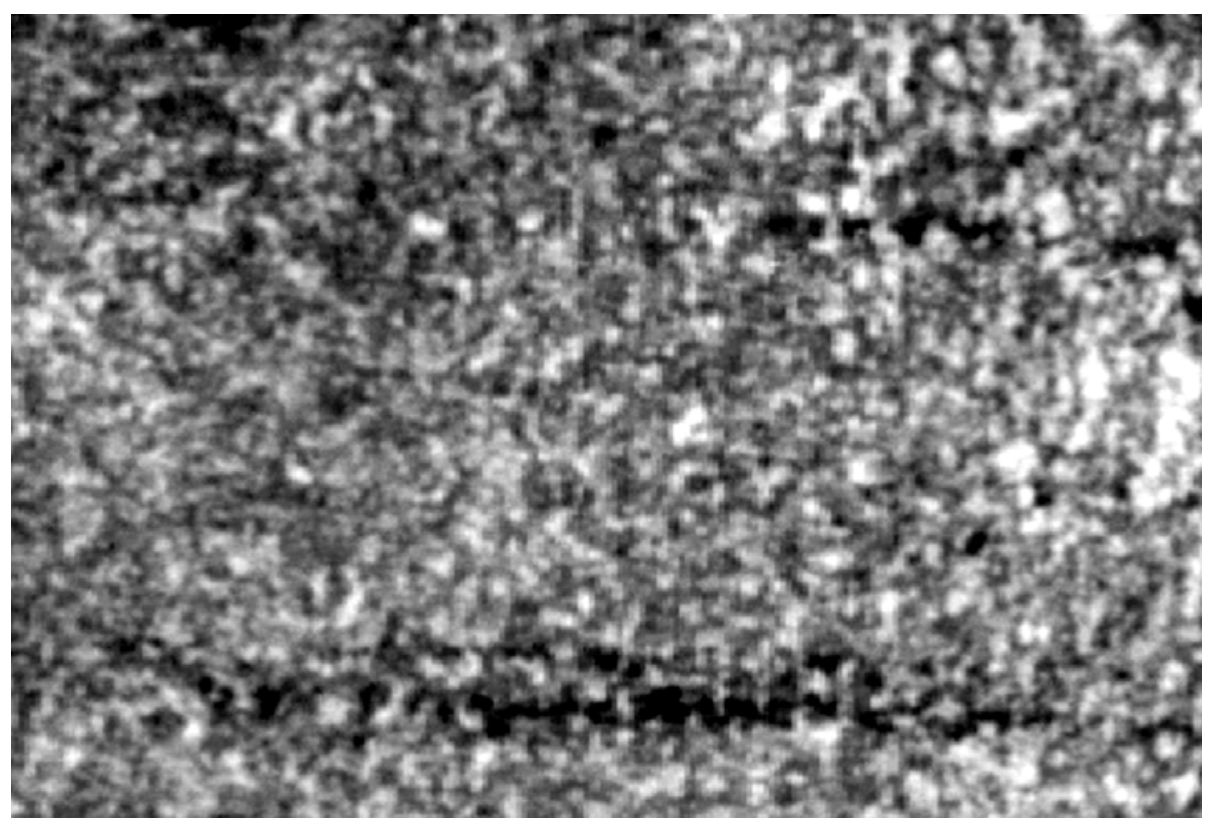

Fig. 66. Pilar Dolz. Detalle. LAM. XXIV. Serie Cordes. Aguatinta y laca de cabello. 1972

En LAM. XXV podemos ver cómo una mancha producida fortuitamente por la caída de una botella de ácido, es el pretexto para intensificar una forma orgánica sugerente a través de la técnica del lavis, como método directo de trabajo. Esta técnica se realiza mediante la exposición de la plancha a la acción directa del ácido sin la protección de ningún tipo de resina o barniz, provocando la quema directa del metal en el que se procede a cubrir únicamente la zona donde no se quiere que actúe.

Podemos apreciar en esta lámina que la mancha originada casualmente es la excusa para iniciar una obra; de esta forma se retoma la plancha para incidir sobre ella sin dejar que sea sólo el azar el que funcione. Una mancha completamente abstracta se convierte en otra más figurativa; así podemos ver un conjunto de 
cuerdas que aparece colgando de forma desordenada de esta especie de nube o mancha y que se encuentran trabajadas por medio del aguafuerte. (Véase Fig. 67)

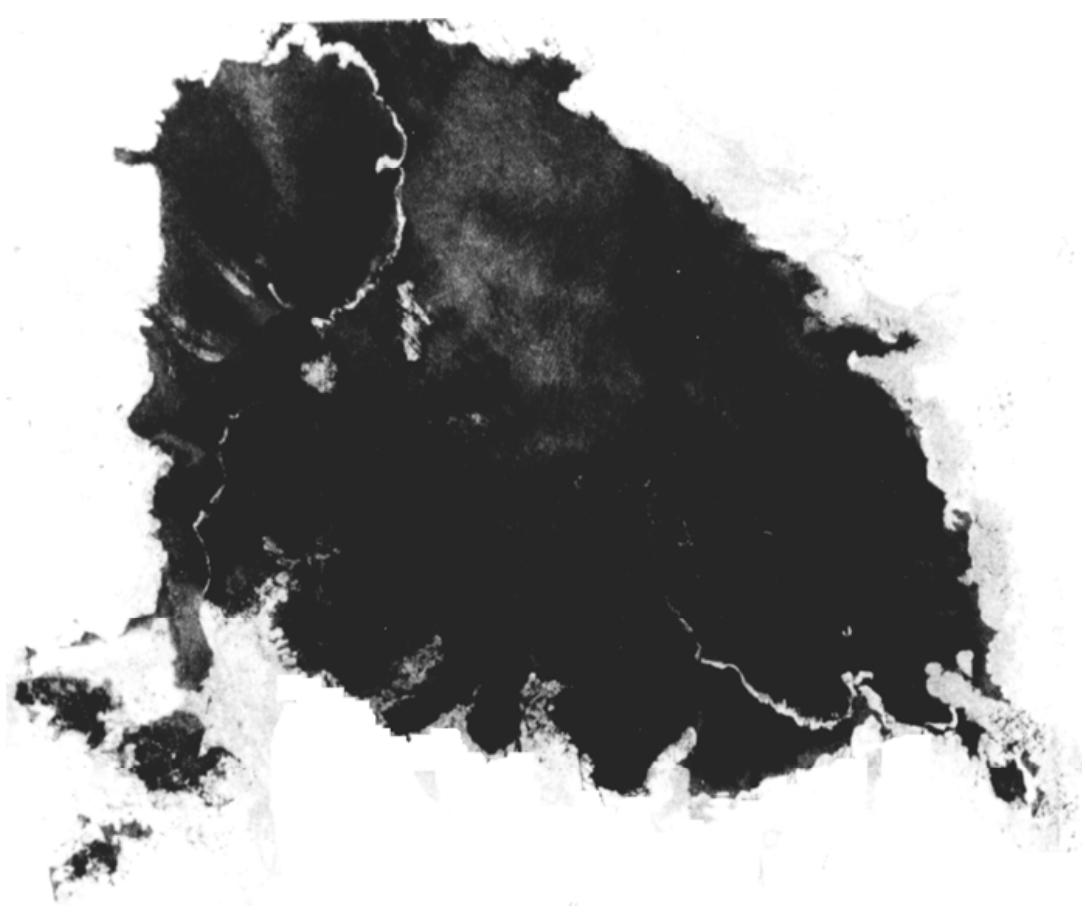

Fig.67. Pilar Dolz. Detalle. LAM. XXV. Serie Cordes. Aguafuerte 1972.

Allí me caería la botella de ácido o se le caería a alguien y la recogería de la basura o a lo mejor es una plancha por detrás, eso que a veces lo has puesto en el ácido y te has olvidado de cubrirla. Esas cosas que el azar hace me fascinan, sé que lo hacía mucho y lo sigo haciendo (...) me dejo ir. Tampoco digo <yo quiero hacer tal cosa>, yo me encuentro allí y potencio ciertas cosas que me da el azar ${ }^{116}$

${ }^{116}$ Entrevista mantenida con la autora en Castellón de la Plana. 16/05/2005 
Otra forma de manejar la técnica del lavis ${ }^{117}$ es a través de un trabajo no tan fortuito como en la lámina anterior, sino que se elabora con una idea premeditada con el fin de conseguir efectos suaves de tonos delicados, consiguiendo resultados pictóricos parecidos a los de la acuarela o la aguada. En LAM. XXVII se utiliza esta técnica para realizar un degradado en el que observamos la suave sucesión de tonos, que va del más oscuro al más claro de forma paulatina y nos brinda una mancha tenue y sutil, que permite alcanzar cierto efecto visual.

Esta serie guarda cierta unidad procesual con las anteriores; en ella mantiene la intención de utilizar técnicas y materiales ya existentes y de extraer al máximo sus posibilidades aprovechando incluso el hallazgo casual y accidental, que se pudiera descubrir en el material así como en el proceso de trabajo.

\footnotetext{
117 Técnica calcográfica de ejecución directa. Para obtener delicados tonos se ataca directamente la superficie de la matriz con un pincel empapado de mordiente, que corroe el metal. La técnica del lavis es muy sencilla, los efectos que se pueden conseguir son como el de un lavado o una suave mediatinta barrida de apariencia afín a la técnica de la acuarela. Véase VIVES PIQUÉ, R.: 1994, p. 59.
} 


$$
\text { LÁMINAS }
$$

\section{ORDES}





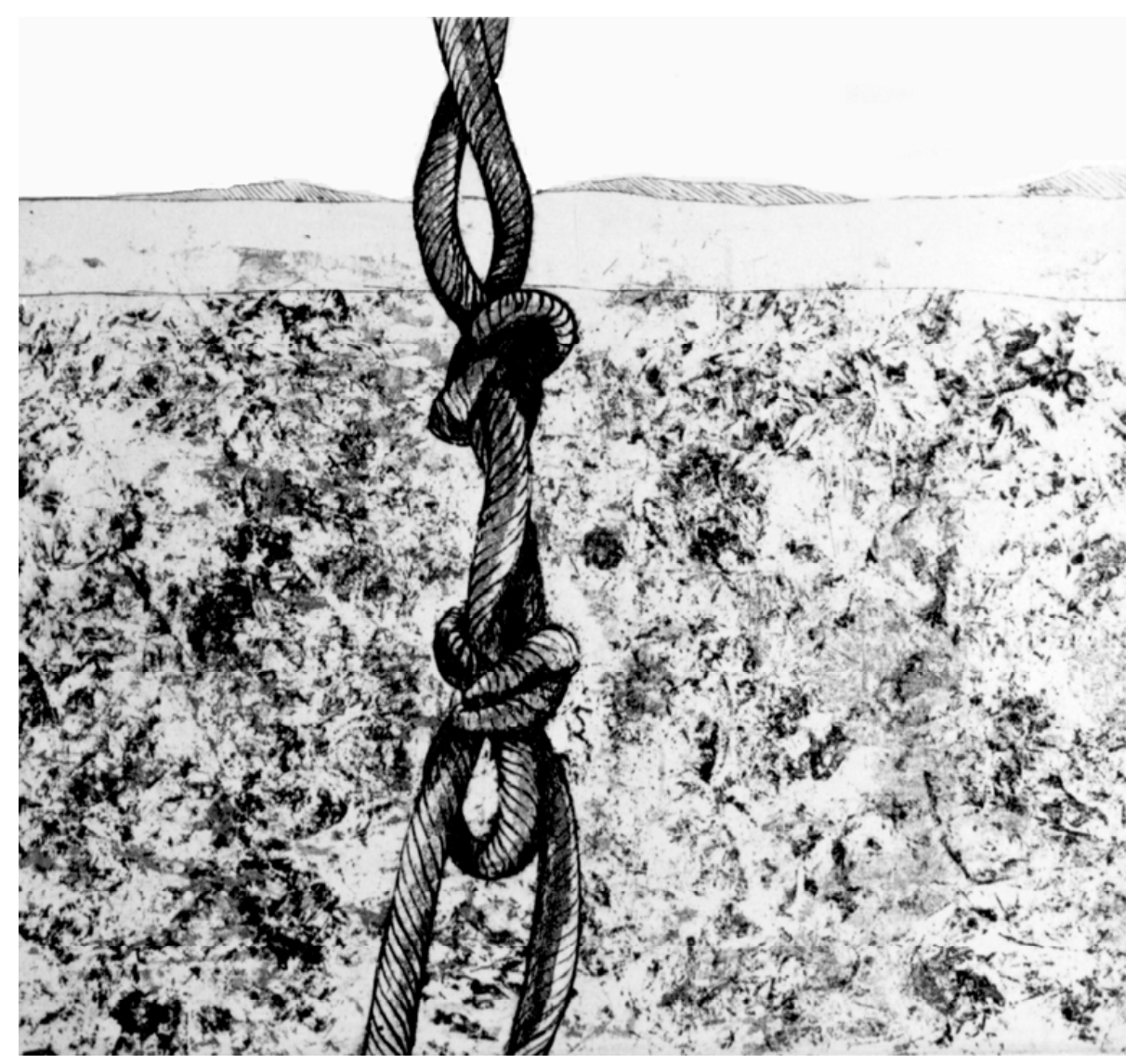

\section{LÁMINA XXIII}

"Corda"

Aguafuerte y betún de Judea

$26 \times 28 \mathrm{~cm}$.

1971 


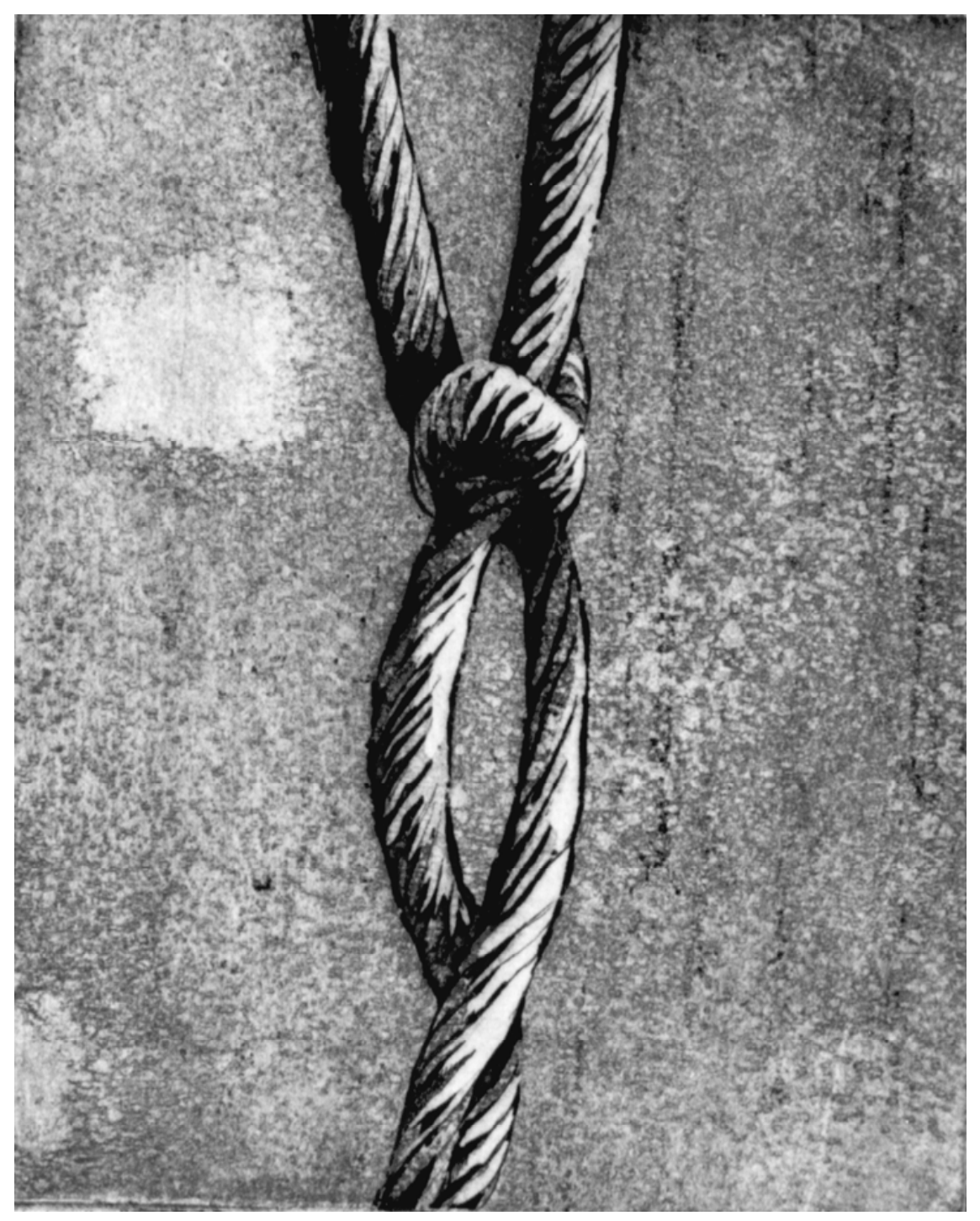

\section{LÁMINA XXIV}

"Corda"

Aguatinta y laca de cabello.

$17 \times 14 \mathrm{~cm}$.

1972 


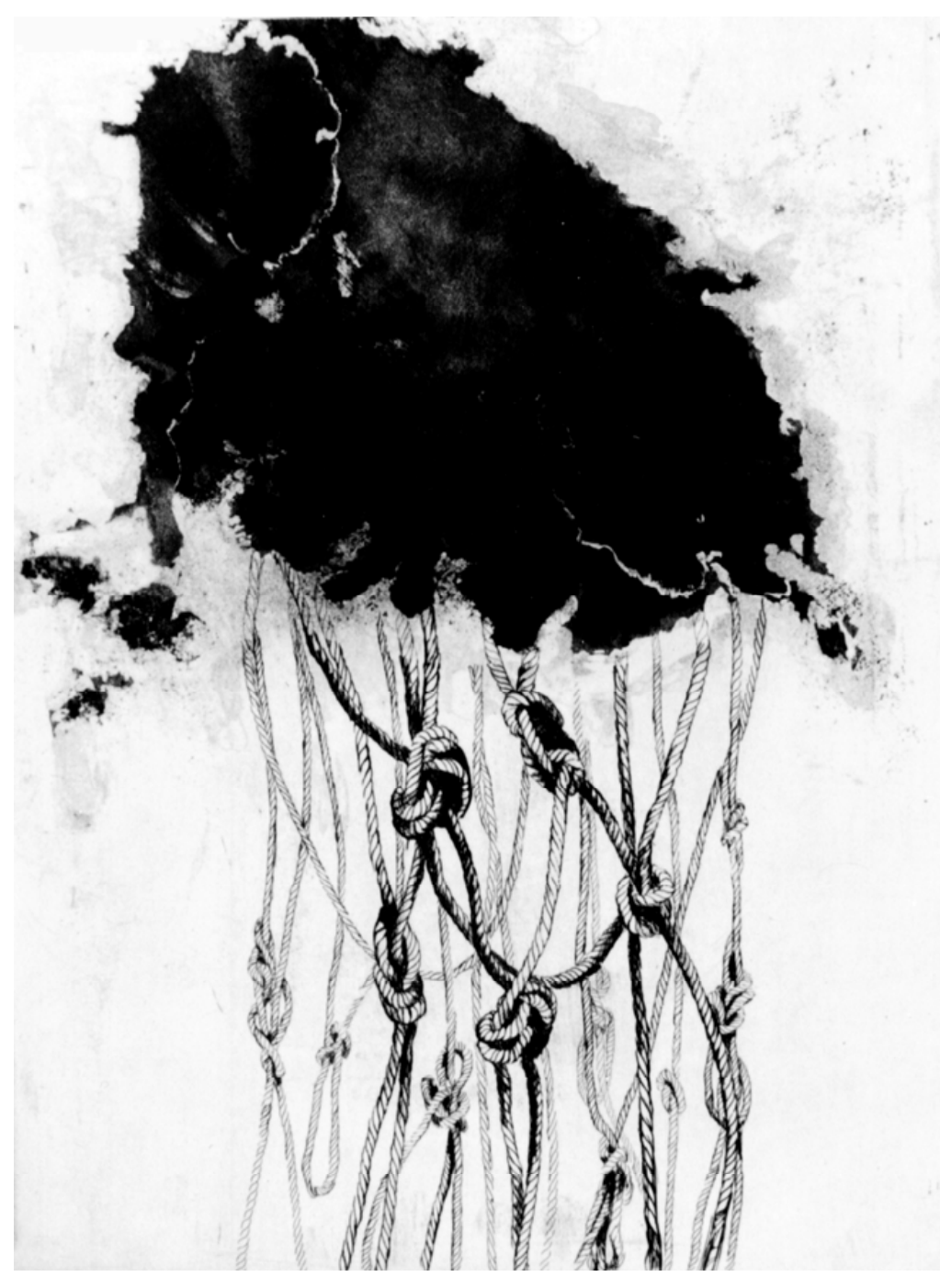

\section{LÁMINA XXV}

"Cordes"

Aguafuerte y aguatinta

$32 \times 24.5 \mathrm{~cm}$.

1972 


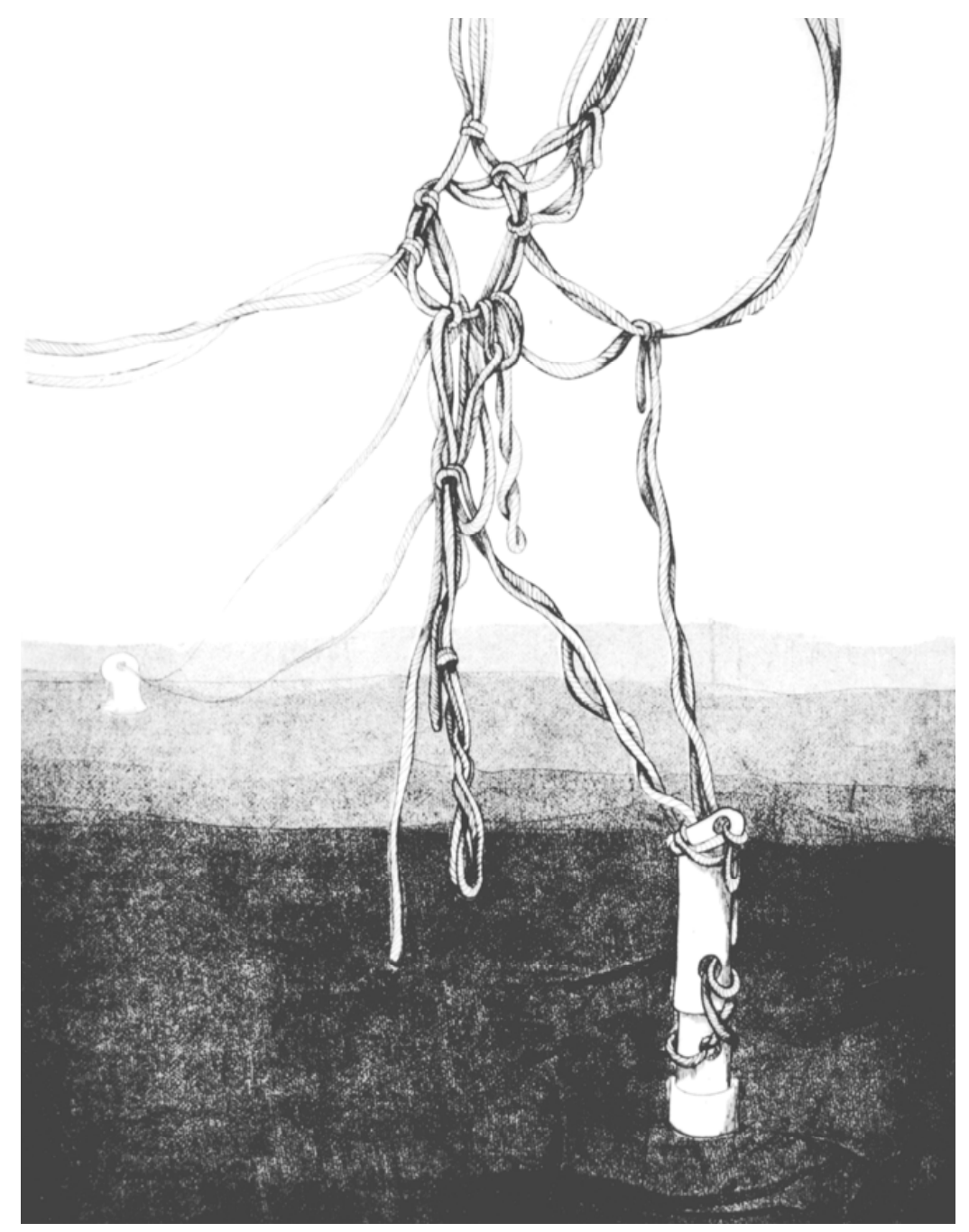

\section{LÁMINA XXVI}

"Sin título"

Aguafuerte y barniz blando.

$33 \times 22.5 . \mathrm{cm}$.

1971 


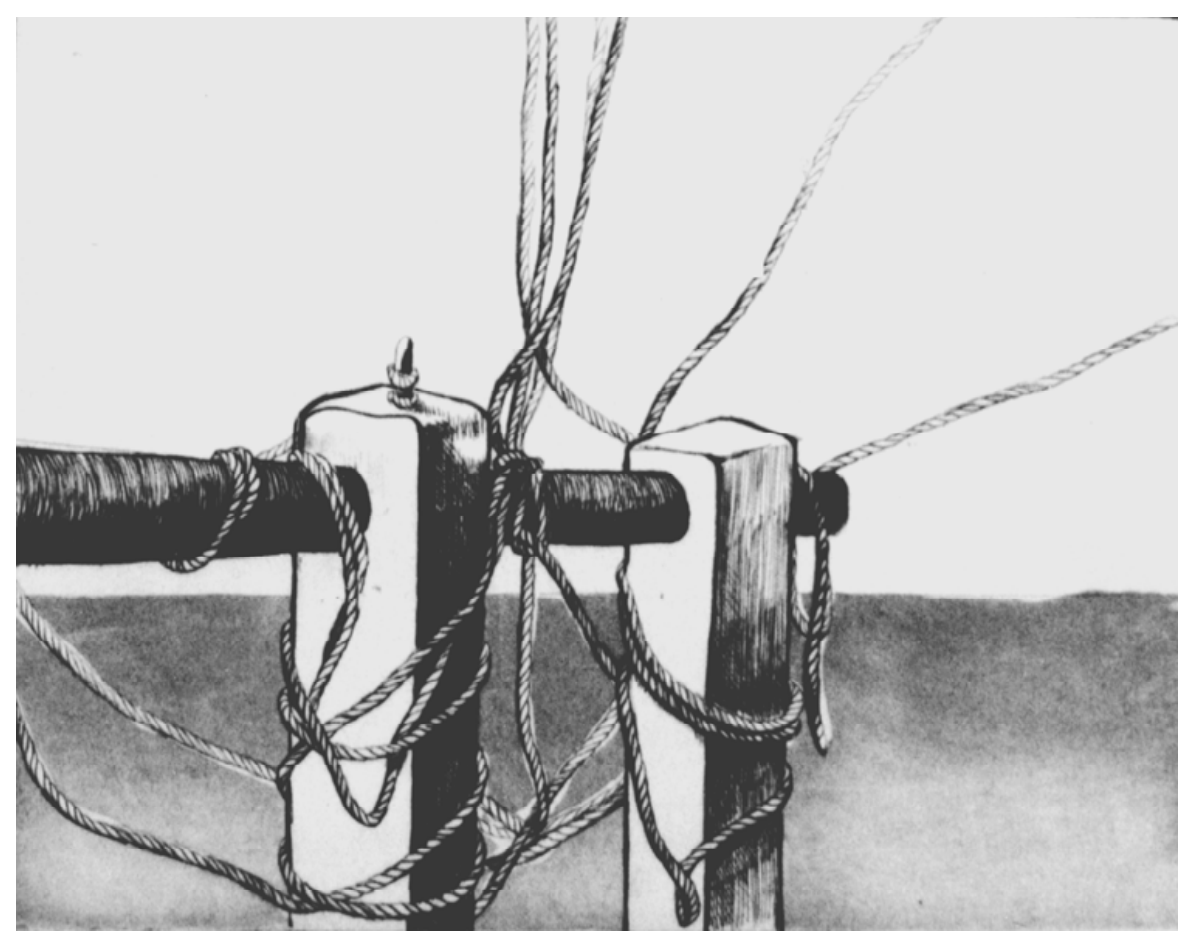

\section{LÁMINA XXVII}

"Sin título"

Aguafuerte y lavis.

$12 \times 16 \mathrm{~cm}$.

1972 
REIXES 



\section{4}

\subsubsection{CONCEPCIÓN}

Reixes, realizada entre los años 1972 y 1975, supone una afirmación del pensamiento ideológico de Pilar Dolz, un testimonio de continuidad con las series anteriores en lo que se refiere a su postura decidida de reproche hacia todo lo que significa opresión y dominio de la libertad del hombre, pensamiento abiertamente manifestado por la artista en múltiples ocasiones. (Véase Cap. III.1.1)

Sus grabados presentan una metáfora de carácter social y crítico donde se recogen aspectos de una realidad dura y cotidiana, 
cuya simbología vislumbra la ansiedad y el drama de la realidad político-histórico de la dictadura franquista. ${ }^{118}$

Las rejas se convierten en una ventana al mundo exterior a través de la cual podemos mirar lo que hay al otro lado, pero sin pasar, los barrotes se transforman en barreras infranqueables difíciles de salvar, que hacen imposible que podamos gozar abiertamente de aquellos cielos diáfanos y hermosos paisajes que afloran insinuantes por detrás de las rejas.

Esta situación nos recuerda sin duda, a aquellas propuestas iniciales de formas y mujeres, donde ciertos huecos o agujeros, atraviesan completamente la imagen y nos permiten echar un vistazo hacia el otro lado, pero no cruzar. Más tarde en la serie de cuerdas, vuelve a incidir sobre este planteamiento, a través de una complicada y enmarañada trama de hilos y cuerdas, que también impiden el paso, mientras cercan otra vez el camino.

Ahora, en Reixes, la artista continúa con este planteamiento, de una forma completamente abierta y atrevida; nos encontramos ante una obra con claras connotaciones políticas y de profundo significado emotivo, que construye con unas formas esquemáticas

\footnotetext{
118. A partir de la década de los sesenta se produce una progresiva modernización de la sociedad y la economía española, paralela a la amplia fisura entre innovación artística y dictadura. Se desarrolla en algunos ambientes intelectuales y universitarios una conciencia política que se identifica contra la política centralizadora franquista. El Plan de Estabilización de 1959, la incorporación al Fondo Monetario Internacional y al Banco Mundial, le abren las puertas a la inversión extranjera. El crecimiento económico da lugar a un desarrollo económico acompañado de una rápida transformación social. El distanciamiento entre la realidad que muestra el régimen y la realidad que se vive en las calles es cada vez mayor. Las transformaciones económico-sociales, propician un resurgimiento del protagonismo ciudadano desde el mundo laboral al universitario. Los intelectuales y artistas empiezan a tomar posturas críticas ante la realidad social, que se expanden por gran parte del país. Ante esta situación de efervescencia social el franquismo sólo supo reaccionar con violencia y represión. Véase BOZAL, V.: 1987, p.174.
} 
que captan lo esencial y conceptual de las cosas y con un estilo aún en proceso de maduración, cuyas imágenes se muestran acordes con lo que ocurre en la sociedad española de este momento.

Recordemos que esta serie se encuentra trabajada entre los años 1972 y 1975, que se corresponden con la última etapa de la dictadura franquista, momento en el que había mucha represión y violencia en las cárceles, que refleja la descomposición interna del régimen, es un período en el que los movimientos de masas alcanzan niveles sin precedentes, la lucha de los obreros, universitarios y demás sectores de la población se extiende rápidamente por toda la geografía nacional, al mismo tiempo que se incorporan a la lucha obrera muchos colectivos profesionales con un deseo de cambio social. El Arte también toma una posición crítica, intelectuales y artistas progresistas desafían la dominación política e intenta dar repuestas a las inquietudes humanas, con expresiones que no coinciden con las ideas que la dictadura quería imponer, por lo que la represión en los últimos años fue cada vez más violenta y dura, muchos artistas y pensadores fueron perseguidos, encarcelados y torturados. ${ }^{119}$ Pilar Dolz al igual que muchos artistas comprometidos del momento, actúa sin ninguna consigna política determinada, lo que le permite actuar con total libertad y autonomía reivindicativa. Durante este período realiza una obra de carácter crítico, que procede de la realidad de su vivencia en la España de la dictadura franquista.

\footnotetext{
${ }^{119}$ La muerte del general Carrero Blanco, el 20 de noviembre de 1973, fue visto como una oportunidad para incrementar la presión al régimen. La incorporación de militantes socialistas, comunistas, cristianos progresistas y de activistas estudiantiles y profesionales sin militancia precisa, desemboca en movimientos sociales de gran empuje. La lucha contra la dictadura, con huelgas y manifestaciones se incrementa, la represión tampoco cesa y hay gran número de detenciones. Véase ROMEU ALFARO, F.: 2002, p. 91.
} 
A finales de los 60 y principios de los 70 había todos esos movimientos sociales y hay mucho arte reivindicativo. Yo hice un grabado muy clásico del momento. (...) Date cuenta que realmente eran los últimos años del franquismo, tenía muchísimos amigos en la cárcel y había mucha represión. No sé, eran unas rejas que no tenían nada que ver con las cárceles, pero eran como un símbolo que refleja la idea política del momento. Eso que yo no pertenezco a ningún partido político realmente. ${ }^{120}$

Desde el punto de vista del planteamiento plástico, las primeras figuras de esta serie muestran un lenguaje figurativo con cierto influjo surrealista, en el que se presentan falsas perspectivas, formas suspendidas en el espacio, y donde la construcción de la forma deriva en una síntesis formal, a través de una esquematización plana, sin dar mayor importancia al volumen.

En cuanto al cromatismo, en un principio la serie no lo utiliza, es monocromática, aunque más tarde empieza a surgir el color a través de manchas planas, sin la menor intención de provocar una fusión óptica, muchos de los recursos que va a emplear posteriormente van a ir enriqueciendo paulatinamente el lenguaje. Algunas de estas obras están trabajadas en planchas de pequeño formato, se trata de pequeñas anotaciones que va haciendo, mientras trabaja en otras obras.

A partir de 1973 continúa con esta propuesta a través de la técnica litográfica, con la que se torna más realista, por medio de una técnica más depurada, y un dibujo más minucioso. Atrás deja

${ }^{120}$ Entrevista personal con la autora en Castellón de la Plana. 16/05/2005. 
aquel discurso tosco y duro de su etapa inicial para dar paso a una expresión de mayor sutileza, donde las rejas ya no se presentan solas y vacías, sino que se muestran confundidas y enredadas con unas reaparecidas cuerdas (recordemos que esta iconografía surge en la primera serie y desde entonces aparecen en todas las series hasta ahora). En combinación con estos elementos aparecen también otros dispositivos del mismo universo; cadenas, candados, bisagras, mecanismos que serán el devenir de posteriores series, y que afloran junto a otras formas emblemáticas de la naturaleza como pájaros, mariposas, insectos, ventanas, con los que se intenta explicar el mundo y demostrar ciertos aspectos de la realidad. Durante su última etapa observamos la aparición de nuevos elementos como paisajes, cielos, nubes y mares que surgen, generalmente en calidad de fondos.

Sin duda esta serie de hondo significado, tiene un lenguaje objetivo y a la vez metafórico de la realidad; su sentido crítico y su decidida postura de denuncia de todo aquello que significa el atropello de una cultura y de un país, son características que definen a la artista durante estos años.

M. Monge al referirse a esta obra nos dice:

Pilar Dolz nos traslada a un mundo de ansias de libertad a todos los niveles, que resulta sugeridor y denunciante. La agresión de la limitación de libertades es una constante clara en su obra y a través de ella canta Pilar Dolz a un mundo exento de cierres y barreras que permita la absoluta realización del hombre a través de todas sus facultades. ${ }^{121}$

121 Véase. MONGE, M.: "Pilar Dolz; de Castellón a Benidorm" La verdad, Alicante, 10/07/1977, p. 10. 


\subsubsection{ASPECTOS COMPOSITIVOS.}

\section{Composición}

Esta serie se encuentra compuesta por dos conjuntos de obras distintas, aunque ambas parten de un sistema de representación figurativo el comportamiento plástico está planteado de diferente manera.

El primer grupo, realizado durante 1972, presenta una serie de imágenes de carácter plano y lineal, con sentido frontal, que no parece tener ninguna intención de realizar un estudio del volumen ni de claroscuro, sino más bien que da mayor importancia a la línea y su expresividad. Presenta un sistema compositivo simple, en el que se puede apreciar fácilmente el esqueleto estructural que la compone. La forma esquemática y sintética de las imágenes, solucionadas en primera instancia en tonos oscuros sobre un espacio vacío, hacen que sobresalga visiblemente del fondo, constituyéndose en la fuerza más activa.

La propuesta compositiva incide en la idea de la expansión de la imagen hacia fuera, que destaca la proyección de la forma más allá de los límites del soporte. Las líneas que dibujan la reja, sobrepasan los bordes del formato imaginariamente, prosiguiendo virtualmente su trayectoria, con un planteamiento que nos trae a la memoria, sin duda, aquellas primeras propuestas de la serie de mujeres y cuerdas donde se dejaba abierta la posibilidad al espectador para continuar la obra imaginariamente sobre un espacio más abierto. (Véase Fig. 68) 


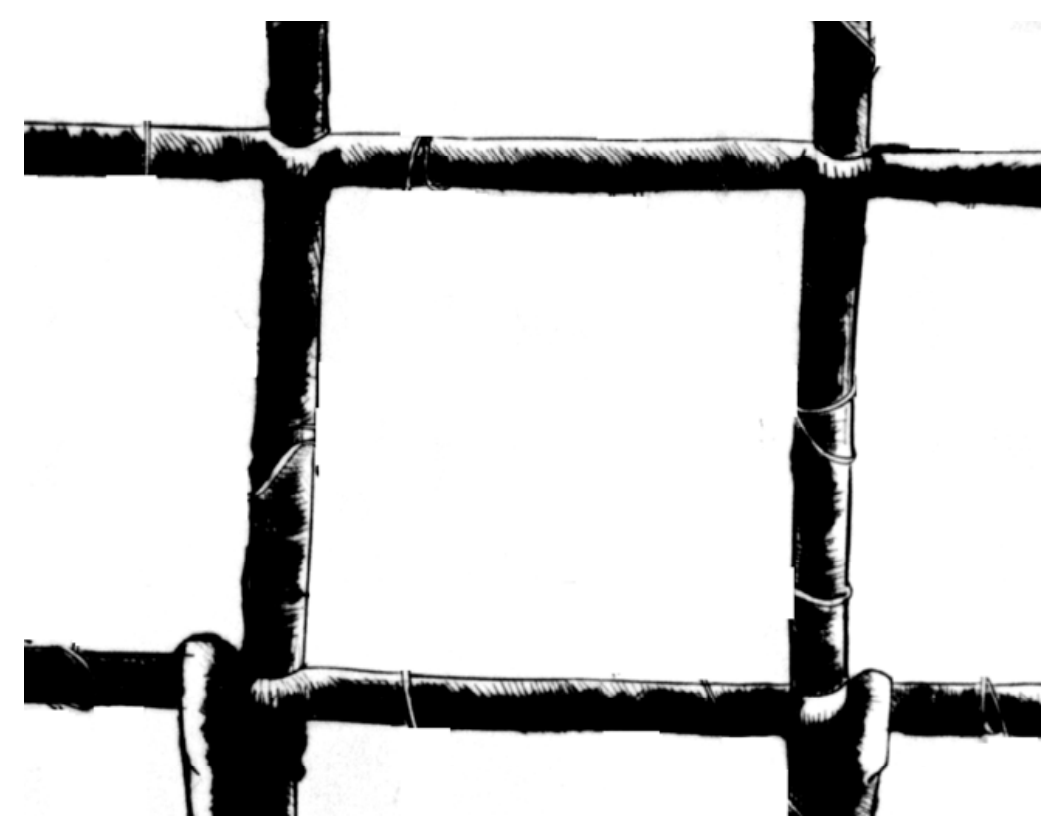

Fig. 68. Pilar Dolz. Detalle. LAM. XXVIII. Serie Reixes. Punta seca. 1972.

En cuanto a la construcción de la forma, ésta se halla solucionada con una serie de líneas rectas que crean las disposiciones alargadas de las rejas, dando origen a una imagen de estructura simple manifestada por los ejes de sentido horizontal y vertical que reducen al mínimo la concepción del espacio y la simplicidad de la materia.

Con estas líneas, establece la idea de dirección a través de un esquema simétrico simple; la verticalidad y la horizontalidad sobre la que descansa la composición. La diferencia entre ambas líneas está dada por el tirón gravitatorio que se proyecta sobre la visión; las dos direcciones establecen un enrejado espacial sólido de carácter dinámico. Su combinación; horizontal y vertical suministra mayor estabilidad a la composición. En este sentido, 
la recta se convierte en un elemento fundamental, no sólo porque cimienta la forma, si no porque marca la extensión y la dirección en el espacio. Recordemos lo que Delacroix dijo: "La línea visualmente más simple, es la recta porque es la línea más temprana que concibe la mente humana, bajo el mandato de la simplicidad". ${ }^{122}$ (Véase LAM. XXIX)

En cuanto a su ubicación en el espacio, ésta tiende a recorrer toda la superficie, estableciendo un juego interactivo entre el lleno (forma) y el vacío (fondo), pues la imagen solucionada a través de un enrejado lineal simple, deja ver siempre un espacio de luz resplandeciente, que corresponde al blanco del papel, si bien el elemento protagonista de la obra es la imagen representada, (tinta) en relación al fondo (sin tinta) que proyecta un espacio de luz. Observamos que también su gran importancia tiene que ver con el hecho de que está llamada a provocar un fuerte contraste entre la forma y el fondo, para producir un efecto cinético en nuestra retina. Este espacio de luz, no hace referencia a nada en concreto, sino más bien que se corresponde a un espacio de irradiación atmosférica, en el que sin duda existe un interés por mostrar lo que hay al otro lado, por descubrir el mundo exterior que se presenta como un ambiente vacío, que increpa abiertamente al espectador $y$ le lleva a mirar hacia el otro lado. (Véase LAM. XXX)

Normalmente la imagen se encuentra dispuesta en un sólo plano, sin embargo en los casos en los que hay más planos, los efectos de profundidad se consiguen por la superposición, en lugar del uso de la perspectiva tradicional, con lo cual, se crean varios

${ }^{122}$ Mencionado por ARNHEIM, R.: 1993, p. 208. 
niveles de sucesión en el espacio, identificados cada uno, de acuerdo con la distinta intensidad tonal, de tal manera que cada plano tiende a apreciarse conservando su individualidad. (Véase Fig. 69)

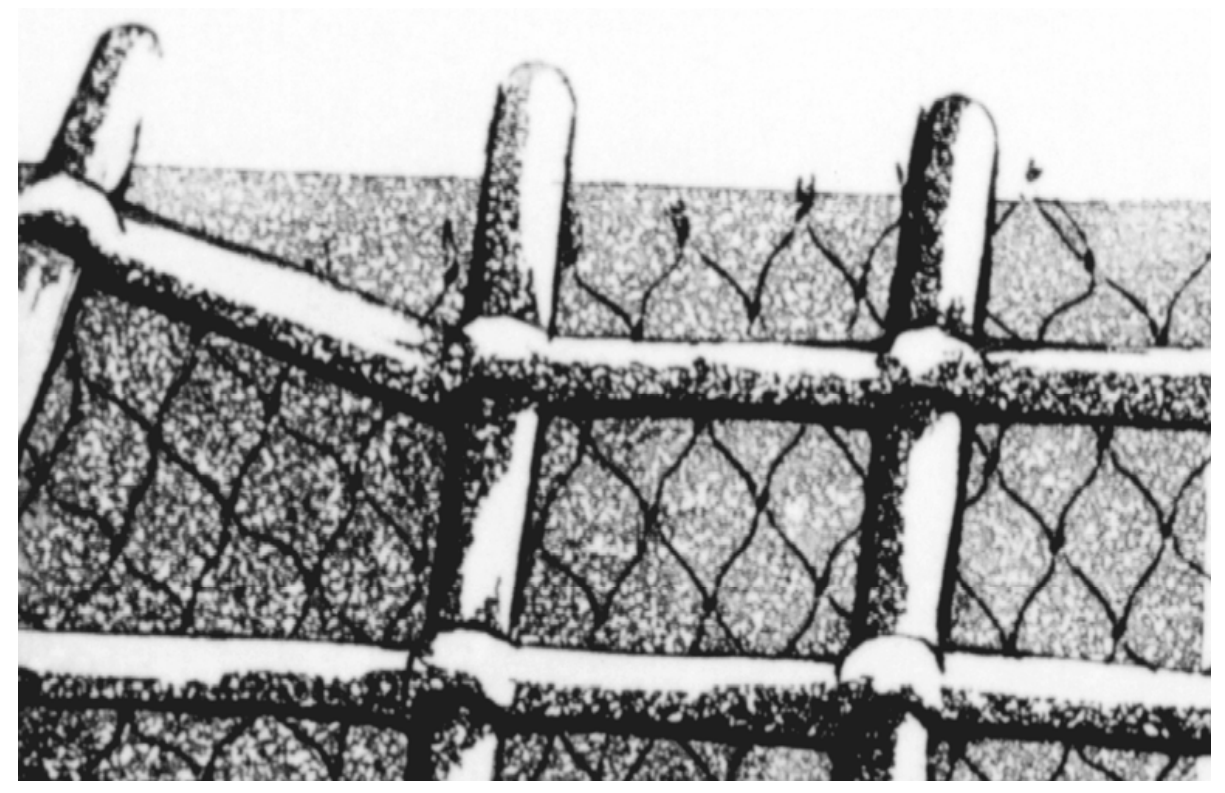

Fig.69. Pilar Dolz. Detalle. LAM. XXXI. Serie Reixes. Aguatinta, aguafuerte y barniz blando. 1972.

Aunque normalmente la composición tiende a situarse en el espacio con una simetría centrada, en algunas ocasiones también podemos encontrar el peso compositivo desplazado, hacia un extremo o un ángulo del plano. El alejamiento de los elementos del centro del plano, genera cierta tensión en la composición, a la vez que produce una sensación dinámica en la imagen; situación que incita al espectador a desplazar la mirada por la obra, y centrar la atención en un punto concreto. Para alcanzar el equilibro se recurre 
al empleo de una segunda matriz, que se estampa a color y es trabajada normalmente a base de manchas planas, que quedan ubicadas por detrás de los trazos lineales y contrarrestan sus energías compositivas; de esta forma equilibran el peso de los elementos de la composición. (Véase LAM. XXXII)

El segundo bloque de obras, realizado a partir de 1973, se caracteriza por tener una proyección más realista. Efectuado por medio de la técnica litográfica, nos muestra un estudio más estricto del claroscuro y con un mayor interés por el volumen. Sin embargo no presenta un trabajo academicista clásico, más bien es la combinación de la estructura compositiva simple del primer grupo de obras con un estudio más minucioso del claroscuro, en el que se sigue manteniendo ciertos rasgos de aplanamiento de las formas, especialmente en los fondos, donde se juega con la presencia de dos elementos, volumen y aplanamiento de forma simultánea. (Véase LAM. XXXIII)

Otro aspecto que supone la ruptura con el academicismo, es el criterio espacio-temporal de representación, por el cual la forma presenta varios puntos de vista, lo que supone situaciones espaciales distintas en la propia imagen, de manera semejante al planteamiento de los surrealistas. El sentido de profundidad se consigue con la combinación de dos elementos; el claroscuro, con el que se obtiene la sensación de volumen, y la superposición de planos, que crea la impresión de que una forma se encuentra delante de otra. En LAM. XXXIV, por detrás del dibujo minucioso de la reja, aparece sin ningún tipo de referencia de volumen, de perspectiva, ni de claroscuro, un plano liso de color gris, que asoma 
irrumpiendo el espacio por superposición, ubicándose en un segundo plano, proporcionando un ambiguo sentido de profundidad en la imagen. (Véase Fig. 70)

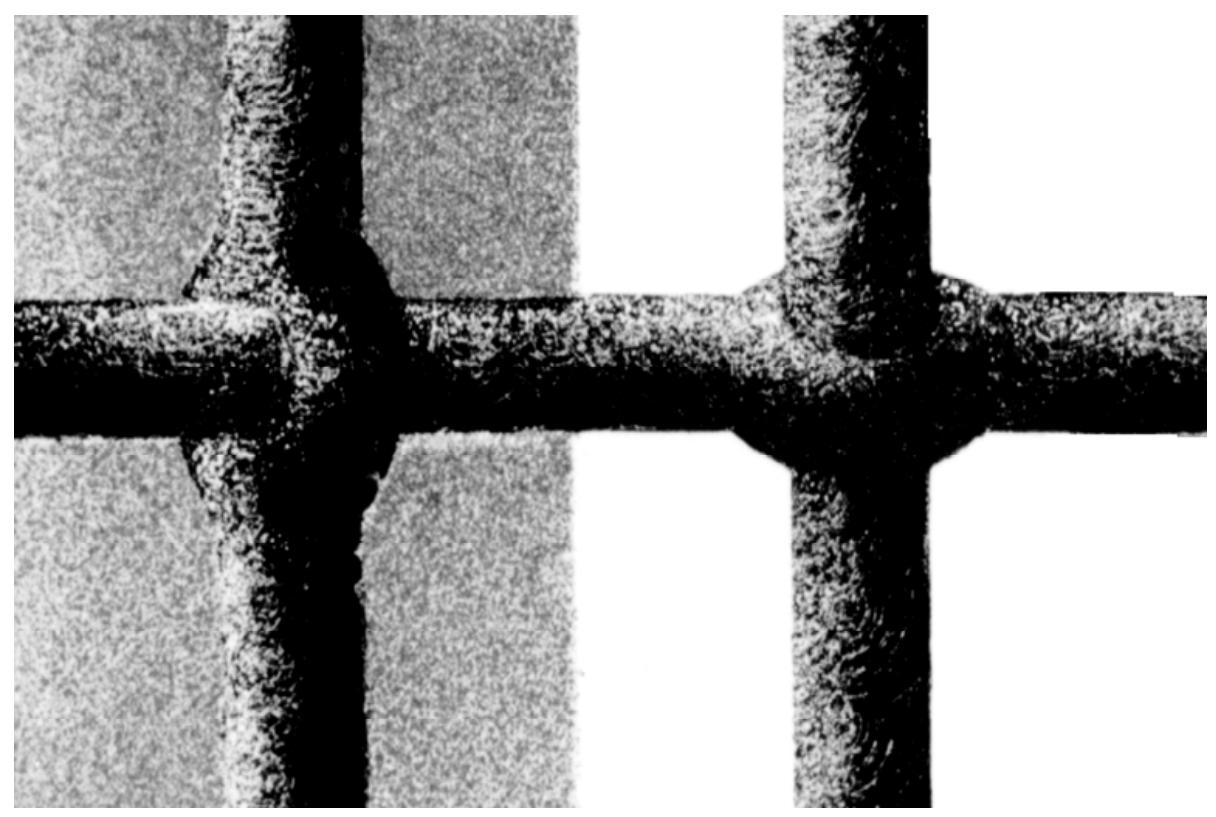

Fig.70. Pilar Dolz. Detalle. LAM. XXXIV. Serie Reixes. Litografía. 1973.

Las rejas poco a poco van transformándose y empiezan a formar parte de algo, o simplemente dejan de ser tales para convertirse en una valla o en el fragmento de una ventana, en la que casi siempre hay algo que impide el paso y limita la mirada del espectador. En este sentido el planteamiento compositivo también cambia; la iconografía, ya no se sitúa en el mismo centro de la superficie como ocurría inicialmente si no que se desplaza hacia un extremo, a partir de donde se extienden alambres o cuerdas de carácter lineal, que apenas si tienen grosor, por lo que dejan ver 
entre sus trazos gran parte del espacio que, a diferencia de las obras anteriores, no permanecen en blanco, sino que es ocupado por el surgimiento de nuevas imágenes, que florecen en un segundo término. (Véase Fig.71)

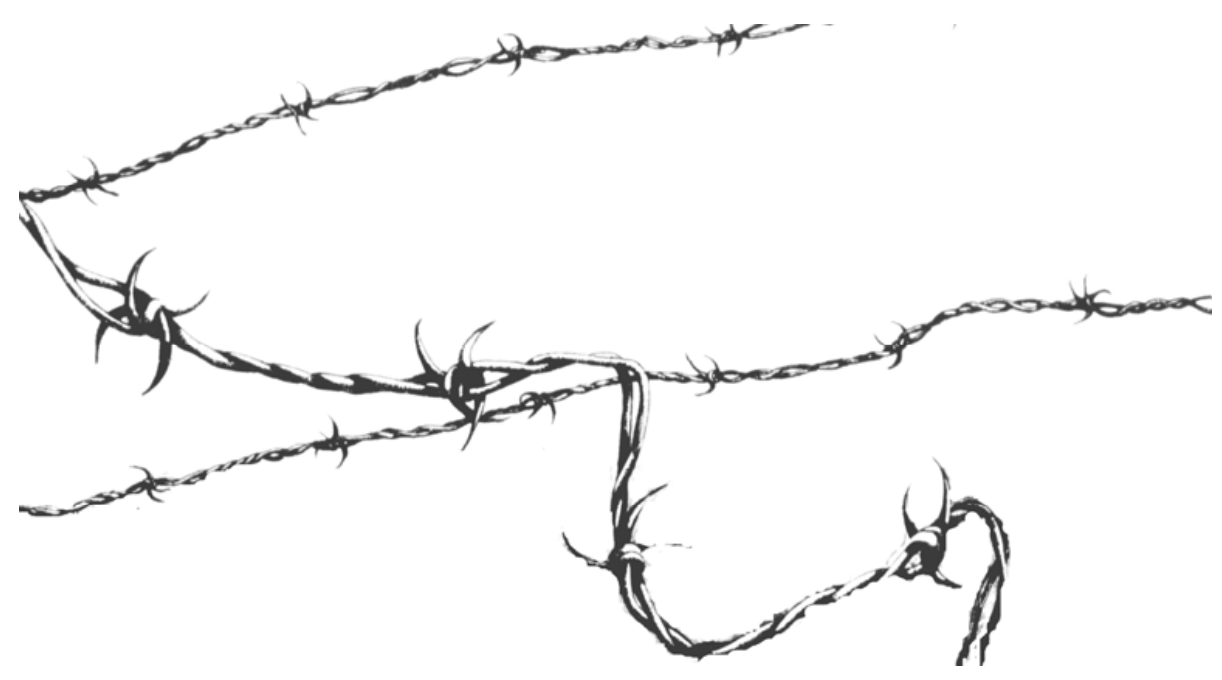

Fig.71. Pilar Dolz. Detalle LAM. XXXV. Serie Reixes. Litografía. 1973.

En cuanto a la distribución de los elementos formales en el espacio, vemos que empiezan a cubrir toda o casi toda la superficie, a través de la creación de campos, cielos o mares, que ocupan los espacios vacíos, y otorgan una mirada más dinámica hacia el exterior, a pesar de lo cual, seguimos percibiendo una sensación de angustia y desolación, quizás provocada por la evidencia de la reja que parcializa la visión de ese mundo exterior. (Véase LAM. XXXVI y XXXVII) 
En otras ocasiones las rejas aparecen con una forma más alegórica, por ejemplo con la representación de un personaje masculino, que grita desgarradoramente su horror interior. Con esta nueva imagen la artista retorna al aguafuerte, a través de un trabajo más complejo y con un total dominio del claroscuro. La iconografía de la reja aparece ante nuestros ojos, gracias a la acertada acción de la artista de cortar la plancha en cuatro partes, a manera de puzzle; con estas particiones se construye la forma de la reja, en el momento en que las distintas partes de aquella matriz original, se imprimen en el soporte reconstruyendo la imagen, pues deja entre sí una ligera separación, que nos permite apreciar el blanco del papel, que adquiere la forma de una cruz que simboliza la reja. (Véase LAM. XXXVIII)

En otras obras de esta serie, la artista cambia de discurso y las rejas presentan un planteamiento espacial distinto al desarrollado en otros grabados.

En LAM. XXXIX nos encontramos con una obra de serigrafía, donde el trazo que construye la imagen se resuelve con un tono claro, mientras que el fondo de halla solucionado con un tono oscuro, a la inversa de lo que ocurría anteriormente, cuando la imagen de la reja se dibujaba en negro sobre fondo blanco. (Véase Fig.72) 

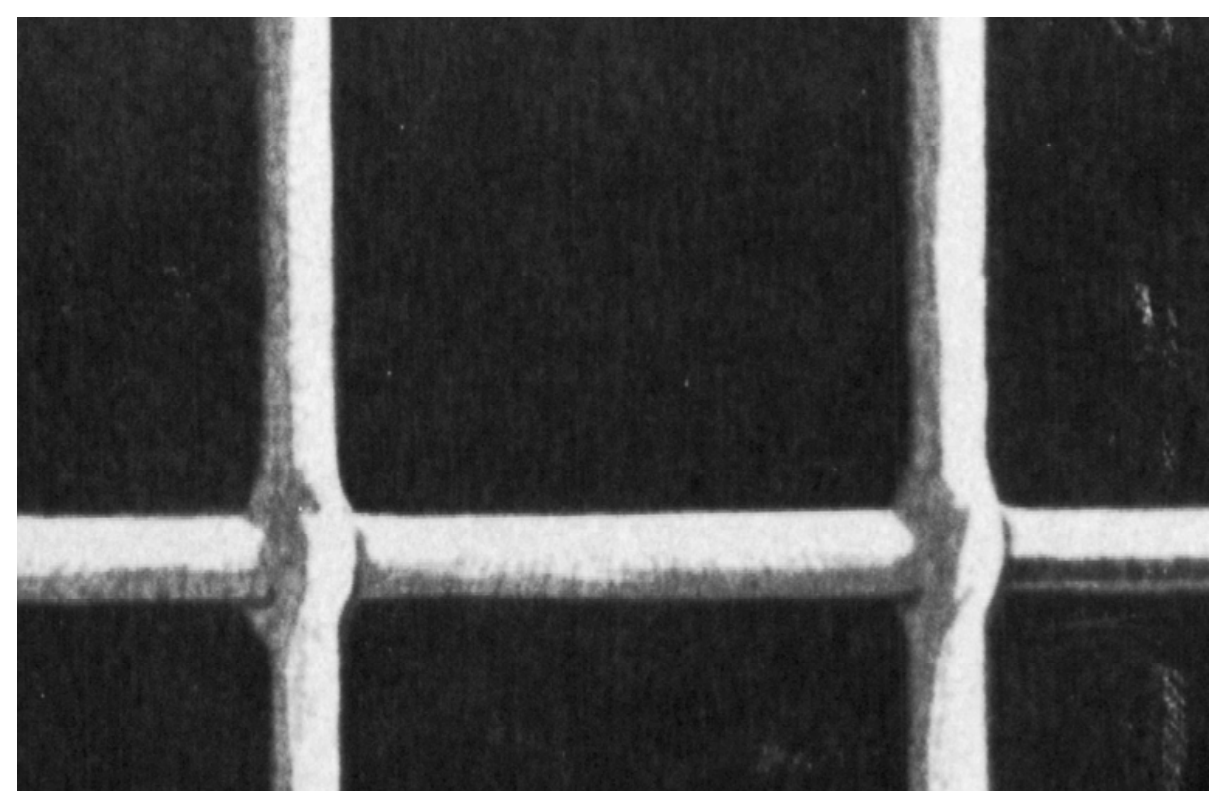

Fig.72. Pilar Dolz. Detalle LAM. XXXIX. Serie Reixes. Serigrafía. 1975.

\section{Grafismo}

Básicamente la construcción de la forma está reducida al empleo de la línea recta, que otorga a la obra un aspecto duro y severo por la ausencia de trazos curvos, con ello resta suavidad a la imagen y le da una lectura más violenta y trágica a la obra.

Entre el primer grupo de obras logramos distinguir dos tipos de trazos; uno que aparece delimitado por la línea que dibuja la forma dentro del espacio que conforman los barrotes, es un trazo más dinámico y vigoroso caracterizado por la presencia de la mancha de aguatinta, en la que observamos la textura y el movimiento ejecutados con el pincel, a través de los cuales se crean ciertos efectos visuales que se determinan por los distintos 
contrastes tonales y formales; la mancha, contribuye así a suavizar la resolución de la imagen. Acompaña a este rasgo otro de carácter lineal, se trata de unas líneas muy finas y pequeñas realizadas al aguafuerte, que se disponen de forma paralela y ondulante sobre la mancha al aguatinta, la dirección, la curvatura y la intensidad de la línea, son elementos perceptivos, que transmiten un cierto efecto volumétrico a la imagen. (Véase Fig. 73)

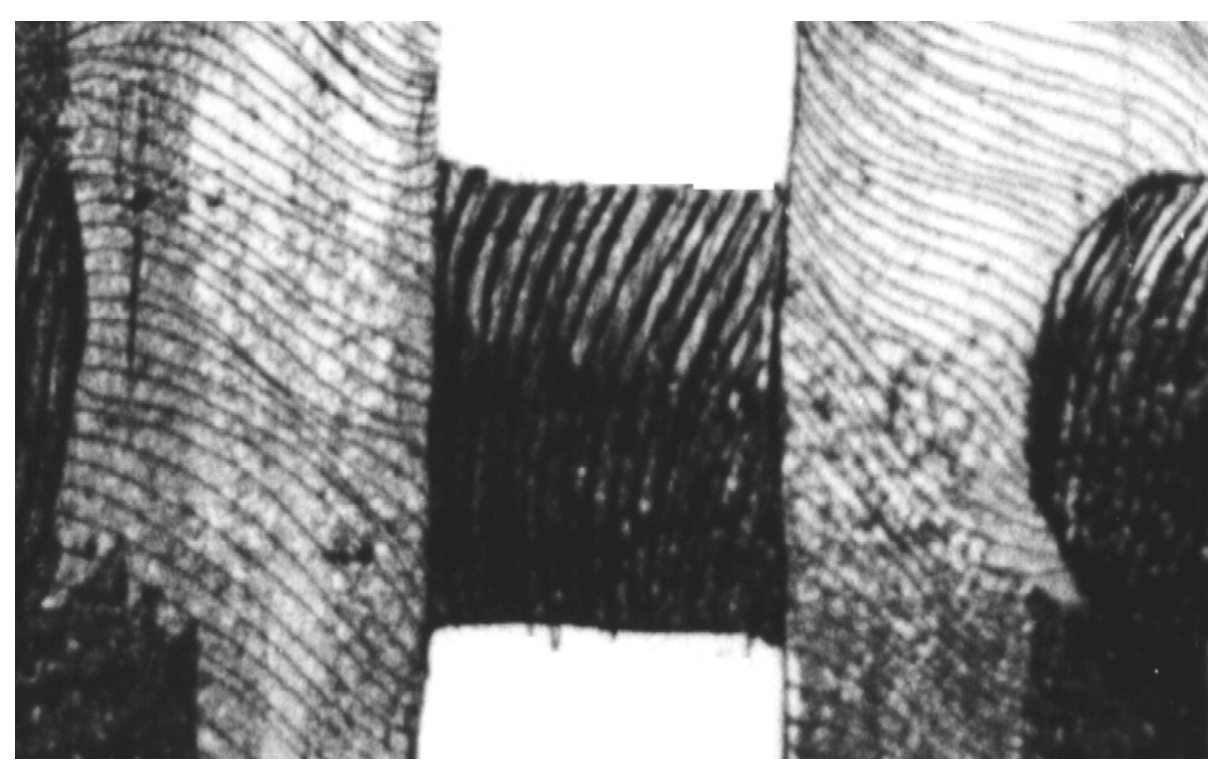

Fig.73. Pilar Dolz. Detalle LAM. XXX. Serie Reixes. Aguafuerte y aguatinta. 1972.

Por otro lado localizamos también la presencia de un tipo de trazo entramado, resuelto a través del entrecruzamiento y la superposición de la línea en todas direcciones, horizontal, vertical y diagonal; esta práctica obtiene como resultado una masa compacta y saturada, creada con la intención de sombrear grandes zonas y generar una sensación atmosférica, especialmente cuando se trata 
de rejas representadas desde un interior, como en LAM. XXXII, donde se intenta dar un tratamiento de claroscuro a través de la introducción de una zona de penumbra y un área de máxima claridad. En contraposición con esta intencionalidad atmosférica, observamos que el trazo empleado para su elaboración es impulsivo y violento, debido a la fuerza y rotundidad que se prodiga en su ejecución. (Véase Fig. 74)

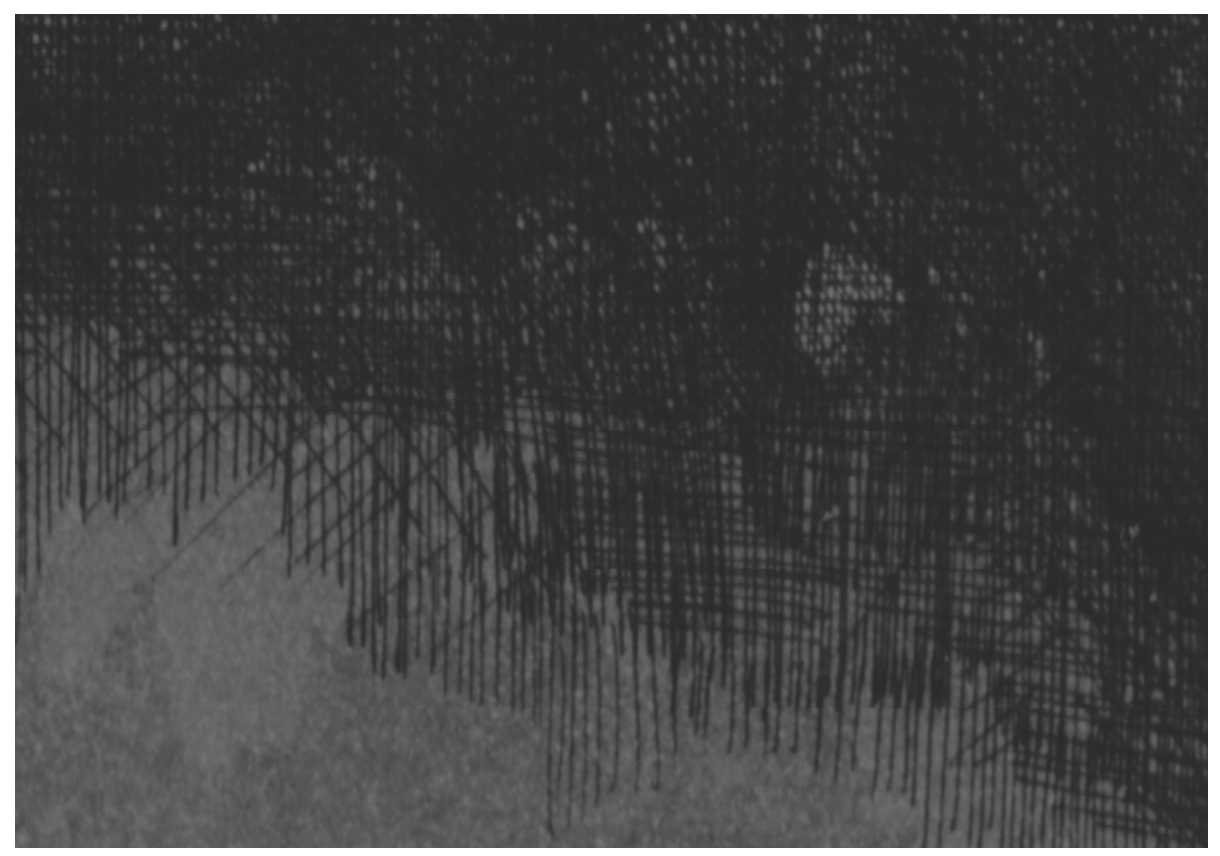

Fig.74. Pilar Dolz. Detalle LAM. XXXII. Serie Reixes. Aguafuerte y aguatinta. 1972.

En el segundo grupo de obras, el trazo se hace más suave y flexible, por medio de la técnica litográfica con la que empieza a trabajar el claroscuro de forma que rompe con la severidad y rigor del trazo, se trata ahora de un rasgo más dócil y delicado, solucionado mediante una escala de grises, en la que conviven 
pacíficamente la luz y la sombra, aunque la representación en conjunto sigue estando estructurada con la referencia de la horizontalidad y verticalidad de la posición de los elementos. El tratamiento de la forma se remedia con un estudio monocromo, que adopta una perspectiva construida por los valores tonales rica en expresividad, que dota a la imagen, de volumen y profundidad, y así termina con el aplanamiento y la dureza de la forma, a la vez que concede a la imagen, un aspecto más realista. (Véase Fig. 75)

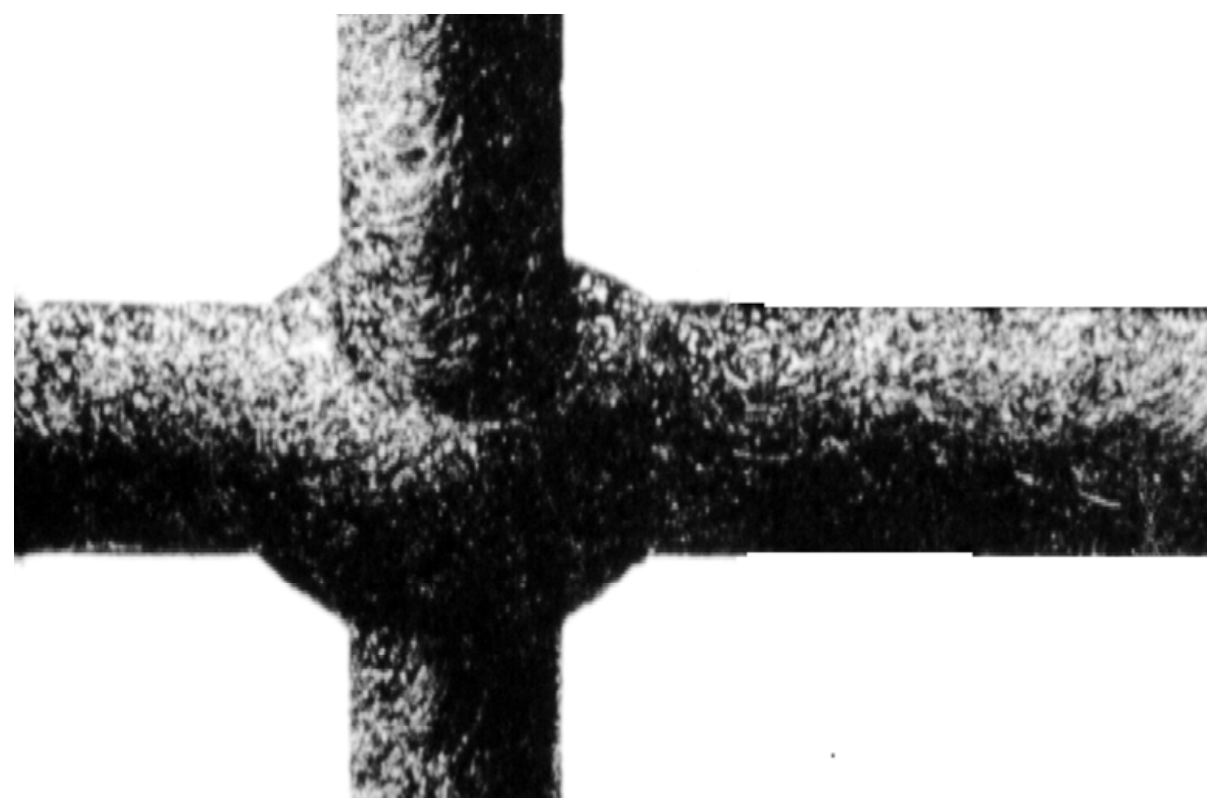

Fig.75. Pilar Dolz. Detalle LAM. XXXIII. Serie Reixes. Litografía. 1973.

\section{Color}

El color reaparece en esta serie, y lo hace con fuerza y de forma permanente, ya que hasta ahora sólo había aparecido 
esporádicamente en dos ocasiones, una en 1970 y otra en 1972, con una obra perteneciente a la serie de formas y otra a la serie de mujeres.

En esta colección de grabados, el sentido cromático surte sólo como un refuerzo de intencionalidad plástica, donde el dibujo se plantea como una base estructural y el color como un elemento complementario, sobre todo en el primer grupo de obras en el que apreciamos el planteamiento de un estudio más elaborado de la forma, mientras que el color se presenta con un trabajo más sintético y esquemático, basado principalmente en el uso de tintas planas dedicadas a cumplir funciones como colorear fondos o pintar amplias superficies de la forma.

En LAM. XXXII, se plantea introducir el color como parte integrante de la obra, sin embargo su aplicación emerge de forma independiente; así topamos en primera instancia con la presencia de un color amarillo, de perfil rectangular que asoma enclavado en el extremo superior derecho del plano, como si estuviera flotando en el espacio, es el color que más atrae la atención, por su intensidad y potencia, el primer impulso que despierta en el espectador, es inquietante y excitante pues transmite una gran fuerza. En contraposición a éste, aparece un color azul, de tono más oscuro, que ocupa el extremo izquierdo y la parte inferior del plano, formando una especie de $\mathrm{L}$, que descansa sobre la línea límite del soporte, es el color que otorga el carácter sereno a la obra, aplacando el efecto vigoroso del amarillo. Los dos colores están dispuestos en el plano ocupando cada uno su espacio, no llegan siquiera a tocarse entre sí, para poder fusionarlos en una imagen 
única, se acude a la aplicación de una segunda matriz de grafismos lineales, trabajada con aguafuerte y aguatinta, estampada en color negro, que se superpone a la anterior y dibuja la forma que estructura la disposición de los colores. Así, el amarillo aparece rodeado en sus cuatro lados por unos espacios agrisados que lo enmarcan, mientras por encima de éste se esbozan unas líneas verticales y horizontales que construyen la reja. En cuanto al color azul, pasa a formar parte de la pared que alberga la reja y se encuentra reforzado por unos trazos lineales, que oscurecen y llegan a cubrir casi su totalidad y dejan visible únicamente una parte en la zona inferior del plano, como representación de la proyección de luz que irradia desde la ventana.

Como podemos ver los efectos visuales del color reposan sobre dos colores que contrastan y se contrarrestan entre sí, no sólo por su fuerza cromática si no también por sus propiedades expresivas.

Aquí hay una plancha que pone el azul y el amarillo, y otra que dibuja, no se mezclan los colores, pero el negro es muy intenso y dibuja, no es pictórico, es como un dibujo que luego lo coloree. Siempre intento meter el color, pero meto el color de una forma que dibuja el negro, no se integra, queda una cosa muy gráfica. ${ }^{123}$

En otros grabados, se concibe el tratamiento del color de una forma muy gráfica, como en LAM. XXXIII, donde observamos el empleo de una mancha plana que aparece cubriendo toda la

${ }^{123}$ Entrevista personal con la autora en Castellón de la Plana. 22/03/2002. 
superficie del espacio, mientras por otro lado, el trazo minucioso, que construye la forma, se superpone a la mancha, por medio de un negro muy intenso, que cede el protagonismo a la imagen, y relega el aspecto cromático a un segundo plano. En este caso la aplicación del color, surge en función de su pura expresividad, hablamos de un color azul, con un tinte plateado, que se extiende uniformemente por toda la superficie; esta coloración hace que la mancha parezca aun más plana, su tono uniforme hace que se perciba cierta atmósfera de calma y serenidad en la obra.

En el grupo de obras de tratamiento más realista, el color no se limita a su representación plana y expresiva, como ocurría anteriormente, sino que evoluciona hacia una forma más pictórica, para adquirir una naturaleza más descriptiva y narrativa, por medio de la creación de nuevas formas. No obstante se continúa con el planteamiento del color de un modo autónomo, donde se piensa primero en el claroscuro y después en el color. En la mayoría de los casos alcanzamos a apreciar la presencia del color de una forma libre y abierta, siempre por detrás de la imagen trabajada con claroscuro; según el color que se utilice para su exposición, éste se convierte o no en el punto de atracción de la obra.

En LAM. XXXIV se elije para la representación de la imagen de una bandera, el color rojo, que aparece de una manera simbólica asociado al símbolo de la sangre, el fuego y la revolución, ${ }^{124}$ dotado de una gran potencia y tenacidad, provoca un efecto directo y espontáneo en el espectador. Evidentemente éste contrasta con el resto de la composición que aparece a contraluz, por su gran

$\overline{{ }^{124} \text { Véase ARNHEIM, R.: 1993, p. } 403 .}$ 
luminosidad. Su significado es expresado en el conjunto global de la obra, no sólo por el color.

La evolución de la autora hacia el color, viene dado sin duda por el dominio de la técnica litográfica, donde sus plasmaciones adquieren un realismo más acentuado por medio de un trazo más propio del dibujo delicado del lápiz, con el que se obtiene toda una escala de tonos, luces y sombras, que proporcionan el efecto volumétrico al color. Sigue funcionando con una libertad del color individualizado, en que primero crea una imagen a color en la piedra y después, sobre ella, coloca la segunda imagen estampada en negro, con la finalidad de terminar de construir la obra.

Aunque todos los colores residen en una misma imagen y las manifestaciones son más artísticas, la representación de diferentes imágenes por matriz, hace que cada una tenga cierta autonomía, por lo que si quisiéramos estamparlas por separado, perfectamente sería posible obtener varias obras individualizadas. De hecho en algunas ocasiones la artista ha llevado a cabo esta experiencia, como queda registrado, en varias pruebas de estado. Un ejemplo lo localizamos en LAM. XXXV, que nos muestra en primer término, el dibujo de un alambrado metálico, solucionado con un perfecto estudio del claroscuro, estampado en tinta negra, de una gran expresividad. Detrás de éste nos encontramos con el dibujo de un prado florido realizado con gran soltura, impreso en tinta ocre con cierta tonalidad amarillo verdosa que irradia brillo y claridad, en el que advertimos una gradación de ricos matices, que confieren un efecto más dinámico a la imagen. 
Por otra parte, en LAM. XXXVI tenemos un conjunto de nubes, que aparecen con un aspecto sólido, como si estuvieran hechas de piedra, de las que incluso brotan una especies de hilos o pelos que se mueven con el viento al más puro estilo surrealista, estampadas con una sola tinta de color azul grisáceo de poca luminosidad, que domina la superficie y le da un aspecto más espacial. Mientras que, estampado en tinta negra, encontramos un fragmento de ventana, realizado con lápiz litográfico, en el que unos blancos muy intensos conviven frente a unos negros muy profundos, el cual aparece para aliviar el peso de las nubes. En otras obras el color parece que empieza a combinarse mejor, aunque sigue siendo muy gráfico.

En LAM. XXXVII la coloración aflora, a través de un fragmento de mar, trabajado con una clara intención narrativa por medio de tres manchas gestuales; una gris, una amarilla y una azul, de acusada claridad, aunque camina más hacia la sutil desaparición del color, frente a un meticuloso estudio del claroscuro de una reja impresa en tinta negra, que llama más la atención por su gran intensidad. Respecto a esto nos comenta la artista:

Alli es cuando empiezo a integrar el color, no lo tenía muy claro, no es muy pictórico. (...) Ahí ya me iba bien, pero hay un momento, en que yo necesito el color todo el rato; éstas son bonitas litografías, pero el color es como un dibujo coloreado, entonces no era eso lo que quería. ${ }^{125}$

${ }^{125}$ Entrevista personal con la autora en Castellón de la Plana. 16/05/2005. 


\subsubsection{PROCESO TÉCNICO}

En esta serie de grabados, la técnica pasa por la intervención de diferentes procesos, de acuerdo con esto podemos diferenciar dos grupos de obras; el primero se caracteriza por la participación del metal, trabajado a través de las diferentes técnicas del grabado calcográfico, especialmente el aguafuerte y el aguatinta, y el segundo conjunto de obras resueltas por medio de la técnica litográfica.

El trabajo realizado sobre el metal se convierte en el protagonista de muchas de las estampas, se identifica sobre todo por ser monocromático, realizado por medio de unos trazos simples y esquemáticos de representación lineal, con los que no se puede alcanzar una gran diversidad de valoración, el trabajo desarrollado sobre la plancha es muy tradicional, donde la intensidad del trazo está dada por la profundidad de la mordida del ácido. (Véase LAM. $\mathrm{XXX}$ y $\mathrm{XXXI)}$

Entre las distintas técnicas de metal utilizadas, contamos también con el empleo de la punta seca, que se identifica por la saturación de tinta, en las zonas donde se acumula la rebaba, producida por el metal levantado que queda a ambos lados de la línea, durante el ejercicio del trazo. Cuando se proceso de entintar la plancha, tanto el surco como la rebaba, retienen la tinta, de modo que los contornos de las líneas no aparecen nítidos, sino a la inversa con un aspecto aterciopelado, efecto que es aprovechado en las zonas de sombreado, para dar espesor y solidez a las imágenes. (Véase LAM. XXVIII) 
Otra de las técnicas empleadas, es la del llamado proceso de levantado, mediante la aplicación de un producto líquido sobre la plancha previamente barnizada, compuesto por aguarrás y óleo blanco, incluso en muchas ocasiones llega a mezclar aceite de oliva, este producto reblandece el barniz, que se levanta frotando enérgicamente con un trapo de algodón, dejando disponible unas zonas, libres para ser resinadas y ser sometidas a la acción del ácido, de esta forma el ácido ataca la mancha con un graneado regular. Una cosa a tomar en cuenta es que hay que controlar que no se caliente demasiado la plancha al fijar la resina, ya que esto puede ablandar el barniz y provocar la entrada de este por las zonas resinadas. En otras ocasiones cuando se levanta el barniz, la artista procede a no limpiarlo del todo bien, obteniendo así unas formas deterioradas como de hierro carcomido, que le permite conseguir unos efectos irregulares y más pictóricos. (Véase Fig. 76)

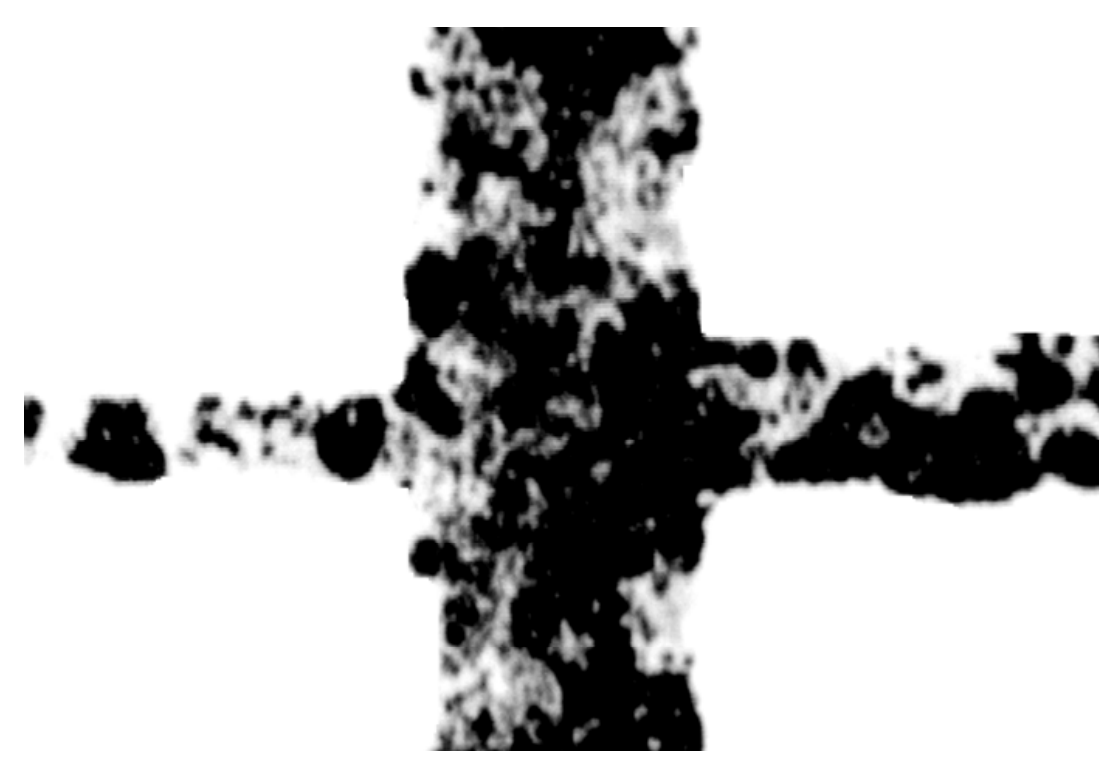

Fig.76. Pilar Dolz. Detalle LAM. XXIX. Serie Reixes. Aguatinta. 1972. 
Cuando aparece el color, lo hace a través de dos tintas superpuestas, (un color y negro) normalmente la plancha de grafismo es la que define la forma de la imagen y el color es un elemento subsidiario. El resultado de este procedimiento, da lugar a la creación de un conjunto de elementos simples y compactos, en la que se ponen de manifiesto las más diversas calidades. (Véase LAM. XXXIII)

En las ocasiones que intervienen más de dos tintas, se procede a utilizar una matriz diferente por cada color. Durante este proceso las tintas no llegan a fundirse entre sí, si no que aparecen como unidades cromáticas individuales, para cada uno de los elementos que intervienen en la obra. Así en LAM. XXXIV, contamos con la participación de tres colores, un rojo que dibuja la bandera, un gris que surge como una mancha plana y un negro que dibuja la reja. De igual manera en LAM. XXXVII, tenemos la participación de cuatro tintas, gris, amarillo y azul, que forman una especie de ola, a través de manchas gestuales y un negro que esboza la reja. Sin duda este trabajo, constituye parte de un proceso de exploración que la artista inicia más conscientemente en estos momentos.

Cuando tú empiezas a estampar cada color con una plancha, Repartes el color de una forma gráfica, muy para imprimir. (...) Allí estoy en un taller y hago cada plancha para un color. No se utilizaba otro tipo de color, (sic) también había a la poupée. ${ }^{126}$ Pero a mí no me gustaba a la poupée; después para hacer dos grabados iguales es muy difícil (...) como pongo yo el

\footnotetext{
${ }^{126}$ En lo que respecta al grabado calcográfico es posible conseguir estampas a color a través del entintado a la poupée, que consiste en poner todos los colores a la vez en la misma plancha con diferentes muñequillas y sólo se mezclan al limpiar con la tarlatana; como consecuencia, en frecuente la fusión de tonos. Véase VIVES PIQUÉ, R.: 1994, p. 63.
} 
color allí, es el grabado que normalmente se hacía; una plancha para cada color. Ya lo demás es el negro que dibuja, (...) como si fuera una cosa de diseño. ${ }^{127}$

El segundo grupo de obras, está definido por el empleo de la técnica litográfica, en la que Pilar Dolz, al contrario de lo que pasa en el metal, se mueve mejor y llega a sentirse segura.

Durante este período se encuentra estudiando en Italia, donde tiene como profesor de litografía a Carlos Ceci, quien imparte el estudio de la técnica de una forma muy clásica. Aquí trabaja la litografía de diferentes maneras, a través del lápiz litográfico, raspado, o acuarela, procedimientos con los que logra obtener distintos resultados.

El dibujo directo sobre la piedra con lápiz litográfico, le permite realizar un trazo más delicado y cuidadoso, sin la intervención de tramas lineales, por lo que se puede reproducir a la perfección los efectos del lápiz, proporcionándole así un efecto más real a la imagen, mientras que la acuarela litográfica saca al grabado de los límites de la expresión puramente lineal, da un efecto de mancha similar al de la aguada, en tanto que el dibujo a la pluma, en cambio le proporciona al trazo un aspecto más plano. Sin duda todos los conocimientos adquiridos le permiten obtener mejores resultados, con los que va abriéndose nuevos horizontes; cuando necesita un gris suave, o un negro profundo lo obtiene fácilmente. Consigue siempre los tonos deseados, sus creaciones surgen de la memoria, evidentemente el dominio de la técnica, le da la seguridad para hacer lo que quiere, sin preocupación alguna de la técnica, a veces

${ }^{127}$ Entrevista personal con la autora en Castellón de la plana. 16/05/2005 
fuerza una luz o una perspectiva, con la intención de darle un carácter más gráfico a la obra. (Véase LAM. XXXV y XXXVI)

Esto es diferente. Aquí tengo un muy buen profesor de litografía, que se llamaba Carlos Ceci. Yo, si hubiese estado primero con $\mathrm{Ceci}$, esto no lo hubiera hecho. Cuando después estuve con un profesor muy bueno, trabajé con una calidad técnica, que lo controlé bien, como técnica éstas ya están logradas. (...) La litografía la trabajé mucho, pero luego es que no puedo tener un taller de litografía en casa.

Después de esta experiencia litográfica, en 1974 retorna al metal y a las rejas de una forma metafórica, con una obra de dibujo más elaborado, en el que interviene el volumen y el claroscuro, en la que aprovecha al máximo el carácter espontáneo y directo de la técnica, beneficiándose de los incidentes que esta le proporciona, sin miedos, ni temores. Así reutiliza una plancha manchada, sin preocupación alguna por limpiarla o borrarla; al contrario, aprovecha su existencia, para dibujar sobre ella. El tono gris de la mancha, es aprovechado como base sobre la que se incide varias veces, con la intención de darle una diversidad tonal, que es lo que le proporciona el carácter real y expresivo a la imagen, que se intensifica al cortar la plancha libremente, para darle el significado metafórico de una reja. (Véase LAM. XXXVIII)

Dentro de este periodo incursiona también dentro de la serigrafía, ${ }^{129}$ con una única obra, de formas planas y de perfiles recortados. (Véase LAM. XXXIX)

\footnotetext{
${ }^{128}$ Ibidem

${ }^{129}$ En la década de los años setenta los artistas más representativos del Pop americano reivindicaron este procedimiento capaz de adaptarse a su imaginería de consumo arrancada a la cultura popular. Véase BLAS, J y BARRENA, C: 1995, p.256.
} 
LÁMINAS

\section{EIXES}





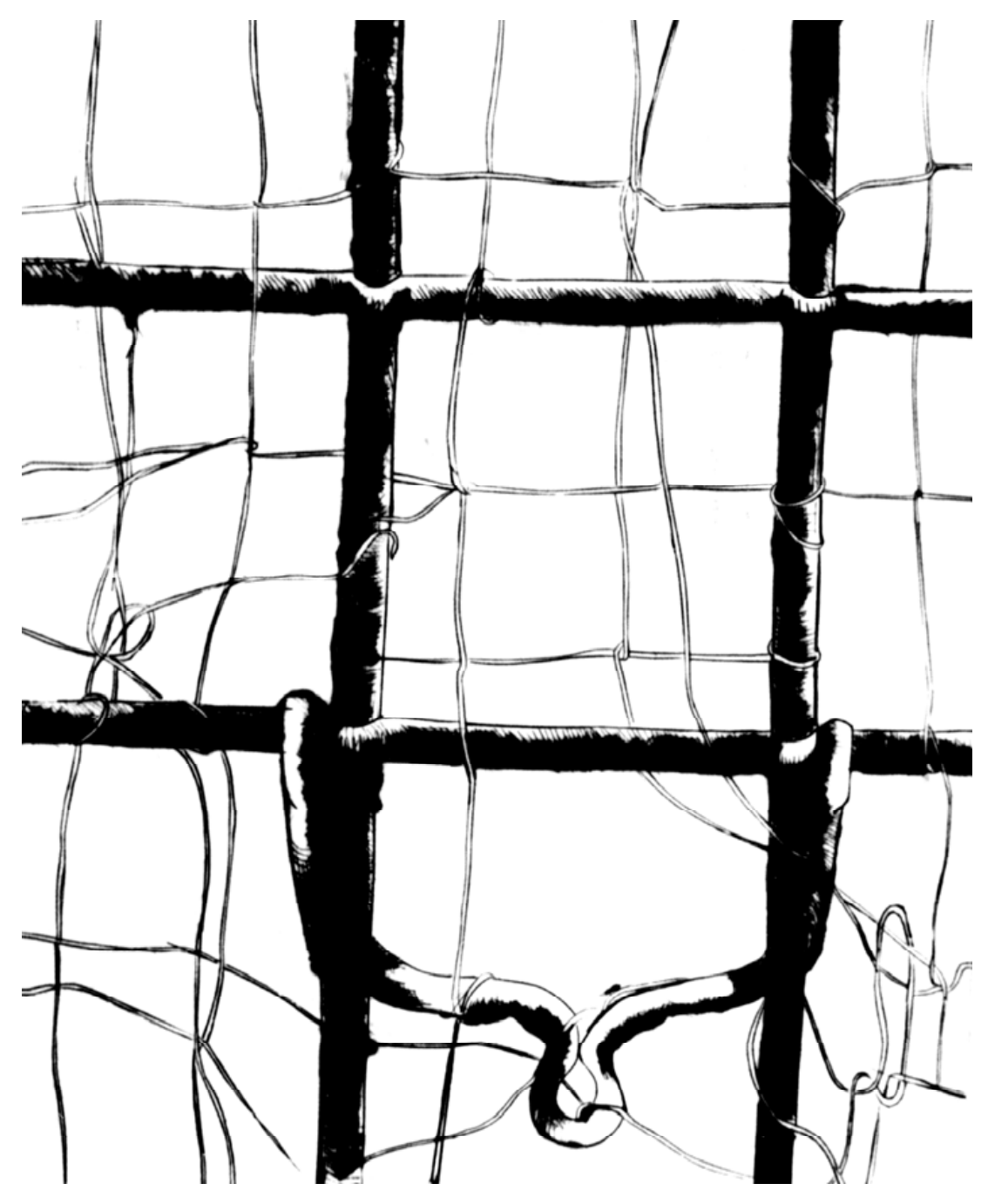

LÁMINA XXVIII

"Sin título"

Punta seca

$18.5 \times 15.5 \mathrm{~cm}$.

1972 


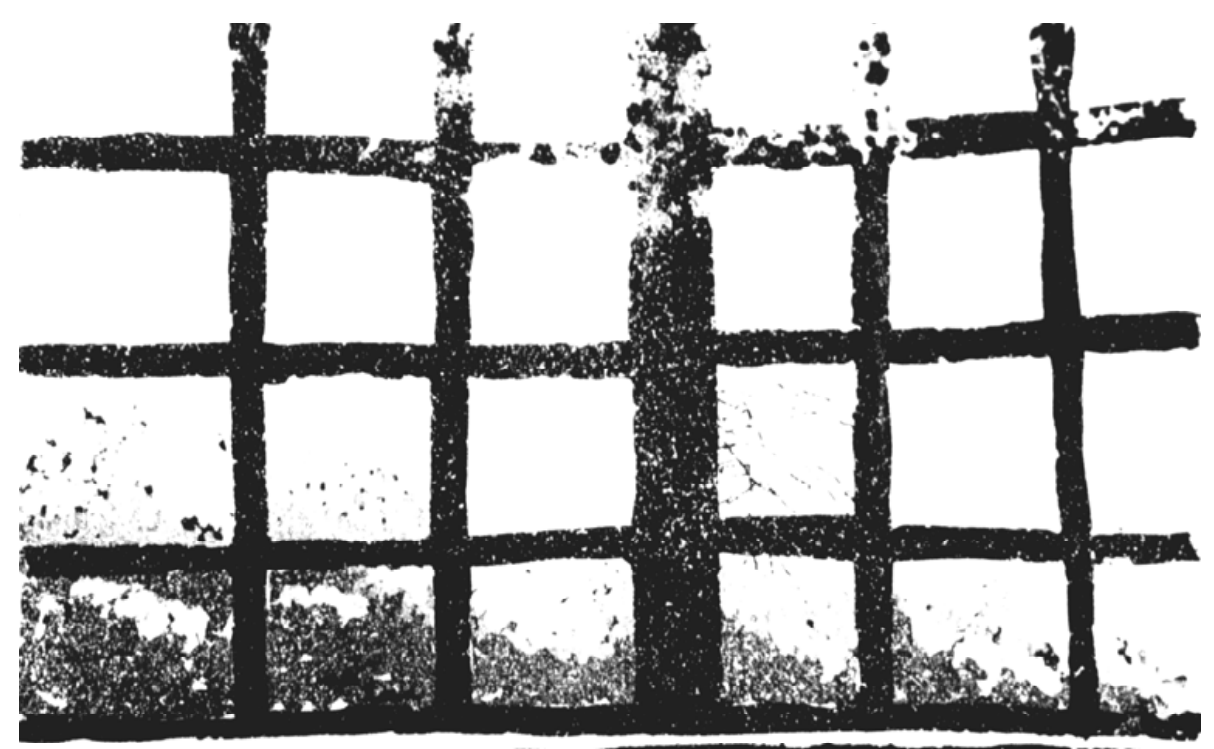

LÁMINA XXIX

"Sin título"

Aguatinta

$11.7 \times 16 \mathrm{~cm}$.

1972 


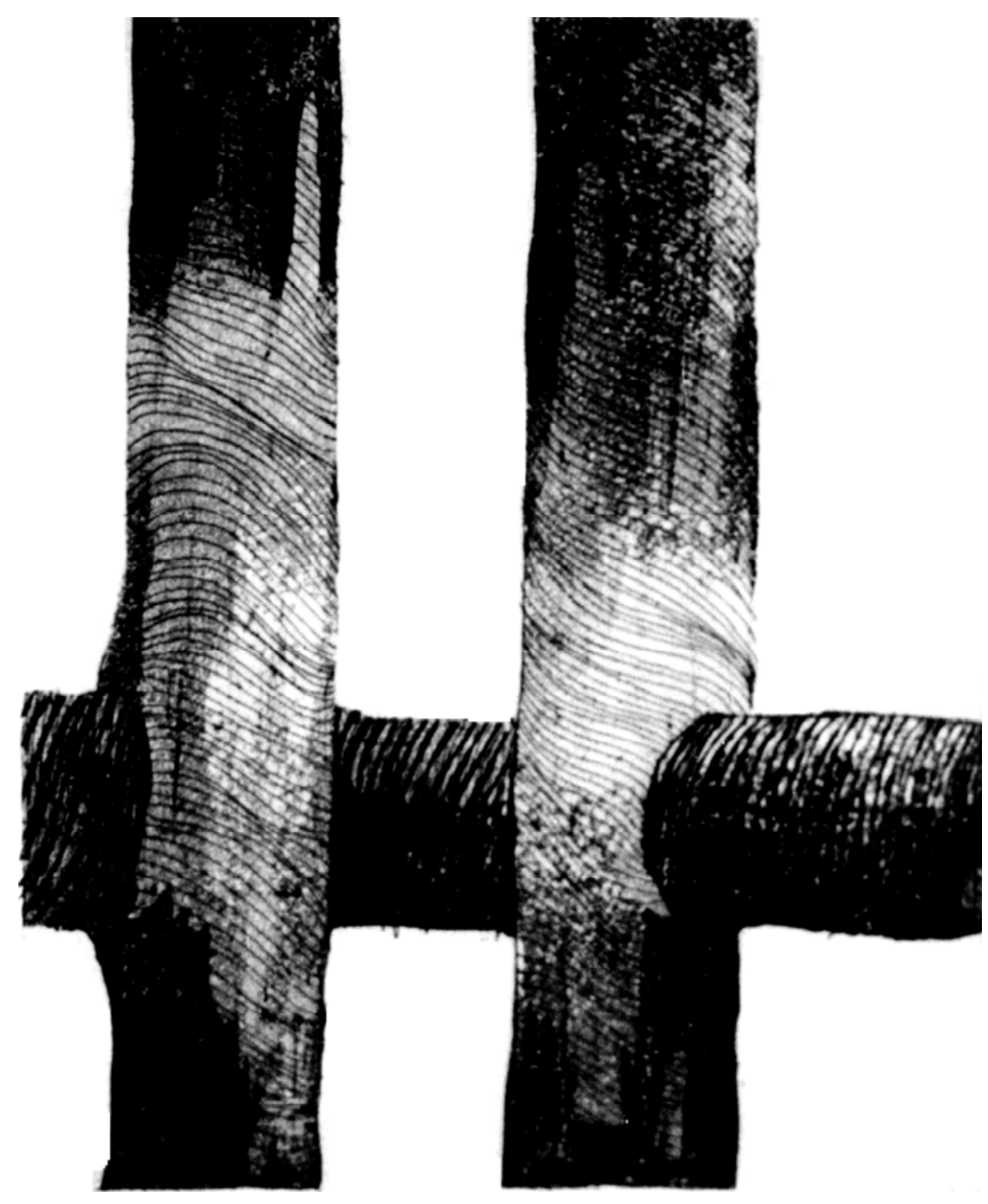

\section{LÁMINA XXX}

"Sin título"

Aguafuerte y aguatinta

$16.5 \times 13.5 \mathrm{~cm}$.

1972 


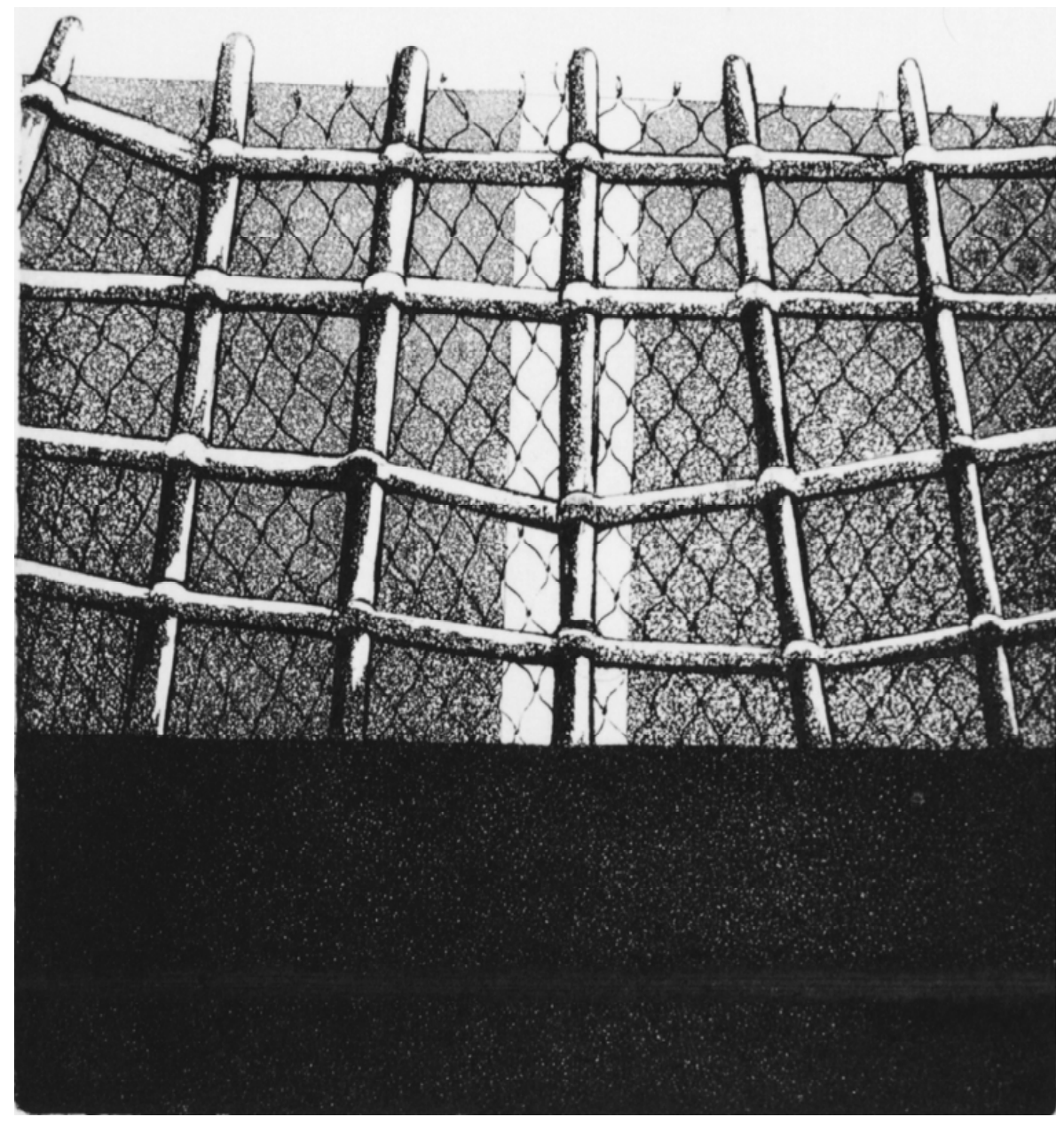

\section{LÁMINA XXXI}

"Sin título"

Aguatinta

22. $x 18.5 \mathrm{~cm}$.

1972 


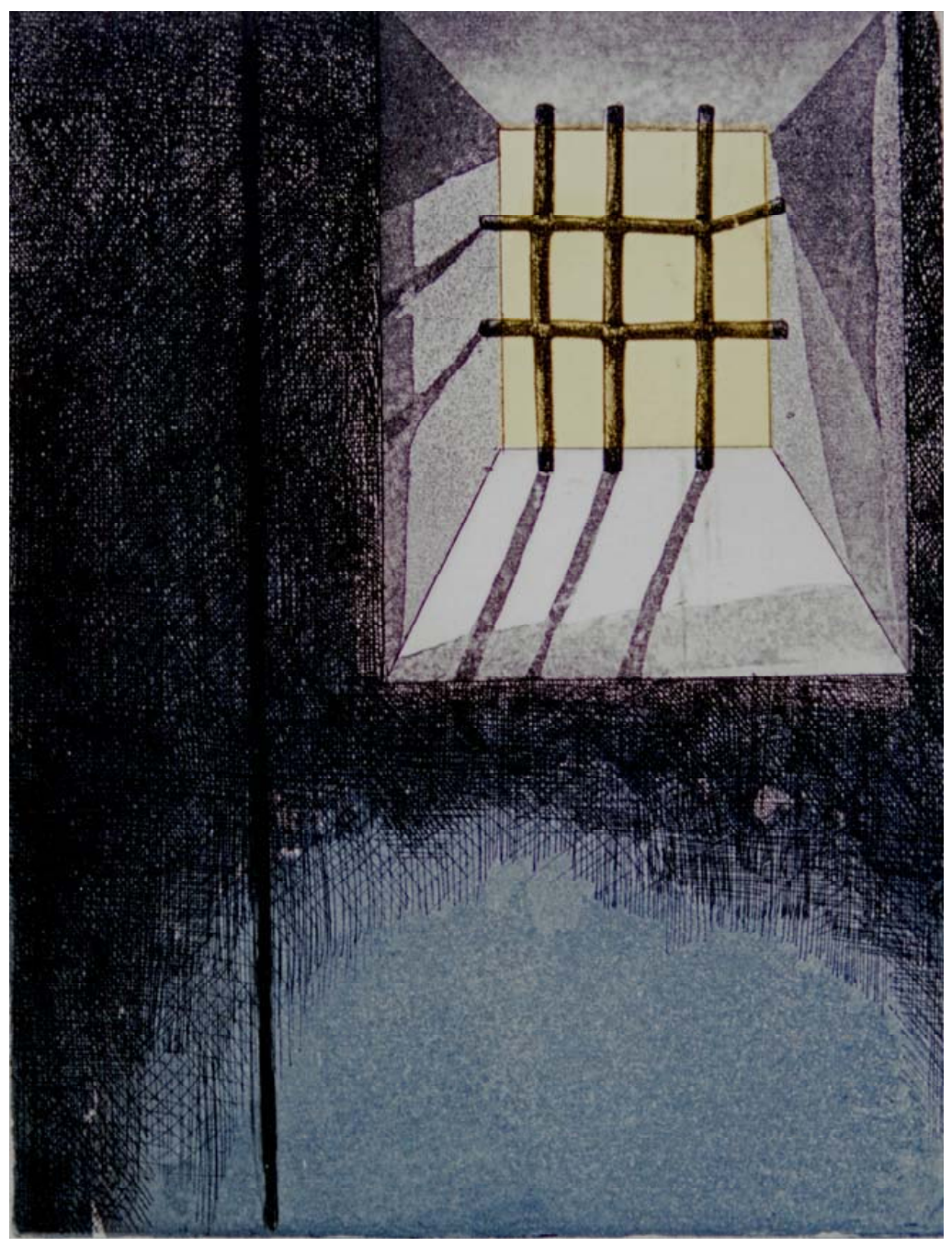

LÁMINA XXXII

"Sin título"

Aguafuerte y aguatinta

$32.5 \times 25.2 \mathrm{~cm}$.

1972 


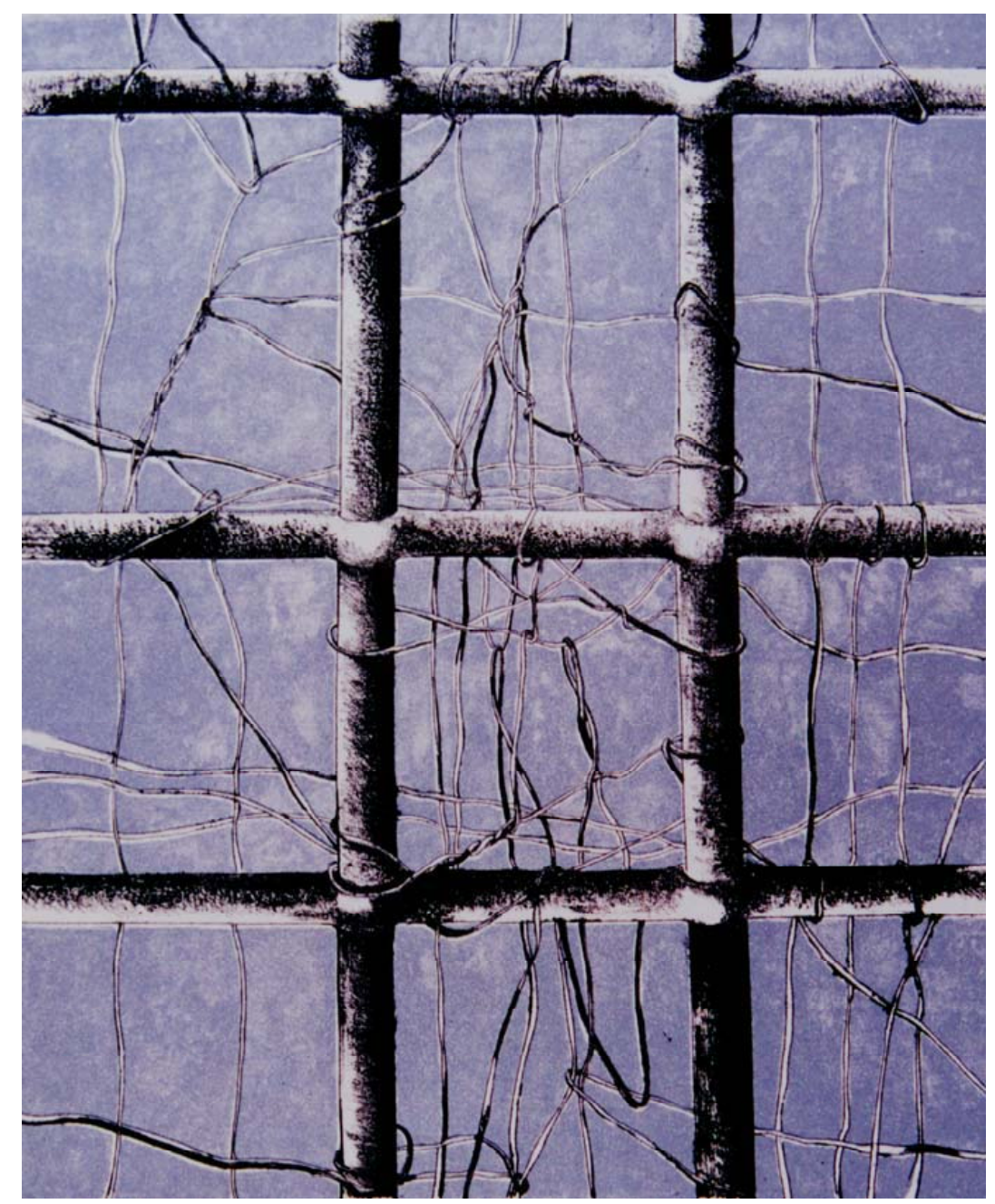

\section{LÁMINA XXXIII}

"Sin título"

Litografía

$26 \times 24 \mathrm{~cm}$.

1973 


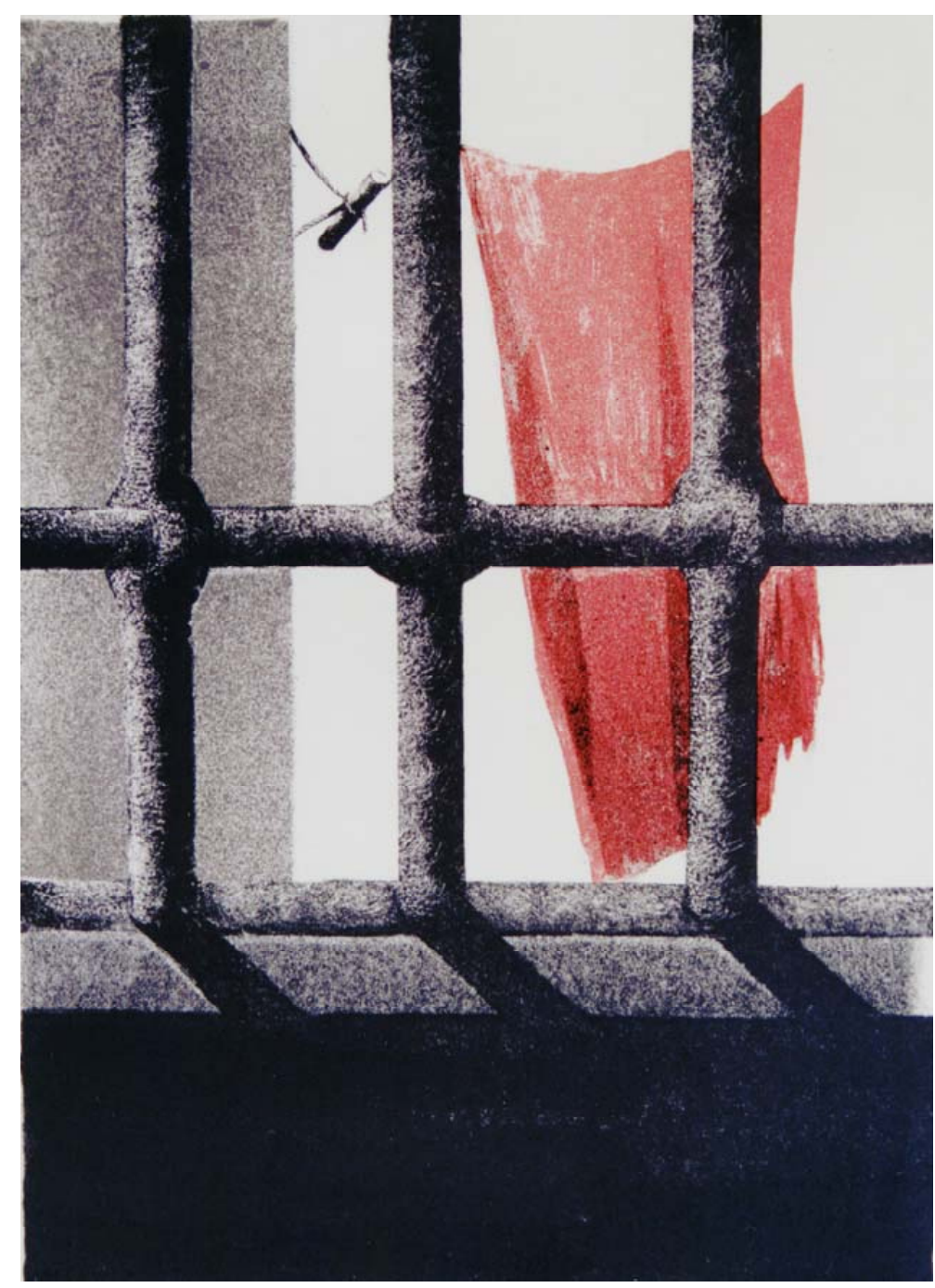

\section{LÁMINA XXXIV}

"Sin título"

Litografía

$38.5 \times 27.8 \mathrm{~cm}$.

1973 


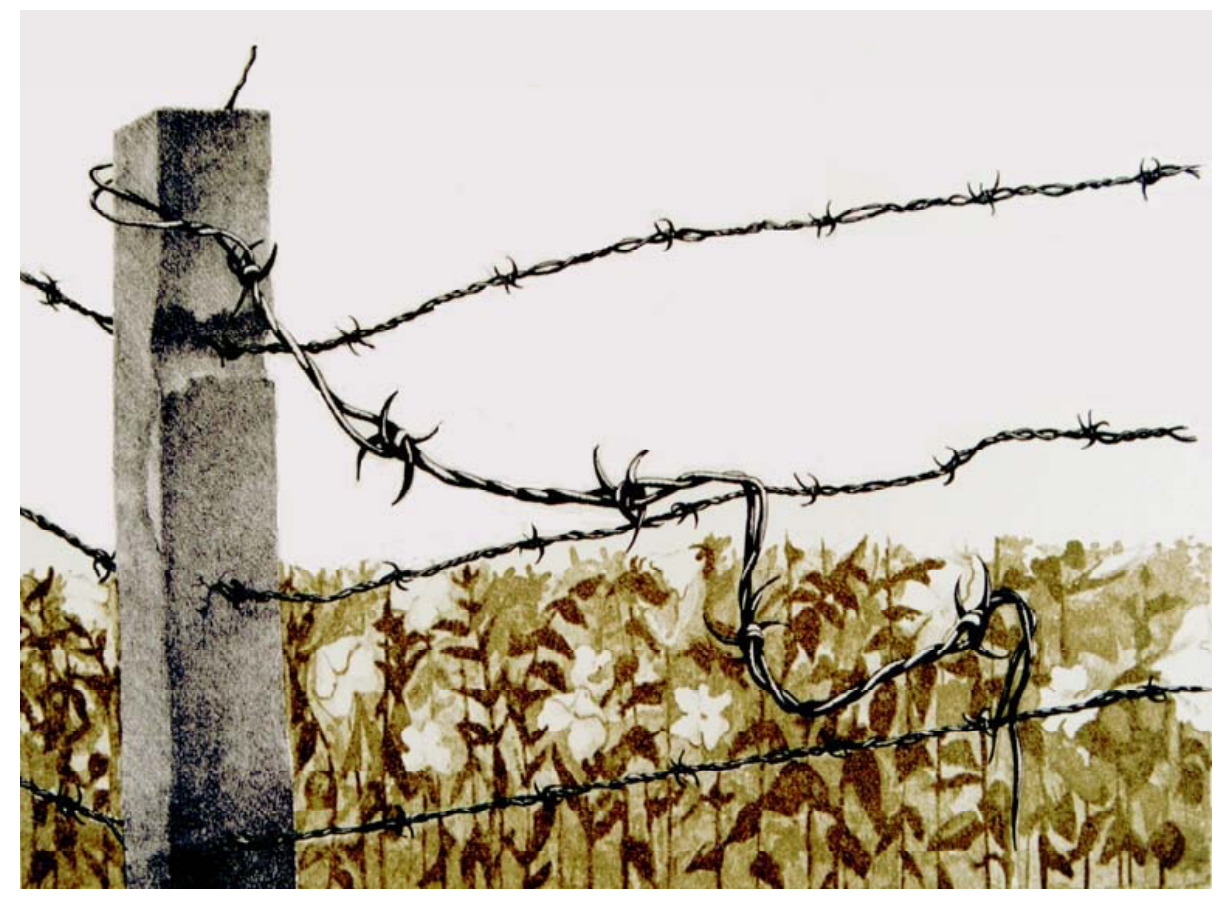

LÁMINA XXXV

"Sin título"

Litografía

$26 \times 38 \mathrm{~cm}$.

1973 


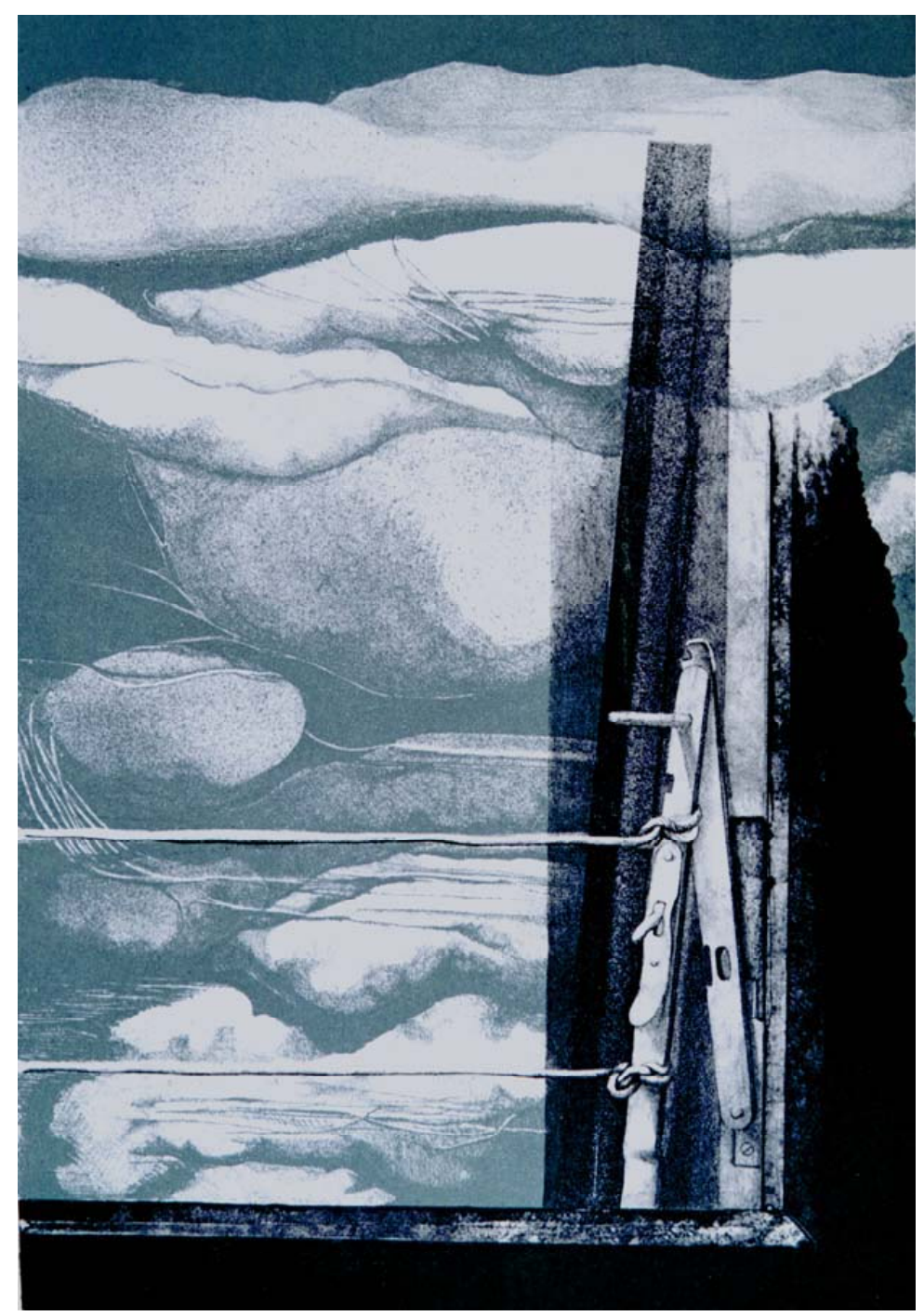

\section{LÁMINA XXXVI}

"Sin título"

Litografía.

$47.5 \times 33.5 \mathrm{~cm}$.

1974 


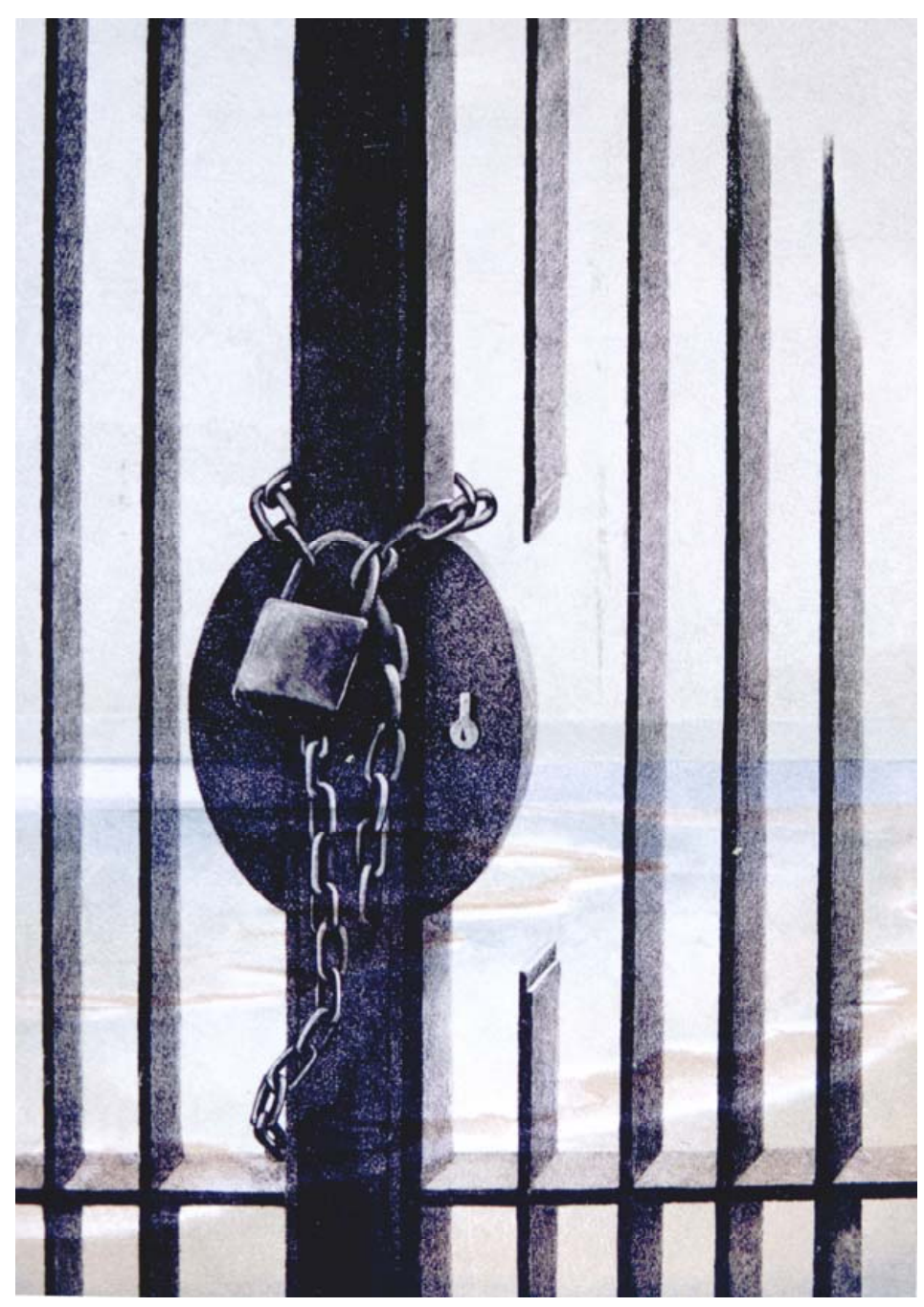

LÁMINA XXXVII

"Sin título"

Litografía

$48 \times 34 \mathrm{~cm}$.

1974 


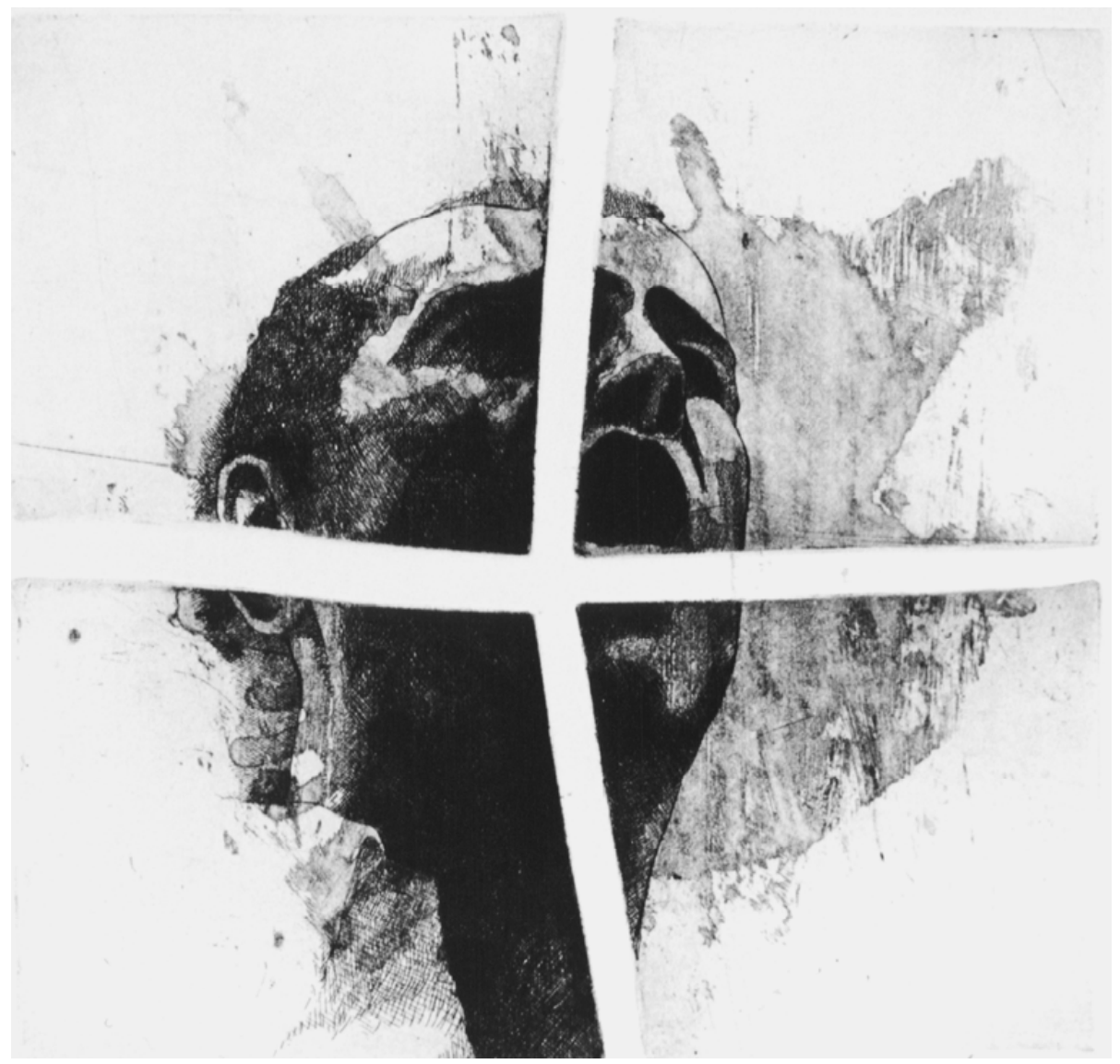

LÁMINA XXXVIII

"Poeta"

Aguafuerte

$22 \times 21 \mathrm{~cm}$.

1974 


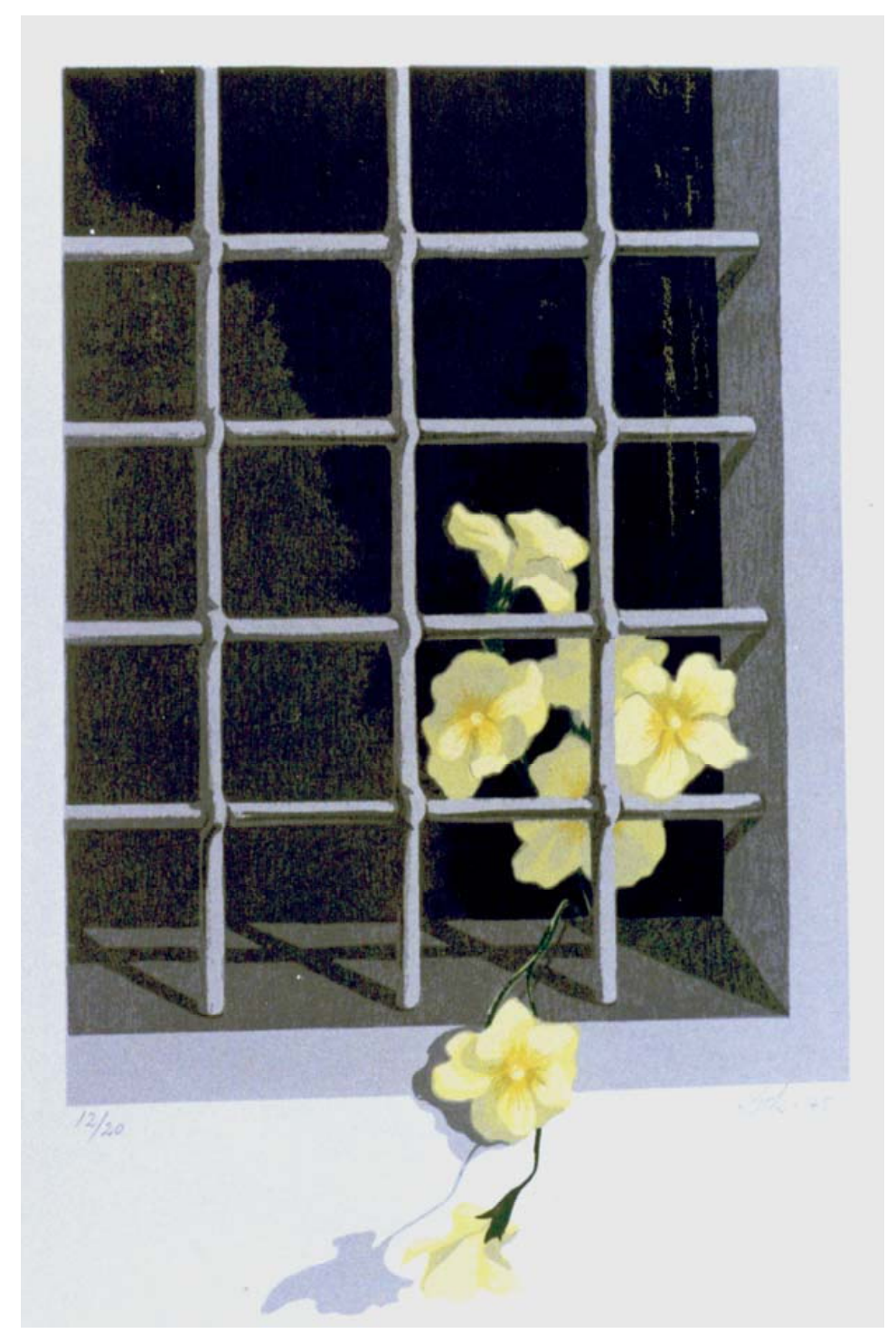

\section{LÁMINA XXXIX}

\section{"Sin título"}

Serigrafía.

$40 \times 25 \mathrm{~cm}$.

1975 
OCELLS MORTS 



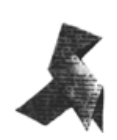

\subsubsection{CONCEPCIÓN}

Este conjunto de obras nace entre los años 1974 y 1975, y como pasa en las anteriores series, surge como una protesta ante una situación social injusta vivida durante el final de la dictadura, que salta a la vista a través del tema representado, con el que rechaza esa realidad odiosa y proyecta una imagen acusatoria que provoca una reacción en el espectador en sentido crítico.

Sus grabados de intenso carácter simbólico se materializan en esta serie a través de un conjunto de representaciones violentas acerca de la muerte, son imágenes frías y desgarradoras de pájaros muertos, colgados y torturados, quizás pretenciosas palomas de la 
paz, que un día fueron encerradas y encarceladas sin poder escapar de la inminente muerte, símbolo de una paz ahogada e ignorada, pero donde la belleza de sus imágenes triunfa sobre este violento espectáculo al que fueron sometidas, restringiendo su libertad y hasta su propia vida.

Con este trabajo Pilar Dolz mira hacia el ambiente desolador que se vive durante el final de la dictadura franquista, cuando la política represiva del régimen aumenta y el Gobierno firma varias penas de muerte, por lo que desde distintos puntos del país se protesta al tiempo que aparecen varios comunicados desde diferentes prisiones anunciando una serie de huelgas de hambre como protesta contra los consejos de guerra y las penas de muerte. Finalmente el 20 de noviembre de 1975 muere el general Francisco Franco, del mismo modo como había nacido, en medio de un baño de sangre. ${ }^{130}$ En declaraciones hechas al respecto Pilar Dolz expresa:

Fíjate como estaba en esta época, completamente dramática, pero en aquella época era así, esto es como una metáfora, la preocupación. Estas obras están hechas en los últimos años del franquismo, quizá es como un símbolo eso de los pájaros muertos. Franco murió en el 75 , en esos años había una represión muy grande, la gente ahora no se acuerda, pero había mucha represión y quizás yo lo acusaba así, ponía rejas, pájaros muertos... ${ }^{131}$

\footnotetext{
${ }^{130}$ El tercer plan de desarrollo elaborado entre los años 1972-1975, comenzó siendo una ilusión y acabó siendo un completo fracaso; con la falta de control y ausencia de una verdadera política, la ruptura de la estabilidad de precios se movió al alza. La inoperancia del sistema, se puso de manifiesto a partir de enero de 1974, lo que dio lugar a luchas y protestas, con un gran número de detenciones. A pesar ello, las luchas sindicales continúan a lo largo de 1975. Unos días después de la muerte de Franco se celebra en Madrid, las primeras jornadas por la liberación de la mujer, en las que participan mujeres de diversos grupos y organizaciones feministas. Véase AGUILERA CERNI, V.: 1976, pp. 52-53.

${ }^{131}$ Entrevista personal con la autora en Castellón de la Plana. 04/08/2006.
} 
A partir de su regreso a Castellón, después de culminar sus estudios en Barcelona, su obra se va haciendo más figurativa, pero esta figuración le viene más del Pop Art con un cierto realismo que del academicismo, ${ }^{132}$ como nos comenta la propia artistas. "Yo no diría que es un trabajo realista, lo que sí, es muy figurativo, sin ninguna perspectiva ni nada, viene más del Pop. ${ }^{133}$

Así en su obra logramos distinguir ciertos aspectos estéticos $y$ formales provenientes de este estilo, aunque de una forma simbólica, ya que una de las características sustanciales de su obra es mostrar un hecho como denuncia, que actúa en contraposición con la pasividad del movimiento pop, ${ }^{134}$ cuyos esquemas conceptuales se basan en la ironía, con una actitud conformista respecto al sistema, pero inconformista respecto al arte. Pilar Dolz emplea la figuración con un carácter crítico, las formas no son interpretadas como meras formas estéticas, sino como elementos inmersos en un todo social, poseedoras de un sentido y un significado representativo de esa realidad.

\footnotetext{
${ }^{132}$ Corriente artística anglosajona, cuyo contenido crítico contra la sociedad de consumo queda fuera del contexto español, ya que la realidad sociopolítica y cultural española, no era la más adecuada para dar cabida a un arte tan ligado a una sociedad de consumo. No embargo sus planteamientos estéticos y formales fueron rápidamente incorporados por algunos artistas españoles. En España el movimiento más cercano al pop fue lo que el crítico catalán Alexander Cirici denominó Nuevo Realismo, que explota las posibilidades iconográficas del arte en sentido no convencional con influencia del pop americano, acompañado de un espíritu crítico respecto a la situación política y social española. La novedad para el panorama artístico español, fue la asimilación del Pop Art, pero con un carácter muy diferenciado con obras de un atractivo visual notable. Véase GRACIA, C.: 1998 , p. 440.

${ }_{133}^{133}$ Entrevista personal con la autora en Castellón de la Plana. 03/03/2000.

${ }^{134}$ La postura pop frente a la realidad nunca es crítica en sentido estricto, su realismo, sin intenciones ideológicas es sólo reflejo del modo de vida americana, capitalista, mecanizada. El Pop-Art rechaza las convenciones estilísticas y temáticas de la tradición aristocrática del arte y desprecia la cultura de museo, el arte institucionalizado y de los grandes maestros. Los temas son simples motivos que justifican el hecho de la pintura. Véase SIMON, W.: 1983, p. 37.
} 
Sus composiciones se descubren por medio de la disposición de imágenes de modo libre e independiente en el espacio, donde llega a un gran realismo, ${ }^{135}$ con otras de un carácter más esquemático y de configuración plana. La falta de perspectiva y de profundidad son otras de sus características sustanciales, así como la aplicación de color plano cuando aparece.

El trabajo sincrónico y simultáneo de esta serie con la anterior, explica la estrecha relación entre ellas, tanto en los planteamientos formales como en la base conceptual. Así podemos encontrar ciertos elementos formales provenientes de Reixes, que aparecen en conexión con los de la nueva serie, formas tales como rejas, vallas, alambrados, emergen junto a los nuevos personajes que asumen el protagonismo en esta serie.

Esta actitud reivindicativa, y su personal manera de trabajar, nos recuerda al realismo crítico ${ }^{136}$ que dominó esta época y que utilizó elementos propios del pop norteamericano y europeo, donde muchos artistas del momento asistieron a una renovación de su lenguaje plástico sin olvidar nunca la vertiente significativo-critica, como verdadero fundamento.

\footnotetext{
${ }^{135}$ Término confuso y de muy difícil definición en lo que respecta a las artes plásticas, en general sólo alude a cierta actitud del artista frente a la realidad, que no debe hacer una copia o imitación pero sí ajustarse a cierta visión generalizada de la realidad; en este sentido es donde se halla su diferencia con la figuración, en la cual se muestran imágenes reales distorsionadas según la propia visión del artista. Véase NOCHLIN, L .: 1991, p. 11.

${ }^{136}$ El arte realista con tono político se desarrolla a lo largo de todo el siglo XX. En España el realismo socialista empieza a tomar cuerpo durante la II República, entre 1931 y 1936 . En los años cincuenta, José Ortega y Ricardo Zamora hacen una pintura comprometida en este sentido. Es una tendencia contraria al informalismo y al academicismo, que propone una pintura de exaltación de la realidad, frente a los valores estéticos absolutos. A partir de los sesenta, resurgen con fuerza renovadas, tomando elementos del Pop y se denomina Realismo crítico. Destacamos a Juan Genovés, Rafael Canogar, Alfredo Alcaín y Equipo Crónica (constituido por Rafael Solbes y Manuel Valdés). Véase GRACIA, C.: 1998, p.441.
} 
3.5.2. ASPECTOS COMPOSITIVOS.

\section{Composición}

En lo que se refiere a la representación podemos ver que los elementos representados son imágenes figurativas extraídas de la realidad, podemos decir que el sistema básico de la composición plantea un sistema de fragmentación del espacio como sistema estructural, ${ }^{137}$ donde se trabaja también con la superposición de elementos, utilizando especialmente una representación icónica reiterativa como es la imagen de la paloma de la paz abatida que constituye el elemento central de la obra. Igualmente plantea situaciones de contrastes, $^{138}$ por las distintas maneras de planteamiento, donde un determinado objeto cobra importancia por ser diferente a los demás, así podemos ver formas de un marcado realismo que coexisten con otras de carácter plano y sintético, de igual manera advertimos la mezcla de imágenes figurativas con otras que no hacen referencia a nada concreto y todo ello ejecutado sobre un plano abierto. Así el espacio asume un gran protagonismo, ya que se convierte en la superficie donde se desarrolla la forma, la disposición de las imágenes sobre el espacio desnudo, hace que emerja un espacio blanco (vacío) que contrasta con la tinta negra

\footnotetext{
${ }^{137}$ Recurso vanguardista, la concepción contemporánea de fragmentación, entendida como una ruptura progresiva del espacio unitario de la herencia renacentista, comienza a desarrollarse a partir de Cezanne, a través de su técnica de reconstrucción de los modelos siguiendo patrones de síntesis, se instala como recurso estilístico con el Cubismo que confirma la ruptura del punto de vista único. Véase ALBELDA, J.: 1992, p. 96.

${ }^{138}$ Magritte es uno de los primeros artistas en ilustrar toda clase de efectos de sentido a través de todo tipo de contraste extremo y de descontextualización. La iconicidad de Gallo es también ante todo fragmentaria, la coexistencia de lo figurativo y lo abstracto, lo simbólico y lo enunciativo, no proviene del deseo de comunicar algo, sino de obtener los beneficios que se desprenden de impedir una secuencia unitaria. Opus cit, p. 141.
} 
que conlleva la imagen (lleno), estableciendo una dinámica entre el lleno y el vacío.

Este tratamiento espacial nos invita a pensar en aquellas propuestas primarias, de las series de formas y mujeres, en las que las distintas iconografías, conservan unas concavidades a la manera de las esculturas de Henry Moore, orificios que sin duda hacen mención al vacío. En esta serie no podemos ver la existencia de ninguna oquedad en la forma, pero su disposición sobre un espacio vacante, sin llegar a cubrir nunca su totalidad, hace que volvamos a reflexionar sobre la relación existente entre el lleno y el vacío, una preocupación siempre presente en la obra de Pilar Dolz.

Por otra parte en lo que respecta a la representación de sus personajes aunque éstos se encuentran en compañía de otros elementos, el hecho de descubrirse cercados por un espacio prácticamente sin detalles, hace que se desarrolle una sensación de soledad y de aislamiento, que potencia un sentimiento de desamparo.

En cuanto a la forma, recordemos que la artista tiende a emparejar formas con estructura más detallada en combinación con otras de carácter más esquemático, habitualmente la figura del pájaro muerto es la imagen que tiende a trabajar con un cuidadoso estudio del claroscuro, convirtiéndola en la protagonista de la obra ya que los demás elementos que la componen usualmente se desarrollan con cierta simplicidad icónica. 
Un ejemplo de esto lo podemos ver en LAM. XL, donde efectivamente la imagen del pájaro muerto, se encuentra tratada de un modo realista, ejecutada con una perfección técnica y una representación minuciosa de los detalles, mientras que por detrás de esta localizamos formas rectangulares colocadas en posición vertical con un tratamiento de imagen sintético y esquemático. Así diferencia un espacio rectangular oblongo, donde aparece dibujado un fragmento de la zona superior de lo que suponemos una vista panorámica de la ciudad, con sus casas, sus edificios, sus antenas de televisión con un tratamiento gráfico sencillo y elemental, a través de un trazo lineal que resume la imagen. Bajo él, adivinamos otro rectángulo que presenta una estructura lineal, solucionada a base de líneas horizontales, verticales paralelas y perpendiculares al plano donde se encuentra el punto de vista. Son de gran espesor y asoman creando una especie de laberinto flotante sobre un fondo plano de tono gris, la disposición y la dirección de las líneas dan una referencia perspectiva, no así su fondo que sugiere un espacio vacío. Sin duda esta estructura laberíntica evoca las rejas de la serie anterior, nunca ausentes del todo.

En cuanto a la disposición de la forma normalmente todos los elementos que integran la obra, tienden a distribuirse por todo el espacio sin saturar la superficie, buscando una coherencia y una relación interna entre ellos. Así por ejemplo la imagen del pájaro muerto se ubica en diferentes zonas del espacio, arriba, abajo, a la derecha, a la izquierda, o en algún ángulo de la superficie; su disposición es compensada por el establecimiento de otras representaciones, como rejas, vallas, alambrados y demás elementos equilibrando la composición, así si un elemento se ubica 
en la parte superior, otro se dispone en la parte inferior, si se instala en el extremo izquierdo, otro se coloca en el derecho, controlando el peso, la tensión espacial y confiriéndole cierto dinamismo a la composición.

Un ejemplo de esto lo podemos ver en LAM. XLI, donde la imagen de una reja rectangular ubicada en sentido horizontal, cruza toda la superficie del formato por la parte superior del plano pegada al limite del soporte, en tanto que en la parte inferior en la zona central del plano encontramos la imagen reclinada de una paloma de la paz muerta, ejecutada sobre un espacio vacío, sobre el cual la artista procede a crear unas sombras por debajo de la imagen con el fin de asentarla y darle una base más sólida, a la vez que establece ciertos lazos gráficos de relación visual. El equilibrio se logra por la ubicación de cada uno de estos dos elementos. En cuando a la combinación de la disposición de la reja en la zona superior donde normalmente se representa el espacio abierto, y la ausencia de detalles en la zona inferior, donde se encuentra la paloma aluden de nuevo a la sensación del vacío y opresión.

En LAM. XLII siguiendo el mismo planteamiento espacial, sobre un formato cuadrado, nos encontramos con la organización iconográfica de una reja ubicado en el extremo superior derecho mientras que en el extremo inferior izquierdo haciendo una diagonal visual nos encontramos con la figura de una pajarita realizada a collage. Para compensar los pesos, en el extremo inferior derecho se coloca una alambrada realizada linealmente que camina desde el límite del formato hacia el centro del plano reclamando la atención hacia el ángulo inferior que se encuentra en oposición a la diagonal 
establecida con las imágenes protagonistas. Los distintos elementos que componen la obra se hallan dispuestos en el espacio, de forma autónoma, su distribución en el plano hace que en ningún momento lleguen a toparse entre sí, si no que su relación compositiva se establece por sugerencias visuales. La composición de la obra genera un mayor contraste y tensión visual por la existencia de una estructura formal que puede dividirse en partes conservando su carácter individual, pero manteniendo sutiles lazos visuales que hacen que no olvidemos la percepción unitaria de la totalidad.

Respecto al sentido de profundidad, como normalmente la artista no recurre al uso de la perspectiva, acude a factores perceptivos aplicados intuitiva o conscientemente para hacer visible las relaciones de profundidad. Usualmente tiende a introducir diversas imágenes de modo disperso sobre el espacio creando cierta ambigüedad entre las relaciones espaciales de la composición, necesita establecer una correspondencia entre las formas para determinar la ubicación de planos en el espacio. Otro recurso empleado para crear profundidad es la superposición de formas a la que apela normalmente para relacionar las distintas representaciones.

En LAM. XLIII se procede a ejecutar la imagen de la paloma de la paz muerta en el extremo superior izquierdo del espacio, mientras que ocupando el resto del espacio aparece un gran plano de color rojo que la rodea y arrincona hacia ese extremo. Sobre esta gran mancha, la imagen de unas alambradas realizadas con un trazo lineal negro (muy saturado), en sentido diagonal y paralelo, ocupan la mitad de la superficie. La forma de incorporación de este 
elemento nos indica que se halla ubicado en primer término respecto a la figura del pájaro ubicada en el extremo superior izquierdo. El hecho de encontrarse enmarcada por la gran mancha de color rojo que ocupa las tres cuartas partes del formato y corta el ángulo inferior del espacio en el que está encerrada, hace que ésta gane en presencia y adquiera una mayor fuerza visual a pesar de la sugerencia de encontrarse en un segundo término detrás de la alambrada, pues el activo color rojo se presenta con más fuerza que el dibujo oscuro del pájaro que permanece quieto. ${ }^{139}$

Lo mismo ocurre con LAM. XLIV donde logramos distinguir varios niveles de profundidad por distintos procedimientos, así en el extremo superior izquierdo advertimos la presencia de una mancha negra plana que por su lado derecho termina en un perfil irregular y sinuoso. En el extremo inferior derecho en cambio topamos con la imagen de una paloma de la paz muerta de un gran detallismo que nada tiene que ver con la mancha plana y frontal que aparece en la parte superior estableciendo un juego ambiguo entre estas formas. La disposición de estas imágenes de manera independiente sobre el espacio vacío hace que se observe su relación para determinar el plano que le corresponde a cada una; así diremos que la figura del pájaro muerto realizada sobre un espacio vacío cuando proyecta sus sombras crea indirectamente espacio alrededor de ella y establece un fondo al asentar sobre él. Cuando la figura proyecta su sombra sobre el espacio le dota automáticamente de profundidad, lo que nos induce a detectar la imagen del pájaro más cerca de nosotros que aquella mancha, pero

\footnotetext{
139 Cuando el observador mira por ejemplo una fotografía, puede interpretarla espacialmente a partir de su propia experiencia, sin embargo el artista si quiere que una figura destaque sobre el fondo habrá de emplear el efecto visual directo de factores perceptuales. Véase ARNHEIM, R.: 1993, p. 236.
} 
a su vez él está detrás de la alambrada, que es el auténtico primer término. De esta manera alude a la muerte de la paloma aprisionada y sin libertad.

Otra manera de determinar su posición en el espacio es a través del análisis de los detalles, la figura más detallada y definida por sí sola se viene más hacia adelante y la mancha oscura, sin elementos que puedan darnos ningún detalle sobre sus características se va más hacia detrás, de este modo la imagen del pájaro solucionada con claroscuro, dentro de una gama de grises se sitúa por delante de la mancha negra pura y plana.

Una vez establecido el nivel de profundidad entre ambas formas, observamos que el dibujo de la alambrada realizado linealmente sobre toda la superficie, integra y unifica los dos elementos. Por último a la altura de la mancha tropezamos con la iconografía de una mariposa realizada con gran colorido, que sobrevuela libremente el espacio; su detallado y realista tratamiento invita a ubicarla ocupando el primer plano, con una sugerencia simbólica muy evidente.

Las distintas imágenes que intervienen en esta serie se funden en una homogeneidad plástica y conceptual en la que la variación de los caracteres, hace que siempre destaque y repita una figura, la de la paloma de la paz muerta, como una evocación simbólica de su pensamiento. Pilar Dolz construye su propia realidad sobre la ambigüedad significativa de estos elementos como estrategia para crear su obra. 
En cuanto a estos protagonistas, podemos decir que normalmente se encuentran representados como formas cadavéricas tendidas en el suelo o colgadas de una cuerda, abatidos boca arriba o de perfil, sin dejarnos ver la expresión de sus facciones físicas. Estos animales sometidos a una fuerza que no pueden dominar, por el cual son torturados y colgados, nos resuenan en más de una ocasión a aquellas mujeres atadas y torturadas de su serie de mujeres, donde éstas aparecen sin rasgos físicos, casi siempre de espaldas o de perfil y atadas y colgadas de cuerdas, como estos infortunados pájaros muertos, cuyas imágenes nos narran escenas de gran angustia.

\section{Grafismo}

La línea aparece en esta serie como estructura básica de la forma con cierta diversidad de soluciones que coexisten en la misma obra. Así localizamos cuatro tipos de trazos diferentes.

Las imágenes de tratamiento realista poseen un trazo descriptivo y de gran expresividad, la línea se torna más plástica sujeta a una estructura de ritmos variables con los que se modelan, las curvas, los entrantes y salientes, para conseguir una mayor definición de la imagen. Junto a éste tenemos otro trazo de factura más pictórica, más difuso que no deja claramente definida la huella de la línea, sino que se trabaja por medio de degradación de tonos a través de un detallado estudio del claroscuro que evoca el volumen y la profundidad. Sin duda salta a la vista la influencia recogida por la artista durante sus visitas a las bibliotecas o gabinetes de estampas para ver grabados antiguos. "Esto es como copiar un poco un 
grabado del S. XVIII, parece ser un grabado del S. XVIII perfectamente". ${ }^{140}$ (Véase Fig. 77)

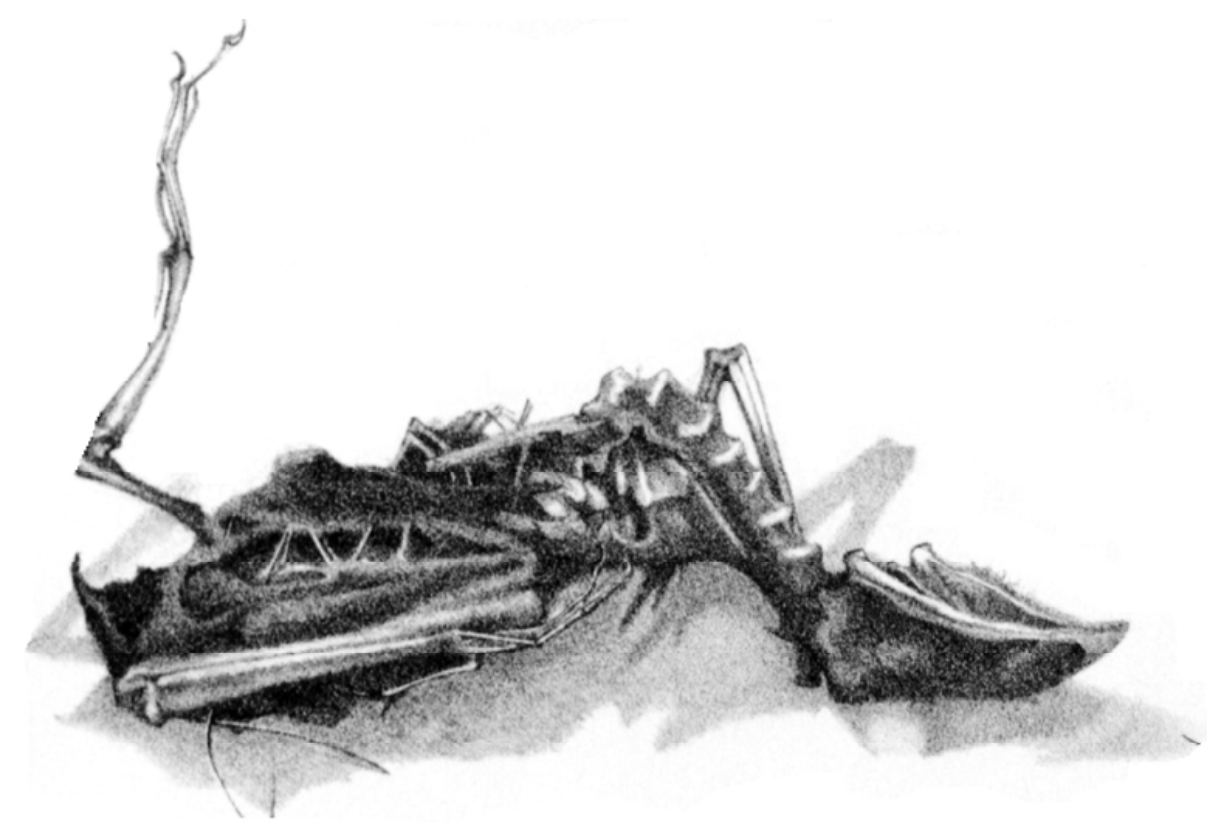

Fig. 77. Pilar Dolz. Detalle LAM. XLIII. Serie Ocells morts. Litografía. 1975.

En otras imágenes de estructura más arquitectónica, la artista realiza un trabajo de síntesis por medio de un trazo simple y esquemático, que se caracteriza por el empleo de la línea recta, que delimita la imagen de manera evidente. Este trazo lleva consigo un juego de líneas verticales, horizontales y oblicuas, muy finas y delicadas, poco profundas, efectuadas al aguafuerte; la oblicuidad de la línea crea la sugerencia perceptiva de profundidad, como un esfuerzo dinámico de aproximación o alejamiento respecto al armazón espacial horizontal y vertical. La sensación de volumen se

${ }^{140}$ Entrevista mantenida con la autora en Castellón de la Plana. 04/08/2006 
consigue con la aplicación de sombras o manchas planas en determinadas áreas del dibujo, reforzando la idea de volumen de la imagen. (Véase Fig. 78)

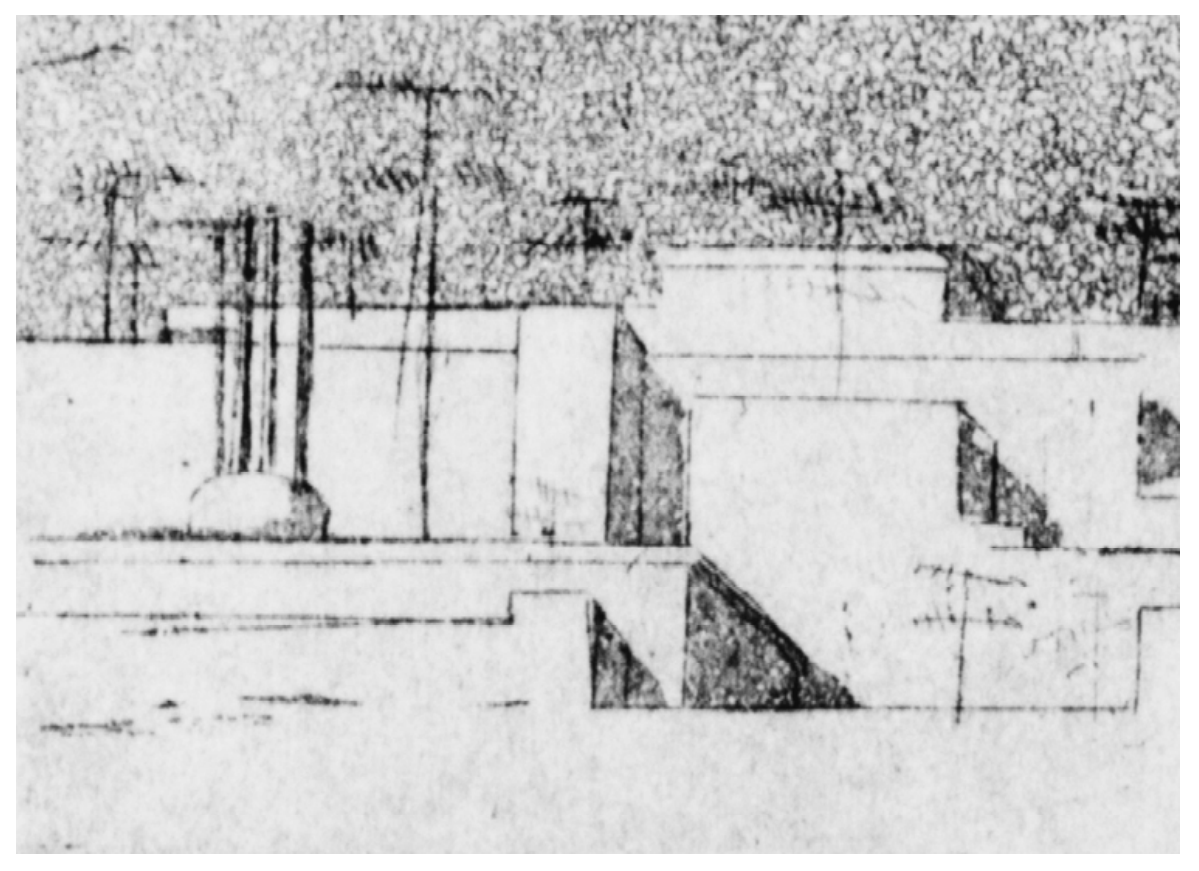

Fig. 78. Pilar Dolz. Detalle LAM. XL. Serie Ocells morts. Aguafuerte y aguatinta. 1974.

También encontramos otro tipo de trazo, fundamentado de igual manera en la línea recta, de carácter abstracto, se trata de trazos rectilíneos de gran espesor, pesados y rugosos que nada tiene que ver con la línea fina y delicada empleada en la imagen anterior a pesar de que su disposición en el espacio toman las mismas orientaciones; horizontal, vertical y oblicua. Estos trazos se sitúan en el plano de modo ordenado, entrecruzándose e intercalándose unos con otros, formando una especie de estructura laberíntica que nos recuerda las rejas de la serie precedente, pero 
ésta sólo es una sugerencia ya que no es la imagen clara de una reja como nosotros conocemos, sino que la artista crea una forma imaginada, que está supeditada a la interpretación del espectador. (Véase Fig. 79)

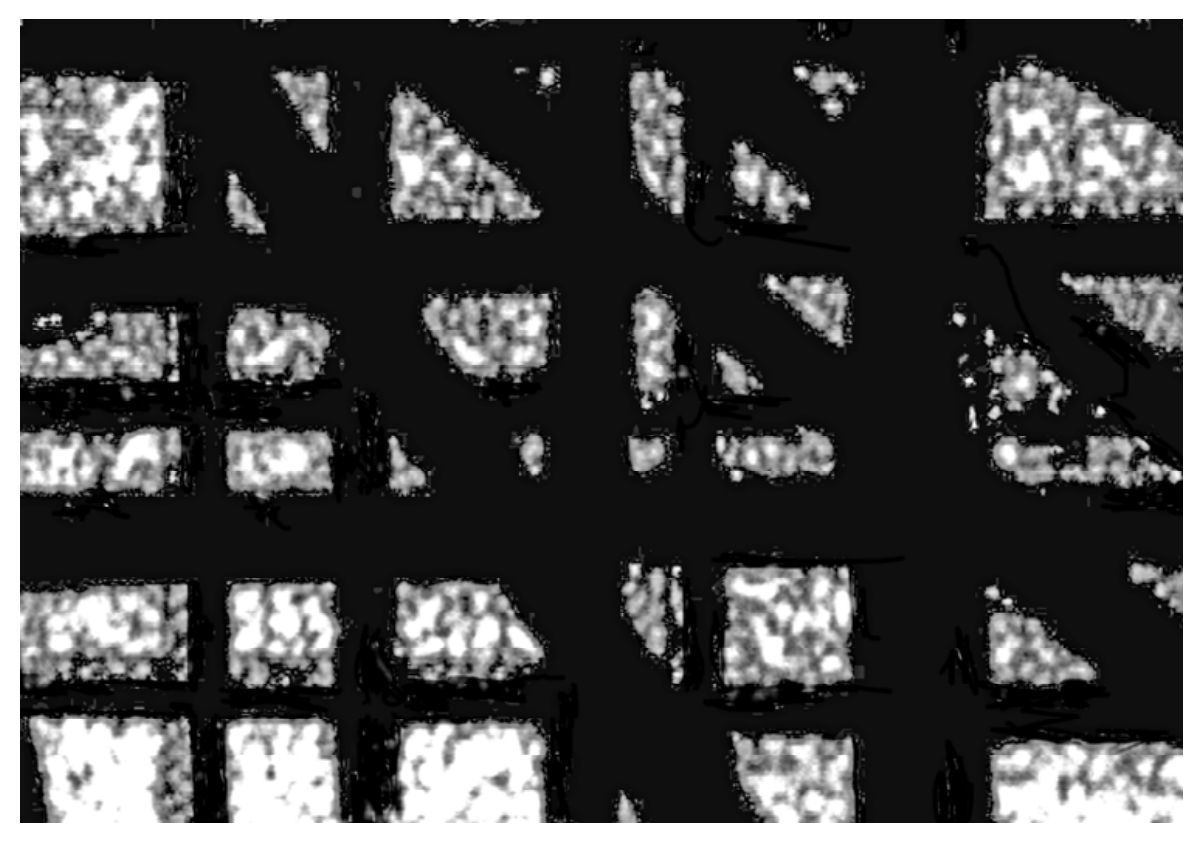

Fig. 79. Pilar Dolz. Detalle LAM. XL. Serie Ocells morts. Aguafuerte y aguatinta. 1974.

Otro tipo de trazo basado también en la recta, es la línea autónoma que se coloca en sentido diagonal, dispuesta de forma paralela y repetitiva en el plano, su inclinación hacia la derecha partiendo de la vertical, además de hacer referencia a la profundidad como en los anteriores casos, sirve para dar mayor dinamismo y contrates a la imagen. Sus rasgos estructurales tienen como principal característica la simplicidad en la construcción, con la que 
se pretende que la figura manifieste lo esencial del objeto. (Véase Fig. 80)

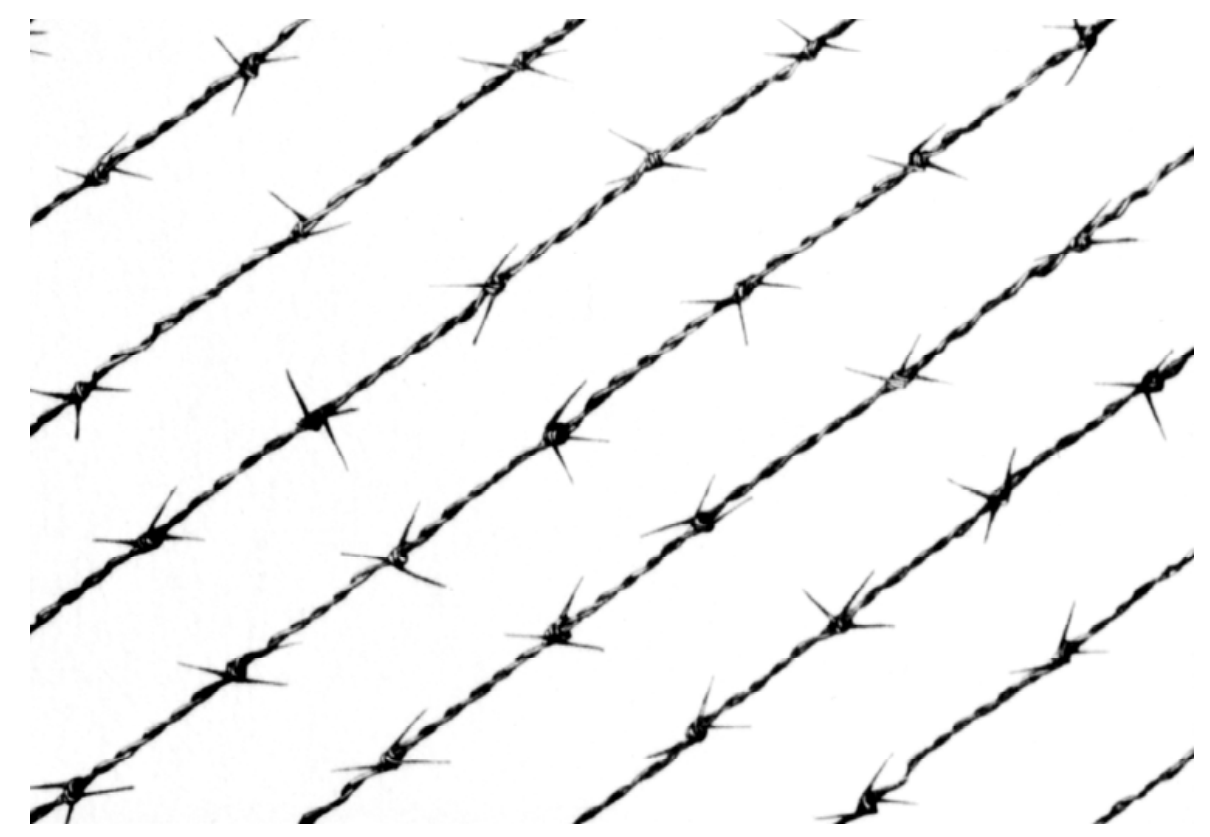

Fig. 80. Pilar Dolz. Detalle LAM. XLIII. Serie Ocells morts. Litografía. 1975.

\section{Color}

El color surge es esta serie como parte integrante, recordemos como en la serie anterior el color cumplía funciones de complemento y el negro era el que dibujaba complementando con el color, en este conjunto de obras por el contrario el color forma parte constituyente de la obra.

Las primeras obras realizadas en 1974 , se caracterizan por ser monocromáticas, ejecutadas a través de un delicado estudio del 
claroscuro, normalmente elaboradas al aguafuerte y al aguatinta. Se trata de unos grabados de pequeño formato de $13 \times 10 \mathrm{~cm}$. aproximadamente, realizadas generalmente por encargo.

Más adelante, en 1975, surge otra vez el color y la distribución de la forma en el espacio de modo fragmentario, da al color las funciones que lo convierten en un componente más. Así unas veces aparece asociado a la forma y otras veces por sí solo ocupando un sitio en el espacio.

Pilar Dolz recurre a seccionar la matriz para introducir el color en la estampa, un ejemplo de esto lo localizamos en LAM. XLII, un grabado realizado a tres tintas estampadas por separado, así en primer lugar en el extremo superior derecho localizamos la imagen de una reja trabajada al claroscuro e impresa en tinta negra, dentro de la cual destaca la figura de una pajarita realizada por medio de collage en papel periódico, esta figura más clara que el fondo establece un fuerte contraste.

Por otra parte en el ángulo inferior izquierdo vuelve a emerger la figura efectuada a collage de la parte superior, pero esta vez se encuentra estampada por encima, aquí la artista se toma la molestia de recortar la plancha con la forma de la pajarita, para posteriormente grabarla y entintarla con un tono sepia amarillento transparente sobre el collage y le otorga una calidad más plástica. Se establece una situación de contraste entre la imagen fría monocromática de la parte superior frente a la calidez de la zona inferior más activa. 
Finalmente en una plancha de formato más grande encontramos grabada la imagen de una malla metálica que ocupa sólo la parte inferior derecha de la matriz, ya que el resto de la superficie está reservada para estampar el resto de planchas en una sola pasada. En lo que respecta al color esta imagen se encuentra estampada en un tono verde suave y liso, confiriendo a la composición calma y tranquilidad, la estructura mínima de su forma, así como el contrates existente entre la potencia cálida del collage y la energía monocromática de la reja, otorgan a este tono un valor más ligero por lo que se hace menos perceptible que los demás.

Esas son tres planchas, no sé tanto trabajo para tres planchas, pero son tres planchas. Muy curioso, porque una es así de pequeña, una es esto, la pajarita, y lo otro es una plancha grande, en la plancha grande sólo está grabado esto. No sé porqué hacía tanto trabajo; no sabía hacer lo mismo con menos trabajo, porque eso podía estar grabado en la misma plancha pero como esta era negra, esta era verde y esto era para hacer otro color. Hacía el gran trabajazo y lo estampaba todo de una vez, eso era una plancha, y esa otra plancha. Entintar no era el problema, sino el recortar. ${ }^{141}$

En la litografía el color emerge de la misma manera que en el grabado calcográfico, de modo fragmentario ocupando una parte del espacio. En LAM. XLIII el color aparece realizado a sangre siguiendo la estructura rectangular del formato, ocupando casi la totalidad de la superficie dejando libre únicamente un rectángulo horizontal en el extremo superior izquierdo donde se ubica la figura monocromática de una paloma muerta.

${ }^{141}$ Entrevista mantenida con la autora en Castellón de la Plana. 04/08/2006. 
En esta obra el color tiene concordancia con la estructura del formato, generando una visión espacial y en relación a su pura expresividad, no asociado a la imagen como ocurría en las imágenes anteriores; se trata de una mancha de color rojo efectuada a través de grandes pinceladas con una disolución de tinta litográfica y agua, sobre la que se procede a colocar una segunda matriz resuelta a través de rayados continuos de lápiz litográfico. La intensión es crear una textura sobre la mancha a través de la superposición de esta plancha entintada con un tono rojo de distinta intensidad cromática. La fusión de estas dos tonalidades diferentes pertenecientes al mismo color crea una mancha rica, de gran plasticidad que proporciona movimiento a esta. ${ }^{142}$

En LAM. XLIV, el color ocupa una mínima parte del espacio pero está integrada en la imagen, que se construye sobre unas formas monocromáticas relativamente mayores. Se trata de la imagen de una mariposa resuelta a través de la aplicación de dos tintas brillantes; un tono amarillo de gran intensidad lumínica que cubre toda la superficie de la forma (la fuerza del color nos obliga a detener la mirada) y en segundo lugar tenemos un tono rojo, también de gran fuerza, que se distribuye en algunas zonas de la imagen dibujando la forma, así mismo encontramos unos ligeros toques de un tono negro casi imperceptible, que aparece a la altura de las alas para crear un poco de volumen entre ellas y el cuerpo de la mariposa. Esta figura nos recuerda aquellas figuras del pop norteamericano extraídas del mundo de la publicidad, de las revistas,

\footnotetext{
142 Todo color posee, además de tonalidad, dos características determinantes: intensidad cromática (brillo) e intensidad luminosa (luminosidad). Se puede decir que al cabo de un entrenamiento se puede llegar a un acuerdo respecto a una relación de luminosidad sin embargo rara vez se puede dar un acuerdo cuando se trata de intensidad cromática, es decir por ejemplo cuál de entre varios rojos es el más rojo. Véase ALBERS, J.: 1982, p. 49.
} 
los carteles, los comics, realizadas sin apenas elaboración plástica, con una iconografía estilizada, principalmente en la elaboración de formas planas con volúmenes esquemáticos.

A pesar de su tamaño y de poseer pequeñas porciones de color, esta figura destaca enormemente sobre el resto de la composición por su gran intensidad lumínica, la conjugación de sus dos colores puros, cálidos y luminosos, arrebatan nuestra mirada con una fuerza magnética, que le dotan un gran poderío y vitalidad desbordante. Sin duda estos colores establecen un fuerte contraste en la obra entre la energía cromática que la mariposa y la oscuridad y frialdad del negro que domina el resto de la composición. ${ }^{143}$

\footnotetext{
${ }^{143}$ Investigaciones fisiológicas revelan que bajo la presencia del color rojo nuestros cuerpos segregan más adrenalina e incrementa la tensión sanguínea y el ritmo de la respiración, en contraste con esto es posible sentir la frescura o frialdad de verdes, azules o negros que reducen la velocidad de los latidos del corazón, menguan nuestra temperatura y relajan los músculos, por ese motivo los matices del rojo se llaman cálidos, mientras que las gamas azules y verdes, fríos. Véase ZELANSKI, P y PAT, M.: 2001, p. 36.
} 


\subsubsection{PROCESO TÉCNICO}

Esta serie desarrolla una diversidad de técnicas con efectos de calidades muy diversas; en unas ocasiones con un carácter esquemático en formas simplificadas y manchas planas, y otras con un laborioso estudio del claroscuro con una extensa gama de valores para proporcionar una apariencia formal más realista.

Igualmente introduce una nueva técnica, el collage, ${ }^{144}$ que establece cierta ambigüedad entre realidad y representación, ya que formas creadas en papel coexisten con formas grabadas en la matriz. El collage aparece como una fragmentación más a través del aditamento de una figura elaborada con papel de periódico, por medio de la técnica de la papiroflexia; ${ }^{145}$ se trata de la figura de una pajarita realizada doblando papel.

Dentro de su línea de investigación en el campo del grabado calcográfico, cuando la artista incorpora el color recurre a cortar la plancha hasta llegar a la ruptura total del grabado. La composición de la obra se hace a partir de la organización de los distintos fragmentos sobre un formato más grande. La necesidad de introducir el color en la estampa y el deseo de aligerar el trabajo en el proceso de estampación le lleva a seccionar la plancha con el

\footnotetext{
${ }^{144}$ La técnica del collage fue inventada por los cubistas. Los dadaístas y los surrealistas lo ampliaron. En la postguerra se convirtió en el "arte del assemblage" un medio de crear obras de arte a partir de elementos preexistentes en los cuales la aportación del artista consistía en establecer los vínculos entre objetos diversos. Véase LUCIE SMITH, E.: 1995, p.115.

${ }_{145}$ Técnica de realizar figuras doblando papel. Tiene su origen en los "noshis", ofrendas alimenticias que se hacían en los templos budistas, envueltas con cintas y papeles de colores cuidadosamente doblados. Poco a poco el envoltorio se convierte en el único elemento de la ofrenda. Derivan directamente las primitivas figuras japonesas. En España la figura más conocida es la pajarita, sin duda con la que más se identifica la Papiroflexia.
} 
propósito de estampar todas las piezas en una única pasada. La disposición fragmentada de las planchas evita la superposición de las imágenes, que aparecen como elementos individuales sobre un espacio abierto.

Recordemos cómo la práctica de recortar la plancha no es una experiencia nueva para la autora, pues desde su primera serie, Pilar Dolz procede a desbastar alguna de sus planchas estampándolas solas o junto a algunos gofrados. (Véase Cap. III.1.2)

En esta serie la artista recorta la plancha siguiendo formas y dimensiones diferentes. Así, de la misma manera que nos encontramos con la presencia de formatos cuadrados $y$ rectangulares de diversos tamaños, nos encontramos con formatos más particulares que tienen una forma personal, como por ejemplo la pajarita realizada previamente con collage.

La aplicación de esta plancha sobre el collage enriquece la forma, acentuando algunos rasgos y proporcionando volumen a la imagen. (Véase Fig. 81) 


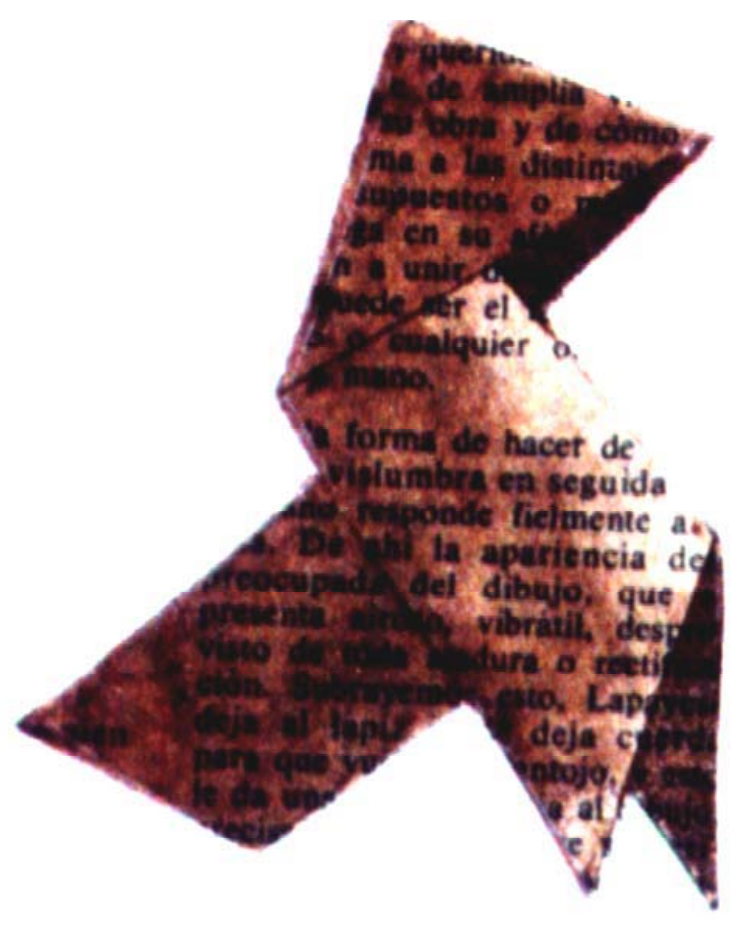

Fig. 81. Pilar Dolz. Detalle LAM. XLII. Serie Ocells morts. Aguafuerte y aguatinta. 1975.

Eso es un collage, pero tiene color. Hay un papel de periódico pero encima está grabado con el color, ¡Hacia unos trabajos que te mueres! pero estampaba todas las planchas a la vez; una encima de otra y de una sola estampada hacía esto. Ésta es una lámina cortada, la pajarita. Esto es recortado; la forma de la pajarita y la estampé en este color $(\ldots) .{ }^{146}$

En el caso de la litografía a pesar de ser de un cromatismo reducido, la artista emplea una diversidad de matrices tanto en piedra litográfica, como en planchas de aluminio para la elaboración de su obra. ${ }^{147}$ Un ejemplo de esto lo tenemos en LAM. XLIII donde

\footnotetext{
${ }^{146}$ Entrevista mantenida con la autora en Castellón de la Plana. 04/08/2006.

${ }^{147}$ La litografía utiliza como matriz la piedra calcárea. Su principio técnico es darle la calidad de retener las sustancias grasas y mantener la humedad. En lugar de piedras igualmente se
} 
la autora emplea cuatro matrices diferentes para la representación de cada elemento de la obra; dos de ellas se encuentran estampadas en tinta roja y las otras dos en tinta negra. Para esto utiliza dos planchas de aluminio de 50 × $68 \mathrm{~cm}$. para la realización de una mancha; una plancha es trabajada por medio de la aguada litográfica y la otra por medio de grafismos realizados con lápiz litográfico. Ambas matrices se hallan estampadas, una sobre la otra, con tinta roja. En el caso de las otras dos planchas; una plancha de aluminio del mismo tamaño es empleada para realizar un dibujo lineal con pluma, que le permite realizar unos trazos finos $y$ delicados, que se estampan con tinta negra. Finalmente utiliza una piedra litográfica de formato más pequeño, $25 \times 35 \mathrm{~cm}$. para realizar el dibujo de una paloma muerta, donde aprovecha la impronta que deja el lápiz, para darle un tratamiento más realista a la imagen, que se imprime posteriormente también con tinta negra.

Pilar Dolz emplea una variedad de matrices trabajadas de distinta manera para obtener los resultados deseados.

El color está hecho con planchas de aluminio, pero estampado con un tórculo de estrella, normal. Eran muy gráficos. Hay dos rojos allí. Fíjate para hacer sólo el rojo hay dos planchas y luego tienes el negro, que es otra plancha. $O$ sea que hay tres planchas y una piedra. Una, está lisa, con un pincel he hecho esa parte, y después por encima, he hecho con un lápiz esa materia, respira el rojo de debajo que es un poco más claro. (...) Eso es muy grafico, pero luego como grabado a lo mejor queda.... Porque es mucho trabajo para a lo mejor algo que podría ser una serigrafía, pero está estampado de la manera tradicional. ${ }^{148}$

utiliza planchas de cinc o aluminio, se sigue el mismo proceso de trabajo cambiando los ácidos para grabar y fijar las imágenes. Véase VIVES PIQUÉ, R.: 1994, p. 67.

${ }^{148}$ Entrevista mantenida con la autora en Castellón de la Plana. 21/03/2007 
LÁMINAS

CELLS MORTS 



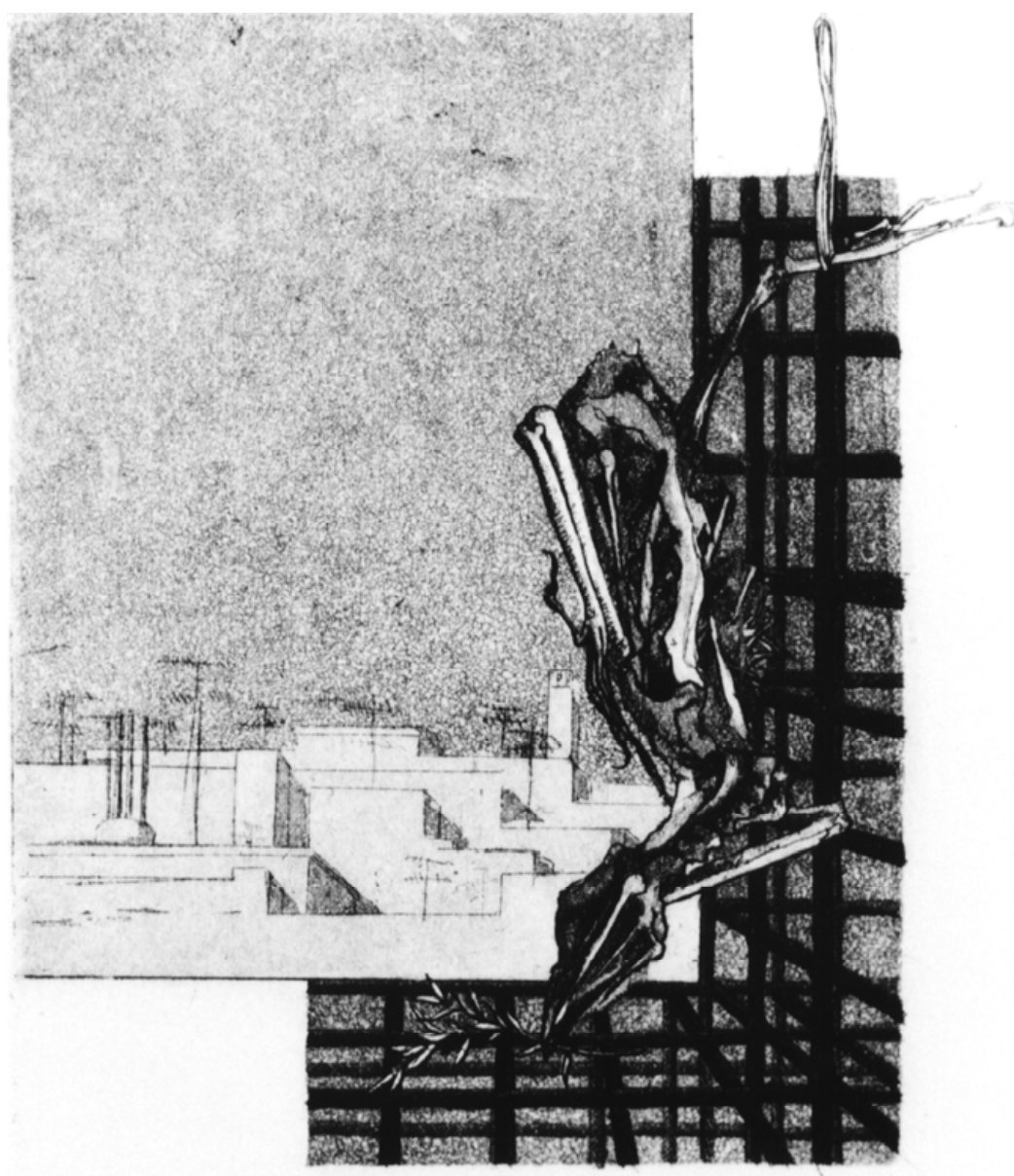

\section{LÁMINA XL}

"Sin título"

Aguatinta y aguafuerte

$15.8 \times 11.7 \mathrm{~cm}$.

1974 


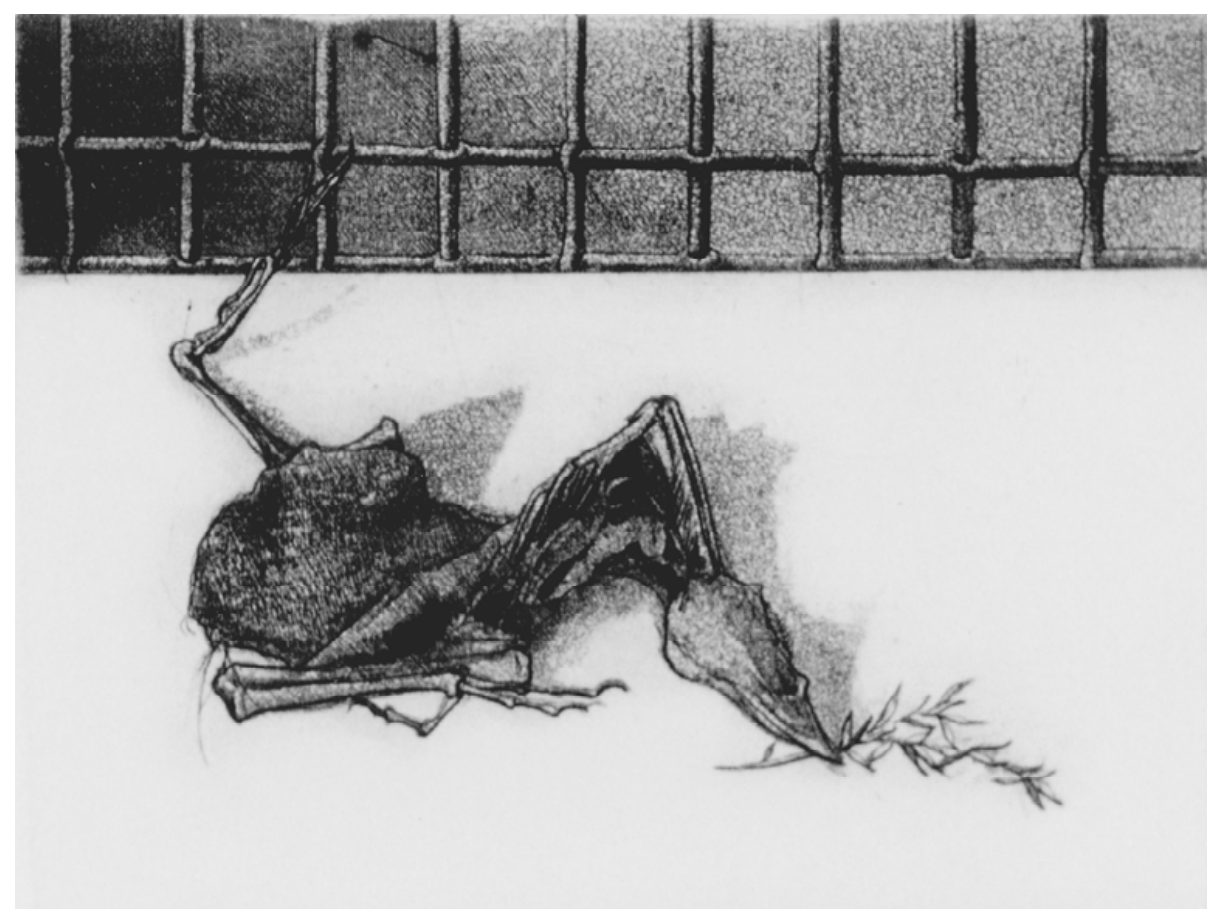

\section{LÁMINA XLI}

"Sin título"

Aguafuerte y aguatinta

$10 \times 13 \mathrm{~cm}$.

1974 


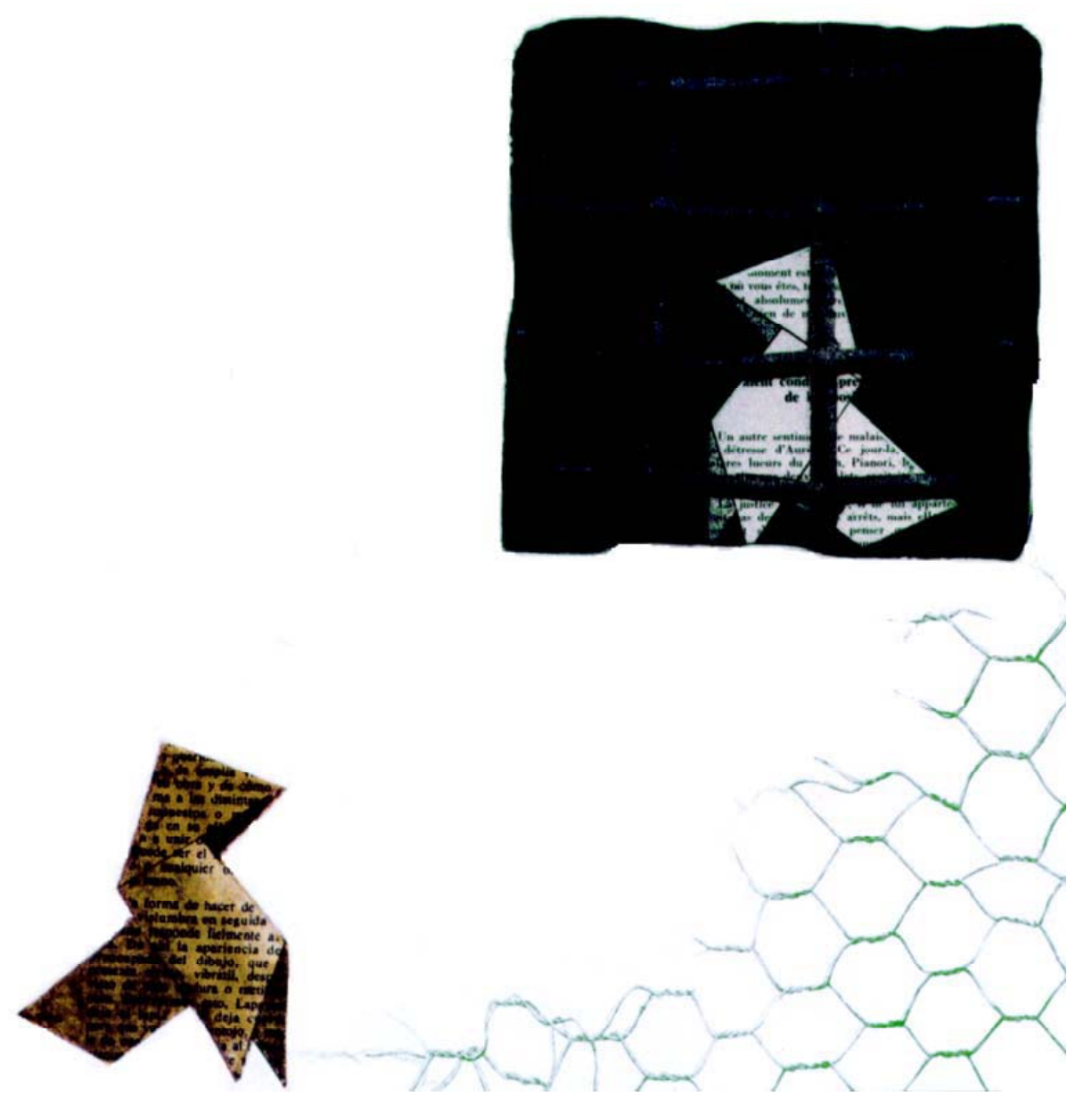

\section{LÁMINA XLII}

"Sin título"

Aguafuerte, aguatinta y collage.

$32 \times 31 \mathrm{~cm}$.

1975 


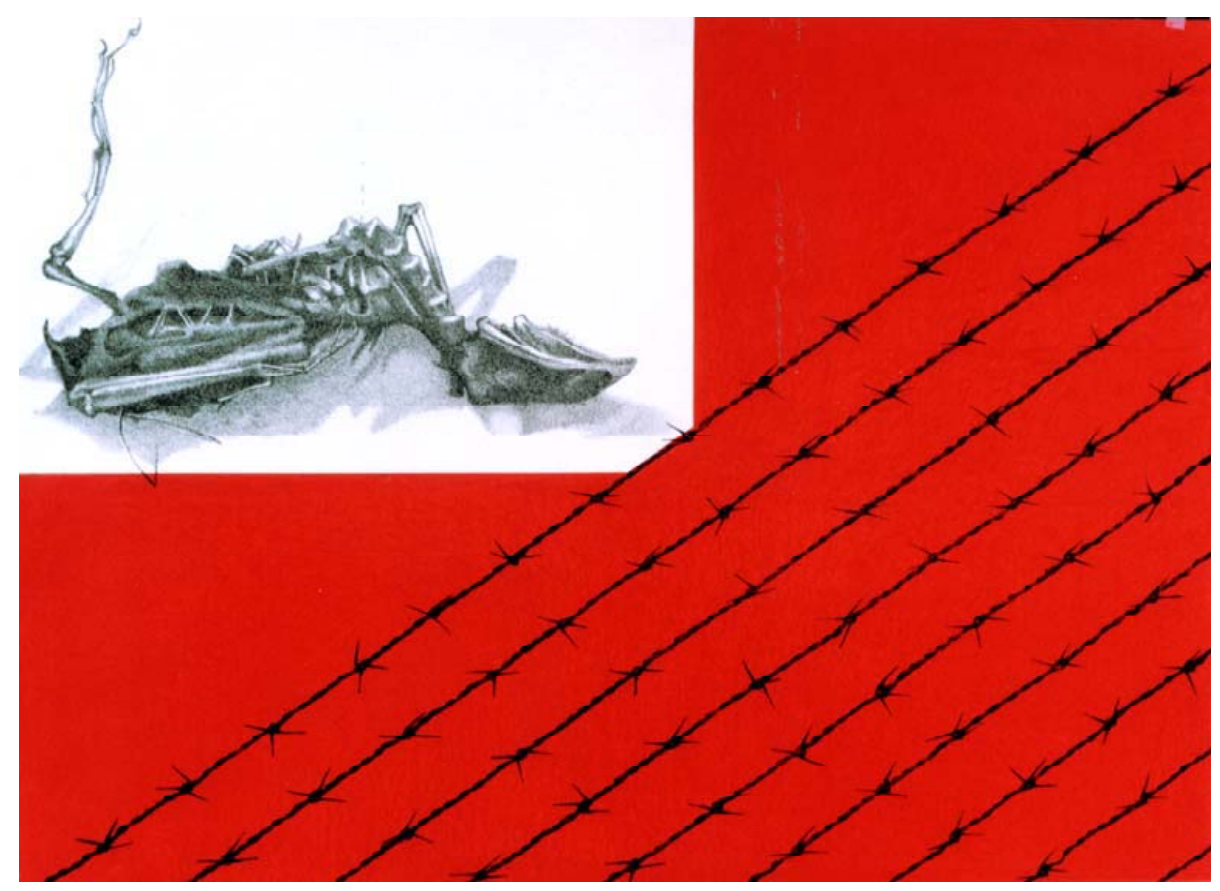

\section{LÁMINA XLIII}

"Sin título"

Litografía

$38 \times 49 \mathrm{~cm}$.

1975 


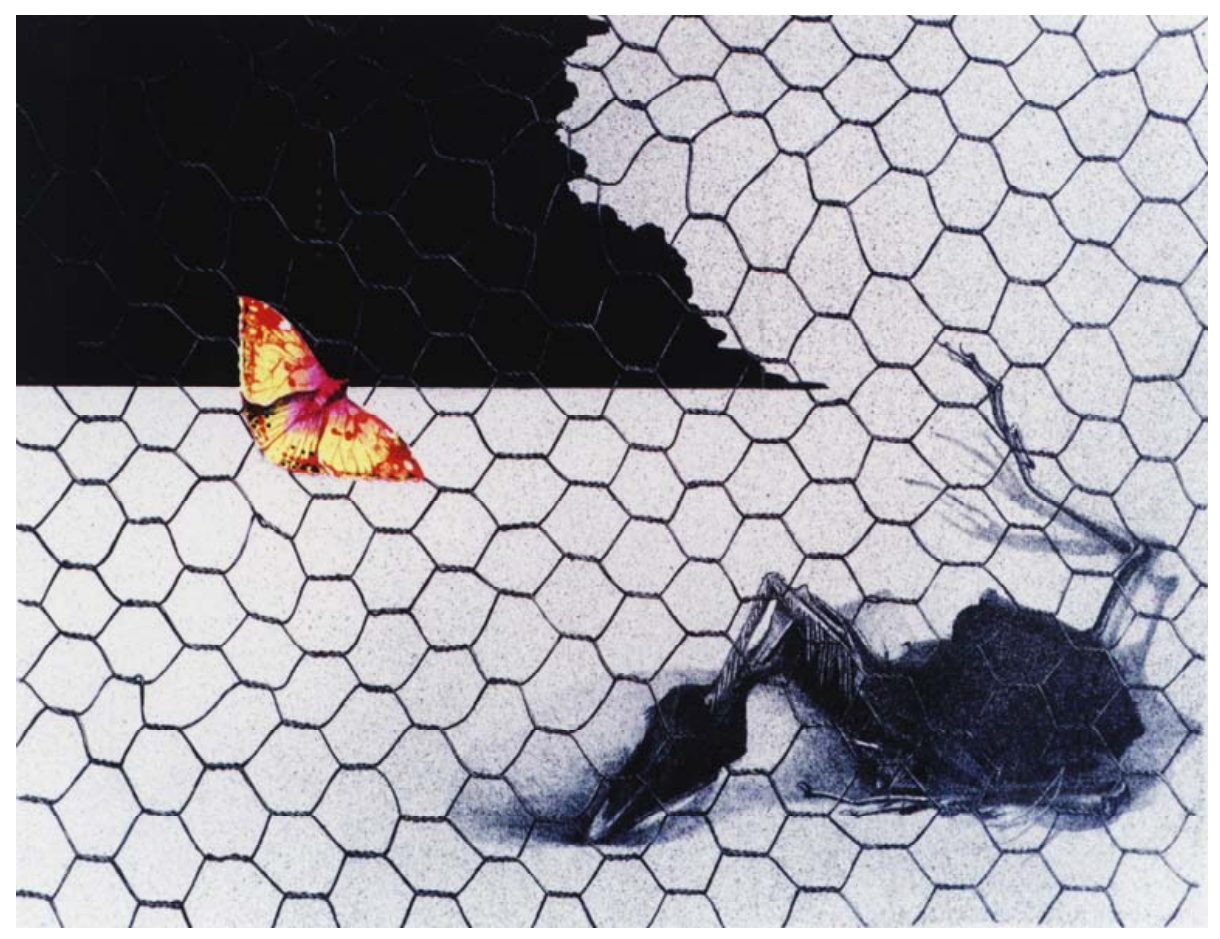

\section{LÁMINA XLIV}

"Sin título"

Litografía

$50 \times 70 \mathrm{~cm}$.

1975 


\section{INSECTES}





\subsubsection{CONCEPCIÓN}

Tras la desaparición de la dictadura franquista, en la que Pilar Dolz, desarrolla una obra comprometida políticamente, cargada de significados críticos en contra del régimen, posteriormente durante el llamado período de transición ${ }^{149}$, la artista sigue manteniendo un contenido crítico en su producción artística.

En esta etapa surge una nueva serie Insectes, que empieza en 1976 y termina en 1978, en la que encontramos unos espléndidos

\footnotetext{
149 Consideramos el período posfranquista desde 1975 a 1978, caracterizado por una inestabilidad colectiva, la transición hacia un sistema político basado en una democracia parlamentaria cimentada en una transición jurídico-institucional fue breve; pero el proceso político completo fue más largo: duró hasta la alternancia política ocurrida en octubre de 1982, cuando se establece un acuerdo tácito entre gobierno y oposición de olvidar el pasado y se pactan las nuevas reglas del juego político. Véase FELIX, J.: 1978, p.13
} 
grabados de gran preciosismo, donde observamos una cierta prolongación de Reixes y Ocells morts, en cuanto a planteamiento plástico y objeto de meditación se refiere.

La desaparición de Franco, ocurrida en 1975, provocó una perdida del impulso generador de las posiciones críticas en contra del régimen, muchos artistas perdieron la ilusión, el referente de sus disputas y peticiones. El cambio de orientación discursiva de los autores que trabajaron dentro de esta tendencia se produce a partir de este momento de un modo escalonado, repercutiendo definitivamente en la década de los 80 , cuando se promueve no sólo la definitiva modernización de las instituciones públicas y privadas en relación con la difusión del arte, sino también un relevo generacional de $\operatorname{artistas}^{150}$. Las nuevas posibilidades tecnológicas de comunicación facilitan el intercambio inmediato de las experiencias artísticas, así como el debate sobre las mismas. Las tendencias y propuestas se suceden con la misma rapidez, con que se separan de los intereses reales de la sociedad, de este modo se crea una fisura entre arte y sociedad sin precedentes. ${ }^{151}$

\footnotetext{
${ }^{150} \mathrm{El}$ final de la dictadura franquista supuso un vendaval de aire fresco en todas las disciplinas, especialmente en las artísticas, donde las corrientes del extranjero producen una eclosión creativa. El retorno del arte estuvo marcado por un debate entre aquellos que optaron por una actitud continuadora del lenguaje conceptual, y los que se adscribieron a un arte pictórico desvinculado de toda ideología y dogmatismo. El retorno y la convivencia con las prácticas conceptuales se advirtieron en algunas exposiciones en un reduccionismo abstracto que procedía de la nueva figuración. A lo largo de los setenta destacan dentro de este grupo los artistas: Carlos Alcolea, Miguel Ángel Campano, Chema Cobo, Gerardo Delgado, Guillermo Pérez Villalta, Manolo Quejido. Mientras que en Barcelona en la misma sintonía encontramos a, José Manuel Broto, Javier Rubio, Gonzalo Tena y Xavier Grau. Otros pintores como Jordi Teixidor y Santiago Serrano participan de una nueva abstracción, más minimalista e inicialmente más constructiva. Gerardo Delgado y Soledad Sevilla se iniciaron en el racionalismo cibernético y avanzaron hacia una pintura menos estructural y más apegada a la superficie. En el transito de los años setenta a los ochenta se van consolidan otras figuras singulares de la pintura española. Véase. RAMIREZ, J.: 1997, pp. 515-516

${ }^{151}$ Los cambios políticos producidos en España en la segunda mitad de la década de los setenta suscitan interés internacional, con todo lo que ello significa de apoyo cultural y artístico. En la década de los 80 se produce la definitiva modernización y difusión del arte
} 
En esta etapa de transformación, surgen nuevas luchas y reivindicaciones, muchos artistas e intelectuales continúan trabajando por la democratización de las artes y su inmersión en las nuevas relaciones sociales que rápidamente se producen en la transición. A lo largo de este periodo Pilar Dolz sigue manteniendo una tendencia crítica, hasta 1978, año en el que abandona definitivamente los postulados críticos.

Durante este período encontramos a la artista, realizando una serie de insectos de carácter muy realista, en los que localizamos vigentes algunos elementos formales pertenecientes a Reixes tales como vallas y alambradas, relacionadas indudablemente con aquellas rejas, cárceles, que nos recuerdan ciertamente al ambiente represivo de los últimos años del franquismo. De la misma manera tropezamos también con los espacios vacíos similares a los de Ocells morts, que hacen alusión al ambiente de aislamiento y desolación que se vive durante esta etapa y con los que la artista representa la muerte.

¿Ves eso? Son las rejas que continúan y se retoman. Esto es de la serie de insectos, pero lo retomo o bien porque es que no se acaban las rejas, pero también son insectos. La presencia de la cortina tiene que ver con Rejas, aunque sea una cortina, no puede salir la mariposa; aunque sean insectos puede ser una reja perfectamente, ¿vez? como las cosas se van entrelazando. ${ }^{152}$

contemporáneo, es el período en el que surge la primera oleada de nuevos artistas que triunfan en el extranjero. Por otra parte, no significa que se haya garantizado una renovada cosecha de genios del arte, sino que se facilita sobre todo su difusión social. Véase. FELIX, J.: 1978, p.128.

${ }^{152}$ Entrevista personal con la autora en Castellón de la Plana. 04/08/2006. 
En esta serie volvemos nuevamente al tema de la muerte con esos insectos extintos, que aparecen como posibles víctimas de un poder superior, para los que evidentemente es demasiado tarde, puesto que ya no tienen salida, ni solución. Junto a estas imágenes hallamos otras llenas de vida presentes en la misma obra, creando una dicotomía entre la vida y la muerte, el fin y el inicio, posiblemente como una alusión a lo que los propios españoles viven en estos momentos de cambio y transformación.

Sus personajes representados en unas superficies desérticas y vacías, aparecen impotentes sin ninguna protección, a merced de ser cazados y torturados por cualquier fuerza exterior. La disposición de estas imágenes sobre el plano franco resulta significativa, pues nos permite ver claramente estos insectos caminando de un lado a otro quizás en búsqueda de un nuevo camino, como símbolo de la inseguridad del ser humano abstraído en el desamparo y la desolación.

(...) eso que te pierdes y no sabes hacia dónde tirar un día, y trabajas por trabajar, a lo mejor porque estás dibujando y hay una mosca, entonces la observas y la dibujas. ${ }^{153}$

La artista emplea estas imágenes como soporte básico para la transmisión de sus mensajes, en los que observamos un cierto compromiso humano-social, expresado de forma silenciosa a través de este modesto tema.

${ }^{153}$ Ibidem. 
Como suele ocurrir normalmente en la obra de esta artista, las imágenes trabajadas en una serie, nunca desaparecen del todo al iniciarse otra, sino que se integran en la nueva serie, como un paso de transición. De este modo como ya hemos mencionado antes nos encontramos con diversos elementos discursivos pertenecientes a Reixes y Ocells morts, de la misma manera que nos topamos con otros nuevos como; piedras y paisajes que serán los protagonistas de futuras series. Así logramos distinguir en este conjunto de obras la existencia de una diversidad de planteamientos formales que se combinan entre sí durante la creación de la obra.

Hemos de tener en cuenta que durante este período, de 1976 a 1978, Pilar Dolz se encuentra trabajando cuatro diferentes series de modo simultáneo, con una diversidad de intereses que quedan reflejados en los distintos temas tratados.

Insectes realizada con un total dominio del claroscuro, de línea suave y delicada, de gran detallismo, se convierte en una de las series más realistas efectuadas hasta ahora por nuestra artista, quien tomando imágenes del mundo externo recogidas en su memoria, crea su propio universo, aportando su particular visión.

Sus figuras se expresan y se representan a través de formas pertenecientes a ese exterior, perfectamente reconocidas por nosotros. "Cuando hago insectos soy completamente realista". ${ }^{154}$

\footnotetext{
${ }^{154}$ Entrevista personal con la autora en Castellón de la Plana. 27/04/2006.
} 


\subsubsection{ASPECTOS COMPOSITIVOS.}

\section{Composición}

En esta colección de obras, Pilar Dolz limita su campo visual a un conjunto de insectos que captan su atención y atraen su mirada. Tras un largo período de observación de unas moscas, detiene la acción y congela la imagen en su mente, posteriormente tomando como punto de partida los datos almacenados en su memoria, plasma estas imágenes después de un cierto período de tiempo, experimentando así un suceso que nos atrevemos a calificar de situación artificial, ya que en la vida real continuamente las cosas se mueven o nos movemos nosotros a su alrededor, pero lo que vemos no se desecha, sino que subsiste en la memoria y vuelve a surgir a medida que perviven en nuestra retentiva. De esta manera las imágenes son transferidas directamente a la plancha calcográfica desde su memoria. ${ }^{155}$

Yo recuerdo que las moscas las dibujaba de memoria, porque las observaba mientras estábamos allí, (...) no la parabas, ni la atrapabas, estaba allí, después cuando se iba la dibujabas, pero no es que la dibujabas en aquel momento, a lo mejor la dibujaba 15 días después, pero la tenía allí en la cabeza. ${ }^{156}$

La alusión psicológica del espacio se hace casi siempre intentando escenificar un lugar carente de dimensión, donde la disposición de la forma se hace de manera disuelta sobre el plano

\footnotetext{
${ }^{155}$ El movimiento es la incitación visual más fuerte a la atención. Véase ARNHEIM, R.: 1993, p. 409

${ }^{156}$ Entrevista personal con la autora en Castellón de la Plana. 27/04/2006.
} 
sin la búsqueda de ningún tipo de punto de fuga, ni niveles de profundidad. La propuesta fundamental del espacio es el vacío puro, donde la forma explora la superficie de modo disperso sin llegar a superponerse, ni traslaparse, por lo que no encontramos distintas profundidades. La composición estructural se sitúa únicamente entre dos concepciones formales; una que hace referencia al fondo vacío y otro que se corresponde a la forma representada. Su disposición disgregada en el plano, deja ver siempre una gran cantidad de espacio sin ocupar, lo que nos plantea una afirmación del blanco puro como un lugar de luz. Sin duda ésta es una de las características más constantes que hemos visto a lo largo de toda su obra, pero más específicamente en Reixes y Ocells morts, donde los espacios luminosos adquieren una gran importancia. (Véase LAM. XLV)

La sugerencia de la tercera dimensión la descubrimos implícita en la forma, por medio del claroscuro, el volumen, la textura, la luz y otras calidades dadas por los distintos medios gráficos que potencian la cualidad dimensional de la forma. La sensación de profundidad en el espacio se consigue únicamente con la proyección de las sombras sobre el plano, fomentando la ilusión de profundidad y proporcionando al plano vacío un aspecto más sólido. La ubicación de los elementos de manera abierta sobre la superficie, guardan sin embargo una relación de distancia y orientación que no altera la adecuada relación proporcional de tamaños. La experiencia visual nos informa que los objetos disminuyen a medida que crece su distancia con respecto al espectador, pero a la vez puede afirmarse que su tamaño permanece constante con independencia de la distancia, debido a 
que nuestra capacidad de observación nos permite imaginar y compensar esa disminución de tamaños con cierta percepción de la distancia, centrándonos en la interpretación de las formas según las normas visuales aprendidas y establecidas. "Todas las cosas se conocen por comparación". ${ }^{157}$ Así por ejemplo una mosca que se encuentra inscrita en la parte inferior del formato recrea para el observador la sensación de encontrarse más cerca, mientras que la que se halla más hacia la zona superior se intuye más distante del observador. Se establece así un efecto de profundidad en un mismo plano, que se basa en el alejamiento de la imagen del observador hacia los límites del formato, proporcionando la impresión de que se pierde en el espacio por fuera de las demarcaciones del soporte. Se confirma con esto la idea de Pilar Dolz, de otorgar al espectador un espacio con elementos suspensivos para dejar que sea éste el que continúe con la obra según sus fantasías. (Véase LAM. XLVI)

El planteamiento espacial basado en la simplicidad compositiva, respecto a la representación y disposición, se descubre por medio del aislamiento de sus elementos de toda atmósfera. La artista opera directamente con la luz pura del fondo, para situarlos como absolutos protagonistas de la obra, ya que nada más llama la atención que sus propias formas elaboradas en positivo (con tinta). La relación entre figura y fondo, queda fijada por el contraste, donde el tono oscuro de la forma destaca incuestionablemente sobre el fondo blanco, estableciendo una cierta tensión debido a la ambigüedad perceptiva generada entre ellos, lo que entraña una gran diferencia dinámica con respecto al fondo que carece de dinamismo propio.

${ }^{157}$ Mencionado por ARNHEIM, R.: 1993, p. 410 
Por otro lado encontramos también otro grupo de obras donde no hay superficies vacías, si no que se llenan de otros elementos de carácter más pictórico que cubren todo el espacio. Para comprender este planteamiento nos remontamos a Reixes, cuando la artista recurría al empleo de varias matrices para solucionar el problema del color. Del mismo modo ahora la autora vuelve a trabajar generalmente con dos matrices para sensibilizar el espacio. Como por ejemplo en LAM. XLVII, una estampa realizada con dos planchas, una de las cuales lleva grabada una malla metálica que reviste todo el espacio y cuya estructura semejante a una red nos permite ver a través de ella un espacio que, por otra parte, no permanece vacío como antes, sino que es ocupado por un paisaje dispuesto con una segunda matriz. A partir de este momento encontraremos un nuevo elemento en esta serie, que ya había sido utilizado en Reixes; la mariposa, que aparecerá en muchos grabados realizados en adelante.

Siguiendo este planteamiento tenemos otra estampa de mayor complejidad formal (Véase LAM. XLVIII) donde se cubre todo el espacio con la representación de una cortina, trabajada por medio de una gran cantidad de tonos, luces y sombras con los que consigue dar el aspecto de suave y frágil tejido. En contraposición a ésta encontramos una mariposa ubicada en la parte inferior derecha trabajada con tonos planos. Este planteamiento parece diferente a las obras iniciales en cuanto se refiere al tratamiento del fondo, que se caracterizaba por el predominio del vacío como oposición a la forma que se representaba con volumen matizado por el claroscuro. Así pues, en esta obra sucede a la inversa; el fondo se muestra más como un cuerpo sólido y con volumen, mientras que la forma es 
solucionada por una síntesis formal, con un aspecto más plano. De todos modos, como ya hemos visto antes, la iconografía de la cortina sigue emulando aquellas rejas, aunque su forma nada tenga que ver con aquéllas, sin embargo su función sigue siendo la misma, la de no permitir el paso de la mariposa ni del espectador.

En cuanto a la naturaleza dinámica de la imagen ésta se encuentra asociada con fórmulas que evocan el dinamismo. Así encontramos una serie de imágenes que parece como si estuvieran en movimiento por la manera en que están representadas. La dinámica de la forma presupone que la artista concibe toda la obra como un acontecimiento, no como un elemento estático, por ello la relación entre los elementos que la componen son de una interacción mutua. En LAM. XLIX encontramos unos insectos que caminan libremente sobre un espacio abierto huyendo de una trampa, mientras que otro parece dirigirse directamente hacia ella buscando la muerte. En ésta, a pesar de ser una obra de gran formato pues mide $50 \times 70 \mathrm{~cm}$. podemos ver que la superficie se encuentra invadida por tres insectos que dejan disponible una gran cantidad espacio. El movimiento planteado por dos de ellos sigue una dirección opuesta en relación al tercero, lo que provoca cierta tensión espacial. En cuanto a su situación en el espacio, respecto a las imágenes que se dirigen de derecha a izquierda, diremos que una de ellas se halla ubicada a la derecha y deslizada hacia la parte inferior, en tanto que la otra se halla en la parte central ligeramente desplazada más hacia arriba. En lo que atañe al animal que camina de izquierda a derecha, este se encuentra en el extremo izquierdo a una altura intermedia entre los otros dos. La disposición de estas formas en el plano establece un triángulo invisible que las relaciona 
por líneas imaginarias. La oblicuidad dota de cierta cualidad dinámica a la composición, de la misma manera que el enfoque triangular genera tensión visual. (Véase Fig. 82)

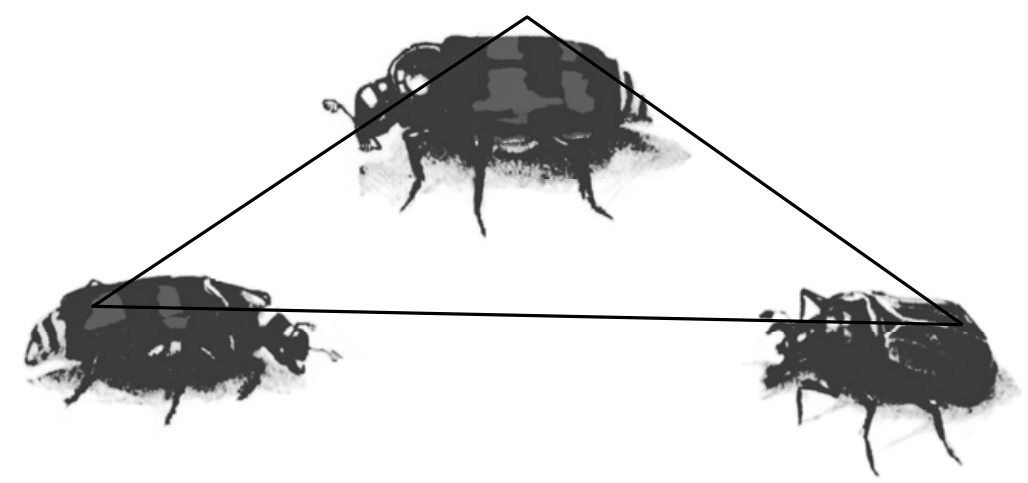

Fig. 82. Pilar Dolz. Detalle LAM. XLIX. Serie Insectes. Litografía. 1978.

La actividad visual de los elementos se determina mediante una disposición que implica cierta tensión. Si examinamos LAM. L, el concepto del espacio vacío se mantiene pero nos encontramos con un nuevo componente; las piedras que localizamos formando un pequeño montículo ubicado en la parte inferior de la superficie. El movimiento está evidenciado con la presencia de las dos mariposas que se hallan sobrevolando el espacio; Una se halla localizada en la parte inferior derecha y la otra en la parte superior izquierda sugiriendo una línea oblicua que cruza todo el espacio y lo divide en dos partes, sinónimo de dinamismo, movimiento y tensión. ${ }^{158}$ La representación de la mariposa ubicada en la zona inferior indica el sentido ascendente de la diagonal, mientras que el vector

\footnotetext{
${ }^{158}$ La orientación oblicua constituye probablemente el medio más básico y eficaz de obtener una tensión dirigida, La oblicuidad se percibe espontáneamente como un esfuerzo dinámico. Véase KANDINSKY, W.: 1993, p. 59.
} 
descendente está dirigido por la otra mariposa que baja de izquierda a derecha. Representado a través de la inversión de la dinámica, este mecanismo direccional añade un elemento de animación a la obra que exige un recorrido visual dinámico. (Véase Fig. 83)

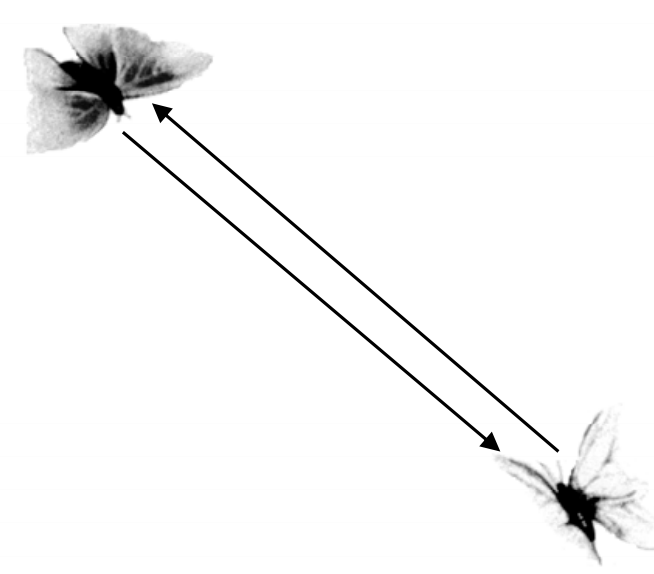

Fig. 83. Pilar Dolz. Detalle LAM. L. Serie Insectes. Litografía. 1978.

\section{$\underline{\text { Grafismo }}$}

En este conjunto de obras encontramos generalmente un trazo controlado y de carácter objetivo y analítico que aparece en combinación con otros planteamientos plásticos. Podemos definir tres tipos de trazos: descriptivo, de valoración y de expresión.

En primer lugar mencionamos el trazo descriptivo, difuminado capaz de definir inmediatamente la forma, mediante una suave fusión de luces y sombras, donde los cuerpos pierden su rigidez y la realidad aparece desvanecida y esfumada, a través de un trabajo donde la línea no existe como tal, pues las distinta áreas tonales 
ejecutadas con el aguatinta se funden y dan lugar a diferentes matices que marcan la forma y modelan el volumen. Estas manchas nunca aparecen solas, sino que están en combinación con otro trazo lineal ejecutado al aguafuerte que refuerza mediante un juego de líneas ondulantes, finas y delicadas, la estructura de la forma dotando de mucha plasticidad a la imagen. (Véase Fig. 84).

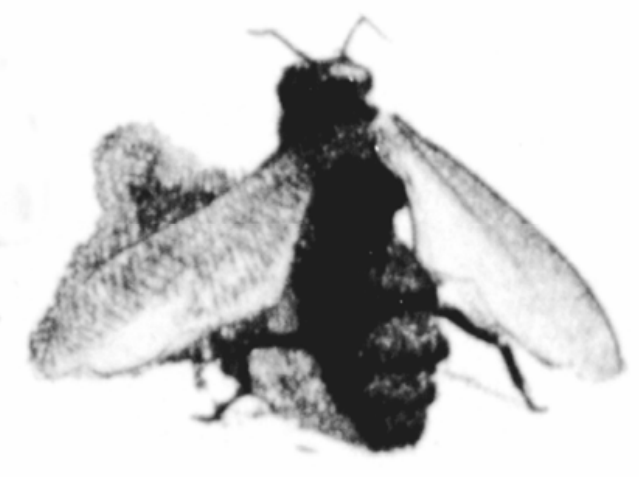

Fig. 84. Pilar Dolz. Detalle LAM. XLV. Serie Insectes. Aguafuerte y aguatinta. 1976.

En segundo lugar localizamos un trazo de valoración construido a base de amplias manchas difuminadas, en donde se mezclan los distintos valores cromáticos de una forma muy pictórica. La intensidad de los valores tonales aunque sean muy contrastados nunca parecen cortantes, sino que se fusionan de un modo suave y delicado.

Cada trazo es el resultado de las reservas hechas con el pincel, en el que podemos recrear el rastro dejado por él en respuesta a los movimientos ejecutados por la artista. En algunas ocasiones da origen a la sutil evidencia de flores, hojas y paisajes. 
En otras ocasiones en cambio nos encontramos con un trazo más indeterminado e impreciso que da lugar a la aparición de una serie de manchas más atmosféricas. (Véase Fig. 85)

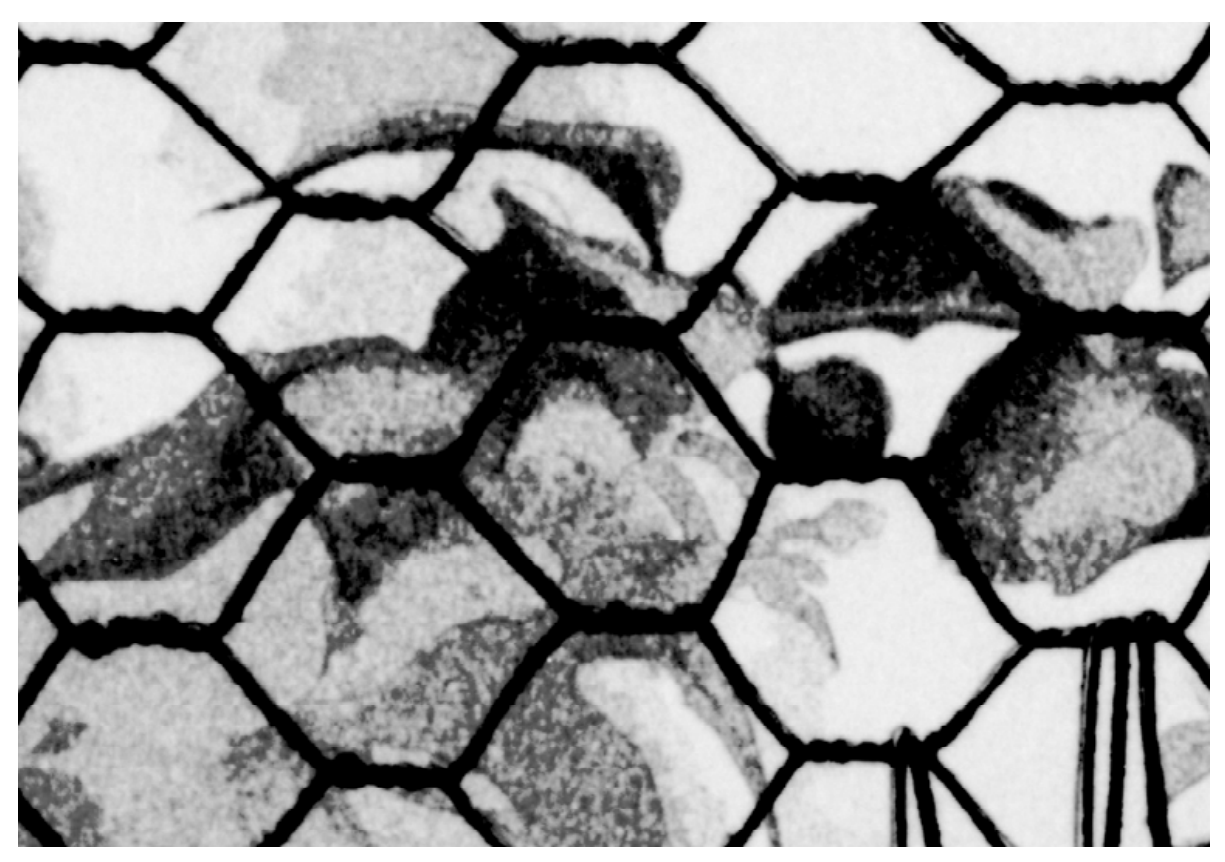

Fig.85. Pilar Dolz. Detalle LAM. XLVII. Serie Insectes. Aguafuerte y aguatinta. 1977.

Por último localizamos un trazo lineal más expresivo, realizado al aguafuerte, en el que una serie de líneas quebradas y gruesas destacan nítidamente. Se trata de un trazo que se entrecruza en todas las direcciones para formar una malla que paraliza el paso al observador. Éste lo podemos apreciar en LAM. XLVII, donde el hilo que zurce la red, surge de un conjunto de líneas retorcidas que facilitan la intervención gestual de la artista. Este concepto de caligrafía aparece en combinación con un trazo más 
pictórico gracias a la incorporación de una segunda plancha. (Véase Fig. 86)

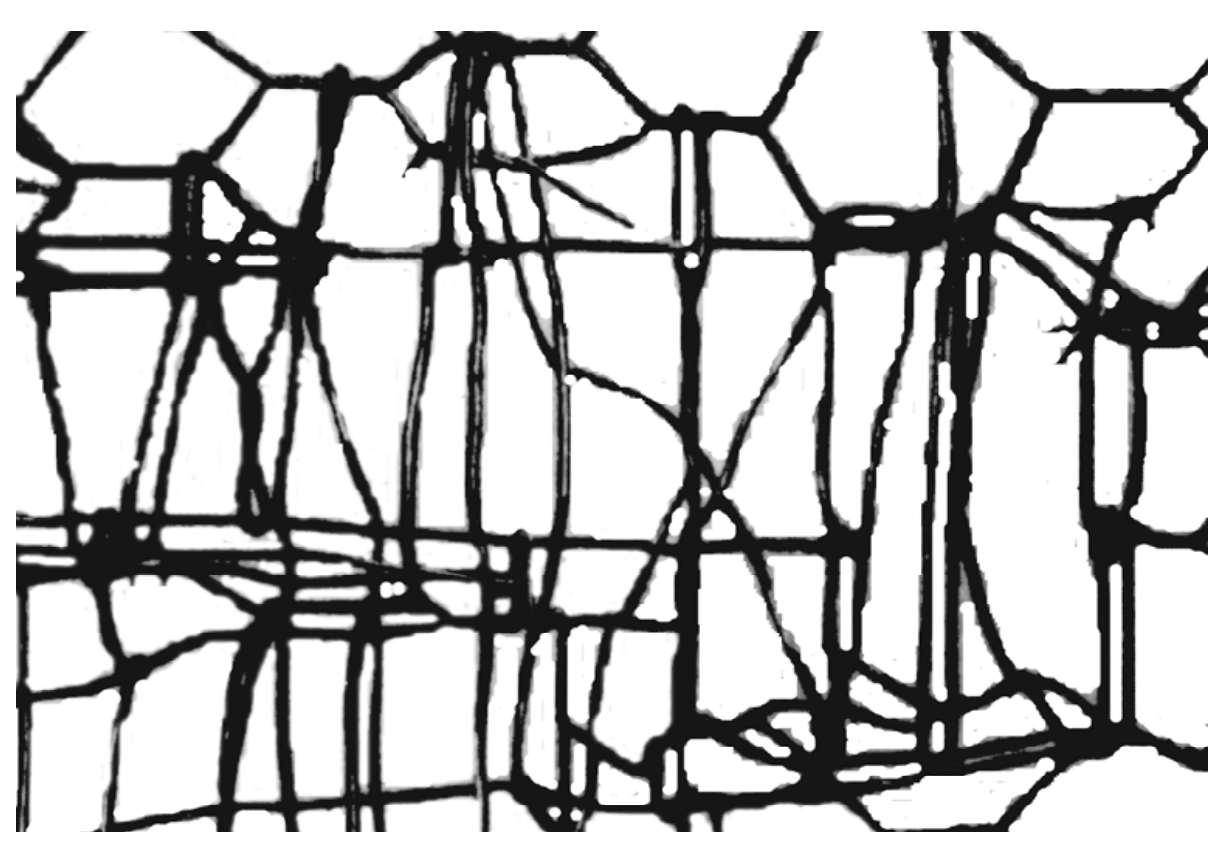

Fig. 86. Pilar Dolz. Detalle LAM. XLVII. Serie Insectes. Aguafuerte y aguatinta. 1977.

\section{Color}

En esta serie podemos clasificar dos grupos de estampas en función del tratamiento de color; las que se representan en color propiamente dicho y las que se realizan en blanco y negro. Este aspecto cualitativo tiene sus repercusiones en el terreno informativo, pues muestra la existencia de dos universos visuales diferentes que van más allá del uso del color y del blanco y negro. 
Las primeras obras se caracterizan por ser monocromáticas a través de la aplicación de la tinta negra. La distribución de la sombra, se hace de modo gradual para dejar paso a valores más claros a medida que avanza. La interpretación del sombreado y el contraste resulta muy realista si observamos la manera de representar el claroscuro. (Véase LAM. XLV y XLVI)

El tratamiento del color de las imágenes polícromas, tanto en el grabado calcográfico como en la litografía, se realiza de la misma manera, a través de la aplicación de tintas independientes que funcionan unas veces como parte de un mismo elemento, incluso fusionándose, y otras veces de distintos.

En ocasiones el color se obtiene por la aplicación de recortes de papel coloreados (collages), sobre los que se procede a imprimir la imagen por medio de una matriz que lleva grabada la forma que se va a representar. Por ejemplo en LAM. XLVII, encontramos un grabado realizado por la presencia de dos matrices compuestas por cuatro colores; dos de los cuales pertenecen a los collages aplicados cada uno sobre cada matriz, y los otros dos colores pertenecen a tinta extendida en las planchas. Así en primer término localizamos un papel de color amarillo, que aparece recortado con la forma de la mariposa y definido a través de la aplicación de una plancha estampada en tinta negra. (Véase Fig. 87). 


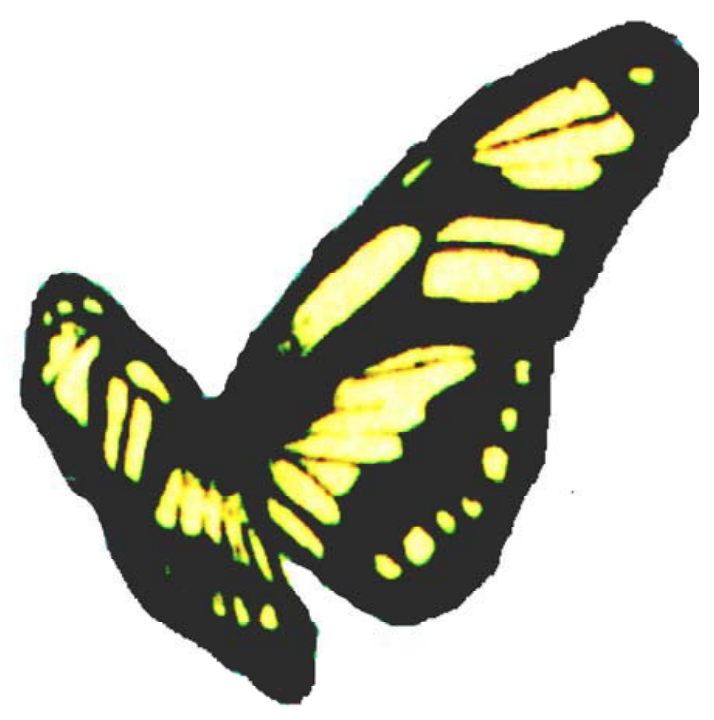

Fig. 87. Pilar Dolz. Detalle LAM. XLVII. Serie Insectes. Aguafuerte y aguatinta. 1977.

De igual manera encontramos otro papel recortado de color violeta sobre el que se imprime un tono verde que construye la imagen de una flor. La matriz correspondiente trabajada al aguatinta por medio de mordidas poco profundas, da a la forma un carácter difuminado, solucionado a base de manchas que se funden suavemente. El color de la tinta impresa con la plancha, vela y absorbe la luminosidad del tono violeta del papel. En cuanto a las dos planchas de metal, cada una funciona independientemente, pues una matriz lleva grabada la imagen de una alambrada con un trazo lineal impreso en tinta negra, mientras que la otra lleva grabado un paisaje elaborado a base de manchas de aguatinta e impreso en tinta verde. (Véase Fig. 88) 


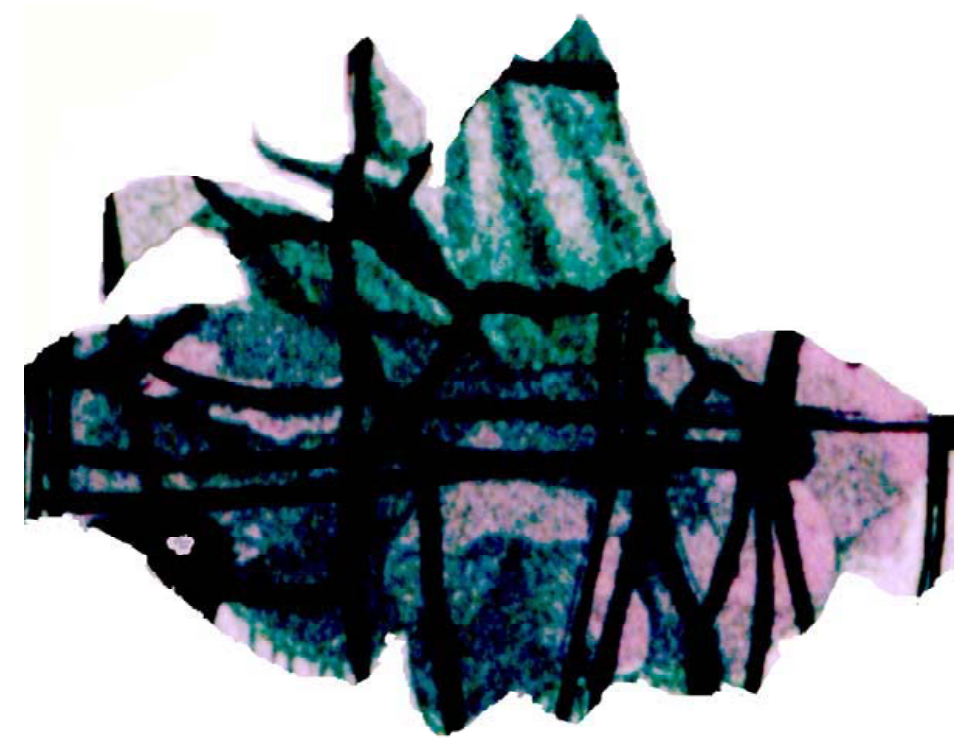

Fig. 88. Pilar Dolz. Detalle LAM. XLVII. Serie Insectes. Aguafuerte y aguatinta. 1977.

Ves la necesidad del color. Eso y esto son fondinos (sic) del color del papel, es decir aquí hay dos planchas, una verde y una negra y las flores violetas y la mariposa son dos fondinos de papel de color estampados, el verde sobre el violeta, y el negro sobre el amarillo. ${ }^{159}$

En la litografía el color surge a través de tintas planas de alta saturación, con rojos y amarillos intensos que parecen mucho más claros debido a que se aplican sobre el blanco del papel que hace que resalten más los valores cromáticos.

En LAM. XLIX, nos encontramos con la iconografía de dos pequeños escarabajos solucionados a tres tintas; una roja que forma el caparazón, una amarilla que compone el cuerpo y una negra que

\footnotetext{
${ }^{159}$ Entrevista personal con la autora en Castellón de la Plana. 27/04/2006.
} 
se superpone a las dos anteriores definiendo la imagen. El tono oscuro conforma la cabeza, las patas, los lunares del caparazón y define el cuerpo del insecto. Pilar Dolz utiliza en su obra colores planos de un cromatismo reducido, con la superposición del negro sobre los diversos tonos de color. Por otra parte nos encontramos con otros dos elementos; una trampa y otro escarabajo realizado con lápiz litográfico e impreso únicamente en tinta negra (igual que la trampa), De este modo juega con la presencia del color y los valores monocromos en la misma obra.

Esto es litografía sobre piedra, (...) pero claro para la litografía tienes que utilizar una plancha para cada color, no puedes hacer a la poupée. Entonces yo he hecho lo negro en piedra y lo otro en planchas. Es que preparar una piedra para poner un poquito de color era un poco absurdo, (...) por tanto hay 3 planchas, porque hay este color allí, el rojo y el amarillo y este negro, (...) una plancha para cada color, son plancha de aluminio estampadas en directo, no es offset. ${ }^{160}$

En otras obras el color adquiere un tono más suave, más difuminado, no tan plano como en la obra mencionada. Para obtener estas calidades utiliza la técnica del salpicado, con la que incluso adquiere una pequeña degradación de tonos. En LAM. XLIX el color se concentra en la imagen de dos mariposas que se deslizan por el espacio en direcciones opuestas. Una de ellas estampada en una tinta azul de matiz suave apenas llama la atención. A medida que el color brota desde el centro de su cuerpo hacia fuera, donde se localizan las alas, el tono se torna más suave. Lo mismo ocurre con la otra imagen impresa en amarillo con un alto grado de saturación

${ }^{160}$ Entrevista personal con la autora en Castellón de la Plana. 04/08/2006. 
central y la degradación del tono suaviza a las alas. Tenemos aquí una confrontación entre un color cálido y otro frío, que se encuentran matizados por la sobreimpresión de una tinta roja con tendencia azulada. En la imagen resuelta en azul el rojo se torna más violáceo debido a la fusión de las dos tintas. En cambio en la imagen amarilla el tono se encuentra dispuesto en grafismos de forma lineal que dibujan la forma; aquí el color se mantiene más puro, en las zonas donde coincide con el amarillo el tono se vuelve anaranjado. Naturalmente esta imagen llama más la atención por su calidez y claridad.

En cuanto al negro vuelve a definir la forma y ocupa sobre todo la parte que corresponde al cuerpo de las mariposas y de paso sombrea un poco las alas. De igual manera construye las piedras que se sitúan en la parte inferior del formato.

En otras obras el color aparece más bien con tonos neutros y matizados, realizados por medio de la técnica serigráfica; éste es un hecho interesante puesto que una de las características de esta técnica es la estampación de tintas planas, sólidas y compactas. ${ }^{161}$ La artista no trabaja la serigrafía por medio de tintas planas como lo venía haciendo hasta ahora, si no por medio de una variedad de tonos y matices creados por la superposición de tintas grasas, que no cubren el color impreso previamente, ya que a pesar de estar superpuestas las tintas se siguen percibiendo matizadas por el color superpuesto. Así en LAM. XLVIII encontramos cubriendo toda la superficie del formato la imagen de una cortina realizada por medio

\footnotetext{
${ }^{161}$ En la década de los sesenta los artistas más representativos del Pop americano reivindicaron este procedimiento, inspirados en una arte popular, de la sociedad de consumo para crear obras figurativas con una temática que las haga accesible al público en general. Véase RAMÍREZ, J.: 1996, p. 353.
} 
de transparencias que se funden en una gama de tonos y matices que permiten obtener efectos delicados, como las ondulaciones y la sugerencia de suavidad y sutileza en la tela. Este recurso es el principal factor del particular efecto realista y de movimiento en esta imagen, que se basa en la configuración de una estructura tonal. (Véase Fig. 89)

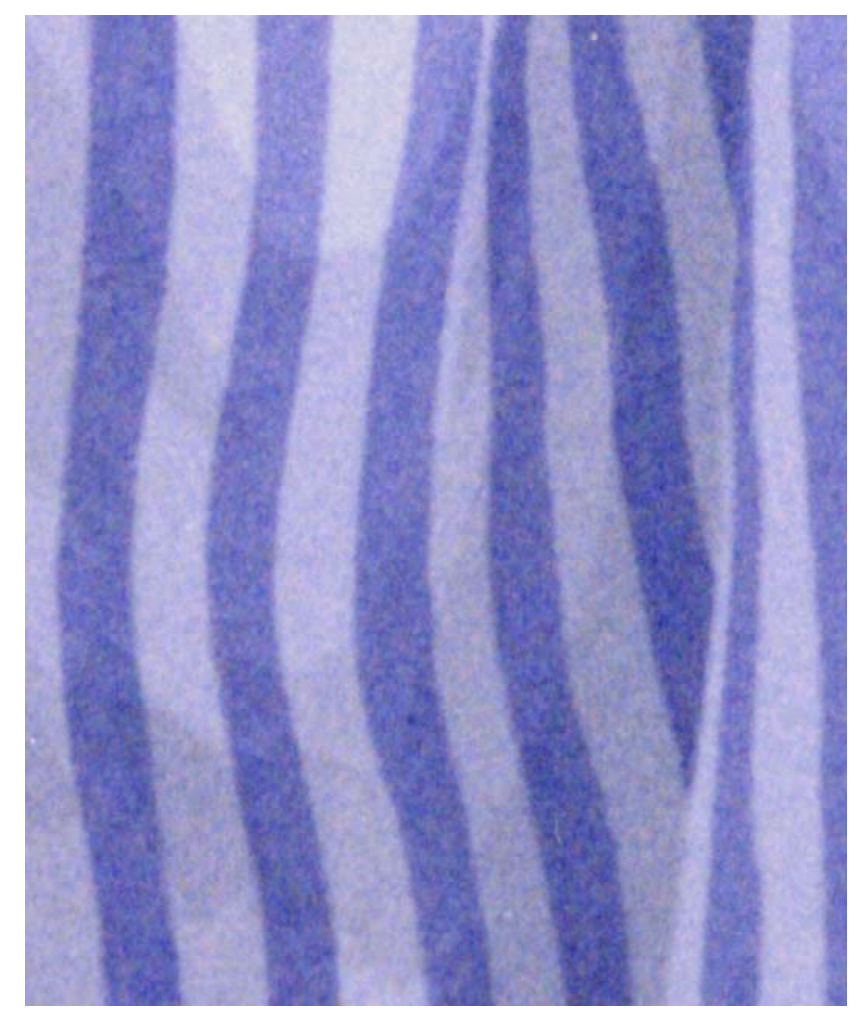

Fig. 89. Pilar Dolz. Detalle LAM. XLVIII. Serie Insectes. Litografía. 1978.

En otros elementos como la mariposa ubicada en la parte inferior derecha del plano, la artista utiliza nuevamente las tintas planas y saturadas, formando una imagen que nos recuerda a la 
frialdad del Pop, por el empleo de colores planos, líneas escuetas y simplificación de la forma.

La imagen elaborada con tintas planas claramente diferenciadas; como amarillo, azul intenso, azul claro y negro, da la impresión de ser un recorte tomado de una revista de comics y haber sido pegada sobre la serigrafía. Este contraste se produce por el diferente tratamiento que se da a cada uno de los elementos. (Véase Fig. 90)

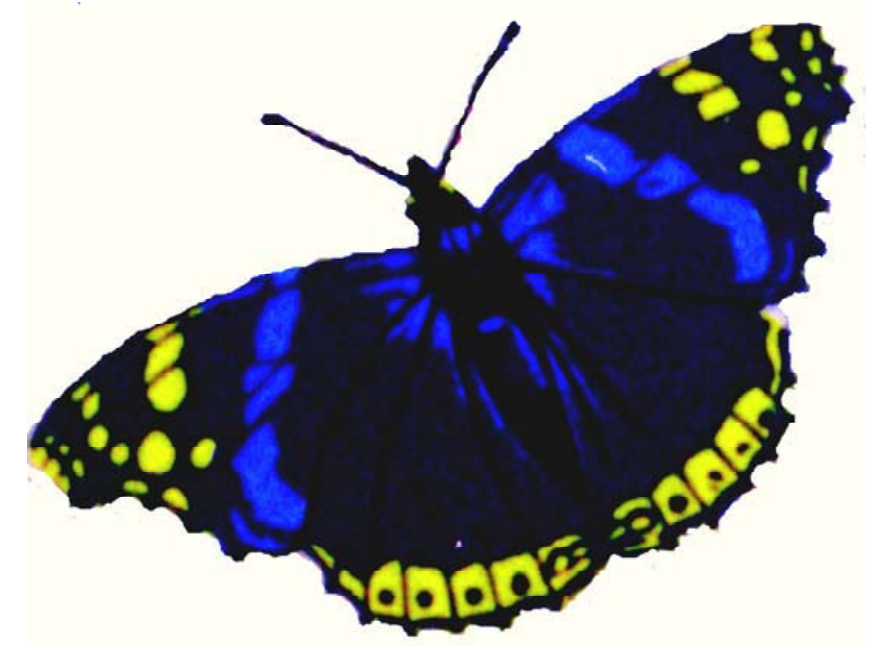

Fig. 90. Pilar Dolz. Detalle LAM. XLVIII. Serie Insectes. Litografía. 1978.

Esto es una serigrafía. Es un color para cada una. Es serigrafía todo, lo que pasa es que esto lo he estampado ya con colores muy transparentes y eso con colores muy planos, muy de publicidad, muy fuertes. ${ }^{162}$

${ }^{162}$ Entrevista personal con la autora en Castellón de la Plana. 04/08/2006. 


\subsubsection{PROCESO TÉCNICO}

En este conjunto de obras encontramos que ha sido realizado sobre todo por dos procesos tradicionales; el grabado calcográfico y la litografía. Técnicas que aparecen trabajadas con un gran dominio técnico. Sus imágenes se imponen directamente al espectador, a través de su belleza estética que se constituye en una fuente de placer para el observador.

La artista alcanza el pleno dominio de la técnica calcográfica, que le permite el haber practicado estos años con el aguafuerte y el aguatinta de manera habitual. El aguatinta la emplea para realizar una diferenciada gama de tonos por medio de manchas. Una vez grabada la plancha, procede a bruñir los distintos tonos producidos con el objetivo de valorar los matices de la mancha, obteniendo así un trabajo delicado y sutil con calidades plásticas. Con esta práctica Pilar Dolz alcanzar en el grabado calcográfico, la agudeza y elegancia que caracteriza su trabajo. (Véase LAM. XLV y XLVI)

Esto es aguafuerte sobre cobre. A lo mejor tengo hasta las planchas. Eran pequeñas planchas de cobre y es dibujado, grabado al aguafuerte $y$ al aguatinta bruñida. Una vez hecha el aguatinta se bruñe para dar suavidad al trazo. ${ }^{163}$

Como hemos visto en otras series preliminares la artista en algunas ocasiones recurre al empleo de matrices ya utilizadas, para volverlas a incidir y estampar junto a otros elementos. En LAM.

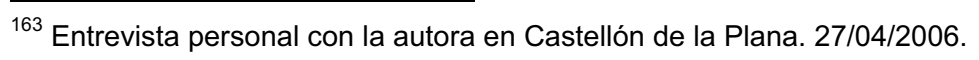


XLVII, Pilar Dolz torna a aprovechar una plancha utilizada en Ocells morts, (Véase Cap. III.5.2) en la que se encontraba grabada una alambrada metálica ocupando una pequeña parte de la matriz. En esta serie la autora recupera esta matriz y termina de cubrir todo el espacio, por medio de una serie de trazos lineales realizados al aguafuerte. Esta nueva imagen aparece estampada en combinación con otra representación que surge en una segunda matriz realizada al aguatinta y que emerge superpuesta en la impresión.

Ésta es la misma plancha. Es aguafuerte. Luego la seguí grabando y fue una de las mariposas. (...) Éste son dos planchas: una plancha con una aguatinta y otra con una aguafuerte. Ésta es la plancha que retomo de Ocells morts y la termino de trabajar. Yo retomo mucho las planchas y las grabo por un lado y por el otro, me gusta más que cuando están limpias completamente. ${ }^{164}$

La litografía se trabaja con el mismo planteamiento metodológico que el grabado calcográfico, esto es por medio del uso de una matriz para cada color.

Pilar Dolz normalmente combina el uso de la piedra litográfica con planchas de aluminio que se estampan en la misma prensa. Para esto coloca la plancha de aluminio sobre una piedra con el fin de conseguir que el grosor de la matriz sea el adecuado para la impresión. Una de las técnicas trabajas en litografía es el spruzzo, ${ }^{165}$ técnica que consiste en realizar salpicados de tinta litográfica sobre la matriz, con la ayuda de un cepillo y una malla de metal, con la que obtiene una textura similar al aguatinta. Un ejemplo

\footnotetext{
${ }^{164}$ Ibidem.

${ }^{165}$ Esta técnica la estudia en Urbino (Italia) lugar al que viaja a hacer un curso de litografía.
} 
de esto lo tenemos en LAM. $\mathrm{L}$ donde localizamos las imágenes de unas piedras realizadas por medio de esta técnica. Para la ejecución de ésta la artista utiliza plantillas, con el objeto de proteger las zonas donde no quiere salpicaduras, obteniendo así unas formas no delimitadas por la línea de dibujo tradicional, sino por el registro empleado. Esta técnica le permite conseguir una amplia gama de tonalidades de la misma manera que el aguatinta. (Véase Fig. 91)

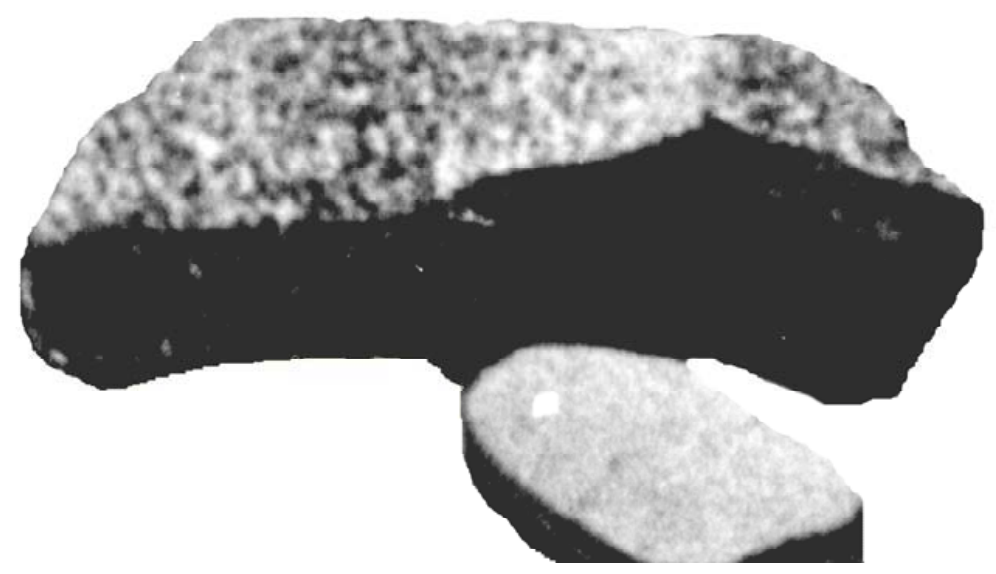

Fig. 91. Pilar Dolz. Detalle LAM. L. Serie Insectes. Litografía. 1978.

El tratamiento plástico de esta serie, como ya se ha señalado antes, supone un trabajo de traducción lingüística, en la creación de imágenes a partir de sugerencias y referencia almacenadas en su memoria siguiendo cánones figurativos, a través de aguatintas y litografías con un tratamiento formal clásico. Práctica que viene ejercitando desde su primera serie, a través del adiestramiento de la observación, habilidad que aprendió cuando era estudiante en la Escuela Massana. (Véase Cap. I.2.2) 
Insectes surge porque yo creo que los veo allí y después de memoria intento dibujarlos, (...) creo que es una cosa de observación. (...) A ti no te ha pasado que si entraba una mosca, mientras el profesor estaba explicando, tú estás mirando, estás pensando algo y ves el pequeño insecto. Yo creo que es una cosa de observación. A veces me sorprendo de cómo yo he dibujado ciertos insectos. Recuerdo que la trampa de los insectos me la puse allí, porque me la encontré oxidada, tirada y la puse allí. Pero los insectos no, ésos me los inventaba, pero después los ves en un libro y son parecidos, si los ve alguien que sabe, dice éste es un tal y cual porque los observaba. ${ }^{166}$

${ }^{166}$ Entrevista personal con la autora en Castellón de la Plana. 27/04/2006. 
LÁMINAS

NSECTES 



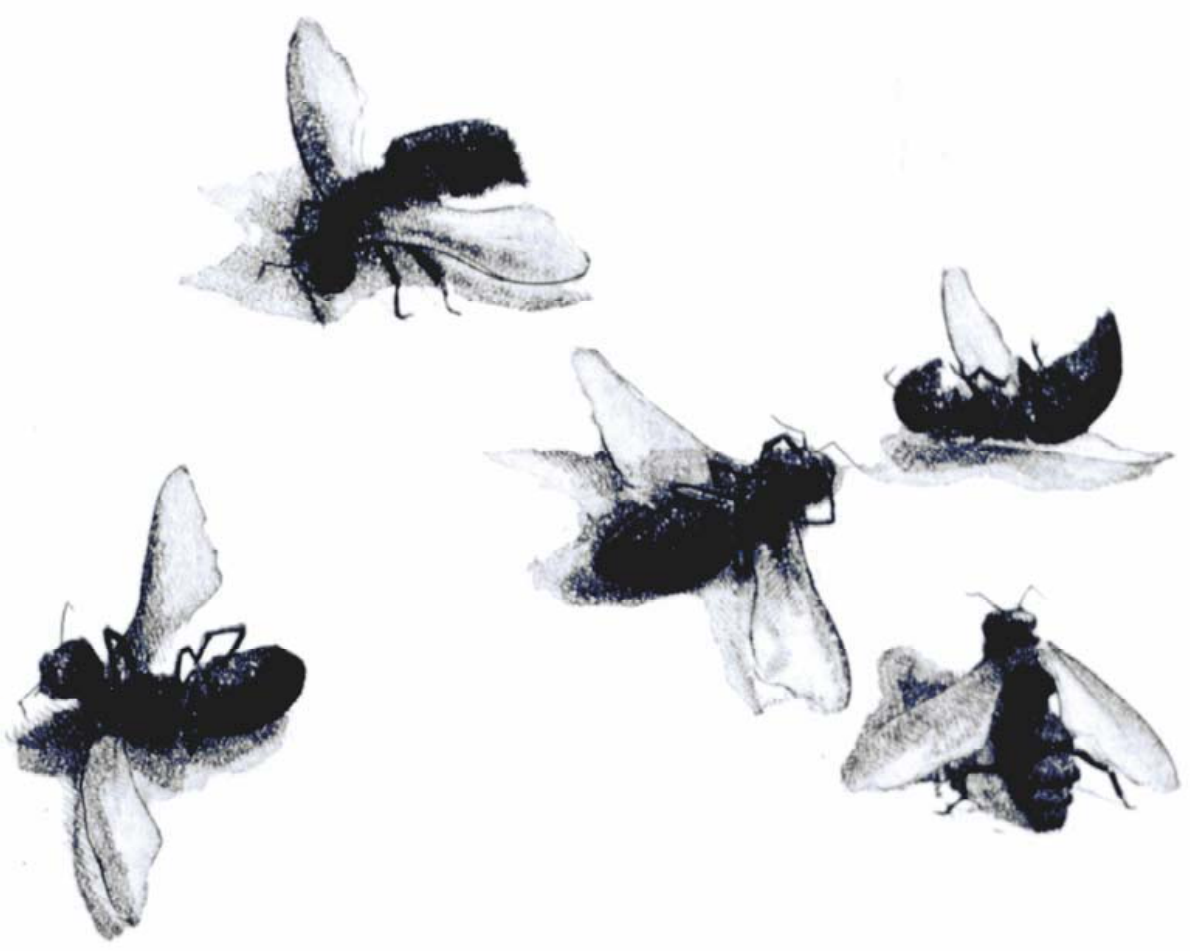

\section{LÁMINA XLV}

"Sin título"

Aguafuerte y aguatinta bruñida

$10 \times 12 \mathrm{~cm}$.

1976 


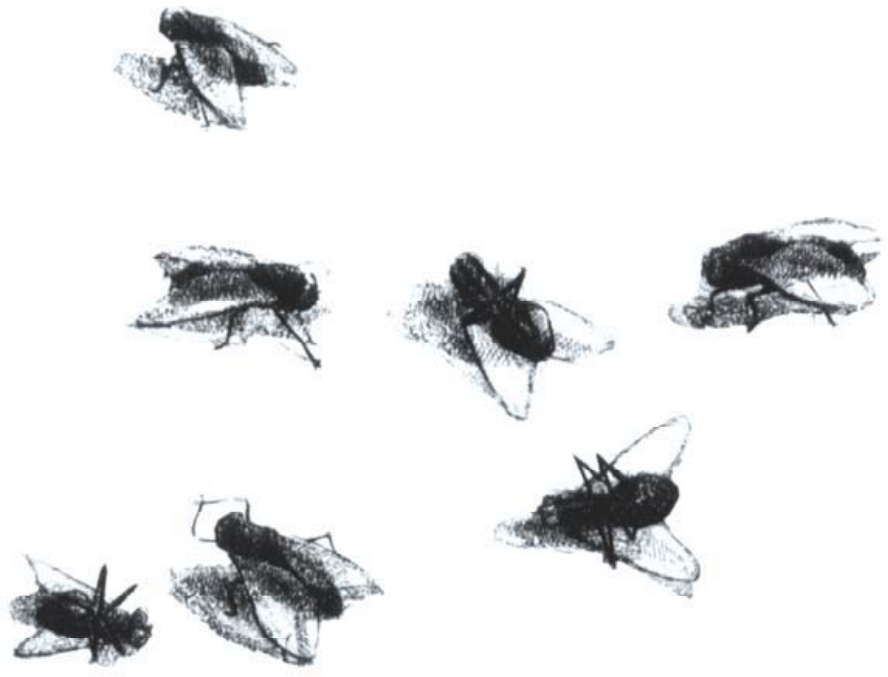

\section{LÁMINA XLVI}

"Sin título"

Aguafuerte y aguatinta bruñida

$10 \times 12 \mathrm{~cm}$.

1976 


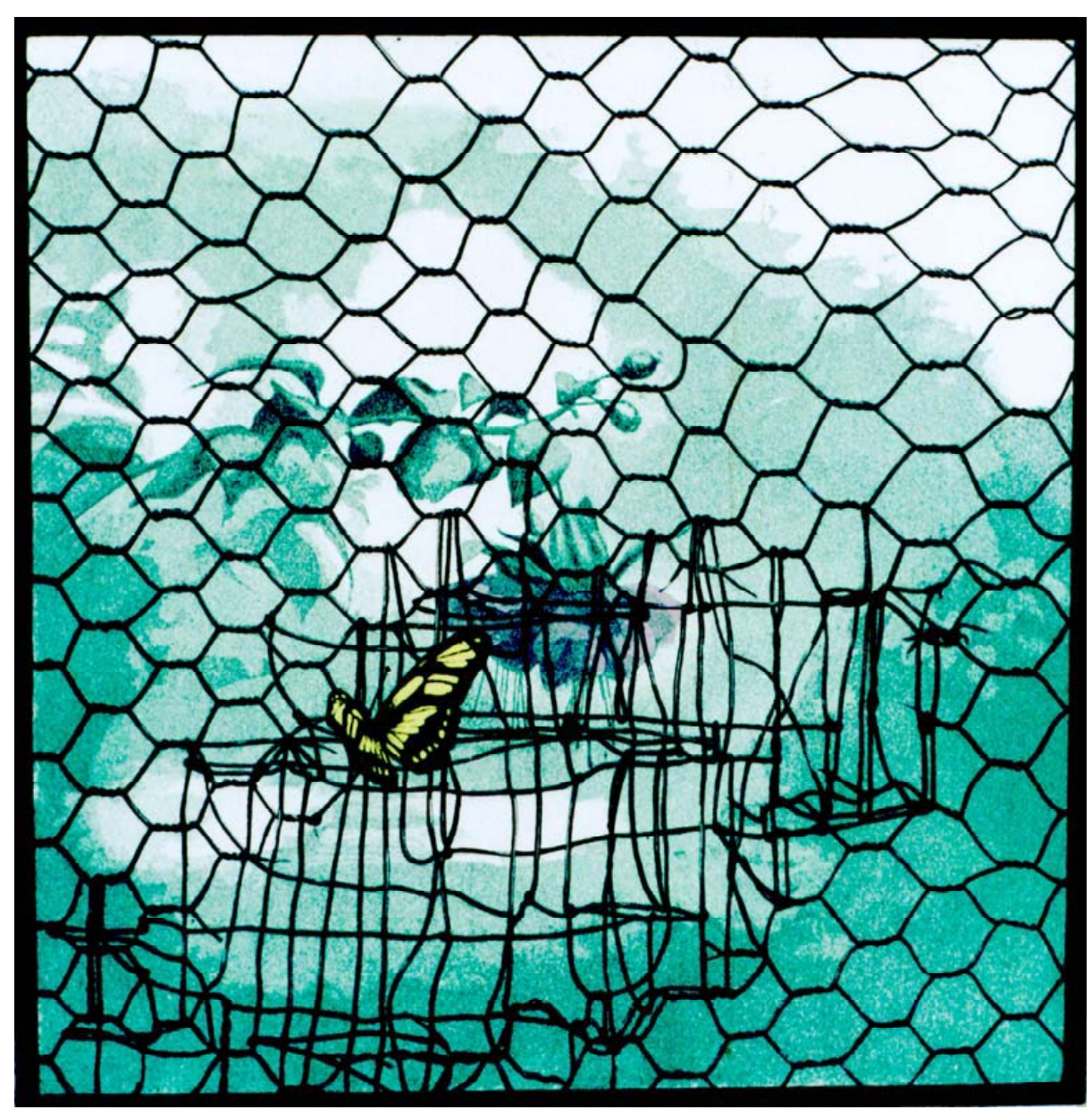

\section{LÁMINA XLVII}

"Sin título"

Aguatinta y aguafuerte.

$32 \times 32 \mathrm{~cm}$. 


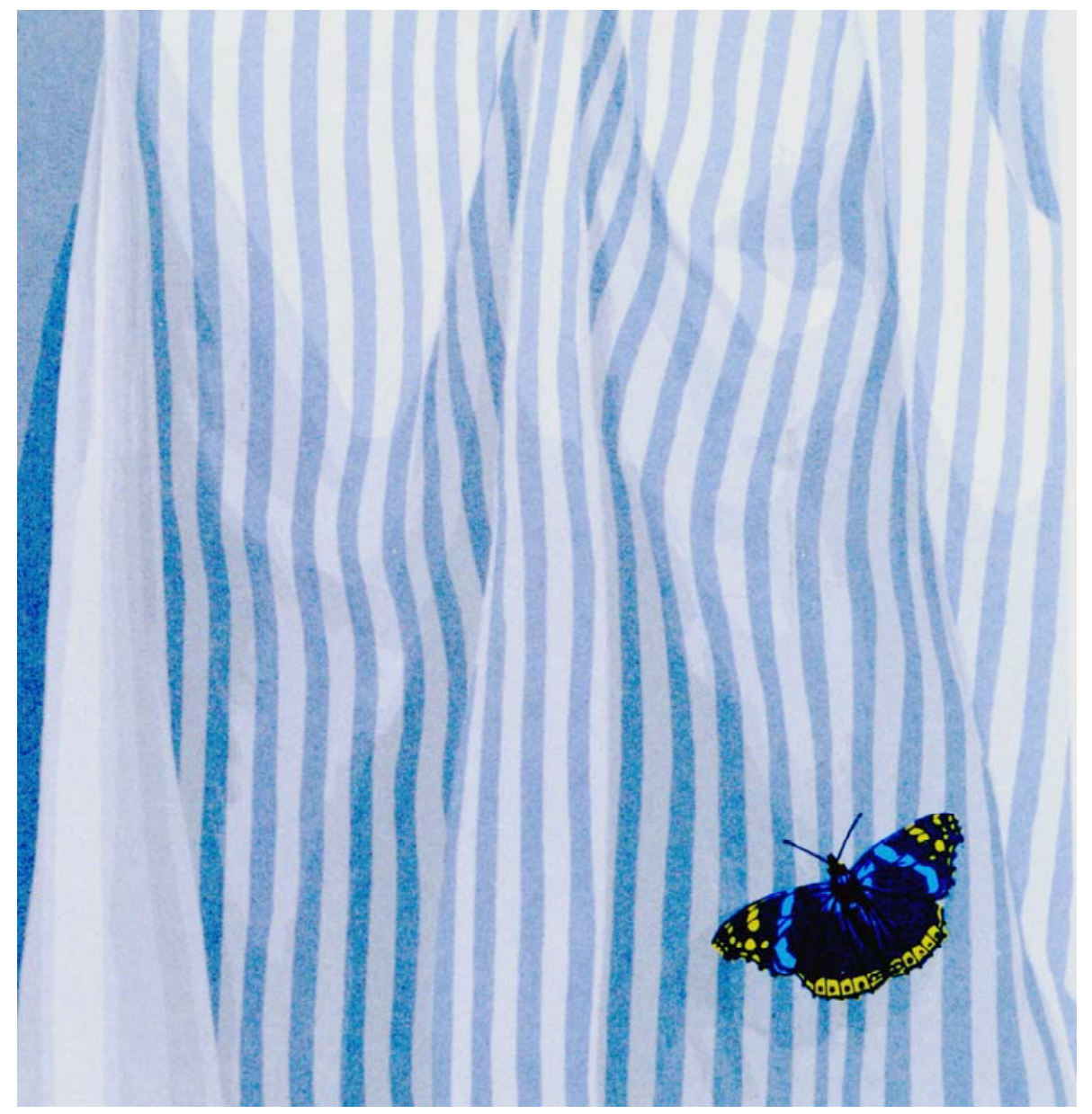

LÁMINA XLVIII

"Sin título"

Serigrafía

$35.5 \times 34 \mathrm{~cm}$.

1978 


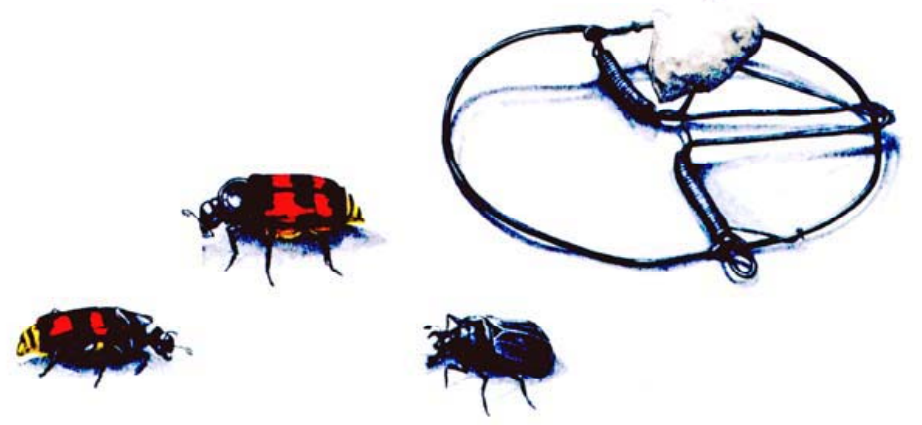

\section{LÁMINA XLIX}

"Sin título"

Litografía

$50 \times 70 \mathrm{~cm}$.

1978

349 


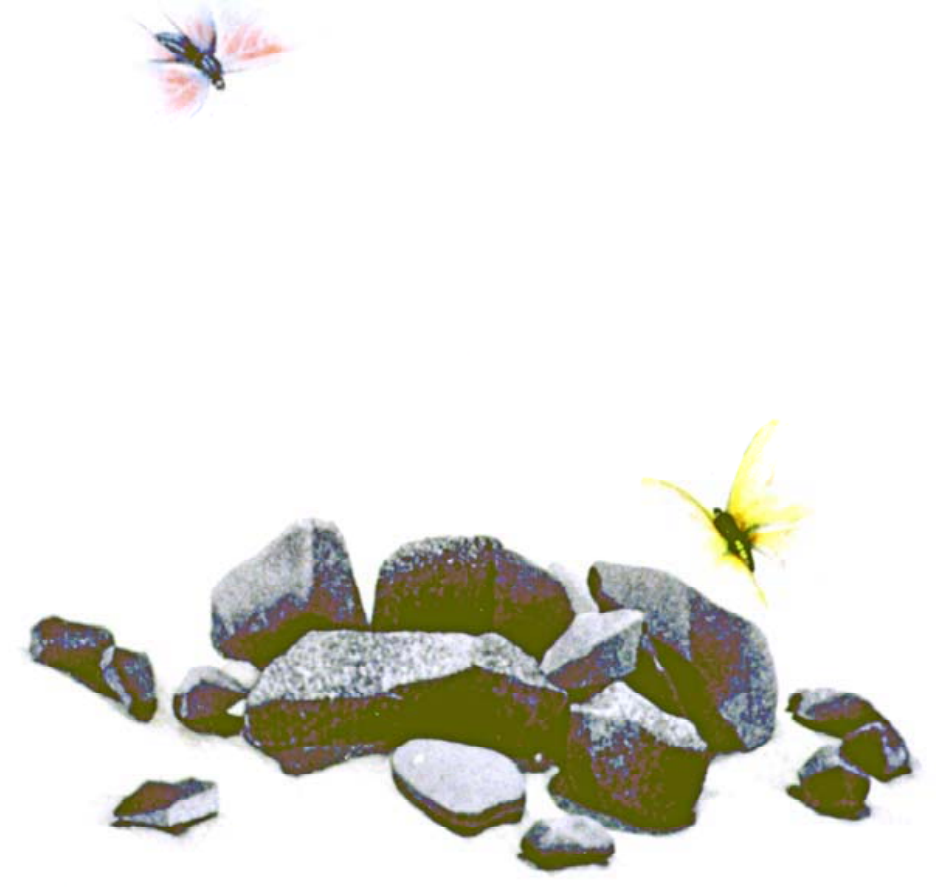

LÁMINA L

"Les pedres"

Litografía

$70 \times 50 \mathrm{~cm}$.

1978

350 
FINESTRES 



\subsubsection{CONCEPCIÓN Y LENGUAJE}

Acabada la dictadura franquista las rejas que permanecían todo el tiempo cerradas, empiezan a abrirse poco a poco hacia el mundo exterior convertidas en ventanas. El deseo de independencia y libertad mantenido a lo largo de toda su producción artística, se continúa percibiendo en esta serie, a través de la representación de esas ventanas generalmente cerradas, que obstruyen la mirada hacia el exterior.

Estas ventanas sugieren que son agujeros abiertos en el plano, que se resuelve con la construcción de una cornisa tradicional. Los ángulos y lados que construyen las ventanas se 
ubican activamente alrededor del espacio de luz, manteniendo su integridad y ofreciendo al espectador la posibilidad de imaginar una vida luminosa al otro lado de ellas. Esta operación se completa con un juego de luces y sombras que ayudan a crear la sensación de contrastes entre el espacio abierto del exterior y el abrumadoramente espacio cerrado del interior.

Cuando uno mira desde una ventana se pone en lugar de quien está en un interior y mira hacia afuera, sin embargo esta acción es más un deseo de libertad que una realidad, en tanto que la ventana cerrada y acristalada se convierte en una barrera que no permite franquear el espacio y ampliar horizontes, creando así un sentimiento de nostalgia y aflicción.

En una ocasión dije que ¡bien ya no hago rejas! y abro las ventanas. Ya no hago rejas, pero estoy en el campo y hago hierbas, al final son lo mismo, las rayas, las piedras que no permiten el paso. ${ }^{167}$

El mundo exterior que percibimos a través de las ventanas, se hace visible ante nosotros por la presencia de una luz resplandeciente que filtra desde el exterior, mas no logramos contemplar ese universo, sólo nos lo imaginamos, ya que no existe ninguna representación que haga referencia a esa realidad física, únicamente unos espacios de luz atmosférica que provienen del blanco del papel, con los que Pilar Dolz quiere dar oportunidad al observador para que entre deliberadamente en la obra y haga su propia elucidación.

${ }^{167}$ Entrevista mantenida con la autora en Castellón de la Plana. 09/04/2002 
De este modo la artista también asume que no obstante la ventana es algo más que eso, es un elemento que da luz y facilita la posibilidad de intercambio social al ser humano, dos cosas de las que no podemos prescindir. El hombre es un ser que mira, quiere ver y ser visto. Por eso la Humanidad ha valorado y celebrado la presencia de este elemento, regocijo que puede verse en el modo de como se han adornado y decorado, convirtiéndolas en algunas ocasiones incluso en verdaderos santuarios. ${ }^{168}$

La utilización en esta serie de ciertos elementos formales pertenecientes a la anterior, Ocells morts de la que extrae la imagen de la paloma de la paz, nos lleva a relacionarla inmediatamente tanto con ella, como con la de Reixes, donde podemos apreciar que aparece encarcelada y torturada, víctima de la represión del ser humano. Ahora, esta figura de la paloma de la paz aparece nuevamente enclaustrada y atada con una cuerda, dentro de una habitación con las ventanas cerradas. Indudablemente esta imagen nos provoca la misma sensación de impotencia que aquellas palomas muertas o aquellas mujeres torturadas realizadas en series preliminares. (Véase LAM. LI)

Si te das cuenta es como una reja, una ventana cerrada con el pájaro, pero cuando se abre la ventana hay una cuerda. Son ventanas de mi taller. Esto es inventado, yo no tenía una paloma atada en la ventana. ${ }^{169}$

En este conjunto de obras intervienen varios factores fundamentales, como son los espacios interiores (llenos) que

\footnotetext{
${ }^{168}$ Véase BELJON, J.: 1993. p. 104.

${ }^{169}$ Entrevista personal con la autora en Castellón de la plana. 27/04/2006.
} 
configuran la propuesta formal de la obra, en combinación con los espacios exteriores, (vacíos) determinados por las áreas de luz que se filtran desde las ventanas.

Estas formas y disposiciones espaciales, mantienen un cierto grado de diferenciado paralelismo con series anteriores y posteriores. Por ejemplo los interiores que tienen que ver con los espacios cerrados, áreas cubiertas, marcadas por la estructura de los muros y tabiques que configuran la construcción del habitáculo, contrastan con los trabajos realizados en las series de mujeres, Reixes, Ocells morts e Insectes, donde los distintos elementos se sitúan en espacios totalmente abiertos.

Esto confirma el interés de Pilar Dolz, por representar los espacios abiertos, espacios que hacen alusión a las zonas de luz que destilan a través de las ventanas, una especie de pequeñas claraboyas por las que es posible mirar hacia el otro lado. Este planteamiento nos transporta a las series de formas y mujeres, en las que unos agujeros $u$ orificios atravesaban sus formas, induciéndonos a imaginar que tal vez podríamos observar a través de ellos. Estas ventanas quieren ser lo mismo, una perforación, un hueco en la pared, por la que se tiene acceso al mundo exterior y se nos ofrece la posibilidad de echar un vistazo a través de ella. ${ }^{170}$

\footnotetext{
${ }^{170}$ En la antigüedad, el hueco era una salida para el humo y una entrada para la luz. No obstante una ventana es mucho más que eso, la ventana física y metafóricamente es un elemento que da paso hacia el mundo exterior. Véase BELJON, J.: 1993. p.104.
} 
En lo que respecta al lenguaje cromático, no utiliza el color con una intención claramente definida, pues se decanta abiertamente por el planteamiento monocromático. ${ }^{171} \mathrm{El}$ volumen y la profundidad, la luz y las sombras son creados con grafismos de tinta negra sobre el blanco del papel, convirtiéndolo en una metáfora de luz en medio de un mundo de penumbras, que es capaz de meter al espectador en un universo mágico y misterioso. Mediante el entrecruzamiento de las líneas y, en algunos casos, a través de la fusión de tonos obtenidos con el graneado de la resina, crea una amplia gama de sombras y texturas que otorgan a las imágenes belleza, claridad y tridimensionalidad, y conceden a su obra un gran realismo.

La composición, la luz, el sombreado y la profundidad espacial mediante la perspectiva lineal, son los intereses de la artista, que utiliza las leyes ópticas de representación de la naturaleza con cierta apariencia de realidad basada en la observación, algo que ya hemos venido viendo en series anteriores como Ocells morts e Insectes.

Sin duda sus experiencias de estudio llevadas a cabo en Italia a partir de 1970, le pusieron en contacto directo con las obras del Renacimiento. Esto sumado a la enseñanza clásica que recibe allí y su pasión por los artistas clásicos a quienes toma como modelo, le llevan a practicar una técnica depurada, donde el juego gráfico de blancos, negros y grises da vida a sus composiciones.

\footnotetext{
${ }^{171}$ Es muy eficaz para expresar el volumen mediante la escala de grises, que es ilimitada. Véase ARNHEIM, R.: 1993, p. 396.
} 
Yo en ese momento miraba la obra de Rembrandt, de Durero y me parecía delicioso. Si me dices a quién tienes como modelo, yo miraba esos grabados. ${ }^{172}$

${ }^{172}$ Entrevista personal con la autora en Castellón de la Plana. 27/04/2006 


\subsubsection{ASPECTOS COMPOSITIVOS}

\section{Composición}

Cuando Pilar Dolz realiza las ventanas, éstas quedan representadas estableciendo una estructura espacial muy definida, que permite apreciar claramente sus relaciones armónicas; para ello se apoya en el juego de luces y sombras que ayudan a mostrar las diferentes relaciones espaciales de la imagen representada.

La luz juega un papel muy activo, la distinguimos conformando unos espacios luminiscentes, que con determinada dirección, penetran en una estancia cerrada y oscura, aplicando toques de luminosidad a cada uno de los elementos que se encuentran en ella. Algunas veces estas formas son acariciadas con bastante intensidad, mientras que otras permanecen en la penumbra e incluso en la oscuridad, creando un efecto atmosférico muy denso. La artista normalmente rompe la relación entre los espacios representados, trazando fronteras de oscuridad y claridad en la superficie muy significativas. Así por ejemplo coloca la imagen clara del hueco de la ventana que se manifiesta dentro del campo oscuro de la estancia, y la mantiene libre de sombras. El resultado son unos interiores que aparecen muy dibujados pero se sugiere que encierran interiores prácticamente vacíos, en donde lo que más llama la atención es la presencia de la luz que penetra por la ventana. En LAM. LII, por ejemplo el espacio de luz se encuentra localizado por detrás de la representación de una cortina gris. Sobre la mesa y las paredes que rodean la instancia se aprecia el reflejo de su esplendor, recreando así una sensación de penumbra en el 
ambiente que fascina. El impacto de los espacios deslumbrantes y su contraste con las zonas de oscuridad se convierte en una fuente de excitación para la imaginación.

La artista hace uso de su conocimiento sobre la luz que es algo más que la causa material de lo que vemos, es una de las experiencias humanas más fundamental y poderosa. ${ }^{173}$

La idea del lleno y el vacío aparece en la obra de forma complementaria, formando parte el uno del otro.

El vacío representado aparentemente por el espacio de luz que penetra por la ventana, surge asociado a la ausencia de tinta y de textura. ${ }^{174}$ Se soluciona dejando esta zona desocupada, sin la representación de detalles, y cuando éstos aparecen es mínima su sugerencia visual. De este modo juega con la dualidad sugerida por el hecho de que la ausencia absoluta de elementos físicos da cabida a la plenitud de elementos imaginarios. Así el carácter indeterminado de esta superficie concede a los objetos resplandecientes un carácter inmaterial.

El lleno figurado por el oscuro, emerge en la obra representado por el muro contenedor de la ventana y constructor de los interiores, donde las formas juegan a hacerse visibles gracias a la valoración del claroscuro. La diferencia entre los dos tipos de

\footnotetext{
${ }^{173}$.La luz es la fuerza visual clave, para el hombre es requisito previo de casi toda actividad En el proceso de la visión dependemos de la observación de las gradaciones de tono para ver objetos. Véase DONDIS D, A; 1985, p.105.

${ }^{174} \mathrm{La}$ textura presta opacidad y solidez a los objetos. Un objeto resplandeciente no cierra el paso a la mirada con esa especie de corteza externa. En términos de David Katz esto es como "un color laminar, más que color superficial". Mencionado en ARNHEIM, R.: 1993. p. 359.
} 
tonalidad, crea una estructura armónica de carácter espacial, construida por el contraste de las luces y sombras. (Véase LAM. LIII)

$\mathrm{Si}$, como ya se ha comentado, la presencia de la luminosidad se sintetiza por la blancura absoluta del espacio, sugerida por el claro del papel, la oscuridad se apunta por la presencia de tinta. La fuerza de matices que van del blanco al negro, contiene una serie de gradaciones tonales que construyen y dan vida a la imagen. El contraste tonal es tan importante en este conjunto de obras, que a través de éste percibimos claramente los efectos gráficos que nos permiten reconocer la penumbra, la profundidad y otras cualidades visuales relacionadas con la figuración y el entorno espacial.

En cuanto a las soluciones compositivas, diremos que la forma de la ventana como elemento constructivo, se convierte en el elemento director de la composición. Con esto Pilar Dolz quiere dejar claro donde empieza y donde acaba su observación a la vez que logra una buena relación de contraste armónico entre los elementos que se hallan a su alrededor. Un buen ejemplo de esto lo tenemos en LAM. LIV, donde la composición aparece claramente dominada por la presencia de la ventana luminosa que somete el resto del espacio. A su alrededor; hacia el lado izquierdo topamos con la figura de una pared solucionada en tonos muy oscuros, mientras que en la parte derecha encontramos otro plano trabajado también en tonos grises, pero un poco más claros. Por tanto toda la atención se centra en la figura de la ventana gracias a una estructura de equilibrio activo, en la que la luz es quien suministra esta jerarquía. Por eso utiliza la luminosidad de una forma estratégica, y como impacto visual, para solicitar la atención del observador. 
Respecto a la construcción de las formas, asistimos a la utilización de la línea recta; horizontales, verticales y diagonales, son el recurso para su creación. Este planteamiento espacial nos presenta una semejanza con respecto a la anterior serie, Reixes, donde el empleo de la recta establece y configura la iconografía del enrejado. Simultáneamente esta propuesta nos plantea también una diferencia, pues en Finestres la recta no se entrecruza, sino que se transforma en una línea angular o quebrada. ${ }^{175}$

En cuanto al sistema para sugerir la profundidad, la artista emplea varios recursos formales. Uno de ellos es la superposición de planos, ${ }^{176}$ procedimiento por el cual se consigue un efecto de profundidad por escalonamiento, lo que nos permite establecer un primer y último plano bien definido. La parte de la imagen que queda oculta se completa mentalmente. Un claro ejemplo de esto lo tenemos en LAM. LI, un grabado compuesto por dos estampaciones dispuestas en el mismo soporte a manera de díptico, en el que logramos localizar varios niveles de profundidad. Así en primer término la figura de una paloma se descubre solitaria en el interior de una habitación. En un segundo plano, aparece la representación de una ventana que en una de las estampas asoma cerrada, mientras que en la otra se exhibe abierta. Por último, en el plano final distinguimos la imagen de una ciudad en el horizonte. Esta forma de ubicar los elementos en la obra, sumado a que asigna a cada uno un tamaño en la escala genera facilita una percepción espacial de carácter profundamente realista.

\footnotetext{
${ }^{175}$ La diferencia entre las innumerables quebradas depende exclusivamente de la amplitud de los ángulos. Véase KANDINSKY, W.: 1993, p. 71.

${ }^{176}$ Nos referimos al uso de las técnicas de claroscuro y las convenciones perspectivas para crear formas volumétricas y espacios. Véase PARINI, P.: 2002, p. 135.
} 
Otro de los recursos manejados para introducir la profundidad es la perspectiva cónica, con la cual el espacio se presenta como un escenario donde los objetos representados se hacen más pequeños a medida que se alejan del espectador, manteniendo entre sí una relación fiel a la percepción realista. Así por ejemplo en LAM. LII y LIV, encontramos un tipo de perspectiva central, que presenta un planteamiento de composición simétrica, en donde el punto de vista de la artista se encuentra en el centro de la obra creando la ilusión de profundidad. Los efectos que produce la perspectiva se intensifican mediante el claroscuro, a través del uso espectacular de luces y sombras. (Véase Fig. 92)

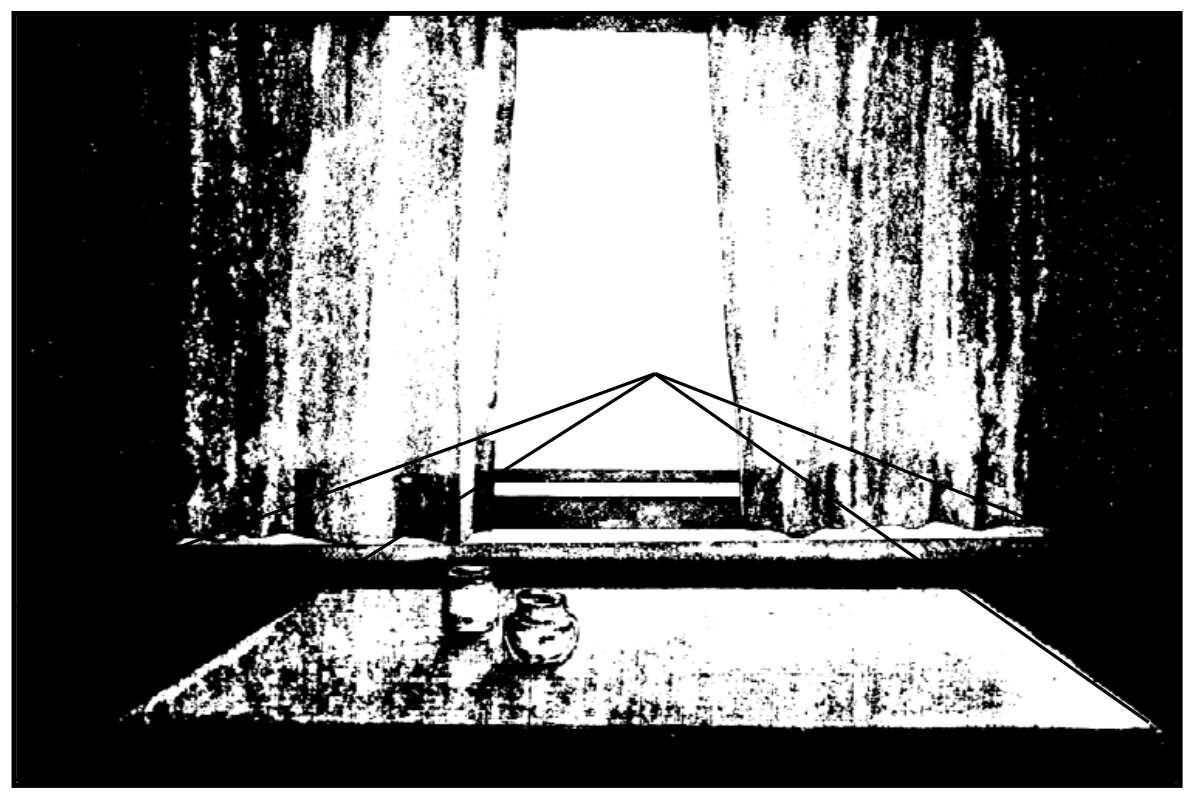

Fig. 92. Pilar Dolz. Detalle LAM. LII. Serie Finestres. Aguatinta. 1977.

En otras ocasiones el punto de fuga se traslada hacia un lateral, así las líneas paralelas se hacen convergentes y se pierde la 
simetría, por lo que la imagen cobra un efecto dinámico. Así por ejemplo en LAM. LIII, las líneas paralelas que conforman la imagen, confluyen desde derecha a izquierda en diagonal, generando en consecuencia una perspectiva oblicua y una imagen en profundidad. (Véase Fig.93)

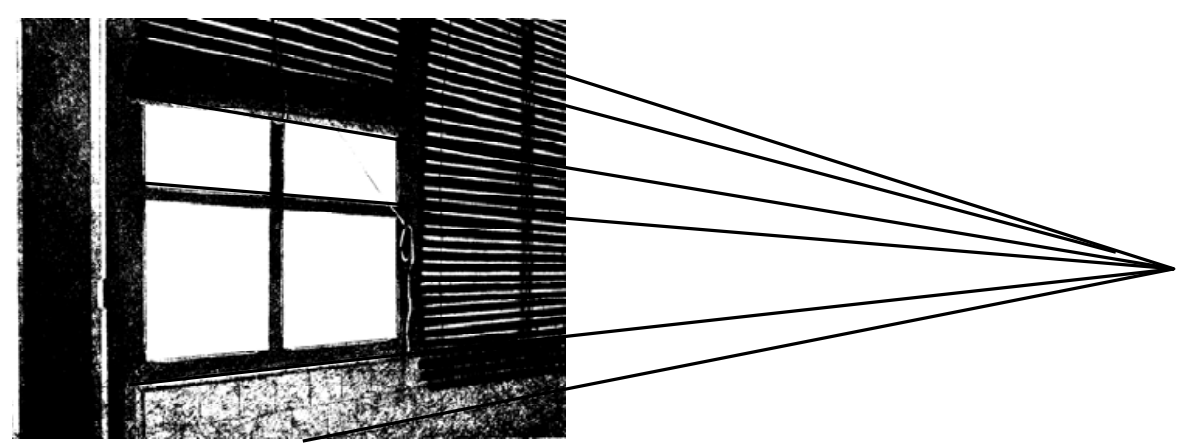

Fig. 93. Pilar Dolz. Detalle LAM. LIII. Serie Finestres. Aguafuerte. 1977.

En LAM. LV, en cambio la autora emplea una perspectiva oblicua en dos direcciones, por medio de la intersección de dos aristas convergentes que se ubican en direcciones opuestas, con la que la artista muestra la escena desde un punto angular con lo que define fácilmente el carácter cúbico de la habitación. Esta deformación de la imagen es el recurso mediante el cual puede representar la profundidad dentro del plano del papel. ${ }^{177}$ Estas obras son un claro ejemplo del proceso de transformación vivido por la artista cuando trata las complejas cuestiones de la luz y el movimiento. (Véase Fig.94)

${ }^{177}$ Véase. ARNHEIM, R.: 1993. p. 293 


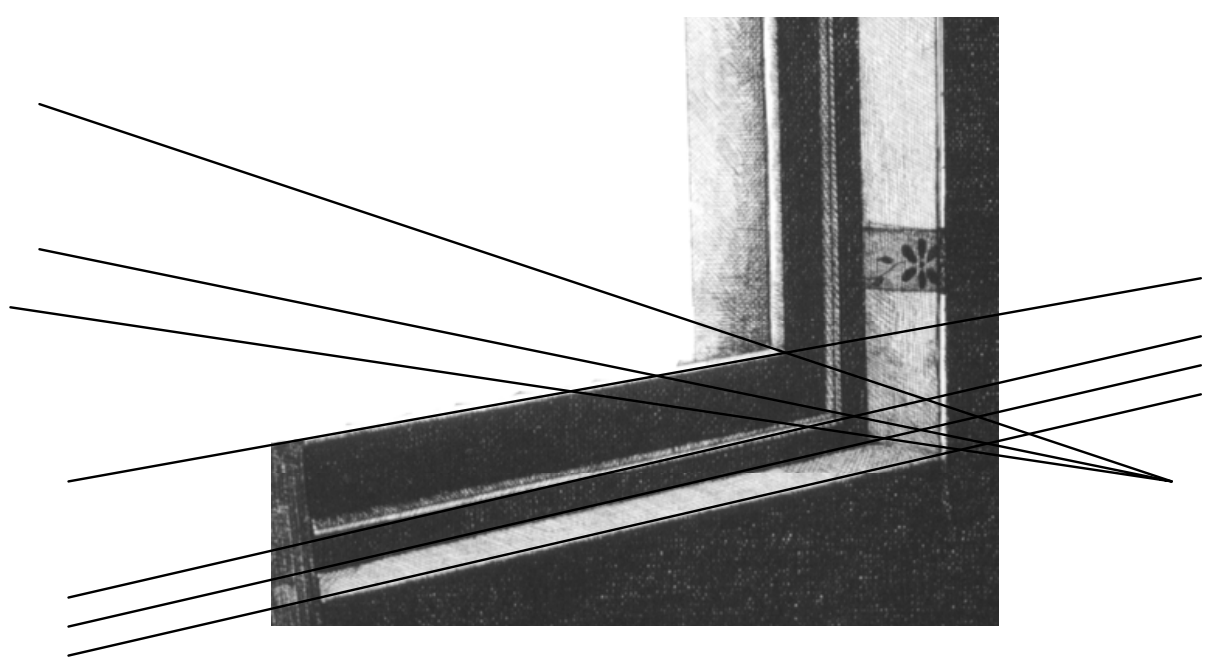

Fig. 94. Pilar Dolz. Detalle LAM. LV. Serie Finestres. Aguafuerte. 1977.

El claroscuro es otro de los elementos que utiliza abiertamente en combinación con las soluciones lineales relacionadas con la perspectiva para resolver el problema de la profundidad. ${ }^{178}$ Esta técnica le sirve para dar volumen, facilitando la percepción tridimensional de la forma, que aumenta y se contrae apoyándose en los tonos claros y oscuros. Las partes más claras se ven como zonas iluminadas, mientras que las zonas más oscuras se aprecian como partes en sombra. ${ }^{179}$

\section{Grafismo}

Si bien en esta serie aparecen nuevas preocupaciones, como los efectos de la luz y los espacios interiores, en lo que se refiere al objeto referencial, éste se encuentra constituido por un conjunto de

\footnotetext{
${ }^{178}$ Véase MARIS DANTZIN, C.: 2004, p. 153

${ }^{179}$ Las representaciones del volumen, la luz y la sombra son siempre construcciones de la mente. Véase PARINI, P.: 2002, p. 75.
} 
líneas finas y delicadas, trabajadas con gran minuciosidad dando lugar a amplias superficies que recrean el carácter de las cosas hasta darles un aspecto real. Se trata de la combinación de líneas paralelas simples, dispuestas ya sea en una sola dirección o en varias, de forma continua o interrumpida, creando grafismos con más o menos densidad que se leen como conjuntos únicos. La línea abandona así toda intención de individualización y se funde en una masa compacta que enriquece plásticamente la superficie. Este trazo tiene un valor constructivo porque cimenta la forma en el espacio de una manera contundente; las superficies tonales formadas modelan el volumen y su sombreado a través de una degradación tonal. En combinación con éste aparece otro gesto particular, más dibujístico, que insinúa la silueta de la forma de un modo casi imperceptible en el conjunto global, pues es neutralizado visualmente por las grandes masas tonales que le rodean. La pericia de su trabajo le permite mantener y aprovechar las líneas que realiza, con gran dominio. (Véase. Fig. 95)

Eso es una época que yo me sentaba allí y eso que lo haces relajado. Eso es todo cruzado con línea. Son una series de ventanas un poco mas abiertas iy me pasaba haciendo rayitas hasta las doce! ${ }^{180}$

${ }^{180}$ Entrevista personal con la autora en Castellón de la Plana. 21/03/2007 


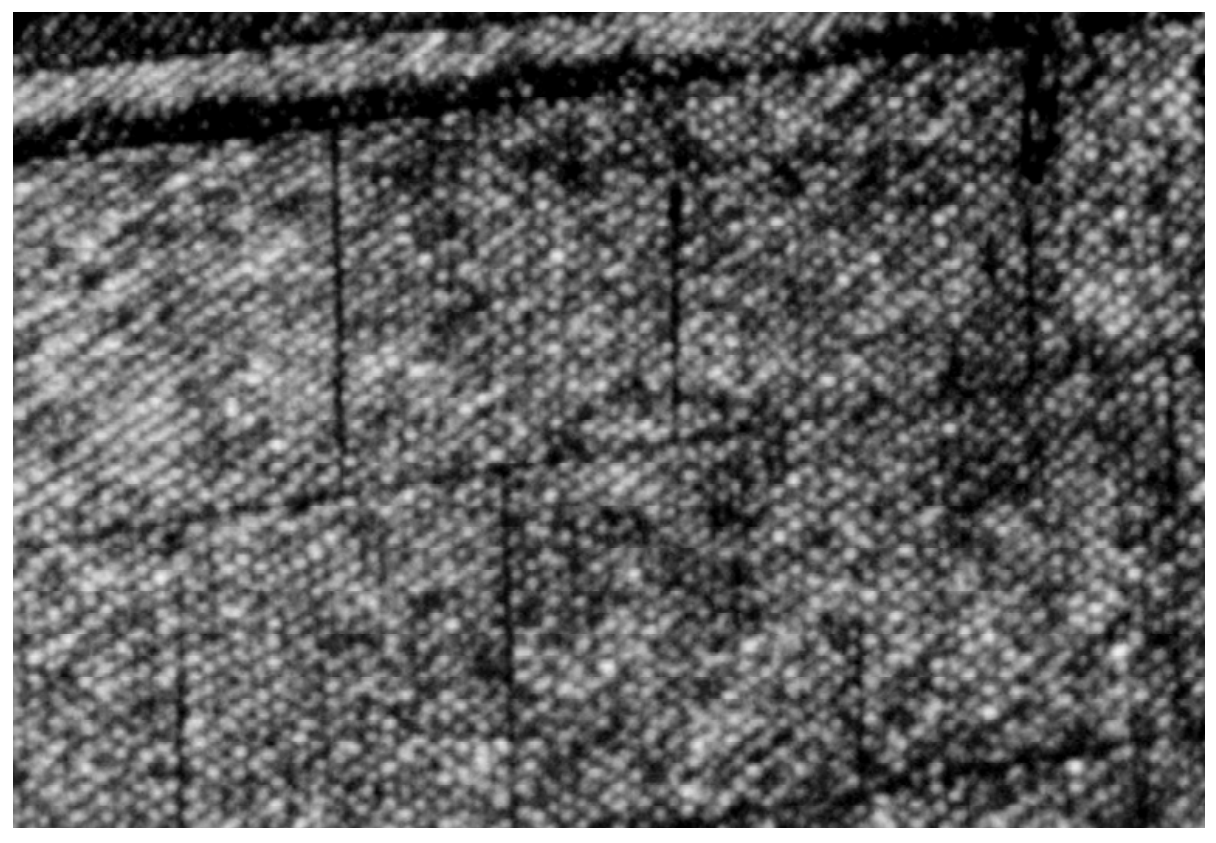

Fig. 95. Pilar Dolz. Detalle. LAM. LIII. Serie Finestres. Aguafuerte. 1977. 


\subsubsection{PROCESO TÉCNICO}

La totalidad de la obra que compone esta serie se halla trabajada con la técnica de aguafuerte, con dos variantes; aguatinta y aguafuerte. La impresión de las estampas en blanco y negro, intensifica la percepción del efecto lumínico de las luces y sombras, cuya finalidad conceptual juega con recrear el ambiente de penumbra de los espacios interiores.

En primer lugar encontramos un grupo de grabados realizados al aguatinta, en los que la línea interviene solamente para definir la forma y delimitar tonos. El aguatinta en esta serie se trabaja de dos formas diferentes. Así, en LAM. LI, la artista recurre a la técnica de la pulverización de la resina y su posterior ataque al ácido. Con lo cual obtiene distintos valores tonales que aparecen claramente diferenciados, en los cuales podemos distinguir manifiestamente la textura dejada por los distintos tipos de grano de la resina, empleados para la creación de la obra.

En LAM. LII, en cambio se trabaja siguiendo el mismo procedimiento, sólo que una vez realizadas las correspondientes mordidas, la artista procede a bruñir la plancha suavemente, de tal manera que el bruñidor actúa sobre la matriz, como una goma de borrar sobre el papel, produciendo un efecto en el que combina la fórmula del aguatinta con la manera de mezzotinto. Normalmente se utiliza este procedimiento para reducir la fuerza de los contrastes en los valores tonales y aclarar ciertas zonas. Con esta acción se consigue un resultado con efectos más sutiles, donde la textura de la resina se hace más suave, dando a la imagen una gran 
transparencia, esto lo podemos ver en LAM. LII, la suavidad de los tonos destaca la nitidez y el deslumbramiento de la cortina, de tal manera que parece que podamos ver a través de ella. El resultado es una obra sensacional que abre nuevas posibilidades a los elementos gráficos. (Véase Fig.96)

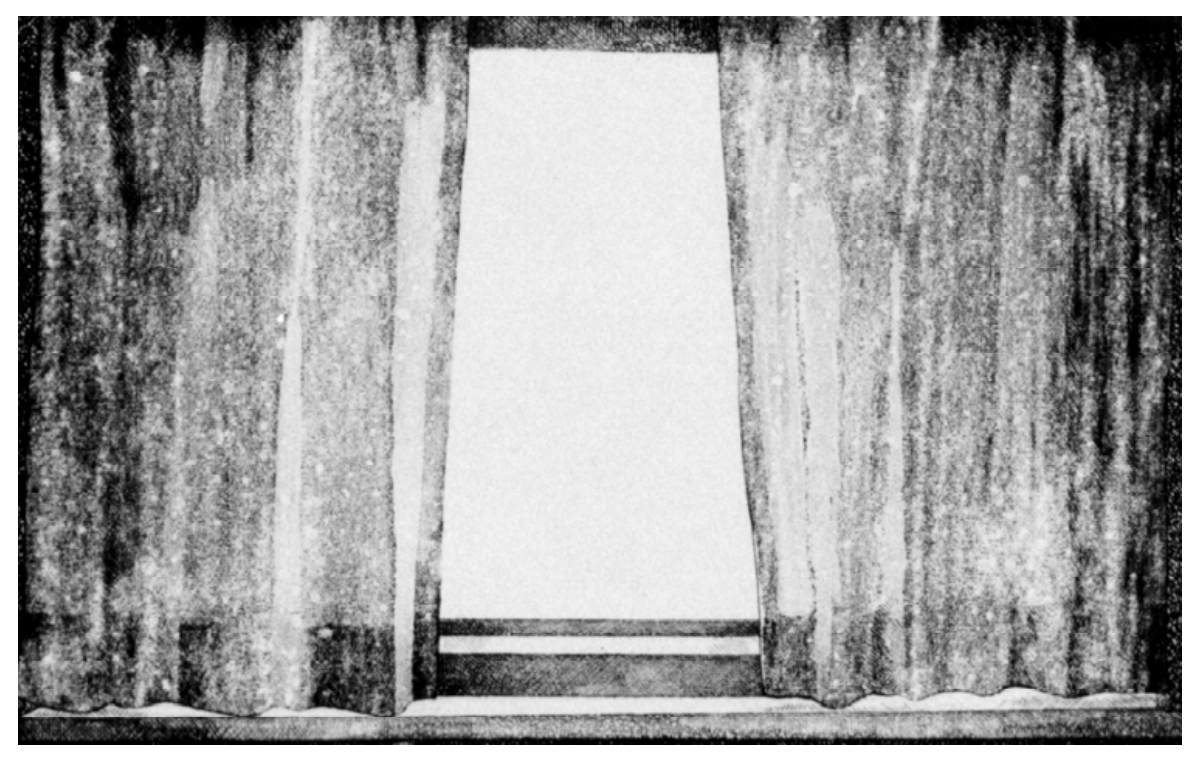

Fig. 96. Pilar Dolz. Detalle. LAM. LII. Serie Finestres. Aguatinta bruñida. 1977.

Un segundo grupo de obras de esta serie, realizadas al aguafuerte con un sentido estrictamente ortodoxo de la técnica, grabadas en planchas trabajadas con una punta de metal fina, que les proporciona unos trazos delicados. La cualidad de la línea precede a la mordida del ácido, el cual aporta, al actuar, una cierta variedad a los surcos y por tanto a los tonos. 
En unos casos la disposición entrecruzada del trazo en horizontal, vertical o diagonal, deja unos espacios de luz entre ellos, que vibran con la luminosidad del papel. En otros casos se sobrecarga de grafismos, que estrechan los espacios con la intención de conseguir negros más profundos y homogéneos, que se convierten en sombras absolutas y proporcionan una atmósfera abrumadora en la imagen. La combinación de gestos gráficos determina la valoración de claroscuro de sus estampaciones, que alcanzan las expresiones más bellas del aguafuerte. (Véase Fig.97)

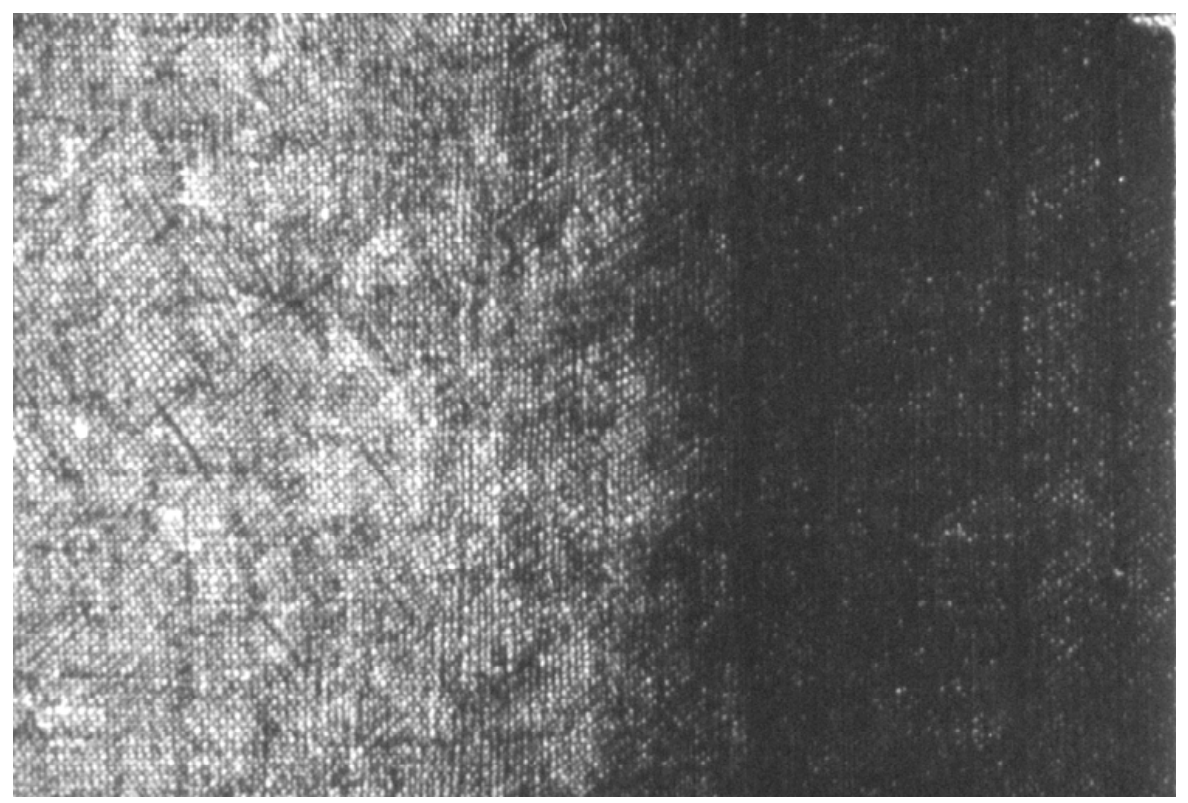

Fig. 97. Pilar Dolz. Detalle LAM. LV. Serie Finestres. Aguafuerte. 1977. 
LÁMINAS

\section{INESTRES}




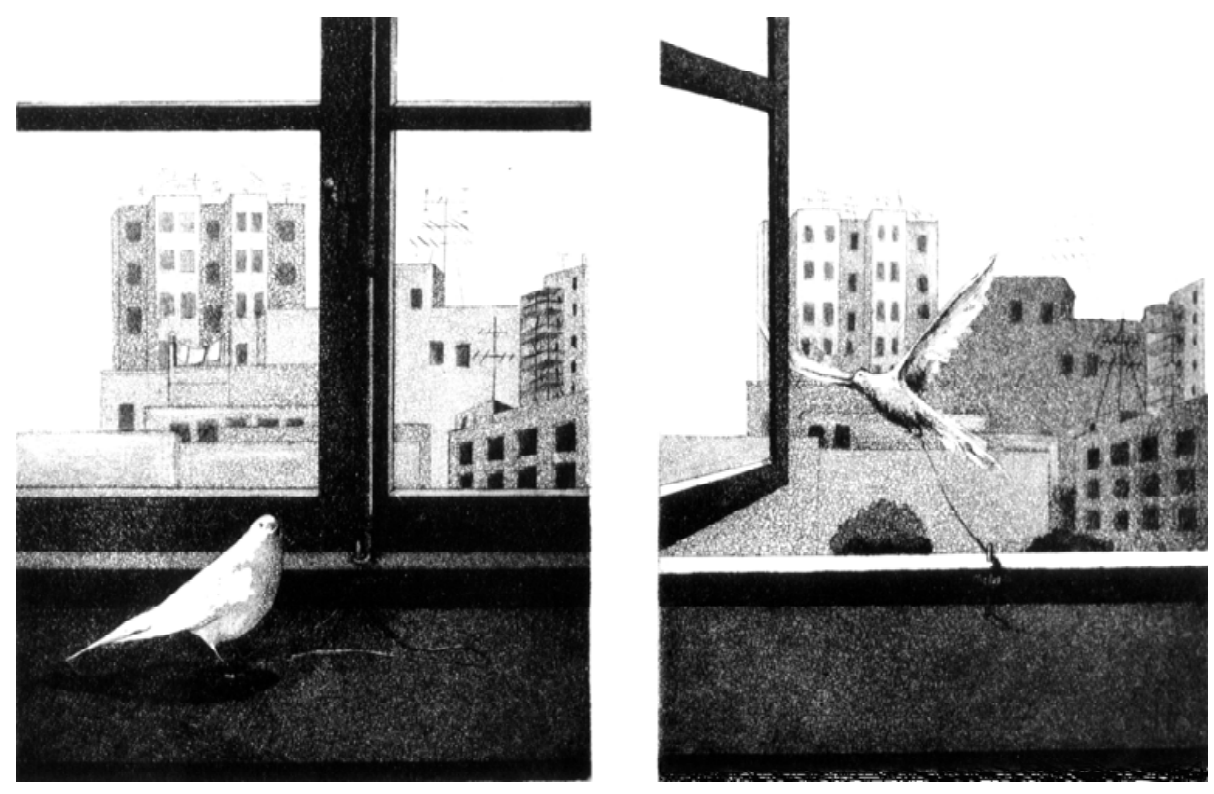

\section{LÁMINA LI}

"Sin título"

Aguatinta

$16 \times 34 \mathrm{~cm}$.

1977 


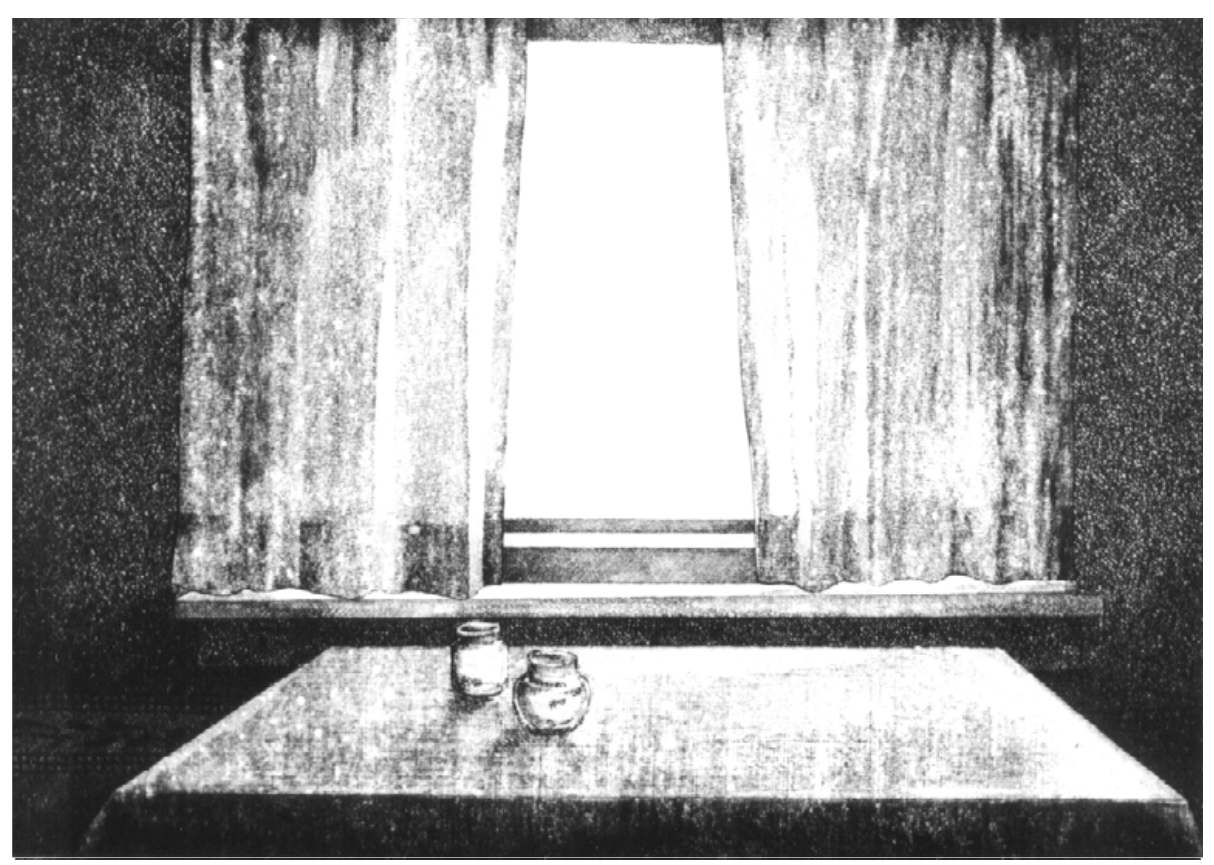

\section{LÁMINA LII}

\section{"Sin título"}

Aguatinta bruñida

$13.5 \times 21.5 \mathrm{~cm}$.

1977 


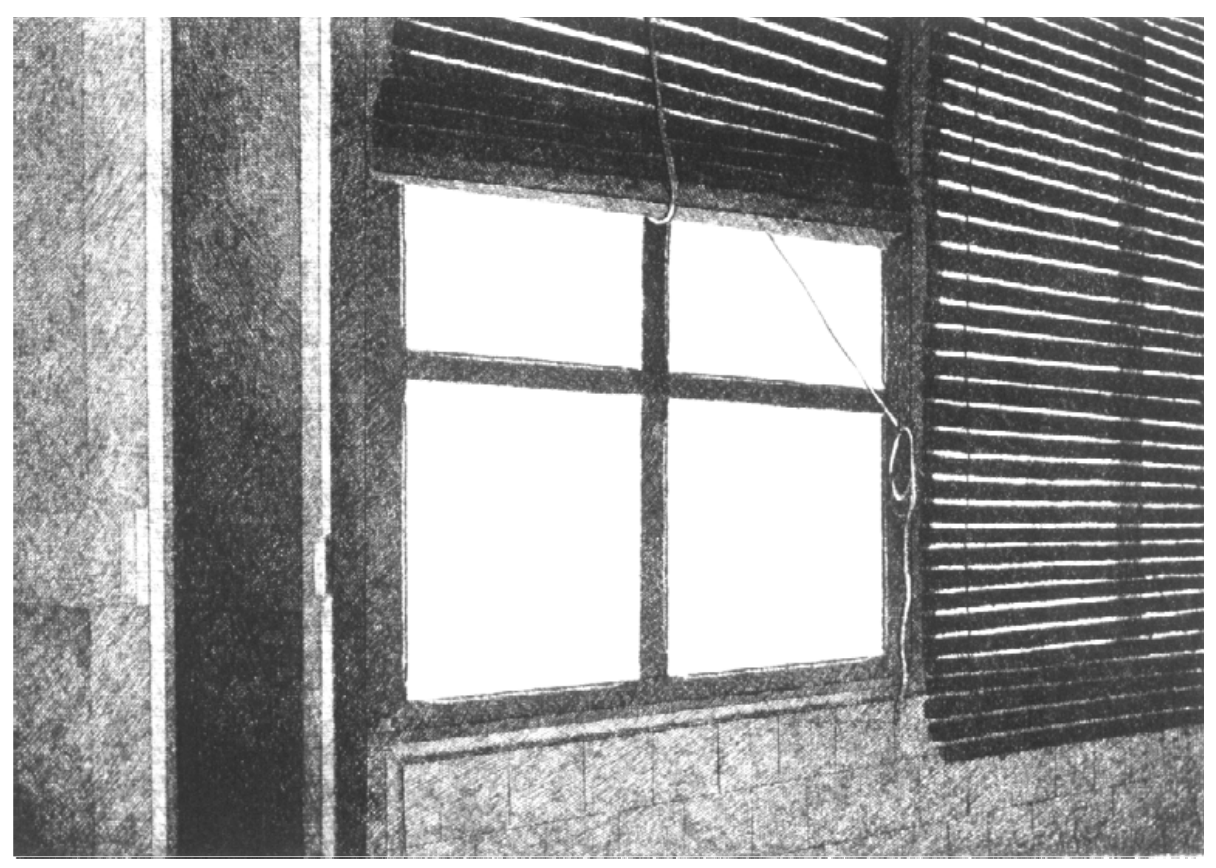

\section{LÁMINA LIII}

"Sin título"

Aguafuerte

$13.5 \times 21.5 \mathrm{~cm}$.

1977 


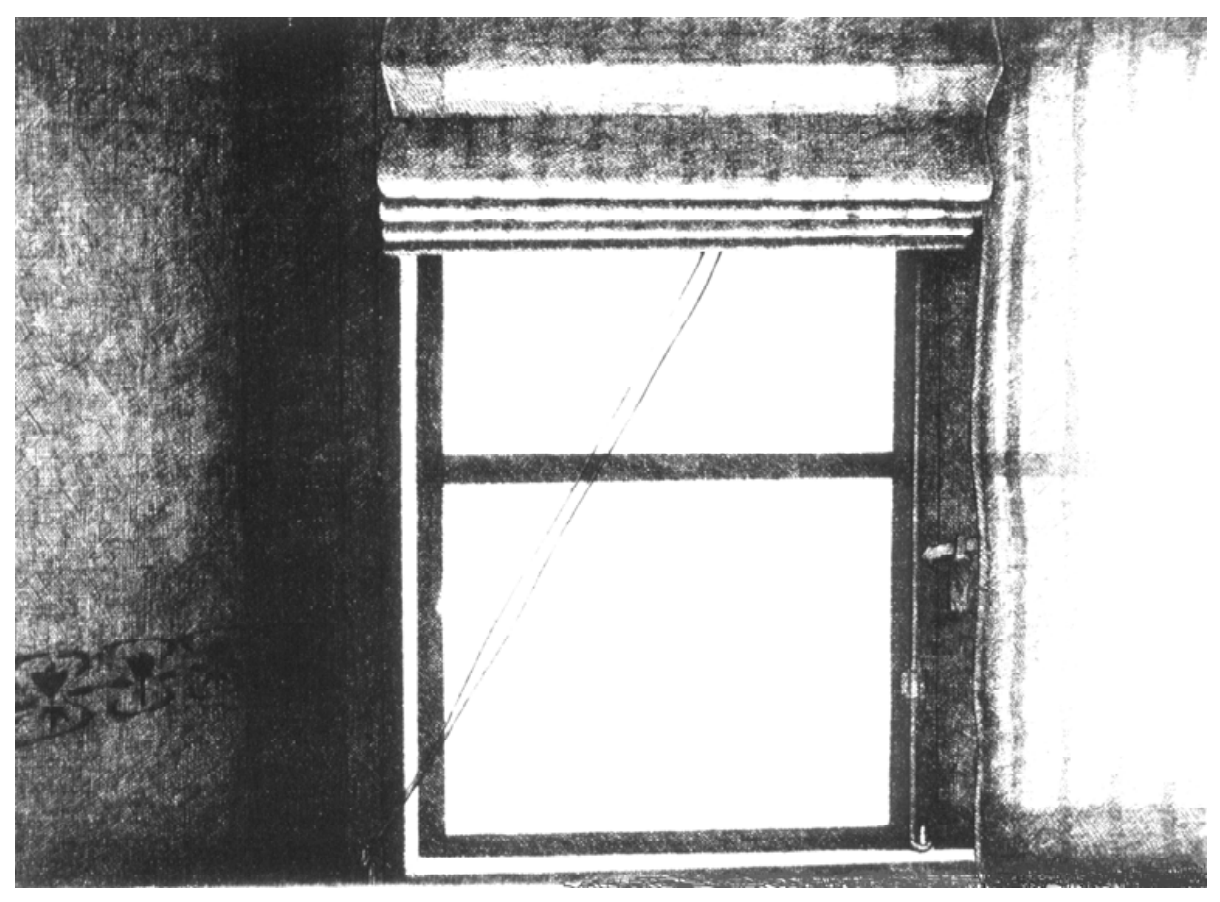

LÁMINA LIV

"Sin título"

Aguafuerte

$13.5 \times 21.5 \mathrm{~cm}$.

1977

376 


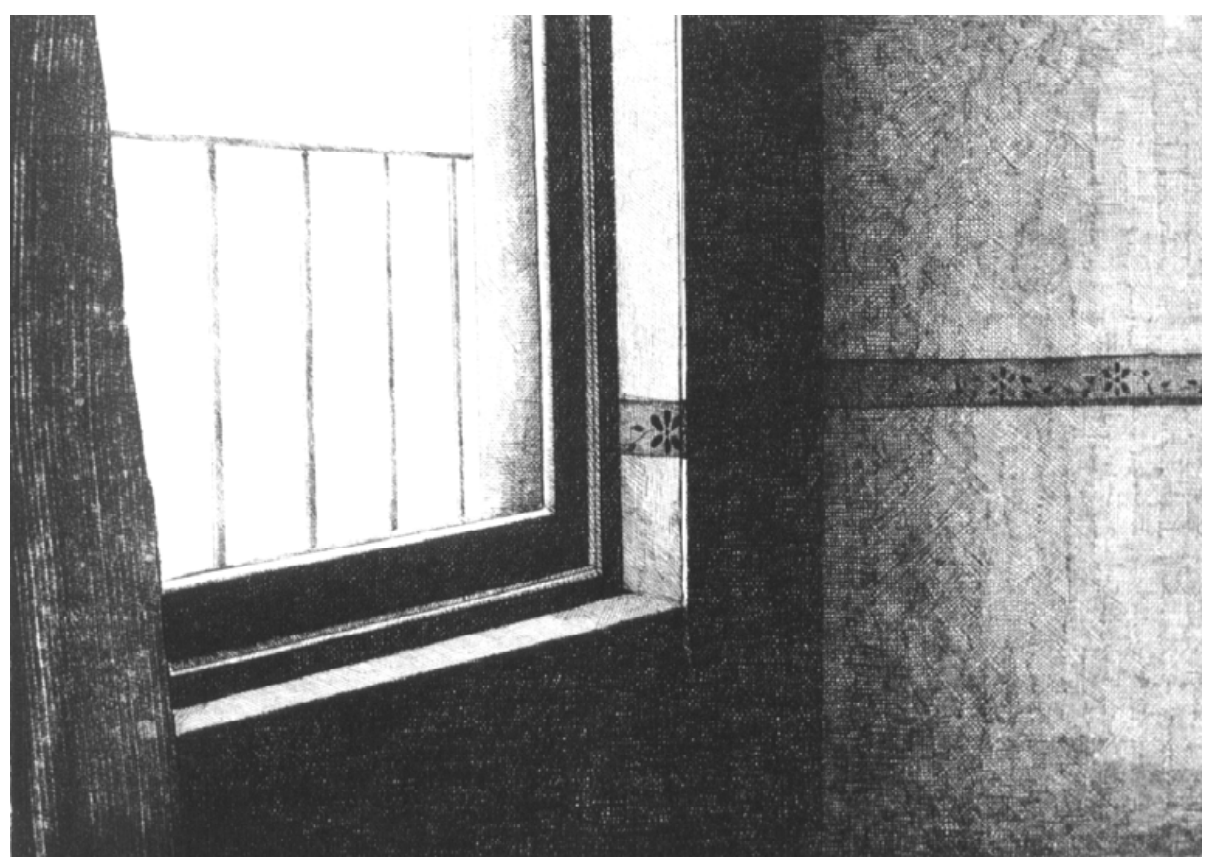

\section{LÁMINA LV}

"Sin título"

Aguafuerte

$13.5 \times 21.5 \mathrm{~cm}$.

1977 
PEDRES I PAISATGES DELS PORTS 



\subsubsection{CONCEPCIÓN}

Pedres i paisatges dels Ports realizada entre 1977 y 1978, marca un antes y un después en la producción artística de Pilar Dolz, evidentemente la muerte de Franco produjo un cambio de dirección en su trabajo creativo, que supuso una reconsideración de las motivaciones estéticas y el alejamiento de la posición crítica que la había caracterizado durante la dictadura. Emprende esta nueva etapa con una obra de contenido esencialmente plástico, en la que hace alusión a otro tipo de preocupación, que nos presenta todo un mundo de esfuerzo y trabajo humano. Éste es uno de los momentos claves de su evolución artística. 
En esta serie la artista dirige la atención hacia la realidad física de su entorno, de la naturaleza, en la que sabe elaborar una eficaz metáfora de la existencia humana, un referente que se prolongará en posteriores series, en las que despliega diversos tratamientos plásticos y conceptuales en una reflexión en la que sigue ocupada hasta el momento.

El objeto de representación de este conjunto de grabados son los paisajes, que mediante formas empíricas simboliza la manera de ser y actuar de los hombres de un lugar concreto, de las comarcas interiores del país valenciano. Encontramos en esta serie unas motivaciones vitales, que son inherentes a la propia artista, que vuelve sobre el recuerdo y las vivencias más personales de su tierra natal, Morella, ${ }^{181}$ lugar habitado por los más íntimos recuerdos de su infancia, donde sus padres estaban en posesión de una propiedad familiar, en la que durante tres generaciones vivió toda la familia y en la que nació y vivió también Pilar Dolz. ${ }^{182}$

Sobre este escenario de especial conformación geográfica, nos transmite algo de sus raíces, a través de la representación de un paisaje diferente, con una belleza que nada tiene que ver con el verde y voluptuoso paisaje de las tierras húmedas. Se trata más bien del seco y árido paisaje, ${ }^{183}$ en el que hallamos una fuerza simbólica

\footnotetext{
181 "Morella está enclavada como una piedra gigante sobre la montaña pétrea, firme, enhiesta, vertical. Es una villa peregrina, siempre señorial y un poco entregada al sueño de los siglos, reliquia venerable de Castellón, lugar de poesía y silencio. Nos atrae la misma expresión de sus semblantes de piedra como si fuesen a contarnos graves secretos de eternidad" Citado en SALCEDO MILIANI, A.: 2000, p. 485.

${ }^{182}$ Era una casa grande donde vivíamos junto a los abuelos y toda la familia (...). Todavía existe tal como lo hizo mi abuelo, ahora vacía porque es muy grande y no vive nadie. Entrevista personal con la autora en Castellón de la Plana, 27/04/2006.

${ }_{183}$ Para el habitante de la huerta o de la ciudad, el secano se identificaba con imágenes negativas de esterilidad. Ya en el siglo XI el poeta "Ibn Jafaya de Alzira, se enfrentaba a estos paisajes agrestes y montañosos como representaciones del ocaso". Posiblemente
} 
que es capaz de transmitir emocionalmente a todo aquel que se aproxima a su obra.

Yo creo que siempre mi paisaje, si te das cuenta es muy árido en todas partes, no son un paisaje con ese verdor, son más paisajes de piedras, y sobre todo eso son dels Ports, (...), pero suele ser de piedra, ¿no se por qué?, claro es mi paisaje, de mi ciudad, dels Ports, de Morella. ${ }^{184}$

Sobre este escenario vital, hay otras motivaciones que explican la fijación de Pilar Dolz por este espacio, y es el azar, la casualidad y el inconciente, que provocan la aparición de una serie de manchas sin ninguna intención estética, pero que se convierten en el elemento generador de su obra.

Para entender el origen y encontrar en ella un planteamiento semejante, nos remontamos hasta su temprana serie de formas, en la que se sirve del automatismo psíquico, que viene de manos del Surrealismo, para por medio de un lenguaje de signos, dar origen a un simbolismo biomorfo, que da vida a unas sugerentes representaciones de cuerpos humanos. (Véase Cap. III.1.1)

Más tarde en la siguiente serie de cuerdas, trabaja con unas formas figurativas que parten inicialmente de la casual aparición de unas manchas. (Véase Cap. III.3.1) Desde el primer momento el automatismo, el azar, lo accidental, resultó ser el medio idóneo para

esta negativa visión se acusaba al contraste vivido entre la ordenada vida de la abundancia agrícola y la dureza de la vida del pastor. Véase. GRACIA, C.: 1998, p. 43.

${ }^{184}$ Entrevista personal con la autora en Castellón de la Plana. 21/03/2007. 
proyectar sus creaciones. Esta relación de paralelismo evidencia la continuidad de ciertos intereses comunes a toda su obra.

En Pedres i paisatges dels Ports, la presencia de unas manchas realizadas por la disposición arbitraria de resina en polvo de diversos calibres sobre la plancha de metal (aguatinta), da lugar a la agrupación orgánica e irregular de unos puntos que ella identifica con la apariencia de unas formas áridas, que se le revelan atractivas y le conectan con las imágenes de su pueblo. Se trata de unas representaciones de carácter ilusorio que no han sido creadas a partir de ningún referente, sino que son fruto del enfoque de la artista, amante de la ficción. La figuración no es equivalente a pensar en formas racionalizadas y asumidas, ya que no es una trascripción mimética de un paisaje o una realidad, sino que entraña cierta ambigüedad, en la que encontramos un parentesco entre formas imaginadas y formas reales. Este planteamiento estético contiene ciertamente influencias surrealistas, que justifican la consideración del Arte como el espacio idóneo para la libre expresión conjugada de la fantasía y la razón, donde lo consciente y lo inconsciente, se funden en una nueva realidad, en la que toda contradicción humana queda aceptada cercana a las ideas que imaginamos afines a Salvador Dalí. ${ }^{185}$

Yo no sé por qué hice paisaje, te lo digo de verdad, no te lo sabría precisar por qué (...), pero a mí me aparece de una forma inconciente. Yo no pretendí explicar algo del paisaje de mi país, o sea realmente después surgió, y después lo explicas, una vez hecho intentas darle un... Pero a mí me parece que yo al inicio lo hice inconcientemente (...). Las formas surgen

${ }^{185}$ Véase nota 100 
de repente, yo parto de una mancha y de repente aparecen estas formas figurativas de piedras, de paisajes áridos y potencio lo que me sugiere, son presencias casuales con un gran poder sugeridor. ${ }^{186}$

En cuanto al planteamiento formal, lo encontramos próximo a los de Reixes y Ocells morts, donde procede a seccionar la plancha para introducir el color. En esta serie de paisajes igualmente recurre a cortar la plancha en dos partes, dispuestas de manera independiente en la estampa, pero con un espacio de separación que las relaciona entre sí. La diferencia con las series anteriores reside en el protagonismo asumido por el espacio existente entre las dos piezas, ahora considerado como elemento protagonista en la composición de la obra.

En cuanto se refiere a su cualidad plástica, el principal valor se halla en la relación de espacio y color, que juega un papel determinante; sugiere una actividad visual que impone la coloración como un hecho que potencia la forma y aporta una mayor riqueza a la imagen. El relieve que se obtiene al estampar las planchas recortadas, contribuye a evidenciar unos valores espaciales que otorgan un carácter envolvente a la imagen, pues al tocarla con los dedos, se percibe ese relieve que forma parte intrínseca de la imagen.

${ }^{186}$ Entrevista personal con la autora en Castellón de la Plana. 21/03/2007. 


\subsubsection{ASPECTOS COMPOSITIVOS.}

\section{Composición}

El tratamiento compositivo referido a la disposición de las formas en el espacio, recurre a considerar prácticamente toda la superficie del formato, dejando en blanco únicamente una zona comprendida entre las estampaciones de los dos trozos de plancha cortada; la relación entre ambas partes propicia la creación de una serie de composiciones con dimensiones aleatorias, que adoptan formatos de límites más o menos cuadrados y rectangulares en posición vertical, que rompen con el tradicional formato horizontal, típico de las representaciones de paisajes. ${ }^{187}$

Las siluetas de las planchas cercenadas, prácticamente llegan a acoplarse unas a otras en una continuidad unitaria, debido a la similitud de sus formas. Sin duda la práctica de seccionar la matriz apremiando la forma representada, da lugar a la aparición de formatos singulares. Esta es una de las propuestas de continuidad ejercida en las diversas series, Reixes, Ocells morts, que sigue practicando también ahora.

El espacio, observamos que es trabajado con la revisión simultánea de dos tamaños de formato; uno que identificamos claramente con las dimensiones de la matriz de metal sobre la que actúa directamente cubriéndola en su totalidad y otro que hace referencia al papel de impresión. Hay que tener en cuenta que éste

\footnotetext{
${ }^{187}$ El recorte de la plancha se hace bordeando las distintas formas representadas en la matriz siguiendo el borde interior de la imagen. Ibidem
} 
no es un espacio estricto, puesto que durante el proceso de estampación la artista juega con la disposición de las piezas individualizadas, con las que genera espacios que después, en la impresión, quedarán integrados en la misma obra, planteamiento que no pierde nunca de vista. Como nos comenta Pilar Dolz que cuando trabaja las planchas, siempre tiene en cuenta que van a ser estampadas.

Cuando recorto la plancha, piensa que lo que hago es que, el espacio de la imagen es todo el papel (sic). Cuando yo estampo sobre papel, tengo en cuenta el papel, es decir que si tú tenías como espacio la plancha es verdad y mentira. La plancha sería una ventana dentro del papel, porque siempre en raras ocasiones he puesto papel de color, pero también lo he puesto y también por algo, es decir, ese espacio existe. ${ }^{18}$

Después de la serie de ventanas en la que la artista se va abriendo paso de forma paulatina al mundo exterior, en Pedres $y$ paisatges dels Ports termina por conseguirlo, apoyada en unos elementos referenciales tales como piedras, nubes y paisajes, aunque no de una forma muy directa, ya que sus representaciones son siempre espacios muy difíciles de atravesar, pues la presencia de rejas, vallas, cuerdas, protagonistas en series anteriores, se convierten en barreras infranqueables difíciles de traspasar. En el caso de esta serie el camino áspero y pedregoso de sus paisajes, hace que su recorrido sea arduo y espinoso, con lo cual para alcanzar la completa libertad se tiene que atravesar primero un

${ }^{188}$ Entrevista personal con la autora en Castellón de la Plana. 22/03/2002 
mundo lleno de obstáculos y dificultades. (Véase LAM. LVI). Respecto a esta idea nos revela la artista:

(...) no suele ser un espacio muy abierto, éstos quizás un poco más, pero son como unos cielos poco amenazadores. Yo en una ocasión dije: 'Menos mal que ya me librado de las rejas y me hice con los paisajes.' No se quién estaba mirando, si un profesor o un compañero, y me dice: 'Sí, pero tienes la mirada de hormiga, tú estas puesta aquí abajo y estas perdida entre esas piedras o esas hierbas'. Las hierbas son rejas igual y eso es difícil de atravesar, esos paisajes no son paisajes que tú puedes pasearte en ellos, es decir que sí, que hay una cosa libre, pero primero tienes que atravesar un mundo de piedras, no son paisajes fáciles. Ves como las nubes son muy amenazadoras, además hay paredes que suelen ser altas, difíciles (...) ${ }^{189}$

Respecto al espacio radiante que se corresponde con el blanco del papel, presente entre las dos impresiones entintadas, esta zona sin tinta hace alusión a un espacio imaginario, sensible, que surge de modo inconciente y que adopta un contenido metafórico estable que no cuestiona su presencia como en el periodo franquista. Así por ejemplo, localizamos en la parte superior de la imagen de la LAM. LVII, una representación de aspecto atmosférico como un cielo nublado, mientras que en la zona inferior encontramos otra con sugerentes formas de paisaje. El espacio que surge entre ambas se constituye en un elemento más de la obra, cuya sugerencia es percibida por nuestros sentidos. Se trata de unos espacios que se encuentran aún por determinar según nuestra percepción.

${ }^{189}$ Entrevista personal con la autora en Castellón de la Plana. 21/03/2007 
(...) ¡Pero ves! Queda allí una franja que forma parte de la misma obra. No sé por qué lo hacía así, yo. Era para hacer el color limpio, era una cuestión de la técnica, más que yo pensara en esos vacíos, porque el grabado te permite reflexionar mucho, y vas viendo tu obra como va creciendo; pero el grabado si tú te lo estampas, tu propio grabado te da muchas posibilidades de reflexionar, porque vas haciendo uno y otro. Lo vas sacando, lo vas dando la vuelta tanto al grabado, como a la plancha; vas viendo. $Y$ una vez hecho, sí que reflexiono sobre esos trozos, pero primero yo creo que llegan de una forma inconsciente, porque mis grabados no cuentan historias, son formas, son líneas, son gestos, no cuentan una historia. ${ }^{190}$

Pedres i paisatges dels Ports está constituida por una serie de formas volumétricas, sinuosas y en algunos casos hasta punzantes, en las que encontramos intereses descriptivos, que se aúnan a las vivencias generadas por la casualidad y los planos emocionales e inconcientes de la propia personalidad, donde se manifiestan dos puntos de observación diferentes: uno con respecto a la técnica y otro a la representación.

Las formas abstractas obtenidas por manchas de una factura muy pictórica, le provocan una gran cantidad de sugerencias visuales, y mediante una reconstrucción mental localiza en sus formas, representaciones de paisajes que asocia a imágenes de su pueblo natal. Posteriormente refuerza estas formas con las técnicas de aguatinta y aguafuerte. (Véase Fig. 98)

${ }^{190}$ Ibidem. 


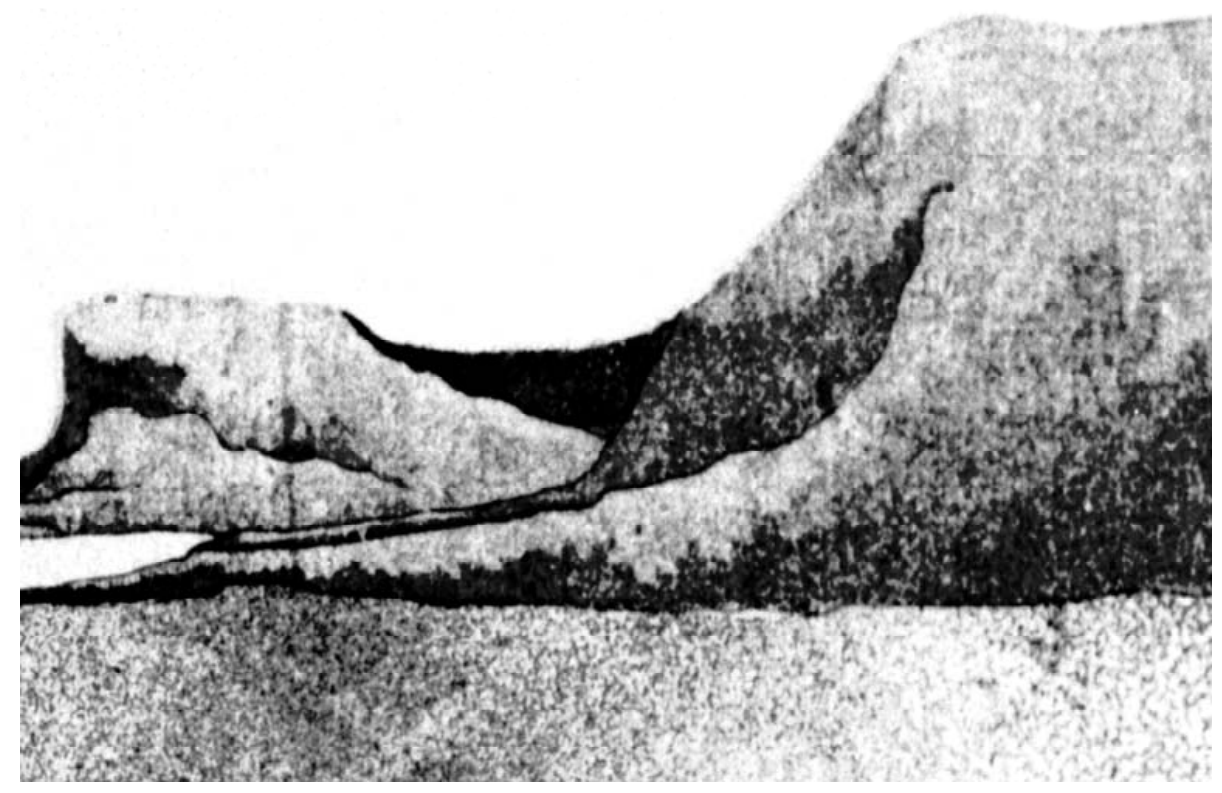

Fig. 98. Pilar Dolz. Detalle LAM. LVII. Serie Pedres i paisatges dels Ports. Aguatinta y aguafuerte. 1977.

\section{Grafismo}

La representación, se materializa por el trazo gestual antes mencionado, pero también localizamos otro realizado al aguafuerte que le permite efectuar soluciones con grafismos. Se trata de un trazo lineal simple realizado con una punta de metal que dibuja directamente sobre la mancha dándole un carácter figurativo. Así en LAM. LIX y LX, localizamos un trazo sencillo, que ni se superpone ni se entrecruza, sino que muestra su dibujo en diversas direcciones para dar forma a la imagen, mientras que los volúmenes y el claroscuro son solucionados con la aplicación de la resina sometida a la acción del ácido. (Fig. 99) 


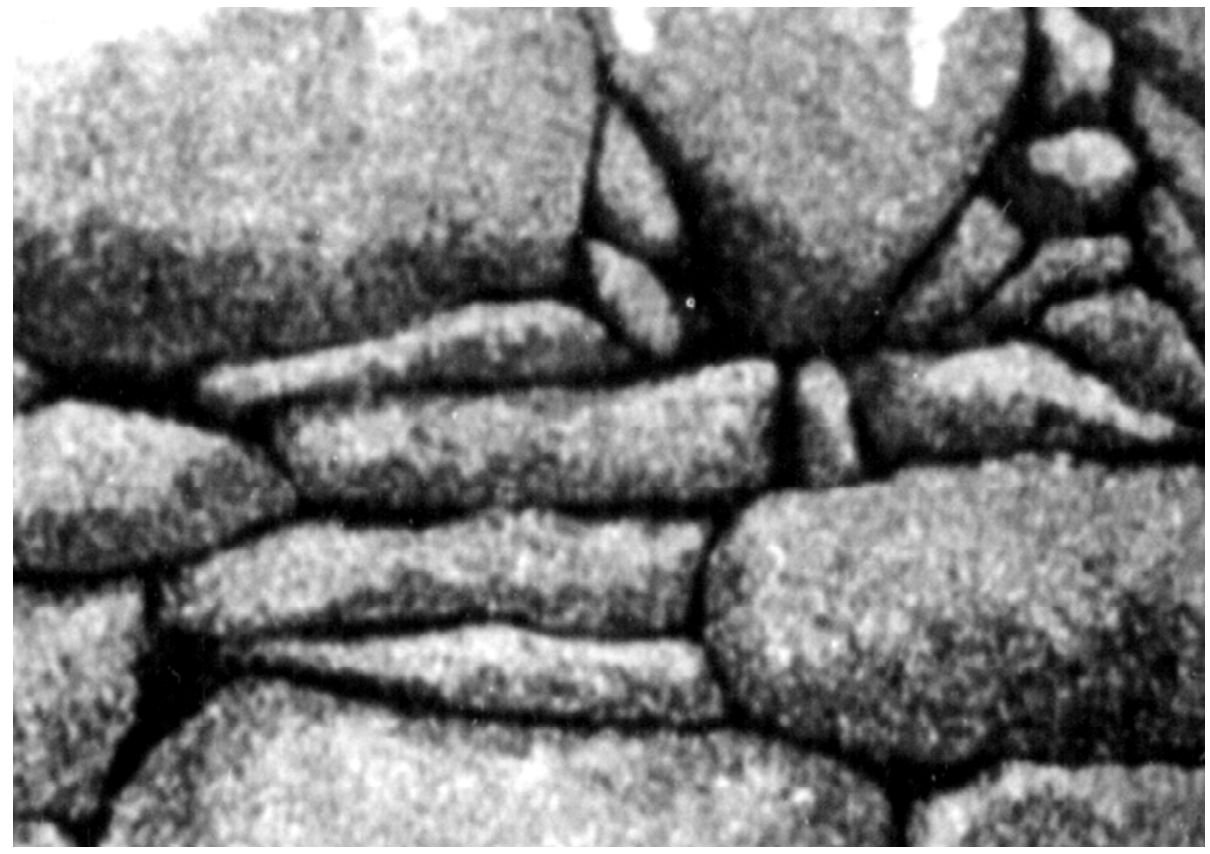

Fig. 99. Pilar Dolz. Detalle LAM. LIX. Serie Pedres i paisatges dels Ports. Aguafuerte y aguatinta. 1979.

Asimismo localizamos un trazo en el que se funde la acción descriptiva de la imagen, con las sugerencias de la aplicación de la técnica. Aquí el gesto juega un papel más controlado, pues el rasgo que dibuja la forma sirve de guía para cortar la plancha. "El recorte es un elemento importante aunque corresponde prácticamente a la silueta de los trazos". ${ }^{191}$ (Véase Fig.100)

${ }^{191}$ Entrevista personal con la autora en Castellón de la Plana. 21/03/2007 


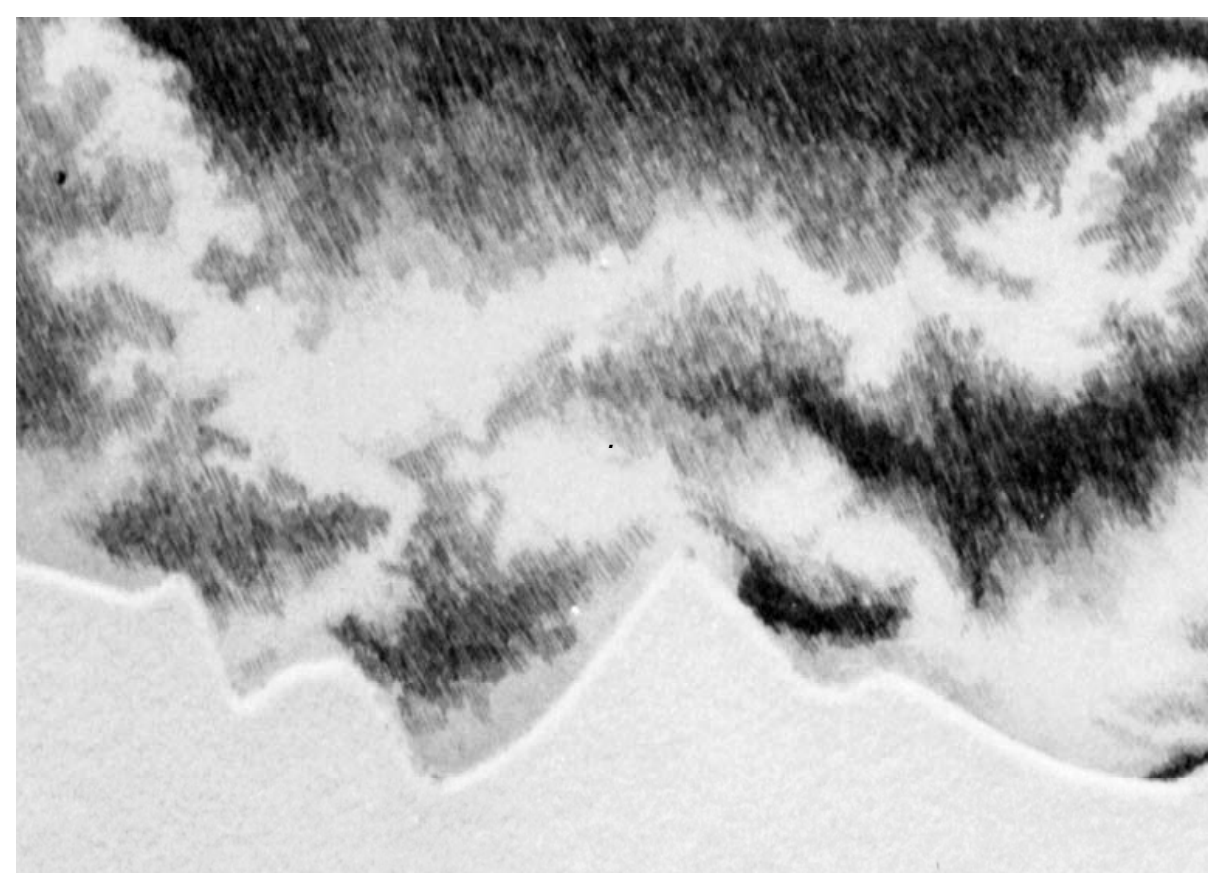

Fig. 100. Pilar Dolz. Detalle LAM. LXI. Serie Pedres i paisatges dels Ports. Aguafuerte. 1980

\section{Color}

Un componente importante de Pedres i paisatges dels Ports es el color, que funciona a través de la impresión de varias imágenes por separado en la misma estampa, proceso que asegura la máxima saturación y luminosidad de las tintas. Éste es sin duda uno de los planteamientos sostenidos por Pilar Dolz, desde el primer momento que interviene el color en sus grabados.

La necesidad de introducir el color limpio en el grabado que no sea hecho "a la poupée", en el que es frecuente que los colores tiendan a ensuciarse, le lleva a cortar la plancha e imprimir cada trozo por separado para evitar que se superpongan las 
tintas y se mezclen. Esta particular forma de trabajar el grabado por medio de planos independientes; uno para el cielo y otro para el paisaje, hace que cada forma se identifique como elementos formales aislados, que pueden integrarse en la misma obra gracias a la intervención del color. Encontramos en este trabajo una intencionalidad consciente de creación compositiva. Para comprender esto citamos la LAM. LVI, un grabado realizado con dos planchas dispuestas horizontalmente sobre la superficie. La impresión ubicada en la parte superior, visiblemente más grande que la inferior, lleva grabado un detallado cielo nublado y tormentoso, impreso en un tono azul claro que aporta una visión atmosférica a la imagen. Mientras que la plancha inferior muchos mas esquemática, nos presenta unas sugerentes formas de paisajes, que se hacen visibles ante nosotros sobre todo por el color verde de la forma, más que por la propia imagen.

En cuanto a la utilización del color en sí, normalmente tiende a recurrir a valores de alta saturación; sepias y naranjas que aparecen en combinación con verdes y azules estridentes que impactan a nuestra retina. Sin duda la impresión de éstos dejando siempre un espacio blanco entre sus formas contribuye a resaltar todavía más el color. A esto le sumamos la variedad de perfiles que muestra la imagen, que hace más clara y marcada sus líneas límites, por lo que percibimos los colores aún con un mayor contraste. (Véase LAM. LVII y LVIII)

Otra forma de definir el espacio del color como ya hemos visto en anteriores series, es a través del empleo de papeles de color encolados fijados sobre el soporte, que animados por la tinta 
impresa sobre ellos cambian sus matices y la luz, con un concepto semejante a los impresionistas en cuanto hace referencia al intento de plasmar la luz, como un argumento visual que va más allá de la descripción formal.

Para comprender esto citamos dos trabajos esenciales, LAM LIX y LX, dos versiones distintas de un mismo grabado. La primera es un grabado resuelto por dos planchas impresas sobre dos tonos distintos de papel; uno gris que corresponde al soporte, en el que se destacan las imágenes de unas piedras en un tono verde claro, y otro fijado en la parte superior de color blanco, sobre el que se aprecia la imagen de un cielo nublado, impreso con el mismo tono verde que el anterior, si bien ahora la tinta lógicamente adopta tonos diferentes condicionada por la cromaticidad del papel; sobre el blanco toma un matiz luminoso y estridente, y sobre el gris se torna más sombrío y apagado.

Acerca del papel gris empleado para la impresión nos explica la artista que lo utiliza: porque cuando trabaja sobre la plancha de zinc, percibe continuamente el tono gris del metal a través de las tintas y esto le sugirió la idea de estampar sobre un papel gris, para que la obra sea percibida por el espectador con los mismos matices que ella, cuando trabaja sobre el zinc.

En LAM. LX sucede lo contrario, trabaja sobre un papel blanco con fondino gris, emplea la misma cantidad de planchas y el mismo color, sin embargo el cambio del color del papel da a la obra calidades diferentes. Resulta muy interesante su experimentación para mostrar cómo cambia la percepción de la luz; la hora del día en 
el mismo paisaje da lugar a una obra completamente diferente, según con qué color de papel se estampe, al igual que sucediera con las obras de los impresionistas. ${ }^{192}$

El color es el mismo, lo que pasa es que este es en papel gris de Canson y blanco. El verde de la imagen es el mismo en los dos grabados, (...) porque el color de la aguatinta y el aguafuerte con aceite es transparente siempre, no es cubriente, entonces allí trasparenta el blanco y allí el gris. De hecho ese color es exactamente igual, lo que pasa es que a lo mejor el papel no es una blanco tan blanco es más tostado. Pero te das cuenta que cambia completamente la hora del día en el paisaje, en la misma plancha, eso nos lo enseñaron los impresionistas que según a que hora cambiaban las sombras. Aquí es según con que color de fondo tenemos una cosa completamente diferente es decir la luz viene de allá y aquí es como si viniera de aquí. ${ }^{193}$

\footnotetext{
192 Claudio Monet realiza una obra en la que refleja una realidad más compleja: distancia, atmósfera, luz, tiempo del día y lugar. Desde el punto de vista impresionista la obra se nos presenta, no como una pintura de verdades universales, sino como un instante, un momento de transición que pronto desaparecerá. Hacia la mitad de su vida, Monet, para demostrar la influencia de los accidentes atmosféricos, de la estación y aún de la hora en el paisaje, pinta el mismo motivo repetidas veces bajo circunstancias diferentes. El resultado fueron varias series de un mismo motivo. Así nacen las magníficas series de "Las catedrales" Véase. RAMÍREZ, J.: 1996, p.166.

${ }^{193}$ Entrevista personal con la autora en Castellón de la Plana. 21/03/2007.
} 


\subsubsection{PROCESO TÉCNICO}

En lo concerniente a la técnica, principalmente maneja dos técnicas ya utilizadas; aguafuerte y aguatinta, y otra nueva, la manera negra. ${ }^{194}$

La técnica del aguatinta, que se emplea prácticamente en todas las obras, se complementa generalmente con el aguafuerte, para dibujar y definir alguna forma. Respecto a su aplicación unas veces se trabaja de una forma detallada, con la disposición controlada y homogénea de la resina, creando calidades tonales suaves de distintas intensidades, con las que se hace un estudio del claroscuro. Otras veces se practica la técnica de manera espontánea y romántica con la aplicación gestual y azarosa de la resina sobre la plancha, por lo que al caer las partículas de polvo se hace de forma irregular lo que produce la acumulación desigual de la materia y origina la aparición de ciertas formas abstractas que después serán potenciadas por la autora:

(...) Por ejemplo estos paisajes míos no son mirando ningún paisaje, simplemente que al tirar la resina, se acumula en un sitio más que en otro y entonces potencio con la punta de acero lo que me sugiere la resina y entonces surge eso. ${ }^{195}$

El trabajo se desarrolla de forma directa, tirando la resina libremente sobre la plancha, a veces como un polvo de grano muy fino y otras como trozos grandes cristalizados que se dan al no

\footnotetext{
${ }^{194}$ Nombre popular que recibe esta técnica, pero el tono negro del que parte no se consigue con el tradicional berceau, si no con una mordida profunda de aguatinta. ${ }^{195}$ Ibidem
} 
molerla bien. La utilización de los diferentes tipos de resina le proporciona unos efectos de texturas en la plancha de gran calidad, sobre los que procede a raspar y bruñir gradualmente para obtener diversas calidades de luz y aprovechar al máximo las posibilidades expresivas de la técnica, que funciona de una manera suave y fluida, con un resultado estético que queda ligado a la par con la solución formal y el contenido expresivo. (Véase LAM. LVI). ${ }^{196}$

En cuanto al aguafuerte, en la mayoría de los casos se emplea para reforzar el aguatinta. Excepcionalmente encontramos una obra realizada íntegramente al aguafuerte, con una línea fina, inclinada y trabajada en una sola dirección; utilizada más que nada para crear grandes zonas tonales. Este conjunto de grafismos superpuestos siempre en la misma dirección, producen una vibración de carácter espacial en la imagen. Desde el principio, la artista, atenta a la renovación del procedimiento, llega a unos resultados inverosímiles mediante el trabajo minucioso y la aplicación manual de la materia. (Véase LAM. LXI)

La manera negra es la técnica menos empleada en esta serie, de hecho sólo aparece en una obra. Esta técnica, basada en la clásica manera negra, produce suaves y difuminadas gradaciones tonales con las que se obtiene efectos de claroscuro: " (...) una resina raspada para mí no es una manera negra, es una resina bruñida, pero bueno la idea es esa, el raspado deja una textura muy bonita". ${ }^{197}$ Aunque los sistemas de raspado y bruñido los trabaja en

\footnotetext{
${ }^{196}$ Aunque en ocasiones también utilizó laca del pelo en spray. Entrevista personal con la autora en Castellón de la Plana. 21/03/2007.

${ }^{197}$ Entrevista personal con la autora en Castellón de la Plana. 27/04/2007.
} 
el aguatinta, es en esta técnica en la que los practica más, pues parte de un fondo completamente negro. (Véase Fig. 101)

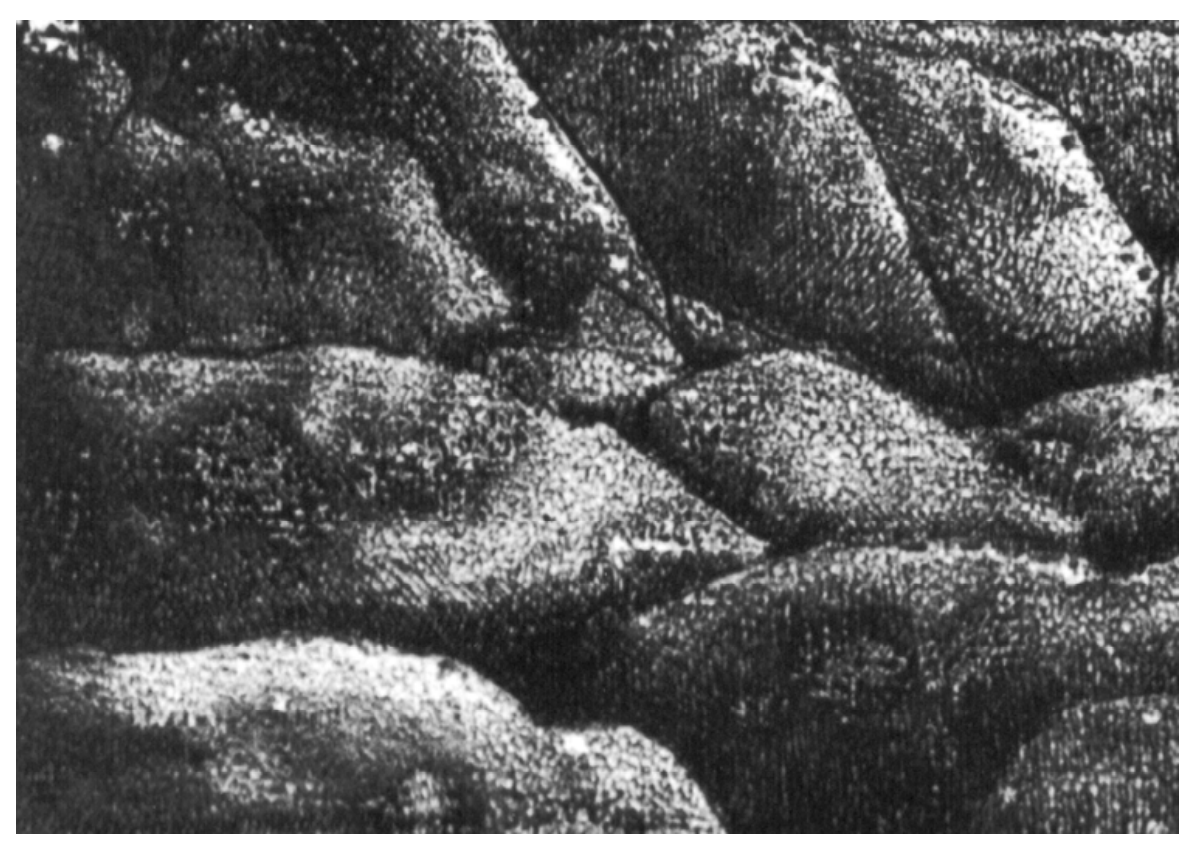

Fig. 101. Pilar Dolz. Detalle LAM. LVIII. Serie Pedres y paisatges dels Ports Aguatinta a la manera negra. 1978.

Acerca del color tiende a emplear con frecuencia colores puros y sin mezcla, quizás emulando a los impresionistas. Este modo de utilizar las tintas le permite manipular el mismo color repetidas veces sin la menor variación tonal. Respecto a este tema, nos explica la artista que trabaja así porque si no hace toda la edición en la misma sesión, después tiene recelo de que los colores no sean exactamente iguales en toda la tirada. La pretensión es que todas las estampas sean idénticas, y si alguna cambia un poco de color ya no la numera, pues está convencida de que: "una de las características del grabado es la capacidad de 
reproducción, y aunque nunca son del todo iguales porque son manuales, (no es una cosa mecánica), ${ }^{198}$ si intenta que sea lo más igual posible.

Esta cuestión tan ortodoxa, tan rigurosa, hace que desde muy temprano escoja una particular forma de trabajar el color que aún hoy en día sigue practicando, y que consiste en la aplicación directa de la tinta, sin la mezcla de ningún otro color, prefiere dejar que se mezclen en la misma plancha. Como consecuencia, su interés por introducir el color en la obra le lleva a recortar las planchas siguiendo la silueta de la imagen con una sierra manual, que da al trazo un aspecto duro y tajante, tanto que a la hora de imprimir la plancha ésta deja a su alrededor unos relieves pronunciados a modo de gofrados. Sin embargo ese irresistible interés por desbastar la plancha le venía de sus inicios en el grabado, hacia 1970, año en el que realiza su primera serie, pero es sobre todo en ésta donde más se evidencia el recorte de la matriz, que aplica con combinaciones de dos y tres piezas.

Eso que recorto es una necesidad de que el grabado no sea un grabado de esos que quedan con unos tonos marrones, que todo está hecho 'a la poupée,' y que a veces es un grabado que se ensucia. Yo tenía una necesidad de los colores muy limpios, entonces lo que hacía era recortar las planchas y eso me da esos relieves y esos cambios. La piedra era sólo piedra, el verde era sólo verde y el cielo era sólo cielo. En ocasiones trabajaba más el cielo y en ocasiones trabajaba más la piedra. ${ }^{199}$

\footnotetext{
${ }^{198}$ Entrevista personal con la autora en Castellón de la Plana. 21/03/2007.

${ }^{199}$ Ibidem.
} 
Dependiendo de la complejidad de cada trozo, el corte se torna más duro o más suave. Por ejemplo en LAM. LVI, podemos ver como el perfil del formato de carácter sencillo y ondeante, presenta un corte dócil y flexible, en tanto que LAM. LXI de forma afinada y puntiaguda con entrantes y salientes, nos muestra un corte más rígido y severo. (Véase Fig. 102)

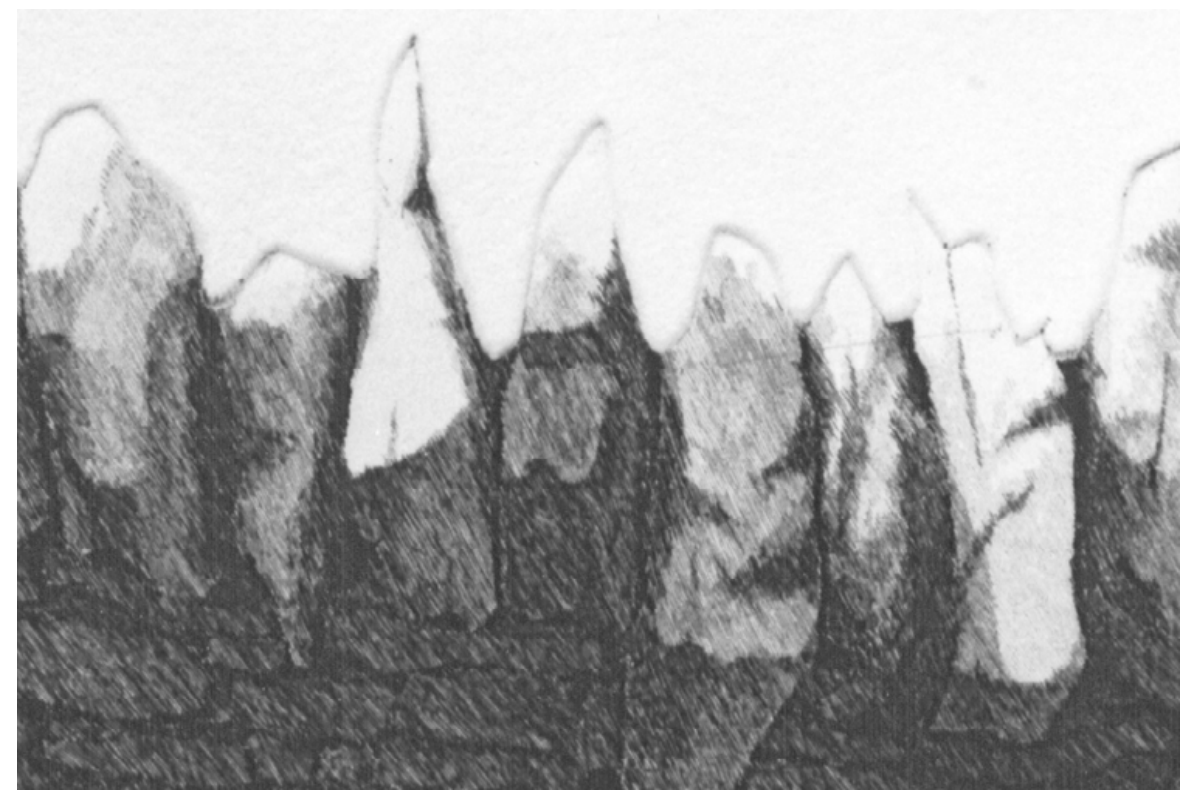

Fig. 102. Pilar Dolz. Detalle LAM. LIX. Serie. Pedres i paisatges dels Ports. Aguafuerte. 1980. 
LÁMINAS

EDRES I PAISATGES DELS PORTS 



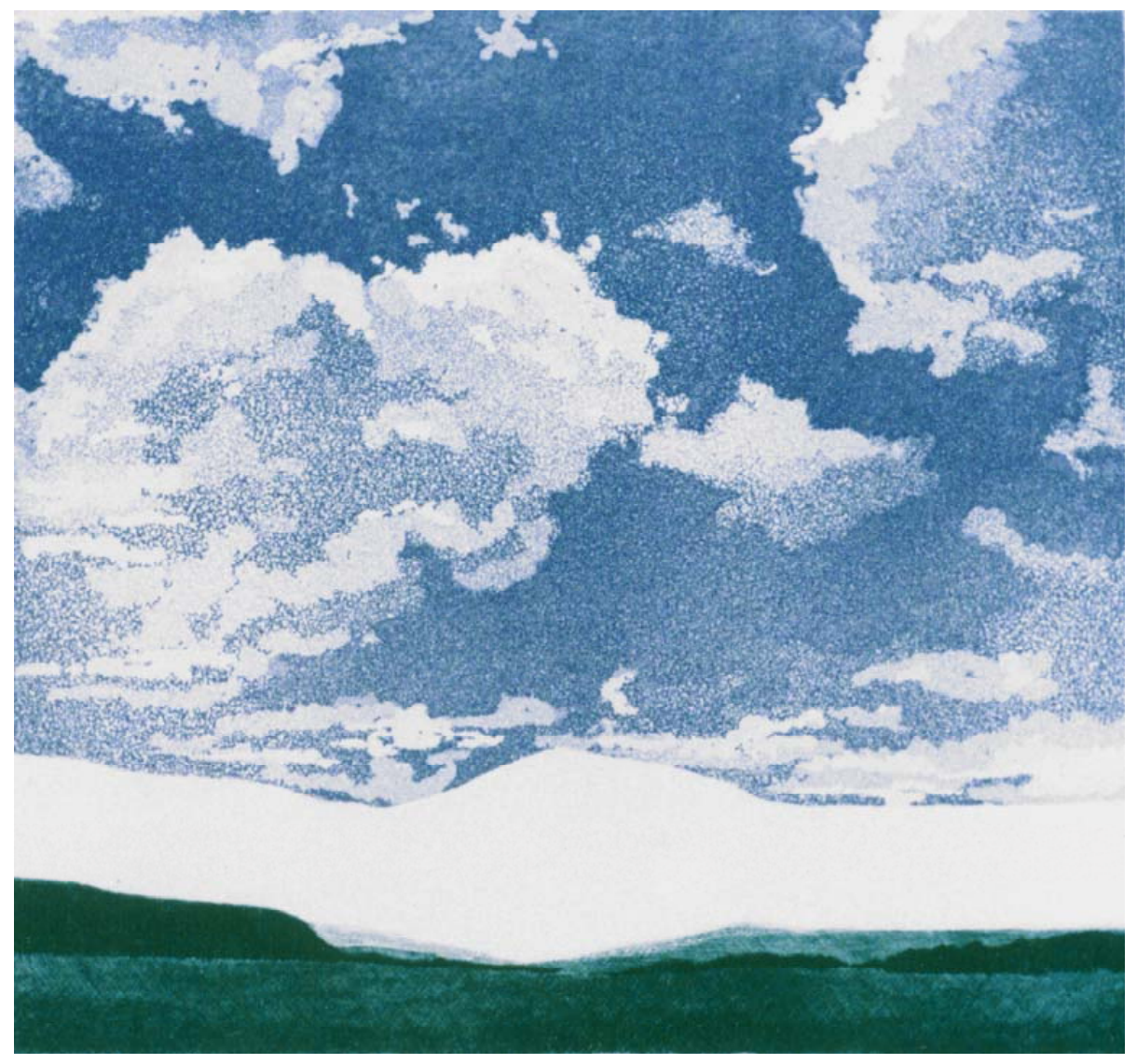

\section{LÁMINA LVI}

\section{"Paisatge I"}

Aguafuerte y aguatinta

$28 \times 29.5 \mathrm{~cm}$.

1977 


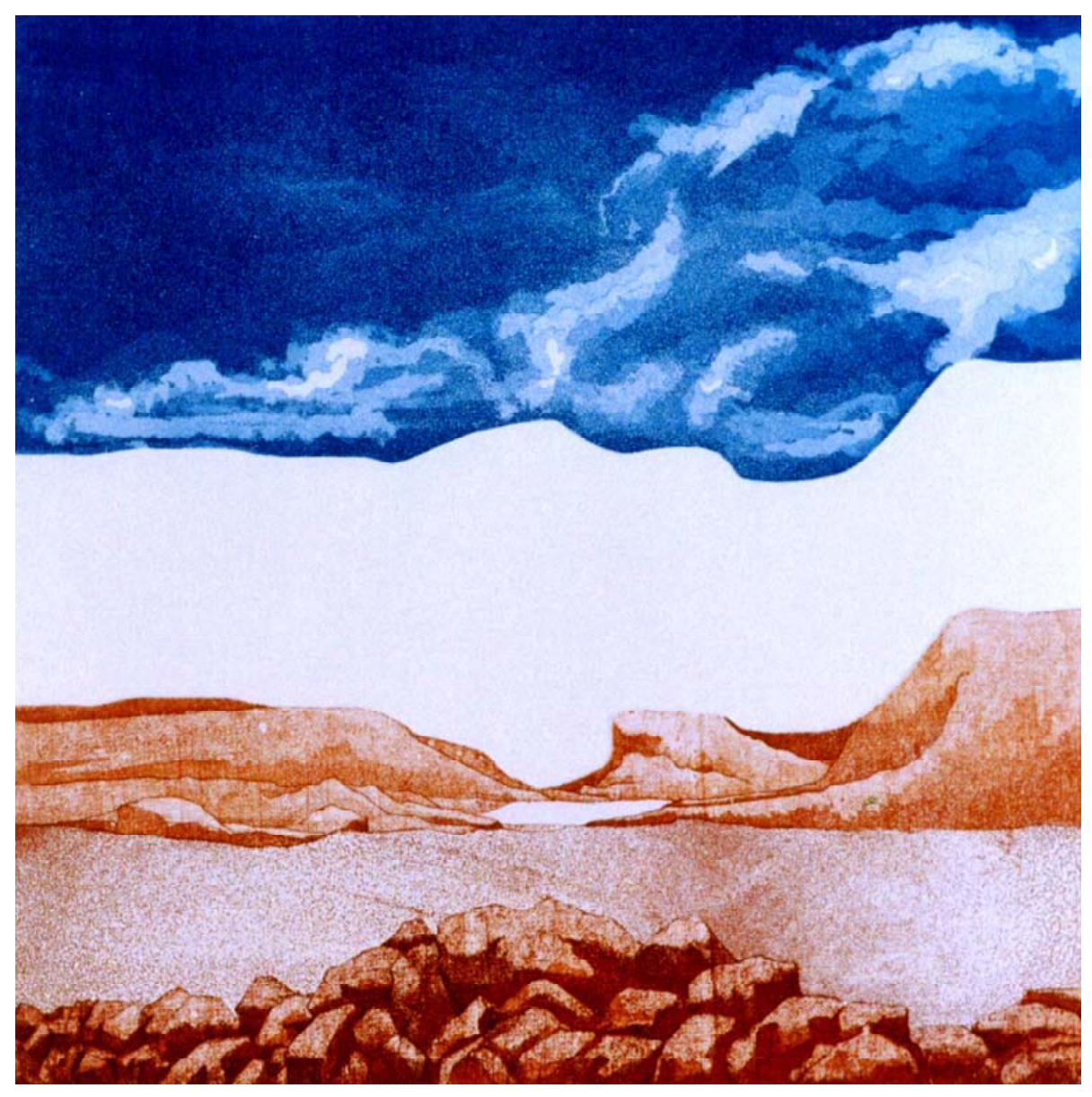

\section{LÁMINA LVII}

"Paisatge II"

Aguafuerte y aguatinta

$31.5 \times 31.5 \mathrm{~cm}$.

1977 


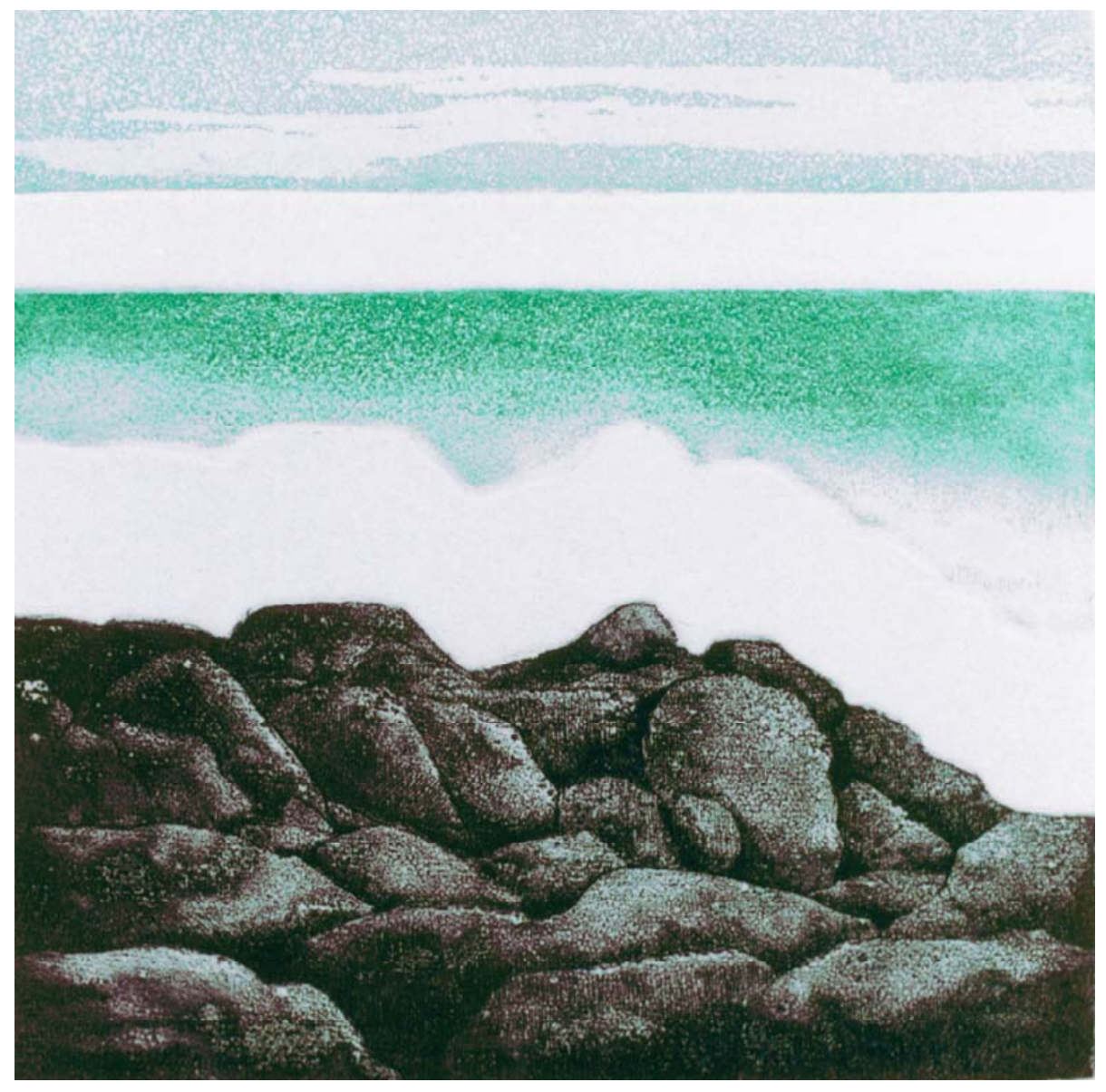

\section{LÁMINA LVIII}

\section{"Pedres"}

Aguatinta a la manera negra.

$16.7 \times 17 \mathrm{~cm}$.

1978 


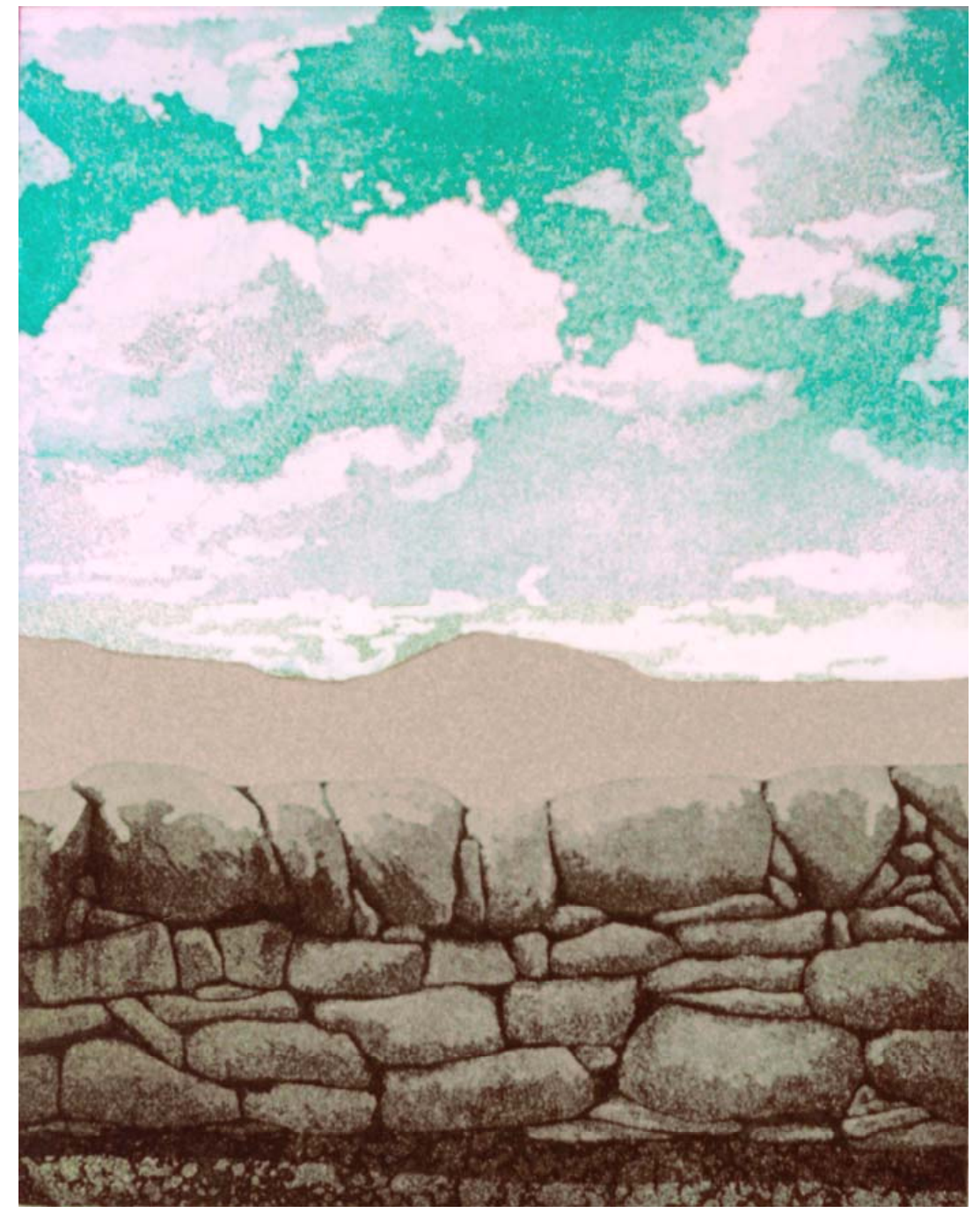

\section{LÁMINA LIX}

"Sin título"

Aguatinta y fondino

$29.5 \times 37.5 . \mathrm{cm}$.

1979 


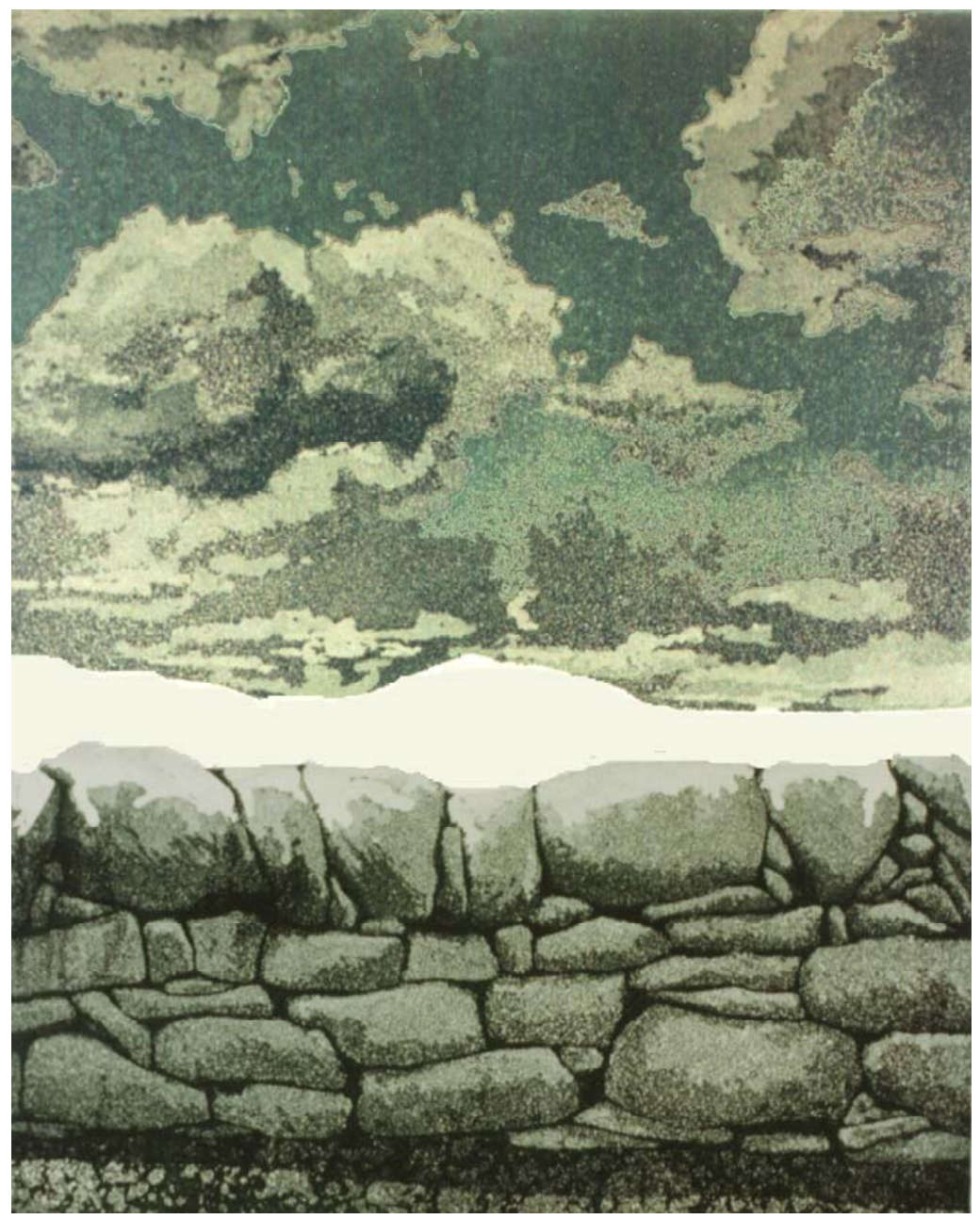

\section{LÁMINA LX}

"Sin título"

Aguatinta y fondino

$29.5 \times 37.5 \mathrm{~cm}$.

1979 


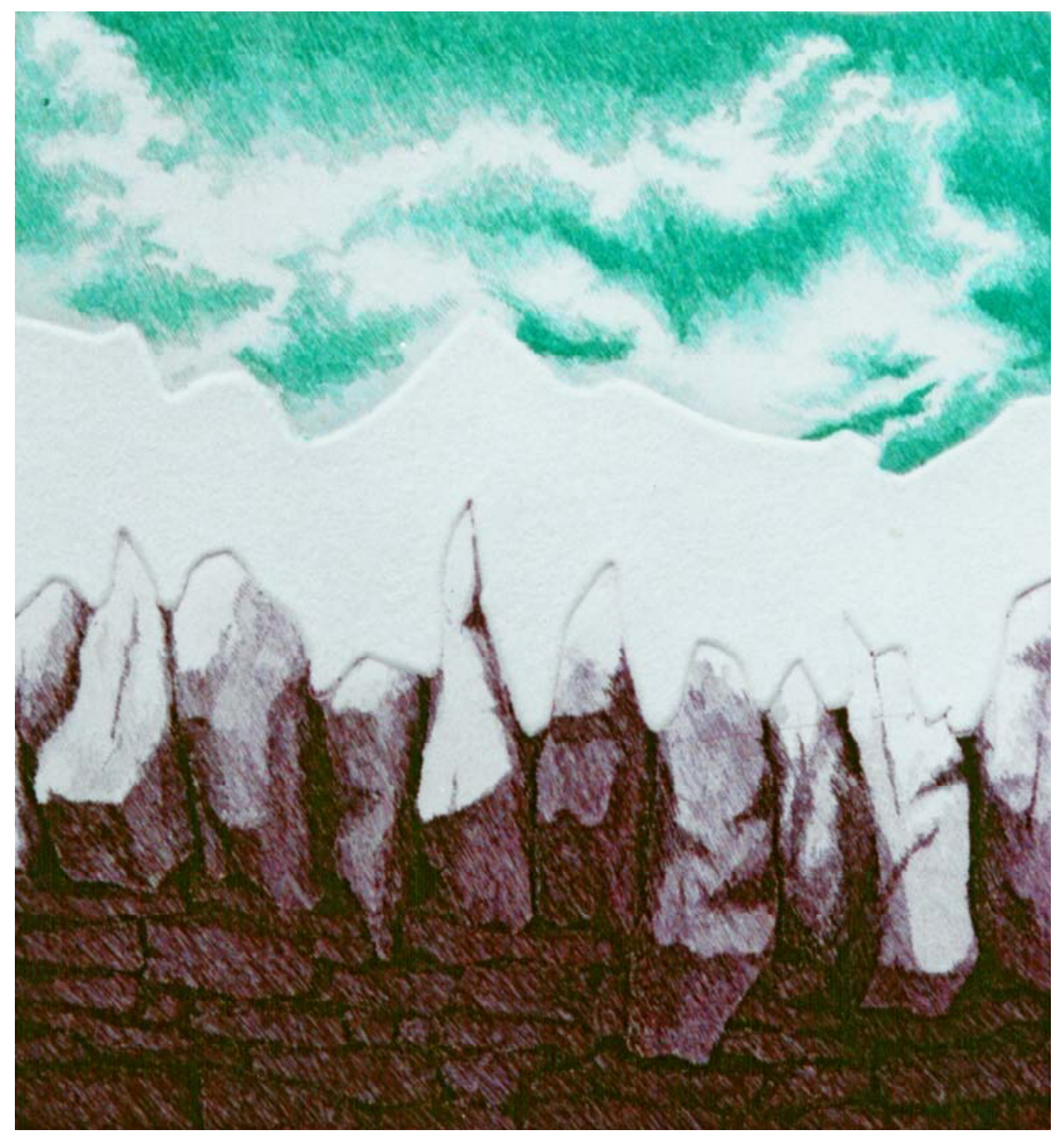

LÁMINA LXI

"Aleres"

Aguafuerte

$18 \times 17 \mathrm{~cm}$.

1980

408 
P. PARETS DE PEDRA SECA 



\subsubsection{CONCEPCIÓN}

Parets de pedra seca, es una serie que surge de la memoria, de los recuerdos, sin embargo sus representaciones adquieren un carácter claramente figurativo, sin duda el dominio del dibujo, del claroscuro y los años de experiencia e investigación en el campo de la gráfica confluyen en esta serie, que protagoniza uno de los momentos claves de su madurez artística. Su creación abarca el período comprendido entre los años 1978 y 1980, año en el que realiza una colección de obras de pequeño formato que ejecuta al mismo tiempo que otro grupo de obras de igual tamaño, perteneciente a la posterior serie Herbes. 
En lo que se refiere a los objetos de reflexión y a los recursos biográficos como idea motora de su trabajo, suponen una continuación de la serie anterior. El recuerdo de su pueblo, las vivencias de su infancia le llevan a centrar su atención en aquel paisaje, tema al que ya hace alusión en la anterior serie Pedres $i$ paisatges dels Ports sólo que esta vez su interés gira en torno a la arquitectura de su tierra, a los muros de piedra, uno de los elementos más importantes y representativos del interior de la Comunidad Valenciana, donde miles y miles de piedras que componen kilómetros de paredes, márgenes y ribazos, nos hablan de un asentamiento humano con miles de años de antigüedad que identifican el perfil ciudadano de su pueblo desde siempre. ${ }^{200}$ "Es curioso comprobar que un país como el nuestro está hecho de tres cuartas partes de secano, roca y montaña (...) Tres cuartos del país hechos con la mano humana, millares de millones de piedras arrancadas, escogidas una a una, llevadas al cuello alineadas y encajadas perfectamente conforman una de las más grandes obras construidas por el hombre". 201

La piedra se convierte en la base generatriz de la obra, paredes de piedra adquieren una nueva visión de manos de Pilar Dolz, que representa en estas formas no unas simples piedras, sino fragmentos de rocas que llevan en sí un trozo de alma ahogada, que simbolizan el duro esfuerzo labriego de miles de hombres y mujeres

\footnotetext{
200 Tras la conquista cristiana el crecimiento agrícola fue paralelo a la ganadería que produjo un impacto paisajístico en estas comarcas. En el siglo XIV la actividad ganadera tuvo un importante desarrollo impulsado por el comercio de la lana con una importante proyección en la arquitectura que activó el intercambio de ganado con otras comarcas. Los trazados recibieron el nombre de assagadors y camins reials, se construyeron paredes, muretes y ribazos. También surgen los abrevaderos, corrales, refugios. La característica más común es la utilización de la técnica de piedra seca, es decir la colocación de piedras sin tallar, sin argamasa, ordenadas sobre un terreno comúnmente de difícil orografía. Véase GRACIA, C.: 1998, pp. 43-44.

${ }^{201}$ Véase FUSTER, J.: 1983.
} 
que generación tras generación ocuparon estos lugares. Como lo definiría el autor Rodríguez Culebra:

"Su obra tiene una entrañable vida humana, sobre todo las piedras. Todo un mundo de esfuerzo, de trabajo humano, de sueños por arrancar a la dura tierra un fruto difícil, de perpetuar una memoria o una presencia. Porque las piedras de este mundo artístico de Pilar no son por lo general las anónimas rocas de una fría y atemporal cosmogonía, sino aquellas arrancadas por el hombre una a una, para que cobrasen vida en sus pobres casas, en los muros de los estrechos bancales, en mojones indicadores". ${ }^{202}$

Inicia Parets de pedra seca en Castellón y la va a continuar en Urbino (Italia) ${ }^{203}$. Un día dibujando en esta ciudad sobre una de las piedras más grandes del taller, se da cuenta de que se encontraba dibujando una piedra sobre otra piedra, al contemplar la imagen la artista considera no se parece a una piedra, por lo que decide ampliar este concepto escribiendo la palabra piedra en distintos idiomas alrededor de la imagen. Este hecho va a dar lugar a una obra con cierta carga conceptual fundamentada en la representación de la imagen y su significado escrito por medio de la palabra. Evidentemente este planteamiento la acerca a propuestas conceptuales formuladas por algunos artistas, tanto surrealistas como René Magritte, ${ }^{204}$ o del Pop Art como Robert Indiana, ${ }^{205}$ que

\footnotetext{
202 Véase RODRIGUEZ CULEBRA, J.: 1982.

203 Pequeña ciudad sobre una colina, lejos del mar y bordeada de murallas, con muchos ligamentos como los de Morella. Entrevista personal con la autora en Castellón de la Plana 21/03/2007.

${ }^{204}$ Rene Magritte dotó al Surrealismo una carga conceptual basada en el juego entre texto e imagen con una clarificadora aplicación de la retórica a la imagen. Véase ALBELDA, J.: 1992, p. 97

${ }^{205}$ A partir de 1960 realiza unas series de cajas, con letras y palabras que, junto a las imágenes comerciales, se convierten en lo esencial de la obra. Véase RAMíREZ, J.: 1996, p.368.
} 
utilizaron imágenes pictóricas en combinación con la palabra en sus creaciones.

Terminada la obra decide continuar con esta iconografía, al tiempo que resuelve tomar unas fotografías de las paredes de Urbino para conocer ciertos detalles de los muros, de los cantones, a pesar de que las paredes de esta ciudad no eran de piedra como las de Morella sino de barro, pero eso no era algo que le importara pues, según Pilar Dolz, no le interesaba que las imágenes se parecieran a la realidad. Lo cierto es que el resultado final fueron unas imágenes figurativas de piedras, y la relación que el espectador puede establecer entre éstas y su lugar de origen es muy evidente, aunque la artista no busca esta relación de forma deliberada y premeditada, sino que surge sola quizás porque es parte de un mundo con el cual se siente plenamente identificada.

Respecto al sentido plástico, se rige por un afán perfeccionista por el detalle, por el cuidado en la ejecución, un trabajo de minuciosidad donde las dificultades aumentan a medida que el perfeccionismo es más elevado. Advertimos en esta serie cierta influencia del Pop Art, con un realismo no academicista, ya que sus imágenes realizadas habitualmente en un primer plano no presentan ninguna perspectiva, y además tiende a combinar estas imágenes con otras menos figurativas, como manchas o formas sintetizadas. La técnica empleada en su realización es el spruzzo, procedimiento que trabaja únicamente por medio de salpicados de tinta con los que intenta crear los efectos de volumen y textura de la imagen. 
Yo no diría que es un trabajo realista. Lo que sí, es muy figurativo, sin ninguna perspectiva ni nada, más bien del pop, además no está dibujado, no está tocado para nada con el lápiz. Eso está todo hecho con spray. Sí que acaba siendo muy figurativo, muy realista pero no tiene el realismo de la academia, es otra cosa, no es fotográfico, pero lo trabajo como si lo fuera. ${ }^{206}$

El objeto de representación es la piedra, iconografía que ya hemos visto en series preliminares como Insectes y Pedres $i$ paisatges dels Ports donde la piedra surge de una forma ingenua como producto de la acción azarosa de la aplicación de la resina, formando parte del paisaje o como un elemento más de la obra. En Parets de pedra seca se convierte en la absoluta protagonista de la obra, mientras la artista desarrolla un trabajo más conciente de creación compositiva, ya que no es un trabajo casual, sino que se informa, investiga previamente sobre la estructura y configuración de la forma.

Podemos apreciar su interés por los campos abiertos como un ideal imposible, ansiedad que venimos advirtiendo en las diversas series estudiadas. Las piedras de unos altos y rústicos tapiales se presentan como elementos indestructibles de eterna consistencia que cortan el paso. En cierta manera los temas de la reja y de la paloma muerta aprisionada surgen ahora otra vez metamorfoseados en rocas, en muros de piedras que impiden que sigamos avanzando. Es un volver a impresiones antiguas que no terminan jamás y que evidencian la existencia de unas inquietudes que se mantienen a lo largo de toda su producción.

${ }^{206}$ Entrevista personal con la autora en Castellón de la Plana. 21/03/2007. 
En cuanto al color hay un tratamiento frecuente de tonos suaves y apastelados con el uso frecuente de amarillos, verdes, violetas, marrones, que funcionan en muchos de los casos en combinación con el negro. Por otro lado los espacios blancos protagonistas en series precedentes son suplantados por espacios de color o por la propia imagen que llena todo el espacio. 


\subsubsection{ASPECTOS COMPOSITIVOS.}

\section{Composición}

En este conjunto de obras desaparecen aquellas zonas blancas que aparecían en casi todas las series de Pilar Dolz. Ahora plantea zonas de color, o la imagen cubre toda la superficie sin dejar espacio para el vacío. Este ejercicio sin embargo no es una experiencia nueva para Pilar Dolz, que ya la puso en práctica en contadas obras de series anteriores de formas, Cordes, Reixes e Insectes, donde unos espacios planos del mismo tono o distinto color o forma, son aplicados por medio de una segunda matriz sensibilizando todo el espacio. Lo que sí es cierto es que este ejercicio estuvo muy poco desarrollado en su quehacer artístico, y es en esta colección de grabados donde realmente se trabaja matizando el espacio.

El estudio de la forma nos remite no solamente a la imagen representada como tal, sino también al color y a un elemento plástico nuevo que se elabora a partir de la LAM. LXII de esta serie, como es la escritura que se proyecta sobre la superficie plana del papel. Su cualidad lineal y de borde hace que los trazos no lleguen a saturar toda la superficie dejando ver entre sus grafías zonas de alta luminosidad, de tal manera que las distintas letras que componen la palabra piedra aparecen como si estuvieran flotando en el espacio. En cuanto a su disposición en el plano está escrita hasta llegar a los límites del formato donde se corta con los márgenes del cuadro, dejando que el observador ultime la imagen mentalmente. La repetición continúa y rítmica de la palabra piedra y su impresión en 
distintos tonos crea un efecto vibrante en la imagen que dinamiza la composición. (Véase Fig. 103)

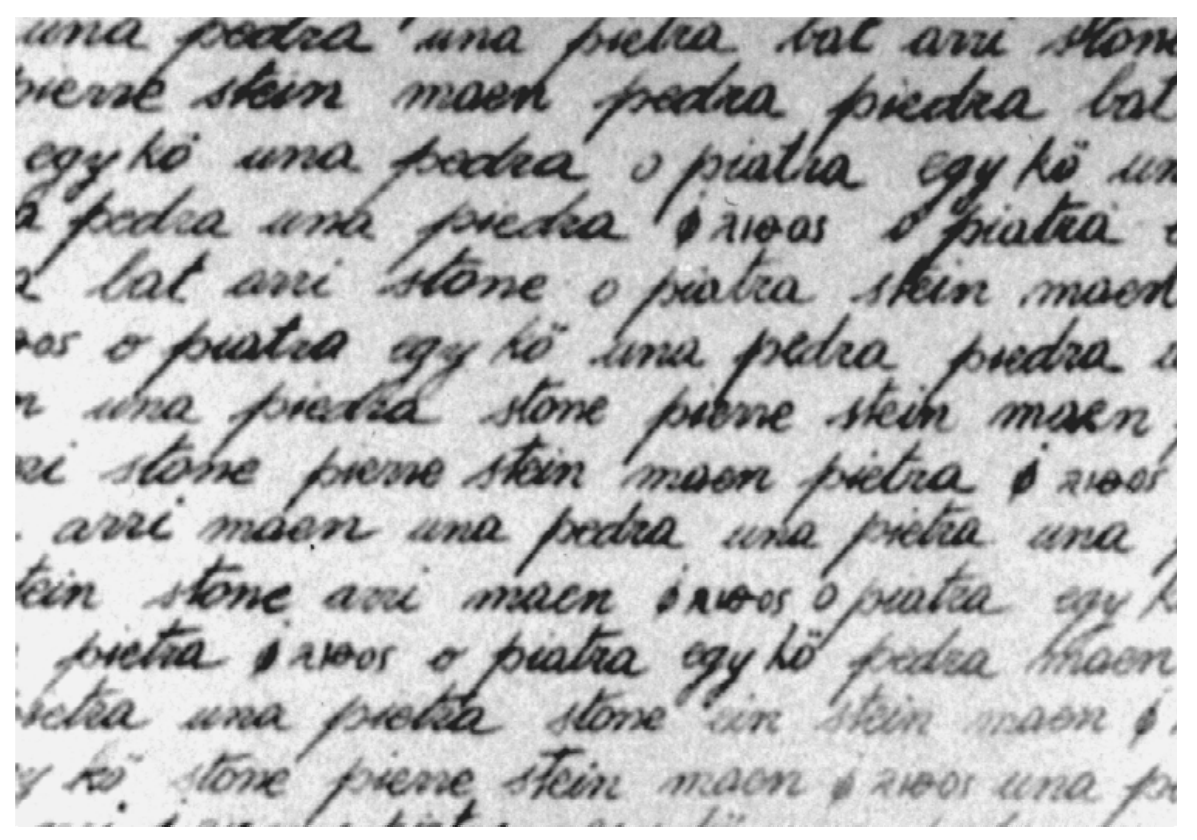

Fig. 103. Pilar Dolz. Detalle LAM. LXII. Serie Parets de pedra seca. Litografía. 1978.

En cuanto a la estructura compositiva en el conjunto de obras realizadas por medio de la técnica litográfica, diremos que la composición esta constituida por dos planos que se extienden paralelamente en el espacio; uno abierto e ilimitado que cubre el espacio, que corresponde al fondo y desarrolla una sugerencia sensible más relacionada con la plenitud, y otro más cerrado que envuelve la forma con un carácter de figuración tridimensional. Se trata de unos muros de piedra que se proyectan generalmente en sentido horizontal dividiendo el espacio en dos partes variables. La imagen efectuada con un meticuloso estudio del claroscuro que 
obtiene un efecto de volumen y profundidad, despunta manifiestamente sobre el fondo solucionado de una manera más pictórica a base de manchas imprecisas e indeterminadas que aparecen con un carácter frontal y permanecen en un plano secundario. (Véase LAM. LXIII, LXIV, LXV y LXVI)

En otro grupo de obras estas manchas de color son sustituidas por un elemento representacional de contenido paisajístico como campos de trigo o fondos solucionados a base de rayados de lápiz litográfico que asoman por detrás de las piedras. Se trata de unas formas lineales esquemáticas, con las que la artista renuncia al detalle y al dibujo meticuloso elaborado en las piedras y da lugar a unas formas de carácter más ingenuo. Así en LAM. LXVII, encontramos en primer término la figura de una pared de piedra que desciende paulatinamente de izquierda a derecha formando un curvatura diagonal en el espacio, en tanto que por detrás de ésta localizamos unas formas vegetales flexibles, que resultan de la disposición paralela y repetitiva de unas líneas entrecortadas que por su carácter discontinuo y alterno crea una vibración óptica en nuestra retina. En LAM. LXVIII por el contrario el fondo se encuentra solucionado por un trazo lineal recto hecho con lápiz litográfico en sentido diagonal, a pesar de que el trazo se descubre discontinuo en ciertas zonas, sigue manteniendo su carácter de continuidad cuando reaparece, pues sigue conservando su dirección de trazo provocando una ilusión de prolongación.

Por último localizamos una colección de grabados donde la imagen cubre todo el espacio a través de la disposición de una imagen única. En estas obras desaparece el fondo y se trabaja 
exclusivamente sobre la forma centrándose en los detalles, la textura, la forma y el color. Se trata de unos fragmentos de muros de piedras, trabajados por medio de la técnica del salpicado (litografía), con la que la artista sensibiliza la superficie y crea una textura capaz de recrear la corteza, la epidermis del mineral, tanto que somos capaces de sentirla con las yemas de los dedos por su esencia táctil así como con nuestros ojos. Igualmente construye la forma, establece planos, volumen y profundidad a través de la aplicación controlada y vigilada de la tinta. (Véase LAM. LXIX, LXX y LXXI)

Excepcionalmente encontramos alguna obra donde la forma aparece centralizada, afirmando el poder del centro. La disposición de la imagen sin rellenar el espacio descubre unas zonas de luz a su alrededor que no son ocupadas por ningún otro elemento conservando el blanco del papel. Ésta es quizá una de las pocas obras en la que la artista sigue defendiendo el vacío. (Véase LAM. LXXII)

En las obras de pequeño formato realizadas por medio de la técnica calcográfica, se trabaja con tres o cuatro matrices que se combinan con la producción de otras imágenes para la obtención de diversos grabados. El sistema compositivo se establece de la misma manera que en las obras de mayor tamaño, es decir con la disposición de una imagen que emergen desde la zona inferior y un fondo más espontáneo que se presenta a veces más traslúcido, con trazos abiertos que descubren zonas de luz, mientras que otras veces es más cubriente, aunque siguen apareciendo pequeños espacios blancos que afloran como una especie de manchas disueltas en el espacio. En otras obras el fondo es reemplazado por 
pedazos de papel de color sobre el que se estampa la imagen grabada. Hay en este proyecto una insistencia de situaciones planteadas en series anteriores como, Insectes y Pedres i paisatges dels Ports con respecto al uso del papel coloreado como un sustitutivo del color. (Véase LAM. LXXIII, LXXIV y LXXV)

Los valores de profundidad se consiguen en el conjunto de obras donde la forma se dispone en dos planos únicos, haciendo alusión a la relación diferenciada de figura y fondo, se establece a través de un estudio meticuloso del claroscuro, donde la distinta intensidad lumínica proporciona volumen a la imagen. Con este procedimiento la artista simplifica la organización espacial y la dimensionalidad de la forma con la que busca una representación convincente del espacio tridimensional. (Véase LAM. LXIII))

La representación en perspectiva es otro de los métodos empleados para obtener profundidad aunque en menor medida. En este caso las referencias se hacen desde un punto de vista angular; así podemos distinguir las relaciones entre dos caras de la figura, que nos revelan su volumen. La perspectiva presenta dos puntos de fuga que se asientan sobre la línea de horizonte y convergen hacia la misma imagen. Descubrimos también otras soluciones, como en LAM. LXIV, donde localizamos un muro de piedra ejecutado con la visión de una arista, cuya posición divide el espacio en dos partes casi simétricas. La proyección de las paredes, una hacia la izquierda y otra hacia la derecha, en sentido diagonal se extienden alejándose del observador, para otorgar a la imagen una sensación de ilusión de continuidad entre nuestro espacio físico y el del cuadro. (Véase Fig. 104) 


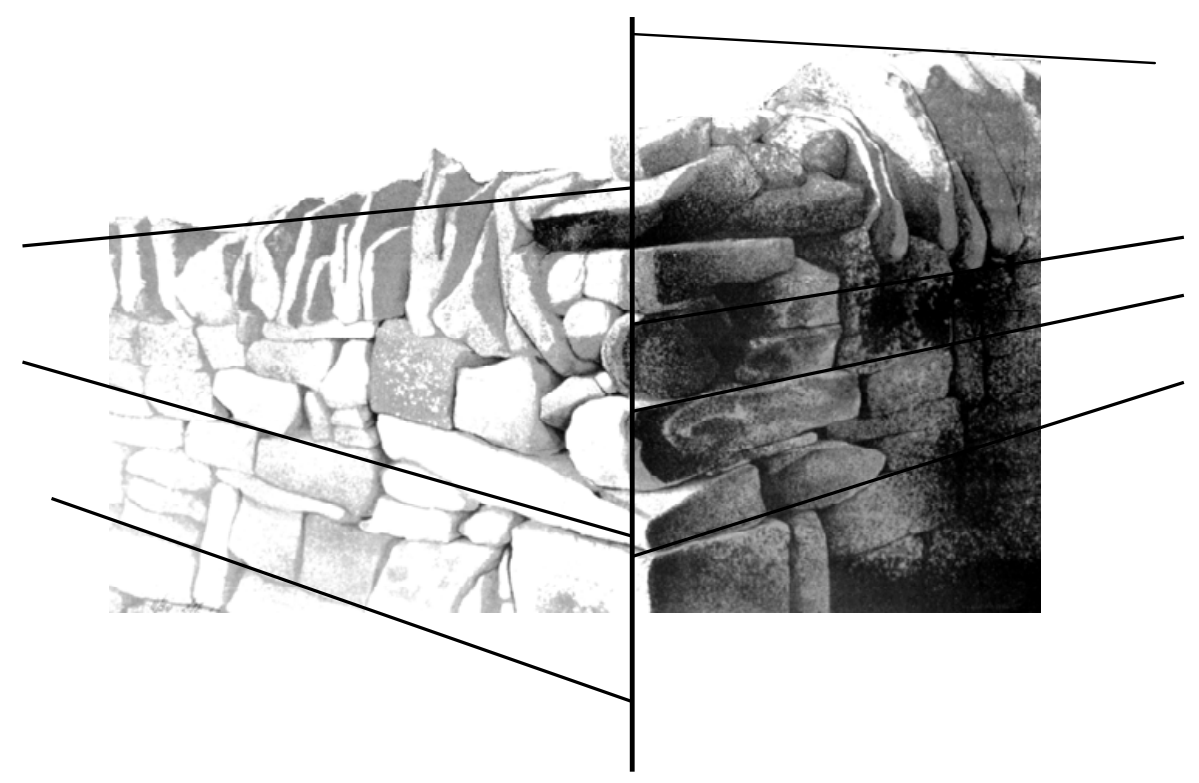

Fig. 104. Pilar Dolz. Detalle LAM. LXIV. Serie Parets de pedra seca. Litografía. 1978.

En otras obras la relación de profundidad se hace visible por medio de la superposición de planos. A diferencia de las litografías donde trabaja únicamente con dos planos, en LAM. LXXII, una obra solucionada con la técnica xilográfica, la autora trabaja con más de dos planos. Así en primer lugar en la banda inferior derecha, podemos apreciar una maleza de hierbas que afloran con un carácter gestual sobre la superficie vacía. En un segundo nivel por detrás de estas, localizamos un montículo de piedras que asumen el protagonismo. Al lado izquierdo en la parte inferior, surge un nuevo grupo de matorrales que se ubican por detrás de las piedras en un tercer plano, el mismo que descansan sobre otras formas vegetales impresas en un tono más claro que se estacionan en un cuarto y último plano. El sentido de profundidad se logra poniendo los diversos elementos a escala, la superposición aparece concebida como una forma basada en la suma de planos. 


\section{Grafismo}

En esta serie asistimos a un planteamiento gráfico variado desarrollado sobre todo por la aplicación de las técnicas. En primer lugar localizamos un grupo de obras trabajadas por medio de la técnica litográfica al spruzzo, donde la creación directa de la imagen se hace por medio del salpicado de tinta. ${ }^{207}$ Los objetos tratados presentan cuerpos minerales inorgánicos como rocas, piedras, cuya compleja conformación física anula la existencia de la línea y reduce la forma a unos aspectos exclusivamente estructurales y texturales generados por puntos. La tinta se esparce por el plano con distinta densidad e intensidad produciendo texturas hoscas y ásperas que evocan sensaciones táctiles, pero también efectos volumétricos.

En este punto la luz juega un papel muy determinante, son unos toques que aparecen agrupando o dispersando el tono de la tinta, estableciendo así movimiento, claridad y sombra en la imagen. Con el spruzzo la artista se aleja del trazo lineal físico desarrollado en series anteriores, si bien en Pedres i paisatges dels Ports ya pudimos observar cómo se va iniciando en la pulverización apasionada de la resina designando el trazo lineal exclusivamente para vigorizar la imagen. (Véase Cap. III.8.2) En la litografía la tinta se esparce al instante construyendo formas, volúmenes y espacio a través de puntos, la artista utiliza el vasto conocimiento que posee del claroscuro para alcanzar la ilusión de tridimensionalidad en la imagen. (Véase Fig. 105)

\footnotetext{
${ }^{207}$ Técnica que la aprende en Urbino (Italia) en 1978, donde trabaja con grandes formatos, incluso en algunas obras más grandes estampa a sangre, lo que entraña mayores dificultades para la técnica empleada. Entrevista personal con la autora en Castellón de la Plana. 27/04/2006
} 


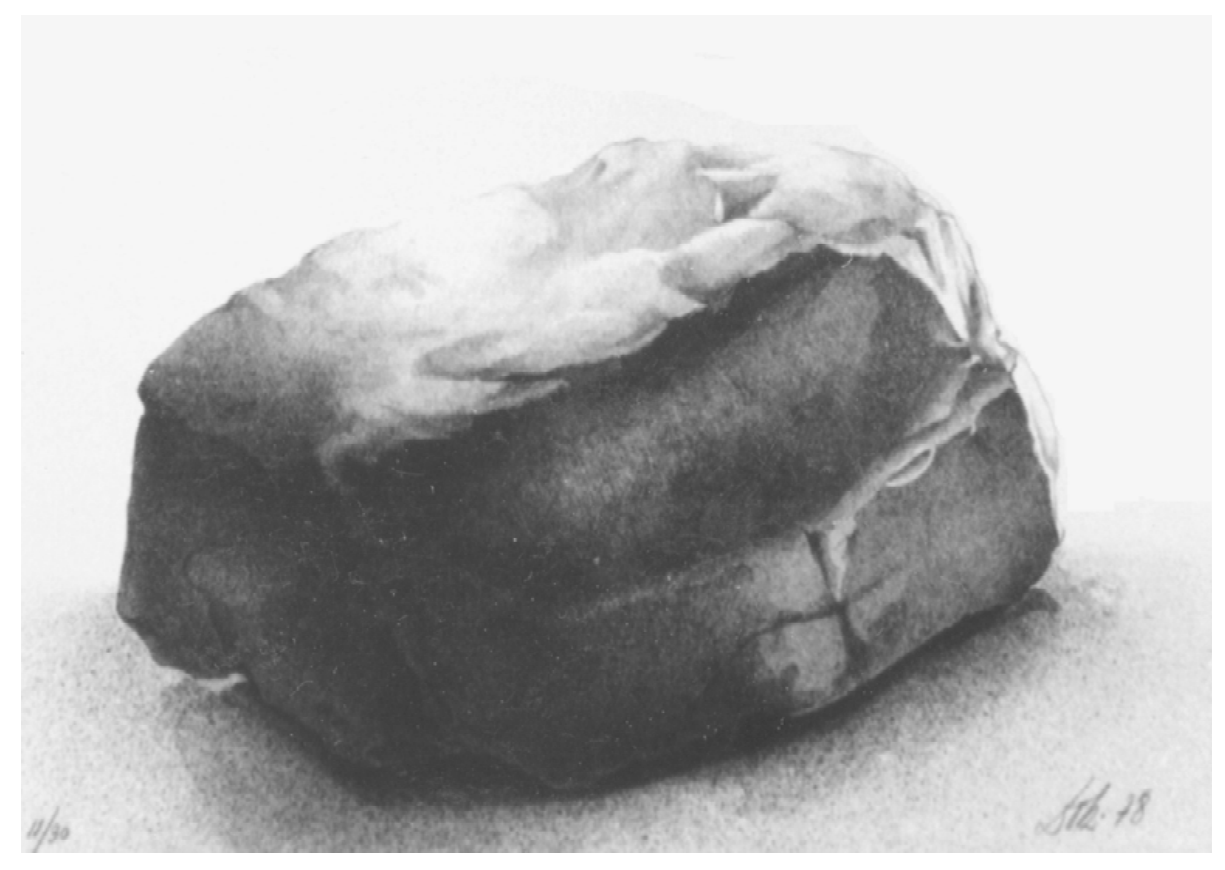

Fig. 105. Pilar Dolz. Detalle LAM. LXIV. Serie Parets de pedra seca. Litografía. 1978.

Junto a este trazo surge otro más libre y gestual realizado por medio de rayados continuos e insistidos de lápiz litográfico conformando grandes masas de tinta que se presentan unas veces densas y compactas resolviendo valores de profundidad, mientras que en otras ocasiones se muestran más manejables, que podemos distinguir las cualidades texturales de la superficie porosa de la piedra litográfica, que produce una sensación grata. (Véase LAM. LXIV)

Este mismo planteamiento gráfico lo utiliza también en la serigrafía donde emplea lápices de labios para rayar la pantalla, su frotamiento enérgico e intensivo hace que la grasa se adhiera sobre la malla de modo irregular obturando su trama en unas zonas más 
que en otras originando así una textura rugosa y áspera próxima a los efectos que se alcanzan con el pastel. La artista experimenta el comportamiento del material adaptándolo a su lenguaje junto a otros más tradicionales que producen superficies más sólidas y homogéneas. (Véase LAM. LXV)

(...) he trabajado la serigrafía también con los lápices de labios, te cubre la malla, la tela de seda; cualquier cosa que le pongas, si tú quieres que te dé esa calidad, y te contrarreste esto tan plano de la serigrafía. ${ }^{208}$

En cuanto a la xilografía vuelve a reaparecer el trazo lineal a través de una estructura simple y esquemática; con unas líneas rectas individualizadas que aparecen en disposición inclinada, manteniendo un ritmo y creando planos en diferentes direcciones que nos señalan la tridimensionalidad espacial. Se trata de un trazo rígido y duro que es arrancado de la superficie de una forma limpia guardando en sí un rasgado liso y sencillo. Este trazo aparece asentado sobre una gran mancha plana calmando la fuerte tensión que nos produce la disposición de las paralelas diagonales. (Véase Fig. 106)

${ }^{208}$ Entrevista personal con la autora en Castellón de la Plana 21/03/2007. 


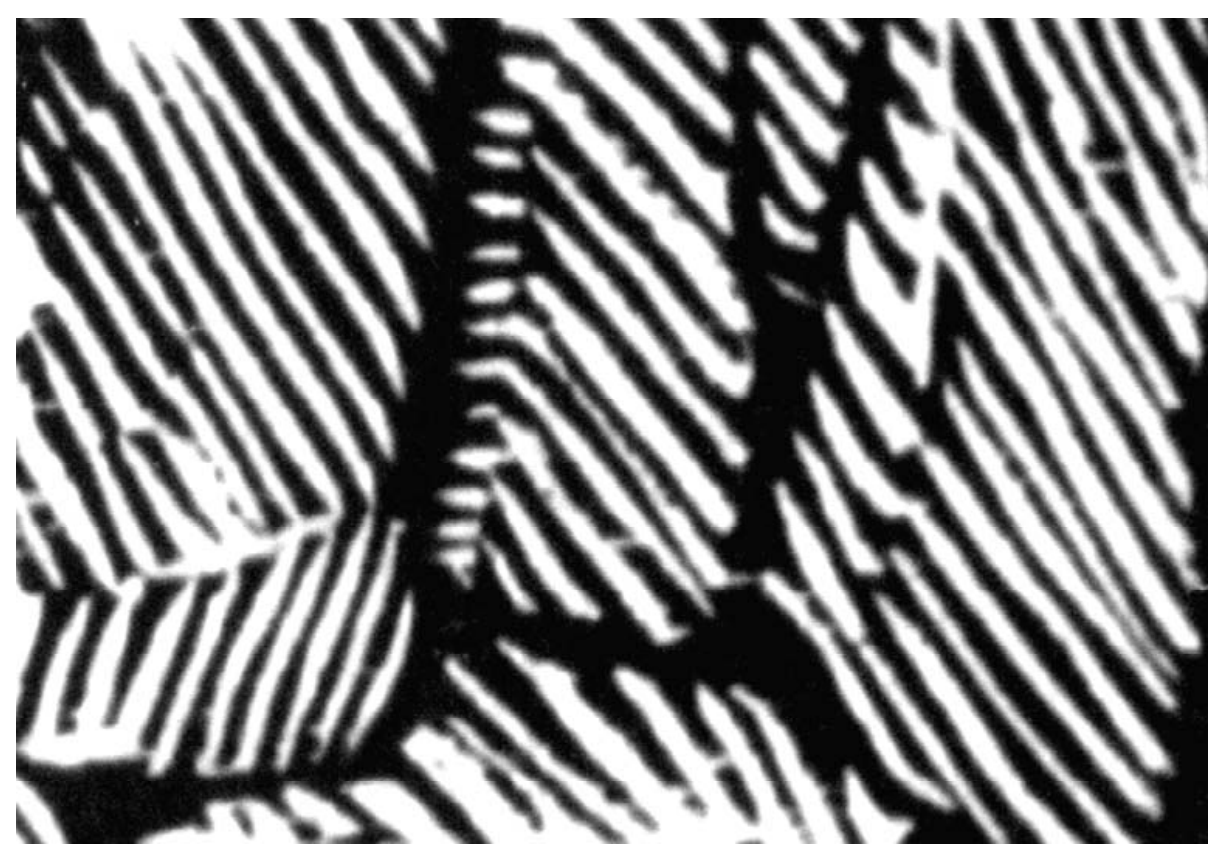

Fig. 106. Pilar Dolz. Detalle LAM. LXVI. Serie Parets de pedra seca. Xilografía. 1979.

En otras obras este trazo es más libre y expresivo con un discurso más cercano al informalismo; es un trazo realizado directamente sobre la matriz de una forma impulsiva y automática con una punta o cuchilla de metal, posiblemente la madera empleada ya esté un poco desgastada y muchas de las rayas sean accidentales. Trazos gestuales cortos, salpicados forman una estructura de líneas muy finas que surgen como si fueran raspaduras y garabatos, que proporcionan a la superficie una textura fibrosa que personifica la epidermis de los muros antiguos y las viejas paredes. (Véase Fig.107) 


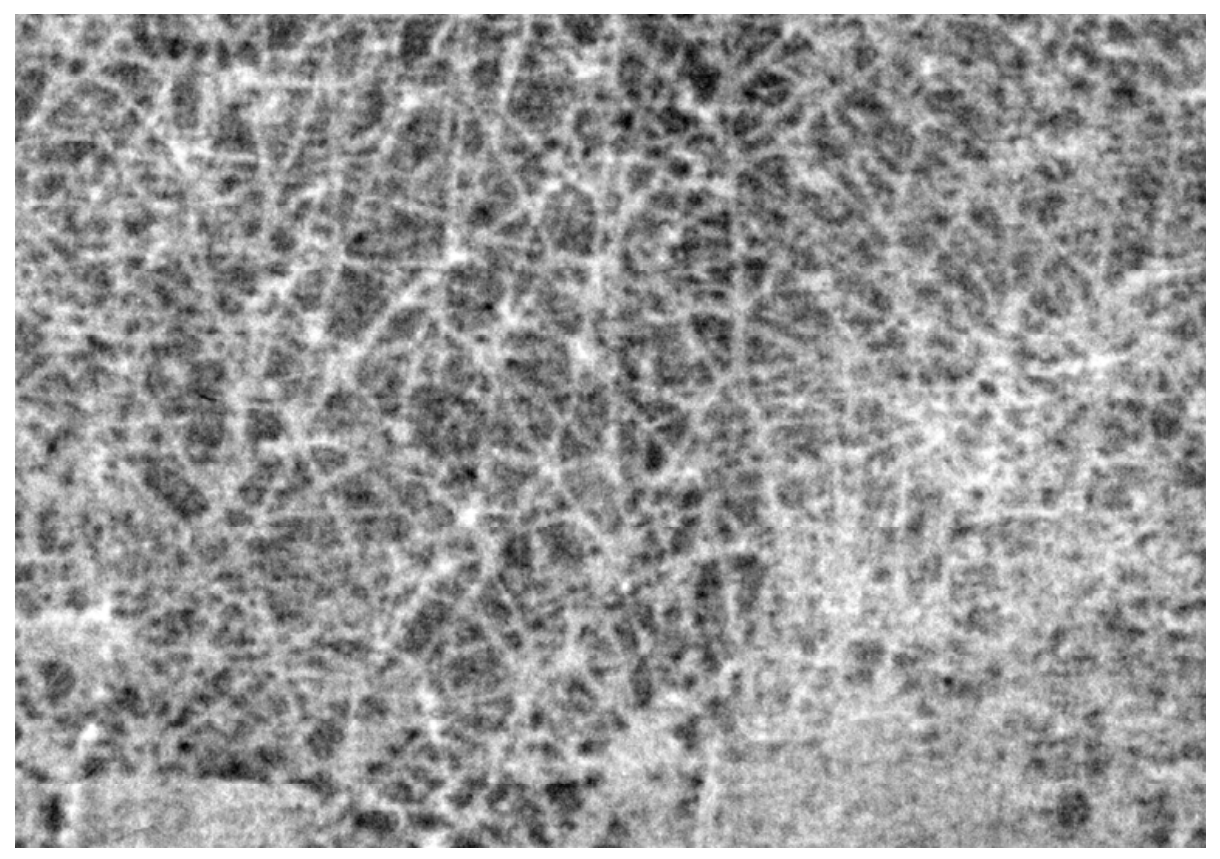

Fig. 107. Pilar Dolz. Detalle LAM. LXXI. Serie Parets de pedra seca. Xilografía. 1979.

En otros casos este trazo aparece con un concepto más caligráfico y gestual, por medio de una línea flexible y dinámica de gran espesor que surge en el espacio formando imágenes de gran expresividad, en las que la artista no se preocupa tanto por el aspecto formal en sí, como más bien en captar la esencia de la imagen. En LAM. LXXII podemos advertir una imagen de piedras apiladas, resuelta de un modo básico con manchas planas y un trazo lineal vigoroso. La factura de la línea de aspecto quebradizo en ciertas zonas otorga a la imagen un semblante nervioso como si se estuviera tambaleando a punto de caer. En las formas vegetales el trazo surge con una mayor libertad gestual siguiendo ondas de ascenso y descenso, que se perciben rápidas y simultáneas, resultado de la acción automática de la mano, que dan lugar a 
formas con una fuerte calidad abstracta pero que se presuponen figurativas. (Véase Fig. 108)

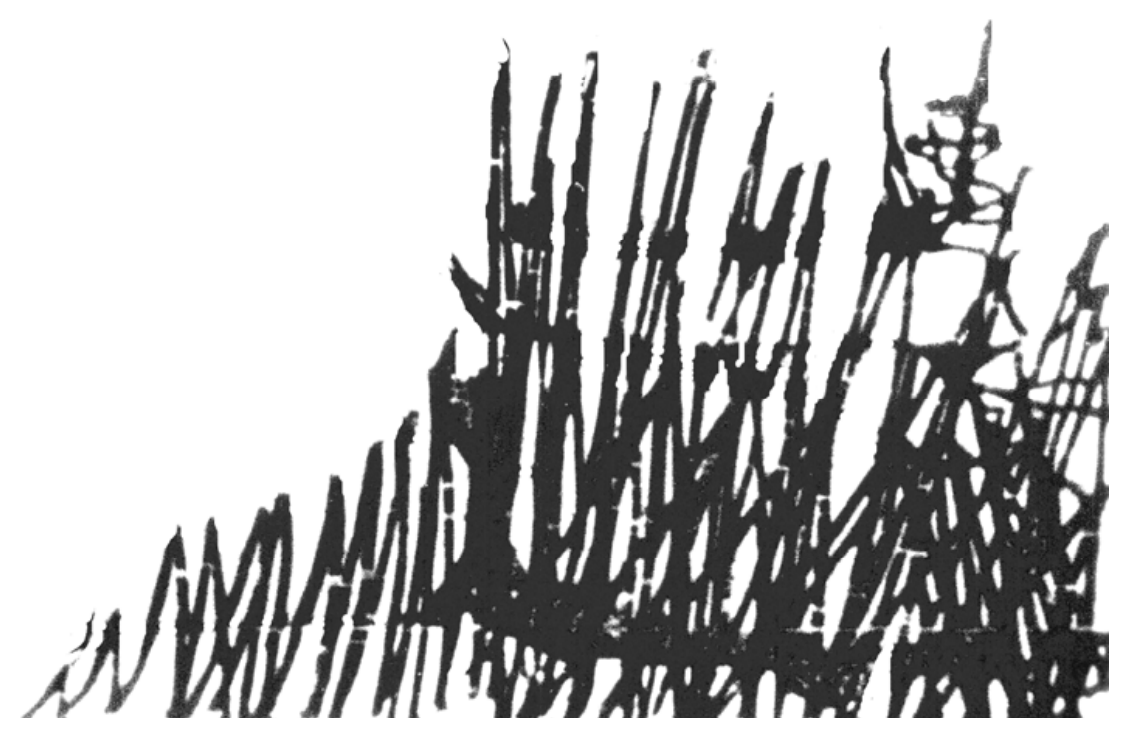

Fig. 108. Pilar Dolz. Detalle LAM. LXXII. Serie Parets de pedra seca. Xilografía. 1979.

En el aguafuerte el trazo sigue una estructura regular, con la repetición continua de líneas paralelas que surgen con una intención de claroscuro. Las líneas se sitúan una junto a la otra creando efectos variables de tono, superficie y forma; según la distancia que se guarde entre ellas se crea diferentes grados de luz. Son líneas paralelas muy finas y delgadas que surgen con precisión y en bandas uniformes proporcionando forma y volumen a la imagen a través de la variable tonalidad que se controla con la intensidad del trazo que depende de la acción del ácido. (Véase Fig. 109) 


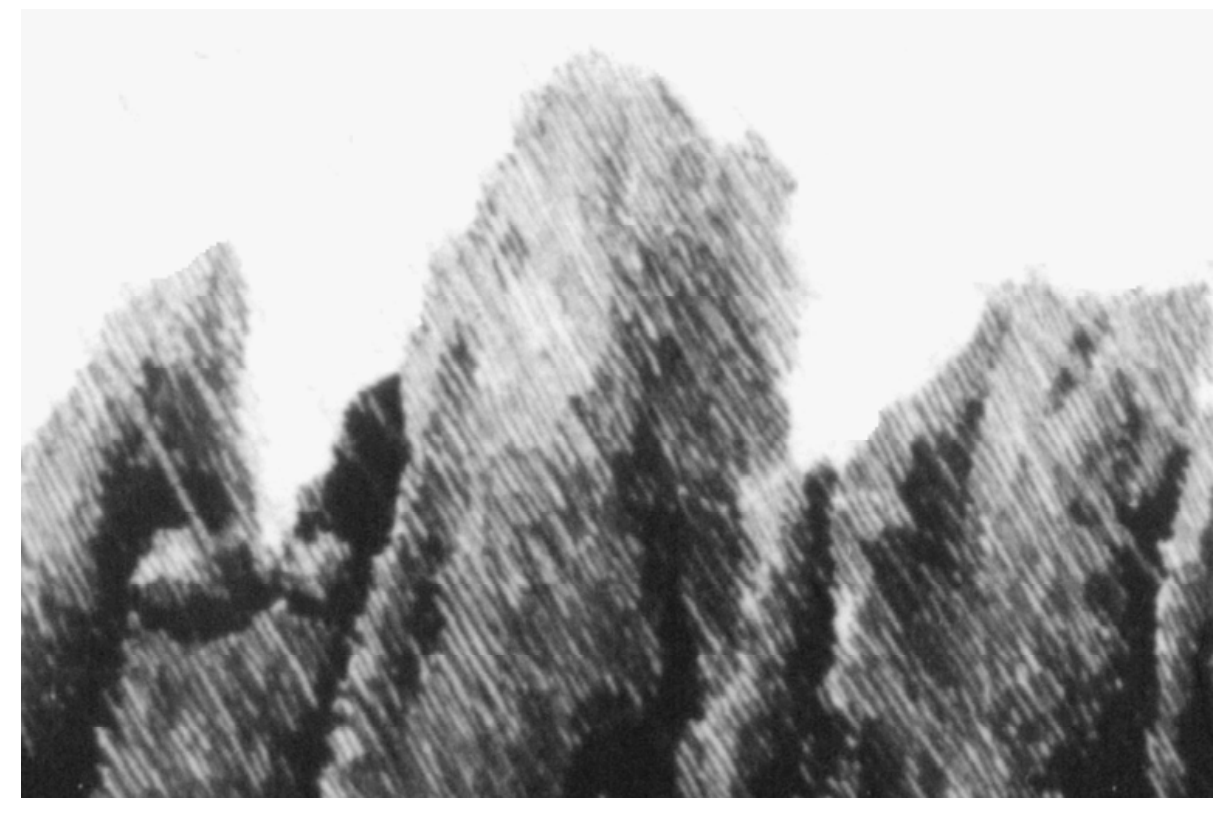

Fig. 109. Pilar Dolz. Detalle LAM. LXXIII. Serie Parets de pedra seca. Aguafuerte y aguatinta. 1978.

Lo curioso a destacar es que tanto en la litografía como en el grabado calcográfico, la línea de contorno desaparece, si bien en el aguafuerte se designa la línea para crear planos que conforman la imagen. El resto del espacio vacío se resuelve con la superposición de planchas trabajadas normalmente de un modo más libre, ya sea por la ejecución de líneas paralelas amplias con aguafuerte o por medio de una serie de manchas claras que fluctúan en el espacio realizadas con la disposición directa de grandes trozos de resina, que se adhieren a la plancha creando formas abstractas que impermeabilizan el plano. 


\section{Color}

En algunas obras de esta serie donde intervienen la figura y el fondo en la composición, el tema cromático está basado en la relación del negro para la forma que se convierte en el punto focal (sobre todo en las primeras litografías y aguafuertes) y el color para el fondo que se resuelve por medio de manchas tonales; texturales o planas, grafías, papeles coloreados y demás recursos que se aplican de acuerdo al proceso técnico. Un claro ejemplo de esto lo tenemos en LAM. LXII, donde localizamos en primera instancia la imagen de una piedra ejecutada con un cuidadoso estudio del claroscuro cerca de la zona central del espacio e impresa en tinta negra, en tanto que un trazo caligráfico que escribe la palabra piedra ocupa el resto del plano estampado en tres tintas de la misma gama tonal; un amarillo claro, otro más intenso y otro más oscuro con los que la artista intenta establecer un degradado. La imposición de la forma estampada en negro sobre un fondo cálido hace que aumente su potencia visual.

Eso es un trabajazo tremendo porque esas son diferentes planchas; el primero es una piedras, pero las demás son diferentes planchas y entonces para que coincidan trabajo mucho. Para que ese color te quede como un degradado, coincide el texto sobre el texto; tres tonos un rojizo, uno mas oscuro y otro más amarillento. ${ }^{209}$

Lo mismo ocurre en LAM. LXIII, la figura de un muro de piedras que surge en la zona inferior hasta la mitad del espacio se halla estampada en negro, mientras que la otra mitad que

${ }^{209}$ Entrevista personal con la autora en Castellón de la Plana. 07/03/2002. 
hace referencia al fondo se soluciona con una mancha de bordes difusos estampada en dos tonos de la misma gama; un verde claro con una fuerte carga de luz y otro más oscuro que se aloja por detrás. La combinación de los dos tonos proporciona cierto movimiento a la mancha que asoma en algunos sitios más plana. Esta manera de trabajar tiene sus precedentes en varias series anteriores, como Reixes, donde la forma se estampa normalmente en negro (Véase Cap. III.4.2) En Ocells morts ocurre algo similar, la imagen principal de la paloma muerta, se imprime en tinta negra y se ubica en el plano con independencia del color, sin superponerse, proporcionando el protagonismo a la figura. (Véase Cap. III.5.2)

En otro grupo de obras interviene el color tanto en la figura como en el fondo manteniendo el mismo planteamiento; la representación figurativa para la forma y la mancha para el fondo. El empleo del color se hace por medio de tintas suaves y atenuadas que pierden su intensidad y surgen como tonos apastelados, descoloridos; verdes, violetas, grises, ocres y amarillos que aparecen combinados con tonos secundarios como el verde y el violeta, que dan a la composición un aspecto más sombrío (Véase LAM. LXIV) En otras ocasiones se aumenta la vitalidad de la obra con tonos más cálidos como el amarillo-ocre que neutraliza la frialdad del verde y aporta más fuerza a la imagen. (Véase LAM. LXV).

En cuanto a las propiedades del color, éste surge unas veces a manera de tintas planas que revisten la superficie creando manchas sólidas, mientras que en otras ocasiones un color se 
superpone para atenuar la densidad de la tinta. Así por ejemplo en LAM. LXVII la artista utiliza dos colores en la misma imagen: un gris plano que se utiliza de base, sobre el que se imprime la forma estampada en un tono sepia-rojizo con lo que se pretende crear una uniformidad en la obra y el color.

En otro grupo de obras la artista aplica dos o tres colores que se funden en la misma estampa con una sola matriz. Para esto se maneja una nueva técnica de estampación llamada sbalzzo, ${ }^{210} \mathrm{~A}$ partir de este momento, el trabajo de intervención creativa se hace sobre el proceso de entintado, la profundidad de la mordida le permite entintar en diversas alturas para lo cual recurre al empleo de diversos tipos de rodillos duros y blandos, que introducen la tinta en las aberturas de manera que con una sola matriz y de una sola pasada se consiguen estampas polícromas. (Véase LAM. LXIX y $L X X)$

Depende de cómo son los colores, cómo es el dibujo; si quieres que sea muy preciso puedes poner dos o tres colores. Es la misma técnica de Hayter, lo que pasa es que en Hayter tiene una cosa añadida que es la viscosidad de las tintas, que no permite que se mezclen los colores, aquí los colores se mezclan. ${ }^{211}$

En el aguafuerte el color interviene de diferente manera, Así en algunas obras aparece por medio de la aplicación de papeles de

\footnotetext{
${ }^{210}$ Impresión de varias coloraciones por niveles. La técnica se trabaja de manera semejante al aguafuerte por medio de la aplicación de ácido nítrico en la piedra que actúa dejando un fuerte relieve en la superficie. Es lo que se diría litografía a relieve, cualidad que permite superponer colores. Esta es una técnica exclusiva de la piedra no se puede trabajar sobre planchas litográficas. Entrevista personal con la autora en Castellón de la Plana. $21 / 03 / 2007$

${ }^{211}$ Ibidem
} 
color pegados generalmente en tonos suaves; naranjas, verdes, grises, marrones que cubren toda la superficie y sobre los que se estampa la imagen en negro o en color (Véase LAM. LXXIII).

En otras ocasiones surge por medio de la combinación de dos planchas que se yuxtaponen mezclando los colores. Muchas de las veces la superposición de las planchas satura el espacio por completo fusionando los colores, mientras que a veces la artista acude a la utilización de plantillas para proteger las zonas que no quiere que sean entintadas. (Véase LAM. LXXIV). Otras obras son estampadas en negativo, a la inversa del proceso tradicional es decir a través de un entintando con un rodillo, haciendo que la tinta permanezca en la superficie y no entre en las hendiduras elaboradas por el ácido dejando de esta manera que el trazo permanezca blanco. (Véase LAM. LXXV)

Son las mismas rayas del inicio pero estampadas en negativo, es decir con un rodillo. El aguafuerte está estampado en negativo. Cuando pasas un rodillo de color por la plancha la tinta se queda arriba no entra a la línea, y como no entra, queda la línea en blanco. ${ }^{212}$

212 Ibidem 


\subsubsection{PROCESO TÉCNICO}

Esta serie presenta un conjunto de obras realizadas en las diferentes técnicas de reproducción gráfica desde xilografías hasta litografías pasando por la serigrafía y el aguafuerte. Pero sin duda una de las más desarrolladas y que da origen a esta serie, es la mencionada litografía al spruzzo.

La litografía se trabaja con un tratamiento poco común a través de pulverizados de tinta sobre una superficie plana. El rociado se ejecuta con un cepillo directamente sobre la matriz, ayudado de una redecilla de metal de distintos entramados que la artista se mandó hacer a un herrero. Esta retícula le permite distribuir la tinta de modo uniforme, creando una estructura homogénea de puntos de manera similar a la de la resina. Para las reservas acude al empleo de plantillas de papel cristal que cubren las zonas que no quiere que sean valoradas, mientras deja libres otras para ser trabajadas. Esta técnica le permite conseguir buenos matizados y unos efectos particulares de texturización.

Me gustaba mucho hacer piedras, me gustaba muchísimo; eran con plantillas. Entonces hacía el spruzzo que es un salpicado, una cosa que era muy divertida para la litografía. Lo hice con esto que me hice hacer con un herrero. Entonces yo cojo un cepillo y pongo tinta allí y tiro; como tengo de distintos gramajes va cayendo, lo hago directamente en la plancha. Si lo hago sólo con el cepillo no me queda uniforme. Si te das cuenta esto es muy uniforme. Entonces pongo una plantilla, destapo el trozo que yo 
quiero y lo hago con esto. Queda como si fuera la resina, muy uniforme, $(\ldots)^{213}$

En el diálogo con la autora, comprobamos su forma de realizar este interesante proceso para obtener diversos resultados. Así en algunas ocasiones emplea arena de distintos gramajes que deposita en la superficie de la piedra, sobre la que esparce posteriormente la tinta, éste ejercicio le permiten obtener diversos tipos de texturas con las que logra dar esa sensación epidérmica a la piedra. (Véase LAM. LXVIII y LXX.)

(...) Tiro arena y luego la tinta, dejo secar. Con el cepillo la quito. Yo no invento nada. A lo mejor otros dirían arenografía. No, no, yo tiro y tiro arena más fina y más gruesa; además tenía un cedazo y cernía la arena. Cuando yo tiraba la arena, a veces tenía una textura más suave y otras más gruesa. Otras veces utilizaba piedras pequeñas reales, que me servían para hacer unas reservas más grandes. Yo trabajaba una cosa y decía: "voy a probar esto" y era algo que me iba a más. ${ }^{214}$

Otras de las técnicas cultivadas en la escuela de Urbino es la mencionada litografía al sbalzzo, con la que la artista alcanza cotas muy altas no sólo en su trabajo de grabado, sino también en la estampación logrando sorprendentes resultados.

En esta época yo trabajé la piedra como si fuera una plancha, es decir les creaba unos relieves y todo a la piedra. Si las tocas tienen una calidad; entonces trabajaba sobre esto. ${ }^{215}$

\footnotetext{
${ }^{213}$ Entrevista personal con la autora en Castellón de la Plana. 24/08/2006

${ }^{214}$ Ibidem

${ }^{215}$ Entrevista personal con la autora en Castellón de la Plana. 21/03/2007
} 
Normalmente para el trabajo de las piedras, Pilar Dolz emplea un ácido fuerte, $40 \%$ ácido y $60 \%$ agua más o menos. En algunas ocasiones se suele poner un poco de goma arábiga, pero nos comenta la artista que ella no utiliza este componente. Una vez preparado el ácido va pasando esta solución con un pincel o una esponja, pues las piedras son demasiado grandes y pesadas para ponerlas en un baño de ácido. Cuando alcanza el relieve deseado lava la piedra con abundante agua interrumpiendo la acción del ácido; el relieve que puede alcanzar con esta técnica es de 2 y 3 milímetros de espesor.

Si pones la piedra dentro de un baño de ácido, destrozas la piedra. De otra forma son unos milímetros y luego cuando la graneas te cuesta un poco más de granear, pero luego lo vuelves a granear, porque son unos milímetros. Ya lo ves que no es mucho, se nota un poco, pero eso puede ser ni un milímetro, menos de un milímetro. Es porque te lo pide el sbalzzo, y ya puedes hacer los colores. ${ }^{216}$

El número de colores que estampa con esta técnica son dos, que se estampan con dos rodillos diferentes; uno más suave y otro mas duro. En las obras donde existen tres colores, la artista emplea normalmente dos piedras con el mismo dibujo; primero dibuja la imagen sobre la piedra, después cuando está terminada hace un calco con papel de arroz y pasa la imagen a la otra piedra. De esta manera obtiene dos piedras con el mismo dibujo; en una hace el sbalzzo, y en la otra trabaja con el proceso habitual. (Véase LAM. LXIX y LXX)

${ }^{216}$ Ibidem 
Otras técnicas ya mencionadas son la serigrafía, la xilografía y calcografía, que las trabaja de una manera tradicional, si bien recurre a diversos materiales y herramientas de carácter personal como lápiz de labios, de ojos, intercambia matrices, raspa, retoma y repite obras, prueba diferentes formas de estampación, efectos y colores que reflejan el carácter investigador que ha ido desarrollando a través de los años. 
LÁMINAS

ARETS DE PEDRA SECA 



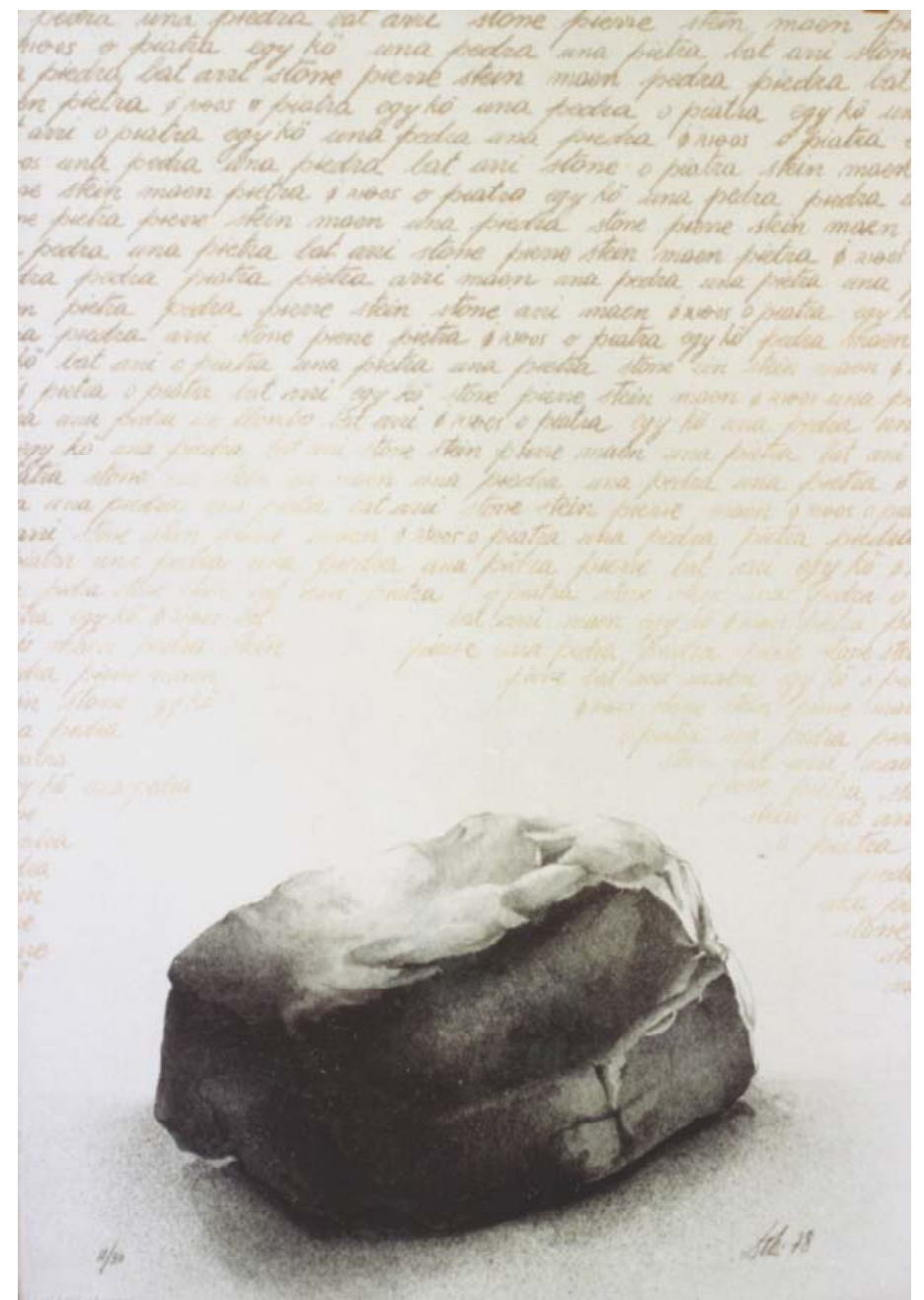

\section{LÁMINA LXII}

"Una pedra"

Litografía al spruzzo

$70 \times 50 \mathrm{~cm}$.

1978 


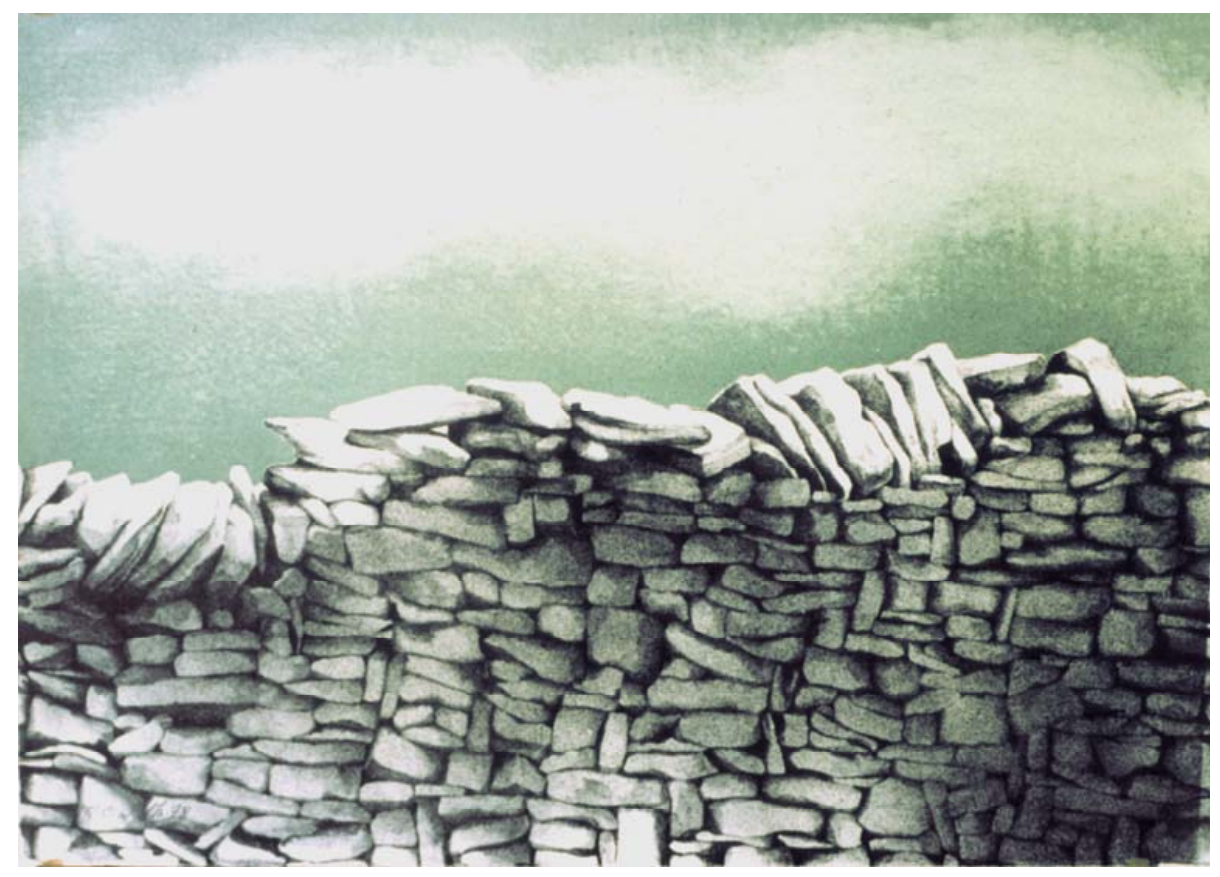

\title{
LÁMINA LXIII
}

\author{
"Paret II" \\ Litografía al spruzzo \\ $50 \times 70 \mathrm{~cm}$. \\ 1978
}




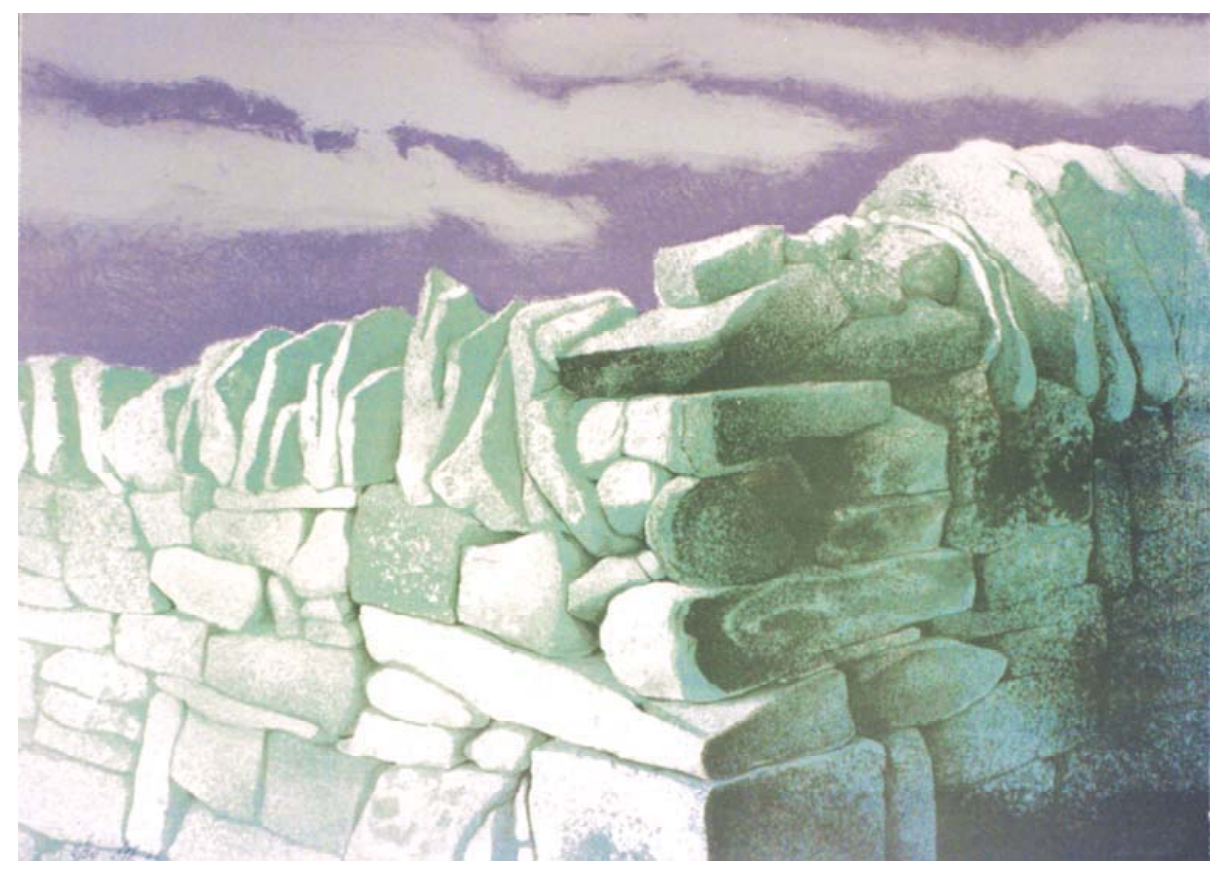

\section{LÁMINA LXIV}

\section{"Angle"}

Litografía al spruzzo

$50 \times 70 \mathrm{~cm}$.

1979 


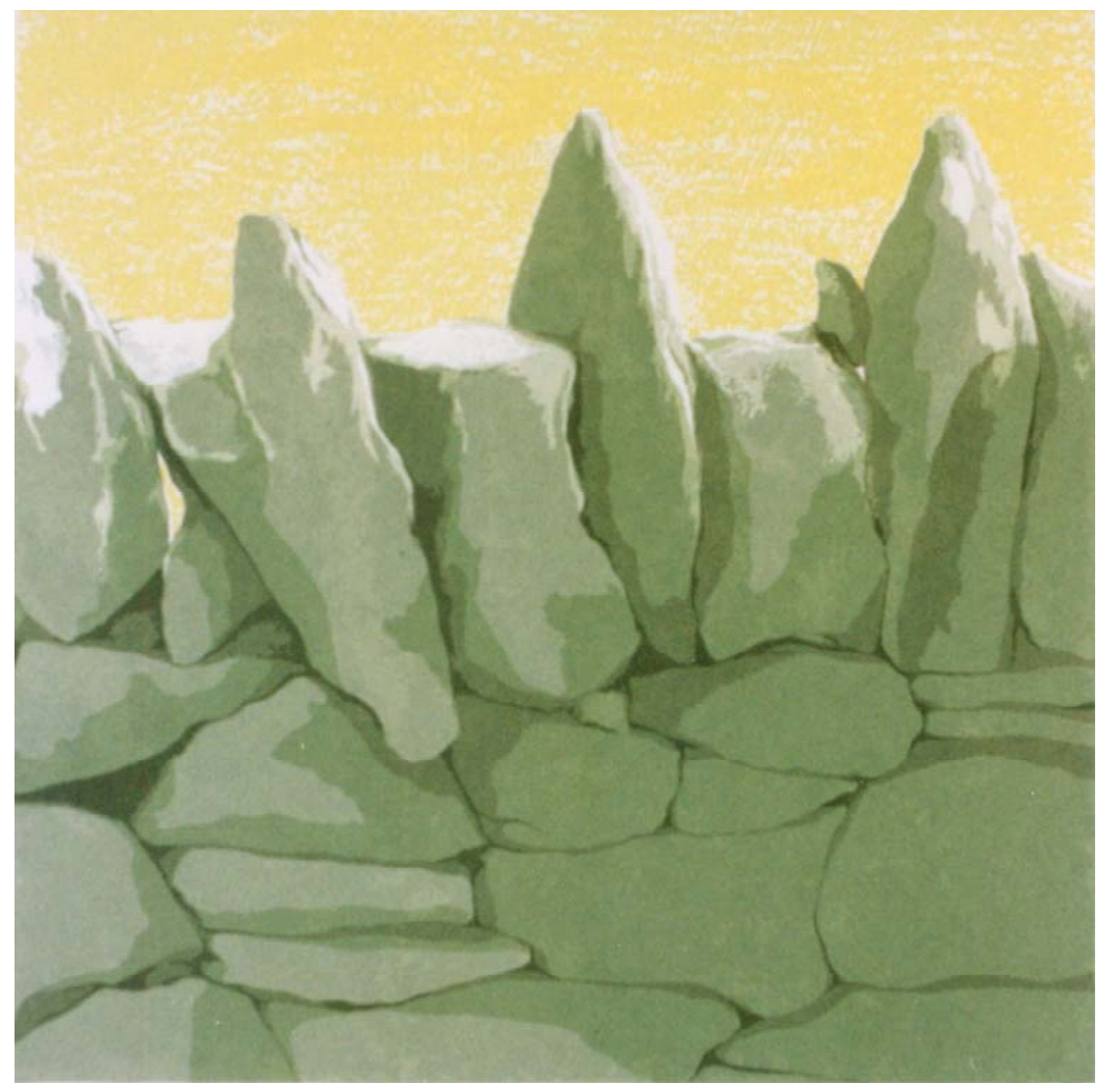

\section{LÁMINA LXV}

"Aleres I"

Serigrafía

$40 \times 40 \mathrm{~cm}$.

1979 


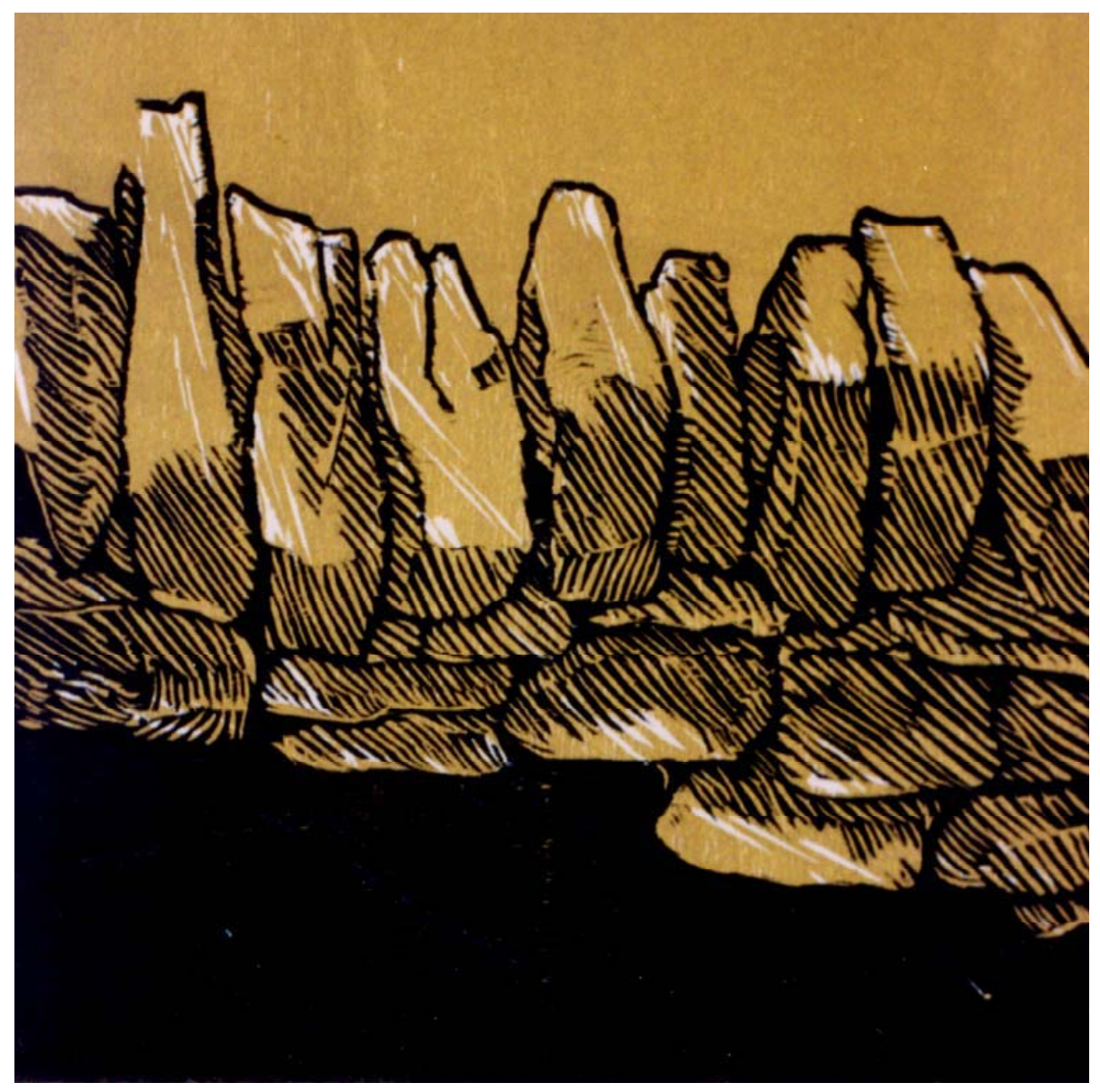

LÁMINA LXVI

"Aleres III"

Xilografía

$25 \times 25 \mathrm{~cm}$.

1979 


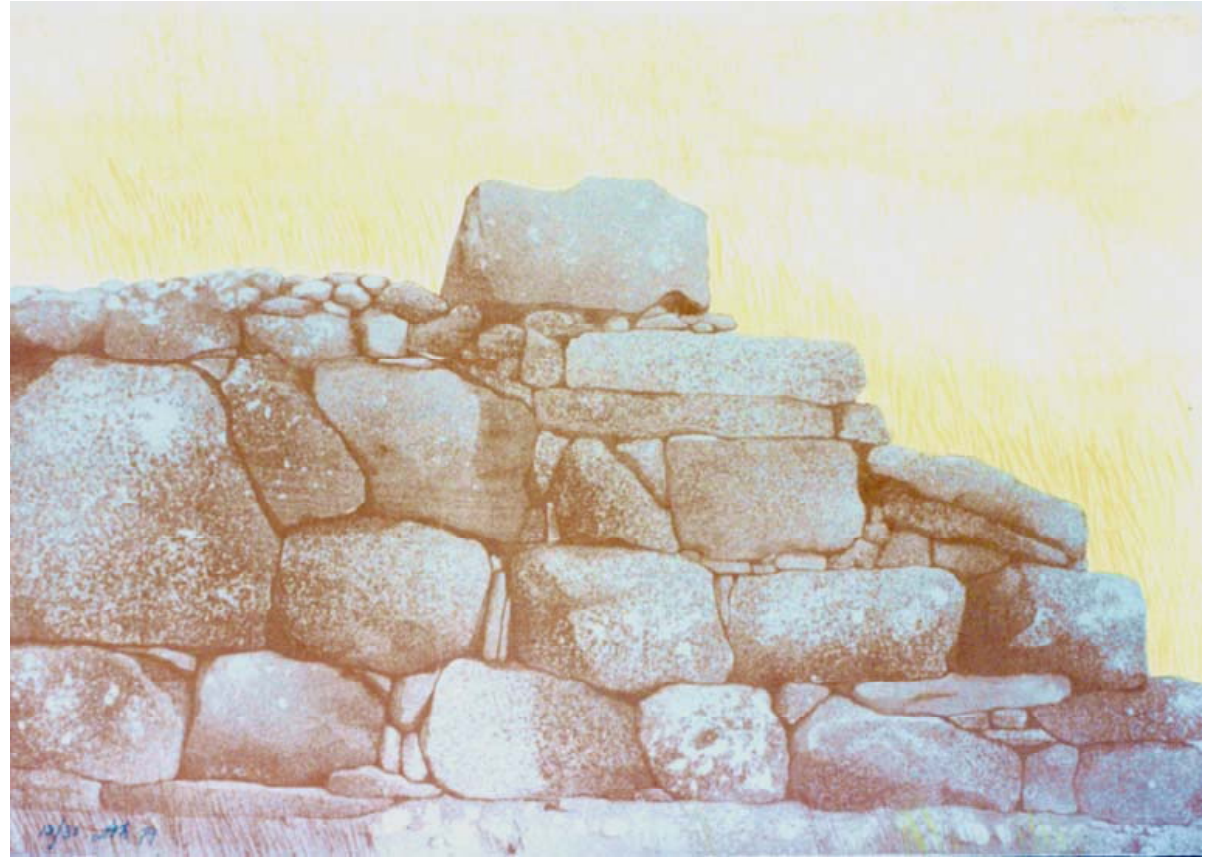

\section{LÁMINA LXVII}

"Blat madur"

Litografía al spruzzo

$50 \times 70 \mathrm{~cm}$.

1979 


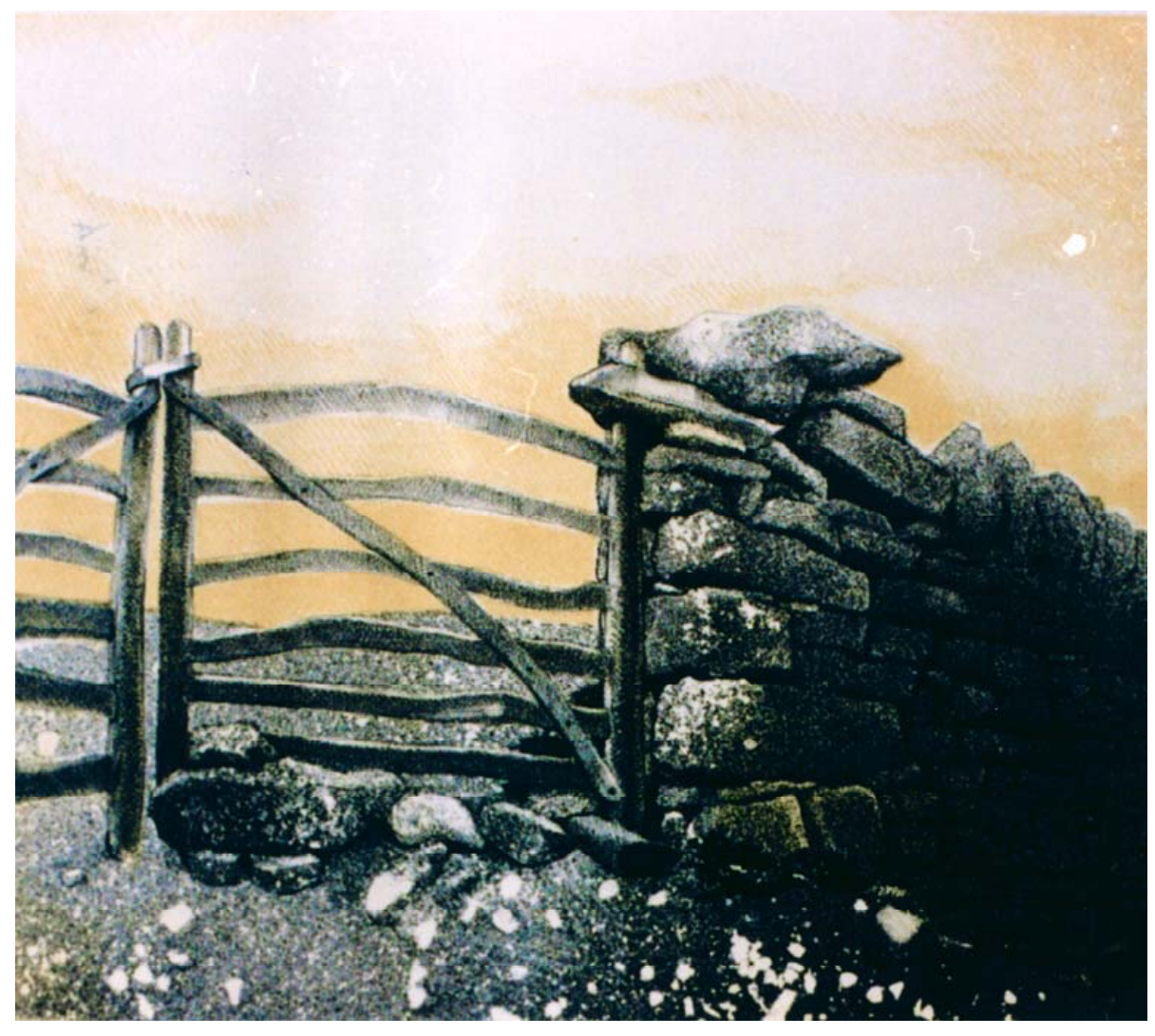

\section{LÁMINA LXVIII}

\section{"Portera"}

Litografía al spruzzo

$21 \times 24 \mathrm{~cm}$.

1979 


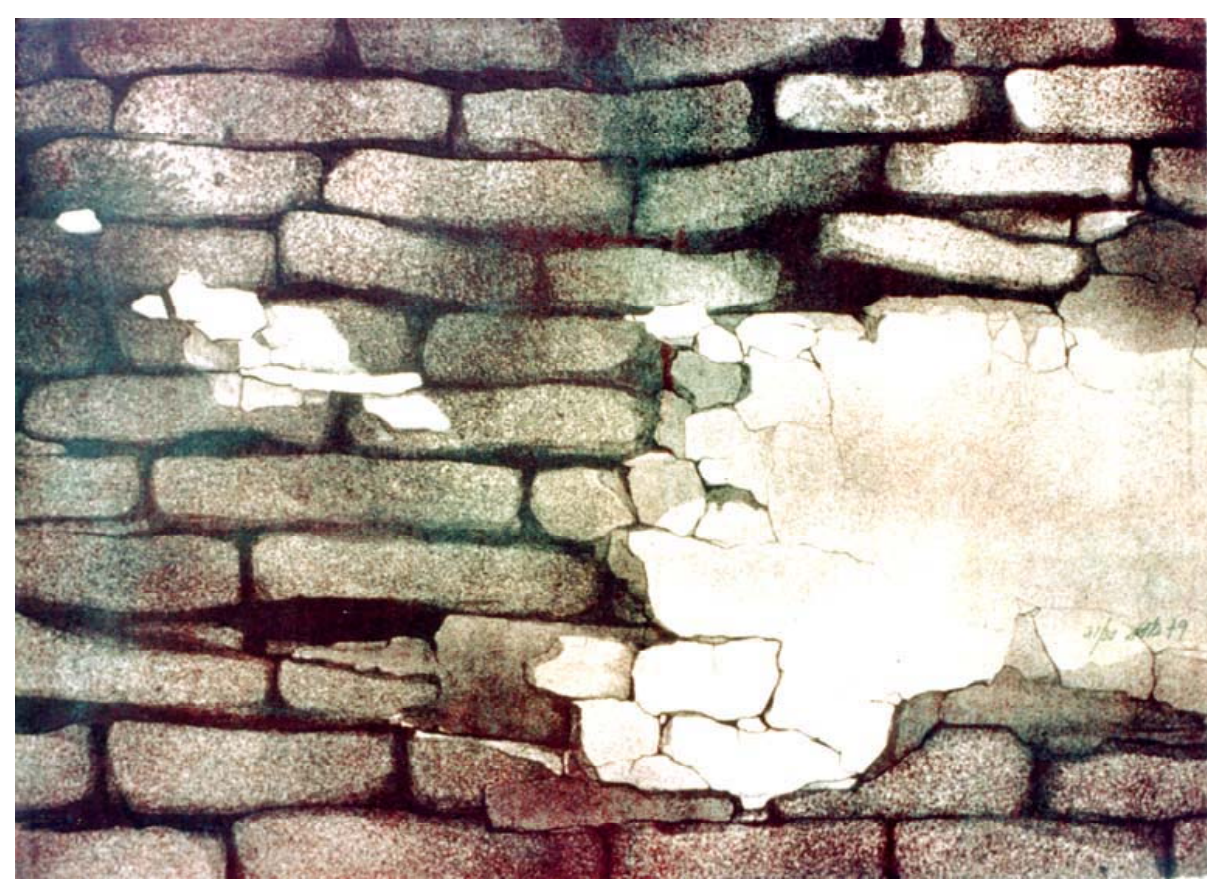

\title{
LÁMINA LXIX
}

\author{
"Maons" \\ Litografía al sbalzzo \\ $52 \times 72 \mathrm{~cm}$. \\ 1979
}




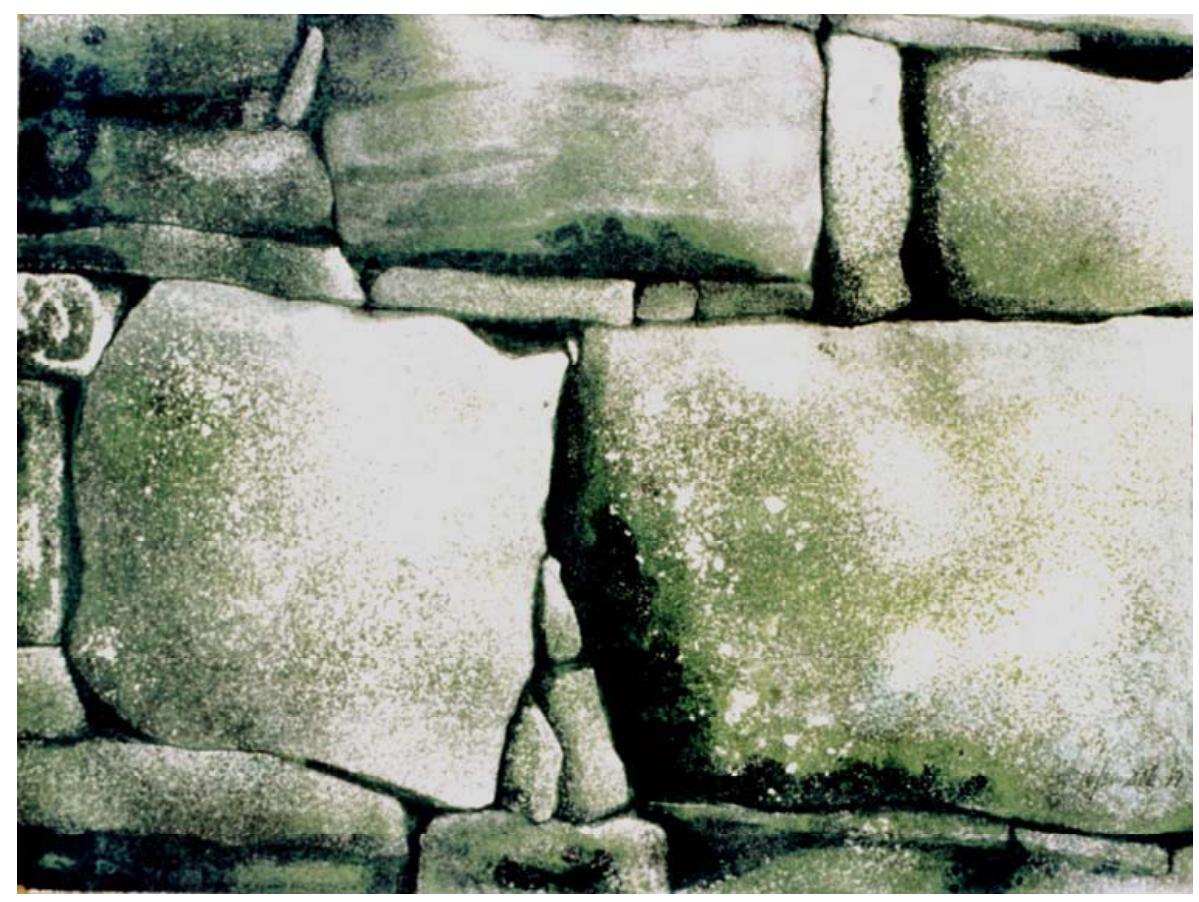

\title{
LÁMINA LXX
}

\author{
"Mur I" \\ Litografía al sbalzzo
}

$52 \times 72 \mathrm{~cm}$.

1979 


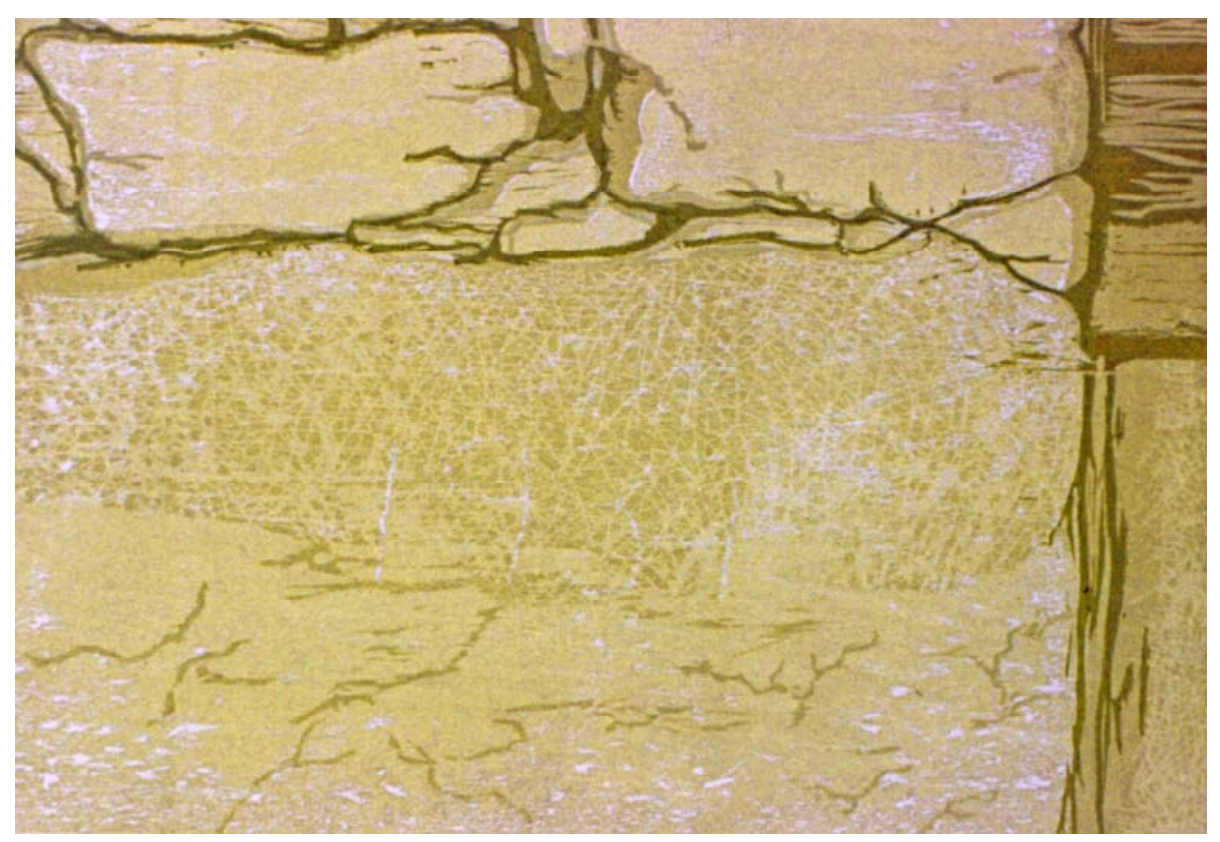

\section{LÁMINA LXXI}

"Mur II"

Xilografía

$28 \times 40 \mathrm{~cm}$.

1979 


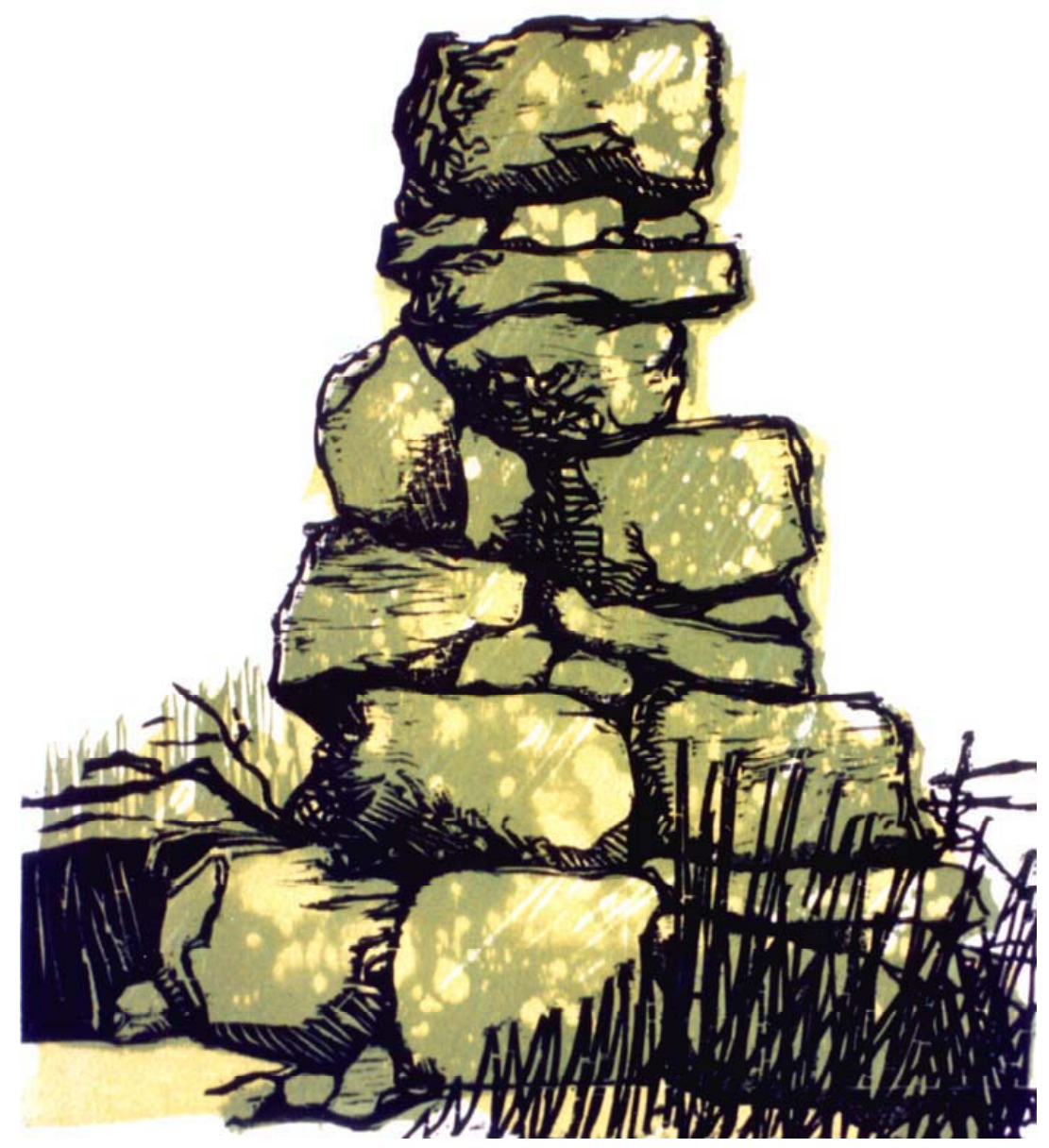

LÁMINA LXXII

"Molló"

Xilografía

$40 \times 32.8 \mathrm{~cm}$.

1979 


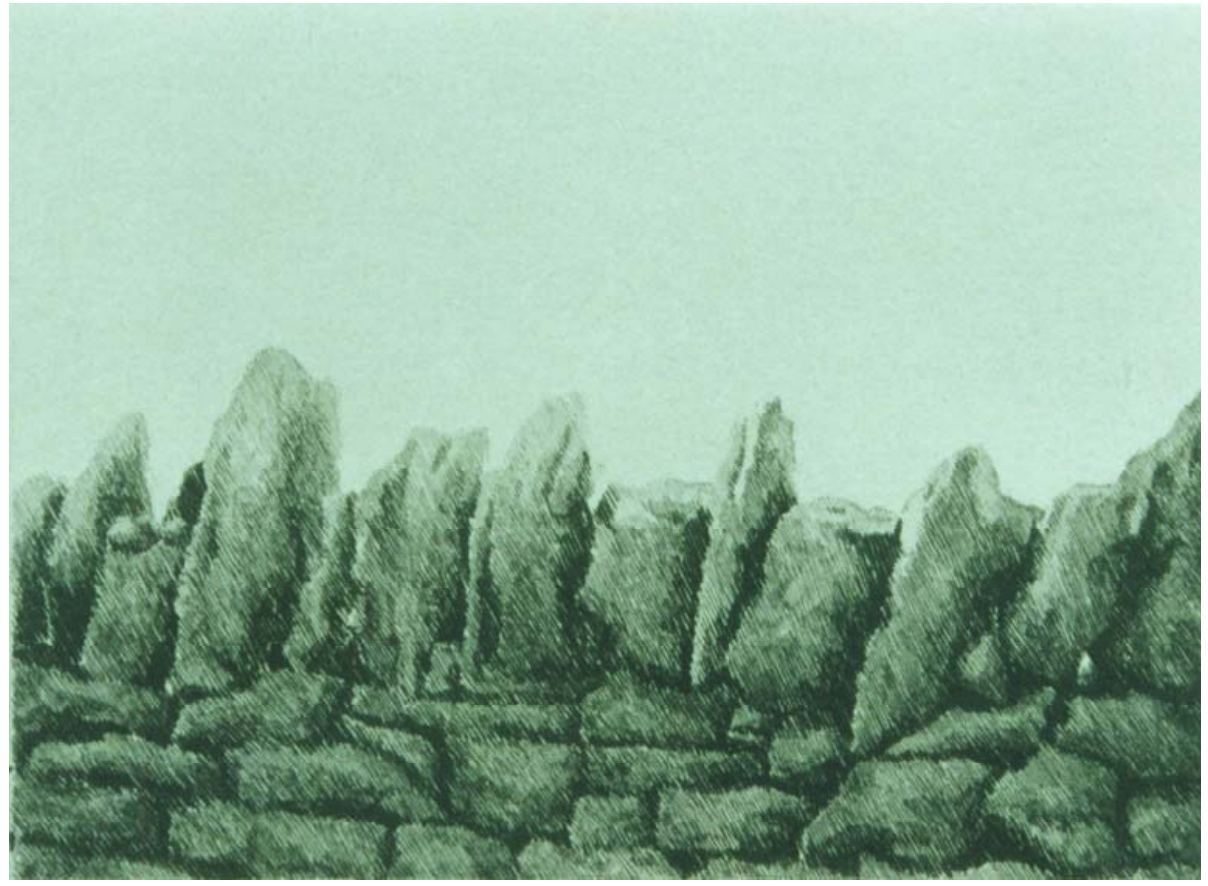

\section{LÁMINA LXXIII}

\section{"Sin título"}

Aguafuerte y fondino

$8.7 \times 11.7 \mathrm{~cm}$.

1980 


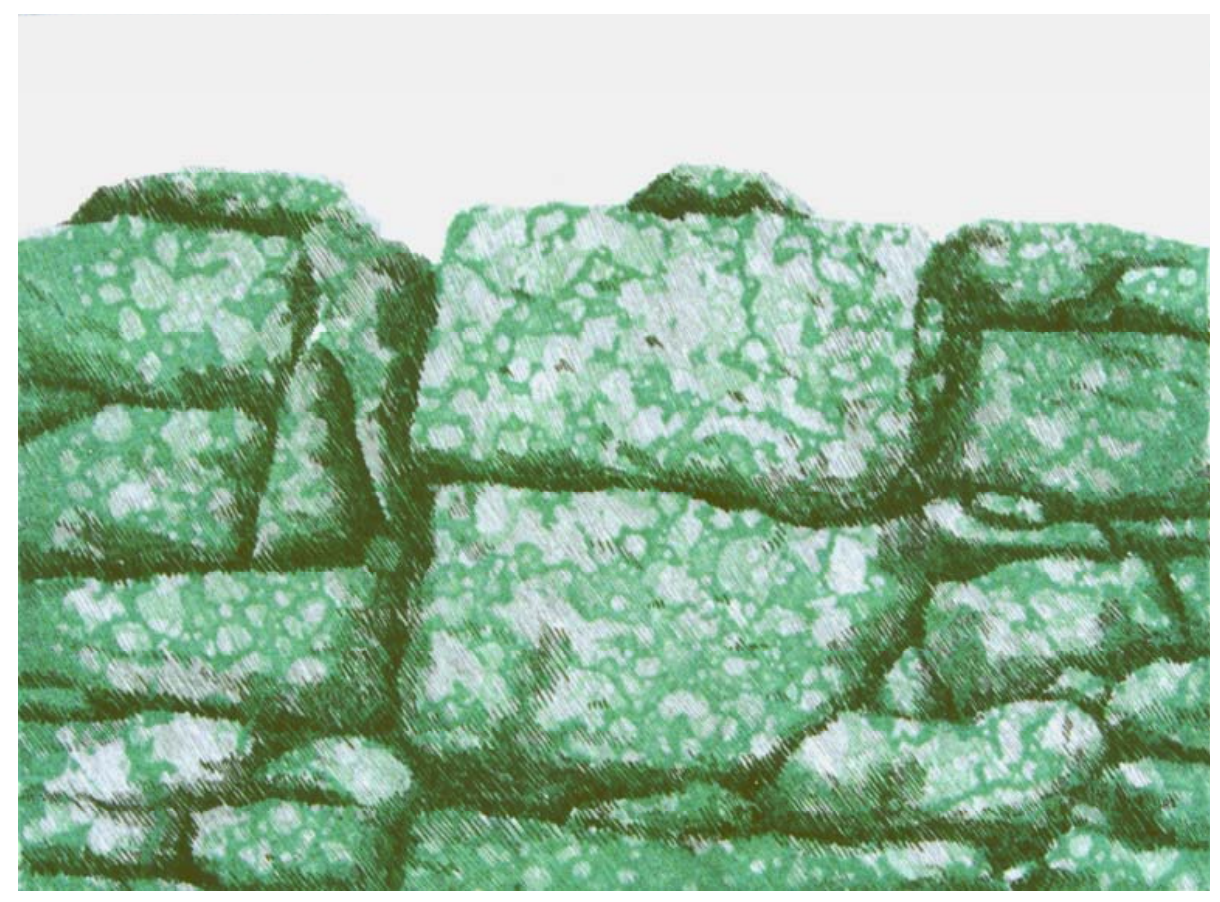

\section{LÁMINA LXXIV}

\section{"Sin título"}

Aguafuerte y aguatinta

$8.7 \times 11.7 \mathrm{~cm}$.

1980 


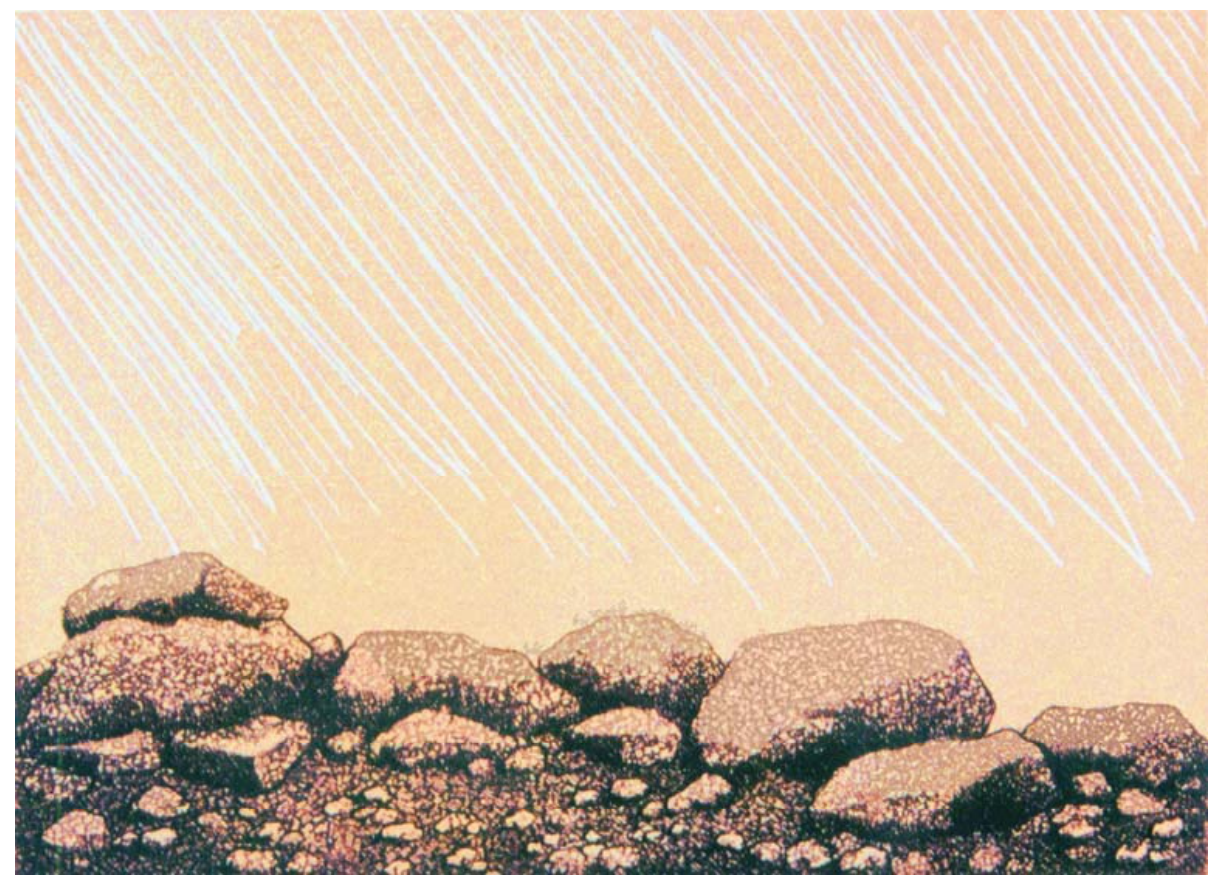

\section{LÁMINA LXXV}

"Sin título"

Aguatinta y fondino

$8.7 \times 11.7 \mathrm{~cm}$.

1980

454 
1. ESPAIS I PAISATGES 



\subsubsection{CONCEPCIÓN}

Espais $i$ paisatges es un pequeño conjunto de obras efectuado entre los años 1980 y 1983, período que coincide con el último año de Parets de pedra seca y con el inicio de la nueva serie Herbes, de tal manera que podemos ver reflejada en esta colección de grabados la conjunción de las dos series. Se recupera así la imagen de la piedra seca trabajada en la anterior serie y se elabora una nueva de carácter vegetal que presta atención a las hierbas, elemento que por otra parte se plasma de forma simultánea, tanto aquí, como en la nueva serie Herbes. 
Junto a estos dos elementos surge otro de carácter más atmosférico y volátil que hace alusión a cielos y nubes, que completa el conjunto de representaciones que componen el paisaje revisado por Pilar Dolz, que adquiere una peculiar dimensión espacial debido a la disposición fragmentada de la forma, en donde cada uno de sus elementos se dispone individualmente.

La motivación vital por los lugares de su tierra natal como motor dinamizador de las dos series anteriores pasa aquí a un segundo plano, la artista se centra ahora en aspectos más puramente plásticos ligados a la creación de nuevos ritmos gestuales y a la voluntad de desarrollar un mayor potencial compositivo. Sin duda la disposición individual de los elementos le permite realizar gran cantidad de combinaciones tanto a la hora de estampar los colores, como en el momento de elaborar la composición de las planchas sobre el papel, en la que la artista juega tanto con la distribución de la forma, como del espacio.

Esta particular manera de trabajar el espacio es una experiencia que la artista ya había desarrollado en las series anteriores de Ocells morts y Pedres i paisatges dels Ports, en donde recorta la plancha siguiendo la forma de la imagen que se encuentra grabada en la matriz y la estampa posteriormente por separado dejando entrever unos espacios de luz, que hacen que destaque aun más la forma definida. (Véase Cap. III.5.2 y III.8.2)

En Espais i paisatges las piezas que conforman la estampa se plantean igualmente por separado, pero el recorte de las planchas se hace recto, dando lugar a piezas de formato rectangular en la 
mayoría de los casos, aunque también encontramos algunas de formato cuadrado.

En cuanto al aspecto iconográfico, hay una intención de mantener cierto orden en la disposición de las formas, de tal manera que nuestros sentidos sean capaces de percibir e imaginar el paisaje creado por la artista. Así encontramos por ejemplo tres planchas ubicadas en el plano; una que se encuentra localizada en la parte inferior que lleva grabada la imagen de unas piedras, otra que se halla en el centro del espacio que representa unas formas vegetales y por ultimo, como coronando la construcción, en la parte superior encontramos la imagen de cielos o nubes que ultiman el paisaje. (Véase LAM. LXXVI)

Respecto a la forma, ésta surge de una serie de elementos tomados del mundo real, dispuestos en el espacio de un modo muy personal, diferente con respecto a la forma tradicional que tenemos de concebir la representación del paisaje, formando parte de un todo indivisible. La artista se sirve de la imagen extraída del entorno natural y del mundo de los símbolos para crear su particular paisaje. La conexión de estos elementos da pie para esta serie, que deja abierto un campo a la interpretación y a la elucidación del espectador.

En cuanto a la construcción de la forma hay, cada vez más, cierta tendencia a la simplificación, a solucionarla de una manera esquemática, aunque se sigue manteniendo una clara figuración. Se trata de formas reales reconstruidas mentalmente por la artista; piedras, hierbas, cielos, en las que muchas veces prima la 
comprensión de lo esencial, lo demás queda supeditado a la imaginación. Hay algunos casos donde el tratamiento de la imagen es diferente, logrado por medio de la reproducción directa de la imagen a la matriz a través del barniz blando, pero en otros casos la imagen se soluciona con unos trazos simples y directos dando a la forma un aspecto más escueto.

En general trabaja siguiendo los procesos técnicos de grabado conocidos, lo que realmente marca su obra es el peculiar carácter plástico y conceptual. Como ya nos ha comentado la artista en varias ocasiones su intención es contar las cosas de la forma más simple que se pueda.

La investigación no es algo que más interesa (...) cuanto más simple, más bonito y más fácil, no se trata de que tú lo hagas más complicado y más distinto". ${ }^{216}$

${ }^{216}$ Entrevista personal con la autora en Castellón de la Plana. 27/04/2006 


\subsubsection{ASPECTOS COMPOSITIVOS.}

\section{Composición}

El esquema compositivo es simple, se basa en la disposición horizontal de cada uno de los elementos en el espacio, colocados uno al lado del otro guardando una distancia de separación, que nos permite ver las formas de manera independiente.

Cabe destacar, la utilización del soporte-matriz como elemento fundamental del tratamiento compositivo, en la que una pieza asociada a otra genera una estructura singular, basada en la distribución horizontal de varios fragmentos de la imagen, relacionados en el espacio vacío, dejando entrever zonas de luz que provienen del blanco del papel para constituir la composición, ya que tanto la forma (con tinta) como el vacío (sin tinta) no se pueden mirar por separado. Cuando la artista dispone la forma sobre el plano, su relación espacial dentro del todo la vemos de tal manera que cada elemento mantiene su correspondiente sitio. Así por ejemplo en la LAM. LXXVII, un grabado constituido por tres planchas colocadas en el espacio de forma armoniosa, dejan unos espacios idénticos de separación, que actúan directamente sobre la forma y permiten que cada una conserve su independencia y autonomía, a la vez que forman parte de un todo. Así cada trozo-unidad representa una forma particular como; hierbas, piedras o nubes, aunque en conjunto forman el paisaje. 
En cuanto al sentido de profundidad, normalmente la representación de la forma se hace en un solo término, para establecer la profundidad se varía la tonalidad de la mancha o se crean unos ligeros toques de luces y sombras que dan movimiento a la imagen. En otras ocasiones hay varios espacios superpuestos, generados en la misma forma y en la misma plancha como suele suceder en el caso de las hierbas, que se intercalan entre sí creando sutiles niveles de profundidad no diferenciados y que constituyen parte de una configuración más compleja. Normalmente para acentuar el efecto de profundidad la artista trabaja con la intensidad lumínica del grafismo, dejando unas formas más contrastadas y otras más leves, que hace que unas formas se vengan hacia delante y otras queden detrás. (Véase LAM. LXXVI y LXXVII)

En ciertas ocasiones la forma se compone de dos imágenes distintas dispuestas relacionándose espacialmente una sobre la otra en el formato del papel, originando una obra única. Un ejemplo de esto lo tenemos en LAM. LXXVIII, un grabado compuesto por dos fragmentos cada uno de los cuales está formado por dos planchas. El segmento ubicado en la parte superior se halla integrado por unas manchas al aguatinta, que hacen referencia al cielo, sobre el que se estampa la imagen de unas hierbas de aguafuerte, que se sitúan automáticamente en un primer plano. Como podemos ver cada una de las partes de la imagen se construye por separado en cada matriz. En el fragmento de la zona inferior localizamos una situación similar; unas piedras construidas por la superposición de dos planchas texturadas realizadas al aguatinta cada una de las cuales se halla impresas en un tono distinto. En este caso la imagen, a diferencia de la anterior, se estructura por la combinación de texturas 
abstractas, así la valoración se consigue por el color. Lo mismo ocurre en LAM. LXXIX, la superposición de dos matrices impresas en distintos tonos, establecen niveles de profundidad diferenciados tanto de la parte superior, como inferior.

\section{Grafismo}

La configuración de esta serie se consigue básicamente con la elaboración de dos trazos, uno de textura realizado al aguatinta, que surge del propio proceso técnico, y otro más gestual ejecutado al aguafuerte que registra la marca de la artista.

El trazo de textura sigue muy de cerca los planteamientos empleados en Pedres i paisatges dels Ports y Parets de pedra seca, en tanto que se ha empleado la iconografía de la piedra trabajada también en aquellas y el proceso gráfico de manera semejante. En principio la autora parte de la voluntad de crear la síntesis de la imagen, por lo que emplea la técnica de aguatinta de manera poco convencional, a través de la utilización de grandes trozos de resina para crear una textura gruesa y tosca que le sirva de base. Recordemos que esta personal manera de trabajar la había practicado ya en la mencionada serie Pedres i paisatges dels Ports, cuando emplea libremente diversos tipos de resina gorda y fina creando unas texturas de gran calidad, sobre los que se dedica a raspar y bruñir para obtener diversas calidades de luz.

En esta serie de igual manera la huella del trazo viene determinada por la técnica, la disolución de los granos de resina produce unas manchas irregulares, que después de ser sometida 
la plancha a la acción del mordiente, aparecerán en blanco. Estos espacios combinados con las zonas de tinta forman una estructura de claros y oscuros de distinta intensidad que encarna la epidermis de las piedras. La artista abandona el trazo descriptivo en beneficio de una texturación, las piedras surgen como mero pretexto temático, reinterpretadas de una manera nueva y fascinante. (Véase Fig. 110)

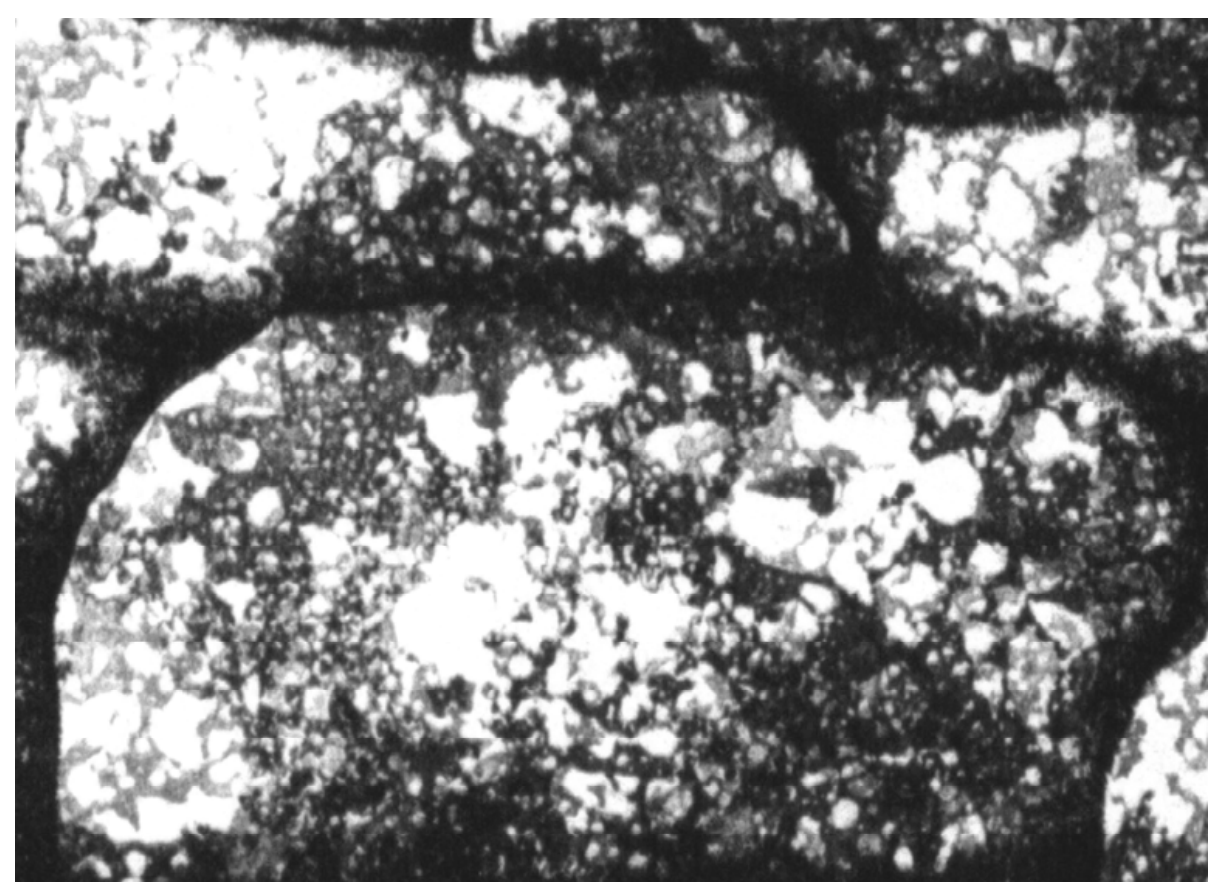

Fig. 110. Pilar Dolz. Detalle LAM. LXXVII. Serie Espais i paisatges. Aguatinta y barniz blando. 1981

De igual modo encontramos un trazo más gestual solucionado con la técnica del aguafuerte, que explora creativamente aspectos de la naturaleza que dan origen a unas formas vegetales ideadas por la artista con una sugerencia casi abstracta. Se trata de un trazo 
inconsciente y repetitivo realizado de forma automática con la punta de metal sobre la matriz barnizada, creando una estructura de rayados limpios y finos que surgen sobre la superficie blanca convirtiéndose en los absolutos protagonistas de la forma. La línea pegada al borde inferior del formato asienta el trazo y evita que lo veamos como si estuviera flotando en el espacio, la aplicación del color transforma al trazo en una forma figurativa, como por ejemplo el tono verde que convierte al trazo en unas hierbas. Con este planteamiento, Pilar Dolz deja abierto un campo a un mundo de grafismos que desarrollará con la más intensa abstracción gestual en la siguiente serie Herbes. (Véase Fig. 111)

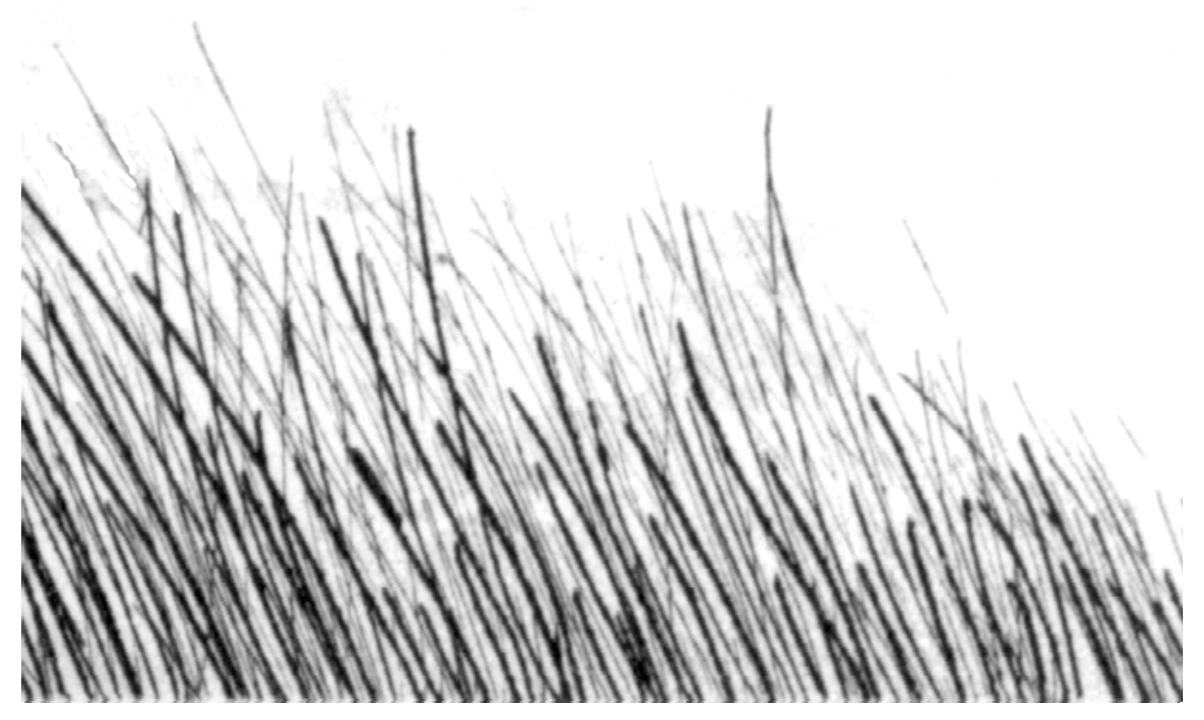

Fig. 111. Pilar Dolz. Detalle LAM. LXXVIII. Serie Espais i paisatges. Aguafuerte y aguatinta. 1982

Asimismo nos encontramos con un trazo más caligráfico realizado a partir de la reproducción de unas texturas naturales 
ejecutadas al barniz blando. Hablamos de un trazo más mecánico que el barniz blando se encarga de reproducir, originando la textura de unas hierbas que nos dan unas grafías serpenteantes, que no existen previamente en las formas ideadas por la artista. Se trata de unos rasgos que se mueven libremente por el espacio, tejiendo una estructura orgánica. Este trazo por su similitud nos recuerda a las formas ternillosas realizadas en la serie de mujeres, en las que unas raíces dibujadas por la artista sobre el barniz blando reproducían unas caligrafías sinuosas emergentes desde las cabezas, brazos y piernas de las figuras femeninas. (Véase Cap. III.2.2) (Véase Fig. 112)

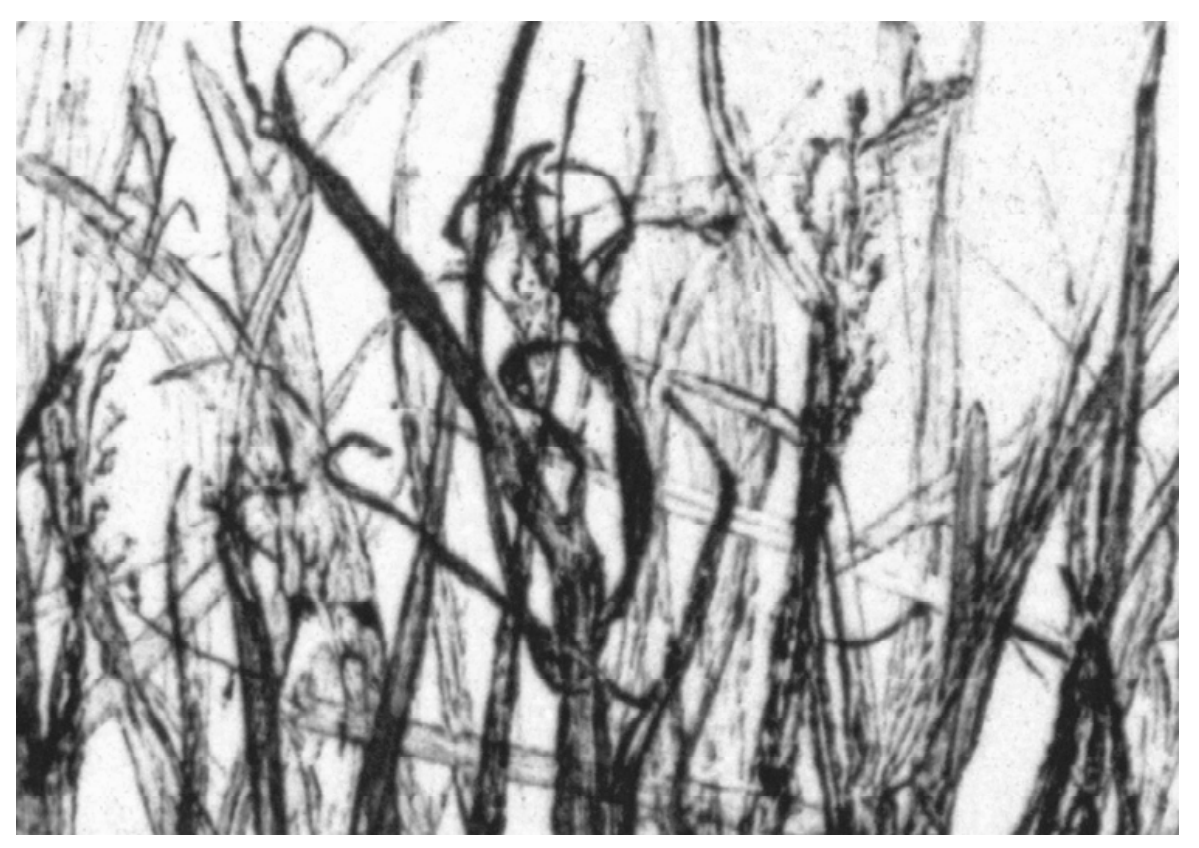

Fig. 112. Pilar Dolz. Detalle LAM. LXXVII. Serie Espais i paisatges. Barniz blando y aguatinta. 1981 


\section{Color}

Respecto al color hay un tratamiento polícromo en todas las obras, facilitado por la utilización individualizada de las planchas, que facilitan la estampación de varios colores en una sola acción de imprimir. Naturalmente, esta disposición permite mantener los colores puros, ya que no llegan a mezclarse entre sí. En los casos en los que sí encontramos una forma compuesta por dos colores, éstos tienden a mezclarse con la superposición de las matrices, aunque en el plano compositivo se sigue manteniendo el planteamiento basado en la disposición fragmentada de la forma.

Como ya hemos visto antes la artista mantiene en esta serie, la idea respecto al color que ya había desarrollado en series preliminares. La distribución individual de la forma sobre el espacio vacío hace que, debido a la luz resplandeciente que emana del fondo blanco del papel, se potencien más los colores.

El cromatismo está centrado en la posibilidad de dar carácter a la forma con el color, ya que en muchos de los casos la artista representa la forma de un modo vago, insinuante por medio de texturas o por la acción gestual y automática de la autora, cuyo resultado adopta una apariencia figurativa con la aplicación del color, que establece así una relación entre realidad y percepción. (Véase LAM. LXXIX)

Hay un uso generalizado de tonos fríos y cálidos que aparecen estampados alternadamente en las diferentes imágenes, 
así podemos encontrar espacios atmosféricos impresos en un color verde pero también en amarillo o naranja, aunque de manera independiente. De igual manera encontramos algunas piedras estampadas tanto en tonos oscuros, como sepias rojizos o azul claro. En lo que respecta a las hierbas normalmente las hallamos impresas en tonos verdes.

En los casos donde la forma se encuentra compuesta por dos fragmentos, éstos mantienen su autonomía pues se utilizan para caracterizar el paisaje más no para crear la forma, como el ejemplo ya analizado en el fragmento superior de LAM. LXXVIII, en donde encontramos unas manchas estampadas en un tono amarillo claro, que hacen mención a un cielo y unas hierbas estampadas en un color verde con carga de azul, que imponen su presencia. El carácter sustancial del color en la imagen forma parte del efecto visual que surge del conjunto.

Por el contrario en el fragmento inferior de la misma lámina, se logra la calidad de la textura por la suma de las dos planchas; una estampada en un tono azul claro y la otra en un sepia rojizo, en este caso el color llega integrarse en una sugerencia única. 


\subsubsection{PROCESO TÉCNICO}

En esta serie se trabaja básicamente con barniz blando, aguatinta y aguafuerte, sin que se mezclen entre sí las técnicas.

En primer lugar analizamos los fragmentos que son trabajados con barniz blando de una manera clásica, a través de la reproducción de texturas naturales de carácter vegetal, trasladadas fielmente a la estampa. (Véase LAM. LXXVI, LXXVII y LXXIX)

El grabado con barniz blando tiene posibilidades infinitas, lo que pasa es que depende de la mentalidad de uno. Hay quien pone un trozo de tela y tal, yo empleo ramas. Ahora utilizo mucho el barniz blando con mallas, tela... ${ }^{217}$

En otros fragmentos se trabaja con la técnica del aguatinta como la empleada en la construcción de las piedras, con la resina en grano gordo, teniendo en cuenta la diversidad de tamaño de los gránulos para obtener una estructura de perfiles variados. Dependiendo del grosor de la resina, se obtienen manchas de un perímetro más o menos grande donde predomina el blanco, pero en otras ocasiones la artista juega con la mezcla de resinas gruesas y finas para crear superficies más oscuras con tropezones de luz. La imagen adopta una luminosidad especial debido al juego óptico que se establece entre el fondo blanco del papel y el valor tonal de la tinta. (Véase LAM. LXXVI y LXXVII)

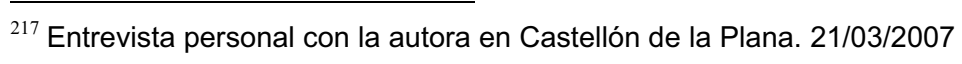


En otros momentos la artista emplea el aguatinta de una manera más común, a través de la pulverización tradicional de granos de resina en polvo para crear una película homogénea de puntos, con la que se obtiene unas manchas lisas y suaves, que son destinadas especialmente para la creación de espacios atmosféricos. (Véase LAM. LXXIX)

Aquí empleo piedras grandes de resina, para que dé ese efecto. Es resina gorda. La pongo encima y al quemarla todavía se ensancha más. Es que aquí juego con estas tres cosas; ésta que es más gaseosa. $Y$ esto en cambio, da más la sensación de piedras. ${ }^{218}$

La última de las técnicas, el aguafuerte, aunque en menor medida, la encontramos en un fragmento de LAM. LXXVIII, aunque la mayoría de piezas están elaboradas al aguatinta y al barniz blando. En lo que respecta a éste procedimiento, tampoco encontramos ninguna novedad técnica, la artista trabaja el medio de una manera tradicional.

${ }^{218}$ Ibidem 
LÁMINAS

SPAIS I PAISATGES 


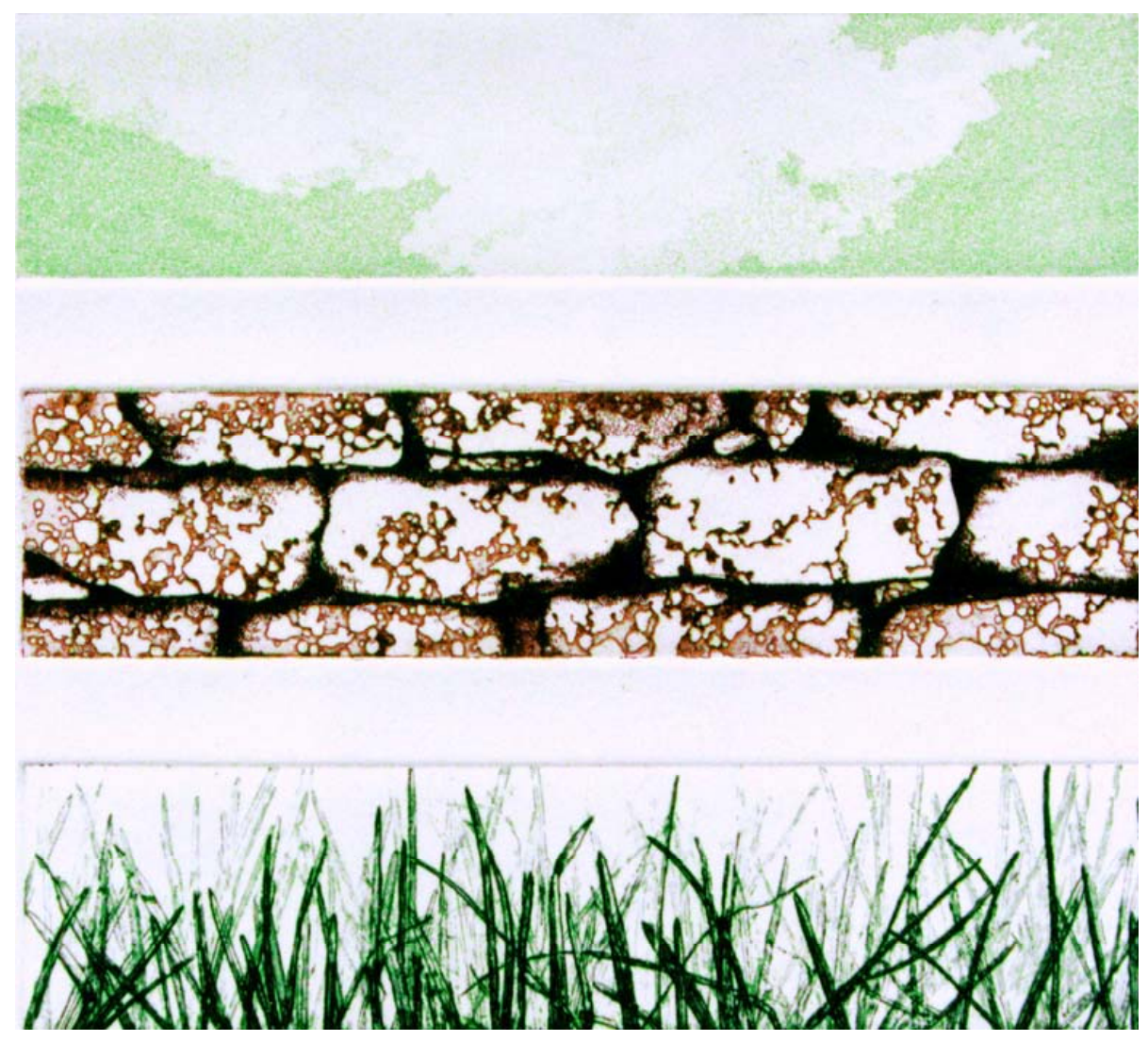

\section{LÁMINA LXXVI}

"Sin título"

Aguatinta y barniz blando

$16 \times 17.5 \mathrm{~cm}$.

1980 

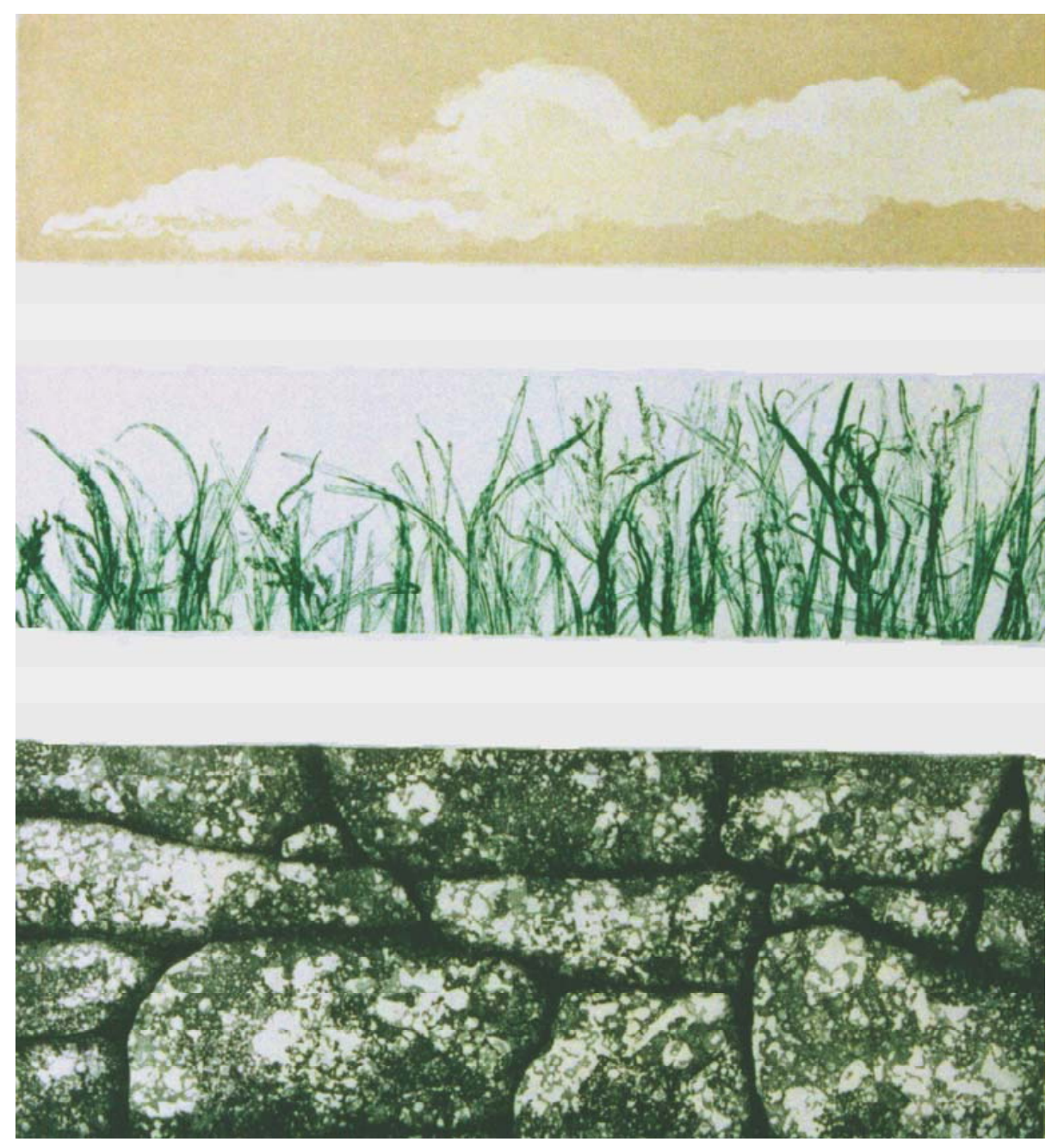

\section{LÁMINA LXXVII}

"Sin título"

Aguatinta y barniz blando

$44.5 \times 24.5 \mathrm{~cm}$.

1981 

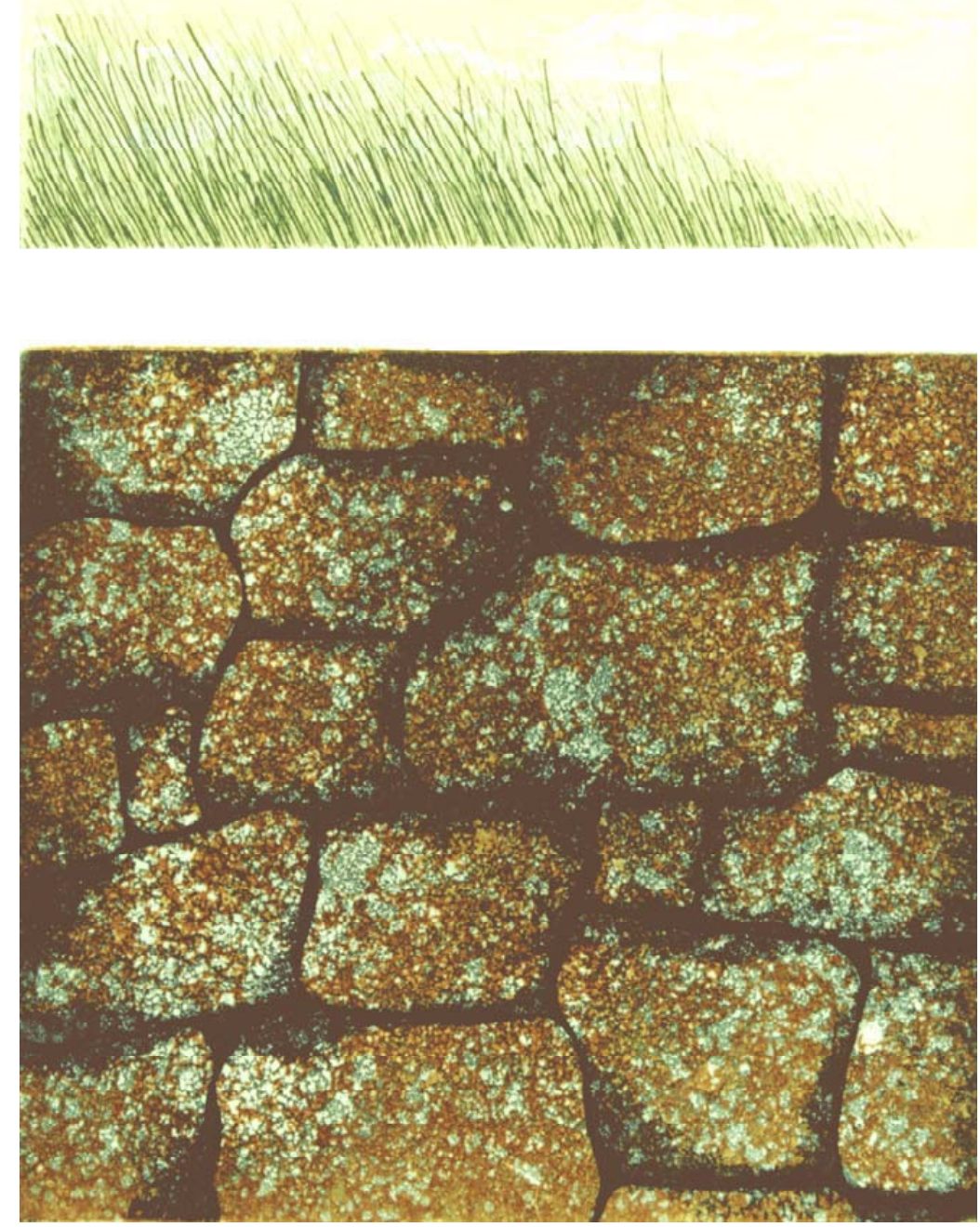

\section{LÁMINA LXXVIII}

"Sin título"

Aguafuerte y aguatinta

$27.5 \times 21.5 \mathrm{~cm}$.

1982 


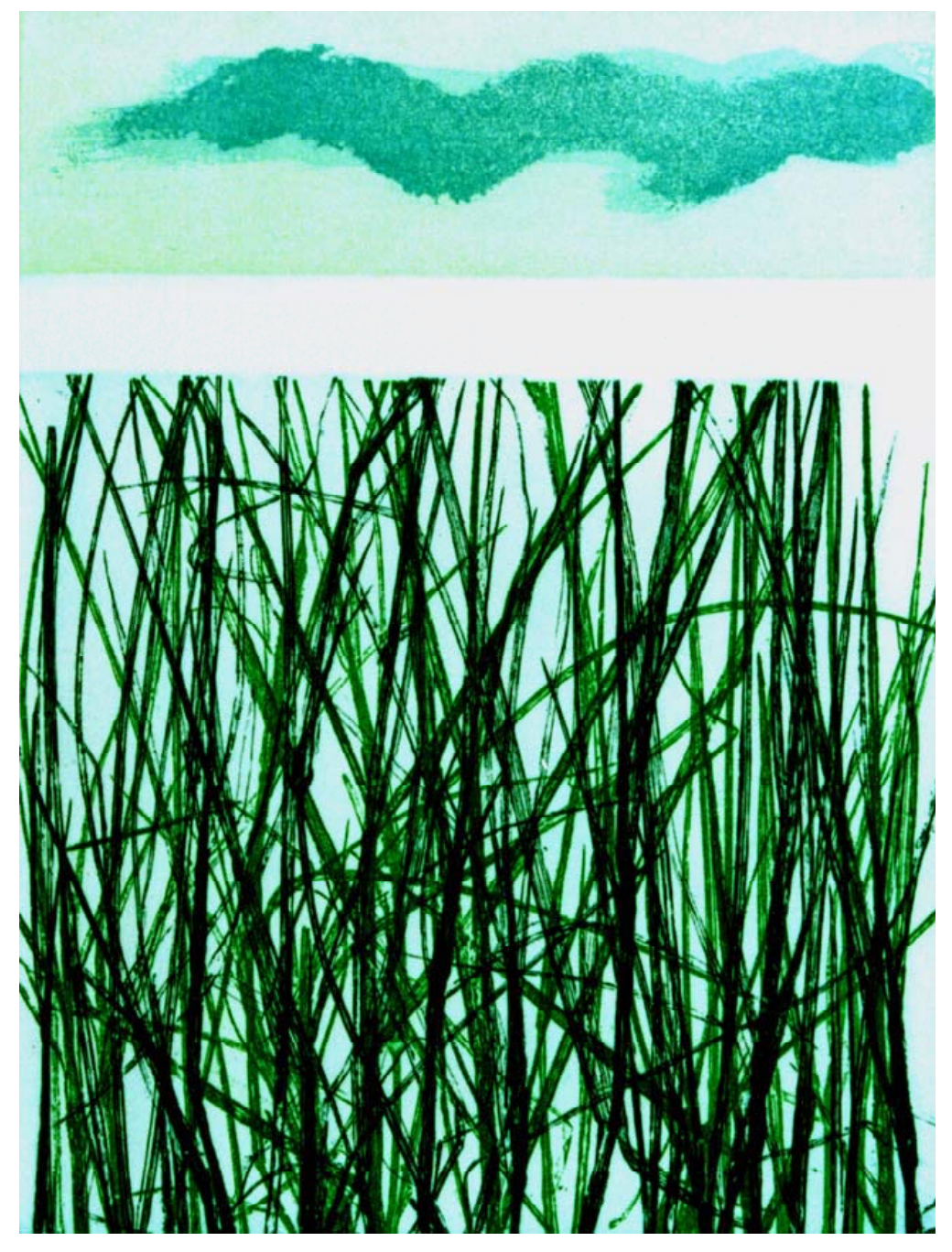

\section{LÁMINA LXXIX}

"Sin título"

Aguatinta y barniz blando

$30 \times 22 \mathrm{~cm}$.

1983 
1 HERBES 



\subsubsection{CONCEPCIÓN}

Desde 1980 hasta la actualidad, Pilar Dolz trabaja en un interesante conjunto de obras que lleva por título Herbes, uno de los más extensos que ha podido generar durante cerca de tres décadas de constante indagación artística y más de doscientas obras de producción, concentradas en diferentes propuestas formales como; Troncs, Fulles, Paisatges, Branques, Tiges, Herbes, Matolls, Mars, que son las que generan la auténtica serie Herbes.

En esta serie la autora dirige la mirada hacia la naturaleza, hacia el entorno vegetal, en el que desarrolla un amplio abanico de opciones interpretativas que le permiten obtener autenticas 
variaciones sobre el paisaje. Pilar Dolz es una artista que guarda la naturaleza sin complejos; la recrea de una manera insistente, fundando y recreando constantemente fragmentos de la naturaleza, entintado y recortando una misma matriz en diversas ocasiones hasta llevarla a los límites. Sin lugar a duda esta particular manera de incidir sobre un mismo tema y sobre una misma obra, es el hecho que desde un primer momento le va a llevar a producir la totalidad de su obra por series.

No conec a ningú que haja fet una cosa semblant. Si es mira amb la perspectiva dels anys $\mathrm{i}$ del seu resultat, és una d'aquelles obres que poden semblar concentrades en una temática obsesiva, limitada i curta, i d'aparença simple, i que són en realitat exactamente el contrari, perquè són - el conjunt de l'obra de Pilar Dolz, és una cosa més exhaustivament difícil que un artista es puga propasar; tan exhaustivamente difícil com és explorar fins als límits un fragment del món, i en el curs de la mateixa exploració, crear-lo una altra vegada. ${ }^{219}$

Si bien en series preliminares como, Pedres i paisatges, y Parets de pedra seca la artista atiende al entorno natural mediante una iconografía agreste y seca, como peculiar metáfora de la existencia humana, en esta serie las hierbas, constituyen un homenaje a la naturaleza, una reivindicación de aproximación a la realidad, a nuestro entorno, a través de la representación de unos motivos normales y corrientes que pocas veces nos detenemos a mirar, quizá porque los consideramos intranscendentes, poco

${ }^{219}$ MIRA, J.: 1993. 
importantes, pero a los que Pilar Dolz magnifica y engrandece, enseñándonos a mirar ese universo del cual todos formamos parte.

Las primeras propuestas de esta serie las podemos en contrar en algunas obras de Parets de pedra seca, en donde unos sectores de bancales, aparecen acompañados por unos trazos caligráficos que representan a unas hierbas, que se acumulan y se superponen en la superficie dando vida a una parte del paisaje. Ciertamente estas propuestas iniciales le van a llevar a la siguiente serie Espais $i$ paisatges, en donde vuelven a surgir estas formas vegetales acompañados de otros elementos de la naturaleza como cielos nubes, piedras dispuestos en el espacio de modo fragmentado, configurando así un paisaje fraccionado. En este caso tanto las hierbas, como los otros elementos constituyen parte del organismo total de la imagen, por lo que se convierten en un elemento fundamental del paisaje. Esta aproximación a lo vegetal deja el camino abierto a la magistral serie Herbes, en la que la artista se centra especialmente en los fragmentos de la naturaleza, para convertirlos en los auténticos protagonistas de su obra. El tratamiento aplicado y los resultados obtenidos demuestran una nueva evolución, las obras tienen una unidad formal y discursiva que explora exhaustivamente el tema del trazo y del color.

En 1980 surgen las primeras obras de Herbes a través de un conjunto de obras de pequeño formato $(10 \times 12$. $\mathrm{cm}$.) en las que la artista regresa a la forma tradicional de estampación, según el cual se emplea una plancha para cada color (recordemos que antes recurre a seccionar la matriz). Normalmente estas obras se encuentran constituidas por dos matrices; una solucionada con una 
serie de manchas y trazos, y otra que lleva grabada la grafía de la hierba, aunque también en algunas ocasiones la primera matriz es sustituida por un trozo de papel de color (fondino), sobre el que estampa la imagen. Hay que tomar en cuenta que durante este periodo la artista se encuentra trabajando de forma simultánea en otro grupo de obras de igual formato, perteneciente a la serie de Parets de pedra seca, por lo que tiende a utilizar las mismas matrices, tanto en la una como en la otra serie, combinándolas con las diferentes imágenes de piedras o de hierbas.

Más tarde en 1982, nace otro conjunto de hierbas de formato más grande $(56 \times 46 \mathrm{~cm})$ en la que la artista continúa trabajando con la superposición de planchas. Así sobre la impresión de una primera plancha, en la cual se graban manchas abstractas realizadas con pincel, se estampa otra de idénticas proporciones entintada con otro color y grabada con las formas de unas hierbas. Esta superposición crea una serie de planos en la superficie final de la estampa que invitan a mover nuestra mirada en un continuo desplazamiento por la superficie dando origen a una ilusión de profundidad. El espectador toma parte activa de la contemplación de la obra y establece un diálogo entre su manera subjetiva de percibir y la propia presencia de la obra. Por otra parte se percibe un gran frescor en la imprenta de las formas vegetales, debido al uso del barniz blando, sobre el que se chafan las hierbas naturales, que dejan grabadas una pluralidad de líneas y perfiles espontáneos pocos definidos, que se escampan sobre la superficie como un gesto. De igual manera localizamos un trazo más caligráfico que surge de forma instintiva, dando a la línea un carácter sinuoso que adopta la forma de unas 
representaciones herbácea. Llegado a este punto, Pilar Dolz aborda un planteamiento de trabajo basado en el principio motriz, en el propio acto físico de la ejecución de la obra, idea que abre un campo de reflexión en las siguientes obras. (Véase LAM. LXXX)

Entre 1983 y 1984 viaja a Paris a Atelier $17^{220}$ y Atelier Goetz, $^{221}$ (Paris) a estudiar nuevas técnicas de grabado, la experiencia desarrollada en estos sitios va a ser muy importante para la artista, pero sobretodo la desplegada en Atelier 17, porque le permite cultivar un elemento esencial y primordial en su obra como es el color. En este centro estudia la técnica del roll-up, procedimiento que consiste en la estampación de diversos colores en una sola matriz, para esto se trabaja una placa de metal con diversos niveles de profundidad, y posteriormente se aplica la tinta de distinto grado de viscosidad con diferentes tipos de rodillos, consiguiendo una estampa polícroma de una sola pasada.

La necesidad del color que en series anteriores le habían llevado a seccionar la plancha, con la intensión de estampar varios colores en un solo acto de impresión, ahora le llevan a cultivar la técnica de Hayter, método que en cierta medida mantiene el mismo principio, estampar diversos colores en una sola pasada por el

\footnotetext{
${ }^{220}$ Fundado por Hayter en 1927. Entonces inició la técnica de estampación, que aplica varias tintas en la plancha de metal con rodillos blandos y duros; la denominó "método del rodillo blando y el rodillo duro". Hoy se llama Método Hayter. Véase RODRIGUEZ CULEBRA, J.: El país, p. 3

${ }^{221}$ En Atelier Goetz Pilar Dolz trabaja con la técnica del carborúndum, que trata de añadir materia a la plancha. Se utilizan diversos materiales con pegamento; polvo de carbón, limaduras de hierro, polvo de mármol y similares. En combinación con otras técnicas produce efectos de texturas y relieves. La artista no utiliza esta técnica, porque el material que se emplea es muy duro y destruye los rodillos. Entrevista personal con la autora en Castellón de la Plana. 13/12/2007.
} 
tórculo. La gran aportación de esta técnica en la obra de Pilar Dolz, se encuentran en todas sus facetas, pero sobretodo en el momento final del proceso; el entintado y la estampación, algo que la propia autora ha ido descubriendo por medio del trabajo y de la reflexión sobre la matriz, de la que extrae todas las posibilidades. Sin duda este procedimiento dota a sus grabados de una mayor complejidad compositiva y mayores contrates cromáticos, en los que consigue globalizar perfectamente todos los elementos de la obra. Una frase de la propia autora describe muy bien el carácter inminente que tiene el color en su obra.

Cuando voy a Hayter, yo tengo necesidad del color, no ese que recorta la plancha o que dibuja, si no un color atmosférico en cierto modo, yo necesitaba una cosa más. ¡Ves esa idea mía del color! Yo voy a Hayter porque tengo mucho interés en el color para ahorrar tiempo, y ahí aprendo sobre todo, sobre el color, ya lo veo como un todo. ${ }^{222}$

Respecto al aspecto temático su mirada se mantiene atenta a la realidad natural circundante, el paisaje producto de su imaginación surge de formas casi puras de gran belleza estética por su simplicidad. Este vínculo referencial con la naturaleza que la autora ha asumido como eje principal de su trabajo, demuestra una especial atracción por este tema, y como consecuencia llena sus grabados de trozos de paisajes, que se generan a partir del ritmo eufórico y vital de la artista, en la que somos nosotros los que creemos reconocer unos frondosos bosques, campos floridos, hojas, hierbas, troncos, formas que surgen de una manera ilusionista, visionaria, de modo semejante a como lo hicieran algunos artistas

${ }^{222}$ Entrevista personal con la autora en Castellón de la Plana. 13/12/2007. 
surrealistas desde otra perspectiva. ${ }^{223}$ La misma artista nos comenta que los elementos que aparecen en su obra no son extraídos de un paisaje concreto, ni tan sólo del subconsciente, sino que son imágenes que afloran indistintamente de una plena libertad gestual. ${ }^{224}$

El objeto expresado en estos trabajos es la más pura y directa manifestación de la sensibilidad, donde realmente lo único que importa, es la voluntad de posibilitar el acto de creación concentrado en la actividad gestual, acción que concede mayor importancia al proceso de creación, más que a la misma obra. Sin duda esta opción estética nos recuerda la obra de los expresionistas norteamericanos, que se deja llevar más por la mirada subjetiva del autor que por seguir una representación fiel de lo natural.

No hay que olvidar que este estilo surge de la influencia del Surrealismo europeo, tendencia por la cual se sienten fuertemente atraídos, pero sobre todo por la práctica del automatismo, que les permite alcanzar la completa y absoluta libertad creadora. ${ }^{225}$ De ahí que podamos reconocer también en la obra de Pilar Dolz ciertos rasgos del surrealismo automático, estilo que además desde un

\footnotetext{
${ }^{223}$ Dalí tenía el vicio de interpretar todo lo que se le ocurría: "Me pareció uno de los descubrimientos capitales de mi vida y se apoderó de mí un verdadero vicio de autointerpretación, no sólo de los sueños, sino de todo lo que me sucedía por más casual que pareciese". Dalí pinta sus obsesiones que bautiza en 1929 como método paranoicocrítico, que consiste en materializar las imágenes de la irracionalidad concreta, es decir detalles de la realidad, más otros originados por los sueños. Véase BRIHUEGA, J.: 1993, p. 67

${ }^{224}$ Véase CASALÉ, R.: Zerovuittresquarant $N^{\circ} 107,1999$, p.12.

225 La emigración masiva de artistas europeos al final de la Segunda guerra mundial favoreció un cambio estético en el arte americano, que sirvió de detonante de las artes. La mayoría de los surrealistas se relacionaron con los artistas neoyorquinos, que practicaron el automatismo y desecharon el ilusionismo formal a favor de la gestualidad expresiva. Véase. JULIÁN, I.: 2002, p.63.
} 
primer momento y a lo largo de toda su producción siempre ha ejercido una especial influencia en ella.

De igual manera cuando contemplamos algunas obras de apariencia más figurativa no podemos evitar pensar en la obra de ciertos artistas franceses como Bonnard y Monet, no sólo por su especial devoción por el paisaje, sino también por la personal captación de la luz y el manejo del color, con el que consigue dar a la obra un ambiente mágico, naturalista. En 1985 Pilar Dolz realiza un conjunto de obras tituladas "Homenaje a Bonnard", en las que efectúa la representación de unos paisajes elaborados con diferentes colores, pero utilizando la misma matriz. La artista introduce alteraciones en el orden de aplicar los colores, para conseguir diferentes resultados en la imagen, de esta manera proporciona una atmósfera distinta a cada uno de los paisaje, llevándonos a pensar en el paisaje en las diferentes épocas del año (invierno, otoño, primavera) por su calidez y frescura. (Véase LAM. LXXXI, LXXXII y LXXXIII)

Había una exposición en el Museo Pompidou en homenaje a Bonnard. Entonces yo hice un homenaje a Bonnard, por eso lo llame así. Hice tres grabados; uno oscuro, otro no tan oscuro, y uno más claro, y simplemente cambié el orden de los colores, son los mismos colores, ide hecho utilizaba la paleta de los impresionistas! Azul, amarillo y rojo, mezclando estos tres colores te dan todos (...) te dan unos ocres muy Bonnard; es como una experiencia, no es una investigación, simplemente juego. ${ }^{226}$

${ }^{226}$ Entrevista personal con la autora en Castellón de la Plana. 13/12/2007 


\subsubsection{ASPECTOS COMPOSITIVOS.}

\section{Composición}

En Herbes el tema compositivo se materializa en el propio proceso de trabajo, no se articula, ni evalúa en términos de composición sino en términos de la propia necesidad expresiva. La misma artista nos comenta que cuando ella realiza una obra no tiene una idea fija de lo que va a hacer, sino que se enfrenta a la obra de un modo impulsivo, y de forma espontánea surgen unos trazos que se convierten en germen de la composición.

Así muchas veces la imagen surge de gestos casuales o accidentales que brotan de su interior en forma de trazos rectos o curvos, que ocupan toda la matriz. En otros casos brota por medio de salpicados de barniz, o manchas efectuadas con sus propios dedos, que pisa y arrastra sobre la matriz dejando grabada su impronta. De igual manera en muchas ocasiones la artista deja actuar el azar, así acude al empleo de planchas desechadas por otras personas, o a la utilización de láminas que han sufrido algún desperfecto, ya sea porque se han quemado en el ácido, porque se han olvidado a la intemperie, o porque se han rayado con el cutter, accidental o intencionalmente. En realidad no importa lo que utilice, porque lo que realmente le interesa es el carácter mágico que poseen esas imperfecciones. ${ }^{227}$ (Véase LAM. LXXXIV)

\footnotetext{
${ }^{227}$ Este planteamiento de trabajo coincide con los surrealistas que trascienden el mundo romántico de las representaciones, y establecen técnicas de dibujo para eludir el control racional. Joan Miró, artista surrealista recoge las pruebas que los operarios del taller no consideran buenas, para aprovechar sus efectos, pues le apasiona jugar con lo imprevisto. Véase BRIHUEGA, J.: 1993, p.24
} 
Yo utilizo una plancha que otra persona ha tirado, (...) me da igual, es como utilizar un papel que tiene una textura, porque me gusta mucho lo que ya tiene, yo le he puesto en el ácido para poder reutilizar la plancha y después he raspado, pero ese juego es el que me gusta a mi, ese juego de mensajes que cambian. ${ }^{228}$

En otros casos la forma surge incluso antes de que el propio límite del formato estuviera determinado, pues muchas veces la artista parte de gestos realizados en una matriz grande, a la que después corta en trozos más pequeños para darles diferentes lecturas. En este caso no existe ni soporte, ni composición a priori, sino que la imagen surge de una forma ya establecida. "Es como cuando tú sales al campo y con una cámara de fotos recoges fragmentos de las hierbas". ${ }^{229}$ De esta manera nos encontramos con la presencia magnificada de los detalles de hierbas, hojas, matorrales, organizados en composiciones abiertas en las que el margen del papel impide las trayectorias de los objetos representados. Así podemos ver por ejemplo como LAM. LXXXV, $(12 \times 17.5)$ resulta ser el recorte inferior derecho practicado en otra plancha mayor (43 x 50. cm.) realizada un año antes en 1992.

En este grabado distinguimos unas formas tentaculares que cruzan el espacio de forma desordenada e intercalada creando un entramado lineal que establece diferentes niveles de profundidad. Esta imagen entintada con los mismos tonos rojos, amarillos y azules grisáceos que la plancha original, surge ahora como enormes

\footnotetext{
${ }^{228}$ Entrevista personal con la autora en Castellón de la Plana 13/12/2007.

${ }^{229}$ Ibidem.
} 
raíces resecas que aparecen en un primer plano como vistas con un lente.

Yo corto la plancha y voy haciendo grabados que me llevan a otro mundo completamente distinto, tengo muchísimos grabados, los corto y cambio el color, según como vaya haciendo una plancha me da para mucho. (...) Yo sigo cortando; como cortar el paisaje, no sé si es una cosa que tiene un interior, pero yo disfruto con eso, me lo paso muy bien, es mi lenguaje. ${ }^{230}$

Discutir si su obra es abstracta o figurativa no viene al caso, porque como podemos ver la artista parte de unos gestos totalmente abstractos, para después con el trazo o simplemente con el color darle una intención figurativa, pero no una figuración realista, sino una figuración simbólica que hace referencia a unos espacios naturales en los que realmente lo que predomina es el equilibrio de las formas. Así en algunas formas donde el espectador cree distinguir algunas imágenes figurativas, lo que verdaderamente prevalece es el lenguaje de sus elementos plásticos. El resultado será una apuesta tácita por la abstracción, aunque sin llegar a desplazar del todo la naturaleza figurativa de la obra. Un ejemplo de esto lo podemos percibir en LAM. LXXXVI, un grabado solucionado a partir de la disposición libre de una serie de pequeñas salpicaduras de barniz que aparecen como manchas fluctuantes en el espacio. Sobre estos gestos, la artista intercala unos trazos lineales verticales e inclinados que aparecen dando forma a la imagen, de tal manera que las pequeñas manchas surgen ahora como un espeso bosque, en medio del cual podemos distinguir los trazos realizados

${ }^{230}$ Entrevista personal con la autora en Castellón de la Plana. 16/05/2005. 
anteriormente, convertidos en tallos, ramas de los árboles. La imagen queda así plasmada por los rasgos esenciales de la forma.

Yo no le doy mucha importancia a eso. Yo si un día me sale una cosa más figurativa la reivindico totalmente, y si un día es completamente abstracto también. Yo a una cosa abstracta le pongo un título figurativo, y a una cosa figurativa le pongo un título más poético; es como un juego de ambigüedades. Soy figurativa porque le doy la intención que quiero. ${ }^{231}$

En cuanto al planteamiento espacial hay una apuesta tácita por el lleno; forma y fondo cubren todo el espacio con el color. Desaparece así el fondo vacío, como espacio en blanco presente en muchas series anteriores como; Reixes, Insectes, Ocells morts, y demás (donde incluso llega a asumir un gran protagonismo). El fondo asoma ahora como un espacio coloreado, pictórico sobre el que se dispone la forma, ya sea a través de manchas libres y salpicadas, o por medio de trazos lineales que se disponen en el plano de modo rítmico y espontáneo, para generar un juego óptico, donde forma y fondo muchas veces llegan a confundirse debido al contraste cromático que se establece. Así por ejemplo en LAM. LXXXVII, localizamos un conjunto de líneas rectas y ondulantes de diferente espesor, que atraviesan el espacio de forma paralela en sentido vertical.

La disposición rítmica y repetitiva de la línea manteniendo cierta distancia, deja traslucir unos espacios secuenciales de fondo que se integran con los de la forma, para establecer una relación ambigua entre forma y fondo. La concordancia entre color, espacio y

${ }^{231}$ Entrevista personal con la autora en Castellón de la Plana. 27/04/2006. 
forma produce un efecto óptico en la imagen que se traslada a nuestra retina.

Este trabajo nos recuerda en cierta medida a la obra de algunos artistas del Op. Art, ${ }^{232}$ que por medio del empleo de líneas paralelas, tanto rectas como sinuosas, pretenden crear ilusiones ópticas. Por otra parte también nos resuena a la obra de algunos artistas expresionistas abstractos como Louis Morris y Kenneth Noland, entre otros, ${ }^{233}$ que frecuentemente recurren al empleo de bandas de colores puros en horizontal o vertical para la construcción de la forma, reduciendo al mínimo su configuración y estructura.

Respecto a la distribución de la forma en el plano, en la mayoría de casos ésta cruza toda la superficie del formato, unas veces en sentido vertical, otras en horizontal o inclinado, y proyecta la forma por fuera de los límites del formato, de tal manera que la imagen parece continuar más allá del plano y sugiere una infinita extensión en el espacio. (Véase LAM. LXXXVIII y LXXXIX)

En otras ocasiones la forma se proyecta hacia el exterior del espacio, pero regresa a su interior por medio de trazos curvos y ondulantes. En este caso el gesto aparece ilimitado, en tanto que el

\footnotetext{
232 Movimiento internacional que surge a finales de los años cincuenta liderado por Vasarely. Pretende producir efectos ópticos sin recurrir al relieve ni la animación real. Los artistas se centran en las relaciones de color y espacio para provocar vibraciones retinianas y conseguir una experiencia física en el espectador. Lo consiguen por la repetición ilimitada de un módulo formal. Véase LAMBERT, R.: 1985, p.73

${ }^{233}$ El Expresionismo Abstracto es un estilo que recoge la "pintura de acción", caracterizada por el gesto y la expresividad, y la vertiente más lírica, que se expresó mediante grandes planos de color, llamada "pintura de campos de color". Sus obras evidenciaban las superficies planas y la falta de distinción entre figura y fondo. Para lograrlo eliminan la pincelada gestual de la pintura de acción. Opus cit, p. 67.
} 
formato se presenta como un espacio cerrado, de tal manera que la imagen tiene que ser completada por el espectador en su mente. En este caso la línea no se proyecta como infinita, sino que es interrumpida por una curva que vuelve sobre si misma, siguiendo un camino de continuas idas y vueltas, por dentro y fuera del espacio. ${ }^{234}$ (Véase LAM. XC y $\mathrm{XCl}$ )

En cuanto a los valores de profundidad están sugeridos de dos maneras; uno por medio de la superposición de la forma, y dos a través del color.

De acuerdo a la superposición de la forma, la artista realiza una serie de trazos lineales o manchas irregulares en el espacio, que se intercalan unos a otros dando origen a un entramado visual, en el cual logramos distinguir diversos planos de profundidad. Conforme al grado de saturación que presenta la forma podemos descubrir un grupo de obras que exhibe un esqueleto estructural muy complejo, formado por una maraña de trazos que hace difícil distinguir tanto el número, como el nivel de profundidad que ocupa cada trazo en la escala espacial. (Véase LAM. XCII)

En otro grupo de obras el planteamiento espacial es más sencillo, dado por la colocación de la forma en un solo plano. En este caso la forma se inscribe individualmente sobre el fondo de color, la disposición de unos trazos lineales irregulares, de diversas características dado por la textura, espesor y forma, surgen en

\footnotetext{
${ }^{234}$ Cuando dos fuerzas ejercen simultáneamente acción sobre el punto, de tal modo que una de las fuerzas vaya superando en presión a la otra, constantemente y en medida invariable, surge una línea curva. Se trata de una recta que ha sido desviada de su camino a través de una presión lateral constante, cuanto mayor es la presión, más cerrada es la curvatura de la recta y mayor el desplazamiento. Véase KANDINSKY, W.: 1993; p.83-84.
} 
paralelo y mantienen una distancia entre unos y otros, evitando de este modo la superposición. La creación de planos, el movimiento, la armonía, el equilibrio están dados por la distribución espacial del trazo, así como por su intensidad. (Véase LAM. XCIII)

Asimismo en otros casos la disposición de la forma es tan saturada que desaparece el fondo, la forma cubre todo el espacio por medio de la repetición continua del trazo, que se superpone hasta recubrir el fondo, estableciendo así una estructura espacial progresiva que se pierde en el interior de la plancha. La falta de un fondo que ponga fin a la creación continua de planos, hace que se sugiera una escala espacial infinita, supuesta por el espectador. De la misma manera que la artista proyectaba la extensión perenne de la forma, por fuera de las demarcaciones del plano con el empleo de la línea recta, en este caso nos plantea la misma situación pero con el espacio en profundidad. El sucesivo encadenamiento de planos, hace que sea un espacio sin límites. (Véase LAM. XCIV).

Otro de los elementos con el cual la artista consigue dar la impresión de tridimensionalidad a la obra es el color. Las manchas, los trazos combinados con distintos atributos puramente cromáticos dan la sensación de profundidad, por medio de la combinación de peso e intensidad. En las estampas donde la superposición del trazo es extensa y profusa, es el color trabajado con una gama reducida, pero con una multiplicidad de matices el que identifica el trazo, atrayendo unas formas hacia delante y abandonando otras atrás. Con esto la artista consigue dar a la imagen un carácter poético y figurativo, suministrándole así la impresión de ser un mundo imaginario creado por ella. (Véase LAM. XCV) 
Un aspecto a tomar en cuenta es la disposición entrelazada y agitada de la forma, tejiendo una red de grafismos que obstaculizan el paso de quien mira la obra; esta propuesta nos recuerda las series iniciales donde aparecen las mujeres atadas con cuerdas, las rejas y las palomas muertas; en definitiva las imágenes simbólicas tratadas en las diferentes series, que se convierten en metáfora de una libertad soñada. En Herbes, Pilar Dolz nos presenta el mismo planteamiento, formas lineales rectas o serpenteantes conforman un entramado visual que comporta una barrera infranqueable para el espectador; examinar varias lecturas de su obra es hallarse en un enrejado.

"No se porque lo hago, ya no hago rejas, pero estoy haciendo hierbas que tampoco te dejan pasar al otro lado, a lo mejor toda la vida estás diciendo lo mismo. Aunque cambie de lenguaje, sigo diciendo lo mismo, tengo la sensación de estar diciendo siempre lo mismo. ${ }^{235}$

\section{Grafismo}

Tal y como se ha expuesto en el apartado anterior, el tratamiento gestual de la forma, es uno de los factores dominantes de esta serie, lo que confirma la atención de Pilar Dolz por los componentes; gestual y automático, trabajados bajo la influencia del surrealismo y las teorías del psicoanálisis. (Véase Cap. III.1.1) Aunque normalmente encontramos que en toda su producción artística la representación es figurativa, muchas veces resulta que

\footnotetext{
${ }^{235}$ Entrevista personal con la autora en Castellón de la Plana. 13/12/2007
} 
ésta emerge de una mancha o de la caligrafía automática, que potencia según lo que le sugiere para proporcionarle un carácter netamente figurativo. En Herbes, mantiene el mismo principio; muchas veces parte de manchas accidentales o trazos gestuales libres a los que da una apariencia figurativa con el color. Se trata de formas objetivadas en trazos, colores y texturas, donde el discurso formal, al contrario de lo que sucedía en las anteriores series no es descriptivo, sino que apunta a una total libertad gestual, en la que el gesto se convierte en el verdadero protagonista de la obra. Trazos lineales de todas las características conforman la obra, sin más añadidura que el color. De acuerdo con este planteamiento nos encontramos con el empleo de diversos recursos gestuales en la construcción de la forma.

En una parte de las obras, apreciamos un trazo caligráfico sinuoso que recorre la superficie en trayectorias sinuosas y serpenteantes que configuran un entramado de diversas longitudes y curvaturas con un cierto dinamismo e interacción de fuerzas; que se presentan unas veces armonizadas y otras contrapuestas. La expresión del ritmo de la forma se identifica con unas formas vegetales, representadas por los nervios de las hierbas, las raíces, los matorrales, cuya voracidad hace difícil que podamos visualizar el trazo individualmente. Sin duda estas formas cartilaginosas, nos recuerdan a las formas tentaculares trabajadas en las series de mujeres y cuerdas de su etapa inicial, en donde unas líneas alargadas y ondulantes dan forma a las cuerdas, o a los tubérculos exuberantes que emergen de las cabezas y cuerpos femeninos de mujeres. (Véase Cap. III.2.1 y III.3.1) 
En cuanto al proceso técnico Pilar Dolz realiza un trabajo expresivo basado en las posibilidades que le ofrece el proceso, así unas veces utiliza el pincel empapado de barniz líquido para ejecutar el trazo directamente sobre la matriz, lo que le faculta la creación fluida y espontánea de la forma, hecho que conlleva una serie de variaciones en su trayectoria debido al cambio de velocidad, densidad de la solución o a la presión que pueda ejercer sobre la matriz. El empleo del pincel le permite obtener diversas cualidades gráficas; líneas finas, delicadas, otras más gruesas, alargadas, rugosas, en las que advertimos la acción modulada del gesto. (Véase Fig. 113)

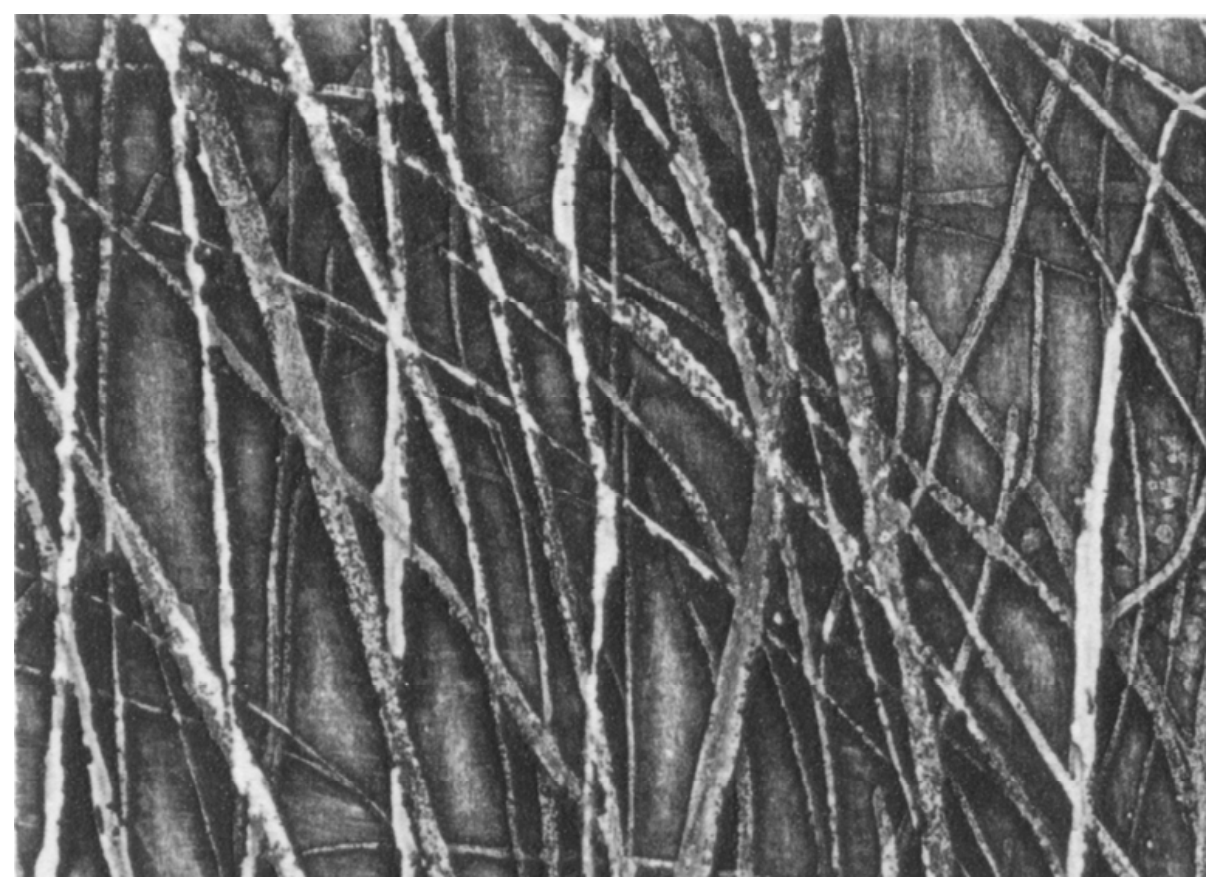

Fig. 113. Pilar Dolz. Detalle LAM. LXXXV. "Branques VI", Serie Herbes. Barniz aplicado con pincel. Aguafuerte. 1990. 
En otros grabados encontramos un trazo más gestual realizado por medio de salpicados de barniz, de manera similar a los drippings realizados por Jackson Pollock. ${ }^{236}$ Sin duda este gesto obedece a la necesidad de la autora de traspasar las posibilidades de la línea automática, que evidencia la idea de no limitar figuras y describir contornos, sino de realizar un ejercicio más enérgico, en el que una red de puntos disipa la individualidad del trazo. La plancha se constituye en un campo de acción donde la artista actúa, graba sus movimientos con gran energía y vitalidad, a la vez que exterioriza sus emociones. El salpicado crea una maraña de puntos y manchas de distinta intensidad, donde el color desempeña un papel fundamental, pues es el elemento que realza la estructura de los espacios y proporciona a la obra un carácter atmosférico. Junto a estas manchas gestuales en algunas ocasiones, localizamos escuetos trazos lineales, dispuestos estratégicamente, que dan el detalle figurativo a la imagen, lo que advierte la reaparición de la línea en su función tradicional. De este modo algunos salpicados abstractos surgen combinados con rasgos de figuración. (Véase Fig.114)

Esto es un salpicado, "drippings de barniz" pero eso es automático completamente, y eso es un salpicado con un pincel grande. Fíjate; parece un campo con una perspectiva y todo. Eso es totalmente automático. $^{237}$

\footnotetext{
${ }^{236}$ Uno de los artistas más representativos del Expresionismo abstracto. Su obra se realiza con pintura derramada sobre el lienzo. El artista arroja goteos de pintura formando un entramado fluido de gestos. Todo el trabajo da la impresión de ser física y mentalmente agotador, rememora la energía empleada y algún tipo de lucha interior. Véase GÓMEZ MOLINA J.: 1995, p. 443.

${ }^{237}$ Entrevista personal con la autora en Castellón de la Plana. 13/12/2007.
} 


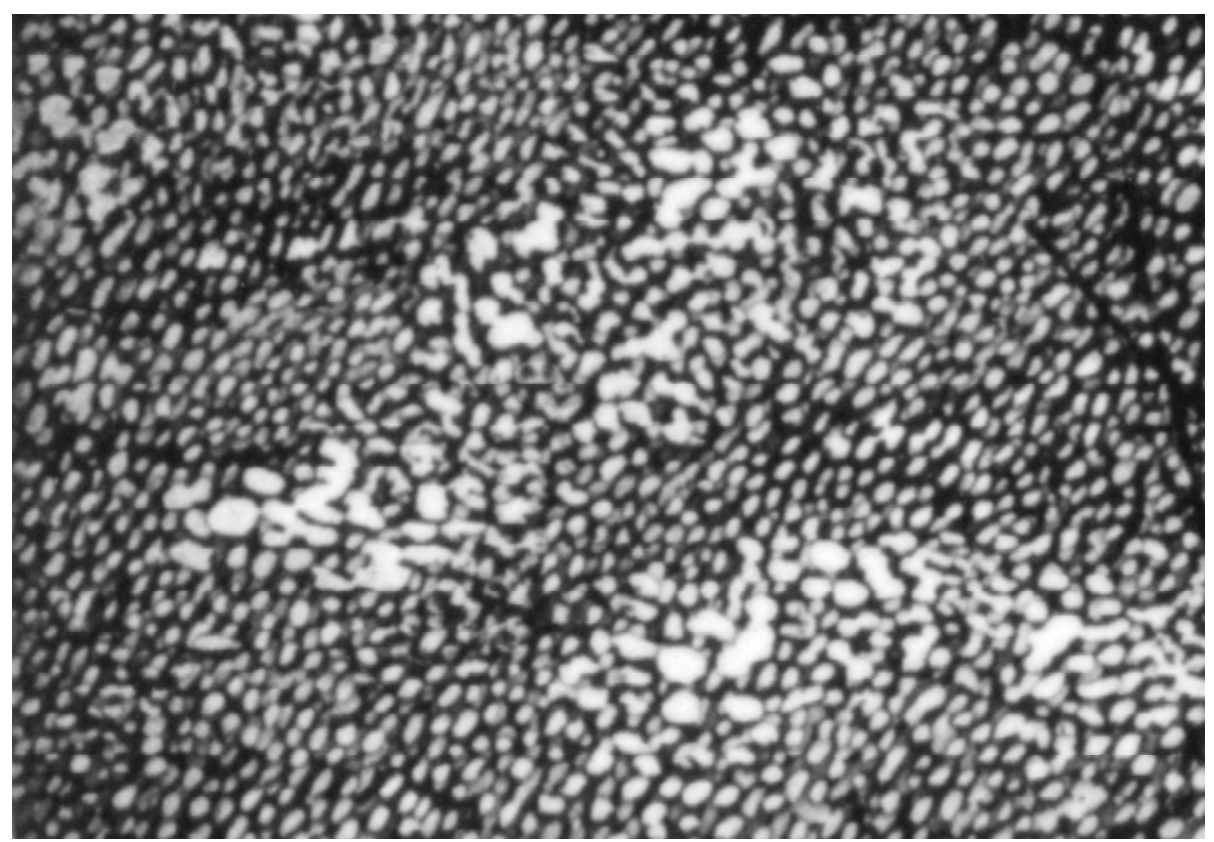

Fig. 114. Pilar Dolz. Detalle LAM. LXXXVI. "Fulles XIV", Serie Herbes. Salpicados de barniz. Aguafuerte. 1989

En otro conjunto de obras hallamos un trazo lineal más recto que mantiene cierta flexibilidad, se trata de un trazo dinámico que se proyecta en sentido vertical u horizontal, y presenta unas leves ondulaciones que rompen con su rigidez a la vez que le proporciona movimiento. Por su forma y apariencia texturada resulta muy expresivo. La artista trabaja con lápices grasos de distinto grosor y componente graso; lápices de labios, de ojos, de litografía, lo que le supone la obtención de distintas calidades gráficas. Según la dureza o suavidad de la cera, ésta resbala por la superficie lisa de la plancha de una forma más fluida o entrecortada dibujando unas texturas de gran riqueza óptica. (Véase Fig. 115) 


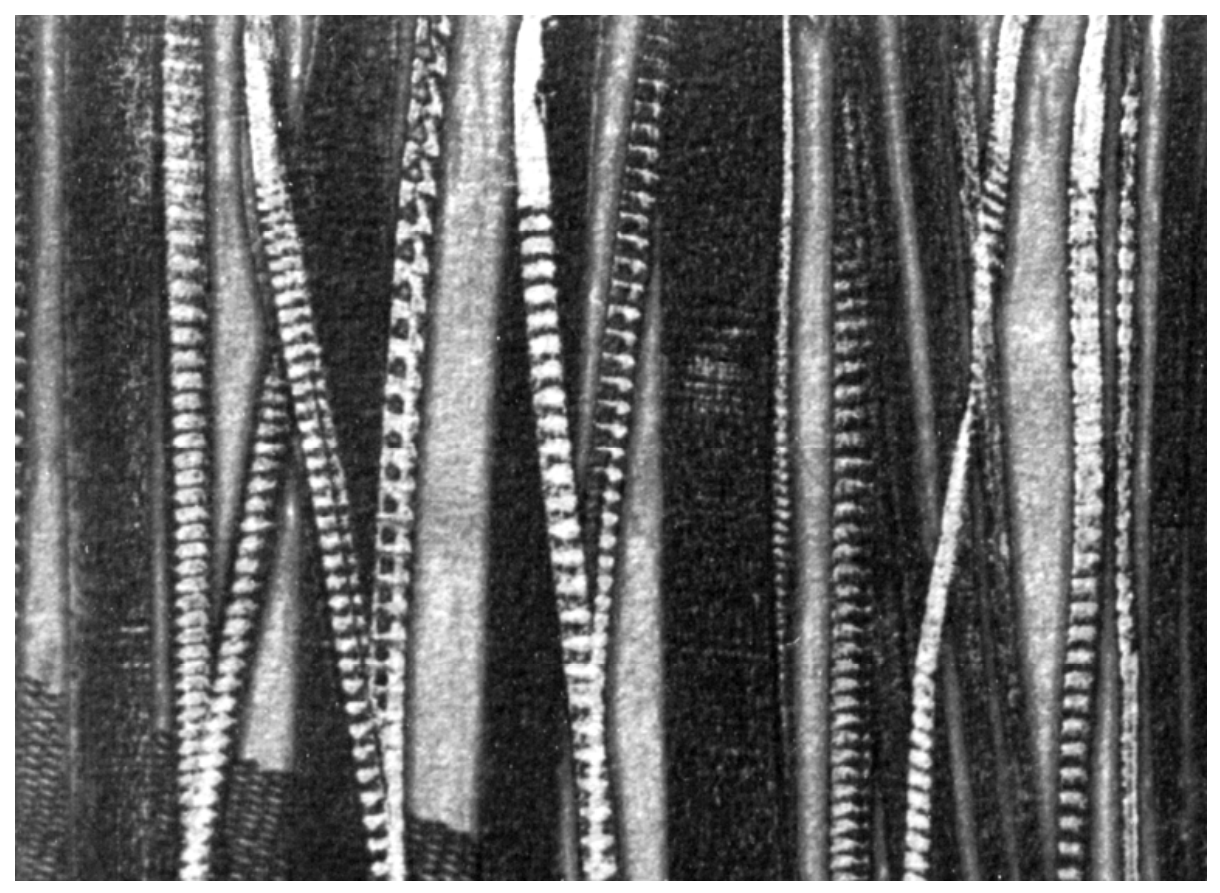

Fig. 115. Pilar Dolz. Detalle LAM. LXXXVII, “Tiges XXVI”, Serie Herbes.”, Reservas con lápiz graso. Aguafuerte. 1998

Por otra parte en otro grupo de obras localizamos un trazo lineal más rígido; se trata de unas líneas rectas, que siguen las pautas geométricas a la hora de su creación. Para esto la artista utiliza tiralíneas que le permiten mantener la precisión del trazo. La forma surge simplificada y abstracta por medio del empleo de líneas puras, dispuestas de forma paralela o entrecruzada, en sentido horizontal o vertical, con un estructura compositiva más reposada y tranquila, que fundamentan un orden de lectura de arriba hacia abajo en la vertical, o de izquierda a derecha en la horizontal, según la ordenación de las partes. La disposición repetida de la línea presenta una composición sin jerarquías focales, equilibrada mutuamente por la relación que existe entre ellas y que establece una armonía interna. La vertical surge como un elemento de gran 
fuerza, que sugiere actividad y equilibrio, mientras que la horizontal aparece más quieta, fría, su lectura sugiere reposo. Por otra parte localizamos también la utilización de la línea inclinada que surge dispuesta sobre las otras rectas, rompiendo la calma y creando tensión y dinamismo. La presencia de este trazo rígido lo podemos reconocer también en las series anteriores Reixes y Finestres. (Véase Fig. 116)

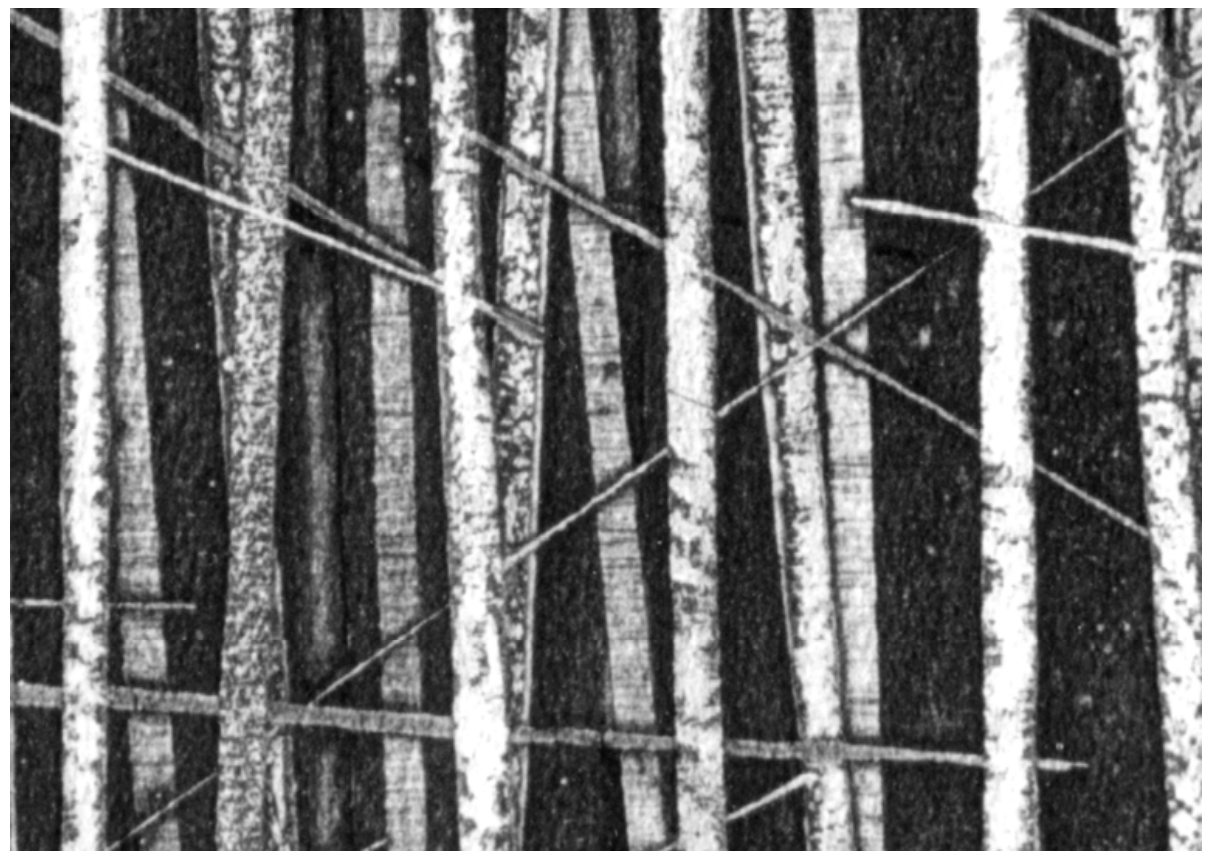

Fig. 116. Pilar Dolz. Detalle LAM. LXXXVIII. "Tiges XIX", Serie Herbes. Reservas con tiralíneas. Aguafuerte. 1997

De igual manera en otras obras localizamos un trazo más mecánico, automático, realizado con lápices grasos, lo que le supone la creación libre e instantánea de la línea, generada en un momento breve de acción sin fraccionamientos de tiempo. En este 
caso el trazo no adopta unas formas tentaculares, sino que sigue unas formas curvas, espirales de gran expresividad, que surgen de la repetición continua y aleatoria del gesto sin levantar la mano, potenciando de esta manera el sentido dinámico y la apreciación psicológica de movimiento. Las combinaciones de curvas, bien sea como esquemas abiertos o cerrados demuestran un carácter tridimensional, articulado por formas cóncavas y convexas, entrantes y salientes que proporcionan gran plasticidad a la obra. Por las múltiples direcciones que toma el trazo, éste se convierte en el más dinámico, exalta agitación, velocidad, vértigo, incluso violencia. Sin duda la forma, la orientación, el alcance viene determinado por la construcción mecánica del brazo y de la mano, así como por la carga emocional de la artista que queda reflejada en el ritmo. La regularidad e irregularidad de los movimientos corporales dejan grabada la huella en el material. ${ }^{238}$ (Véase Fig. 117)

Yo trabajo directamente sobre la plancha, nunca hago boceto, son gestos que son muy casuales. Hago una caligrafía sin una intención previa, la intención previa es que son grabados y que yo me pongo delante de la plancha y hago gestos. Yo no paso de hierbas a paisajes, lo que cambio es el gesto, aquí lo hago más minucioso y lo que hago ahora es el gesto más grande, es el conjunto de todo, porque es el movimiento de todo mi cuerpo. Después, para hacerla figurativa, hago una raya que es cuando le doy un carácter narrativo, pero de inicio no tengo una idea previa de decir voy hacer un paisaje o voy hacer hojas. ${ }^{239}$

\footnotetext{
${ }^{238}$ La acción creativa representa el sentimiento emocional que tiene el artista en el momento de ejecutar la obra, las imágenes surgen del acto gestual, donde se registra el paso del artista y la energía de su movimiento, de la preponderancia del trazo se llega a un gesto caligráfico cuyo contenido es el resultado de un acto total, libre y dramático de la realidad interior. La acción física del creador, no sólo es de su mano y de su muñeca, sino de su brazo, de su hombro y de todo su cuerpo. Véase LAMBERT, R.: 1985, p.69

${ }^{239}$ Entrevista personal con la autora en Castellón de la Plana. 27/04/2006.
} 


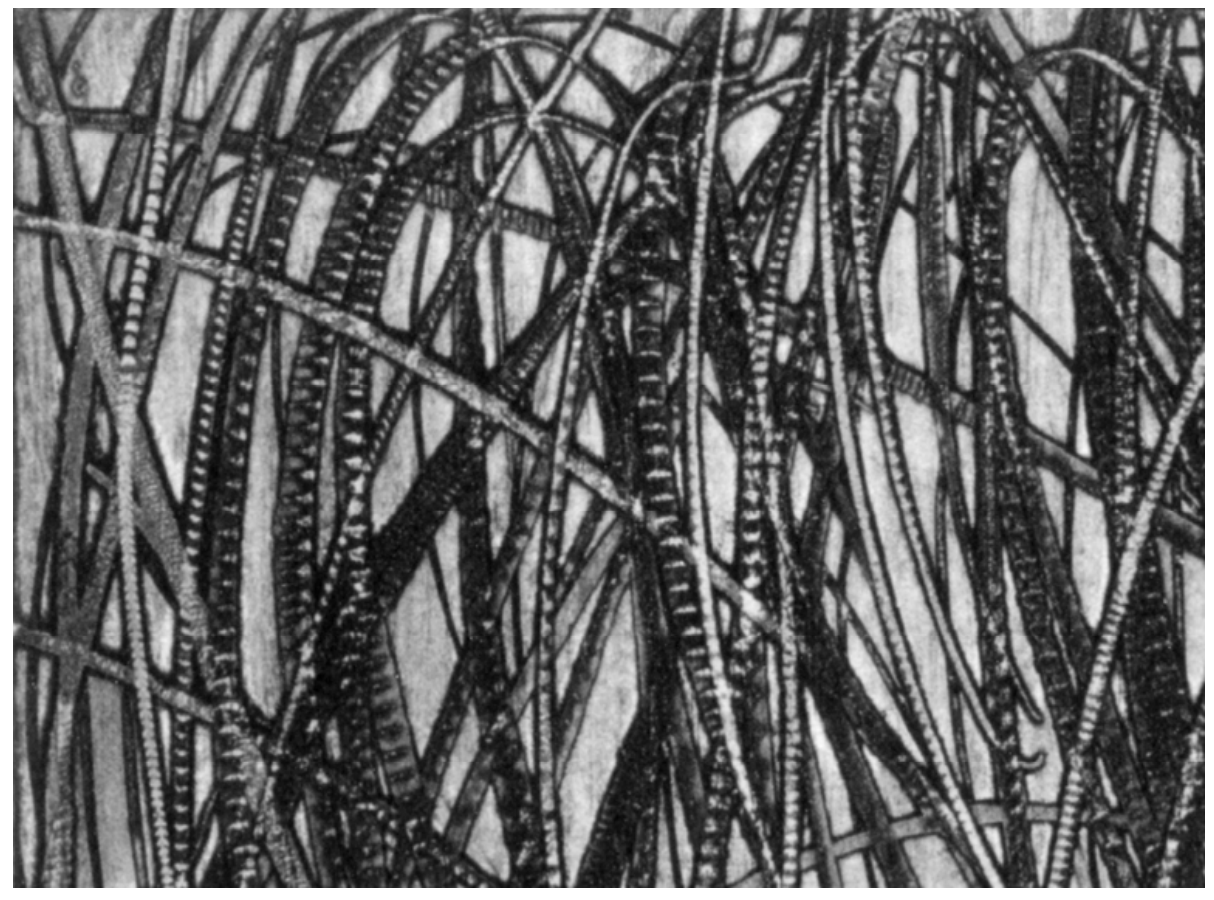

Fig. 117. Pilar Dolz. Detalle LAM. XCI. "Herbes LI", Serie Herbes. Reservas con lápiz graso. Aguafuerte. 1994

Con la misma dinámica encontramos otro conjunto de estampas donde el trazo se realiza directamente en la plancha sin la intervención de ningún tipo de material, sino que es la propia artista la que se introduce de la obra, trabajando con los dedos, improntas que en un principio surgen de forma casual. El perfil redondeado de la forma le va agradar y le van a sugerir ciertas imágenes, que después adoptarán un semblante figurativo con el color.

El gesto surge espontáneo, impulsivo, la artista actúa con absoluta libertad, caminando sobre la plancha en diversas direcciones, arrastrando los dedos, superponiendo la forma una y otra vez, creando niveles de profundidad indefinidos debido a la 
acumulación de pisadas. La presencia de la forma en diferentes tamaños realizada alternando los dedos, aumenta el efecto de profundidad, de esta manera las huellas más grandes se ubican en primer plano, mientras que las más pequeñas se disponen detrás, en una escala espacial de perspectiva. En otras ocasiones el trazo es un poco más controlado, ya que la autora camina sobre la superficie siguiendo direcciones determinadas, ya sea en sentido diagonal, caminando hacia el centro del plano desde todas las direcciones, trepando el plano de abajo hacia arriba, degradando el tamaño de la forma a medida que avanza al borde del formato, para crear de este modo una perspectiva visual que funda un recorrido visual determinado. (Véase Fig. 118)

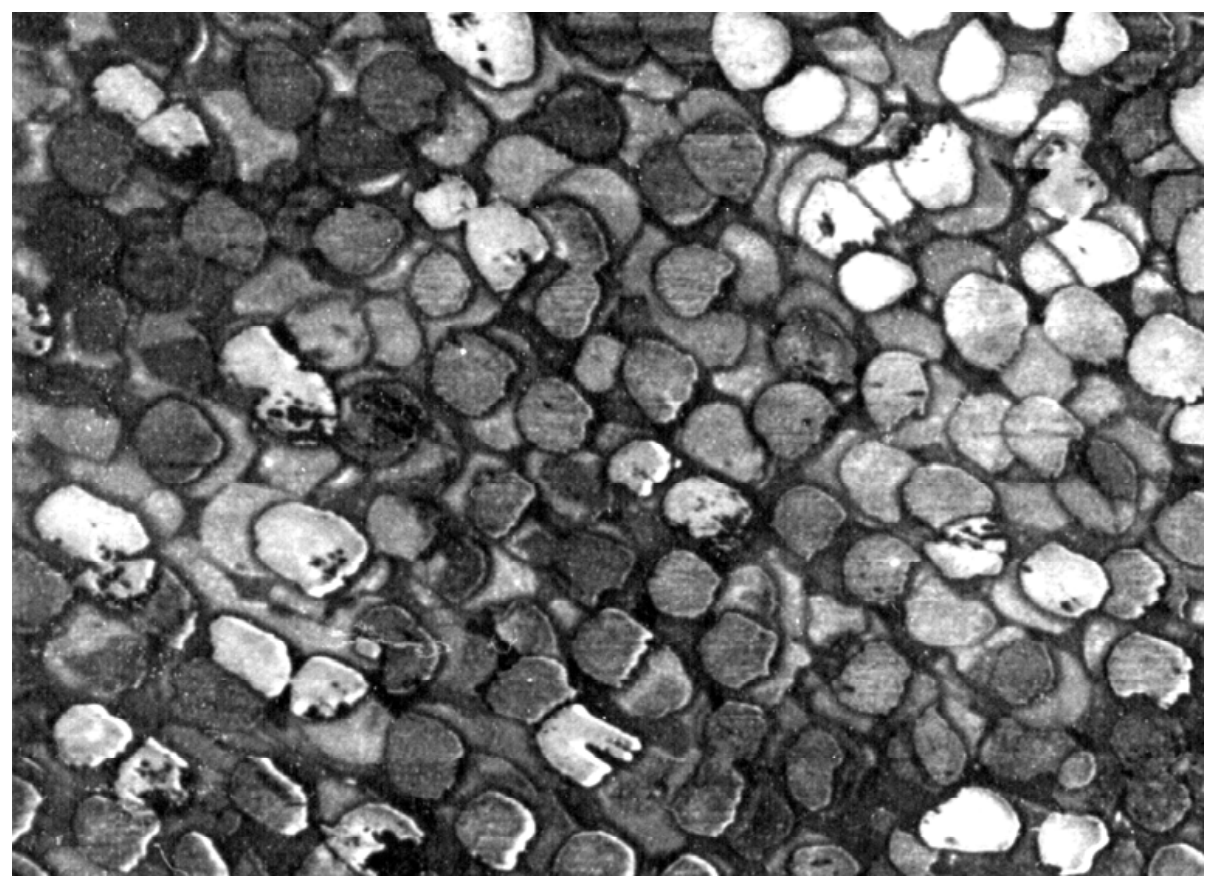

Fig. 118. Pilar Dolz. Detalle LAM. XCIV. "Fulles XXXII", Serie Herbes. Reservas realizadas con dedos. Aguafuerte. 1996 


\section{Color}

Sin duda un componente importante de Herbes es el color, componente incesantemente indagado en toda su producción. Desde su estancia en Atelier 17, desarrolla una concepción diferente en cuanto al tratamiento del color, que aprovecha y utiliza para expresar sus intenciones plásticas. Pilar Dolz se va a dar cuenta que la variación de una sola gota de aceite en la tinta, puede cambiar el discurso completo de la obra, ya que según la intensidad, éste puede percibirse delante 0 detrás, proporcionando un enfoque totalmente diferente a la imagen. ${ }^{240}$

A continuación mostramos una reflexión de la artista, en la que expone claramente su forma de trabajo en relación con sus experiencias en Hayter.

Esta es una obra de troncos. Hayter me dijo: "Tienes que hacerlo sólo en verde porque es mucho mejor." Hice muchas pruebas, primero una con un rodillo, otra con otro rodillo y finalmente, cuando Bill (así lo llamaban a Hayter) ve mi estampa y mi elección de colores, dice que he hecho demasiado trabajo para obtener los mismo resultados. Él cree que si estampo esta plancha sólo con verde esmeralda, será mucho mejor, más luminosa, el espacio más intenso, me aconseja probar. Entonces hice seis pruebas más, sólo en verde esmeralda, y evidentemente el verde es un color curioso y es curioso porque da desde el negro hasta el azul celeste, o sea, el mismo verde según si está más intenso o menos, sólo al entallo (sic), no se

\footnotetext{
${ }^{240}$ Los colores pigmento son colores substanciales, cuya condición material determina el carácter de la imagen, por la factura y tratamiento, que el fondo coadyuva. El carácter substancial del color forma parte del efecto indivisible del conjunto. Véase PAWLIK, J.: 1996. p. 27.
} 
ve nada y si lo estampo con la forma de Hayter, saco un montón de colores. ${ }^{241}$

Atraída fuertemente por el color, Pilar Dolz se ha ido centrando cada vez más, con mayor dominio e interés en el proceso de estampación; recurso que le ayuda a extraer el máximo partido de las planchas una vez trabajadas a fondo. De esta manera parte de una matriz, introduce variaciones significativas, no nomás en relación a los diferentes valores cromáticos, si no también altera el grado de viscosidad de la tinta, lo que genera resultados plásticos tan sorprendentes como dispares. Las diferentes propuestas de grabado surgen así a base de combinadas estrategias de trabajo, que dan lugar a toda una cadena de variaciones posibles relativas a los códigos cromáticos, pero también a las modificaciones que se hacen en la propia forma a través de recortar, invertir la plancha y hasta permitirse por sobre la marcha hacer algunas incisiones. De este modo consigue modificar abiertamente el grado de referencias de la forma. Estos continuos y variados cambios, son los que en realidad generan las auténticas miniseries constituidas por las diferentes propuestas formales de Herbes como; Troncs, Fulles, Paisatges, Branques, Tiges, Herbes, Matolls y demás.

Un ejemplo de esto lo tenemos en LAM. LXXXI, LXXXII y LXXXIII, donde la artista parte de una matriz para crear varias estampas sin alterar los colores ni la viscosidad de la tinta, solamente cambia el orden de su aplicación, aunque utiliza los mismos colores en todas las estampas; amarillo, azul y rojo, obtiene diferentes resultados, (en muchas ocasiones los colores puros son

${ }^{241}$ Entrevista personal con la autora en Castellón de la Plana. 04/08/2006. 
considerados como tonos básicos). Por ejemplo en LAM. LXXXI, el color rojo se encuentra en la superficie, el azul y el amarillo se mezclan con diferente proporción y el azul casi no se percibe. Como consecuencia, la combinación de tonos crea una imagen donde predominan los tonos cálidos. En LAM. LXXXII, por el contrario prevalecen los tonos marrones azulados, el amarillo es absorbido por el rojo y el azul y se baja la intensidad, creando unos tonos sombríos, al tiempo que el rojo se transforma en un tono gris violáceo.

Finalmente en LAM. LXXXIII predomina toda una gama de tonos verdes, que consiguen efectos de profundidad en la imagen, que no parece proceder de la misma plancha que la imagen anterior. Así podemos encontrar verdes donde antes prevalecían los tonos rojos y amarillos, además de otros más oscuros donde el azul resulta más influyente.

Aquí se mezclan los colores, y aquí en cambio no, no sé por qué. A lo mejor porque he tardado menos en introducir el color. (...) El color te da eso, por eso me gusta estampar las planchas, coger y darles vueltas. Así tú vas viendo tus posibilidades. Tienen los mismos colores, pero tiene un orden diferente. El color te cambia completamente una cosa. Es la misma plancha, fijate lo que te puede dar el color. Una sola plancha, tres colores; amarillo, rojo y verde. ${ }^{242}$

Evidentemente los conocimientos adquiridos en Hayter dotan a su obra de formidables calidades pictóricas. La mezcla de colores transparentes en la misma plancha, crea una diversidad de tonos

${ }^{242}$ Entrevista personal con la autora en Castellón de la Plana. 27/04/2006 
que muchas veces hace que sus grabados se conviertan en verdaderas pinturas. Resulta sorprendente ver como la plancha entintada deja sobre el papel una sutileza de transparencias y una degradación de planos, donde color y forma aparecen integrados en un todo. Ya no hay una plancha que dibuja y un color que colorea como en las series anteriores, ahora la coloración surge creando atmósfera y espacio. Un ejemplo de esto lo tenemos en LAM. LXXXVI, cuya forma representada por un conjunto de manchas amarillas de distinta intensidad, combinadas con otras más claras y distribuidas sobre un espacio oscuro, producen una fusión óptica de las distintas áreas de puntos, que se mezclan y yuxtaponen para producir unos efectos similares a los de los impresionistas. Su riqueza de colores y alta luminosidad suministran a la obra un efecto envolvente y una atmósfera que otorga a la obra un aire típico de otoño.

Posteriormente la artista estampa la misma plancha con variaciones cromáticas. El interés de esta repetición reside en la búsqueda de otros efectos lumínicos, que sugieran el paisaje otra época del año. Este concepto nos acerca al planteamiento de los impresionistas, cuyo interés referencial residía expresamente en captar un momento de luz del día, a través de la indefinición del color, pues a medida que trascurre el día, los colores cambian. Sin duda referencias a este planteamiento de trabajo ya las hemos visto en series anteriores como Pedres i paisatges dels Ports y Parets de pedra seca, cuando la artista utiliza los fondinos sobre los que imprime con la intención de crear efectos de luz diferenciados. (Véase Cap. III.9.2 y III.8.2) 
Esto no es como yo trabajaba antes, aquí empiezas a pintar. Es otro rollo completamente distinto, porque tú no piensas en las distintas planchas para hacerlo, sino que son colores que se mezclan y que tienen un valor por sí mismos. ${ }^{243}$

Analizamos ahora el sentido de profundidad que consigue con el color, así sobre un conjunto de trazos gestuales incesantes, en los que la línea y la mancha se superponen en múltiples direcciones y tamaños para crear un entramado visual confuso, es el color el que se encarga de separar, de diferenciar los diversos niveles de profundidad, designando un lugar determinado a cada trazo. El color establece un contraste claro entre forma, textura y dirección; así da lugar a cierta percepción de una tridimensionalidad virtual que proporciona mayor equilibrio y armonía a la composición. Al desplazarse el ojo por la superficie, la mirada es atraída por el brillo del color, con lo que los planos avanzan o retroceden, se mueven o se quedan estáticos, mientras las líneas y los colores crean una estructura con acento rítmico que se disuelve en una armonía perfecta.

Un ejemplo de esto lo encontramos en LAM. LXXXVII. En ella la artista trabaja con una gama de colores cálidos; naranjas, amarillos y rojos de distinta intensidad. La diferencia entre estos tonos, realza la estructura de la forma. Así en primer término localizamos a un amarillo anaranjado de gran luminosidad, que consigue que el conjunto de líneas finas y delgadas de la parte superior invadan varios niveles. La textura de su trazo nos permite visualizar como los tonos amarillo y rojo se mezclan en distinta

243 Ibidem 
proporción y crean una diversidad de tonos que ubica a la línea en varios planos. En segundo término localizamos un rojo más claro, que en algunas zonas se mezcla más con el amarillo y en otras más con el azul, con lo que su intensidad varía. Este tono ubica el grupo de líneas anchas y rectas por debajo de las anteriores, también en varios planos. Finalmente por detrás de éstas, visualizamos otro rojo más oscuro, que surge en último lugar en calidad de fondo. Así, la distribución paralela de las líneas y el empleo de tonos cálidos provoca una llamada de atención enérgica en el espectador. ${ }^{244}$ Más ejemplos de esto los podemos ver claramente en LAM. LXXXVIII y LXXXIX.

De igual manera, de acuerdo a la disposición, la proporción y la distancia de los colores, logra introducir un efecto óptico en la obra. La mezcla de tonos de la misma gama o de gamas diferentes, con distinta proporcionalidad, produce una sensación óptica importante y decisiva. La fusión de los colores origina un movimiento continuado en la forma, de tal manera que ésta parece subir y bajar. Para conseguir la estabilidad que persigue, muchas veces la artista recurre a colores contrastados que se ubican en la superficie para apaciguar la forma. Así por ejemplo en LAM. XCII, apreciamos una obra compuesta por la disposición vertical y oblicua de líneas oscuras con vibración óptica, tanto por la repetición de la forma como por la disposición del color, que se funde con el verde del fondo. Para calmar la tensión, la artista aplica un tono rosa más cálido, que frena la movilidad visual frenética de la forma. De igual manera en LAM. XCIV, compuesta por tonos cálidos superpuestos,

\footnotetext{
${ }^{244}$ Recordemos que un color cálido avanza, mientras que uno frío retrocede y así se crean espacios de color. En el siglo $X X$ se plantea invertir la regla como oposición a la composición clásica del espacio. Véase PAWLIK, J.: 1996, p. 64.
} 
que van del rojo al naranja y se fusionan creando una ilusión óptica. En este caso el color es más frío, es un verde que da cierta serenidad a la composición. En los casos en los que la diferencia cromática no se establece por contraste, la valoración se plantea por medio de la intensidad de la luz, así juega con tonos claros y oscuros que consolidan la forma.

Finalmente hay que apuntar las ocasiones que el color encarna los tonos fieles a una reflexión realista de la naturaleza, como por ejemplo los tonos verdes y amarillos que acompañan a sugerentes formas vegetales, perfectamente reconocibles por el espectador (Véase LAM. XCV). Pero en otras ocasiones el color se dispone de una forma más subjetiva e imaginaria y la imagen toma un perfil figurativo más que por la forma o el color, por el título de la obra, que nos invita a suponer ciertas imágenes en el trazo. En otros casos el color aporta cierto significado a la obra de una manera simbólica; así, unos trazos gestuales estampados en azul se convierten en mares y otros verdes en hierbas. 


\subsubsection{PROCESO TÉCNICO}

Pilar Dolz, ha sido un artista entregada por completo al grabado en sus más diversas técnicas, de tal modo que sus propuestas en este rico campo no constituyen una actividad complementaria de otras tareas plásticas, sino una genuina forma de expresión, en la que controla absolutamente todo el proceso, desde el dibujo inicial sobre la plancha, hasta la obtención de la última estampa.

El sistema conocido como Roll-up, desarrollado por Hayter, tiene la importante característica de aprovechar el diferente comportamiento de las tintas por su grado de viscosidad. ${ }^{245}$ Una cosas a tener en cuenta en este sistema de creación de imagen, es que pueden haber zonas en las que las distintas tintas entren en contacto entre si y pueden tanto ensuciar como enriquecer la estampa según el dominio que se tenga.

Cuando Pilar Dolz se inició en esta técnica, trabaja primero sobre una plancha experimental que le ocupó durante varios meses; ésta es una situación necesaria, que lleva a muchos artistas a renunciar y marcharse del taller. Después de algunos meses en la misma plancha en los cuales van apareciendo líneas, formas y manchas difíciles de reconocer, se procede a rascar, bruñir la superficie, hasta que aparecen unos contrapuntos que retienen la tinta y es cuando aparece el color.

\footnotetext{
${ }^{245}$ En este sentido se podría decir que el Roll-Up es una generalización del principio litográfico aplicado sobre las planchas calcográficas. Para esto se graba el metal con gran precisión a niveles de profundidad escalonados y se entinta por orden, de mayor a menor viscosidad. Véase CORRADO MALTESE, (coordinador): 1973, p. 67
} 
Para estudiar y aprender el procedimiento en el taller de Hayter, la artista acostumbraba a llevar un cuaderno de bitácora, en el que apunta todo lo concerniente a la estampación:

Teníamos un bloc, donde anotábamos las cosas, un cuaderno de bitácora. Esto lo aprendí mucho en Italia. Son las planchas como las he ido entintado, es el primer año de Hayter. Incluso me escribo donde he estampo, si en la parte derecha o izquierda, porque los rodillos pueden tener una cierta variación. $Y$ digo, imprimo en la parte izquierda donde los rodillos son más grandes y más duros. Entonces pongo el entallo con azul, con unas gotas de aceite en el rodillo duro. Después pongo amarillo transparente con muchísimo aceite; tengo que pasarlo dos veces. Después paso el otro con verde esmeralda ¡claro! porque si voy hacer el tiraje después de un año, tengo que saberlo todo. ${ }^{246}$

Sin embargo ella opina que esta forma de estampación es más sencilla, más simple: "Quien cree que es más compleja es porque no se ha detenido a estudiar a fondo," ${ }^{247}$ pues esta técnica se hizo precisamente para simplificar el proceso y hacerlo todo de una forma más directa. Una vez controlados todos los pasos, esta técnica es más fácil, mágica, y de colores más vivos.

Sin embargo, un rasgo importante de su concepción es que no le da excesiva importancia al procedimiento, porque considera que la técnica aporta simplemente un medio de expresión, y lo que realmente importa es lo que se tiene que decir y cómo se dice:

\footnotetext{
${ }^{246}$ Entrevista personal con la autora en Castellón de la Plana. 04/08/2006

${ }^{247}$ Ibidem.
} 
Yo creo que la técnica de Hayter para quien la necesita está bien. Tampoco es que sea una cosa vital. Es importante por lo que aporta al grabado. Son descubrimientos importantes. Luego, no creo que una obra, porque tenga una técnica más depurada o mejor sea buena; si tienes un lenguaje bueno, si estás muy bien con la materia y si, además, has podido llegar a alguien, es maravilloso. ${ }^{248}$

En cuanto al método de trabajo, sus intenciones siguen siendo las mismas; la sencillez, la simplificación de las cosas y una forma de grabar directa y espontánea, son la clave de la creación en su obra. La artista se apropia de todo tipo de incidentes y casualidades, manchas e imperfecciones que surgen en la plancha de forma accidental y que dan calidades agradables que la artista sabe aprovechar.

Utiliza todo tipo de objetos que tiene a su alcance y que le pueden servir tanto para grabar como para reservar, tales como plantillas, plásticos de forrar libros que se adhieren a la superficie, barnices que aplica en ocasiones con pincel, tiralíneas, pluma, así como lápices grasos que emplea de manera personal y que le ofrecen una total libertad gestual a la hora de ejecutar la obra.

En este sentido en algunas ocasiones emplea un barniz de fumistería. ${ }^{249}$ Dibuja directamente sobre la plancha con el barniz, ya sea con un pincel o por medio de salpicados libres y automáticos que surgen siempre de forma casual y espontánea, lo que permite ir creando la imagen en positivo. Hace reservas progresivas, mientras va sometiendo la plancha a la acción del ácido, en una suma de

\footnotetext{
${ }^{248}$ Entrevista personal con la autora en Castellón de la Plana. 27/04/2006

249 Laca muy fuerte, para proteger metales expuestos al calor. De fácil aplicación y secado relativamente rápido.
} 
acciones que claramente podemos encontrar en cualquier tradicional proceso de grabado al aguafuerte. Sin embargo su planteamiento de trabajo difiere ligeramente del proceso tradicional, pues el dibujo de la forma no lo hace con un fondo oscuro, barnizado, sino sobre la plancha limpia. (Véase. Fig. 119)

Esto está todo hecho con pincel y reservado con barniz, es como ir pintando y, claro, eso ya te da tres o cuatro tonos. Yo voy haciendo diferentes mordidas para que te dé el relieve; siempre con el pincel improvisando, gestual. Yo no utilizo mucho el barniz de reserva, yo utilizo más un barniz de fumistería, que se utiliza para pintar tubos de estufas, es un barniz comercial, porque es mucho más barato y resistente al ácido. Después, para sacarlo, con el petróleo se saca tranquilamente. ${ }^{250}$

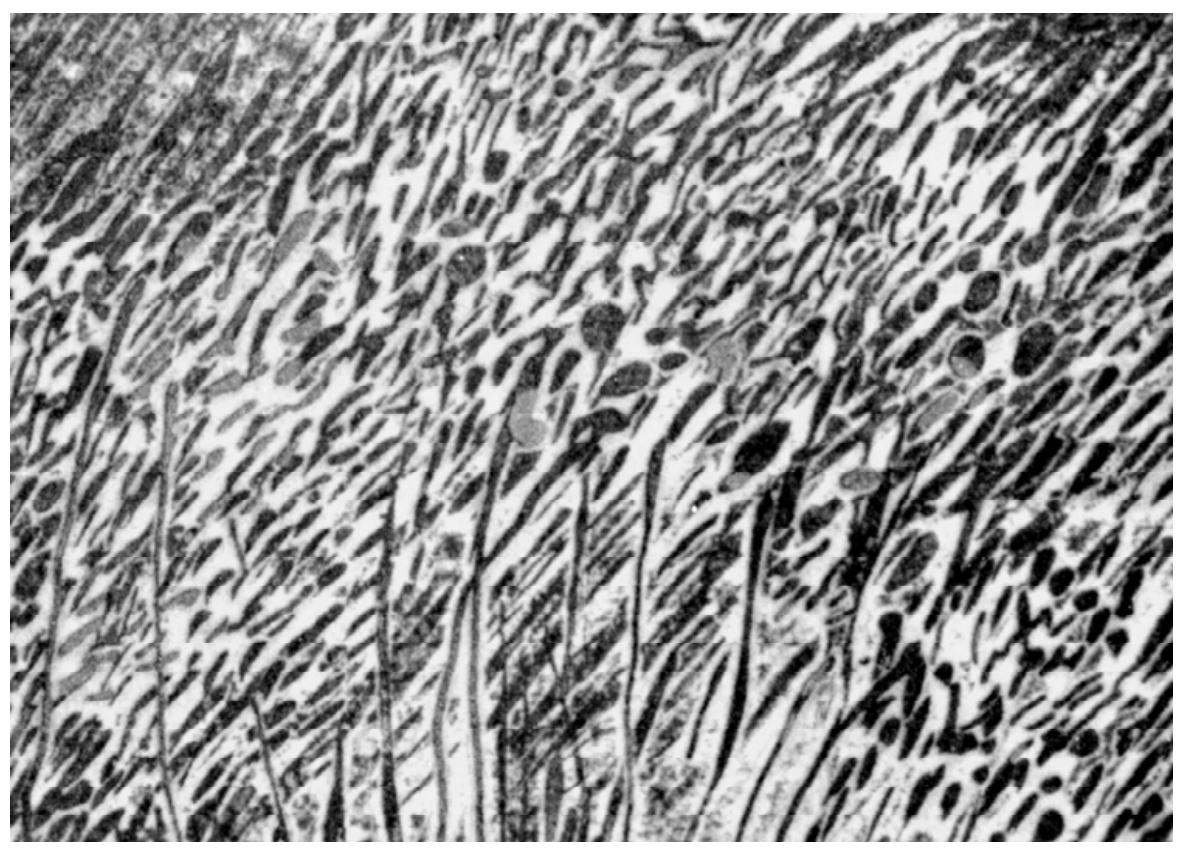

Fig. 119. Pilar Dolz. Detalle LAM. LXXXII. "Homenatge a Bonnard II", Serie Herbes. Reserva de barniz con pincel. Aguafuerte. 1985

${ }^{250}$ Entrevista personal con la autora en Castellón de la Plana. 13/12/2007 
De igual manera utiliza lápices grasos de distinta densidad y grosor; lápices litográficos, de labios, de ojos, que le permiten obtener distintas calidades lineales y textuales, que proporcionan a la obra unos efectos muy pictóricos. En unos casos el trazo aparece por medio de gestos lineales rectilíneos o serpenteantes de gran libertad, pero en otras ocasiones surgen en forma de texturas. Para conseguirlo, raya la plancha insistentemente con la cera y disfruta de las imperfecciones que se producen cuando el lápiz se rompe; son precisamente estos desperfectos los que le gustan a la artista porque dotan a su obra de una especial riqueza. Como el componente graso cubre la superficie de la plancha de forma irregular, según la presión, velocidad y dureza del material, el ácido, provoca la mordedura irregular del metal y crea unas ricas texturas, muy próximas a los efectos de la tiza o el pastel.

En cuantiosas ocasiones usa el raspador para rebajar la intensidad de la mordida del ácido y conseguir muy buenas calidades que dan la sensación de que la plancha tiene mucho relieve; algo completamente falso, ya que su grosor oscila entre 1,5 y $2 \mathrm{~mm}$, por lo tanto nunca hay mordida muy profunda. De hecho podemos apreciar que en las hendiduras más profundas, aparece una especie de halo al alrededor del color. (Véase Fig. 120)

Yo voy al "Todo a cien" y compro lápices para maquillaje de ojos o pintalabios. Son muy gruesos, y entonces hacen una barrera sobre plancha de zinc. El raspador da muy buenas calidades. Yo raspo mucho; me gusta trabajar el metal así, el hierro raspado. Se crea una materia primero con el lápiz graso y eso crea una cosa irregular que, después con el raspador, lo raspo, y te da una calidad. ${ }^{251}$

${ }^{251}$ Entrevista personal con la autora en Castellón de la Plana. 27/04/2006 


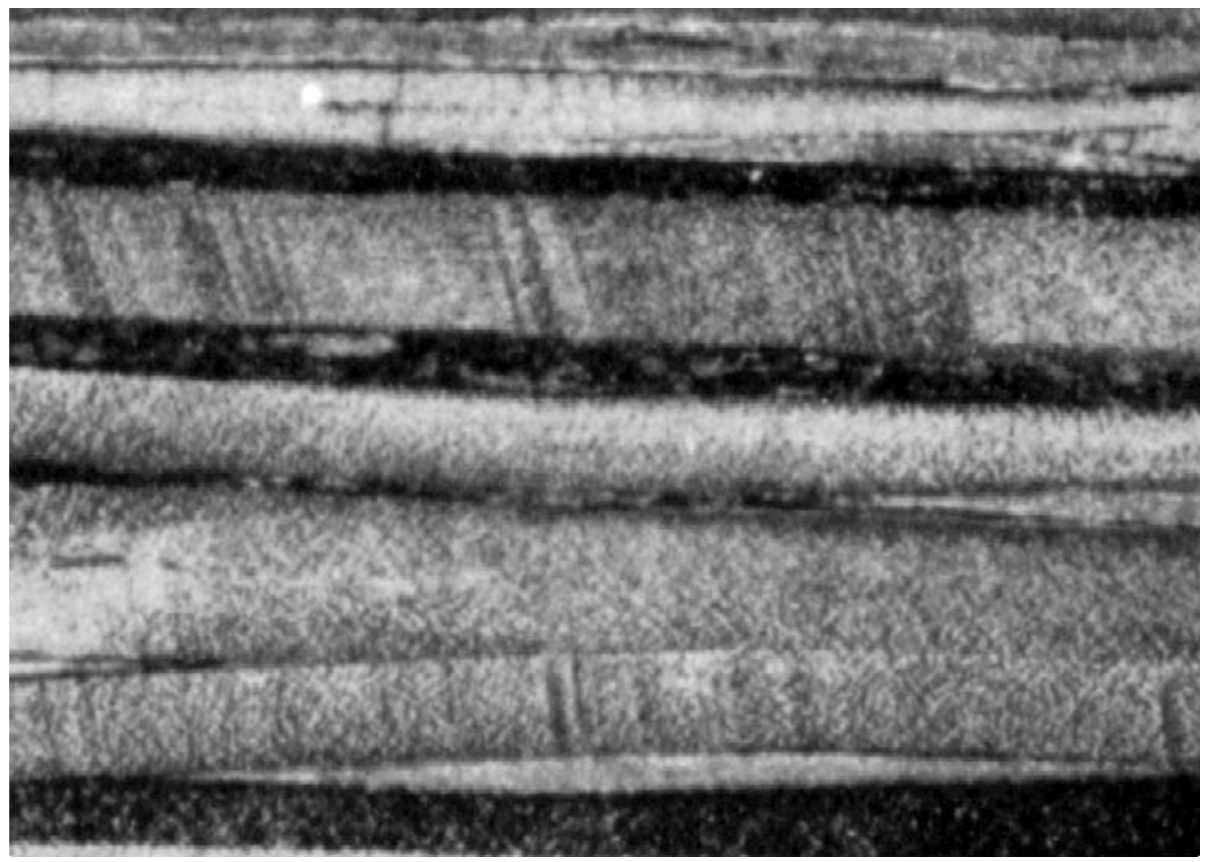

Fig. 120. Pilar Dolz. Detalle. LAM. LXXXIX. "Paisatge LII". Serie Herbes. Reservas con lápices grasos. Aguafuerte. 2000.

En el caso de los trazos rectilíneos, la artista recurre a plumas o tiralíneas cuando quiere hacer líneas rectas y precisas de diferente espesor. Emplea el mismo principio que en los salpicados de tinta, donde el trazo se va realizando en positivo, es decir que consigue los efectos por medio de reservas de barniz que se van sumando en la plancha, hasta que queda completamente cubierta. El tiralíneas le permite obtener un trazo más limpio y plano que el pincel. (Véase Fig. 121) 


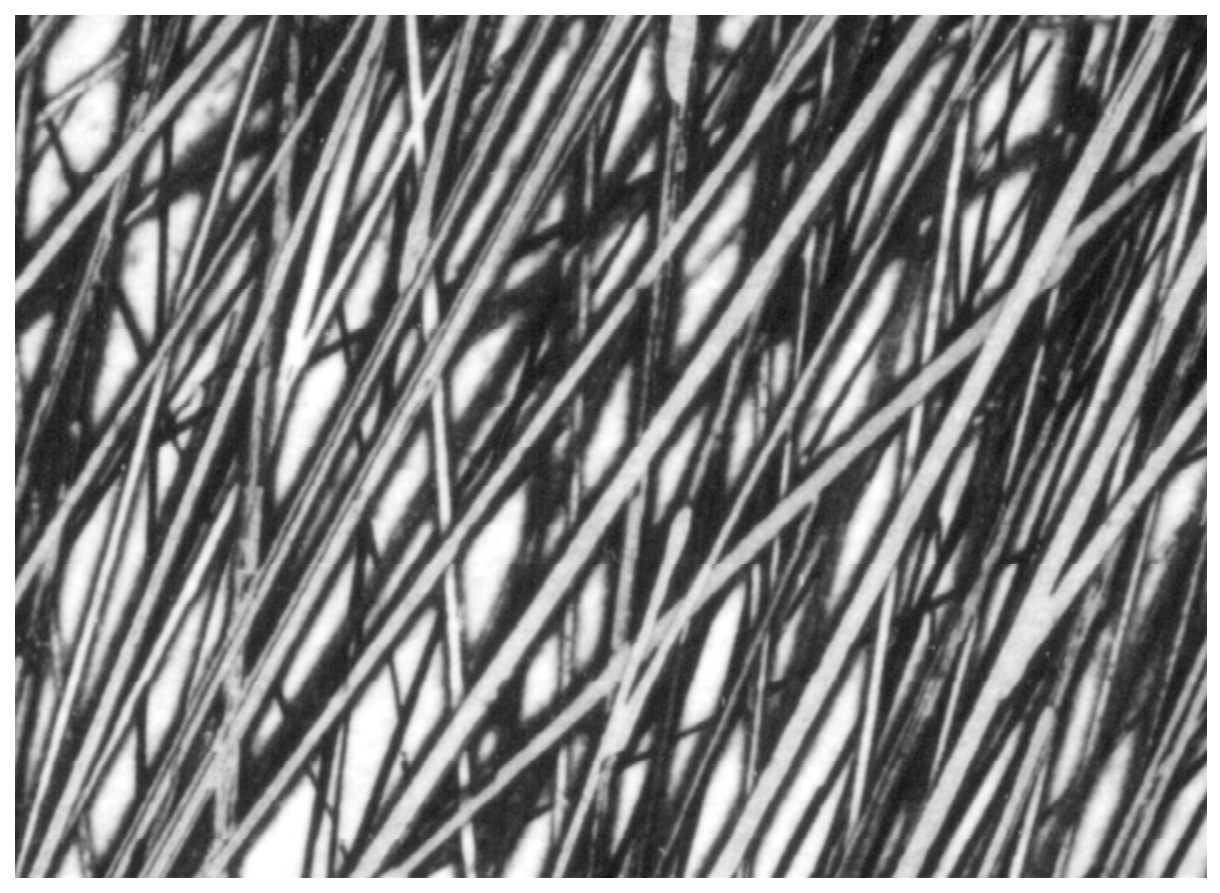

Fig. 121. Pilar Dolz. Detalle LAM. XCII. "Herbes XXXVIII". Serie Herbes. Reservas con tiralíneas. Aguafuerte. 1989

De igual modo el aprovechamiento de todo tipo eventualidades y desperfectos que pueden surgir en la plancha, proveen de nuevas posibilidades a su obra. En este sentido, en algunas ocasionas se beneficia de los efectos producidos por el óxido, por quemas o trazos involuntarios perpetrados de forma accidental o incluso de trabajos realizados por otras personas y que han tirado a la basura; una práctica común que viene repitiendo en las sucesivas series. Un claro ejemplo de esto lo tenemos en LAM. LXXXIV, un grabado realizado a partir de una plancha desechada, que lleva una serie de daños y desperfectos que seducen a la artista. Para reutilizar la plancha la somete a la acción del ácido y después la raspa dejando un efecto borroso y suave que podemos apreciar. Sobre este fondo una serie de trazos horizontales y verticales crean 
un efecto visual sorprendente, combinados con la textura producida. (Véase Fig. 122)

Yo utilizo mucho el azar. A veces dejo una plancha en la terraza y llueve y se oxida. La dejo días, meses... A partir de allí es cuando la estampa es y la potencio de alguna forma ¡Sola ya sugiere mucho! pero no se por qué razón tengo que poner la pezuña y hacer las hierbas o el agua. También utilizo planchas que otra persona ha tirado. Me da igual. Es como utilizar un papel con una textura. Ese juego es el que a mí me gusta; ese juego de mensajes que cambian. ${ }^{252}$

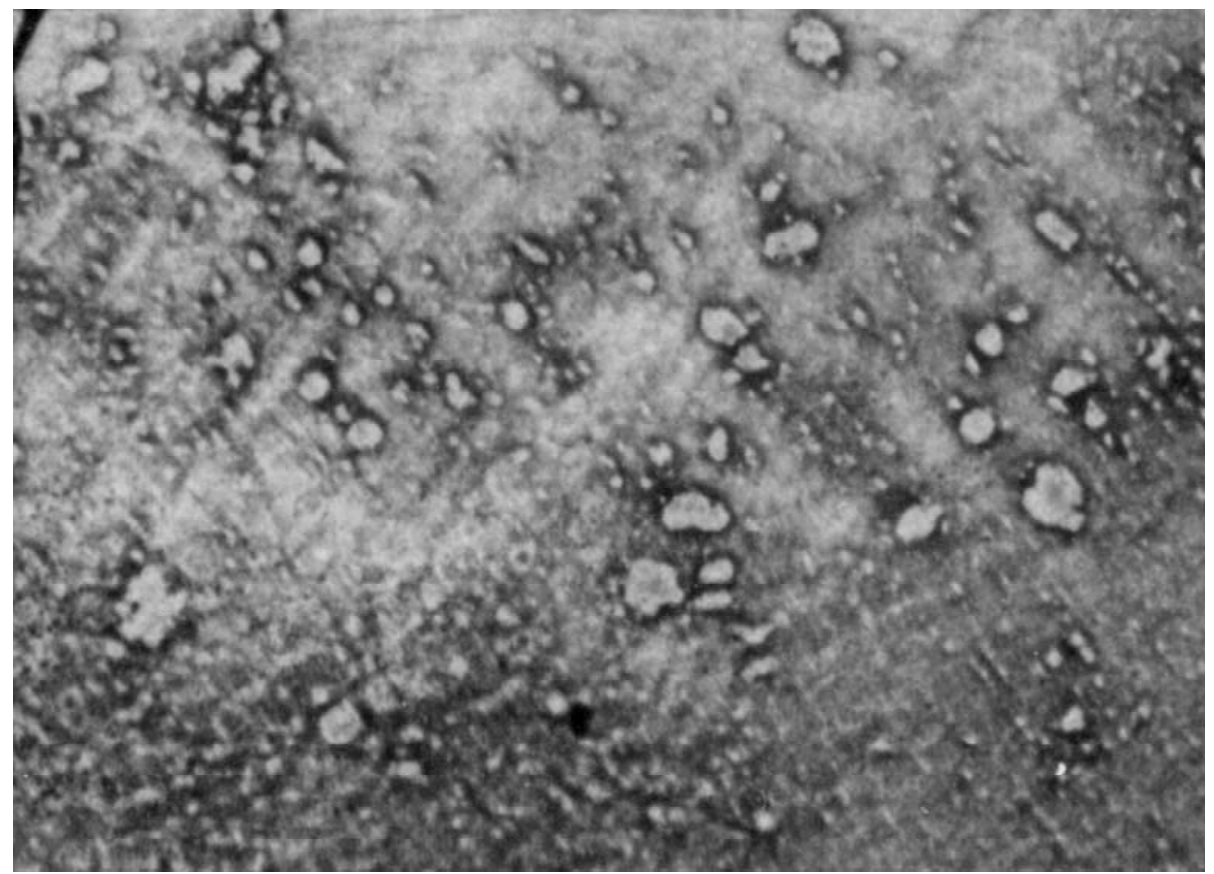

Fig. 122. Pilar Dolz. Detalle LAM. LXXXIV. "Paisatge XX". Serie Herbes. Aguafuerte raspada. 1990.

${ }^{252}$ Entrevista personal con la autora en Castellón de la Plana. 13/12/2007. 
En otros casos utiliza sus propias improntas digitales para crear la imagen; huellas que surgen de modo casual, cuando un día sin darse cuenta se toca desprevenidamente la frente y después la superficie sensible de la plancha. Entonces deja grabada la huella de sus dedos en la matriz, que aparece de modo inesperado. Son unas formas que captan su atención y le sugieren la idea de empapar los dedos en barniz para continuar impregnando la plancha. (Véase LAM. XCIV)

Finalmente, también la última etapa del proceso; el entintado y la estampación, poseen una gran importancia a la hora de la creación. Esto es algo que ha ido descubriendo por medio del trabajo y la reflexión en torno a la matriz. De este modo, una vez terminada la obra recorta la matriz, le da vueltas, cambia el color y prueba todas las posibilidades para darle un significado que le interese. Hay que destacar que normalmente utiliza el formato cuadrado y rectangular, que facilitan la manipulación. Así, en ocasiones gira la plancha, y unos trazos que en unas obras aparecen en vertical, ahora pueden surgir en horizontal y cambiar completamente el significado de la imagen. (Véase LAM. LXXXIV):

Cuando estampo, voy dando vueltas a la plancha, y me doy cuenta que es un paisaje o unas hierbas. Entonces potencio eso. La plancha puede ser muy grande luego yo corto o no, tampoco me preocupa mucho. Es la misma plancha estampada en vertical u horizontal. Esas mismas rayas que en un momento son hierbas, después son paisajes, porque a unas líneas que son verticales, yo doy la vuelta y son un paisaje, entonces por eso los paisajes y las hierbas, se mezclan. ${ }^{253}$

${ }^{253}$. Entrevista personal con la autora en Castellón de la Plana. 16/04/2005 
LÁMINAS

ERBES 



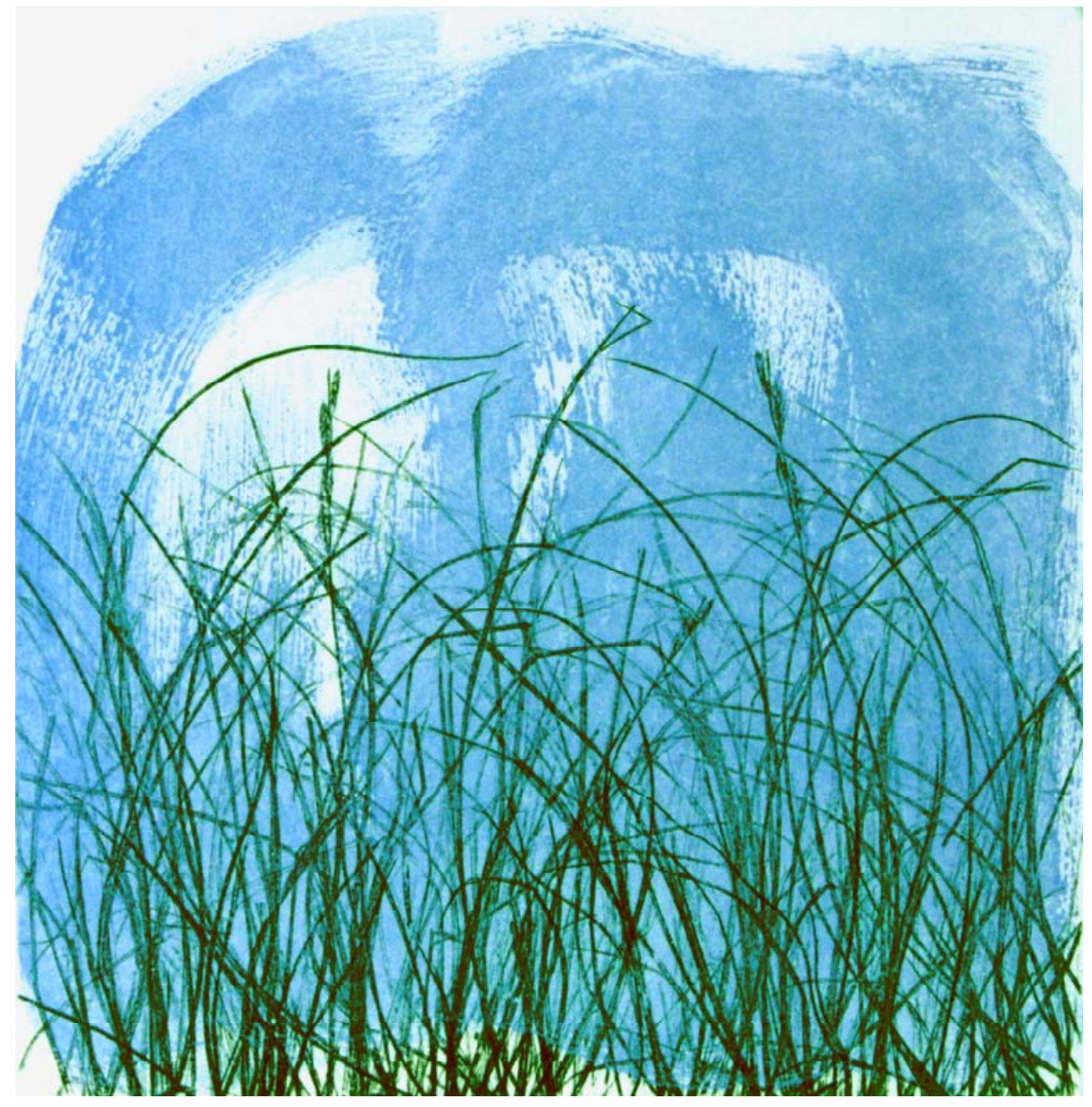

\section{LÁMINA LXXX}

"Herbes"

Barniz blando y azúcar

$32 \times 32 \mathrm{Cm}$.

1983 


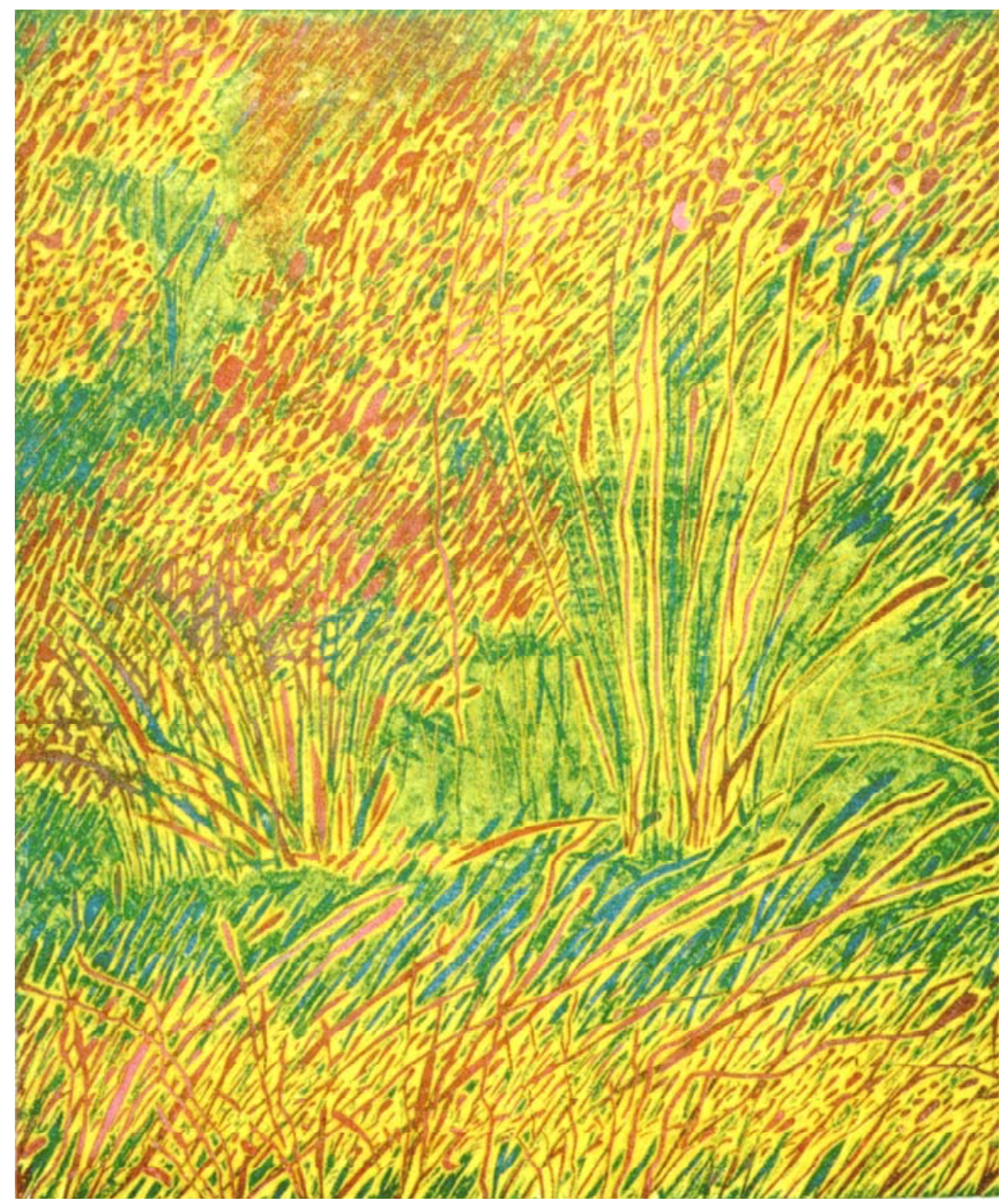

\section{LÁMINA LXXXI}

"Homenatge a Bonnard"

Aguafuerte, reservas con pincel

$29.5 \times 24.5 \mathrm{Cm}$.

1985 


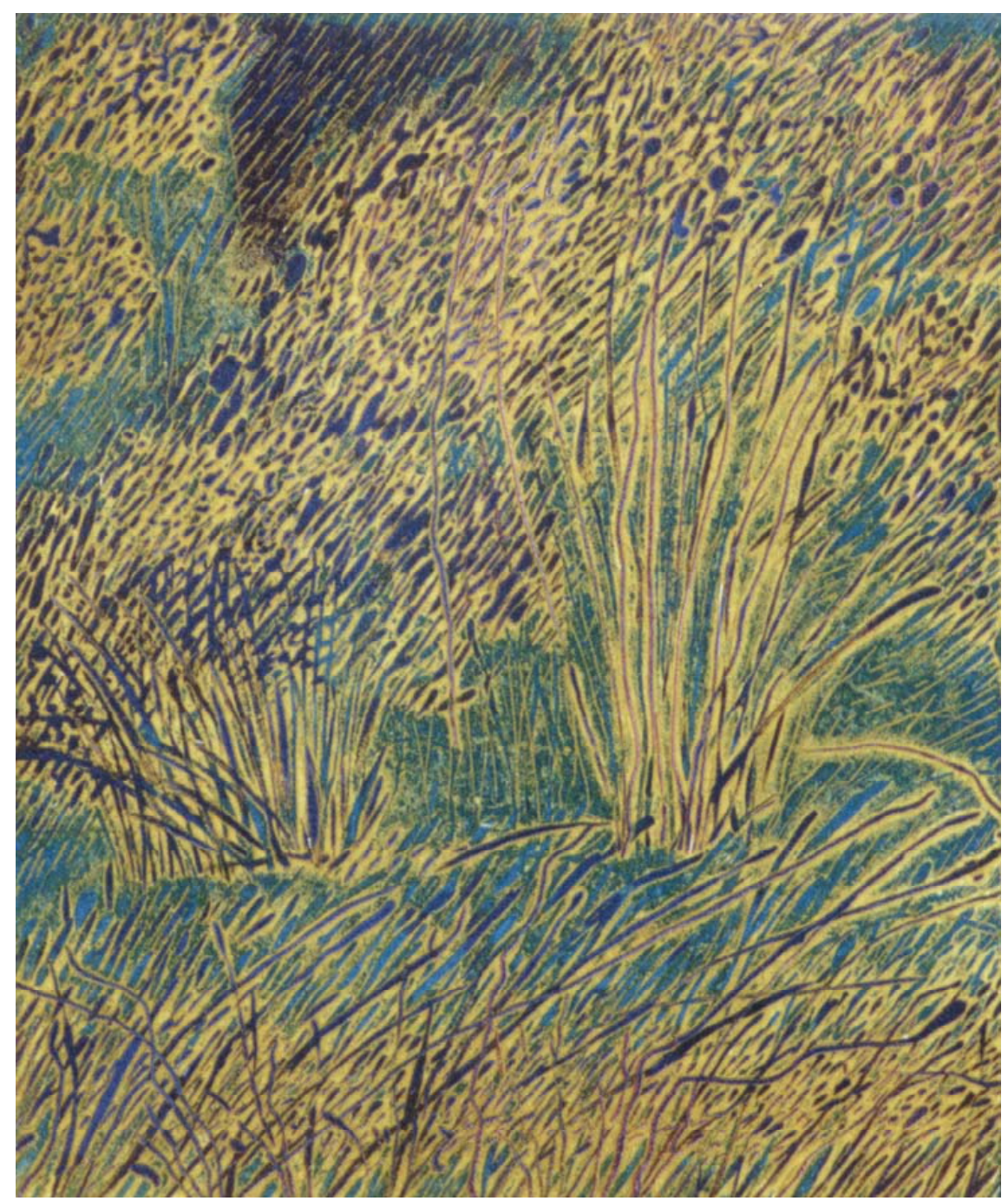

\section{LÁMINA LXXXII}

"Homenatge a Bonnard II"

Aguafuerte, reservas con pincel.

$29.5 \times 24.5 \mathrm{Cm}$.

1985 


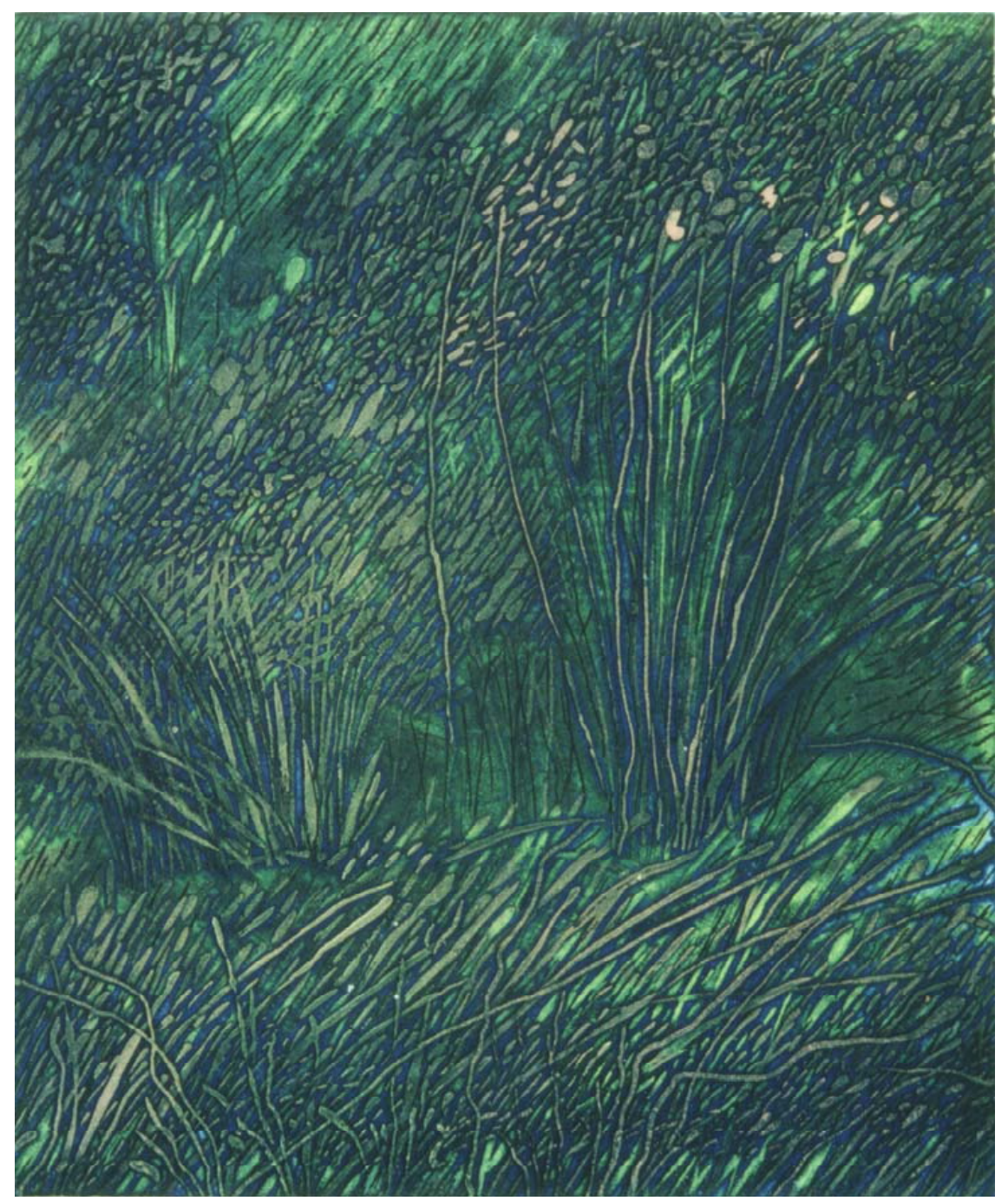

\section{LÁMINA LXXXIII}

"Homenatge a Bonnard III"

Aguafuerte, reservas con pincel

$29.5 \times 24.5 \mathrm{Cm}$.

1985 


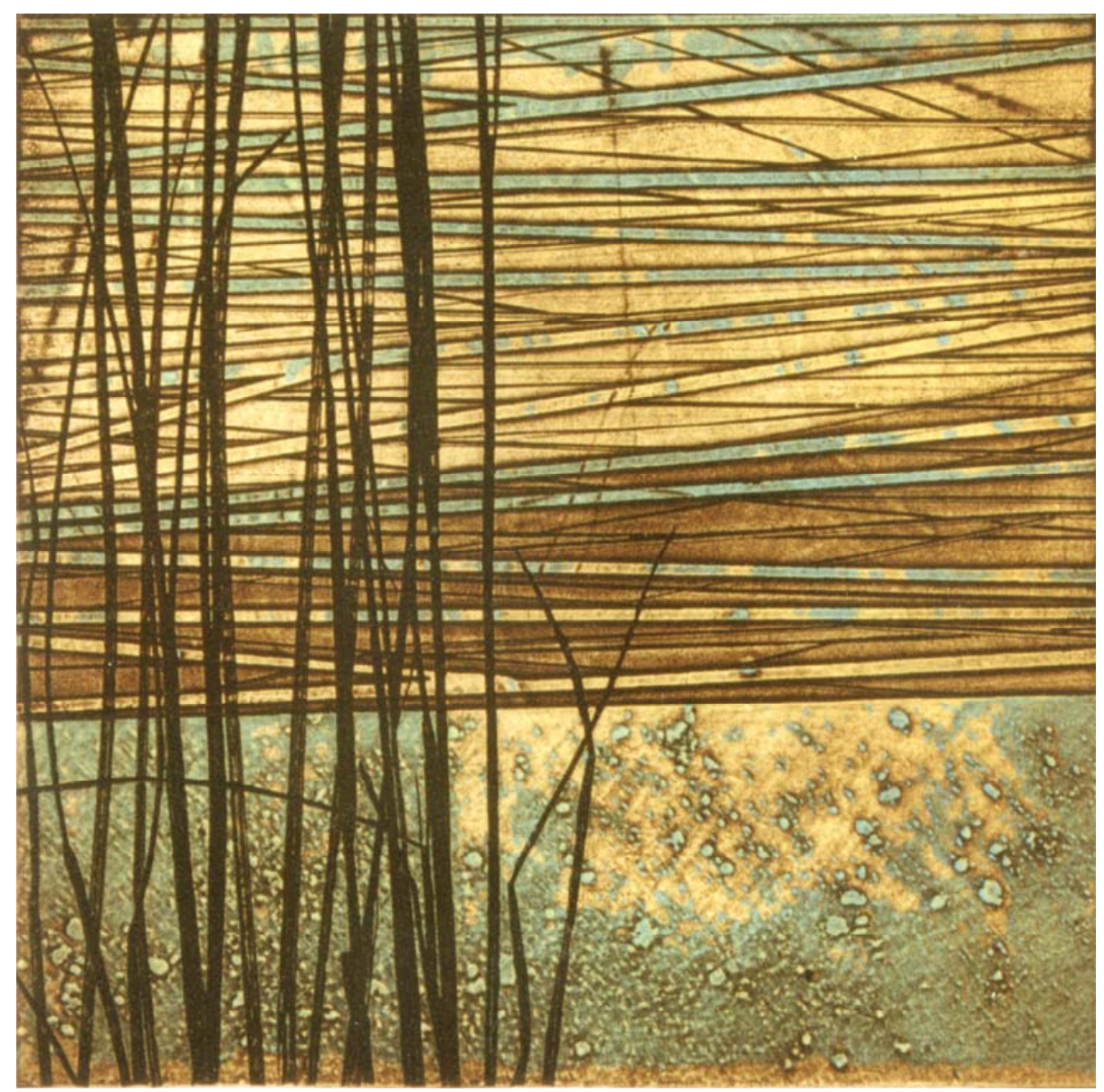

\section{LÁMINA LXXXIV}

\section{"Paisatge XX"}

Aguafuerte, resina raspada

$30 \times 30 \mathrm{~cm}$.

1990 


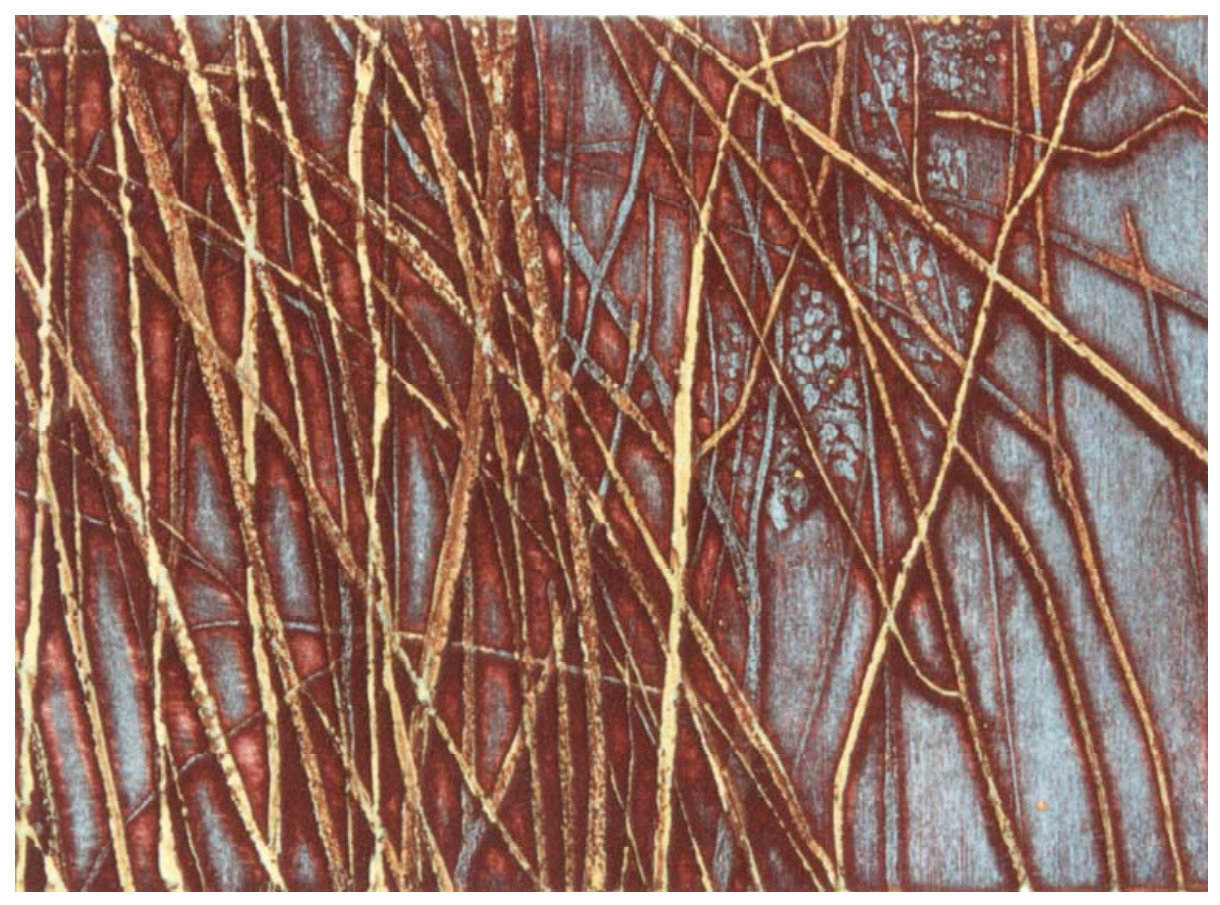

\section{LÁMINA LXXXV}

"Branques VI"

Aguafuerte, reservas con pincel.

$12 \times 17.5 \mathrm{~cm}$.

1990 


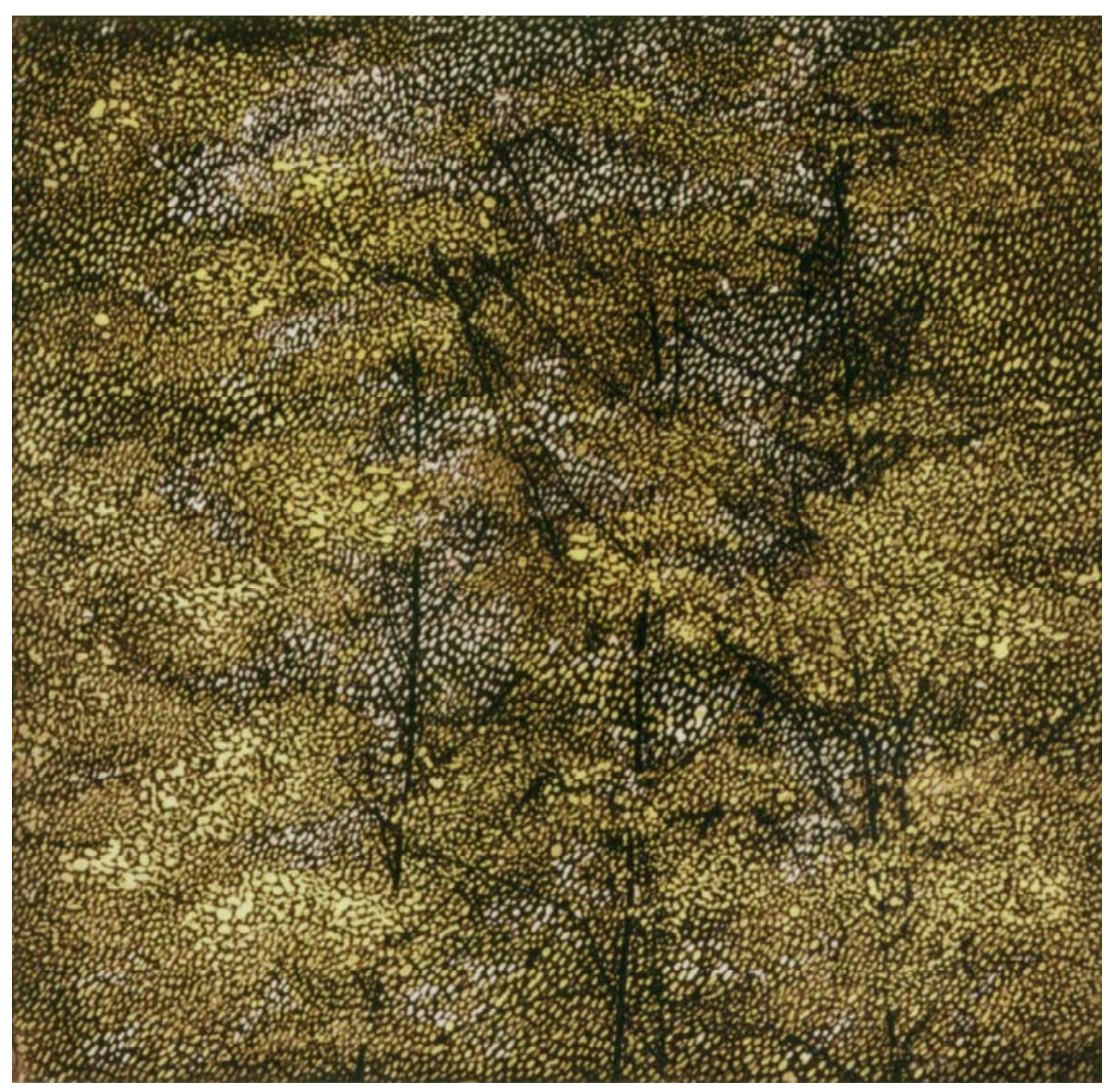

\section{LÁMINA LXXXVI}

"Fulles XIV"

Aguafuerte, salpicados de barniz

$32.5 \times 32 \mathrm{~cm}$.

1989 


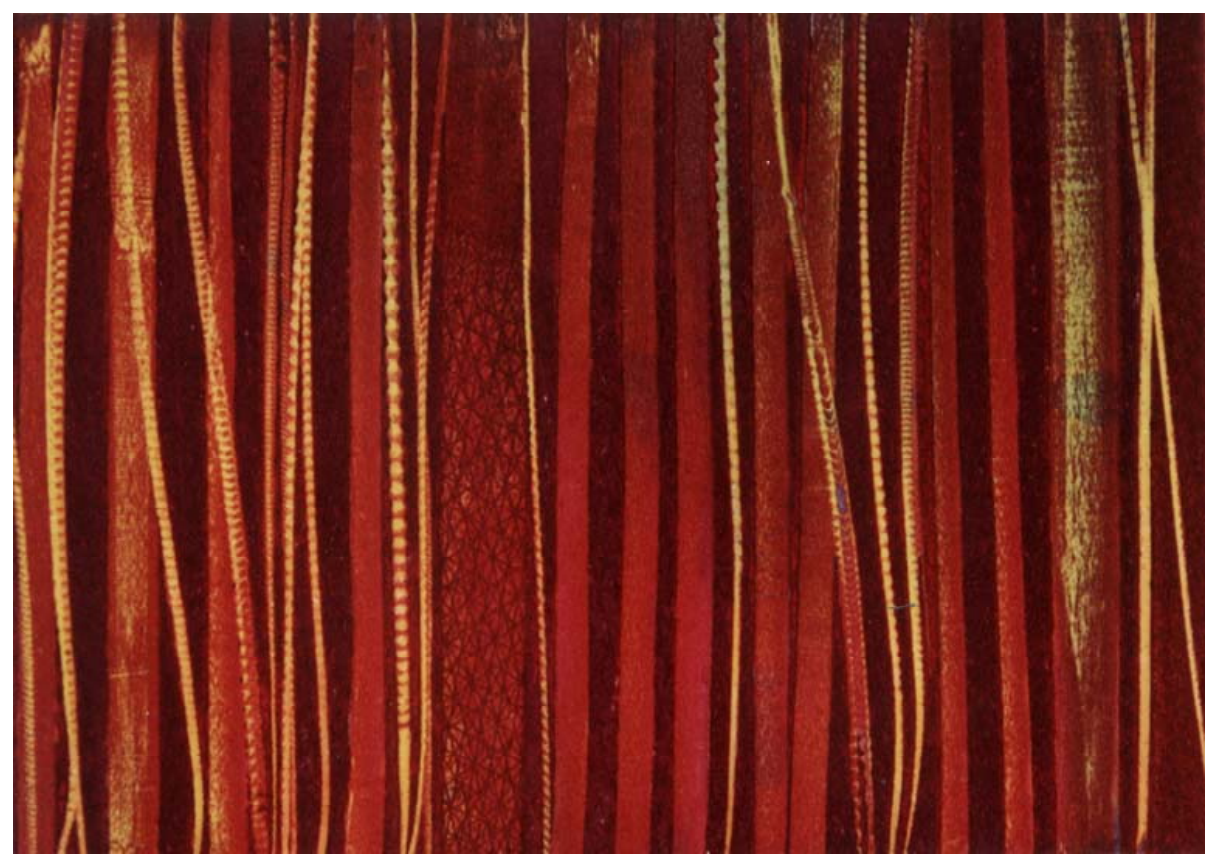

\section{LÁMINA LXXXVII}

"Tiges XXVI"

Aguafuerte, reservas con lápiz graso.

$20 \times 33 \mathrm{~cm}$.

1998 


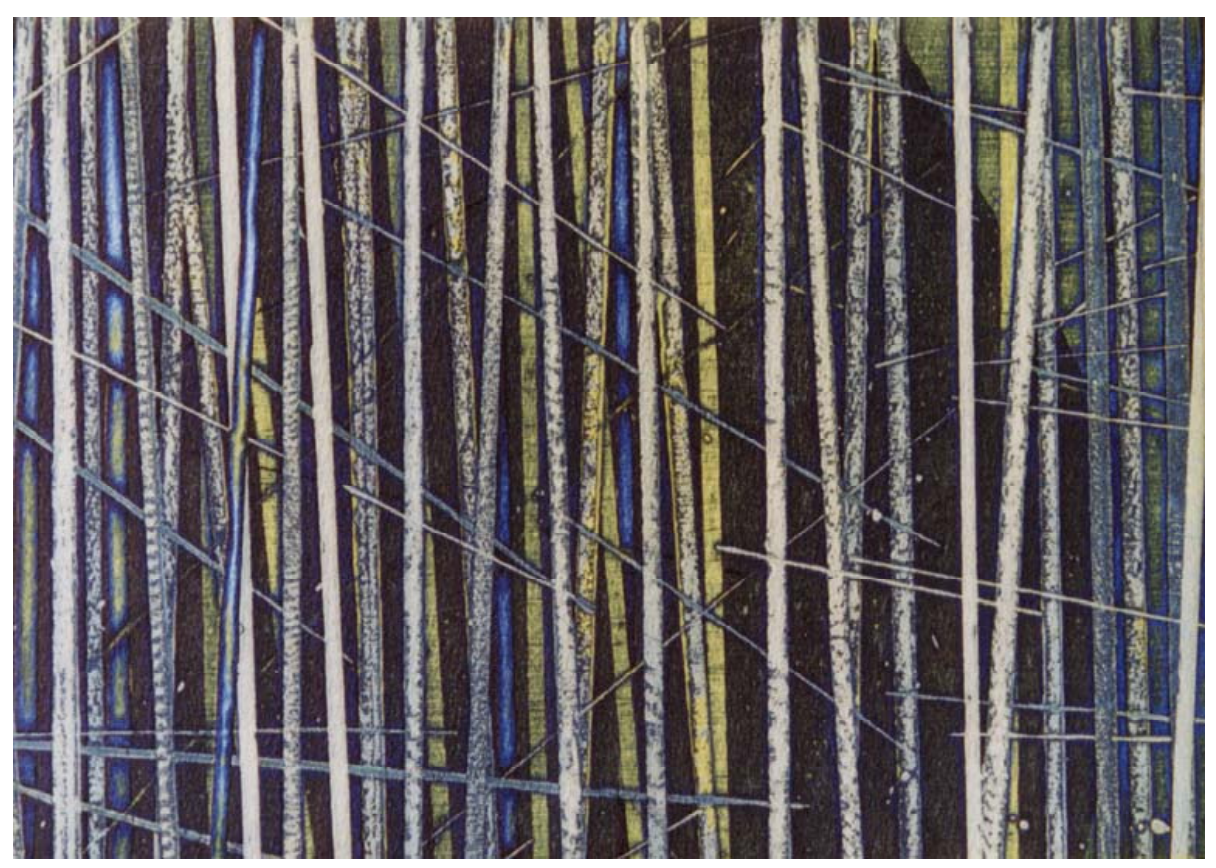

\section{LÁMINA LXXXVIII}

"Tiges XIX"

Aguafuerte, reservas con tiralíneas.

$21.5 \times 33 \mathrm{~cm}$.

1997 


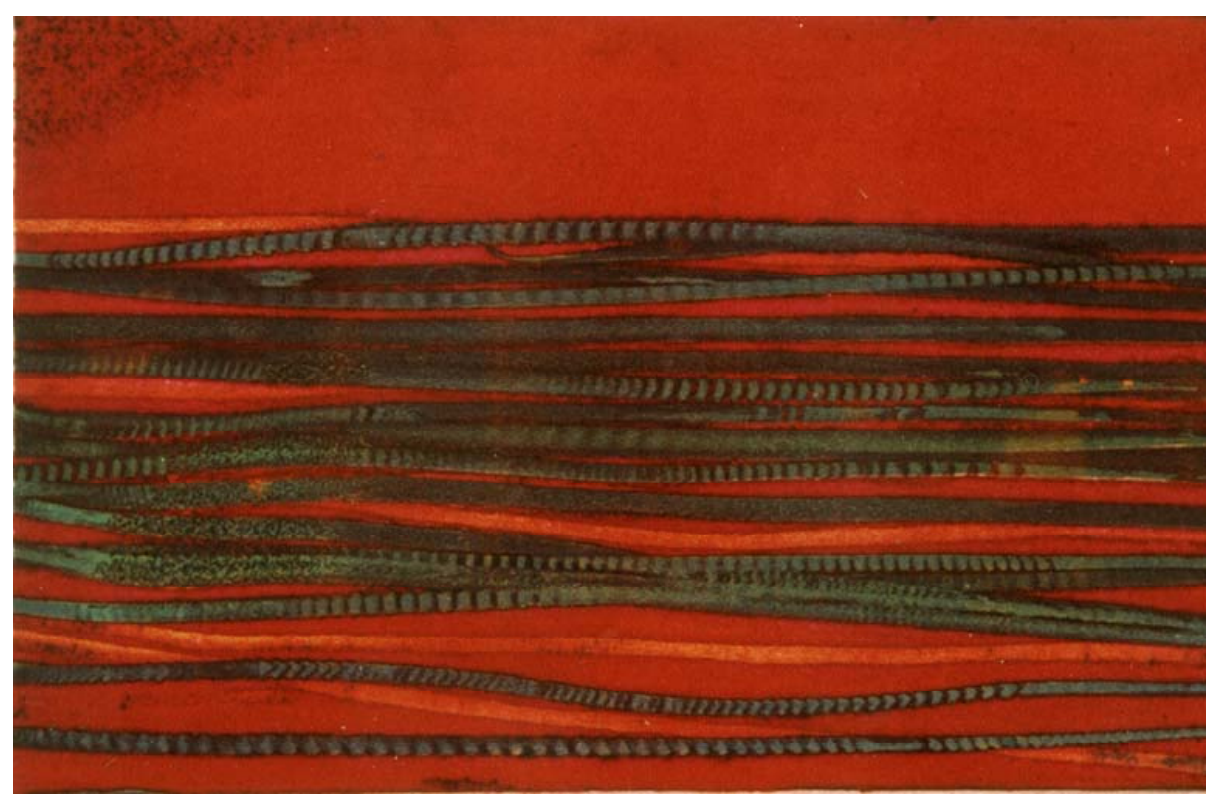

\section{LÁMINA LXXXIX}

"Paisatge LII"

Aguafuerte, reserva con lápiz graso.

$20.5 \times 33 \mathrm{~cm}$.

2000 


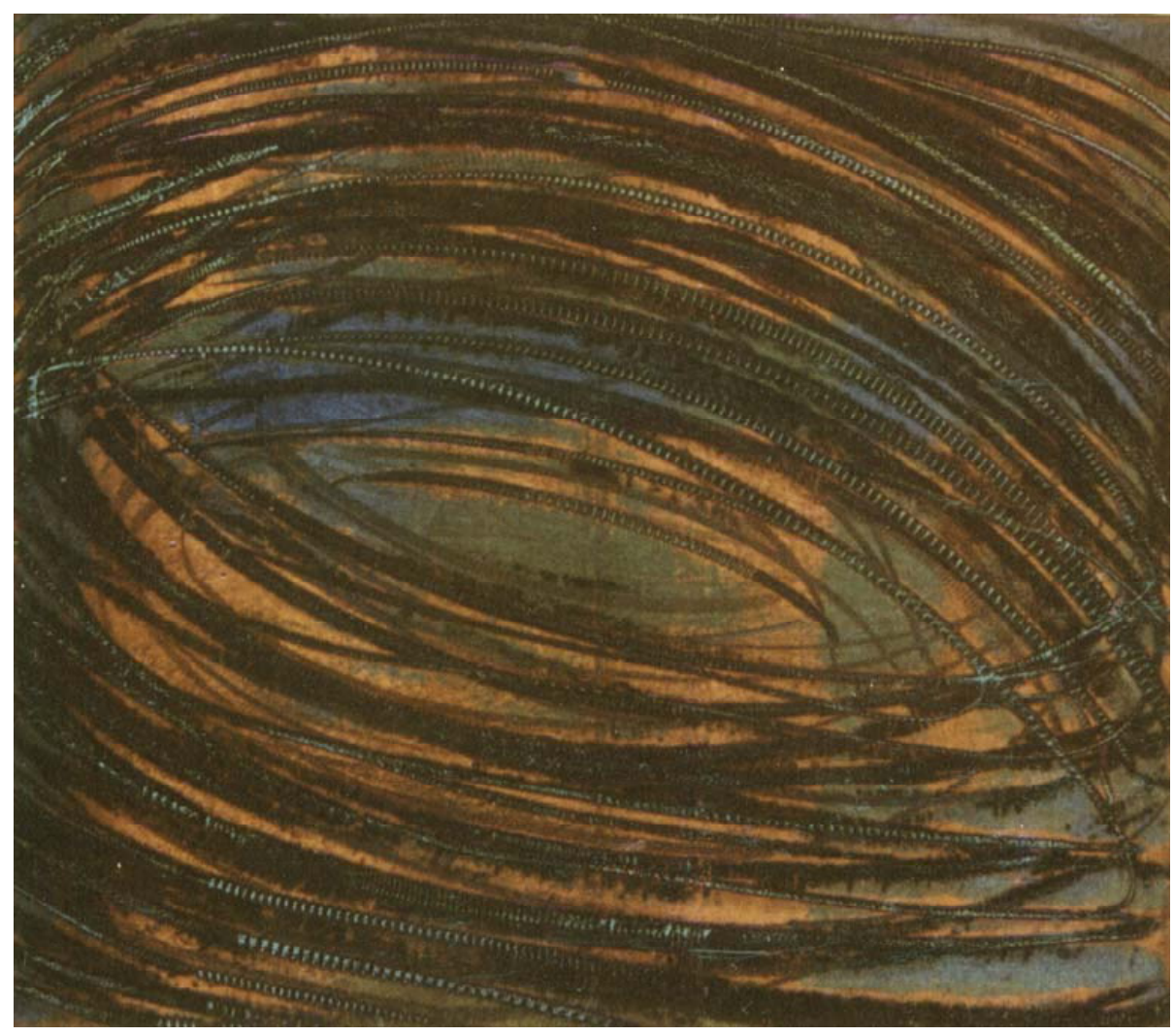

\section{LÁMINA XC}

"Paisatge XL (Mares)"

Aguafuerte, reservas con lápiz graso.

$42 \times 48.5 \mathrm{~cm}$.

1997 


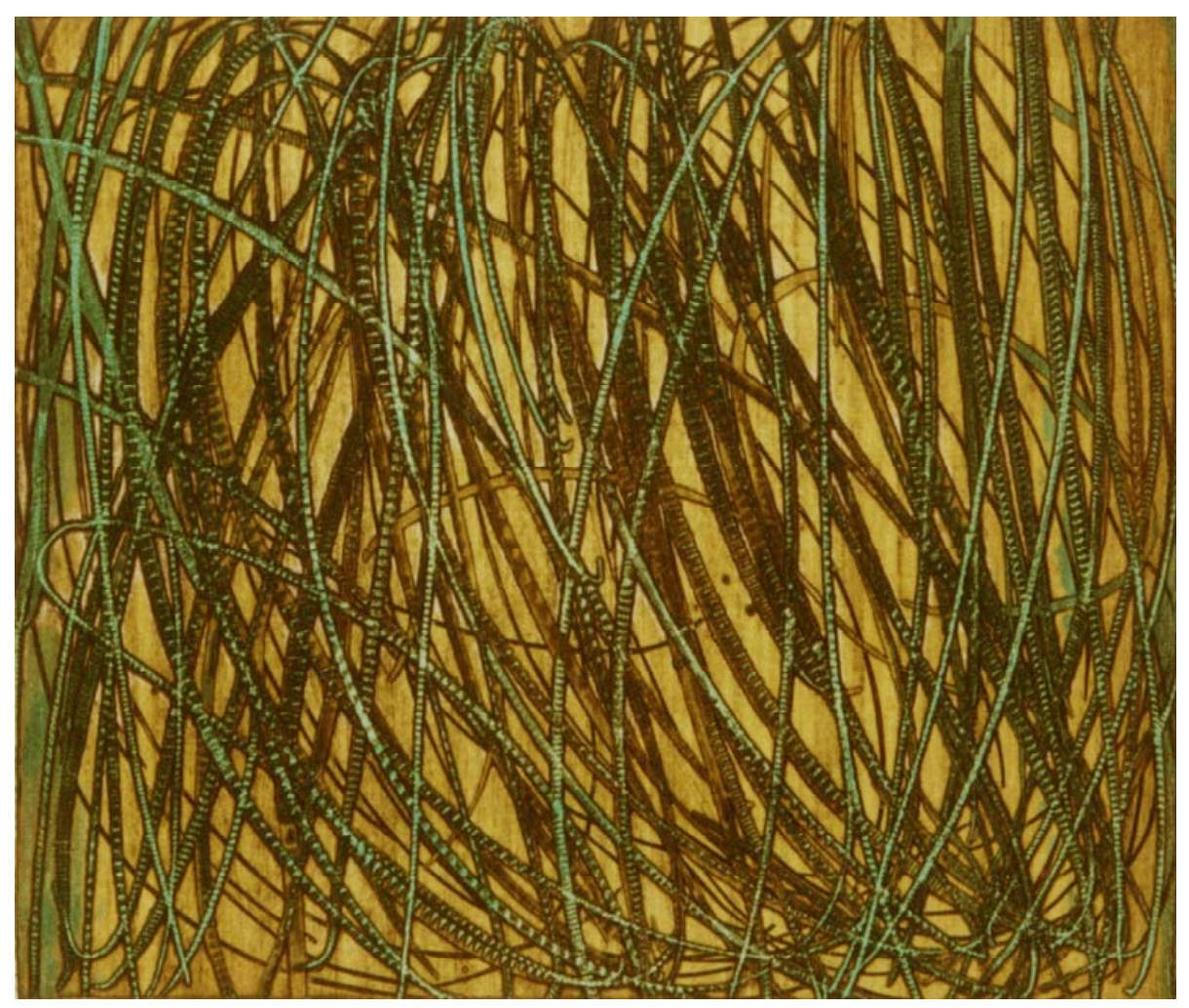

\section{LÁMINA XCI}

"Herbes LI"

Aguafuerte, reservas con lápiz graso.

$42 \times 50 \mathrm{~cm}$.

1994 


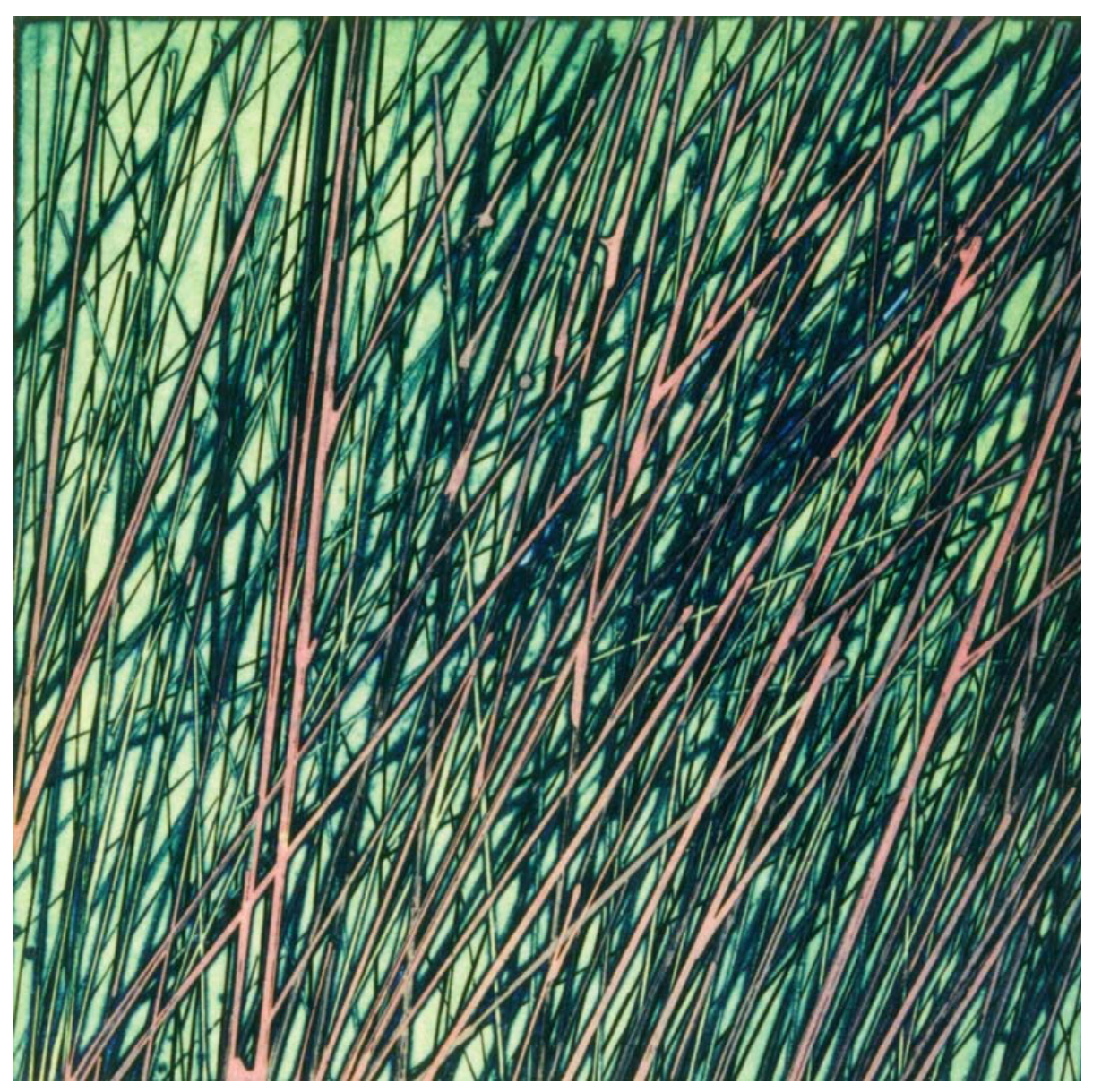

\author{
LÁMINA XCII \\ “Herbes XXXVIII" \\ Aguafuerte, reserva con tiralíneas. \\ $31.3 \times 31.3 \mathrm{~cm}$. \\ 1989




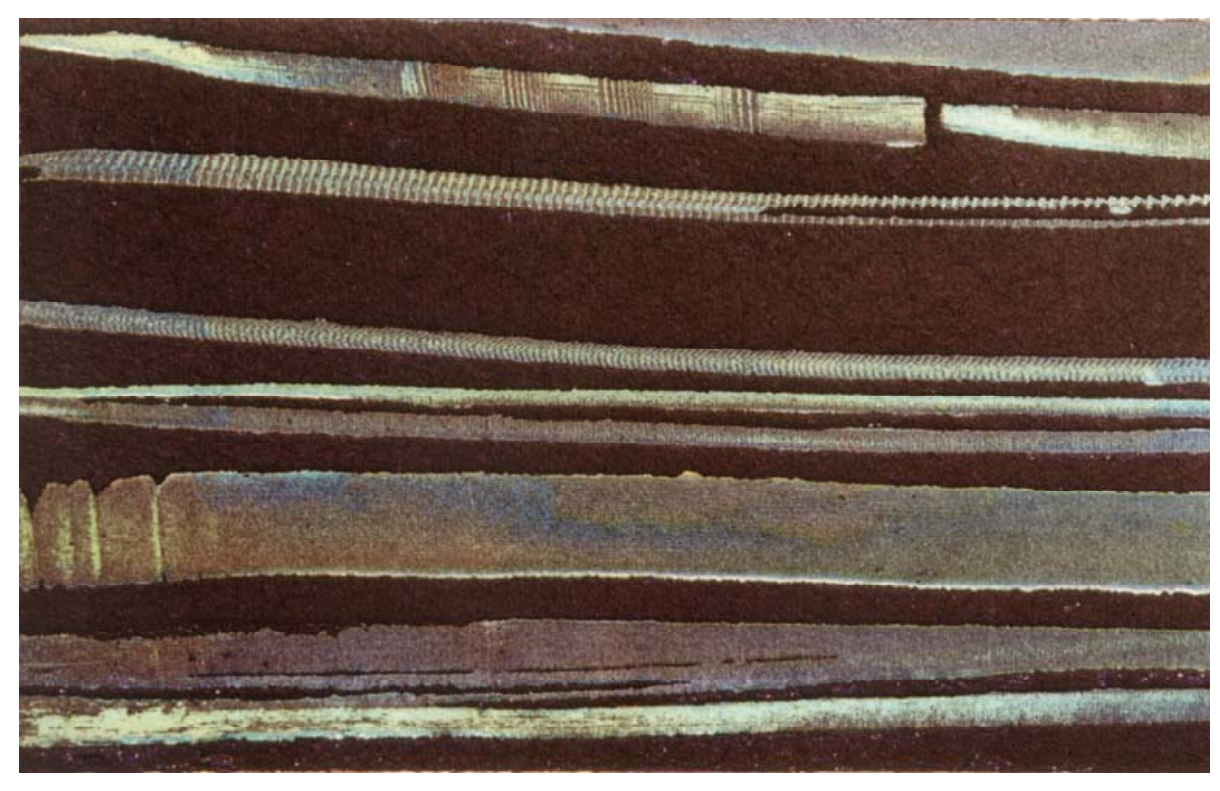

\section{LÁMINA XCIII}

"Paisatge XL"

Aguafuerte, reservas con lápiz graso.

$13.5 \times 22 \mathrm{~cm}$.

2001 


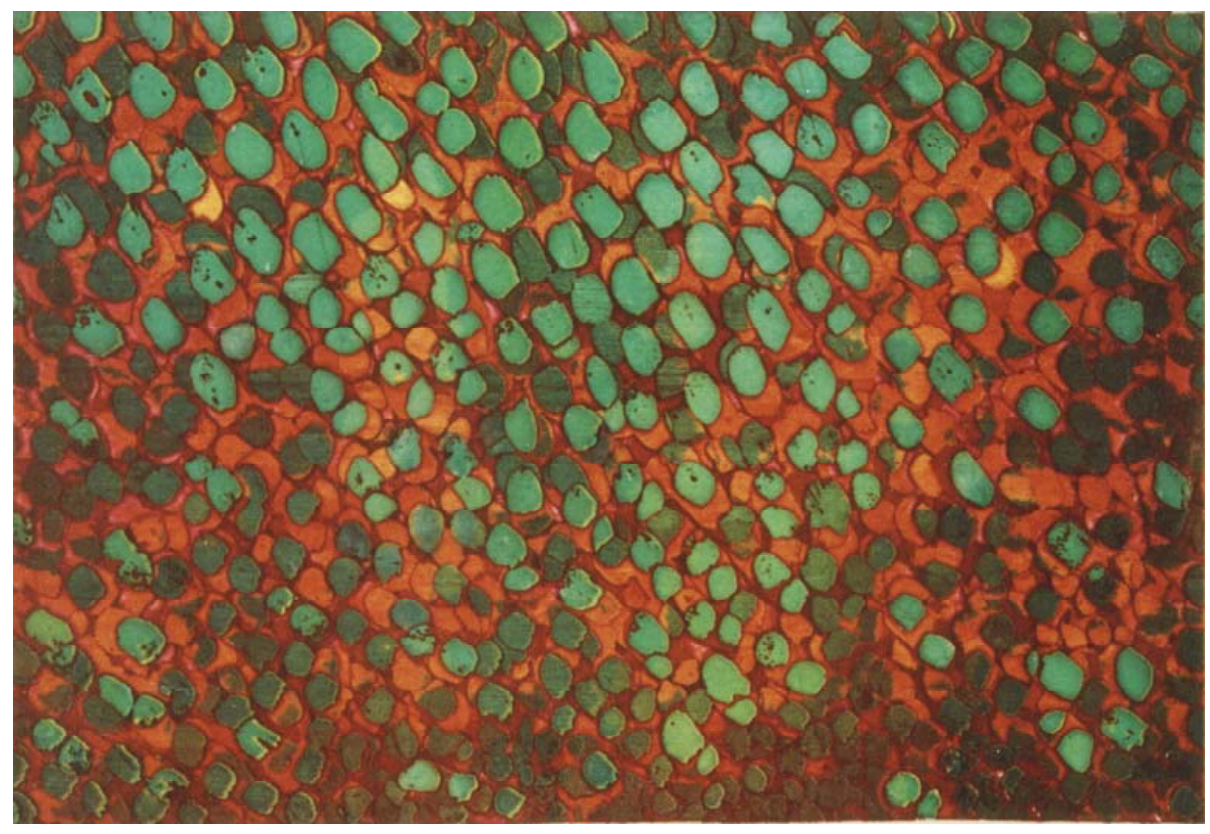

\section{LÁMINA XCIV}

"Fulles XXXII"

Aguafuerte, reservas realizadas con dedos

$31 \times 50 \mathrm{~cm}$.

1996 


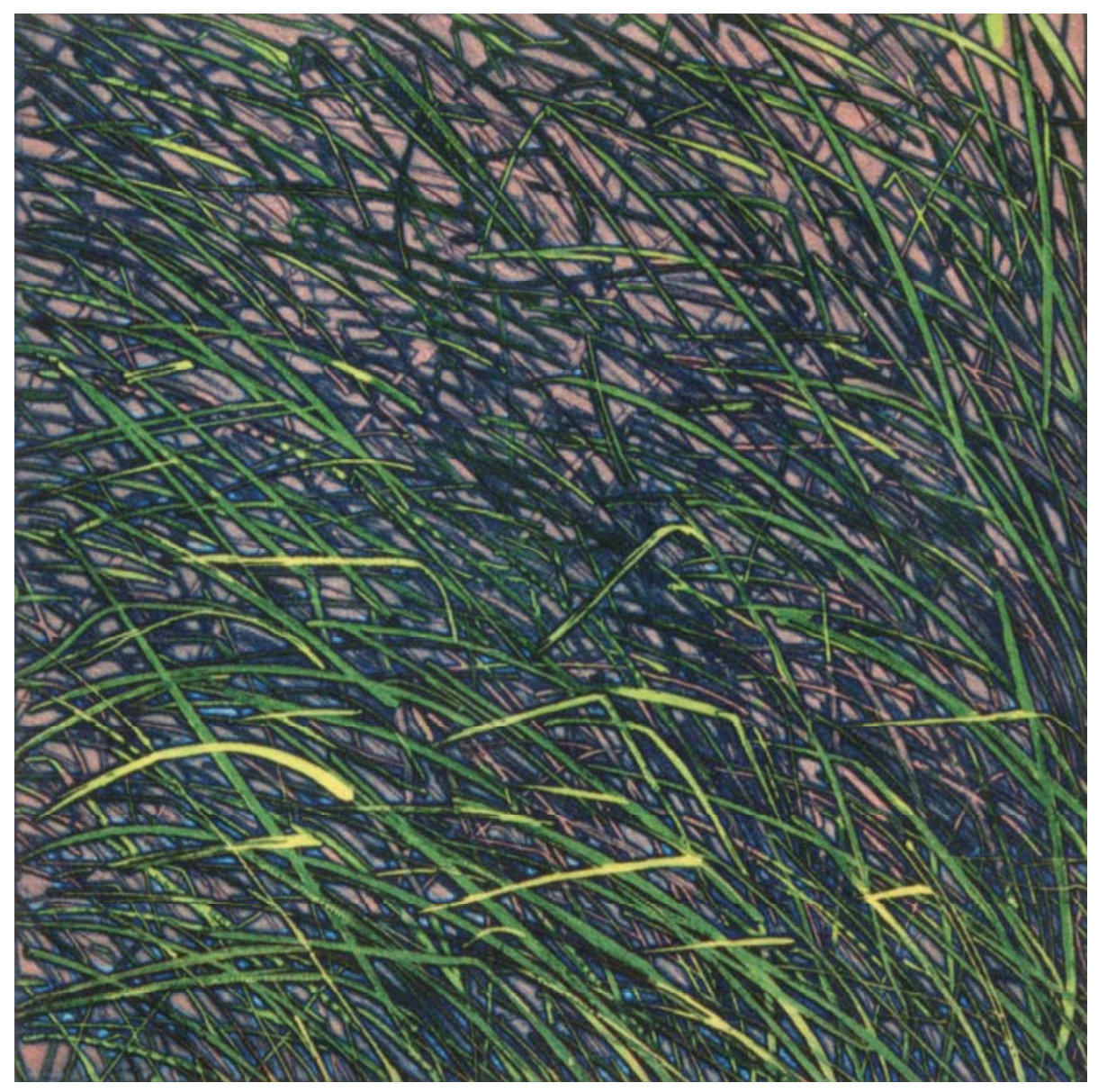

\section{LÁMINA XCV}

"Herbes XLI"

Aguafuerte, reservas con pincel.

$32 \times 32 \mathrm{~cm}$.

1991 


\section{ONCLUSIONES}





\section{CONCLUSIONES}

El propósito de este trabajo de investigación era dar conocer la obra gráfica de Pilar Dolz, porque a nuestro juicio supone una importante aportación al panorama artístico valenciano en una época de resurgimiento artístico tanto de carácter sociológico como de planteamiento técnico, por sus apreciables cualidades artísticas y por su actitud testimonial a favor de un reconocimiento igualitario como mujer que desarrolla su profesión en el campo del Arte. 
Pilar Dolz se formó y comenzó su andadura artística en el período de la dictadura franquista, con todo lo que eso supuso, conoció un mundo y una época difícil, vivió muchos hechos que hoy reconocemos como históricos y los hizo suyos, mostrando a través de su obra los más profundos sentimientos que estas experiencias le despiertan.

Sus primeros trabajos reflejan la dramática vida social en un tiempo con falta de libertades. Ella misma lo explica en sus palabras aparecidas en numerosos catálogos de la época. Estos grabados de profundo simbolismo representan una serie de imágenes cargadas de un contenido crítico contra la dictadura y las clases dominantes; mujeres atadas, rejas a las que se abrazan unos brazos doloridos ansiosos de libertad, palomas de la paz fosilizadas y mariposas enzarzadas en punzantes alambres de espino, en una obra que asocia elementos metafóricos a través de la figuración, con un dibujo descriptivo de profundo impacto visual. Advertimos en estas series el reiterado empleo de contenidos temáticos, lenguaje y conceptos, que muestran un ambiente de repulsa y desolación que se prolongará más allá de la dictadura, concretamente hasta 1978, año en que da un giro a su producción artística.

Posteriormente la artista pasa por una etapa menos reivindicativa, más intimista, en la que se plantea un paréntesis en sus propuestas de carácter social y perpetra una transformación introspectiva en torno a sus propias vivencias. La obra que desarrolla está ligada a su amor por su tierra natal, a través de una peculiar metáfora del trabajo y esfuerzo del hombre, de la existencia humana 
que a su vez da sentido a las piedras del secano, al paisaje árido de las comarcas interiores del país valenciano.

Concluido este periodo surge de nuevo una alusión a la naturaleza, identificada con la hierba, que constituirá la manifestación de sus intereses, sus vivencias cerca de la naturaleza, sus formas, sus colores, sus texturas; son un toque a la sensibilidad al tiempo que llevan a pensar en cuánto estamos perdiendo con la degradación del paisaje y la vegetación.

Respecto a su planteamiento conceptual y creativo, podríamos decir que hemos comprobado que Pilar Dolz se muestra desde su juventud como una artista influida por el Surrealismo, la escritura automática, el azar, elementos que le permiten instaurar su propio universo a través de formas que surgen de su interpretación personal matizada de la realidad, los sueños y la irracionalidad. Las manchas, realizadas consciente o involuntariamente actúan como provocador óptico que estimula su fantasía y le induce a descubrir en estas formas una serie de imágenes, que después potenciará dando sentido a su obra. Esto unido a su particular sensibilidad para manipular los materiales, son los aspectos más significativos de su expresión personal en el campo de la creación gráfica.

Metodológicamente sin duda una de sus mayores aportaciones tiene relación con la etapa final en el proceso de creación de la obra; el entintado y la estampación. (Ella investiga en profundidad todas las posibilidades). Así una vez terminada la fase de grabado, acude a una serie de recursos que cambian completamente el significado de la imagen; utiliza plantillas, 
fondinos, rodillos, combina planchas de otros grabados, cambia colores, alterna el orden de los mismos. En cuanto a la matriz, la estampa en diferentes posiciones cambiando el discurso. Sin duda la producción de casi cuatrocientas obras nos descubre a una artista prolífica y con una actitud abierta conceptualmente y rigurosamente respetuosa del proceso técnico, de manera que puede dominar el discurso planteado con los distintos lenguajes del grabado y la estampación.

Desde el punto de vista iconográfico, quizá una de las características que hemos podido ratificar como más destacables en la obra gráfica de Pilar Dolz, es la relación de continuidad que existe entre las series, que enlazan ideas y conceptos, de manera que podemos ver ciertas formas que nunca desaparecen del todo cuando finaliza una serie e inicia la siguiente, si no que se integran como un paso de transición evolutiva entre una serie y otra.

La relación de continuidad que encadena las experiencias creativas de las series, se deba quizás a que mucho de estos trabajos se suceden en el tiempo casi de forma simultánea. No hay que olvidar que la artista trabaja siempre sobre distintas series a la vez, esto estable una relación de paralelismo creativo entre las series.

En cuanto al planteamiento formal definimos como conclusiones, ciertos aspectos que son una constante en la que reincide a lo largo de toda su producción artística: 
- Elementos instintivos de reiteración de determinadas manchas y trazos caligráficos, que dan origen primeramente a cuerdas, hilos deshilachados, raíces, presentes en las series preliminares, y posteriormente toda una gama de formas vegetales.

- Gesto gráfico con dos vertientes; una que construye la imagen y otra que da textura y carácter a la representación.

- Color distribuido en el espacio por separado, impidiendo la mezcla y asegurando la máxima saturación y luminosidad de las tintas.

- Espacios de luz planteados por una afirmación del blanco puro del papel. Esto nos invita a reflexionar sobre la relación entre el elemento manifestado gráficamente sobre el papel (lleno) y la ausencia de tinta (vacío), una preocupación plástica siempre presente en la obra de Pilar Dolz.

- Expansión de la imagen por fuera de los límites del formato estampado tradicional. Crea un juego visual con varias impresiones de manera que sugiere al espectador una trayectoria visual imaginaria que le invita a expandir su mirada más allá de los límites de la imagen impresa.

- Secciona la matriz para crear una imagen impresa fraccionada, donde los colores no se mezclan y permanecen puros y luminosos. 
- Elemento temático que obstaculiza el paso de quien mira; rejas, ventanas entreabiertas, altos muros de piedra, caminos pedregosos, entramado de cuerdas, raíces y hierbas; unas y otros llegan a conformar una barrera visual infranqueable para el espectador.

- Utilización de pequeños formatos, que le faciliten el disfrutar de lo que hace, a la vez que refuerzan el carácter de cercanía en la relación con el espectador, que facilita la comunicación y evita los protagonismos abrumadores que limitan la percepción sutil del mensaje.

Acerca de la técnica, nuestra conclusión es que podemos definir su proceso como una acción libre de convencionalismos, con un tratamiento técnico ajeno a cualquier preocupación sobre la crítica ajena. Sus grabados nos hablan de la evolución en cuanto a la forma de afrontar los problemas técnicos, paralela a su capacidad creadora. En sus grabados recurre a diferentes técnicas y procedimientos: desde el grabado en relieve de la xilografía hasta la serigrafía, pasando por el aguafuerte, barniz blando, aguatinta, punta seca, buril, manera negra y la litografía entre otros, si bien esta última junto al aguafuerte es una de las más practicadas desde sus años de estudios en la Escuela de las Artes del Libro, en Barcelona, aunque la dificultad para disponer de un taller litográfico, le llevó a dirigir su atención hacia el grabado calcográfico, que terminó por convertirse en uno de los recursos más dominantes de su obra. 
Sin embargo su personal aportación en la práctica nos lleva a confirmar en los resultados logrados, que identifica la técnica como un elemento enriquecedor de su lenguaje plástico. En primer lugar, en la fase de grabado y sensibilización de las matrices, aunque actúa técnicamente de manera clásica, siempre se plantea el uso de herramientas no usuales que maneja libremente para lograr su propio lenguaje, ampliando las posibilidades expresivas del medio; lápices para ojos, lápices de labios, ceras de distinto grosor, laca del cabello, pinceles, plásticos, planchas encontradas en la basura, bruñidores, raspadores, tiralíneas son algunos de los útiles con los que trabaja las matrices. Su objetivo parece ser investigar en la simplificación del proceso y encontrar los medios más acordes y más fáciles para la expresión de su obra.

En cuanto a la fase de reproducción, también mantiene un planteamiento muy ortodoxo respecto a la cualidad de multiplicidad de la obra, algo que le va a llevar desde muy temprano a adoptar una forma rigurosa de aplicación de la tinta sobre la plancha, de forma directa sin mezcla previa y sin ninguna otra complicación añadida; el fin es que la reproducción de los colores sea exactamente igual en todas las estampas. Esta forma de actuación la asume con mayor intensidad si cabe, cuando hace uso del grabado en su versión comercial, realizando encargos para organizaciones, empresas gráficas y llevando a cabo ediciones para otros artistas. En este sentido la autora reivindica el trabajo artesanal del grabado y el dominio de los materiales. No podemos olvidar otra forma de introducir el color por medio de recortes de papel coloreado, sobre los que imprime la imagen, con dos objetivos; 
investigar sobre los efectos del color (cambios de luces, matices) y la síntesis del proceso de estampación con varios colores a la vez.

Con la técnica del Roll-up, logra mantener su intención de estampar varios colores a la vez "para ahorrar tiempo" sin necesidad de tener que recortar la plancha. Esta técnica le permite evolucionar hacia una concepción diferente en cuanto al tratamiento del color.

Completando las conclusiones con una síntesis general diremos que:

Pilar Dolz es un artista consagrada al grabado, que adopta esta técnica como una forma de expresión básica, que siempre se ha mostrado abierta a la investigación, hasta tal punto que se convierte en su único medio de creación desde 1970, abandonando por completo la práctica de la pintura. A nuestros ojos es una figura sobresaliente, versátil con los medios y rigurosa y exigente en su práctica, como bien puede constatarse a lo largo de este estudio que muestra más de tres décadas de constante indagación artística, experiencia y aprendizaje, que se desglosa en un conjunto de obras bien diferenciadas, pero articuladas con acierto en series.

De igual manera las distintas actividades como galerista y editora, han restado tiempo a su producción gráfica, pero han acrecentado su conocimiento en este medio.

El estudio de su obra nos confirma que tuvo determinantes influencias tanto de índole artística, de manos de grandes maestros como Rembrandt, Durero, Goya y Picasso a los que observa 
detenidamente, así como de diversos movimientos artísticos, como el impresionismo, Surrealismo, Automatismo, Expresionismo. De ellos extrae ideas sobre el empleo del color y la actividad gestual automática. Filosóficamente en cierta etapa de su vida estuvo influenciada por grandes pensadores como Freud, Kant, Arp, a los que leía asiduamente, sin embargo en el plano político recibe las primeras influencias feministas, durante sus primeros viajes de estudios a Italia, cuando se estaban gestando los primeros movimientos italianos con este espíritu. Por otra parte, también podemos recordar la influencia de los profesores que le transmitieron un gran amor y entrega al arte, además de conocimientos teóricos y técnicos en el campo de litografía y de la estampación calcográfica.

Por último queremos destacar la actitud abierta y reivindicativa que ha mantenido Pilar Dolz a lo largo de su carrera artística en pro del arte y de la lucha por la igualdad de sexos. Mujer, artista, galerista, ha sabido compaginar el mundo del arte con la defensa más férrea de los derechos de la mujer y, sobre todo por la liberación femenina. La artista articular sus experiencias desde una óptica social y política, dando una nueva visión, rediseñando el papel de la mujer como sujeto activo en la sociedad, dejando de lado el papel pasivo al que había estado sometida. 
IBLIOGRAFÍA 



\section{BIBLIOGRAFÍA GENERAL}

ADES, D.: El Dadá y el Surrealismo. Traducido por Marcelo Covián. Ed. Labor SA. Barcelona, 1975. Título original: Dada and Surrealism. Ed. Thames and Hudson Ltd, London, 1974.

AGRAMUNT LACRUZ.: Arte y represión en la guerra civil española. Ed. Museum Line, Valencia, 2005.

AGUILERA CERNI, V.: Arte y compromiso histórico. Sobre el caso español. Ed. Fernando Torres, Valencia, 1976.

AGUILERA CERNI, V.: Iniciación al nuevo arte español de la postguerra. Ed. Península, Barcelona, 1970. 
ALBELDA, J. L.: El sentido dilatado. Reflexiones sobre arte contemporáneo. Ed. Universidad Politécnica de Valencia, Valencia, 1992.

ALBERS, J.: La interacción del color. Traducido por María Luisa Balseiro, Ed. Alianza Forma, Madrid, 1982. Título original: Interaction of Color. Ed. Yale University. s/d. 1963.

ARNHEIM, R.: Arte y percepción visual. Traducido por María Luisa Balseiro. Ed. Alianza Forma, Madrid, 1993. Título original: Art and Visual Perception. Ed. University of California Press, California, 1954.

BARRAL I ALTET, X. (coordinador): Historia del arte de España. Ed. Lunwerg. Barcelona, 1996.

BARTRA, E.: Mujer, ideología y arte. Ed Icaria, Barcelona, 1994.

BELJON, J. J.: Gramática del arte, Traducido por Menchu GómezMartín. Ed. Celeste, Madrid, 1993. Título original: Ogen open: grondbeginselen van vormgeving. s/d, 1987.

BERENGUER PALAU, L.: Artistas valencianos contemporáneos. Ed. Archival, Valencia, 1998.

BIEDERMANN, H: Diccionario de los Símbolos, Traducido por Juan Godo Costa. Ed. Paidós Ibérica, SA, Barcelona, 1993. Título original Lexikon der Symbole. Ed. Droemersche Verlagsarslt. Th. Munich. 1989. 
BONET CORREA, A. (coordinador): Arte del franquismo. Ed. Cátedra SA. Madrid, 1981.

BOZAL, V.: Historia del arte en España. Desde Goya hasta nuestros días. Ed. Istmo, Madrid, 1987.

BOZAL, V \& CARRETE, J.: El grabado en España, (Vol. XXXII), Col. Summa Artis. Ed. Espasa Calpe, Madrid, 1988.

BRETON, A.: El surrealismo puntos de vista y manifestaciones. Traducido por Santos Torroella. Ed. Barral, Barcelona, 1970. Título original: Entretiens (1913-1952). Ed. Gallimard, París, 1952.

BRIHUEGA, J.: Miró y Dalí: dos grandes surrealistas. Ed. Anaya SA. Madrid, 1993.

CALVO SERRALLER, F.: España, medio siglo de arte de vanguardia 1937-1985. Ed. El Viso, Madrid, 1985.

CATALA, M.: 100 años de pintura, escultura y grabado valenciano 1878-1978. Ed. Caja de ahorros de Valencia, Valencia, 1978.

CHAVARRI, R.: La pintura española actual. Ed. Ibérica Europea, Madrid, 1973.

CIRICI PELLICER, A.: El surrealismo, Ed. Omega SA. Barcelona, 1957. 
CIRICI PELLICER, A.: La estética del franquismo, Ed. Gustavo Gili SA. Barcelona, 1977.

COMBALÍA, V.: Amazonas con pincel. Vida y obra de las grandes artistas del siglo XVI al siglo XXI. Ed. destino SA. Barcelona, 2006.

DE BEAUVOIR, S.: El segundo sexo, traducido por Alicia Martorell. Ed. Ediciones Cátedra, Madrid, 1998. Título original: Le deuxième sexe. II. L'expérience vécue, Ed. Gallimard, s/d, 1949.

DE DIEGO, E.: La mujer y la pintura del XIX español. (Cuatrocientas olvidadas y algunas más) Ed. Cátedra SA, Madrid, 1987

DE LA CALLE, R. (Coordinador): El arte valenciano en la década de los ochenta. Ed. Asociación Valenciana de Críticos de Arte, Valencia, 1993.

DE MICHELE, M.: Las vanguardias artísticas del siglo XX. Traducido por Ángel Sánchez Gijón. Ed. Alianza Forma, Madrid, 1998. Título original: La avanguardie artistiche del Novecento. Ed. Giangiacomo Feltrinelli, Milán, 1966.

DONDIS D, A.: La sintaxis de la imagen. Introducción al alfabeto visual. Traducido por De Justo G. Beramendi. Ed. Gustavo Gili SA. Barcelona, 1985. Título original: A Primer of Visual Literacy, Ed. The Massachussets Institute of Technology, Massachussets, 1973.

ESTEVE BOTEY, F.: Historia del grabado, Ed. Clan, Madrid, 1993. 
ESTEVE, R.: Colección de grabados, Ed. Excmo Ayuntamiento de Valencia, Valencia, 1983.

FREUD, S.: Psicoanálisis del arte. Traducido por Luís López Ballesteros y de Torres. Ed. Alianza Editorial SA. Madrid, 1970. Título original: Eine Kindheitserinnerung aus Dichtung und Wahrheit, s/d.

GALLEGOS, A.: Historia del grabado en España. Ed. Cátedra SA. Madrid, 1979.

GANDIA CASIMIRO, J. (Coordinador): Estampa Popular. Ed. IVAM. Centre Julio González, Valencia, 1996.

GARAU, A.: Las armonías del color. Traducido por Rosa Premat. Ed. Paidós Ibérica SA. Barcelona, 1992. Título original: Le armonie del colore, Ed. Giangiacomo Feltrinelli. Milán, 1984.

GARCÍA FELGUERA, M.: El arte después de la guerra. Ed. Historia 16, Madrid, 2000.

GARCÍA, M.: Un siglo de arte valenciano. Ed. Excma Diputación Provincial de Valencia, valencia, 1965.

GOMBRICH E, H; El sentido del orden. Traducido por de Esteve Riambau i Saurí. Ed. Gustavo Gili SA, Barcelona, 1980. Título original: The Sense of Order, Ed. Phaidon Press, Oxford, 1979.

GRACIA, C.: Arte valenciano, Ed. Cátedra SA. Madrid, 1998. 
HERZOG, H. M.: EL expresionismo alemán. Traducido por Catalina Martínez, Julio Grande y Dwight Porter, Ed. Centro Atlántico de Arte Moderno. Las Palmas de Gran Canaria, 1995.

JULIÁN, I.: Historia del arte español. El siglo de los creadores. TOMO X. Ed. Planeta, Barcelona, 2002. Coordinador: Joan Sureda.

JUNG G, C.: El hombre y sus símbolos. Traducido por Luís Escolar Bareño, Ed. Paidós, Barcelona. 2002. Título original: Man and his simbols, Ed. Anchor Books, New York, 1964.

KANDINSKY, W.: Punto y línea sobre el plano. Traducido por Roberto Echavarren. Ed. Labor SA. Barcelona, 1993. Título original: Punkt und Linie zu Fläche. Ed. Verlag Albert Lancen. Munich, 1926.

KRIS, E.: Psicoanálisis del arte y del artista. Traducido por Floreal Mazia. Ed. Paidós. Buenos Aires (Argentina), 1964. Título original: Psychoanalytic explorations in art. Ed. Internacional Universities Press. 1955.

LAMBERT, R.: Introducción a la historia del arte. El siglo XX. Ed. Gustavo Gili SA, Barcelona, 1985. Título original: The Twentieth Century, Ed. Press Syndicate of the University of Cambridge, s/d, 1981.

LITA SÁEZ, F.: Métodos y Conceptos del Grabado Valenciano desde 1934 al 1982, en las Instituciones Valencianas; Diputación, Ayuntamiento y Bellas Artes. Tesis doctoral dirigida por; Manuel Silvestre Visa. Universidad Politécnica de Valencia, Valencia, 1989. 
LUCIE SMITH, E.: Movimientos artísticos desde 1945. Traducido por Hugo Mariano. Ed. Destino SA, Barcelona, 1995. Título original: Movements in Art Since 1945. Ed. Thames and Hudson Ltd, London, 1969.

MARÍN VIADEL, R.: El realismo social en la plástica valenciana, (1964 -1975). Ed. NAU Ilibres, Valencia, 1981.

MEANA, J. C.: El espacio entre las cosas, Ed. Diputación Provincial de Pontevedra, Segovia, 2001.

NOCHLIN, L.: El realismo. Traducido por José Antonio Suárez. Ed. Alianza Editorial, Madrid, 1991. Título original: Realism. Ed. Penguin, s/d, 1975.

PAEZ RIOS, E.: Repertorio de grabados españoles. Tomo II, Ed, Ministerio de Cultura, Madrid, 1993.

PARINI, P.: Los recorridos de la mirada. Traducido por María Jesús Fenero, Ed. Paidós Ibérica SA. Barcelona, 2002. Título original: Routes of sight, Ed. Artemisia, s/d, 1996.

PAWLIK, J.: Teoría del color. Traducido por Carlos Fortea. Ed. Paidós, Barcelona, 1996. Título original: Theorie der Farde, Ed. Inter Nationes, Bonn, 1969.

PUERTA, F.: Análisis de la forma. Fundamentos y aproximación al concepto. Ed. Universidad Politécnica de Valencia, Valencia, 2001. 
PUELLES R, L.: El desorden necesario. Filosofía del objeto surrealista. Ed. Universidad de Málaga, Málaga, 2002.

RAFFA, P.: Vanguardismo y realismo. Traducido por $\mathrm{R}$ de la Iglesia. Ed. Ediciones de Cultura popular SA. Barcelona, 1968. Título original: Avanguardia e realismo. Ed. Rizzoli, Milán (Italia), 1967.

RAMÍREZ, J.: Historia del arte. El mundo contemporáneo. TOMO IV. Ed. Alianza Editorial, Madrid, 1996.

ROMEU ALFARO, F.: Mujeres contra el franquismo. Ed. Intervención Cultural, Palma de Mallorca, 2002.

SCHNEIDER ADAMS, L.: Arte y psicoanálisis. Traducido por $\mathrm{M}^{\mathrm{a}}$ Luisa Rodríguez Tapia. Ed. Ediciones Cátedra SA, Madrid, 1996. Título original: Art and Psychoanálysis. Ed. Haper Collins Publishers, s/d.

SIMON, W.: El arte pop. Traducido por Marcelo Covián. Ed. Labor, Barcelona, 1983. Título original: The pop art, Ed. Thames and Hudson Ltd, Londres, 1974.

TOMÁS FERRÉ, J. L.: Recorridos Visuales, Ed. Universidad Politécnica de Valencia, Valencia, 1989.

TOMAS SANMARTÍN, A Y SILVESTRE, M.: Estampas y planchas de la Real Academia en el Museo de Bellas Artes de Valencia, Ed. Ministerio de Cultura, Madrid, 1982. 
VILLAFAÑE, J: Introducción a la teoría de la imagen, Ed. Pirámide, Madrid, 2000.

ZELANSKI, P y FISHER, M. P.: Efectos psicológicos del color. Traducido por Guillermo S, Alonso. Ed. Tursen-H Blume, Madrid, 2001. Título original: Color. Ed. Calmann \& King Ltd., Londres. 1989.

\section{BIBLIOGRAFÍA DE TÉCNICAS}

ALEGRE CREMADES, A.: El grabado, técnicas y su repercusión, Ed. Cátedra de eméritos de la Comunidad Valenciana, Valencia, 2006.

CORRADO MALTESE, (coordinador): Técnicas artísticas. Traducido por José Miguel Morán y María de los Santos García. Ed. Editorial Cátedra SA, Madrid, 2001, Título original: Le tecnique artistiche. Ed. Ugo Mursia Editore, Milano (Italia), 1973.

DAWSON, J.: Guía completa de grabado e impresión. Técnicas y materiales. Ed. Hermann Blume, Madrid, 1982.

HAYTER, S. W.: About Prints. S.W. Hayter. Ed. Oxford University Press, London, 1975.

MORENO RIVERO, T.: El color. Historia, teoría y aplicaciones. Ed. Ariel SA. Barcelona, 1996. 
PLA, J.: Técnicas del grabado calcográfico y su estampación, Ed. Omega SA, Barcelona, 1986.

RUBIO MARTINEZ, M.: Ayer y Hoy del grabado. Sistemas de estampación. Ed. Tarraco, Tarragona, 1979.

VIVES PIQUÉ, R.: Del cobre al papel. La imagen múltiple. Ed. Icaria SA, Barcelona, 1994.

\section{BIBLIOGRAFÍA ESPECÍFICA}

ARAZO, Ma Á.: "Pilar Dolz: La estrategia cromática." Las Provincias. Valencia. 02/06/1989, p. 34.

ARIAS SERRANO, L.: Tránsitos. Artistas españoles antes y después de la guerra civil, Ed. Fundación Caja de Madrid, Madrid, 1999.

BLAS, J y BARRENA, C.: I Trienal de Arte Gráfico: La estampa contemporánea, Ed. Obra Social y Cultural de Caja de Asturias, Oviedo-Asturias, 1995.

CARBONELL, Amparo. (Coordinador): Fons d'art contemporani de la Universitat Politècnica de València, Ed Universidad Politécnica de Valencia, Valencia, 1995.

CASALÉ, R.: "Pilar Dolz. El Gravat com a via immanent a la realitat". Zerovuittresquaranta. Revista d'informació, d'opinió i de cultura. Any 
10, No 107, Ed. Ayuntamiento de Vilassar de Mar, Barcelona, octubre 1999, p.12.

DE LA CALLE, R.: Pilar Dolz; aiguaforts, Galería Dávila-art, 30 de mayo, 1989.

DOLZ, P.: "Art ecològic a la comarca dels Ports". Mediterráneo Castellón de la Plana, 12/07/1983, s/p.

FERNÁNDEZ TOLEDO, T.: Pilar Dolz; grabados. Sala Goya, Casa de España, París (Francia) 24 de mayo al 11 de junio, 1984.

FUSTER, J.: María Pilar Dolz; exposició de gravat, Cercle mercantil i industrial, Castellón 16 al 30 marzo, 1972.

FUSTER, J.: Pilar Dolç. Sala municipal de exposiciones de Onda, Castellón, 4 al 18 de diciembre 1983.

GASCÓ, A.: "Exposición de grabados de Pilar Dolz, tras un nuevo aprendizaje" Mediterráneo, Castellón de la Plana. 05/06/1984, p.5.

GASCÓ, A.: "Pilar Dolz, una artista que ignora su leyenda". Levante. Valencia, 20/10/1995, p. 8

MIRA, J.: Ensenyar a mirar. Sala municipal Ferrés i Puig, Museu Monjo, Vilassar de Mar, 9 de junio a 1 julio, 1990.

MIRA, J.: Aiguaforts de Pilar Dolz, Ed. Centro Cultural d'Alcoi., Alicante, 1993. Coordinador: Jordi Botella. 
MONGE, M: "Pilar Dolz: de Castellón a Benidorm", La Verdad, Alicante, 10/07/1977, p.10.

OLIVER, L.: "Pilar Dolz", Mediterráneo, Castellón de la Plana, 10/06/1996, p.8

PERIS, S.: "Fiel a la multiplicidad" Mediterráneo, Castellón de la Plana, 23/12/1993, p.3.

PRATS RIVELLES, R.: "El grabado es apasionante" Levante, Valencia, 02/06/1989, p. 25

PUERTO, G.: "María Pilar Dolz, artista especializada en grabado que expone con gran éxito en el Círculo Mercantil", Mediterráneo, Castellón de la Plana, 19/03/1972, p.23

RAMBLA, W.: "Pilar Dolz, una gravadora del País Valencià, Reüll $n^{\circ}$ 7, Departament d'estètica. Universitat Literària de València, Valencia, 1984, pp. 8-9.

RAMBLA, W.: "Pilar Dolz: una dedicación constante al grabado", Formas Plásticas $n^{\circ} 32$, Universitat de València, Valencia, octubre de 1985 , pp. 8,9 y 10.

RIBERA, T.: María Pilar Dolz. Setmana d'art. Saló Quatre cantons, Ayuntamiento de Burriana, Castellón, 2 al 10 de febrero 1974. 
RIBERA, T.: Exposició de dibuixos: Pilar Dolz. Sala Municipal de Exposiciones de Onda, Castellón, 30 diciembre al 13 de enero, 1974.

RODRIGUEZ CULEBRA, J.: Artistas Castellonenses. Museo de Bellas Artes de Valencia, Valencia, mayo de 1982.

RODRÍGUEZ, C.: "Hayter, la retórica del grabado", El País, Madrid, 07/01/1984, p. 3.

RODES, V.: Pilar Dolz, Aguafuertes, Casa de Cultura de Villena, Alicante, 8 al 27 de noviembre, 1991.

RUBIO, V.: "Pilar Dolz: Rompiendo esquemas", Levante, Valencia, 06/10/1991, p.30.

SALCEDO MILIANI. A.: Actes de la XL Assemblea Intercomarcal d’Estudiosos, Morella. Ed. Diputación de Castellón, Castellón de la Plana, 2000.

SENABRE, C.: Pilar Dolz: Grabado, Institut Valencià de la Dona, Valencia, abril 1989.

TORRENT, R.: "La galería de arte Cànem una plataforma cultural", Mediterráneo, Castellón de la Plana, 02/08/1983, p.14.

TORRENT, R.: Pilar Dolz. Galería de Arte Mona, Alicante, 2 al 31 de agosto, 1991. 
TORRENT, R.: "Pilar Dolz" Mediterráneo, Castellón de la Plana. 20/10/1989, p.4.

\section{PÁGINAS WEB DE INTERÉS}

Página oficial del Ayuntamiento de Morella.

www.morella.net. (08/10/2005)

SAHAGÚN, F.: "Una revolución fallida que cambió la vida de generaciones".

www.elmundo.es/especiales/2008/04/internacional/mayo68/francia. $(28 / 06 / 2005)$

TORRES GARCIA, F.: "Los orígenes de la transición política española". www.arbil.org/(77)torr.htm, (06/12/2005)

TORRADO, A.: "1968: de la protesta a la resistencia". www.rebelion.org/noticia.php?id=68051. $(05 / 10 / 2006)$ 


\section{NDICE DE LÁMINAS}





\section{1. ÍNDICE DE LÁMINAS}

\subsection{DE FORMAS}

LÁMINA I $\quad$ (1970) "Sin título"........................ 147

LÁMINA II $\quad$ (1970) "Sin título"....................... 148

LÁMINA III $\quad$ (1970) "Sin título"......................... 149

LÁMINA IV $\quad$ (1972) “Sin título"....................... 150

LÁMINA V (1970) "Sin título"...................... 151

LÁMINA VI (1970) "Sin título"........................ 152

LÁMINA VII (1972) "Sin título"....................... 153

LÁMINA VIII $\quad$ (1971) "Sin título"....................... 154

LÁMINA IX (1972) "Sin título".......................... 155

LÁMINA X (1971) "Sin título"....................... 156 
LÁMINA XI (1970) “Sin título”..................... 157

LÁMINA XII (1970) “Yerma”......................... 158

\subsection{DE MUJERES}

\begin{tabular}{|c|c|c|}
\hline LÁMINA XIII & $(1971)$ & “Sin título $1 " . .$. \\
\hline LÁMINA XIV & $(1972)$ & "Sin título 5"... \\
\hline LÁMINA XV & (1971) & "Sin título"..... \\
\hline LÁMINA XVI & $(1972)$ & "Sec"... \\
\hline LÁMINA XVII & $(1972)$ & "Sin título 3".. \\
\hline LÁMINA XVIII & (1972) & "Sin título 6".. \\
\hline LÁMINA XIX & $(1972)$ & "Sin título 4".... \\
\hline LÁMINA XX & $(1972)$ & "Sin título"................... \\
\hline LÁMINA XXI & (1972) & "Fita"......... \\
\hline LÁMINA XXII & (1972) & "Sin título".. \\
\hline
\end{tabular}

\subsection{CORDES}

LÁMINA XXIII (1971) “Corda”.......................... 231

LÁMINA XXIV (1972) “Corda”............................ 232

LÁMINA XXV (1972) “Cordes”.......................... 233

LÁMINA XXVI (1971) "Sin título"........................... 234

LÁMINA XXVII (1972) "Sin título"........................... 235

\subsection{REIXES}

LÁMINA XXVIII (1972) "Sin título".......................... 269

LÁMINA XXIX (1972) "Sin título"......................... 270

LÁMINA XXX (1972) "Sin título".................................. 271

LÁMINA XXXI (1972) "Sin título".......................... 272 
LÁMINA XXXII (1972) "Sin título"....................... 273

LÁMINA XXXIII (1973) "Sin título".......................... 274

LÁMINA XXXIV (1973) "Sin título"......................... 275

LÁMINA XXXV (1973) "Sin título.......................... 276

LÁMINA XXXVI (1974) "Sin título"............................ 277

LÁMINA XXXVII (1974) "Sin título".......................... 278

LÁMINA XXXVIII (1974) “Poeta”............................ 279

LÁMINA XXXIX (1975) “Sin título".......................... 280

\subsection{OCELLS MORTS}

LÁMINA XL (1974) “Sin título"............................ 309

LÁMINA XLI (1974) “Sin título"................................ 310

LÁMINA XLII (1975) “Sin título”............................ 311

LÁMINA XLIII (1975) “Sin título"............................. 312

LÁMINA XLIV (1975) “Sin título"............................. 313

\subsection{INSECTES}

LÁMINA XLV (1976) “Sin título"........................... 345

LÁMINA XLVI (1976) “Sin título"........................... 346

LÁMINA XLVII (1977) “Sin título".......................... 347

LÁMINA XLVIII (1978) “Sin título”.......................... 348

LÁMINA XLIX (1978) “Sin título".......................... 349

LÁMINA L (1978) “Les pedres”....................... 350

\subsection{FINESTRE}

LÁMINA LI (1977) “Sin título"......................... 373

LÁMINA LII (1977) "Sin título".............................. 374 
LÁMINA LIII (1977) “Sin título"................................... 375

LÁMINA LIV (1977) "Sin título"........................... 376

LÁMINA LV (1977) “Sin título"............................ 377

\subsection{PEDRES I PAISATGES DELS PORTS}

LÁMINA LVI (1977) "Paisatge l"........................... 403

LÁMINA LVII (1977) "Paisatge II".............................. 404

LÁMINA LVIII (1978) "Pedres"............................... 405

LÁMINA LIX $\quad(1979)$ "Sin título".............................. 406

LÁMINA LX (1979) “Sin título"............................. 407

LÁMINA LXI (1980) "Aleres"................................ 408

\subsection{PARETS DE PEDRA SECA}

LÁMINA LXII (1978) “Una pedra”............................ 441

LÁMINA LXIII (1978) "Paret II".............................. 442

LÁMINA LXIV (1979) "Angle"............................. 443

LÁMINA LXV (1979) "Aleres I"............................. 444

LÁMINA LXVI (1979) “Aleres III".......................... 445

LÁMINA LXVII (1979) "Blat madur"........................ 446

LÁMINA LXVIII (1979) "Portera"............................ 447

LÁMINA LXIX (1979) "Maons"........................... 448

LÁMINA LXX (1979) “Mur l"............................ 449

LÁMINA LXXI (1979) “Mur II"........................... 450

LÁMINA LXXII (1979) "Molló".............................. 451

LÁMINA LXXIII (1980) "Sin título"............................. 452

LÁMINA LXXIV (1980) “Sin título"............................. 453

LÁMINA LXXV (1980) “Sin título"............................. 454 


\subsection{ESPAIS I PAISATGES}

LÁMINA LXXVI (1980) "Sin título"............................ 473

LÁMINA LXXVII (1981) "Sin título"........................... 474

LÁMINA LXXVIII (1982) "Sin título"........................ 475

LÁMINA LXXIX (1983) “Sin título".......................... 476

\section{11. HERBES}

LÁMINA LXXX (1983) “Herbes".............................. 523

LÁMINA LXXXI (1985) "Homenatge a Bonnard"............... 524

LÁMINA LXXXII (1985) “Homenatge a Bonnard II"............ 525

LÁMINA LXXXIII (1985) "Homenatge a Bonnard III"........... 526

LÁMINA LXXXIV (1990) "Paisatge XX"........................ 527

LÁMINA LXXXV (1990) “Branques VI”......................... 528

LÁMINA LXXXVI (1989) "Fulles XIV”......................... 529

LÁMINA LXXXVII (1998) “Tiges XXVI"....................... 530

LÁMINA LXXXVIII (1997) “Tiges XIX”........................ 531

LÁMINA LXXXIX (2000) "Paisatge LII"......................... 532

LÁMINA XC (1997) "Paisatge XL"...................... 533

LÁMINA XCI (1994) “Herbes LI"........................... 534

LÁMINA XCII (1989) “Herbes XXXVIII"..................... 535

LÁMINA XCIII (2001) "Paisatge XL"....................... 536

LÁMINA XCIV (1996) “Fulles XXXII"....................... 537

LÁMINA XCV (1991) “Herbes XLI"......................... 538 
PÉNDICE 



\section{CURRÍCULUM VITAE DE PILAR DOLZ}

\section{DATOS PERSONALES}

\begin{tabular}{|l|l|}
\hline 1945 & $\begin{array}{l}\text { Nace en Morella (provincia de Castellón) el 16 de abril } \\
\text { de } 1945 .\end{array}$ \\
\hline $1964-1968$ & $\begin{array}{l}\text { Estudios de dibujo y pintura en la Escola Massana de } \\
\text { Barcelona. }\end{array}$ \\
\hline $1965-1971$ & $\begin{array}{l}\text { Estudios de dibujo y pintura en la Escuela Superior de } \\
\text { Bellas Artes de San Jorge de Barcelona. }\end{array}$ \\
\hline $1970-1073$ & $\begin{array}{l}\text { Estudios de grabado en la Escola d'Arts i Oficis de } \\
\text { Barcelona. Secció Arts del Llibre. }\end{array}$ \\
\hline
\end{tabular}




\begin{tabular}{|l|l|}
\hline 1973-1979 & $\begin{array}{l}\text { Estudios de grabado, litografía y xilografía en el Istituto } \\
\text { Statale d'Arte y en la Accademia Raffaello de Urbino } \\
\text { (Italia). }\end{array}$ \\
\hline $1983-1985$ & Atelier 17 con S. W. Hayter y Atelier de Goetz de París.
\end{tabular}

\section{EXPOSICIONES INDIVIDUALES}

\begin{tabular}{|c|c|c|}
\hline 1972 & $\begin{array}{l}\text { Castellón de la Plana } \\
\text { (Castellón) }\end{array}$ & Círculo mercantil. \\
\hline 1973 & Tarragona & Galería Fort \\
\hline 1974 & Onda (Castellón) & Sala municipal de exposiciones. \\
\hline \multirow[t]{2}{*}{1975} & Tarragona & Llibrería de la rambla. \\
\hline & Vilarreal (Castellón) & Biblioteca pública municipal \\
\hline 1977 & Benidorm (Alicante) & $\begin{array}{l}\text { Biblioteca municipal Gregorio } \\
\text { Marañón. }\end{array}$ \\
\hline 1978 & Valencia & Galería l'Eixam \\
\hline \multirow[t]{5}{*}{1981} & Castellón de la Plana & Galería Cànem \\
\hline & Vinarós (Castellón) & Galería Babel \\
\hline & Alcoy (Alicante) & Galería Canigó \\
\hline & Altea (Alicante) & Galería Lanuza \\
\hline & Torrente (Valencia) & Torre I. Sala municipal. \\
\hline
\end{tabular}




\begin{tabular}{|c|c|c|}
\hline \multirow[t]{2}{*}{1983} & Onda (Castellón) & Sala municipal de exposiciones. \\
\hline & Urbino (Italia) & $\begin{array}{l}\text { Círcolo ARCI / Centro Culturale } \\
\text { A.Masolo / I'Universita degli Studi } \\
\text { d'Urbino. }\end{array}$ \\
\hline 1984 & París (Francia) & Sala Goya. Casa de España \\
\hline 1986 & Kioto (Japón) & Galería Tadasu \\
\hline 1989 & Valencia & Galería Dávila-Art \\
\hline \multirow[t]{2}{*}{1990} & $\begin{array}{l}\text { Vilassar de Mar } \\
\text { (Barcelona) }\end{array}$ & $\begin{array}{l}\text { Sala municipal Ferrés i Puig. } \\
\text { Museu Monjo. }\end{array}$ \\
\hline & Ginebra (Suiza) & $\begin{array}{l}\text { Conservatoire et Jardin botanique. } \\
\text { Villa "Le Chêne" }\end{array}$ \\
\hline \multirow[t]{2}{*}{1991} & Denia (Alicante) & Galería Mona \\
\hline & Villena (Alicante) & Casa de la cultura. \\
\hline \multirow[t]{2}{*}{1992} & Brescia (Italia) & La Bottega delle Stampe. \\
\hline & Alicante & Sala municipal de exposiciones. \\
\hline \multirow[t]{2}{*}{1993} & Alcoy (Alicante) & Centre cultural de Alcoy \\
\hline & Milán (Italia) & Palazzo Sormani \\
\hline \multirow[t]{3}{*}{1994} & Zaragoza & Galería Odeón \\
\hline & Tortosa (Tarragona) & Museu de l'Ebre \\
\hline & Morella (Castellón) & Fundació Caixa Castelló \\
\hline
\end{tabular}




\begin{tabular}{|l|l|l|}
\hline 1996 & $\begin{array}{l}\text { Horta de Sant Joan } \\
\text { (Tarragona) }\end{array}$ & $\begin{array}{l}\text { Espais Picassians, Mas de } \\
\text { Quiquet. }\end{array}$ \\
\hline 1997 & $\begin{array}{l}\text { La Vall d'Uixó } \\
\text { (Castellón) }\end{array}$ & Fundación Bancaja \\
\hline 1999 & $\begin{array}{l}\text { Vilassar de Mar } \\
\text { (Barcelona) }\end{array}$ & Sala Ferrés i Puig. Museu Monjo. \\
\hline 2001 & Valencia & Galeriacuatro. \\
\hline
\end{tabular}

\section{EXPOSICIONES COLECTIVAS}

\begin{tabular}{|l|l|l|}
\hline 1972 & Onda (Castellón) & $\begin{array}{l}\text { "Arte Castellonense", Sala } \\
\text { municipal. }\end{array}$ \\
\hline 1974 & $\begin{array}{l}\text { Castellón de la Plana } \\
\text { (Castellón) }\end{array}$ & $\begin{array}{l}\text { "10 Centenario del } \\
\text { Impresionismo". } \\
\text { Ateneo municipal. }\end{array}$ \\
\hline 1975 & $\begin{array}{l}\text { Castellón de la Plana } \\
\text { (Castellón) }\end{array}$ & $\begin{array}{l}\text { "Obra Gráfica Original". Galería } \\
\text { Cànem. }\end{array}$ \\
\hline 1976 & Kettwing (Alemania) & $\begin{array}{l}\text { "Junge Spanische Grafik", } \\
\text { Galería in der Wilhemstrasse. }\end{array}$ \\
\hline 1977 & $\begin{array}{l}\text { Castellón de la Plana } \\
\text { (Castellón) }\end{array}$ & $\begin{array}{l}\text { "Dibuixos i gravats en l'art actual } \\
\text { de Castelló". Ateneo municipal }\end{array}$ \\
\cline { 2 - 4 } & Valencia & $\begin{array}{l}\text { "Art Seriat del País Valencià", } \\
\text { Galería l'Eixam }\end{array}$ \\
\hline
\end{tabular}




\begin{tabular}{|c|c|c|}
\hline \multirow[t]{3}{*}{1978} & Almassora (Castellón) & $\begin{array}{l}\text { "Quatre artistes nostres", Saleta } \\
\text { Quatre. }\end{array}$ \\
\hline & Ibiza & $\begin{array}{l}\text { "VII Bienal de Ibiza" Ibizagrafic- } \\
\text { 78. Museo de Arte } \\
\text { Contemporáneo. }\end{array}$ \\
\hline & Castellón & $\begin{array}{l}\text { "Grans Obres de Petit Format”, } \\
\text { Galería Cànem. }\end{array}$ \\
\hline \multirow[t]{3}{*}{1979} & Provence (Francia) & $\begin{array}{l}\text { "Cinq artistes espagnols et quatre } \\
\text { artistes polonaises" Office } \\
\text { municipal de tourisme. Galería } \\
\text { Sigbrit/ M. Sten Sarborn. }\end{array}$ \\
\hline & Paris (Francia) & $\begin{array}{l}\text { "Hombres y tierras de España”, } \\
\text { Sala Goya. Casa de España }\end{array}$ \\
\hline & $\begin{array}{l}\text { Itinerante por el País } \\
\text { Valencià. }\end{array}$ & $\begin{array}{l}\text { “57 artistes i un País”, Galería } \\
\text { l'Eixam y Exmo. Ayuntamiento de } \\
\text { Valencia. }\end{array}$ \\
\hline \multirow[t]{3}{*}{1980} & Castellón & $\begin{array}{l}\text { "80 años de arte castellonense", } \\
\text { Museo municipal de Bellas Artes. }\end{array}$ \\
\hline & Vinarós & $\begin{array}{l}\text { "Art Gràfic al País Valencià", } \\
\text { Galería Babel. }\end{array}$ \\
\hline & Ibiza & $\begin{array}{l}\text { “IX Bienal de Ibiza. Ibizagrafic- } \\
80 ”, \text { Museo de Arte } \\
\text { Contemporáneo. }\end{array}$ \\
\hline
\end{tabular}




\begin{tabular}{|c|c|c|}
\hline \multirow[t]{4}{*}{1981} & $\begin{array}{l}\text { Castellón de la Plana } \\
\text { (Castellón) }\end{array}$ & $\begin{array}{l}\text { "Deu dones artistes". Museo de } \\
\text { Bellas Artes }\end{array}$ \\
\hline & Alcoy (Alicante) & $\begin{array}{l}\text { "Mostra Cultural del País } \\
\text { Valencià" Ayuntamiento de Alcoy }\end{array}$ \\
\hline & Gandía (Valencia) & $\begin{array}{l}\text { "Obra gráfica original", Galería } \\
\text { Charpa. }\end{array}$ \\
\hline & Girona & $\begin{array}{l}\text { "Obra Gráfica Internacional”, } \\
\text { Galería } 3 \text { i } 5 .\end{array}$ \\
\hline 1982 & Valencia & $\begin{array}{l}\text { "Artistas castellonenses I", Museo } \\
\text { de Bellas Artes de Valencia. }\end{array}$ \\
\hline \multirow[t]{2}{*}{1984} & Bradford (Inglaterra) & $\begin{array}{l}\text { "Print Biennale eighth British } \\
\text { Internacional". Cartwright Hall, } \\
\text { Lister park, Bradford. }\end{array}$ \\
\hline & Sjöbo (Suecia) & $\begin{array}{l}\text { “Internacional Grafik Hayter } \\
\text { eleven”, Galería Maria och Birger } \\
\text { Halden. }\end{array}$ \\
\hline \multirow[t]{3}{*}{1985} & Lodz (Polonia) & $\begin{array}{l}\text { "Mate Formy Grafiki”, Galería } \\
\text { Szutuki BWA. }\end{array}$ \\
\hline & $\begin{array}{l}\text { Castellón de la Plana } \\
\text { (Castellón) }\end{array}$ & $\begin{array}{l}\text { "Grans Obres de Petit Format". } \\
\text { Galería Cànem. }\end{array}$ \\
\hline & Segorbe (Castellón) & $\begin{array}{l}\text { "IV Centenario de la Cartuja de } \\
\text { Val de Christo". Biblioteca } \\
\text { municipal. }\end{array}$ \\
\hline
\end{tabular}




\begin{tabular}{|c|c|c|}
\hline \multirow[t]{6}{*}{1986} & Valencia & $\begin{array}{l}\text { "Plástica Valenciana } \\
\text { Contemporánea". Palacio de la } \\
\text { Lonja }\end{array}$ \\
\hline & $\begin{array}{l}\text { Castellón de la Plana } \\
\text { (Castellón) }\end{array}$ & $\begin{array}{l}\text { "Plástica Valenciana } \\
\text { Contemporánea". Palau de la } \\
\text { Diputació }\end{array}$ \\
\hline & $\begin{array}{l}\text { Castellón de la Plana } \\
\text { (Castellón) }\end{array}$ & $\begin{array}{l}\text { "Al voltant de l'Atelier 17”, Galería } \\
\text { Cànem }\end{array}$ \\
\hline & $\begin{array}{l}\text { Castellón de la Plana } \\
\text { (Castellón) }\end{array}$ & "Per la pau", Galería Pictograma \\
\hline & Denia (Alicante) & "Obra Gráfica", Galería Mona \\
\hline & Barcelona & $\begin{array}{l}\text { "Signs of Summer" Galería Vicent } \\
\text { Bernat }\end{array}$ \\
\hline \multirow[t]{2}{*}{1987} & Almassora (Castellón) & $\begin{array}{l}\text { "Gráfica Internacional", Sala } \\
\text { municipal. }\end{array}$ \\
\hline & Barcelona & $\begin{array}{l}\text { "Obra gráfica", Galería Vicent } \\
\text { Bernat }\end{array}$ \\
\hline 1988 & Madrid & $\begin{array}{l}\text { "La Estampa Contemporánea en } \\
\text { España". Centro Cultural Conde } \\
\text { Duque. }\end{array}$ \\
\hline 1989 & $\begin{array}{l}\text { Castellón de la Plana } \\
\text { (Castellón) }\end{array}$ & $\begin{array}{l}\text { "Tres Dones" Institut valencià de } \\
\text { la Dona. }\end{array}$ \\
\hline 1990 & Valencia & "Feria Interarte", Galería Mona \\
\hline
\end{tabular}




\begin{tabular}{|c|c|c|}
\hline & Valencia & $\begin{array}{l}\text { "Col.lectiva de Gráfica", Galería } \\
\text { Viciana }\end{array}$ \\
\hline 1991 & Denia (Alicante) & Galería Mona \\
\hline 1992 & $\begin{array}{l}\text { Exposición itinerante; } \\
\text { Elche, Alicante y } \\
\text { Valencia }\end{array}$ & $\begin{array}{l}\text { "Miguel Hernández } 50 \text { x 50". } \\
\text { Sala de Exposiciones de la CAM, } \\
\text { (Alicante). Museu d'Art } \\
\text { Contemporani (Elche). Casa de } \\
\text { Cultura (Alcoi). Casa de Cultura } \\
\text { (Villena) }\end{array}$ \\
\hline 1993 & $\begin{array}{l}\text { Castellón de la Plana } \\
\text { (Castellón) }\end{array}$ & "Ara i Abans", Galería Cànem \\
\hline 1994 & $\begin{array}{l}\text { Castellón de la Plana } \\
\text { (Castellón) }\end{array}$ & $\begin{array}{l}\text { "Sota Marbre Blau", Institut } \\
\text { Valencià de la Dona. }\end{array}$ \\
\hline 1995 & Gijón (Asturias) & $\begin{array}{l}\text { "I Trienal de Arte Gráfico", } \\
\text { Palacio de Revillagigedo. }\end{array}$ \\
\hline 1996 & Madrid & $\begin{array}{l}\text { "Estampa 96”, Stand Galería } \\
\text { Cànem. }\end{array}$ \\
\hline \multirow[t]{3}{*}{1997} & Zaragoza & $\begin{array}{l}\text { "Memorial Book". Edificio } \\
\text { Pignatelli }\end{array}$ \\
\hline & Madrid & $\begin{array}{l}\text { “Estampa 97”, Stand Galería } \\
\text { Cànem }\end{array}$ \\
\hline & Valencia & $\begin{array}{l}\text { "Huellas. Grabadores de fin de } \\
\text { siglo", Sala de exposiciones de } \\
\text { lbercaja. }\end{array}$ \\
\hline
\end{tabular}




\begin{tabular}{|c|c|c|}
\hline \multirow[t]{3}{*}{1998} & Terrassa (Barcelona) & $\begin{array}{l}\text { "Memorial Book", Centro cultural } \\
\text { Caixa de Terrassa }\end{array}$ \\
\hline & Madrid & $\begin{array}{l}\text { “Estampa 98”, Stand Galería } \\
\text { Cànem. }\end{array}$ \\
\hline & Gijón (Asturias) & $\begin{array}{l}\text { "Il Trienal Arte Gráfico". Centro } \\
\text { de Arte de Revillagigedo. }\end{array}$ \\
\hline \multirow[t]{7}{*}{1999} & Valencia & "Deu Gravadors", Galería Viciana \\
\hline & Tortosa (Tarragona) & $\begin{array}{l}\text { “Llibres d’Artista, Escola d’Arts } \\
\text { Aplicades de la Diputació de } \\
\text { Tarragona }\end{array}$ \\
\hline & Tortosa & $\begin{array}{l}\text { "Brossarada; Homenatge Joan } \\
\text { Brossa. Museu de l’Ebre. }\end{array}$ \\
\hline & Amposta (Tarragona) & $\begin{array}{l}\text { "Brossarada", Biblioteca comarcal } \\
\text { Sebastiá J. Arbó. }\end{array}$ \\
\hline & Madrid & $\begin{array}{l}\text { "Estampa 99", Stand Galería } \\
\text { Cànem. }\end{array}$ \\
\hline & Valencia & $\begin{array}{l}\text { "Páginas singulares". Sala Josep } \\
\text { Renau. Universidad Politécnica } \\
\text { de Valencia. }\end{array}$ \\
\hline & Alicante & $\begin{array}{l}\text { "La memoria que nos une", } \\
\text { Museo de la Universidad }\end{array}$ \\
\hline 2000 & Madrid & $\begin{array}{l}\text { “Estampa 00”, Stand Galería } \\
\text { Cànem. }\end{array}$ \\
\hline
\end{tabular}




\begin{tabular}{|c|c|c|}
\hline \multirow[t]{2}{*}{2001} & Madrid & $\begin{array}{l}\text { "Estampa 01". Stand Galería } \\
\text { Cànem. }\end{array}$ \\
\hline & Gijón (Asturias) & $\begin{array}{l}\text { "III Trienal Arte Gráfico", Centro } \\
\text { de Arte de Revillagigedo. }\end{array}$ \\
\hline \multirow[t]{2}{*}{2002} & Valencia & $\begin{array}{l}\text { "Distintas miradas, miradas } \\
\text { distintas", Museo de Bellas Artes } \\
\text { de Valencia. }\end{array}$ \\
\hline & Madrid & $\begin{array}{l}\text { "Estampa 02". Stand Galería } \\
\text { Cànem. }\end{array}$ \\
\hline \multirow[t]{2}{*}{2003} & Madrid & $\begin{array}{l}\text { “Estampa 03”. Stand Galería } \\
\text { Cànem. }\end{array}$ \\
\hline & $\begin{array}{l}\text { Città di Campobasso } \\
\text { (Italia) }\end{array}$ & "III Biennale dell'Incisione". \\
\hline
\end{tabular}

\section{MUSEOS Y COLECCIONES OFICIALES CON OBRA DE PILAR DOLZ}

Museo de Bellas Artes San Pio V, Valencia

Centro de Gráfica e di Documentacione, C. de San. Bernanrdino.

Urbino (Italia)

Exmo. Ayuntamiento de Castellón de la Plana (Castellón)

Diputación Provincial de Castellón de la Plana (Castellón)

Exmo. Ayuntamiento de Alicante 
Ayuntamiento de Villena (Alicante)

Biblioteca Nacional de España, Madrid

Biblioteca Sormani, Milán (Italia)

Artilibre, Madrid

Fundación Bancaja. Castellón de la Plana (Castellón)

Biblioteca de Cataluña, Barcelona

Institut d'Estudis Catala, Barcelona 
2. ACTIVIDAD DE LA GALERÍA CÀNEM EN LOS ÚLTIMOS 10 AÑos.

\begin{tabular}{|c|c|c|}
\hline \multirow[t]{2}{*}{$1999-2000$} & \multicolumn{2}{|l|}{ EXPOSICIONES } \\
\hline & Artistas & Técnica \\
\hline & $\begin{array}{l}\text { BERNHARD G, LEHMANN. } \\
\text { ANTONI GIRBES. } \\
\text { CARME VIDAL. } \\
\text { PEPE CERDA. } \\
\text { RAFAEL G, BIANCHI. } \\
\text { AMPARO DOLS. } \\
\text { SABEL TRISTAN. }\end{array}$ & $\begin{array}{l}\text { Escultura } \\
\text { Fotografía } \\
\text { Pintura y dibujo. } \\
\text { Pintura y dibujo. } \\
\text { Instalación y } \\
\text { fotografía. } \\
\text { Pintura } \\
\text { Pintura }\end{array}$ \\
\hline & \multicolumn{2}{|l|}{ PARTICIPACIÓN EN FERIAS } \\
\hline & Feria & Lugar \\
\hline & $\begin{array}{l}\text { ESTAMPA'99. 05/11/1999 } \\
\text { NEW-ART BARCELONA'99 } \\
\text { ARCO'00 } \\
\text { ART A L'HOTEL }\end{array}$ & $\begin{array}{l}\text { Madrid } \\
\text { Barcelona } \\
\text { Madrid } \\
\text { Valencia }\end{array}$ \\
\hline
\end{tabular}

\section{0-2001 EXPOSICIONES}

Artistas

Técnica 


\begin{tabular}{|c|c|}
\hline $\begin{array}{l}\text { HANS DIETER ZINGRAF } \\
\text { ROSA FUENTES } \\
\text { CHEMA ALVARGONZÁLEZ } \\
\text { ADRIÀ PINA } \\
\text { JOSE MANUEL VELA } \\
\text { ANTONIO ALCARAZ } \\
\text { COLECTIVA: "Colección para } \\
\text { una oficina” }\end{array}$ & $\begin{array}{l}\text { Pintura } \\
\text { Pintura } \\
\text { Fotografía } \\
\text { Pintura } \\
\text { Pintura } \\
\text { Pintura y obra gráfica } \\
\text { Colaboración Galería } \\
\text { CAVE CANEM de } \\
\text { Sevilla. }\end{array}$ \\
\hline \multicolumn{2}{|l|}{ PARTICIPACIÓN EN FERIAS } \\
\hline Feria & Lugar \\
\hline $\begin{array}{l}\text { ESTAMPA'00 } \\
\text { NEW-ART BARCELONA'00 } \\
\text { ARCO'01 } \\
\text { ART A L'HOTEL'01 } \\
\text { ART MIAMI'01 }\end{array}$ & $\begin{array}{l}\text { Madrid } \\
\text { Barcelona } \\
\text { Madrid } \\
\text { Valencia } \\
\text { Miami (EEUU) }\end{array}$ \\
\hline
\end{tabular}

\section{1-2002 EXPOSICIONES}

\begin{tabular}{|l|l|}
\hline Artistas & Técnica \\
\hline $\begin{array}{l}\text { ROSSANA ZAERA } \\
\text { JORDI ALCARAZ } \\
\text { ISIDRE MANILS }\end{array}$ & Dibujo \\
COLECTIVA: "Joves" & Poemas visuales \\
& Pintura \\
& (Colaboración con la \\
& Galería Ferran Cano) \\
\hline
\end{tabular}




\begin{tabular}{|l|l|l|}
\hline $\begin{array}{l}\text { MAVI ESCAMILLA } \\
\text { CARME BALLESTER }\end{array}$ & $\begin{array}{l}\text { Pintura } \\
\text { Cerámica }\end{array}$ \\
\hline \multicolumn{2}{|l|}{ PARTICIPACIÓN EN FERIAS } & \\
\hline Feria & Lugar \\
\hline $\begin{array}{l}\text { ESTAMPA'01. } \\
\text { NEW-ART BARCELONA' 01. } \\
\text { ARCO'02. } \\
\text { ART MIAMI'02. }\end{array}$ & $\begin{array}{l}\text { Madrid } \\
\text { Barcelona } \\
\text { Madrid } \\
\text { Miami (EEUU) }\end{array}$ \\
\hline
\end{tabular}

\section{2-2003 EXPOSICIONES}

\begin{tabular}{|l|l|l|}
\hline Artistas & Técnica \\
\hline $\begin{array}{l}\text { LAURA AMBROSI, Irina } \\
\text { Novarese y Luisa Raffaelli. } \\
\text { “Mínima e marginalia” } \\
\text { FRANCISCO BERDONCES. } \\
\text { “La disolución del Narciso" } \\
\text { JOAQUIM CHANCHO. }\end{array}$ & s/d \\
$\begin{array}{l}\text { EUROPA VIDEO-ARTE: } \\
\text { “Jornadas de Video-Arte y Video } \\
\text { de Artista” (con Asociación } \\
\text { cultural Darko's Store de Modena } \\
\text { y Galería Digit de Weimar y } \\
\text { Cultura 2000). } \\
\text { PERLA FLORS: "Nacional 340 } \\
\text { Km.-A5" }\end{array}$ & $\begin{array}{l}\text { Pintura } \\
\text { Instalaciones }\end{array}$ \\
\hline
\end{tabular}




\begin{tabular}{|c|c|}
\hline $\begin{array}{l}\text { MIQUEL GOZALBO } \\
\text { ESTUDI BLANC. "La Ilum" } \\
\text { REGINA GIMENEZ. } \\
\text { "Tus ojos son ventanas } \\
\text { ENRIQUE LARROY. } \\
\text { "Juegos artificiales" }\end{array}$ & $\begin{array}{l}\text { Escultura en hierro } \\
\text { Escultura lumínica } \\
\text { Pintura y fotografía. } \\
\text { Pintura }\end{array}$ \\
\hline \multicolumn{2}{|l|}{ PARTICIPACIÓN EN FERIAS } \\
\hline Feria & Lugar \\
\hline $\begin{array}{l}\text { ESTAMPA'02 } \\
\text { NEW-ART' BARCELONA' } 02 \\
\text { ART-MIAMI'03 } \\
\text { ARCO'03 }\end{array}$ & $\begin{array}{l}\text { Madrid } \\
\text { Barcelona } \\
\text { Miami (EEUU) } \\
\text { Madrid }\end{array}$ \\
\hline
\end{tabular}

2003-2004 EXPOSICIONES

\begin{tabular}{|c|c|}
\hline Artistas & Técnica \\
\hline $\begin{array}{l}\text { GINO RUBERT: “Deliris } \\
\text { Col.laterals" } \\
\text { LLUIS VIVES: “Estiu a l'hivern" } \\
\text { MANUEL REY FUEYO } \\
\text { MARIO PASQUALOTTO } \\
\text { PEPEBEAS: "Eremitas" } \\
\text { XIMO AMIGÓ: “Ullar" } \\
\text { BARTOMEU FERRANDO: "Crits } \\
\text { es Crits" }\end{array}$ & $\begin{array}{l}\text { Pintura } \\
\text { Fotografía } \\
\text { Pintura } \\
\text { Pintura y escultura. } \\
\text { Video-instalación } \\
\text { Pintura } \\
\text { Poesía visual y } \\
\text { Performances }\end{array}$ \\
\hline
\end{tabular}




\begin{tabular}{|l|l|l|}
\hline \multicolumn{2}{|l|}{ PARTICIPACIÓN EN FERIAS } & \multicolumn{2}{|l|}{ Lugar } \\
\hline \multicolumn{1}{|l|}{ Feria } & Barcelona \\
\hline $\begin{array}{l}\text { LOOP'03. } \\
\text { Con Pepebeas: “Las tablas de la } \\
\text { ley” } \\
\text { ART MIAMI'04. } \\
\text { Con: Mar Arza, Joel Mestre, } \\
\text { Yuyo Minami y Héctor Sos. } \\
\text { ARCO'04 } \\
\text { Con: Mar Arza, Pilar Beltrán, } \\
\text { Miquel Gozalbo, Enrique Larroy, } \\
\text { Isidre Manils, Manel Margalef, } \\
\text { Irina Novarese, Manuel Rey } \\
\text { Fueyo y Hans Dieter Zingraff. }\end{array}$ & Miami (EEUU) \\
\hline
\end{tabular}

\section{4-2005 EXPOSICIONES}

\begin{tabular}{|l|l|l|}
\hline Artistas & Técnica \\
\hline $\begin{array}{l}\text { MARIA ZARRAGA: “Workshops" } \\
\text { MAR ARZA: "de lo precario, } \\
\text { eterno, humano...” } \\
\text { RAMÓN ROIG. } \\
\text { COLECTIVA: "Rostres". } \\
\begin{array}{l}\text { Con: Pepe Agost, Rafael } \\
\text { Armengol, Lidón Artero, } \\
\text { Yotta Kippe... }\end{array}\end{array}$ & Pintura \\
\end{tabular}




\begin{tabular}{|c|c|}
\hline $\begin{array}{l}\text { JOSEP UCLÉS } \\
\text { CONCHA GARCIA. } \\
\text { ANNA OLIVILLA. } \\
\text { LUIGI MULAS DEBOIS: } \\
\text { "Containers of contents" }\end{array}$ & $\begin{array}{l}\text { Pintura y escultura } \\
\text { s/d } \\
\text { s/d } \\
\text { s/d }\end{array}$ \\
\hline \multicolumn{2}{|l|}{ PARTICIPACIÓN EN FERIAS } \\
\hline Feria & Lugar \\
\hline $\begin{array}{l}\text { LOOP’04. } \\
\text { Con: Maria Zarraga y Alex } \\
\text { Campoy. } \\
\text { ART-MIAMI’05. } \\
\text { Con: Mar Arza, Pepebeas, Pilar } \\
\text { Beltrán, Enrique Larroy, Joel } \\
\text { Mestre, Manuel Rey Fueyo, } \\
\text { Ramón Roig y Héctor Sos. } \\
\text { ARCO'05. } \\
\text { Con: Antonio Alcaraz, Mar Arza, } \\
\text { Pilar Beltrán, Miquel Gozalbo, } \\
\text { Manel Margalef, Irina Novarese, } \\
\text { Mario Pasqualotto, Pepebeas, } \\
\text { Manuel Rey Fueyo, Ramón Roig, } \\
\text { Josep Uclés, Lluis Vives y Hans } \\
\text { Dieter Zingraff. }\end{array}$ & $\begin{array}{l}\text { Barcelona } \\
\text { Miami (EEUU) }\end{array}$ \\
\hline
\end{tabular}




\begin{tabular}{|l|l|l|}
\hline $\begin{array}{l}\text { ARTE SANTANDER'05. } \\
\text { Con: Mar Arza, Pilar Beltrán, } \\
\text { Vicent Carda, Manel Margalef, } \\
\text { Pepebeas, Alfred Porres, Ramón } \\
\text { Roig, Josep Uclés y María } \\
\text { Zárraga. }\end{array}$ & Santander \\
\hline Celebración 30 aniversario de Galería Cànem. 21/12/2004. \\
\hline
\end{tabular}

\section{5-2006 EXPOSICIONES}

\begin{tabular}{|c|c|}
\hline Artistas & Técnica \\
\hline $\begin{array}{l}\text { TOMAS MIÑAMBRES } \\
\text { COLECTIVA: “Made in U.K.” } \\
\text { Con: Mar Arza, Pilar Beltrán, } \\
\text { Benedict Carpenter, John } \\
\text { Gibbons, Natuka Honrubia, } \\
\text { Cecilia Mandrile y Yugo Minami. } \\
\text { ENCARNA SEPÚLVEDA: } \\
\text { "Retazos" } \\
\text { MANUEL VELASCO. } \\
\text { YOTTA KIPPE: "Yottak!” } \\
\text { ARANCHA GOYENECHE: "El } \\
\text { gran ilusionista” } \\
\text { COLECTIVA: Es mou, et mou” } \\
\text { con: Alex Campoy, Regina Jose, } \\
\text { Galindo, Alfred Porres, } \\
\text { Pepebeas, Zev Robinson. }\end{array}$ & $\begin{array}{l}\text { Pintura } \\
\text { Pintura } \\
\text { Fotografía } \\
\text { Sin datos } \\
\text { Video instalaciones, } \\
\text { video performances, } \\
\text { video esculturas y } \\
\text { video proyecciones. }\end{array}$ \\
\hline
\end{tabular}




\begin{tabular}{|l|l|l|}
\hline \multicolumn{2}{|l|}{ PARTICIPACIÓN EN FERIAS } & Lugar \\
\hline Feria & Santander \\
\hline $\begin{array}{l}\text { ARTE SANTANDER'05. } \\
\text { Con: Mar Arza, Pilar Beltrán, } \\
\text { Vicent Carda, Manel } \\
\text { Margalef, Pepebeas, Alfred Porres } \\
\text { Ramón Roig, Josep Uclés y María }\end{array}$ & \\
$\begin{array}{l}\text { Zárraga. } \\
\text { VALENCIA ART' 05. } \\
\text { Con: Natuka Honrubia y } \\
\text { Yugo Minami. } \\
\text { LOOP '05. } \\
\text { Con: Alfred Porres. } \\
\begin{array}{l}\text { ARCO'06. } \\
\text { Con: Mar Arza, Pilar Beltrán, } \\
\text { Benedict Carpenter, Natuka } \\
\text { Honrubia, John Gibbons, Miquel } \\
\text { Gozalbo, Manel Margalef, Isidre } \\
\text { Manils, Pepebeas, Ramón Roig, } \\
\text { Lluis Vives. } \\
\text { LOOP '06. } \\
\text { Con: Zev Robinson }\end{array}\end{array}$ & Valencia \\
\hline
\end{tabular}

\section{6-2007 EXPOSICIONES}

Artistas

Técnica 


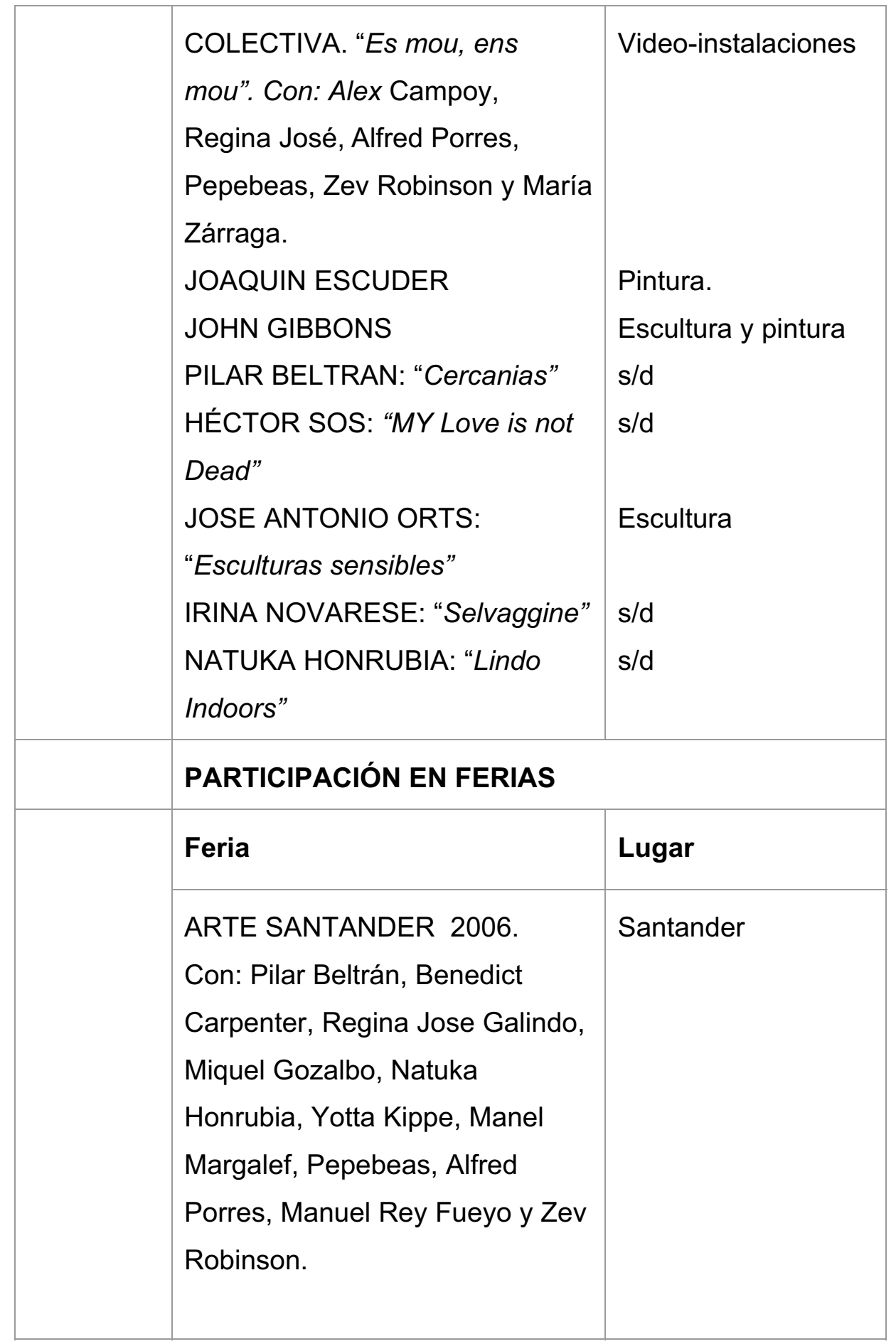




\begin{tabular}{|l|l|l|}
\hline VALENCIA ART 2006. & Valencia \\
Con: Mar Arza y Pilar Beltrán. & \\
VENICE VIDEOART FAIR 2006 & Venecia \\
Con: Alfred Porres y Zev & \\
Robinson. & Madrid \\
ARCO 2007. & Con: Pilar Beltrán, Vicent Cardà, & \\
Jonh Gibbons, Miquel Gozalbo, & \\
Natuka Honrubia, Yotta Kippe, & \\
Isidre Manils, Manel Margalef, \\
Yugo Minami, Irina Novarese, \\
Alfred Porres, Manuel Rey \\
$\begin{array}{l}\text { Fueyo, Zev Rovinson y Rossana } \\
\text { Zaera. } \\
\text { LOOP'07. } \\
\text { Con: Alex Campoy }\end{array}$ \\
\hline
\end{tabular}

\section{7-2008 EXPOSICIONES}

\begin{tabular}{|l|l|l|}
\hline Artistas & Técnica \\
\cline { 2 - 3 } & $\begin{array}{l}\text { NATUKA HONRUBIA: “Lindo } \\
\text { Indoors" } \\
\text { JOSE RAMÓN BAS: “Icaro y } \\
\text { Mukalo" } \\
\text { MANEL MARGALEF: } \\
\text { "Deconstruint" }\end{array}$ & $\mathrm{s} / \mathrm{d}$ \\
& $\mathrm{s} / \mathrm{d}$ \\
\hline
\end{tabular}




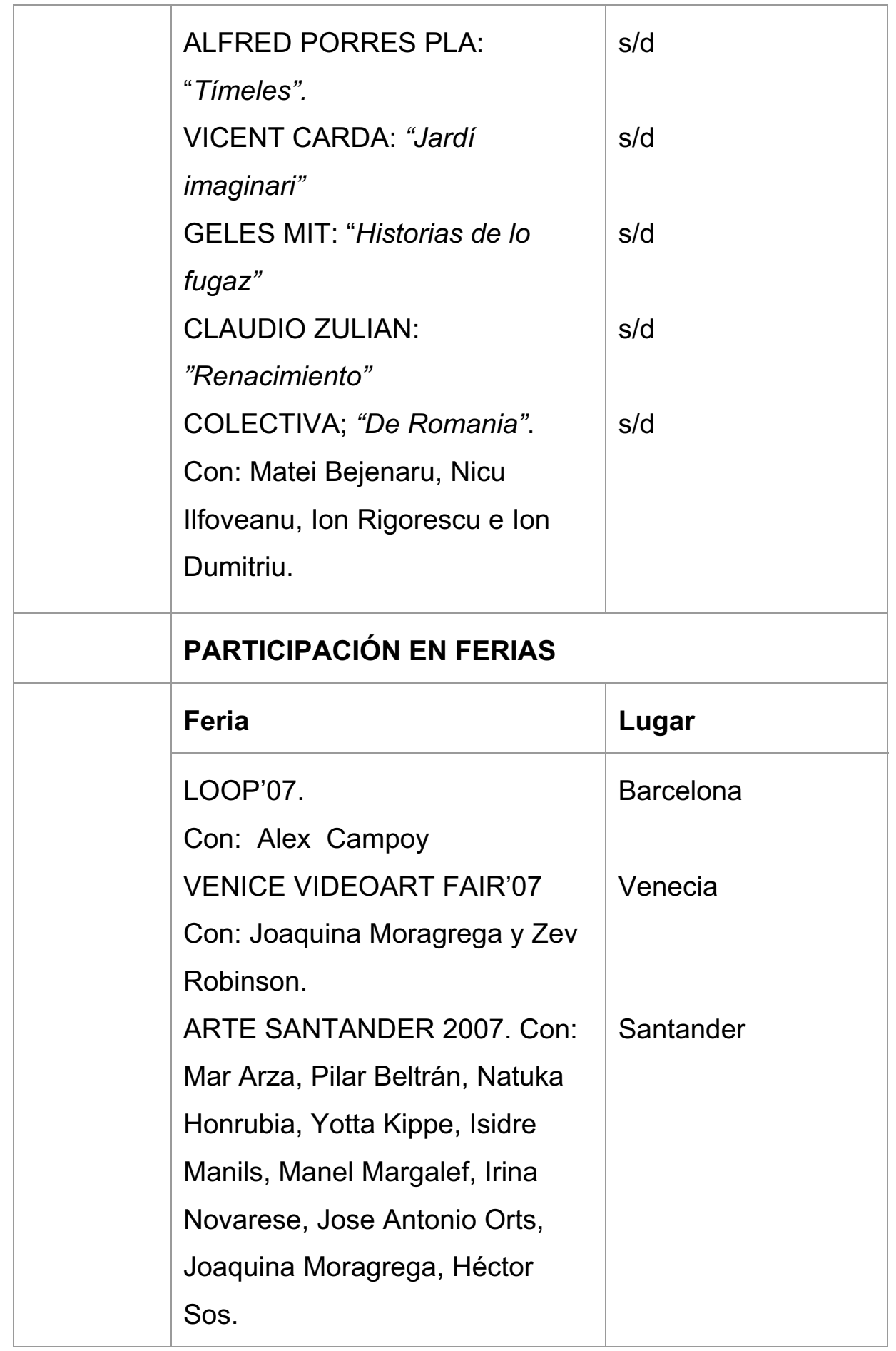




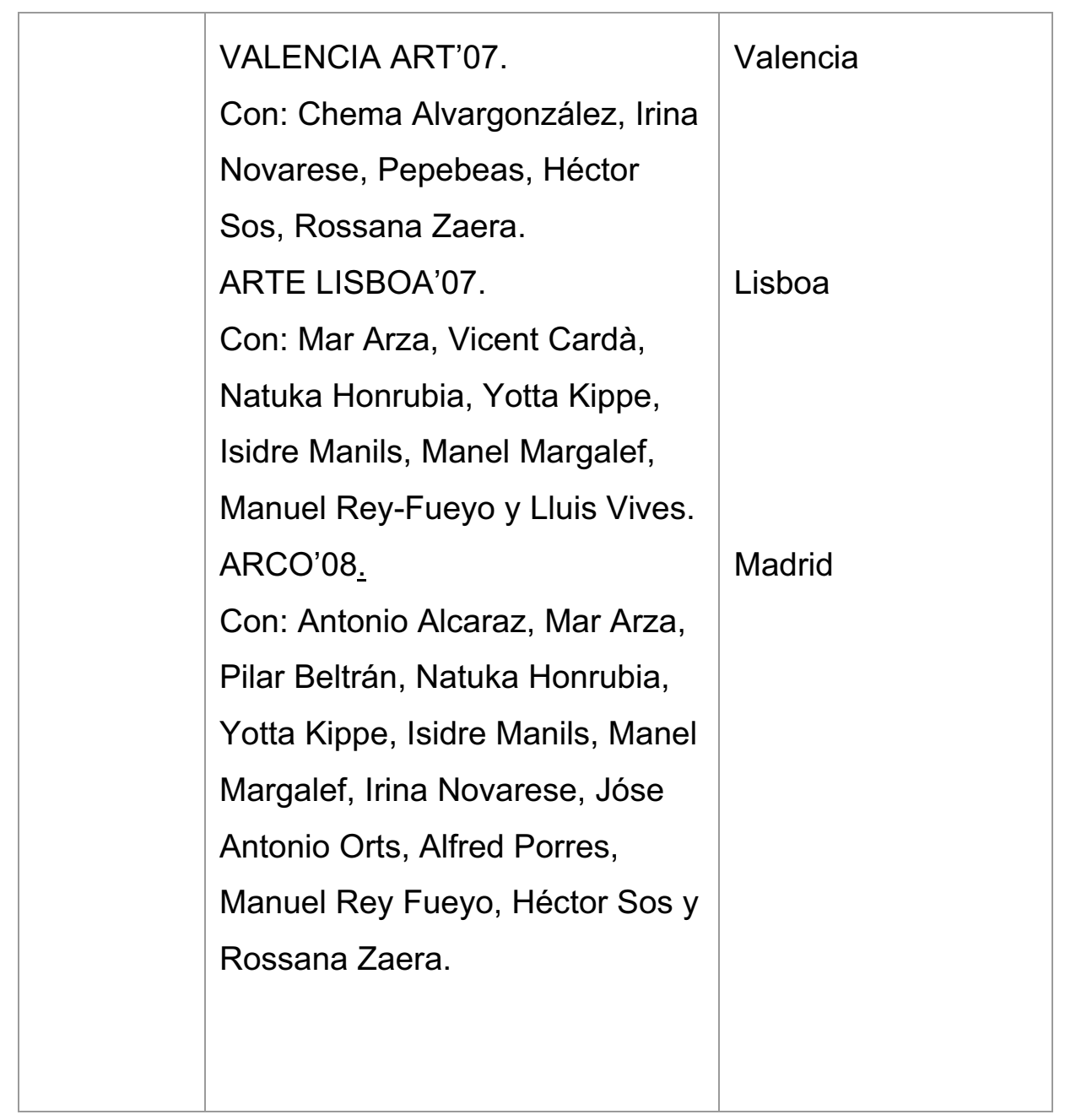

\section{8-2009 EXPOSICIONES}

\begin{tabular}{|l|l|}
\hline Artistas & Técnica \\
\hline $\begin{array}{l}\text { PEP SEBASTIÀ: De PE a pe } \\
\text { Pintura Sebastià. } \\
\text { MIQUEL GOZALBO }\end{array}$ & Pintura \\
\hline
\end{tabular}




\begin{tabular}{|c|c|}
\hline $\begin{array}{l}\text { JAVIER PUÉRTOLAS: } \\
\text { “Hipervincle” } \\
\text { ROSSANA ZAERA: “Habitación } \\
450 " \\
\text { PEP GUERRERO } \\
\text { ANTONI LLENA. } \\
\text { ANTONI ALCÀSSER: “Una } \\
\text { aproximació... una relectura” } \\
\text { LAURA AMBROSI: "Circolo- } \\
\text { cercle-circulo- circle.” }\end{array}$ & $\begin{array}{l}\text { s/d } \\
\text { s/d } \\
\text { s/d } \\
\text { s/d } \\
\text { s/d }\end{array}$ \\
\hline \multicolumn{2}{|l|}{ PARTICIPACIÓN EN FERIAS } \\
\hline Feria & Lugar \\
\hline $\begin{array}{l}\text { ARTE SANTANDER } 2008 . \\
\text { Con: Mar Arza, Matei Bejenaru, } \\
\text { Pilar Beltrán, Ion Dumitriu, Vicent } \\
\text { Cardà, Nicu Ilfoveanu, Yotta } \\
\text { Kippe, Geles Mit y Claudio } \\
\text { Zulián. } \\
\text { VALENCIA ART } 2008 . \\
\text { Con: Joaquina Moragrega. } \\
\text { ARTE LISBOA } 2008 . \\
\text { Con: Antonio Alcaraz, Mar Arza, } \\
\text { Ion Dumitriu, Nicu Ilfoveanu, } \\
\text { Yotta Kippe, Isidre Manils, Alfred } \\
\text { Porres, Manuel Rey Fueyo, } \\
\text { Josep Uclés y Lluis Vives. }\end{array}$ & $\begin{array}{l}\text { Valencia } \\
\text { Lisboa }\end{array}$ \\
\hline
\end{tabular}


ARCO 09.

Con: Mar Arza, Matei Bejenaru,

Pilar Beltrán, Miquel Gozalbo,

Yotta Kippe, Isidre Manils, Manel

Margalef, Geles Mit, Irina

Novarese, Alfred Porres, Manuel

Rey Fueyo y Josep Uclés.

LOOP'09.

Con: Irina Novarese.
Madrid

Barcelona 
ESUMEN 



\section{RESUMEN}

El objetivo fundamental de esta tesis es estudiar la obra gráfica de Pilar Dolz, una artista profundamente testimonial, en su afán por el impulso de los lenguajes artísticos, en su defensa por los derechos de la mujer, en su lucha por las libertades en el sentido más amplio y absoluto. De hecho, su actitud reivindicadora en los últimos años de la dictadura, junto a otros artistas de su generación puede considerarse histórica, aunque la propia artista sea la primera en minimizar su leyenda.

En esta tesis se ha llevado acabo el estudio de la obra gráfica desde 1970 hasta el 2002, momento en que iniciamos la investigación con la recopilación de datos y documentos, y la realización de un archivo fotográfico de su obra. Dicho estudio se plantea de un modo riguroso, agrupando las imágenes en series, por cuanto desde un primer momento la autora trabaja la obra con este planteamiento.

El análisis se ha llevado a cabo desde tres puntos de vista; conceptual, formal y técnico, con el fin de situarla dentro de un contexto vital y estético determinado. Así hemos podido establecer los aspectos que han influido y marcado su creación artística, tanto en el orden político, social e ideológico, así como su repercusión en el orden artístico y técnico, que marcan unos intereses plásticos personales. 
En la obra de Pilar Dolz podemos apreciar una magnífica creatividad y un pleno dominio de la técnica, que va simplificando a medida que avanza en la búsqueda de un lenguaje propio, inmerso en la investigación de las posibilidades intrínsecas que le otorga el medio, así como el empleo de herramientas y materiales sencillos que posibilitan una forma de expresión simple y espontánea. Los valores plásticos de su obra entrañan una actitud disciplinada, perseverante y reflexiva.

En definitiva Pilar Dolz ha sido y es una artista entregada por completo al grabado en sus más diversas técnicas, procedimientos y recursos. Mas sus investigaciones y propuestas en este rico campo no constituyen una tarea complementaria, sino su genuina forma de expresión. Tal como se puede apreciar en este estudio. Sin duda podemos considerarla como una de las grabadoras más cualificadas y destacadas de la Comunidad Valenciana. 


\section{RESUM}

L'objectiu fonamental d'aquesta tesi és estudiar l'obra gràfica de Pilar Dolz, una artista profundament testimonial, en el seu interés per encaminar tots els esforços a impulsar els llenguatges artístics, en la defensa a ultrança pels drets de la dona, en la lluita per les llibertats en el sentit més ampli i absolut. De fet, l'actitud reivindicadora en els últims anys de la dictadura al costat de les altres artistes de la seua generació pot considerar-se històrica, encara que la mateixa artista siga la primera a minimitzar la seua llegenda.

En la tesi s'ha portat a terme l'estudi de l'obra gràfica des del 1970 fins al 2002, moment que iniciem amb la recopilació de dades i documents, i la realització d'un arxiu fotogràfic de l'obra. L'estudi es planteja d'un mode rigorós, agrupant les imatges en sèries perquè des d'un primer moment l'autora treballa l'obra amb este plantejament.

L'anàlisi s'ha dut a terme des de tres punts de vista; conceptual, formal i tècnic, amb l'objectiu de situar-la dins d'un context vital i estètic determinat. Així hem pogut establir els aspectes que han influït i marcat la seua creació artística, tant en l'ordre polític, social i ideològic, així com la repercussió en l'ordre artístic i tècnic, que marquen uns interessos plàstics personals.

En l'obra de Pilar Dolz podem apreciar una creativitat magnífica i un domini ple de la tècnica, que simplifica a mesura que avança en la búsqueda d'un llenguatge propi, immers en la 
investigació de les possibilitats intrínseques que l'atorga el mig; així com la utilització de ferramentes i materials senzills que possibiliten una forma d'expressió simple i espontània. Els valors plàstics de l'obra comporten una actitud disciplinada, perseverant i reflexiva.

En definitiva, Pilar Dolz ha sigut i és una artista entregada per complet al gravat en les tècniques, procediments i recursos més diversos. Més encara, les investigacions i propostes en aquest ric camp no constituïxen una tasca complemetària, sinó la seua forma genuïna d'expressió, tal com s'aprecia en la seua biografia i en aquest estudi. Sense dubte podem considerar-la com una de les més qualificades i anomenades gravadores de la Comunitat Valenciana. 


\section{SUMMARY}

The fundamental aim of this thesis is to study Pilar Dolz's graphic work. She is a very symbolic aritst in her fight for artistic languages, as well as in her extreme defence for the women's rights and in her fight for freedom in the most wide and absolute sense. In fact, her demanding attitude during the last years of the dictatorship, beside other artists of her generation, can be considered as historical. Though she is the first one in minimizing her legend.

In this thesis I have carried out the study of the artist's work from 1970 until 2002. It starts with a summary of information and documents, and with a photographic file of her work. It appears in a rigorous way, grouping the images in series, because from the very beginning the artist works with this approach.

I have carried out the analysis from three points of view; conceptual, formal and technical, with the aim of placing it inside a vital and aesthetic specific context. In this way I have been capable of establishing the potical, social and ideological aspects that have influenced and marked her artistic creation. These aspects have had an impact in her artistic and technical order, that stress some plastic personal interests.

In Pilar Dolz's work we can appreciate a glorious creativity and full mastery of the technique, that go simplifying the reserching for her own language while she is immersed in the investigation of the intrinsic possibilities that the technique awards her. The employment of tools and simple materials make possible a simple and 
spontaneous way of expression. The plastic values of her work involve a disciplined persistent and reflexive attitude.

In conclusion Pilar Dolz has been and still she is an artist delivered completely to the engraving in its diverse technical, procedures and resources. Moreover her investigations and proposals in this rich field do not constitute a complementary task, but his genuine way of expression. Such as you can appreciate in her biography and in this study, without doubt, we can consider her as one of the most well-kwon engraver of the Valencian Community. 